Cochrane Database of Systematic Reviews

\title{
Effects of low sodium diet versus high sodium diet on blood pressure, renin, aldosterone, catecholamines, cholesterol, and triglyceride (Review)
}

Graudal NA, Hubeck-Graudal T, Jurgens G

Graudal NA, Hubeck-Graudal T, Jurgens G.

Effects of low sodium diet versus high sodium diet on blood pressure, renin, aldosterone, catecholamines, cholesterol, and triglyceride.

Cochrane Database of Systematic Reviews 2017, Issue 4. Art. No.: CD004022.

DOI: 10.1002/14651858.CD004022.pub4.

\author{
www.cochranelibrary.com
}

Effects of low sodium diet versus high sodium diet on blood pressure, renin, aldosterone, catecholamines, cholesterol, and triglyceride (Review) 
TABLE OF CONTENTS

HEADER

ABSTRACT

PLAIN LANGUAGE SUMMARY

SUMMARY OF FINDINGS

BACKGROUND

OBJECTIVES

METHODS

RESULTS

Figure 1.

Figure 2.

Figure 3.

Figure 4.

Figure 5.

Figure 6.

DISCUSSION

AUTHORS' CONCLUSIONS

ACKNOWLEDGEMENTS

REFERENCES

CHARACTERISTICS OF STUDIES

DATA AND ANALYSES

Analysis 1.1. Comparison 1 Effect of salt reduction on systolic blood pressure (SBP) and diastolic blood pressure (DBP) in Whites, Outcome 1 White population, normotensive, SBP.

Analysis 1.2. Comparison 1 Effect of salt reduction on systolic blood pressure (SBP) and diastolic blood pressure (DBP) in Whites, Outcome 2 White population, normotensive, DBP.

Analysis 1.3. Comparison 1 Effect of salt reduction on systolic blood pressure (SBP) and diastolic blood pressure (DBP) in Whites, Outcome 3 White population, hypertensive, SBP.

Analysis 1.4. Comparison 1 Effect of salt reduction on systolic blood pressure (SBP) and diastolic blood pressure (DBP) in Whites, Outcome 4 White population, hypertensive, DBP.

Analysis 2.1. Comparison 2 Effect of salt reduction on systolic blood pressure (SBP) and diastolic blood pressure (DBP) in Blacks, Outcome 1 Black population, normotensive, SBP.

Analysis 2.2. Comparison 2 Effect of salt reduction on systolic blood pressure (SBP) and diastolic blood pressure (DBP) in Blacks, Outcome 2 Black population, normotensive, DBP.

Analysis 2.3. Comparison 2 Effect of salt reduction on systolic blood pressure (SBP) and diastolic blood pressure (DBP) in Blacks, Outcome 3 Black population, hypertensive, SBP.

Analysis 2.4. Comparison 2 Effect of salt reduction on systolic blood pressure (SBP) and diastolic blood pressure (DBP) in Blacks, Outcome 4 Black population, hypertensive, DBP.

Analysis 3.1. Comparison 3 Effect of salt reduction on systolic blood pressure (SBP) and diastolic blood pressure (DBP) in Asians, Outcome 1 Asians population normotensive, SBP.

Analysis 3.2. Comparison 3 Effect of salt reduction on systolic blood pressure (SBP) and diastolic blood pressure (DBP) in Asians, Outcome 2 Asian population, normotensive, DBP.

Analysis 3.3. Comparison 3 Effect of salt reduction on systolic blood pressure (SBP) and diastolic blood pressure (DBP) in Asians, Outcome 3 Asian population, hypertensive, SBP.

Analysis 3.4. Comparison 3 Effect of salt reduction on systolic blood pressure (SBP) and diastolic blood pressure (DBP) in Asians, Outcome 4 Asian population, hypertensive, DBP.

Analysis 4.1. Comparison 4 Effect of salt reduction on systolic blood pressure (SBP) and diastolic blood pressure (DBP) in Whites, subgroup analysis, Outcome 1 White population, normotensive, SBP.

Analysis 4.2. Comparison 4 Effect of salt reduction on systolic blood pressure (SBP) and diastolic blood pressure (DBP) in Whites, subgroup analysis, Outcome 2 White population, normotensive, DBP.

Analysis 4.3. Comparison 4 Effect of salt reduction on systolic blood pressure (SBP) and diastolic blood pressure (DBP) in Whites, subgroup analysis, Outcome 3 White population, hypertensive, SBP.

Analysis 4.4. Comparison 4 Effect of salt reduction on systolic blood pressure (SBP) and diastolic blood pressure (DBP) in Whites, subgroup analysis, Outcome 4 White population, hypertensive, DBP.

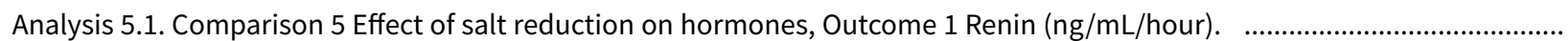

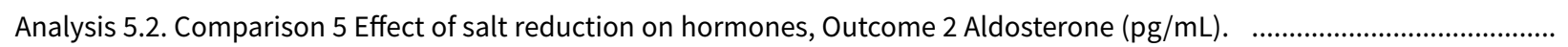

Effects of low sodium diet versus high sodium diet on blood pressure, renin, aldosterone, catecholamines, cholesterol, and triglyceride 
Analysis 5.3. Comparison 5 Effect of salt reduction on hormones, Outcome 3 Noradrenaline $(\mathrm{pg} / \mathrm{mL})$.

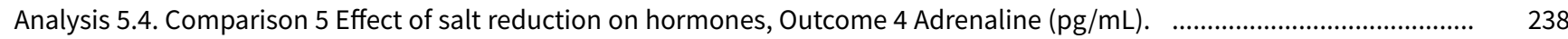

Analysis 6.1. Comparison 6 Effect of salt reduction on hormones, subgroup analysis, Outcome 1 Renin (ng/mL/hour). ........... 239

Analysis 6.2. Comparison 6 Effect of salt reduction on hormones, subgroup analysis, Outcome 2 Aldosterone $(\mathrm{pg} / \mathrm{mL}) . \quad \ldots \ldots \ldots . . \quad 240$

Analysis 6.3. Comparison 6 Effect of salt reduction on hormones, subgroup analysis, Outcome 3 Noradrenaline $(\mathrm{pg} / \mathrm{mL}) . \quad \ldots \ldots . \quad 241$

Analysis 6.4. Comparison 6 Effect of salt reduction on hormones, subgroup analysis, Outcome 4 Adrenaline (pg/mL). ........... 242

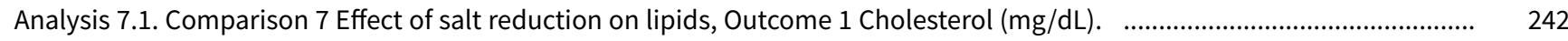

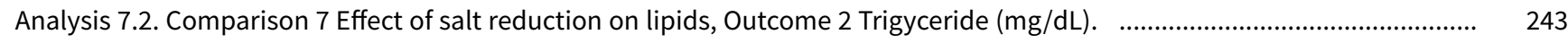

Analysis 7.3. Comparison 7 Effect of salt reduction on lipids, Outcome 3 High density lipoprotein, HDL (mg/dL). ................... 244

Analysis 7.4. Comparison 7 Effect of salt reduction on lipids, Outcome 4 Low density lipoprotein, LDL (mg/dL). .................... 244

Analysis 8.1. Comparison 8 Effect of salt reduction on lipids, subgroup analysis, Outcome 1 Cholesterol (mg/dL). ................. 245

Analysis 8.2. Comparison 8 Effect of salt reduction on lipids, subgroup analysis, Outcome 2 Trigyceride (mg/dL). ................. 246

Analysis 8.3. Comparison 8 Effect of salt reduction on lipids, subgroup analysis, Outcome 3 High density lipoprotein, HDL (mg/ 246 $\mathrm{dL})$.

Analysis 8.4. Comparison 8 Effect of salt reduction on lipids, subgroup analysis, Outcome 4 Low density lipoprotein, LDL (mg/ $\mathrm{dL})$.

Analysis 9.1. Comparison 9 Bias analyses, Outcome 1 White population, normotensive, SBP blinding-high.

Analysis 9.2. Comparison 9 Bias analyses, Outcome 2 White population, normotensive, SBP blinding-low.

Analysis 9.3. Comparison 9 Bias analyses, Outcome 3 White population, normotensive, SBP outcome-assesed-high

Analysis 9.4. Comparison 9 Bias analyses, Outcome 4 White population, normotensive, SBP outcome-assesed-low. ...............

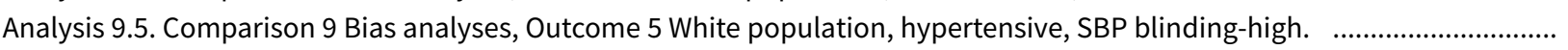

Analysis 9.6. Comparison 9 Bias analyses, Outcome 6 White population, hypertensive, SBP blinding-low.

Analysis 9.7. Comparison 9 Bias analyses, Outcome 7 White population, hypertensive, SBP outcome-assesed-high. ............... 255

Analysis 9.8. Comparison 9 Bias analyses, Outcome 8 White population, hypertensive, SBP outcome-assesed-low. $\quad \ldots . . . . . . . . . . . . . .255$

ADDITIONAL TABLES

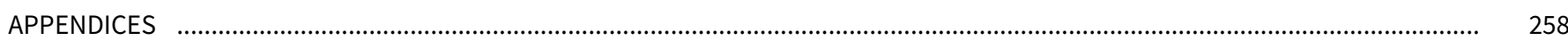

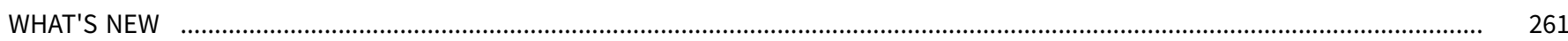

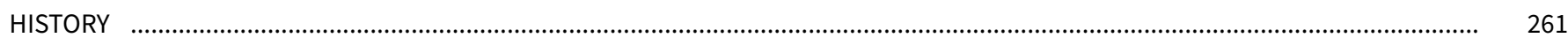

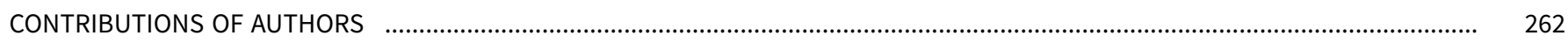

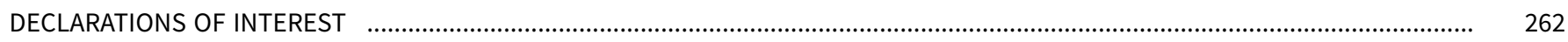

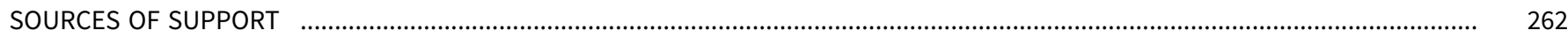

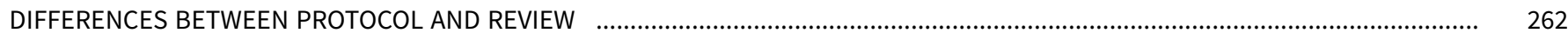

INDEX TERMS

Effects of low sodium diet versus high sodium diet on blood pressure, renin, aldosterone, catecholamines, cholesterol, and triglyceride 
[Intervention Review]

\section{Effects of low sodium diet versus high sodium diet on blood pressure, renin, aldosterone, catecholamines, cholesterol, and triglyceride}

Niels Albert Graudal ${ }^{1}$, Thorbjorn Hubeck-Graudal2 ${ }^{2}$, Gesche Jurgens ${ }^{3}$

1Department of Rheumatology VRR4242, Copenhagen University Hospital Rigshospitalet, Copenhagen, Denmark. 2Department of Nuclear Medicine, Herning Hospital, Herning, Denmark. ${ }^{3}$ Clinical Pharmacology Unit, Roskilde Hospital, Roskilde, Denmark

Contact address: Niels Albert Graudal, Department of Rheumatology VRR4242, Copenhagen University Hospital Rigshospitalet, Blegdamsvej 9, Copenhagen, DK-2100 Ø, Denmark. graudal@dadlnet.dk.

Editorial group: Cochrane Hypertension Group.

Publication status and date: New search for studies and content updated (no change to conclusions), published in Issue 4, 2017.

Citation: Graudal NA, Hubeck-Graudal T, Jurgens G. Effects of low sodium diet versus high sodium diet on blood pressure, renin, aldosterone, catecholamines, cholesterol, and triglyceride. Cochrane Database of Systematic Reviews 2017, Issue 4. Art. No.: CD004022. DOI: 10.1002/14651858.CD004022.pub4.

Copyright $\odot 2017$ The Cochrane Collaboration. Published by John Wiley \& Sons, Ltd.

\section{A B S T R A C T}

\section{Background}

In spite of more than 100 years of investigations the question of whether a reduced sodium intake improves health is still unsolved.

\section{Objectives}

To estimate the effects of low sodium intake versus high sodium intake on systolic and diastolic blood pressure (SBP and DBP), plasma or serum levels of renin, aldosterone, catecholamines, cholesterol, high-density lipoprotein (HDL), low-density lipoprotein (LDL) and triglycerides.

\section{Search methods}

The Cochrane Hypertension Information Specialist searched the following databases for randomized controlled trials up to March 2016: the Cochrane Hypertension Specialised Register, the Cochrane Central Register of Controlled Trials (CENTRAL) (2016, Issue 3), MEDLINE (from 1946), Embase (from 1974), the World Health Organization International Clinical Trials Registry Platform, and ClinicalTrials.gov. We also searched the reference lists of relevant articles.

\section{Selection criteria}

Studies randomising persons to low-sodium and high-sodium diets were included if they evaluated at least one of the above outcome parameters.

\section{Data collection and analysis}

Two review authors independently collected data, which were analysed with Review Manager 5.3.

\section{Main results}

A total of 185 studies were included. The average sodium intake was reduced from $201 \mathrm{mmol} /$ day (corresponding to high usual level) to $66 \mathrm{mmol} /$ day (corresponding to the recommended level).

The effect of sodium reduction on blood pressure (BP) was as follows: white people with normotension: SBP: mean difference (MD) -1.09 $\mathrm{mmHg}(95 \%$ confidence interval $(\mathrm{Cl}):-1.63$ to -0.56 ; $\mathrm{P}=0.0001)$; 89 studies, 8569 participants; DBP: $+0.03 \mathrm{mmHg}$ (MD 95\% Cl: -0.37 to 0.43 ; $\mathrm{P}=0.89) ; 90$ studies, 8833 participants. High-quality evidence.

Effects of low sodium diet versus high sodium diet on blood pressure, renin, aldosterone, catecholamines, cholesterol, and triglyceride 
Black people with normotension: SBP: MD -4.02 mmHg (95\% Cl:-7.37 to -0.68; $\mathrm{P}=0.002)$; seven studies, 506 participants; DBP: MD -2.01 $\mathrm{mmHg}$ (95\% Cl:-4.37 to 0.35; $\mathrm{P}=0.09)$; seven studies, 506 participants. Moderate-quality evidence.

Asian people with normotension: $\mathrm{SBP}$ : MD $-0.72 \mathrm{mmHg}(95 \% \mathrm{Cl}:-3.86$ to $2.41 ; \mathrm{P}=0.65)$; DBP: $\mathrm{MD}-1.63 \mathrm{mmHg}(95 \% \mathrm{Cl}:-3.35$ to 0.08 ; $\mathrm{P}=0.06)$; three studies, 393 participants. Moderate-quality evidence.

White people with hypertension: SBP: MD $-5.51 \mathrm{mmHg}(95 \% \mathrm{Cl}:-6.45$ to -4.57 ; $\mathrm{P}<0.00001)$; 84 studies, 5925 participants; DBP: MD -2.88 $\mathrm{mmHg}(95 \% \mathrm{Cl}:-3.44$ to $-2.32 ; \mathrm{P}<0.00001) ; 85$ studies, 6001 participants. High-quality evidence.

Black people with hypertension: SBP MD $-6.64 \mathrm{mmHg}(95 \% \mathrm{Cl}$ :-9.00 to $-4.27 ; \mathrm{P}=0.00001$ ); eight studies, 619 participants; $\mathrm{DBP}-2.91 \mathrm{mmHg}$ (95\% Cl:-4.52, -1.30; $\mathrm{P}=0.0004)$; eight studies, 619 participants. Moderate-quality evidence.

Asian people with hypertension: SBP: MD $-7.75 \mathrm{mmHg}(95 \% \mathrm{Cl}:-11,44$ to -4.07 ; $\mathrm{P}<0.0001)$ nine studies, 501 participants; DBP: MD -2.68 $\mathrm{mmHg}$ (95\% Cl: -4.21 to $-1.15 ; \mathrm{P}=0.0006)$. Moderate-quality evidence.

In plasma or serum, there was a significant increase in renin $(P<0.00001)$, aldosterone $(P<0.00001)$, noradrenaline $(P<0.00001)$, adrenaline $(P<0.03)$, cholesterol $(P<0.0005)$ and triglyceride $(P<0.0006)$ with low sodium intake as compared with high sodium intake. All effects were stable in 125 study populations with a sodium intake below $250 \mathrm{mmol} /$ day and a sodium reduction intervention of at least one week.

\section{Authors' conclusions}

Sodium reduction from an average high usual sodium intake level $(201 \mathrm{mmol} / \mathrm{day})$ to an average level of $66 \mathrm{mmol} / \mathrm{day}$, which is below the recommended upper level of $100 \mathrm{mmol} /$ day $(5.8 \mathrm{~g}$ salt), resulted in a decrease in SBP/DBP of $1 / 0 \mathrm{mmHg}$ in white participants with normotension and a decrease in SBP/DBP of 5.5/2.9 mmHg in white participants with hypertension. A few studies showed that these effects in black and Asian populations were greater. The effects on hormones and lipids were similar in people with normotension and hypertension. Renin increased $1.60 \mathrm{ng} / \mathrm{mL} /$ hour (55\%); aldosterone increased $97.81 \mathrm{pg} / \mathrm{mL}(127 \%)$; adrenalin increased $7.55 \mathrm{pg} / \mathrm{mL}(14 \%)$; noradrenalin increased $63.56 \mathrm{pg} / \mathrm{mL}$ : (27\%); cholesterol increased $5.59 \mathrm{mg} / \mathrm{dL}(2.9 \%)$; triglyceride increased $7.04 \mathrm{mg} / \mathrm{dL}(6.3 \%)$.

\section{PLAIN LANGUAGE SUMMARY}

\section{The effect of a low salt diet on blood pressure and some hormones and lipids in people with normal and elevated blood pressure}

\section{Review question}

Studies in which participants were distributed by chance into groups with high and low salt intake were analysed to investigate the effect of reduced salt intake on blood pressure (BP) and potential side effects of sodium reduction on some hormones and lipids.

\section{Background}

As a reduction in salt intake decreases blood pressure (BP) in individuals with elevated BP, we are commonly advised to cut down on salt. However, the effect of salt reduction on BP in people with a normal BP has been questioned. Furthermore, several studies have shown that salt reduction activates the salt conserving hormonal system (renin and aldosterone), the stress hormones (adrenalin and noradrenalin) and increases fatty substances (cholesterol and triglyceride) in the blood.

\section{Search date}

The present evidence is current to April 2016.

\section{Study characteristics}

One hundred and eighty-five intervention studies of 12,210 individuals lasting four to 1100 days were included, which evaluated at least one of the effect measures. Participants were healthy or had elevated blood pressure. Longitudinal studies have shown that the effect of reduced salt intake on BP is stable after at maximum seven days and population studies have shown that very few people eat more than $14.5 \mathrm{~g}$ salt per day. Therefore, we also perfomed subgroup sub-analyses of 125 studies with a duration of at least seven days and a salt intake of maximum $14.5 \mathrm{~g}$.

\section{Study funding sources}

Forty-four studies did not mention support. One hundred and twenty-two studies were supported by public foundations. Twelve studies were supported by the pharmaceutical industry and one study by an electronic company. Six studies were supported by food industry organisations.

\section{Key results}

The mean dietary sodium intake was reduced from $11.5 \mathrm{~g}$ per day to $3.8 \mathrm{~g}$ per day. The reduction in SBP/DBP in people with normotension was about $1 / 0 \mathrm{mmHg}$, and in people with hypertension about $5.5 / 2.9 \mathrm{mmHg}$. In contrast, the effect on hormones and lipids were similar

Effects of low sodium diet versus high sodium diet on blood pressure, renin, aldosterone, catecholamines, cholesterol, and triglyceride 
in people with normotension and hypertension. Renin increased $1.60 \mathrm{ng} / \mathrm{mL} / \mathrm{hour}(55 \%) ;$ aldosterone increased $97.81 \mathrm{pg} / \mathrm{mL}(127 \%)$; adrenalin increased $7.55 \mathrm{pg} / \mathrm{mL}$ (14\%); noradrenalin increased $63.56 \mathrm{pg} / \mathrm{mL}(27 \%)$; cholesterol increased $5.59 \mathrm{mg} / \mathrm{dL}(2.9 \%)$; triglyceride increased $7.04 \mathrm{mg} / \mathrm{dL}(6.3 \%)$.

\section{Quality of evidence}

Only randomised controlled trials were included and the basic grade of evidence was therefore considered to be high, although the grade of evidence was downgraded in some of the smaller analyses. In general, the description of the randomisation procedure was insufficient, introducing a bias which could exaggerate the effects, but many of the studies were published in a period where it was not customary to report such descriptions. The majority of studies were open, but the outcomes of these did not differ from the outcomes of the double-blind studies. Almost all individual studies of participants with normal blood pressure (BP) show no significant effect of sodium reduction on BP, whereas a large number of studies in people with hypertension did show significant effect of sodium reduction on BP. Thus, there was a high grade of consistency between the outcomes of the individual studies and the outcomes of the meta-analyses. Sensitivity analyses of studies lasting at least one week (the time of maximal efficacy) confirmed the primary analyses. Finally, the impact of commercial interests on the outcomes was negligible. 


\section{SUMMARY OF FINDINGS}

\section{Summary of findings for the main comparison.}

\section{Low sodium intake compared with high sodium intake for blood pressure}

Patient or population: White population with normal or elevated blood pressure, but otherwise healthy

Settings: Hospitals units in Europe and North America

Intervention: Low sodium intake

Comparison: High sodium intake

\begin{tabular}{|c|c|c|c|c|}
\hline Outcomes & $\begin{array}{l}\text { Relative effect } \\
(95 \% \mathrm{CI})\end{array}$ & $\begin{array}{l}\text { No of Partici- } \\
\text { pants } \\
\text { (studies) }\end{array}$ & $\begin{array}{l}\text { Quality of the evi- } \\
\text { dence } \\
\text { (GRADE) }\end{array}$ & $\begin{array}{l}\text { Com- } \\
\text { ments }\end{array}$ \\
\hline $\begin{array}{l}\text { White population, normotensive, } \\
\text { SBP } \\
\mathrm{mmHg}\end{array}$ & $-1.09(-1.63$ to -0.56$)$ & $\begin{array}{l}8569 \\
(89)\end{array}$ & $\begin{array}{l}\oplus \oplus \oplus \oplus \\
\text { high }\end{array}$ & \\
\hline $\begin{array}{l}\text { White population, normotensive, } \\
\text { DBP } \\
\mathrm{mmHg}\end{array}$ & 0.03 (-0.37 to 0.43$)$ & $\begin{array}{l}8833 \\
(90)\end{array}$ & $\begin{array}{l}\oplus \oplus \oplus \oplus \\
\text { high }\end{array}$ & \\
\hline $\begin{array}{l}\text { White population, hypertensive, SBP } \\
\mathrm{mmHg}\end{array}$ & $-5.51(-6.45$ to -4.57$)$ & $\begin{array}{l}5925 \\
(84)\end{array}$ & $\begin{array}{l}\oplus \oplus \oplus \oplus \\
\text { high }\end{array}$ & \\
\hline $\begin{array}{l}\text { White population, hypertensive, DBP } \\
\mathrm{mmHg}\end{array}$ & $-2.88(-3.44$ to -2.32$)$ & $\begin{array}{l}6001 \\
(85)\end{array}$ & $\begin{array}{l}\oplus \oplus \oplus \oplus \\
\text { high }\end{array}$ & \\
\hline
\end{tabular}

GRADE Working Group grades of evidence

High quality: Further research is very unlikely to change our confidence in the estimate of effect.

Moderate quality: Further research is likely to have an important impact on our confidence in the estimate of effect and may change the estimate.

Low quality: Further research is very likely to have an important impact on our confidence in the estimate of effect and is likely to change the estimate.

Very low quality: We are very uncertain about the estimate.

DBP: diastolic blood pressure; SBP: systolic blood pressure

\section{Summary of findings 2.}

\section{Low sodium intake compared with high sodium intake for blood pressure}

Patient or population: Black population with normal or elevated blood pressure, but otherwise healthy

Settings: Hospital units in North America, UK and Africa

Intervention: Low sodium intake

Comparison: High sodium intake 


\begin{tabular}{|c|c|c|c|c|}
\hline Outcomes & $\begin{array}{l}\text { Mean difference } \\
(95 \% \mathrm{CI})\end{array}$ & $\begin{array}{l}\text { No of Partici- } \\
\text { pants } \\
\text { (studies) }\end{array}$ & $\begin{array}{l}\text { Quality of the evidence } \\
\text { (GRADE) }\end{array}$ & $\begin{array}{l}\text { Com- } \\
\text { ments }\end{array}$ \\
\hline $\begin{array}{l}\text { Black population, normotensive, } \\
\text { SBP } \\
\mathrm{mmHg}\end{array}$ & $-4.02(-7.37$ to -0.68$)$ & $\begin{array}{l}506 \\
(7)\end{array}$ & $\begin{array}{l}\oplus \oplus \oplus \ominus \\
\text { moderate }^{\mathbf{1}}\end{array}$ & \\
\hline $\begin{array}{l}\text { Black population, normotensive, } \\
\text { DBP } \\
\mathrm{mmHg}\end{array}$ & $-2.01(-4.37$ to 0.35$)$ & $\begin{array}{l}506 \\
(7)\end{array}$ & $\begin{array}{l}\oplus \oplus \oplus \ominus \\
\text { moderate }^{1}\end{array}$ & \\
\hline $\begin{array}{l}\text { Black population, hypertensive, } \\
\text { SBP } \\
\mathrm{mmHg}\end{array}$ & $-6.64(-9.00$ to -4.27$)$ & $\begin{array}{l}619 \\
(8)\end{array}$ & $\begin{array}{l}\oplus \oplus \oplus \ominus \\
\text { moderate }\end{array}$ & \\
\hline $\begin{array}{l}\text { Black population, hypertensive, } \\
\text { DBP } \\
\mathrm{mmHg}\end{array}$ & $-2.91(-4.52$ to -1.30$)$ & $\begin{array}{l}619 \\
(8)\end{array}$ & $\begin{array}{l}\oplus \oplus \oplus \ominus \\
\text { moderate }\end{array}$ & \\
\hline
\end{tabular}

GRADE Working Group grades of evidence

High quality: Further research is very unlikely to change our confidence in the estimate of effect.

Moderate quality: Further research is likely to have an important impact on our confidence in the estimate of effect and may change the estimate.

Low quality: Further research is very likely to have an important impact on our confidence in the estimate of effect and is likely to change the estimate.

Very low quality: We are very uncertain about the estimate.

DBP: diastolic blood pressure; SBP: systolic blood pressure

1. Downgraded due to the wide confidence intervals

\section{Summary of findings 3.}

\section{Low sodium intake compared with high sodium intake for blood pressure}

Patient or population: Asian population with normal or elevated blood pressure, but otherwise healthy

Settings: Hospital units in Japan and China

Intervention: Low sodium intake

Comparison: High sodium intake

\begin{tabular}{|c|c|c|c|c|}
\hline Outcomes & $\begin{array}{l}\text { Mean difference } \\
(95 \% \mathrm{CI})\end{array}$ & $\begin{array}{l}\text { No of Partici- } \\
\text { pants } \\
\text { (studies) }\end{array}$ & $\begin{array}{l}\text { Quality of the evidence } \\
\text { (GRADE) }\end{array}$ & $\begin{array}{l}\text { Com- } \\
\text { ments }\end{array}$ \\
\hline $\begin{array}{l}\text { Asian population, normotensive, } \\
\text { SBP } \\
\mathrm{mmHg}\end{array}$ & $-0.72(-3.86$ to 2.41$)$ & $\begin{array}{l}393 \\
(3)\end{array}$ & $\begin{array}{l}\oplus \oplus \oplus \ominus \\
\text { moderate }^{\mathbf{1}}\end{array}$ & \\
\hline $\begin{array}{l}\text { Asian population, normotensive, } \\
\text { DBP }\end{array}$ & $-1.63(-3.35$ to 0.08$)$ & $\begin{array}{l}393 \\
(3)\end{array}$ & $\begin{array}{l}\oplus \oplus \oplus \ominus \\
\text { moderate }\end{array}$ & \\
\hline
\end{tabular}

Effects of low sodium diet versus high sodium diet on blood pressure, renin, aldosterone, catecholamines, cholesterol, and triglyceride 


\begin{tabular}{|c|c|c|c|}
\hline \multicolumn{4}{|l|}{$\mathrm{mmHg}$} \\
\hline $\begin{array}{l}\text { Asian population, hypertensive, } \\
\text { SBP }\end{array}$ & $-7.75(-11.44$ to -4.07$)$ & $\begin{array}{l}501 \\
(8)\end{array}$ & $\begin{array}{l}\oplus \oplus \oplus \ominus \\
\text { moderate1 }\end{array}$ \\
\hline \multicolumn{4}{|l|}{$\mathrm{mmHg}$} \\
\hline
\end{tabular}

GRADE Working Group grades of evidence

High quality: Further research is very unlikely to change our confidence in the estimate of effect.

Moderate quality: Further research is likely to have an important impact on our confidence in the estimate of effect and may change the estimate.

Low quality: Further research is very likely to have an important impact on our confidence in the estimate of effect and is likely to change the estimate.

Very low quality: We are very uncertain about the estimate.

DBP: diastolic blood pressure; SBP: systolic blood pressure

1. Downgraded due to the wide confidence intervals

\section{Summary of findings 4.}

\section{Low sodium intake compared with high sodium intake for hormones}

Patient or population: Participants with normal or elevated blood pressure, but otherwise healthy

Settings: Hospital units

Intervention: Low sodium intake

Comparison: High sodium intake

\begin{tabular}{|c|c|c|c|c|}
\hline Outcomes & $\begin{array}{l}\text { Mean difference } \\
(95 \% \mathrm{CI})\end{array}$ & $\begin{array}{l}\text { No of Partici- } \\
\text { pants } \\
\text { (studies) }\end{array}$ & $\begin{array}{l}\text { Quality of the } \\
\text { evidence } \\
\text { (GRADE) }\end{array}$ & $\begin{array}{l}\text { Com- } \\
\text { ments }\end{array}$ \\
\hline $\begin{array}{l}\text { Renin } \\
\text { SMD }\end{array}$ & $\begin{array}{l}1.22 \text { (1.07 to } 1.37) \\
N^{*}: 1.44(1.24 \text { to } 1.65) \\
H^{*}: 0.91(0.71 \text { to } 1.10)\end{array}$ & $\begin{array}{l}5498 \\
(88)\end{array}$ & $\begin{array}{l}\oplus \oplus \oplus \oplus \\
\text { high }\end{array}$ & \\
\hline $\begin{array}{l}\text { Aldosterone } \\
\mathrm{pg} / \mathrm{mL}\end{array}$ & $\begin{array}{l}97.81 \text { (82.56 to } 113.05) \\
\left.N^{*}: 115.83 \text { (91.74 to } 139.91\right) \\
H^{*}: 73.02(55.94 \text { to } 90.09)\end{array}$ & $\begin{array}{l}4884 \\
(65)\end{array}$ & $\begin{array}{l}\oplus \oplus \oplus \oplus \\
\text { high }\end{array}$ & \\
\hline $\begin{array}{l}\text { Noradrena- } \\
\text { line } \\
\mathrm{pg} / \mathrm{mL}\end{array}$ & $\begin{array}{l}63.56(42.66 \text { to } 84.46) \\
N^{*}: 66.50(41.72 \text { to } 91.29) \\
H^{*}: 57.36(14.10 \text { to } 100.61)\end{array}$ & $\begin{array}{l}1736 \\
(36)\end{array}$ & $\begin{array}{l}\oplus \oplus \oplus \oplus \\
\text { high }\end{array}$ & \\
\hline Adrenaline & $7.55(0.85$ to 14.26$)$ & $\begin{array}{l}662 \\
(16)\end{array}$ & $\begin{array}{l}\oplus \oplus \oplus \ominus \\
\text { moderate}^{1}\end{array}$ & \\
\hline
\end{tabular}

Effects of low sodium diet versus high sodium diet on blood pressure, renin, aldosterone, catecholamines, cholesterol, and triglyceride (Review)

Copyright @ 2017 The Cochrane Collaboration. Published by John Wiley \& Sons, Ltd. 
$\mathrm{pg} / \mathrm{mL}$

$$
\begin{aligned}
& \left.N^{*}: 4.45 \text { (3.43 to } 12.33\right) \\
& \left.H^{*}: 13.45 \text { (1.25 to } 25.66\right)
\end{aligned}
$$

GRADE Working Group grades of evidence

High quality: Further research is very unlikely to change our confidence in the estimate of effect.

Moderate quality: Further research is likely to have an important impact on our confidence in the estimate of effect and may change the estimate.

Low quality: Further research is very likely to have an important impact on our confidence in the estimate of effect and is likely to change the estimate.

Very low quality: We are very uncertain about the estimate.

SMD: standardised mean difference

$\mathrm{N}^{\star}$ : Study populations with mean SBP $<140 \mathrm{mmHg}$

$\mathrm{H}^{\star}$ :Study populations with mean SBP $>140 \mathrm{mmHg}$

1. Downgraded due to the wide confidence interval

\section{Summary of findings 5 .}

\section{Low sodium intake compared with high sodium intake for lipids}

Patient or population: Participants with normal or elevated blood pressure, but otherwise healthy

Settings: Hospital units

Intervention: Low sodium intake

\begin{tabular}{|c|c|c|c|c|}
\hline Outcomes & $\begin{array}{l}\text { Mean difference } \\
(95 \% \mathrm{CI})\end{array}$ & $\begin{array}{l}\text { No of Partici- } \\
\text { pants } \\
\text { (studies) }\end{array}$ & $\begin{array}{l}\text { Quality of the evi- } \\
\text { dence } \\
\text { (GRADE) }\end{array}$ & $\begin{array}{l}\text { Com- } \\
\text { ments }\end{array}$ \\
\hline $\begin{array}{l}\text { Cholesterol } \\
\mathrm{mg} / \mathrm{dL}\end{array}$ & $\begin{array}{l}5.64(2.46,8.82) \\
N^{*}: 7.46(3.65,11.28) \\
H^{*}: 2.55(-2.69,7.80)\end{array}$ & $\begin{array}{l}1800 \\
(27)\end{array}$ & $\begin{array}{l}\oplus \oplus \oplus \ominus \\
\text { moderate }^{\mathbf{1}}\end{array}$ & \\
\hline $\begin{array}{l}\text { Trigyceride } \\
\mathrm{mg} / \mathrm{dL}\end{array}$ & $\begin{array}{l}7.04(3.04,11.05) \\
N^{*}: 6.88(1.18,12.59) \\
H^{*}: 7.19(1.57,12.81)\end{array}$ & $\begin{array}{l}1390 \\
(19)\end{array}$ & $\begin{array}{l}\oplus \oplus \oplus \ominus \\
\text { moderate }^{\mathbf{1}}\end{array}$ & \\
\hline $\begin{array}{l}\text { High-density lipoprotein } \\
\text { (HDL) } \\
\mathrm{mg} / \mathrm{dL}\end{array}$ & $-0.29(-1.66,1.08)$ & $\begin{array}{l}1442 \\
(19)\end{array}$ & $\begin{array}{l}\oplus \oplus \oplus \odot \\
\text { moderate }^{\mathbf{1}}\end{array}$ & \\
\hline $\begin{array}{l}\text { Low-density lipoprotein } \\
\text { (LDL) } \\
\mathrm{mg} / \mathrm{dL}\end{array}$ & $3.12(-0.41,6.64)$ & $\begin{array}{l}1358 \\
(17)\end{array}$ & $\begin{array}{l}\oplus \oplus \oplus \ominus \\
\text { moderate }^{\mathbf{1}}\end{array}$ & \\
\hline
\end{tabular}

Comparison: High sodium intake

GRADE Working Group grades of evidence

High quality: Further research is very unlikely to change our confidence in the estimate of effect.

Effects of low sodium diet versus high sodium diet on blood pressure, renin, aldosterone, catecholamines, cholesterol, and triglyceride 
Moderate quality: Further research is likely to have an important impact on our confidence in the estimate of effect and may change the estimate.

Low quality: Further research is very likely to have an important impact on our confidence in the estimate of effect and is likely to change the estimate.

Very low quality: We are very uncertain about the estimate.

Downgraded due to the wide confidence intervals. 


\section{B A C K G R O U N D}

\section{Description of the condition}

Some health institutions (WHO 2012), and dietary recommendations (ADG 2015), assume that reduction in salt intake from "high" to "low" levels is associated with reduction in systolic and diastolic blood pressure (SBP and DBP), which might result in a decrease in mortality. However, the definitions of "high", "normal" and "low" sodium intake are unclear. The present usual sodium intake indicates that an intake in the interval $109 \mathrm{mmol} /$ day to $209 \mathrm{mmol} /$ day (McCarron 2013; Powles 2013, Table 1) would be "normal", a high sodium intake would be above $209 \mathrm{mmol} /$ day and a low sodium intake would be below $109 \mathrm{mmol} /$ day, but according to the health institutions a "normal" sodium intake is below 100 $\mathrm{mmol} /$ day (ADG 2015), or below $87 \mathrm{mmol} /$ day (WHO 2012), and a sodium intake above $100 \mathrm{mmol} /$ day is "high", whereas a "low" sodium intake is not defined. The confusion is strengthened by the use of different terms to describe salt (salt (sodium chloride) and sodium) and different units for salt/sodium intake $(\mathrm{mg} /$ day or $\mathrm{mmol} /$ day). To reduce the confusion we have shown the different definitions and units for salt and sodium intake in Table 1 . In the present review, which represents a third update of the first meta-analysis that includes an analysis of hormones and lipids in addition to blood pressure (Graudal 1998), updated in 2003 (Jürgens 2003) and 2011 (Graudal 2011), we use the term "sodium" and the unit "mmol".

Blood pressure is associated with mortality (Collins 1990).The hypothesis that a reduced sodium intake (sodium reduction) will reduce blood pressure (BP) and subsequently reduce morbidity and mortality was raised in 1904 on the basis of individual patient cases (Ambard 1904). Subsequently in 1907, these results were opposed (Löwenstein 1907). The clinical and physiological effects of salt published in studies during the first half of the 20th century were reviewed in 1949 (Chapman 1949). Consequently, scientific studies have been performed for almost 70 years before modern standard scientific randomised controlled trials (RCTs) (1000 Parijs 1973) and observational studies (Kagan 1985) were performed in humans. However, these scientific studies are interpreted differently (Taubes 1998, Graudal 2005, Bayer 2012). While health institutions (ADG 2015, WHO 2012) support sodium reduction below $100 \mathrm{mmol} /$ day sceptics have claimed that this recommended upper limit (UL) for sodium intake is based on a biased selection of evidence (Folkow 2011), and is inconsistent with Institute of Medicine's definition of an adequate nutrient intake, which is "the approximate intake found in apparently healthy populations" (IOM 2006; Heaney 2013). For sodium "the approximate intake in apparently healthy populations" is between $90 \mathrm{mmol} /$ day and 248 $\mathrm{mmol} /$ day (Table 1).

The present Cochrane review is based on a meta-analysis published in 1998 (Graudal 1998). In 1998, the usual sodium intake was known in some populations, but it was not well-defined worldwide until recently (Table 1). The present upper level of $100 \mathrm{mmol} / \mathrm{day}$ was defined in 2005 (IOM 2005). Furthermore, the significance of the duration of sodium reduction was not established. In 1998, we therefore included all available randomised studies, irrespective of sodium intake and duration of intervention, assuming that the average values of multiple studies would be relevant for the general population. We separated study populations in a group of populations with normal BP to investigate the potential effect of sodium reduction in the general population and in a group of hypertensive populations to investigate the potential effect of sodium reduction as a treatment for hypertensive individuals. In a cross-sectional multiple regression analysis including many covariates we found that the duration of the sodium reduction intervention had no impact on the effect of sodium reduction on BP (Graudal 1998). In addition to this cross-sectional metaregression analysis, a recent meta-analysis of longitudinal studies measuring the BP-effect of sodium reduction several times during the observation period showed that there was no difference in SBP effect or DBP effect between week one and week six, thus estimating the time point for maximal efficacy to be at maximum at one week (Graudal 2015). These results are shown in Table 2. In the Graudal 1998 analysis, the average sodium intake in the nonreduced group was $203 \mathrm{mmol} / \mathrm{day}$ and in the reduced group it was $62 \mathrm{mmol} /$ day. In the two following updates of the review, the corresponding sodium reductions were from $205 \mathrm{mmol} /$ day to 64 $\mathrm{mmol} /$ day (Jürgens 2003) and from $202 \mathrm{mmol} /$ day to $67 \mathrm{mmol} /$ day (Graudal 2011). We now know (McCarron 2013; Powles 2013) that this reduction corresponds to a reduction from a high usual level to the present recommended levels (defined in 2005 (IOM 2005) and in 2012 (WHO 2012) i.e. the present review is relevant in the context of evaluating the consequences of the present recommendations to reduce sodium intake to a level below $100 \mathrm{mmol} /$ day.

\section{Description of the intervention}

As in the previous meta-analyses, RCTs are included, which allocate participants to two diets with a different content of salt (sodium chloride) or to either salt tablets or placebo tablets. The compliance in the RCTs is ensured by measurement of sodium excretion in the urine, which is accepted to be a reliable surrogate for the measuring of sodium intake. The sodium content of the "high" and "low" sodium diets were not defined according to the recommendations or the usual sodium intake, but just to describe the relative content of the two randomised study populations.

\section{How the intervention might work}

Extracellular fluid volume (ECFV) is determined by the balance between sodium intake and renal excretion of sodium. A steady state exists whereby sodium intake equals output, while ECFV is expanded during salt loads and shrunken during salt restriction (Palmer 2008). Thus, the idea behind sodium reduction is to shrink ECFV in order to decrease BP. The precondition for this idea is that the smaller ECFV associated with the decrease in BP has no counteracting effects on health outcomes that could outweigh the BP-effect.

\section{Why it is important to do this review}

A verification of the hypothetical sodium-BP relationship would support continuous attempts to lower sodium intake in order to reduce mortality. In this context it is important to define the correct UL for a healthy sodium intake, which would have a significant impact on the strategy to lower sodium intake. For instance if $100 \mathrm{mmol} /$ day is the correct UL, more than $95 \%$ of the World's populations should reduce sodium intake, but if the UL is 250 $\mathrm{mmol} /$ day, only about $5 \%$ should reduce sodium intake. In the latter case, a strategy to lower sodium intake in the general population would not be necessary, which would save significant efforts and costs. The same would be the case if the sodium$B P$ relationship could be denied, as indicated by many RCTs of participants with normal BP (Graudal 2011). Worst case scenario

Effects of low sodium diet versus high sodium diet on blood pressure, renin, aldosterone, catecholamines, cholesterol, and triglyceride 
is that sodium reduction could lead to side effects, which might trump the potential BP effect and result in increased mortality, as indicated by longitudinal observational studies (Alderman 2010, Pfister 2014, O'Donnell 2014, Graudal 2014; Mente 2016). Consequently, it is important to investigate the effect of sodium reduction not only on $\mathrm{BP}$, but also on potential surrogate markers for clinical side effects.

\section{O B J E C T I VES}

The purpose of the present review was to estimate the influence of low- versus high-dietary sodium intake on systolic blood pressure (SBP) and diastolic blood pressure (DBP), and blood concentrations of renin, aldosterone, catecholamines, cholesterol, high-density lipoprotein (HDL), low-density lipoprotein (LDL) and triglyceride to contribute to the evaluation of the possible suitability of sodium reduction as a prophylaxis initiative and treatment of hypertension.

\section{ME T HODS}

\section{Criteria for considering studies for this review}

\section{Types of studies}

Randomised controlled trials (RCTs) allocating participants to diets with different sodium contents, the lowest defined as "low" and the highest defined as "high", and in which the sodium intake was estimated by the 24-hour urinary sodium excretion (either measured on the basis of a 24-hour urine collection, or estimated from a sample of at least eight hours).

\section{Types of participants}

Persons with normal or elevated blood pressure irrespective of race and age were included. Studies systematically investigating unhealthy patients with other diseases than elevated blood pressure, for instance diabetes or heart failure, were excluded.

\section{Types of interventions}

The intervention was a change in sodium intake, the study populations randomly being divided into a group eating a "low" sodium diet or a "high" sodium diet. As "low" and "high" were not specifically defined in relation to the usual intake or the definitions of the health institutions (Table 1 ), both diets could contain any amount of sodium, the assumption being that in most studies a "low" sodium diet would contain sodium within the low range (< $100 \mathrm{mmol}$ )/day or usual range ( $100 \mathrm{mmol}$ to $250 \mathrm{mmol} /$ day) and the "high" sodium diet would contain sodium within the usual range ( $100 \mathrm{mmol}$ to $250 \mathrm{mmol} /$ day) or above the usual range $(\geq 250 \mathrm{mmol} /$ day). Confounding was not allowed, i.e. studies treating persons with a concomitant intervention such as an antihypertensive medication, potassium supplementation or weight reduction were only included if the concomitant intervention was identical during the low and the high-sodium diet.

\section{Types of outcome measures}

Outcome measures were effects on SBP, DBP, renin, aldosterone, adrenaline, noradrenaline, triglyceride, cholesterol, LDL and HDL. In studies reporting BP only as mean arterial pressure (MAP), $\mathrm{SBP}$ was estimated from SBP $=1.3 \mathrm{MAP}+1.4$, and $\mathrm{DBP}$ was estimated from DBP $=0.83 \mathrm{MAP}-0.7$ (Tozawa 2002). Separate metaanalyses were performed for each outcome measure. Concerning blood pressure, participants were stratified according to ethnicity
(Whites, Blacks and Asians) and according to level of blood pressure (hypertension or normotension). Hypertension was defined as SBP $\geq 140 \mathrm{mmHg}$ and/or DBP $\geq 90 \mathrm{mmHg}$. Study populations in which participants were treated with antihypertensive treatment were defined as hypertensive irrespective of baseline BP. In studies that investigated different ethnicities and different BP levels, the first priority was to separate these subgroups. If separate data were not given, the study data would be analysed according to the biggest subgroup. Concerning all other outcome variables, no stratifications were performed.

\section{Primary outcomes}

All outcomes were considered primary outcomes.

\section{Secondary outcomes}

None.

\section{Search methods for identification of studies \\ Electronic searches}

The Cochrane Hypertension Information Specialist conducted systematic searches in the following databases for randomised controlled trials without language, publication year or publication status restrictions:

- the Cochrane Hypertension Specialised Register via the Cochrane Register of Studies (searched 7 March 2016);

- the Cochrane Central Register of Controlled Trials (CENTRAL; 2016, Issue 3) via the Cochrane Register of Studies Online (CRSO) (searched 7 March 2016);

- MEDLINE Ovid (from 1946 onwards), and MEDLINE Ovid InProcess \& Other Non-Indexed Citations (searched 7 March 2016);

- Embase Ovid (searched 7 March 2016);

- ClinicalTrials.gov (www.clinicaltrials.gov) searched 7 March 2016).

The Hypertension Group Specialised Register includes controlled trials from searches of CAB Abstracts \& Global Health, CINAHL, Cochrane Central Register of Controlled Trials, Embase, MEDLINE, ProQuest Dissertations \& Theses, PsycINFO, Web of Science and the WHO International Clinical Trials Registry Platform (ICTRP).

The Information Specialist modelled subject strategies for databases on the search strategy designed for MEDLINE. Where appropriate, they were combined with subject strategy adaptations of the sensitivity and precision-maximising search strategy designed by Cochrane for identifying randomised controlled (as described in the Cochrane Handbook for Systematic Reviews of Interventions Version 5.1.0, Box 6.4.d. (Handbook 2011)). Search strategies for major databases are provided in Appendix 1.

\section{Searching other resources}

- The Cochrane Hypertension Information Specialist searched the Hypertension Specialised Register segment (which includes searches of MEDLINE for systematic reviews) to retrieve existing systematic reviews relevant to this systematic review, so that we could scan their reference lists for additional trials.

- We checked the bibliographies of included studies and any relevant systematic reviews identified for further references to relevant trials.

Effects of low sodium diet versus high sodium diet on blood pressure, renin, aldosterone, catecholamines, cholesterol, and triglyceride 
- Where necessary, we contacted authors of key papers and abstracts to request additional information about their trials.

\section{Searches carried out for previous versions of this review}

Trial search: Parijs and colleagues published the first RCT of the effect of sodium reduction on BP in 1973 (1000 Parijs 1973). In our first meta-analysis (Graudal 1998), a literature search in MEDLINE (1966-through December 1997) was performed using the following combinations of search terms: 1) salt or sodium, 2) restriction or dietary, 3) blood pressure or hypertension, 4) randomized or random. We combined 1, 2, 3 and 4 and found 291 references. Of these, 76 randomised trials from 60 references met the inclusion criteria. From the reference lists of these articles and from four previous meta-analyses (Grobbee 1986, Law 1991, Cutler 1991, Midgley 1996), an additional 23 references reporting on 39 trials were identified, resulting in a total of 83 references.

Similar searches were made for hormones and lipids changing the third search term (blood pressure or hypertension) with the hormone or lipid term resulting in additional five sub-studies dealing with hormones and lipids (Jula-Karanko 1992, JulaMäki 19921026 Koolen 1984(2), 1104 Overlack 1993, Ruppert 1994). Of these 88 references, three dealing exclusively with diabetes patients were excluded in the 2003 update (Dodson 1989, Mühlhauser 1996, Miller 1997).

In January 2002, a repeated search was performed through December 2001, revealing an additional 12 references, of which one was excluded because it only included patients with diabetes (Imanishi 2001). Accordingly, the 2004 updated review included a total of 96 references.

In December 2009, a literature search for the 2011 update was performed from 1950 through December 2009. This search revealed a total of 511 references in Ovid MEDLINE, 282 in Ovid EMBASE and 1428 in Cochrane CENTRAL. Headlines and abstracts were read and 44 articles from MEDLINE (26 included), eight from Embase (one included) and 129 from CENTRAL (45 included) were retrieved as full-text papers for further review. A total of 72 new references investigating at least one of the effect variables met the inclusion criteria for this review. The search was not limited to English language studies. Two studies in Italian were identified and included. During the present revision, we discovered that in a few of the previously included studies, some subgroup data were published in two papers. To avoid duplication due to including subgroup data from several papers, we included them from the main paper only. As a result, three previously included references were excluded (Steegers 1991, Ruppert 1991, Ruppert 1994). The most recent search was performed on July 21, 2011, revealing 293 additional references. After screening of titles and abstracts, four full-text papers were retrieved, of which two contained data to be included. Consequently a total of 167 studies were supposed to be included in the 2011 updated version of this systematic review. However, in connection with the present update, a recount revealed a counting error, as the number of references in reality was 166 .

\section{Data collection and analysis}

\section{Selection of studies}

See Search methods for identification of studies.
Review author NG performed the study selection for the 1998 version (Graudal 1998) and the 2003 version (Jürgens 2003). Review authors NG and GJ independently performed the supplementary study selection for the 2011 version (Graudal 2011. NG and THG independently performed the supplementary study selection for the current 2016 version. Discrepancies were resolved by agreement.

\section{Data extraction and management}

Two authors independently recorded the following data from each trial:

1. the sample size $(\mathrm{N})$;

2. the mean age of participants;

3. the fraction of females, males; Whites, Blacks and Asians;

4. the duration of the intervention;

5. the sodium reduction measured as the difference between 24hour urinary sodium excretion during low-sodium and highsodium diets and standard deviation (SD);

6. SBP (SD) and DBP (SD) before and after intervention;

7. difference between changes in SBP and DBP obtained during low-sodium and high-sodium diets and the SD of these differences;

8. for cross-over studies, when possible, the overall effect estimate and standard error (SE);

9. levels of hormones and lipids in the blood and their standard deviations during low-sodium and high-sodium diets. Concerning lipids, cholesterol units of $\mathrm{mmol} / \mathrm{L}$ were transformed to $\mathrm{mg} / \mathrm{dL}$ by means of the factor 38.6 and triglyceride units of $\mathrm{mmol} / \mathrm{L}$ were transformed to $\mathrm{mg} / \mathrm{dL}$ by means of the factor 88.4 . Other renin units than $\mathrm{ng} / \mathrm{mL} /$ hour were when possible transformed to $\mathrm{ng} / \mathrm{mL} /$ hour, and units of aldosterone, noradrenalin and adrenalin other than $\mathrm{pg} / \mathrm{mL}$ were transformed to $\mathrm{pg} / \mathrm{mL}$ by means of the molecular weights.

If there were discrepancies between review authors they looked at the data together and came to an agreement.

\section{Assessment of risk of bias in included studies}

This was performed using the Cochrane 'Risk of bias' tool, including recording of allocation, blinding, incomplete outcome data and selective reporting. Subgroup analyses of the primary analysis of SBP were performed for contrasting sources of bias appearing from the 'Risk of bias' analysis.

\section{Measures of treatment effect}

This was defined as the mean difference (MD) between the changes from baseline to end of treatment during low- and high-sodium diets. When units within an analysis were different the standardised mean difference (SMD) was used.

\section{Unit of analysis issues}

\section{Blood pressure (BP)}

Combined analyses were performed including both parallel and cross-over studies. The generic inverse variance data type was used to analyse the effect in order to ensure that the weight of the crossover studies was not underestimated compared with the parallel studies. For parallel studies, the SE was calculated in the usual way as follows: $\mathrm{SE}$ (diff) $=$ sqrt $\mathrm{SE}_{1} 2+\mathrm{SE}_{2} 2$. For cross-over studies the

Effects of low sodium diet versus high sodium diet on blood pressure, renin, aldosterone, catecholamines, cholesterol, and triglyceride 11 
given SE (difference) was used. A linear regression equation linking the given $\mathrm{SE}$ to the calculated $\mathrm{SE}$ (sqrt $\mathrm{SE}_{1} 2+\mathrm{SE}_{2}{ }^{2}$ ) was calculated by means of the studies which reported both SE (difference) and SE on BP during both intervention periods. This equation was used to transform all calculated SEs to estimated "true" SEs (difference) in cross-over studies that did not report SE (difference). In this way, it was ensured that cross-over studies were attributed proper weight compared with the parallel studies. There were not enough studies to calculate separate equations for Black and Asian populations and therefore the equations calculated in the white populations were used to transform these SEs when necessary.

\section{Hormones and lipids}

The very few parallel studies were excluded and the large fraction of cross-over studies were analysed separately. As the large majority of cross-over studies reported separate data for each intervention period instead of overall estimates of effect, the continuous data type was used in the separate analyses of the cross-over studies.

\section{Dealing with missing data}

If the SD was not reported it was calculated from a given SE, 95\% confidence interval $(\mathrm{Cl}), \mathrm{P}$ value or $\mathrm{t}$ value, estimated from a figure or imputed from the formula SD (change) $=$ sq root $(S D 1 s q+S D 2 s q)$, SD1 is SD on blood pressure before intervention and SD2 is SD on blood pressure after intervention.

\section{Assessment of heterogeneity}

A Chi ${ }^{2}$ test included in the forest plot was used to assess whether observed differences in results are compatible with chance alone. A low $\mathrm{P}$ value (or a large $\mathrm{Chi}^{2}$ statistic relative to its degree of freedom) provides evidence of heterogeneity of intervention effects (variation in effect estimates beyond chance).

\section{Assessment of reporting biases}

Funnel plots were assessed for asymmetry. Selective reporting of SBP and DBP was recorded

\section{Data synthesis}

Individual study subgroup data defined before randomisation based on ethnicity and state of hypertension were included in the meta-analysis as subgroups, whereas sodium sensitivity subgroups, which were defined by the authors of the individual studies after they had analysed the data, were combined by the present authors and subsequently the combined data were included in the meta-analyses.

The mean difference (MD) was calculated for outcome measures with identical units in the included studies (BP without transformation of data (all measured as $\mathrm{mmHg}$ ), adrenaline, aldosterone, noradrenalin and lipids, after transformation). The standardised mean difference (SMD) was calculated for outcome measures with different units (renin), but a separate calculation of MD for the majority of renin studies with identical unit ( $\mathrm{ng} / \mathrm{mL} /$ hour) was also performed. With the MD method, the difference in effect between two treatments is divided by the SD of the measurements. By that transformation, the effect measures become dimensionless and the outcomes from trials, which have used different units, can consequently be combined. As we accumulated data from a series of studies that had been performed by researchers operating independently, and as the goal of the analysis was to extrapolate to other populations, we used a random-effects model in our primary analysis to estimate the summary measure as the mean of a distribution of effects.

Level of significance: In case of multiple independent comparisons, it is important to avoid coincidental significance. Ten metaanalyses were performed. However, the SBP and DBP comparisons are not independent of each other and BP depends on renin and aldosterone as well as catecholamines. Concerning lipids, these are mutually dependent, whereas the dependency on BP and hormones is not obvious. Consequently, the 10 meta-analyses could be sub-classified into a group of meta-analyses of mutually dependent BP and hormones and an independent group of metaanalyses of mutually dependent lipid fractions. Consequently, the level of significance was reduced by means of the formula 1-0.95 $\times 1$ / $\mathrm{N}=1-0.95 \times 1 / 2=0.025,(\mathrm{~N}=$ number of independent investigations $=2$ ).

\section{Subgroup analysis and investigation of heterogeneity}

Since the previous version of this review, we now have reasonable evidence to determine the time of maximal efficacy to be one week (Table 2). Therfore, there is a risk that studies lasting for less than one week may underestimate the effect of sodium reduction. Furthermore, evidence has appeared to indicate that all of the world's populations have a mean sodium intake below $250 \mathrm{mmol} /$ day (Table 1), and as dose-response studies have indicated that sodium reductions from very high levels have bigger effects than reductions from usual levels (Graudal 2015), such studies may contribute to overestimate the effect. We therefore performed a subgroup analysis intending to eliminate these potential biases on SBP and DBP (stratified according to normal BP or hypertension) and renin, aldosterone, noradrenalin, adrenalin, cholesterol triglyceride, HDL and LDL by exclusion of studies with a duration of less than seven days and sodium intake above 250 $\mathrm{mmol} / \mathrm{day}$.

Sources of bias: subgroup analyses were performed for contrasting sources of bias appearing from the 'Risk of bias' analysis.

\section{Sensitivity analysis}

Sensitivity analyses were performed excluding studies giving rise to asymmetry in the funnel plots.

\section{RES U L T S}

\section{Description of studies}

\section{Results of the search}

During this 2016 update, we identified two studies with duplicate data, which were subsequently excluded (Jula-Karanko 1992; JulaMäki 1992), as all data could be extracted from a later paper (1110 Jula 1994).

In September 2014, a literature search for the present update was performed as described in "Search methods for identification of studies". The de-duplicated results from the searches revealed 626 articles. On the basis of titles, 549 were excluded. Seventy-seven abstracts were read and 27 full-text articles obtained, of which, nine fulfilled the inclusion criteria. In a supplementary search in April 15 2015, an additional 102 references were identified. Six articles were obtained, of which three fulfilled the inclusion criteria.The last updated search was performed on 7 March 2016. The de-

Effects of low sodium diet versus high sodium diet on blood pressure, renin, aldosterone, catecholamines, cholesterol, and triglyceride 
duplicated results from the searches revealed 994 articles. During the primary screening, 687 were excluded and on the basis of titles and abstracts, a further 236 articles were eliminated. Seventy-one abstracts were read in detail and 29 full-text articles obtained, of which, seven fulfilled the inclusion criteria. Additionally, two articles were identified from a reference list of a review article. A WHO International Clinical Trials Registry Platform search using the search term "diet and sodium" revealed 141 trials, but none were included.

A total of 185 references (164 from the 2011 review plus $9+3+9$ new references) were thus included in the present updated 2016 version.

\section{Included studies}

See Characteristics of included studies.

One hundred and eighty-five references were included in the review. Eight included only data on hormones and lipids, whereas 177 included BP data, as well as hormone and lipid data in a significant number of these. The total number of study populations with BP outcomes included in the primary analysis was 206. The median of the mean ages was 44 years (range: 12 to 73), which is a little higher than the median age of most populations (typically 35 years) and the mean sodium intake in the high-sodium group was $201 \mathrm{mmol} /$ day (SD: 69) and in the low-sodium group was 66 $\mathrm{mmol} /$ day (SD: 47), corresponding to a mean sodium reduction of $135 \mathrm{mmol} /$ day.The median of the mean ages of the study's
125 white populations included in the subgroup analysis (duration of at least seven days, a sodium intake of less than $250 \mathrm{mmol} /$ day) was 45.4 years (range: 13 to 73 ) the mean sodium intake in the high-sodium group was $177 \mathrm{mmol} /$ day (SD: 35) and in the low-sodium group was $68 \mathrm{mmol} / \mathrm{day}$ (SD: 36), corresponding to a mean sodium reduction of $109 \mathrm{mmol} / \mathrm{day}$. The mean BP in the normotensive study populations was $119 / 71 \mathrm{mmHg}$, which is close to the population mean of the USA population $(119 / 71 \mathrm{mmHg})$ (Wright 2011), and a little higher than the mean of the normotensive fraction of the USA population $(115 / 70 \mathrm{mmHg}$ ) (Wright 2011). The mean BP in the untreated hypertensive study populations was $151 / 93 \mathrm{mmHg}$ and in the treated hypertensive study populations was $144 / 88 \mathrm{mmHg}$, both of which are higher than corresponding pressures in the USA population $(146 / 84 \mathrm{mmHg}$ and $131 / 72 \mathrm{mmHg}$ ) (Wright 2011).

In 83 studies including 7729 participants, there was information of the baseline 24-hour sodium excretion, not influenced by diets. This was $159 \mathrm{mmol} / 24$-hour (range: $90-274 \mathrm{mmol}$ ) (10-90 percentiles: 123-194 mmol).

\section{Excluded studies}

See Characteristics of excluded studies.

\section{Risk of bias in included studies}

See Characteristics of included studies and Figure 1

Figure 1. 'Risk of bias' graph: review authors' judgements about each risk of bias item presented as percentages across all included studies.



The obligatory trial quality criterion was randomisation. Doubleblind, single-blind or open studies with a parallel or a cross-over design were accepted. A study was defined as single-blind if an investigator measured BP without knowledge of the diet or by a computerised manometer, and as open if precautions to decrease observer bias were not mentioned.

We found two important contrasts: general blinding and blinding of outcome detection (Figure 1). We performed subgroup analyses of $\mathrm{BP}$ in both normotensive and hypertensive white populations, but not in the black and Asian populations due to the small numbers of trials. We did not perform subgroup analyses on the biochemical outcomes (hormones and lipids) as they are supposed to be performed blindly in $100 \%$ of cases.

\section{Allocation}

Only 14 studies (1034 Watt 1985; 1078 Egan 1991; 1081 TOHP I 1992; 1107 MacFadyen 1994;1135 TOHP II 1997; 1136 van Buul 1997;1142 Knuist 1998; 1195 Jessani 2008; 1197 Dickinson 2009; $1198 \mathrm{He}$ 2009; 1206 Graffe 2012; 1208 Todd 2012; 1217 Markota 2015; 1225 Gijsbers 2015), either partly or sufficiently explained the allocation

Effects of low sodium diet versus high sodium diet on blood pressure, renin, aldosterone, catecholamines, cholesterol, and triglyceride 
sequence generation and concealment. Consequently, there is a general significant risk that allocation was not unbiased.

\section{Blinding}

Fifty-six studies were reported to be double-blind and in 115 studies, the risk of detection bias was estimated to be low (Figure 1). Separate analyses were performed on studies with low and high risks of general blinding and outcome detection.

\section{Incomplete outcome data}

Based on the information given in the individual articles, incomplete outcome data generally was a small problem (Figure 1). However, only a few studies showed flow charts of the fate of the participants. Therefore, this bias may be significant.

\section{Selective reporting}

Based on the information given in the individual articles, reporting bias was small (Figure 1). However, as protocols did not exist for the vast majority of studies, this evaluation may be imprecise.

\section{Other potential sources of bias}

The effect of an intervention on BP may depend on factors such as baseline BP and ethnicity. Therefore, a biased distribution of such factors in the included study populations compared with the general population may bias the effect of the intervention found in the meta-analysis to be different from the potential effect in the general population. We therefore performed separate analyses for hypertensive and normotensive individuals and for different ethnicities.

\section{Effects of interventions}

See: Summary of findings for the main comparison; Summary of findings 2; Summary of findings 3; Summary of findings 4; Summary of findings 5

See Data and analyses.

\section{Blood pressure in white participants}

See Summary of findings for the main comparison

In the meta-analyses of trials of white participants with normal blood pressure (BP), the mean difference (MD) was a change in systolic blood pressure (SBP) of $-1.09 \mathrm{mmHg}(95 \% \mathrm{Cl}:-1.63$ to -0.56$)$ $(\mathrm{P}=0.0001)$ (89 trials, 8569 trials) (Analysis 1.1; Figure 2), and in diastolic blood pressure (DBP) of $+0.03 \mathrm{mmHg}(95 \% \mathrm{Cl}:-0.37$ to $0.43)(P=0.89)$ (90 trials, (8833 participants) (Analysis 1.2; Figure 3 ) (high-quality evidence). 
Figure 2. Forest plot of comparison: 1 Effect of salt reduction on systolic blood pressure (SBP) and diastolic blood pressure (DBP) in whites, outcome: 1.2 Whites, normotensive, SBP.

\begin{tabular}{|c|c|c|c|}
\hline Study or Subgroup & $\begin{array}{l}\text { Mean Difference } \\
\text { IV, Random, } 95 \% \mathrm{CI}\end{array}$ & $\begin{array}{l}\text { Mean } \\
\text { IV, Rand }\end{array}$ & $\begin{array}{l}\text { fference } \\
\mathrm{m}, 95 \% \mathrm{Cl}\end{array}$ \\
\hline 1003 Sullivan 1980 & $6.90[4.21,9.59]$ & & \\
\hline 1005 Rankin 1981 & $-3.00[-14.96,8.96]$ & $\longleftarrow$ & \\
\hline 1006 Skrabal 1981 & $-2.70[-6.76,1.36]$ & & \\
\hline 1010 Myers 1982 & $-3.30[-5.06,-1.54]$ &  & \\
\hline 1013 Puska 1983 & $-1.50[-10.36,7.36]$ & $\longleftarrow$ & \\
\hline 1019 Cooper 1984 & $-0.60[-1.97,0.77]$ & & - \\
\hline 1021 Skrabal 1984 & $-3.14[-11.76,5.48]$ & $\longleftarrow$ & \\
\hline 1031 Tuthill 1985 & $0.00[-2.20,2.20]$ & & \\
\hline 1032 Skrabal 1985 & $-3.10[-7.41,1.21]$ & & - \\
\hline 1034 Watt 1985 & $-1.00[-1.98,-0.02]$ & & \\
\hline 1036 Richards 1986 & $-2.00[-5.51,1.51]$ & & \\
\hline 1037 Teow 1986 & $-0.60[-2.85,1.65]$ & & \\
\hline $1040 \mathrm{El} \mathrm{Ashry} 1987$ & $0.00[-2.55,2.55]$ & & \\
\hline 1042 Fuchs 1987 & $-3.60[-7.91,0.71]$ & & - \\
\hline 1048 Lawton 1988 & $-1.70[-4.25,0.85]$ & & - \\
\hline 1053 Sudhir 1989 & $-7.90[-14.56,-1.24]$ & $\longleftarrow$ & \\
\hline 1054 Hargreaves 1989 & $-6.00[-10.37,-1.63]$ & & \\
\hline 1057 Dimsdale 1990 w & $1.40[-1.74,4.54]$ & & \\
\hline 1061 Schmid 1990 & $-3.00[-6.72,0.72]$ & & - \\
\hline 1063 HPTRG 1990 & $0.10[-1.84,2.04]$ & & \\
\hline 1064 Bruun 1990 & $-5.00[-8.37,-1.63]$ & & \\
\hline 1066 Sharma 1990 & $-0.90[-4.72,2.92]$ & & \\
\hline 1067 Sharma 1990,2 & $-2.10[-4.30,0.10]$ & & \\
\hline 1068 Friberg 1990 & $0.00[-3.92,3.92]$ & & \\
\hline 1073 Sharma 1991 & $-4.50[-6.34,-2.66]$ & & \\
\hline 1074 Howe 1991 & $-1.00[-2.33,0.33]$ & & - \\
\hline 1075 Mascioli 1991 & $-3.60[-5.36,-1.84]$ & & \\
\hline 1078 Egan 1991 & $1.00[-1.74,3.74]$ & & \\
\hline 1079 Gow 1992 & $-8.00[-11.16,-4.84]$ & $\longleftarrow$ & \\
\hline 1080 Huggins 1992 & $-1.00[-3.37,1.37]$ & & \\
\hline 1081 TOHP । 1992 & $-1.70[-2.86,-0.54]$ & & \\
\hline 1082 Cobiac 1992 & $-2.80[-5.94,0.34]$ & & - \\
\hline 1088 Ruppert 1993 & $-2.20[-3.49,-0.91]$ & & \\
\hline 1091 Burnier 1993 & $-1.00[-2.96,0.96]$ & & - \\
\hline 1093 Sharma 1993 & $-1.40[-3.22,0.42]$ & & 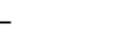 \\
\hline 1095 Fliser 1993 & $-1.30[-8.16,5.56]$ & & \\
\hline 1097 Nestel 1993 & $-3.24[-8.53,2.05]$ & & \\
\hline 1099 Donovan 1993 & $-2.00[-5.35,1.35]$ & & \\
\hline 1107 MacFadyen 1994 & $7.00[2.75,11.25]$ & & \\
\hline 1113 Miller 1995 & $1.90[-1.24,5.04]$ & & \\
\hline 1114 Fliser 1995 & $-1.10[-6.78,4.58]$ & & \\
\hline 1115 Doig 1995 & $-2.30[-4.34,-0.26]$ & & \\
\hline 1116 Stein 1995 & $1.40[-2.64,5.44]$ & & \\
\hline 1125 Grey 1996 & $1.00[-1.27,3.27]$ & & \\
\hline 1126 Feldman 1996 & $6.50[2.97,10.03]$ & & \\
\hline 1128 Schorr 1996 & $-1.00[-6.29,4.29]$ & & \\
\hline 1135 TOHP || 1997 & $-1.00[-2.02,0.02]$ & & \\
\hline 1136 van Buul 1997 & $0.00[-3.53,3.53]$ & & \\
\hline 1137 Schorr 1997 & $0.80[-0.45,2.05]$ & & \\
\hline 1143 Bech 1998 & $-1.30[-8.55,5.95]$ & & \\
\hline 1144 Foo 1998 & $-7.70[-13.31,-2.09]$ & & \\
\hline 1147 Feldman 1999 & $0.00[-10.78,10.78]$ & $\longleftarrow$ & \\
\hline 1148 Damasceno 1999 & $0.50[-8.91,9.91]$ & & \\
\hline 1149 Davrath 1999 & $8.00[5.80,10.20]$ & & \\
\hline 1150 Schorr 1999 & $-0.20[-0.91,0.51]$ & & - \\
\hline 1152 Chiolero 2000 & $0.00[-6.08,6.08]$ & & \\
\hline 1153 Bruun 2000 & $0.00[-2.39,2.39]$ & & \\
\hline 1154 Burnier 2000 & $-1.00[-3.23,1.23]$ & & \\
\hline 1155 Heer 2000 & $1.00[-6.80,8.80]$ & & \\
\hline 1156 Barba 2000 & $-3.20[-13.98,7.58]$ & $\longleftarrow$ & \\
\hline 1160 DASH 2001 'w & $-4.00[-6.35,-1.65]$ & & \\
\hline 1174 Kleij 2002 & $0.20[-6.27,6.67]$ & & \\
\hline 1175 Karrtane 3 Sח & 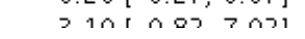 & & \\
\hline
\end{tabular}

Effects of low sodium diet versus high sodium diet on blood pressure, renin, aldosterone, catecholamines, cholesterol, and triglyceride 


\section{Figure 2. (Continued)}

110 U UASH $\angle U U \perp$ W 1174 Kleij 2002

1175 Kerstens 2003

1176 Dishy 2003

1177 Nowson 2003

1178 Perry 2003

1180 Palacios 2004

1185 Zanchi 2004

1194 Tzemos 2008

1195 Jessani 2008

1196 Paulsen 2009

1197 Dickinson 2009

1201 Nowson 2009

1203 Starmans-Kool 2011

1204 Carey 2012

1206 Graffe 2012

1207 Krikken 2012

1208 Todd 2012

1209 Bonfils 2013

1212 Mak 2013

1214 Dickinson 2014

1215 Allen 2014

1218 Visser 2008

1219 Sharma 31993

1221 Facchini 1999

1222 Pechere-Bertschi 2000

1223 Pechère-Bertschi 2003

$1224 \mathrm{Ho} 2007$

1226 Cavka 2015

\section{Total $(95 \% \mathrm{Cl})$}

Heterogeneity. $\mathrm{Tau}^{2}=3.56 ; \mathrm{Chi}^{2}=297.87, \mathrm{df}=88(\mathrm{P}<0.00001) ; \mathrm{I}^{2}=70 \%$ Test for overall effect: $Z=3.99$ ( $P<0.0001)$
-4 un $1-0.53,-1.021$

$0.20[-6.27,6.67]$

$3.10[-0.82,7.02]$

$2.00[0.04,3.96]$

$0.40[-1.17,1.97]$

$0.00[-3.43,3.43]$

$-0.10[-3.04,2.84]$

$-4.00[-7.12,-0.88]$

$-1.00[-2.51,0.51]$

$-1.00[-3.29,1.29]$

$-5.00[-7.86,-2.14]$

$-1.10[-4.92,2.72]$

$-2.00[-8.70,4.70]$

$-4.10[-6.84,-1.36]$

$2.00[-3.49,7.49]$

$-1.30[-3.65,1.05]$

$-0.10[-7.35,7.15]$

$-1.50[-9.93,6.93]$

$1.00[-3.31,5.31]$

$-2.00[-8.47,4.47]$

$-1.00[-4.72,2.72]$

$-5.00[-10.15,0.15]$

$-4.00[-7.53,-0.47]$

$-0.30[-8.34,7.74]$

$-2.40[-5.54,0.74]$

$-1.00[-6.10,4.10]$

$-5.00[-11.68,1.68]$

-1.09 [-1.63, -0.56]
$-3.00[-11.25,5.25]$

$-5.00[-7.74,-2.26]$

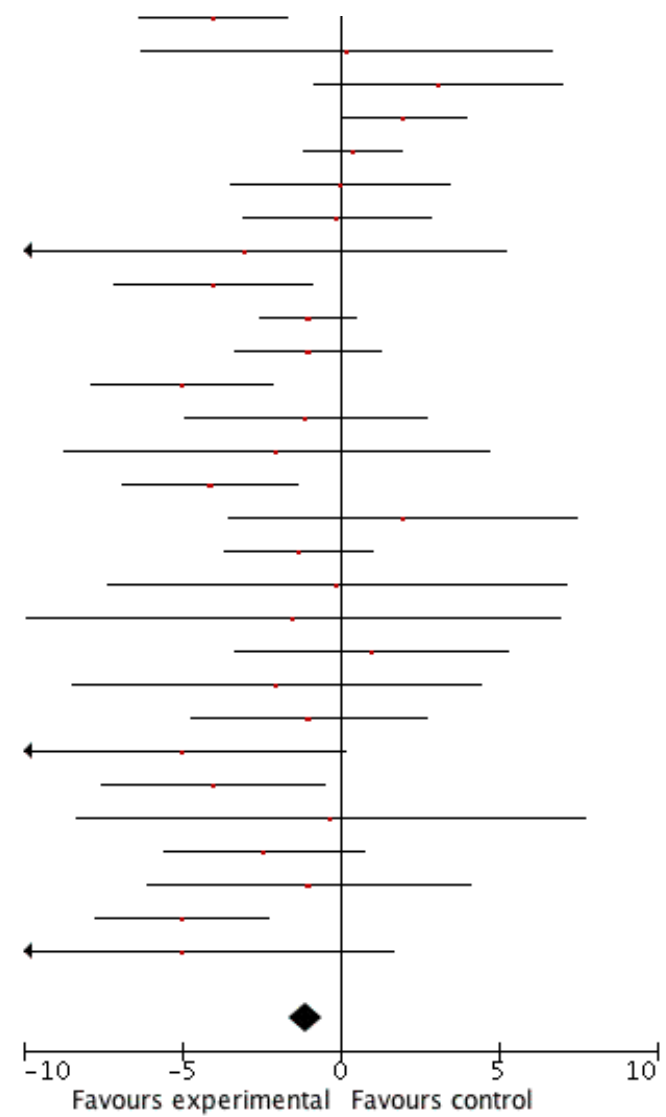


Figure 3. Forest plot of comparison: 1 Effect of salt reduction on systolic blood pressure (SBP) and diastolic blood pressure (DBP) in whites, outcome: 1.2 Whites, normotensive, DBP.

\begin{tabular}{|c|c|c|c|}
\hline Study or Subgroup & $\begin{array}{l}\text { Mean Difference } \\
\text { IV, Random, 95\% CI }\end{array}$ & $\begin{array}{r}\text { Mean D } \\
\text { IV, Rando }\end{array}$ & $\begin{array}{l}\text { fference } \\
\mathrm{m}, 95 \% \mathrm{CI}\end{array}$ \\
\hline 1003 Sullivan 1980 & $1.10[-1.59,3.79]$ & & \\
\hline 1005 Rankin 1981 & $-1.90[-9.54,5.74]$ & & \\
\hline 1006 Skrabal 1981 & $-3.00[-5.86,-0.14]$ & & \\
\hline 1010 Myers 1982 & $-2.70[-4.27,-1.13]$ & & \\
\hline 1013 Puska 1983 & $-2.10[-7.53,3.33]$ & & \\
\hline 1019 Cooper 1984 & $-1.40[-3.36,0.56]$ & & - \\
\hline 1021 Skrabal 1984 & $-1.85[-7.02,3.32]$ & & \\
\hline 1031 Tuthill 1985 & $0.00[-2.61,2.61]$ & & \\
\hline 1032 Skrabal 1985 & $-1.50[-3.26,0.26]$ & & \\
\hline 1034 watt 1985 & $1.30[0.12,2.48]$ & & \\
\hline 1036 Richards 1986 & $7.00[3.82,10.18]$ & & \\
\hline 1037 Teow 1986 & $-2.70[-5.46,0.06]$ & & \\
\hline 1040 El Ashry 1987 & $-2.60[-5.74,0.54]$ & & 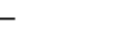 \\
\hline 1042 Fuchs 1987 & $1.90[-0.06,3.86]$ & & \\
\hline 1048 Lawton 1988 & $2.33[0.08,4.58]$ & & \\
\hline 1053 Sudhir 1989 & $-5.00[-9.12,-0.88]$ & & \\
\hline 1054 Hargreaves 1989 & $-3.00[-6.88,0.88]$ & & - \\
\hline 1057 Dimsdale 1990 w & $4.10[1.94,6.26]$ & & \\
\hline 1061 Schmid 1990 & $3.00[-0.19,6.19]$ & & \\
\hline 1063 HPTRG 1990 & $0.20[-1.19,1.59]$ & & \\
\hline 1064 Bruun 1990 & $-1.00[-4.98,2.98]$ & & \\
\hline 1066 Sharma 1990 & $-3.70[-7.25,-0.15]$ & & \\
\hline 1067 Sharma 1990,2 & $-3.10[-5.14,-1.06]$ & & \\
\hline 1068 Friberg 1990 & $-1.00[-4.92,2.92]$ & & \\
\hline 1073 Sharma 1991 & $-2.20[-4.34,-0.06]$ & & \\
\hline 1074 Howe 1991 & $-0.56[-1.95,0.83]$ & & 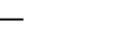 \\
\hline 1075 Mascioli 1991 & $-2.30[-3.87,-0.73]$ & & \\
\hline 1078 Egan 1991 & $0.60[-2.14,3.34]$ & & \\
\hline 1079 Gow 1992 & $-3.00[-7.35,1.35]$ & & \\
\hline 1080 Huggins 1992 & $-2.00[-5.74,1.74]$ & & \\
\hline 1081 TOHP । 1992 & $-0.80[-1.62,0.02]$ & & \\
\hline 1082 Cobiac 1992 & $-1.00[-4.53,2.53]$ & & \\
\hline 1088 Ruppert 1993 & $1.00[-0.20,2.20]$ & & \\
\hline 1091 Burnier 1993 & $0.80[-1.36,2.96]$ & & \\
\hline 1093 Sharma 1993 & $-0.50[-2.89,1.89]$ & & \\
\hline 1095 Fliser 1993 & $-0.90[-5.21,3.41]$ & & \\
\hline 1097 Nestel 1993 & $-1.37[-5.29,2.55]$ & & \\
\hline 1099 Donovan 1993 & $1.00[-1.63,3.63]$ & & \\
\hline 1107 MacFadyen 1994 & $10.00[5.75,14.25]$ & & \\
\hline 1113 Miller 1995 & $-0.10[-2.98,2.78]$ & & \\
\hline 1114 Fliser 1995 & $-0.70[-4.23,2.83]$ & & \\
\hline 1115 Doig 1995 & $0.00[-2.61,2.61]$ & & \\
\hline 1116 Stein 1995 & $-1.20[-4.90,2.50]$ & & \\
\hline 1125 Grey 1996 & $1.00[-0.71,2.71]$ & & \\
\hline 1126 Feldman 1996 & $4.20[1.99,6.41]$ & & \\
\hline 1128 Schorr 1996 & $0.00[-3.39,3.39]$ & & \\
\hline 1135 TOHP || 1997 & $-0.50[-1.28,0.28]$ & & - \\
\hline 1136 van Buul 1997 & $0.00[-2.27,2.27]$ & & \\
\hline 1137 Schorr 1997 & $0.40[-0.85,1.65]$ & & \\
\hline 1142 Knuist 1998 & $0.00[-2.27,2.27]$ & & \\
\hline 1143 Bech 1998 & $-0.80[-5.31,3.71]$ & & \\
\hline 1144 Foo 1998 & $2.40[-0.64,5.44]$ & & \\
\hline 1147 Feldman 1999 & $0.00[-7.06,7.06]$ & & \\
\hline 1148 Damasceno 1999 & $0.30[-5.78,6.38]$ & & \\
\hline 1149 Davrath 1999 & $5.00[2.12,7.88]$ & & \\
\hline 1150 Schorr 1999 & $0.30[-0.41,1.01]$ & & $\leftarrow$ \\
\hline 1152 Chiolero 2000 & $0.00[-3.92,3.92]$ & & \\
\hline 1153 Bruun 2000 & $1.00[-1.21,3.21]$ & & \\
\hline 1154 Burnier 2000 & $5.00[2.77,7.23]$ & & \\
\hline 1155 Heer 2000 & $-1.00[-7.61,5.61]$ & & \\
\hline 1156 Barba 2000 & $-2.10[-8.96,4.76]$ & & \\
\hline $1160 \mathrm{DASH} 2001 \mathrm{~W}$ & $-1.40[-2.97,0.17]$ & & \\
\hline 1174 Vlnii $3 \cap 03$ & 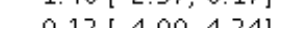 & & \\
\hline
\end{tabular}


Figure 3. (Continued)

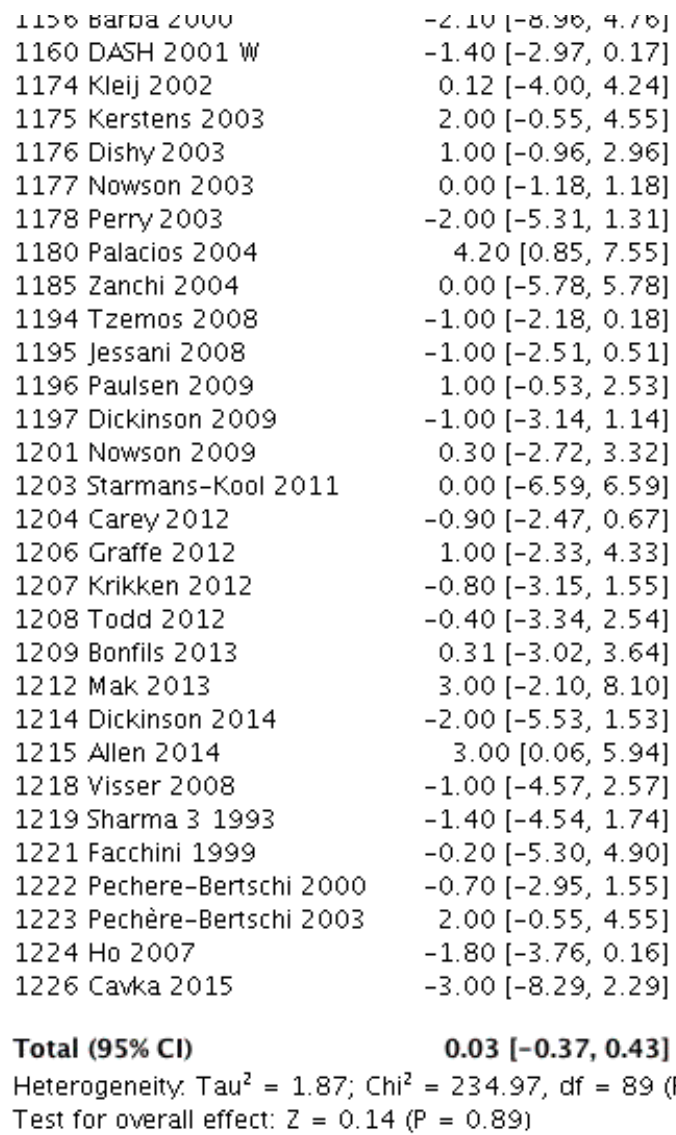

Total $(95 \% \mathrm{Cl})$

$0.03[-0.37,0.43]$

Test for overall effect: $z=0.14(\mathrm{P}=0.89$

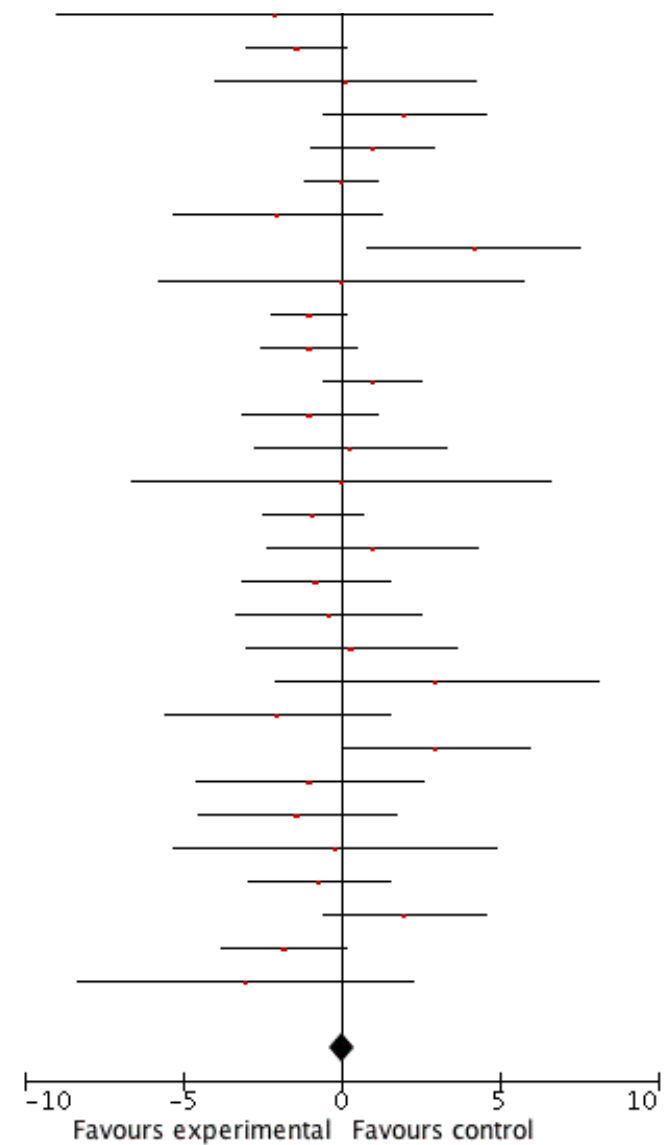

In subgroup meta-analyses of trials with a duration of at least one week and a sodium intake of a maximal $250 \mathrm{mmol} /$ day, the MD showed a decrease in SBP of $-1.31 \mathrm{mmHg}(-1.83$ to -0.80$)(\mathrm{P}=$ $0.00001)$ (59 trials, 7125 participants) (Analysis 4.1) and in DBP of $-0.36 \mathrm{mmHg}(95 \% \mathrm{Cl}:-0.79,0.07)(P=0.10)(61$ trials) (Analysis 4.2). A further elimination of five studies, which, although the mean BP was normal, did include individuals with hypertension, reduced the SBP/DBP effect to $-1.08 /-0.24 \mathrm{mmHg}$.

In the trials of white people with elevated BP, MD showed a decrease in SBP of $-5.51 \mathrm{mmHg}(95 \% \mathrm{Cl}:-6.45$ to -4.57$)(\mathrm{P}<0.00001)$ (84 trials, 5925 participants) (Analysis 1.3), and in DBP of $-2.88 \mathrm{~mm} \mathrm{Hg}(95 \% \mathrm{Cl}$ : -3.44 to -2.32$)(\mathrm{P}<0.00001)$ (85 trials, 6001 participants) (Analysis 1.4) (high-quality evidence).

In subgroup meta-analyses of trials with a duration of at least one week and a sodium intake of a maximal $250 \mathrm{mmol} /$ day, MD showed a decrease in SBP of $-5.02 \mathrm{mmHg}(-6.00$ to -4.05$)(P<0.00001)(63$ trials) ( Analysis 4.3) and in DBP of $-2.78 \mathrm{mmHg}(95 \% \mathrm{Cl}:-3.42$ to -2.14) $(P<0.00001)(64$ trials ) (Analysis 4.4).

\section{Blood pressure in black participants}

See Summary of findings 2

In the meta-analyses of seven trials involving 506 black participants with normal BP, MD showed a decrease in SBP of $-4.02 \mathrm{mmHg}$ (95\% Cl:-7.37 to -0.68$)(P=0.02)$ (Analysis 2.1) and in DBP of -2.01
mmHg (95\% Cl:-4.37, 0.35) ( $\mathrm{P}=0.09)$ (Analysis 2.2) (moderatequality evidence).

In the meta-analyses of eight trials of 619 black participants with elevated BP, MD showed a decrease in SBP of $-6.64 \mathrm{mmHg}(95 \%$ Cl:-9.00, -4.27)

$(\mathrm{P}=0.00001)$ (Analysis 2.3) and in DBP of $-2.91 \mathrm{mmHg}(95 \% \mathrm{Cl}:-4.52$, $-1.30)(P=0.0004)$ (Analysis 2.4) (moderate-quality evidence).

\section{Blood pressure in Asian participants}

\section{See Summary of findings 3}

In the meta-analyses of three trials involving 393 Asian participants with normal BP, MD showed a decrease in SBP of $-0.72 \mathrm{mmHg}(95 \%$ $\mathrm{Cl}:-3.86,2.41)(\mathrm{P}=0.65)$ (Analysis 3.1 ) and in DBP of $-1.63 \mathrm{mmHg}$ (95\% Cl:-3.35 to 0.08$)(\mathrm{P}=0.06)$ (Analysis 3.2) (moderate-quality evidence).

In the meta-analyses of nine trials involving 501 Asian participants with elevated BP, MD showed a decrease in SBP of of $-7.75 \mathrm{mmHg}$ (95\% Cl:-11.44, -4.07) $(\mathrm{P}<0.0001)$ (Analysis 3.3) and in DBP of -2.68 $\mathrm{mmHg}(95 \% \mathrm{Cl}:-4.21$ to -1.15$)(\mathrm{P}=0.0006)$ (Analysis 3.4$)$ (moderatequality evidence).

\section{Renin}

See Summary of findings 4 
Two parallel trials were excluded (1110 Jula 1994; 1155 Heer 2000).

In the remaining 82 cross-over trials (5498 participants) of measurement of renin (including 88 comparisons reported in the Data \& analyses), the standardised mean difference (SMD) of sodium reduction was 1.22 standardized units ( $95 \% \mathrm{Cl}: 1.07$ to 1.37$)$ $(\mathrm{Z}=15.68, \mathrm{P}<0.00001$ ) (Analysis 5.1 ) (high-quality evidence). In 73 comparisons, which all had the same unit $(\mathrm{ng} / \mathrm{mL} / \mathrm{hour})$, either directly or after transformation, the MD was $1.60 \mathrm{ng} / \mathrm{mL} /$ hour $(95 \%$ $\mathrm{Cl}: 1.40$ to 1.79$)(\mathrm{Z}=16.04, \mathrm{P}<0.00001)$.

In comparisons with a duration of at least seven days and a sodium intake of less than $250 \mathrm{mmol} /$ day (44 trials, 3470 participants), the SMD was 1.05 standardized units ( $95 \% \mathrm{Cl}: 0.85$ to 1.24$),(\mathrm{Z}=$ $10.35, \mathrm{P}<0.00001$ ) (Analysis 6.1) In 39 comparisons using $\mathrm{ng} /$ $\mathrm{mL} /$ hour as the unit, the corresponding MD was $1.30 \mathrm{ng} / \mathrm{mL} /$ hour (95\% Cl: 1.06 to 1.53$),(Z=10.65, P<0.00001)$. The effect in normotensive participants was significantly higher than in hypertensive participants (Summary of findings 4).

\section{Aldosterone}

See Summary of findings 4

Three parallel trials were excluded (1110 Jula 1994; 1111 Howe 1994; 1155 Heer 2000).

In the remaining 65 cross-over trials (4884 participants) of measurement of aldosterone, MD was $97.81 \mathrm{pg} / \mathrm{mL}(95 \% \mathrm{Cl}: 82.56$ to 113.05$)(Z=12.58, P<0.00001$ ) (Figure 4 , Analysis 5.2) (highquality evidence). In comparisons with duration of at least one week and sodium intake of less than $250 \mathrm{mmol} /$ day (34 trials, 3128 participants), $\mathrm{MD}$ was $95.59 \mathrm{pg} / \mathrm{mL}$ ( $95 \% \mathrm{Cl}: 74.12$ to 117.05 ), $\mathrm{P}=$ 0.00001 (Analysis 6.2).The effect in normotensive participants was significantly higher than in hypertensive participants (Summary of findings 4). 
Figure 4. Forest plot of comparison: 5 Effect of salt reduction on hormones, outcome: 5.2 Aldosterone (pg/mL).

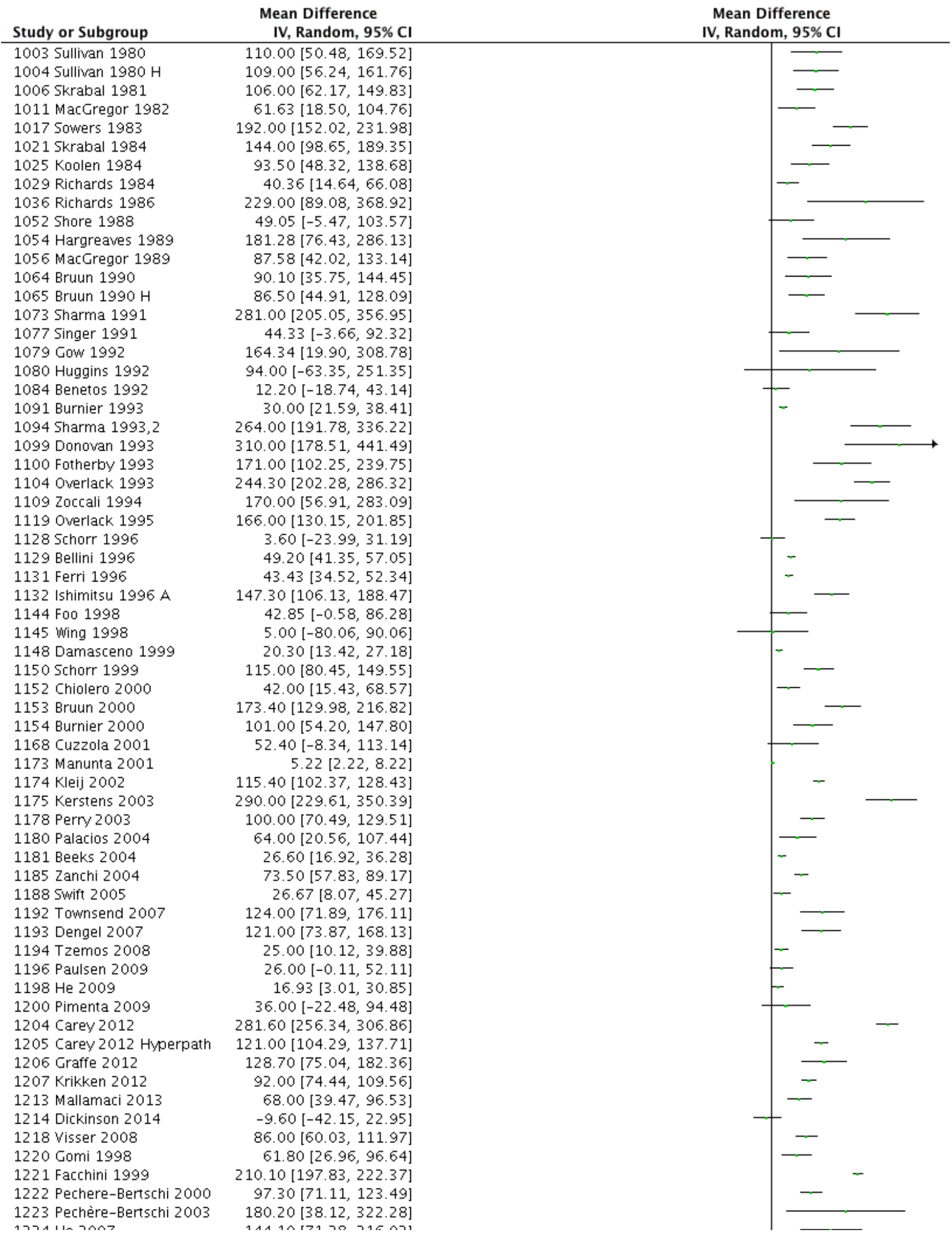


Figure 4. (Continued)

\author{
$1 \angle \angle \angle$ recnere-bertscnı $\angle$ UNo \\ 1223 Pechère-Bertschi 2003 \\ $1224 \mathrm{Ho}_{2007}$ \\ 1227 McManus 2015 \\ Total $(95 \% \mathrm{Cl})$ \\ Heterogeneity. $\mathrm{Tau}^{2}=3298.06 ; \mathrm{Chi}^{2}=2587.63,0$
Test for overall effect: $\mathrm{Z}=12.58(\mathrm{P}<0.00001)$ \\ y/.s0 [/1.11, 125.49] \\ $180.20[38.12,322.28]$ \\ $144.10[71.28,216.92]$ \\ $18.00[-2.01,38.01]$ \\ 97.81 [82.56, 113.05]
}

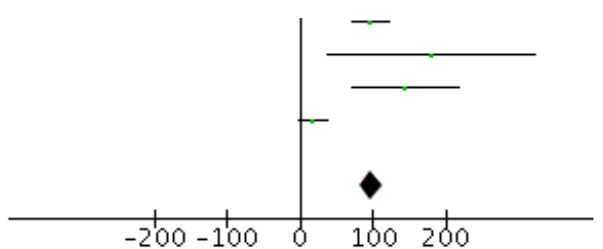

Fav. salt reduction Fav. salt intake

\section{Noradrenaline}

See Summary of findings 4

One parallel trial was excluded (1110 Jula 1994).

In the remaining 34 cross-over trials (1736 participants) of measurement of noradrenaline (including 36 comparisons reported in the Data \& analyses), MD was $63.56 \mathrm{pg} / \mathrm{mL}(95 \% \mathrm{Cl}$ :
42.66 to 84.46), $(z=5.96, P=0.00001)$ (Figure 5, Analysis 5.3) (high-quality evidence). In comparisons with duration of at least one week and a sodium intake of less than $250 \mathrm{mmol} /$ day $(23$ studies, 964 participants) MD was $48.66 \mathrm{pg} / \mathrm{mL}(95 \% \mathrm{Cl}: 28.88$ to 68.44), $\mathrm{P}=0.00001$ (Analysis 6.3). There was no difference between normotensive participants and hypertensive participants (Summary of findings 4).

Figure 5. Forest plot of comparison: 5 Effect of salt reduction on hormones, outcome: 5.3 Noradrenaline $(\mathrm{pg} / \mathrm{mL})$.

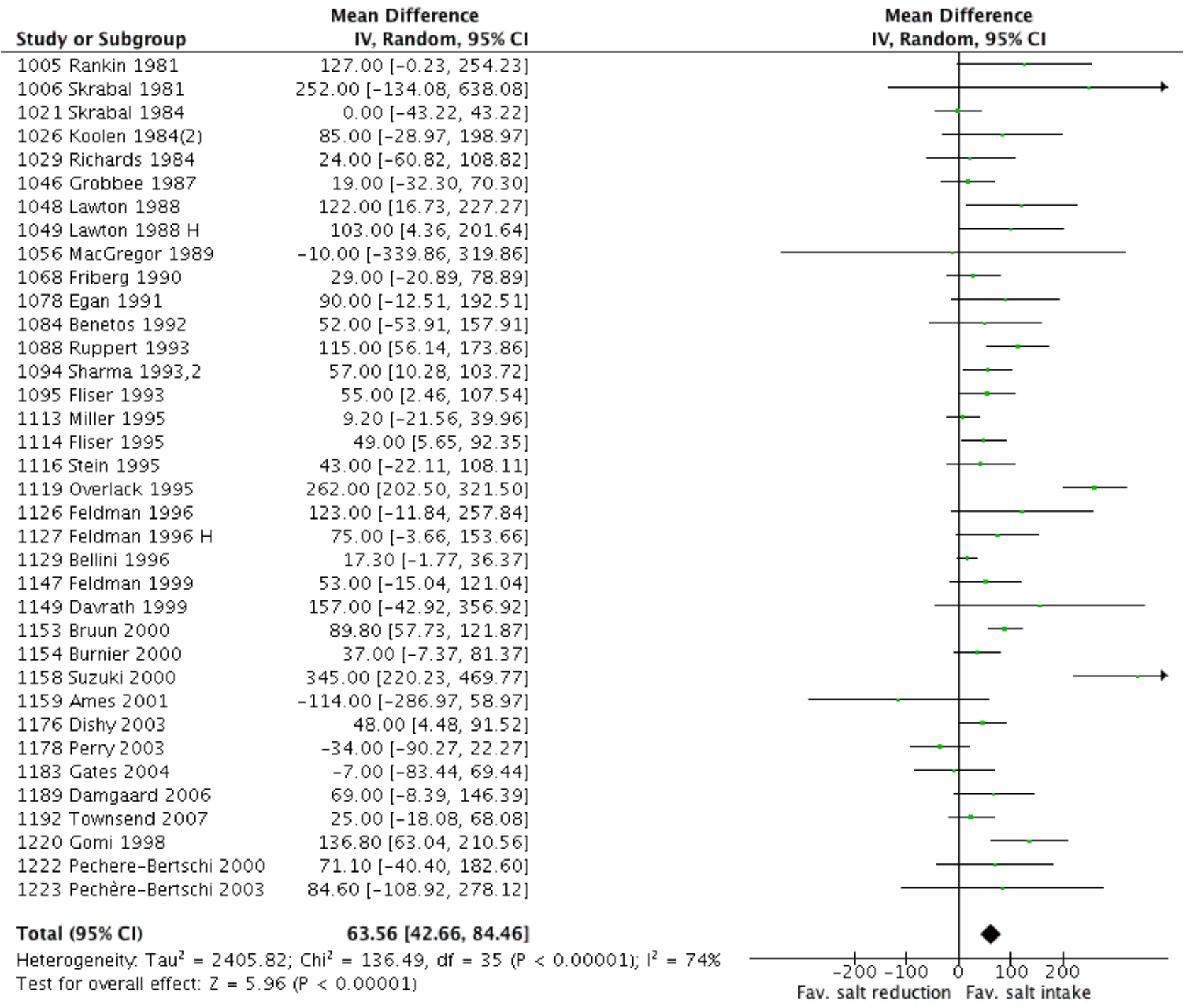

Effects of low sodium diet versus high sodium diet on blood pressure, renin, aldosterone, catecholamines, cholesterol, and triglyceride 


\section{Adrenaline}

See Summary of findings 4

One parallel trial was excluded (1110 Jula 1994).

In the remaining 15 cross-over trials (662 participants) of measurement of adrenaline (including 16 comparisons reported in the Data \& analyses), MD was $7.55 \mathrm{pg} / \mathrm{mL}$ (95\% Cl: 0.85 to 14.26), $(\mathrm{z}=2.21, \mathrm{P}=0.03$ ) (Analysis 5.4) (moderate-quality evidence). In comparisons with duration of at least one week and sodium intake of less than $250 \mathrm{mmol} /$ day (12 studies, 486 participants) MD was $7.79 \mathrm{pg} / \mathrm{mL}$ (95\% Cl: 0.31 to 15.28$), \mathrm{P}=0.04$ (Analysis 6.4). There was no difference between normotensive participants and hypertensive participants (Summary of findings 4).

\section{Cholesterol}

See Summary of findings 5

Three parallel trials were excluded (1015 Bulpitt 1984; 1085 Sciarrone 1992; 1199 Meland 2009). In the remaining 26 cross-over trials (1800 participants) of measurement of cholesterol (including 27 comparisons reported in the Data \& analyses), MD showed an increase of $5.64 \mathrm{mg} / \mathrm{dL}(95 \% \mathrm{Cl}: 2.46$ to 8.82$), \mathrm{P}=0.0005$ (Figure 6, Analysis 7.1) (moderate-quality evidence). In comparisons with duration of at least one week and sodium intake of less than $250 \mathrm{mmol} /$ day (20 trials, 1180 participants) MD was 4.88 $\mathrm{mg} / \mathrm{dL}(95 \% \mathrm{Cl}: 1.19$ to 8.56$), \mathrm{P}=0.01$ (Analysis 8.1 ). The effect in normotensive participants was significantly higher than in hypertensive participants (Summary of findings 5)

\section{Figure 6. Forest plot of comparison: 6 Effect of salt reduction on lipids, outcome: 6.1 Cholesterol.}

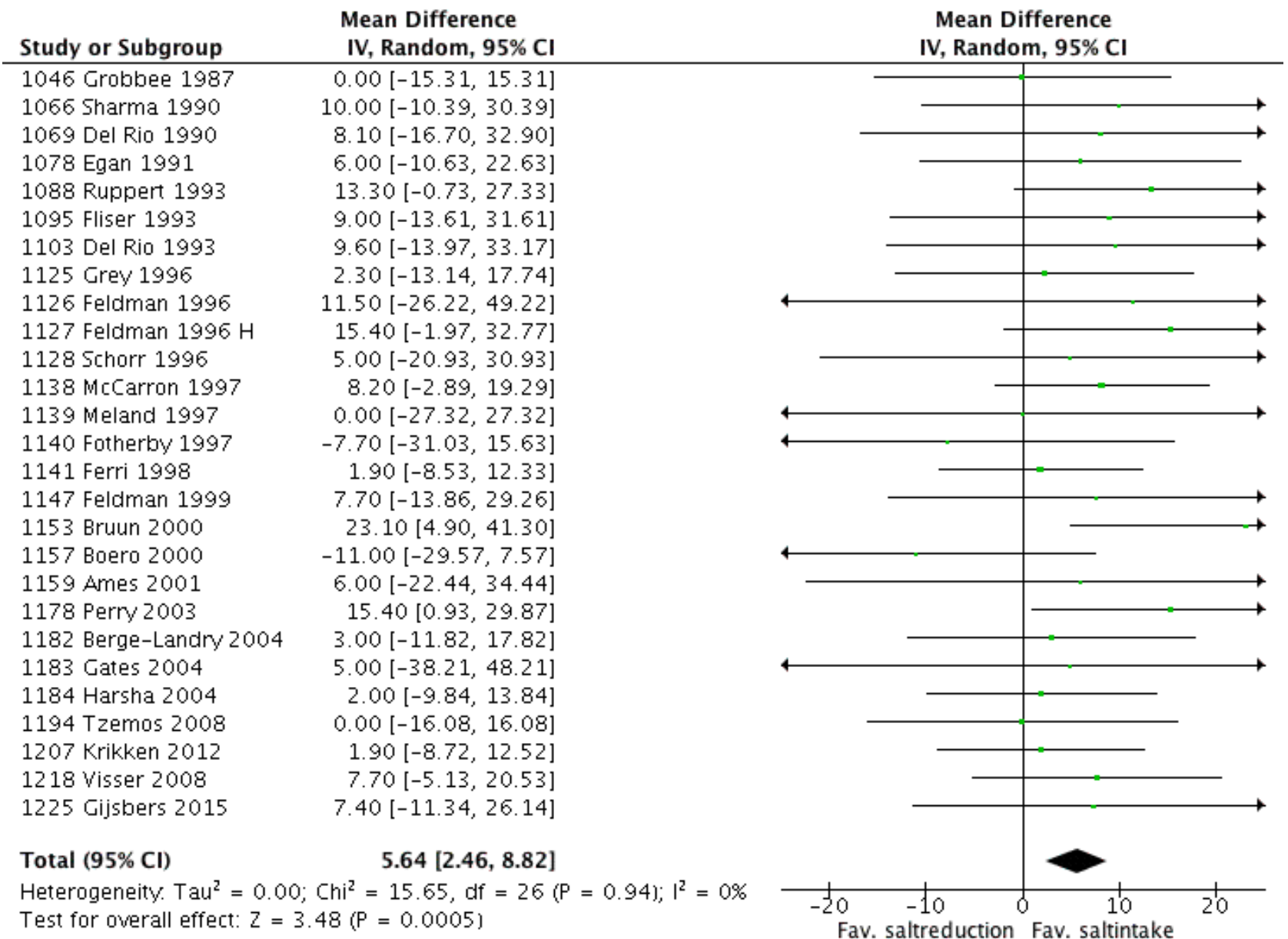

\section{Triglyceride}

See Summary of findings 5

Two parallel trials were excluded (1085 Sciarrone 1992; 1199 Meland 2009) .

In the remaining 19 cross-over trials (1390 participants) of measurement of triglyceride, MD showed an increase of $7.04 \mathrm{mg} /$ $\mathrm{dL}(95 \% \mathrm{Cl}: 3.04$ to 11.05 ), $\mathrm{P}=0.0006$ (Analysis 7.2) (moderatequality evidence). In comparisons with duration of at least one week and sodium intake of less than $250 \mathrm{mmol} /$ day (12 trials, 770 participants) the effect was 6.92 (mg/dL [95\% Cl: 1.82 to 12.02 ), $\mathrm{P}=$ 0.008 (Analysis 8.2). There was no difference between normotensive participants and hypertensive participants (Summary of findings 5)

\section{High-density lipoprotein (HDL)}

See Summary of findings 5

Two parallel trials were excluded (1085 Sciarrone 1992; 1199 Meland 2009).

Effects of low sodium diet versus high sodium diet on blood pressure, renin, aldosterone, catecholamines, cholesterol, and triglyceride 
In the remaining 19 cross-over trials (1442 participants) of measurement of $\mathrm{HDL}$, there was no effect of sodium reduction on serum HDL: MD: $-0.29 \mathrm{mg} / \mathrm{dL}$ ( $95 \% \mathrm{Cl}:-1.66$ to 1.08$) \mathrm{P}=0.68$ (Analysis 7.3) (moderate-quality evidence). This result did not change in comparisons with duration of at least one week and sodium intake of less than $250 \mathrm{mmol} / \mathrm{day}(-0.67 \mathrm{mg} / \mathrm{dL}(-2.18$ to 0.83$), \mathrm{P}=0.38$ (14 trials, 948 participants)) (Analysis 8.3).

\section{Low-density lipoprotein (LDL)}

See Summary of findings 5

One parallel trial was excluded (1085 Sciarrone 1992).

In the remaining 17 cross-over trials (1358 participants) of measurement of LDL, MD showed a non-significant increase of 3.12 mgdL (95\% Cl: -0.41 , to, 6.64$), P=0.08$ (Analysis 7.4 ). In comparisons with duration of at least one week and sodium intake of less than $250 \mathrm{mmol} /$ day (12 trials, 864 participants), MD was $3.63 \mathrm{mgdL}$ ( $95 \%$ $\mathrm{Cl}$ : -0.44 to 7.69 ), $\mathrm{P}=0.08$ (Analysis 8.4 ).

\section{Bias analyses}

Bias analysis: Comparing low bias risk versus high bias risk of general blinding and blinding of outcome detection for SBPoutcomes in white people with normotension and hypertension showed no important differences. See Data and analyses: 9 Bias analyses.

\section{Additional subgroup analyses}

\section{Hormones and lipids}

Inclusion of the few parallel studies did not change any of the results (data not shown).

\section{Sensitivity analyses}

The funnel plots of all analyses were investigated. For each funnel plot, all studies giving rise to asymmetry were eliminated. The resulting effect was compared with the original analysis. All these analyses showed only marginal effects without significance (not shown).

\section{DISCUSSION}

\section{Summary of main results}

The effect of sodium reduction from an average high usual intake (201 $\mathrm{mmol} /$ day) to the recommended level $(66 \mathrm{mmol} / \mathrm{day})$ was small in study populations with normal blood pressure (BP) (-1.09/ $+0.03 \mathrm{mmHg}$ ) corresponding to a mean arterial pressure effect of only $-0.3 \mathrm{mmHg}$. In hypertensive study populations the effect was $(-5.51 /-2.88 \mathrm{mmHg})$. In a subgroup analysis intending to eliminate the potential bias of a very short intervention duration (< seven days) and very high sodium intake (> $250 \mathrm{mmol} /$ day), the decrease in BP in study populations with a normal BP $(-1.31 /-0.36 \mathrm{mmHg})$ and hypertension $(-5.02 /-2.78 \mathrm{mmHg})$ was also small. The effect of sodium reduction on hormones and on lipids showed statistically significant increases in renin, aldosterone, noradrenalin, cholesterol and triglyceride in the primary analysis, as well as in the subgroup analysis, whereas the increase in adrenalin was borderline significant $(P<0.03)$. The increase in cholesterol in the low-salt group seemed mainly to be due to an increase in low-density lipoprotein (LDL), which was borderline significant. The slight decrease in high-density lipoprotein (HDL) in the low-salt group was not significant.

The analysis of black populations showed that the effect of sodium reduction in black people with normotension corresponded to the one found in black people with hypertension. This was in contrast to the analyses of white and Asian populations in whom the effect was smaller in those who were normotensive than in those who were hypertensive. However, compared with previous analyses (Graudal 1998; Jürgens 2003), the diverging results within the black populations and between the black and white populations are smaller. In a recent detailed analysis, we found that a significant fraction of the differences between the three ethnicity groups could be ascribed to differences in baseline BP, age, and amount of sodium reduction. Furthermore there was no difference in BP outcome between ethnicity groups investigated in the same study (Graudal 2015b) indicating that the differences found in the present meta-analysis mainly may be due to confounders rather than ethnical differences.

\section{Overall completeness and applicability of evidence}

In the primary analysis, population samples from the whole BP distribution of the populations were included. In this analysis, the intake of sodium in the "high" sodium group was in the interval 100 $\mathrm{mmol} /$ day to $795 \mathrm{mmol} /$ day in 205 comparisons (99\%), and below $100 \mathrm{mmol} /$ day in one comparison, the mean level being $201 \mathrm{mmol} /$ day. The intake of sodium in the low-sodium group was below 100 $\mathrm{mmol} /$ day in 168 comparisons ( $82 \%$ ) and above $100 \mathrm{mmol} /$ day in 38 comparisons, the mean level being $66 \mathrm{mmol} / \mathrm{day}$. In the subgroup analysis, the intake of sodium in the "high" sodium group was in the interval $109 \mathrm{mmol} /$ day to $248 \mathrm{mmol} /$ day in 143 comparisons (99\%), and below $100 \mathrm{mmol} /$ day in one comparison, the mean level being $167 \mathrm{mmol} /$ day. The intake of sodium in the low-sodium group was below $100 \mathrm{mmol} /$ day in 114 comparisons (80\%) and above $100 \mathrm{mmol} /$ day in 30 comparisons, the mean level being 60 $\mathrm{mmol} /$ day. Consequently, this meta-analysis in general compares the effects of a dietary sodium intake, which is lower than usual and in accordance with the recommendations to reduce sodium below $100 \mathrm{mmol} /$ day with a sodium intake, which is within the present world-wide usual range of sodium intake, the level in the primary analysis being in the high end of the usual intake and the level in the subgroup analysis being close to the world mean of $159 \mathrm{mmol} /$ day (Table 1). The mean and the range of the baseline 24-hour sodium excretion of the included populations before diet manipulation (159 mmol/24 hours (10 to 90 percentile: 123 to 194)) were almost identical with the usual range of sodium intake in the world's populations (McCarron 2013; Powles 2013). Thus, the present review shows the consequences of the recommendations of the health institutions, which is to reduce the usual sodium intake of the world's populations ( $90 \mathrm{mmol} /$ day to $250 \mathrm{mmol} /$ day) to a level below $87 \mathrm{mmol} /$ day to $100 \mathrm{mmol} /$ day.

\section{Quality of the evidence}

The study populations included in the present meta-analysis were in general very heterogeneous with large variations in baseline $\mathrm{BP}$, age, sodium intake and degree of sodium reduction. The analyses of BP and hormones were generally very heterogeneous. Especially, the $\mathrm{I}^{2}$ values for renin and aldosterone were very high, but as renin and aldosterone rise sharply with sodium reduction below 2.3 g sodium, but only moderately above 2.3 g sodium (Brunner 1972; Graudal 1998), the extreme heterogeneity of the

Effects of low sodium diet versus high sodium diet on blood pressure, renin, aldosterone, catecholamines, cholesterol, and triglyceride 
outcomes of these variables is not surprising. In spite of the clinical heterogeneity, no heterogeneity was detected in the metaanalyses of lipid outcomes implying that these outcomes are robust. The number of studies included in the BP analyses $(n=206)$ is substantial as is the number of participants (more than 6000). This should allow robust conclusions. The fundamental quality criterion was randomisation, but a weakness is that very few of the studies described the sequence generation and the random allocation procedures leaving a substantial bias risk of insufficient randomisation, which could not be explored in a meaningful way due to the lack of contrasts between the number of studies with low and high risk of these biases (Figure 1). Another weakness was that a large number of studies were not double-blind. However, concerning this source of bias, there were no obvious trends towards different effects in the low-risk blinded groups compared with the high-risk open groups (Analysis 9.1; Analysis 9.2; Analysis 9.3; Analysis 9.4; Analysis 9.5; Analysis 9.6; Analysis 9.7; Analysis 9.8).

\section{Potential biases in the review process}

The present review is the largest of the many existing metaanalyses on sodium reduction, and other meta-analyses have not identified studies, which were not identified by our search. Our analysis is the largest partly because our selection criteria were less restrict. Therefore, a fraction of the included studies had an experimental character investigating a sodium intake far beyond the sodium intake in the general population for only four to six days, which may not be relevant for the general population on long-term sodium reduction. The fact that the subgroup analysis eliminating the potential short-term intervention bias and very high sodium intake bias showed similar results as the primary analysis indicates that the inclusion of extreme studies had a minor impact on the mean of the outcome effects. Other meta-analyses have extracted almost identical data in the individual studies indicating that our data extraction is unbiased. Finally, elimination of studies giving rise to asymmetry in the funnel plots did not change the results indicating a low risk of publication bias.

\section{Agreements and disagreements with other studies or reviews}

The scientific evidence behind the sodium reduction recommendations is a series of studies and meta-analyses, which are biased by high baseline blood pressure, high age and overweight (Graudal (3) 2016). The most prominent of these studies (DASH 2001), was additionally biased by a control group diet, which was designed to contain only half of the normal amount of potassium. Despite these studies are irrelevant as evidence for pubic health recommendations, the Food and Drug Administration (FDA) has released draft proposed voluntary guideline to encourage companies to steadily reduce sodium in processed foods (Frieden TR 2016), the main argument being a dose-response metaregression analysis of mixed normotensive and hypertensive study populations, which was biased because it included mainly studies with high blood pressure and inappropriately forced the doseresponse relationship through zero and thereby further doubled the postulated effect. In contrast, previous meta-analyses of randomised controlled trials (RCTs) have shown similar results of sodium reduction on BP. In 1986, Grobbee and Hofman combined 13 studies of persons with normal and elevated BP in a metaanalysis and found a significant hypotensive effect of reduced sodium intake on SBP of $-3.6 \mathrm{mmHg}$ and a non-significant effect on DBP of $-2.0 \mathrm{mmHg}$ (Grobbee 1986). In 1991, a second metaanalysis of $24 \mathrm{RCTs}$ showed an effect of $-4.0 /-2.5 \mathrm{mmHg}$ for persons with elevated BP and -1.0/-0.2 for persons with normal BP (Cutler 1991). This was verified in an update from 1997 (Cutler 1997). In 1996, a meta-analysis of 53 RCTs showed an effect of $-3.7 /-0.9$ $\mathrm{mmHg}$ in persons with elevated BP and $-1.0 /-0.1$ in persons with normal BP (Midgley 1996). In an analysis of eight RCTs lasting for at least six months, the effect was $-2.9 /-2.1 \mathrm{mmHg}$ for persons with elevated BP and $-1.3 /-0.8 \mathrm{mmHg}$ for persons with normal BP (Ebrahim 1998). These results were confirmed in an update (Hooper 2002). All these similar results confirm that selection of RCTs based on magnitude of sodium difference or duration of the intervention does not significantly change the overall effect size estimate. These meta-analyses indicate that major disagreements about this effect size no longer seem to exist. However, there is still significant disagreement regarding the relevance of the effect size and the relevance of potential side effects (Taubes 1998).

The effect of sodium reduction on BP in hypertensive and normotensive study populations in the present review matches the effects found in most of these previous reviews, although the effect of sodium reduction on BP in normotensives is marginally lower than in the meta-analysis, which supports the WHO recommendations (Aburto 2013). In hypertensive study populations, there was no differences between the WHO review and our review. In normotensive study populations, the difference was small, the BP effect in the WHO review being $-1.38 /-0.58 \mathrm{mmHg}$ and in ours being $-1.09 / 0.03(-1.31 /-0.36$ in the subgroup analysis).This study differed from ours as it only included studies lasting at least four weeks. However, as duration has no impact on the BP effect (Table 2), a more reliable explanation for the difference between the WHO review and our review is that the study populations with normal BP in the WHO review generally have a high baseline BP in the upper $50 \%$ percentile of the population.

According to WHO, the small effect in normotensive study populations is sufficient to recommend sodium reduction for the whole population, the assumption being that the association between BP and mortality is consistent. This, however, may not be the case. For instance, beta-blockers reduce BP in hypertensive individuals, but not mortality (Wiysonge 2012), and a recent metaanalysis of patients with diabetes showed that antihypertensive treatment reduces the risk of mortality and cardiovascular morbidity in diabetes patients with SBP higher than $140 \mathrm{~mm} \mathrm{Hg}$, but if SBP is less than $140 \mathrm{~mm} \mathrm{Hg}$ further treatment is associated with an increased risk of cardiovascular death, with no observed benefit (Brunström 2016). Such studies indicate that it is not possible to extend the general association of BP with mortality (Collins 1990) to the effect of a BP-reducing intervention on mortality. The reason for this inconsistency may be side effects of the intervention. However, while short duration has been suggested to underestimate the BP effect, it has concomitantly been suggested to overestimate possible adverse effects on hormones and lipids. This idea that the duration of the intervention tends to underestimate some physiological outcomes and overestimate others has not been documented, but still has been used to disregard side effects shown in studies lasting less than four weeks. Very few studies lasting more than for weeks have investigated side effects, and further more these studies do not reduce sodium to the recommended level, but to levels above $87 \mathrm{mmol} / \mathrm{day}$, and therefore the side effects in these few studies may not be fully disclosed. In contrast, the present analysis shows that the adverse effects on hormones

Effects of low sodium diet versus high sodium diet on blood pressure, renin, aldosterone, catecholamines, cholesterol, and triglyceride 
and lipids are significant, when the sodium intake is lowered from a high usual sodium intake to a level in accordance with the recommendations of the health institutions. In addition, we have just shown that sodium reduction results in an increase in heart rate of $2.4 \%$ (Graudal (2) 2016). This may be an important side effect as resting heart rate is directly associated with mortality (Ho 2014; Jensen 2012). The assumption that at least some of these effects may be persistent and not just temporary has been indicated in observational studies. Yanomamo Indians, who persistently ingest very small amounts of sodium, have a three times higher level of renin in the blood and a 10 times higher excretion of aldosterone in the urine than normal controls (Oliver 1975). Furthermore, renin and aldosterone rise slowly as long as the intake is above $100 \mathrm{mmol} / \mathrm{day}$, but exponentially, when sodium intake is reduced to levels below $100 \mathrm{mmol} /$ day (Brunner 1972). Thus, the present meta-analysis provides a possible explanation for the small effect of reduced sodium intake on blood pressure: compensatory activation of the renin-aldosterone system is proportional to the degree of sodium reduction. Furthermore, the increases in noradrenaline and adrenaline may contribute to this counterregulation (Warren 1980) and contribute to an increase in heart rate.

The very small effect of sodium reduction on BP in healthy individuals shown in the present review and other reviews including the WHO review, the risk of significant side effects shown in this review, and the possibility that an intervention to reduce BP may not reduce mortality (Wiysonge 2012), and even may increase mortality in some population groups with a normal BP (Brunström 2016) indicate that the BP-effect is not sufficient as a basis for recommendations in the general population, but should be verified in studies directly relating sodium intake with morbidity and mortality. Unfortunately, RCTs of the effect of sodium reduction below $100 \mathrm{mmol} /$ day on mortality in healthy individuals do not exist (Graudal (1) 2016). A recently updated meta-analysis of eight RCTs with follow-up data on morbidity and mortality found a nonsignificant trend versus reduced cardiovascular (CV) morbidity, but could not demonstrate reduced all-cause mortality in the low-sodium group (Adler 2014). These trials were performed in overweight pre-hypertensive or hypertensive individuals and the sodium reduction was not below $100 \mathrm{mmol} /$ day, but down to 100 $\mathrm{mmol} /$ day.

The sodium-mortality relationship has also been estimated by means of 27 observational studies (Alderman 2010; Mente 2016; O'Donnell 2014; Pfister 2014), which directly asses the relationship between sodium intake in the individual and mortality. Most of these studies were evaluated in an IOM report (IOM 2013). This IOM report did not confirm the $100 \mathrm{mmol} /$ day upper level for sodium intake, which was defined in a previous IOM report (IOM 2005), but concluded that "Science was insufficient and inadequate to establish whether reducing sodium intake below $2300 \mathrm{mg} / \mathrm{d}$ $(100 \mathrm{mmol})$ either decreases or increases CVD risk in the general population". A later meta-analysis of these population studies found that a sodium intake below $114 \mathrm{mmol} /$ day was associated with increased mortality, as was a sodium intake above 214 $\mathrm{mmol} /$ day (Graudal 2014). Increased mortality with high sodium intake has also been shown in another meta-analysis, which, however, did not investigate the effect of a low sodium intake (Strazzulo 2009). This U-shaped relation between sodium intake and mortality has been identified in several individual population studies (O'Donnell 2011; O'Donnell 2014; Pfister 2014; Thomas 2011). The health institutions, however, generally do not accept this evidence from the observational studies (Gunn 2013; Whelton 2012; WHO 2012). In a recent paper, which discusses methodological issues of observational studies, representatives of the American Heart Association state that the association of low sodium intake with increased mortality observed in observational studies may reflect that sick people have a low sodium intake (reverse causality: sick people with a high mortality have a low sodium intake, it is not the low sodium intake, which increases the mortality) (Cobb 2014). This hypothesis is not directly supported by the observational studies, as the outcomes generally are adjusted for confounders such as cardiovascular and renal diseases and diabetes and show that the mortality associated with a low sodium intake is higher in healthy populations than in populations including sick individuals (Graudal 2014; O'Donnell 2014). Table 3 shows a metaanalysis of the risk of all-cause mortality in Study populations within the usual sodium intake range versus a low sodium intake below $114 \mathrm{mmol} /$ day (Graudal 2014) or below $130 \mathrm{mmol} /$ day (O'Donnell 2014). The analysis is confined to include samples of individuals representative of the general populations and all individual study analyses are adjusted for multiple confounders such as cardiovascular disease, hypertension and diabetes. To further reduce the risk of reverse causality, the most healthy subgroup was included in the analysis, when results were given for subgroups, The possibility of reverse causality can never be completely excluded, but as a minimum there is no indication in population studies that sodium intake below $100 \mathrm{mmol} /$ day has beneficial health effects in healthy individuals. In the NHANES I and III studies this was demonstrated by independent groups (Alderman 1998; Cohen 2008; He 1999; Yang 2011).

The BP effect of reduced sodium intake has been related to age. Freedman and Petitti analysed data from Intersalt (Intersalt 1988) and found the paradox that along with the significant association between increase in blood pressure with age and the salt excretion in urine, there was an inverse relationship between estimated BP and salt excretion in urine at age 20. Freedman stated that unless you preferred to conclude that salt should be eaten in high doses by youngsters and in reduced amounts by the elderly, the findings were probably due to uncontrolled confounding, not to variation in salt intake (Freedman 2001). Furthermore, it is now clear that the BP of different age cohorts in a cross-sectional study like Intersalt is not representative of each other, verified by a study showing that recent birth cohorts attained lower BP than did earlier birth cohorts in the period 1887 to 1994 (Goff 2001). According to this study, based on data from more than 50,000 persons, it can be estimated that the median BP is about $15 \mathrm{mmHg}$ lower in a 50 -year old person from a recent birth cohort compared with a 50-year old from a birth cohort from the late 19th century. Consequently, there has been a dramatic fall in BP during the 20th century. In this context, the possible mean arterial pressure effect of sodium reduction of $-0.3 \mathrm{mmHg}$ in normotensive persons seems negligible. Finally, it has been difficult to maintain a significant sodium reduction in longer-term studies, which should be taken into consideration, when recommending sodium reduction. One reason for this could be that the sodium intake is regulated by neuro-physiological and hormonal mechanisms (Geerling 2008), and therefore difficult to diverge from.

The hypothetical consequences of the present findings are that people with normotension would have no benefit from sodium reduction, but may suffer from harms, because sodium reduction has a negligible effect on BP, but results in significant side effects.

Effects of low sodium diet versus high sodium diet on blood pressure, renin, aldosterone, catecholamines, cholesterol, and triglyceride 
People with hypertension may benefit due to the effect on BP, but may also suffer from harms due to the side effects. This is exactly what was found in the most recent meta-analysis of four population studies (133,000 individuals) in which the authors had access to individual participant data (Mente 2016). The conclusion was "Compared with moderate sodium intake, high sodium intake is associated with an increased risk of cardiovascular events and death in hypertensive populations (no association in normotensive population), while the association of low sodium intake with increased risk of cardiovascular events and death is observed in those with or without hypertension. These data suggest that lowering sodium intake is best targeted at populations with hypertension who consume high sodium diets", a conclusion, which matches perfectly with the results of the present metaanalysis.

\section{AUTHORS' CONCLUSIONS}

\section{Implications for practice}

The present meta-analysis shows that a low-versus high-sodium diet in white people with normal blood pressure (BP) decreases BP less than $1 \%$. A significant concomitant increase in plasma renin, plasma aldosterone, plasma noradrenalin, and to a lesser degree of plasma adrenaline may contribute to the small effect of sodium reduction on BP. Furthermore, sodium reduction resulted in a significant increase in plasma cholesterol and plasma triglyceride, which expressed in percentage, was numerically larger than the decrease in BP. Due to the relatively small effects and due to the antagonistic nature of the effects (decrease in BP, increase in hormones and lipids), these results do not support that sodium reduction may have net beneficial effects in a population of white people with normal BP.

In white people with elevated $\mathrm{BP}$, sodium reduction decreases $\mathrm{BP}$ by about $3.5 \%$, indicating that sodium reduction may be used as a supplementary treatment for hypertension. In Asian and black people the effect of sodium reduction was a little larger than in white people, but at present too few studies have been carried out to conclude different from that above.

\section{Implications for research}

The data suggesting that black and Asian populations are more sensitive to sodium reduction than white people requires further studies. In future studies of mixed populations, it is important that the effects on white, black and Asian populations are reported separately. Population studies have shown a U-shaped association between sodium intake and mortality indicating that the beneficial effect of sodium reduction on BP outweigh the harmful effect on hormones and lipids at sodium intake above the usual sodium intake, but that the harms of sodium reduction outweigh the benefits at sodium intake below the usual sodium intake. Longterm randomised controlled trials (RCTs) with mortality and morbidity outcomes would be desirable to confirm or reject these findings. However, such studies may not be practicable. After 185 RCTs and 27 population studies without an obvious signal in favour of sodium reduction below $100 \mathrm{mmol} /$ day, another position could be to accept that the present usual sodium intake may be the optimal intake for the general population.

\section{ACKN OWLEDGEMENTS}

Jacob Riis, Rasmus Moustgaard and Dr Peter C Gøtzsche, The Nordic Cochrane Center, are kindly thanked for assistance during the elaboration of the primary review. Doug Salzwedel, The Cochrane Hypertension Review Group, is kindly thanked for a complete literature search during the update of this review. Doris Christiansen and Johanne Worm are kindly thanked for the acquisition of literature. 


\section{RE F E R E N C E S}

\section{References to studies included in this review}

1000 Parijs 1973 \{published data only\}

Parijs J, Joossens JV, Van der Linden L, Verstreken G, Amery AKPC. Moderate sodium restriction and diuretics in the treatment of hypertension. American Heart Journal 1973;85:22-34

\section{Mark 1975 \{published data only\}}

Mark AL, Lawton WJ, Abboud FM, Fitz AE, Connor WE, Heistad DD. Effects of high and low sodium intake on arterial pressure and forearm vascular resistance in borderline hypertension. Circulation Research 1975;36(6 Suppl 1):194-8.

1002 Morgan 1978 \{published data only\}

Morgan T, Gillies A, Morgan G, Adam W, Wilson M, Carney S. Hypertension treated by salt restriction. Lancet 1978;1(8058):227-30.

\section{Sullivan 1980 \{published data only\}}

Sullivan JM, Ratts TE, Taylor JC, Kraus DH, Barton BR, Patrick DR, et al. Hemodynamic effects of dietary sodium in man. Hypertension 1980;2:506-14.

\section{Sullivan 1980 H \{published data only\}}

Sullivan JM, Ratts TE, Taylor JC, Kraus DH, Barton BR, Patrick DR, et al. Hemodynamic effects of dietary sodium in man. Hypertension 1980;2:506-14.

1005 Rankin 1981 \{published data only\}

Rankin LI, Luft FC, Henry DP, Gibbs PS, Weinberger MH. Sodium intake alters the effects of norepinephrine on blood pressure. Hypertension 1981;3:650-6.

\section{Skrabal 1981 \{published data only\}}

Skrabal F, Auböck J, Hörtnagel H. Low sodium/high potassium diet for prevention of hypertension: probable mechanisms of action. Lancet 1981;2(8252):895-900.

\section{Morgan 1981 \{published data only\}}

Morgan TO, Myers JB. Hypertension treated by sodium restriction. Medical Journal of Australia 1981;2(8):396-7.

1009 Ambrosioni 1982 \{published data only\}

Ambrosioni E, Costa FV, Borghi C, Montebugnoli L, Giordani MF, Magnani B. Effects of moderate salt restriction on intralymphocytic sodium and pressor response to stress in borderline hypertension. Hypertension 1982:;4:789-94.

\section{Myers 1982 \{published data only\}}

Myers J, Morgan T, Waga S, Manley K. The effect of sodium intake on blood pressure related to the age of the patients. Clinical and Experimental Pharmacology \& Physiology 1982;9(3):287-9.

\section{MacGregor 1982 \{published data only\}}

MacGregor GA, Markandu ND, Best FE, Elder DM, Cam JM, Sagnella GA, et al. Double-blind randomised crossover trial of moderate sodium restriction in essential hypertension. Lancet 1982;1(8268):351-5.

\section{Beard 1982 \{published data only\}}

Beard TC, Gray WR, Cooke HM, Barge R. Randomised controlled trial of a no-added-sodium diet for mild hypertension. Lancet 1982;2(8296):455-8.

\section{Puska 1983 \{published data only\}}

Puska P, Iacono JM, Nissinen A, Korhonen HJ, Vartianinen E, Pietinen $P$, et al. Controlled, randomised trial of the effect of dietary fat on blood pressure. Lancet 1983;1(8314):1-5.

1015 Bulpitt 1984 \{published data only\}

Bulpitt CJ, Daymond M, Bulpitt PF, Ferrier G, Harrison R, Lewis, PJ, et al. Is low salt dietary advice a useful therapy in hypertensive patients with poorly controlled blood pressure? Annals of Clinical Research 1984;16(Suppl 43):143-9.

1016 Silman 1983 \{published data only\}

Silman AJ, Locke C, Mitchell P, Humpherson P. Evaluation of the effectiveness of a low sodium diet in the treatment of mild to moderate hypertension. Lancet 1983;1(8335):1179-82.

\section{Sowers 1983 \{published data only\}}

Sowers JR, Martin VI, Beck FW. Effects of dietary sodium on circadian rhythm and physiological responses of 18hydroxycorticosterone. Clinical Science 1983;64:265-301.

\section{Watt 1983 \{published data only\}}

Watt GCM, Edwards C, Hart JT, Hart M, Walton P, Foy CJW. Dietary sodium restriction for mild hypertension in general practice. British Medical Journal 1983;286(6363):432-6.

\section{Cooper 1984 \{published data only\}}

Cooper R, Van Horn L, Liu K, Trevisan M, Nanas S, Ueshima H, et al. A randomised trial of the effect of decreased dietary sodium intake on blood pressure in adolescents. Journal of Hypertension 1984;2:361-6.

\section{Skrabal 1984 \{published data only\}}

Skrabal F, Herholz H, Neumayr M, Hamberger L, Ledochowski M, Sporer H, et al. Salt sensitivity in humans is linked to enhanced sympathetic responsiveness and to enhanced proximal tubular reabsorption. Hypertension 1984;6:152-8.

\section{Gillies 1984 \{published data only\}}

Gillies AH, Carney SL, Smith AJ. Adjunctive effect of salt restriction on antihypertensive efficacy. Clinical and Experimental Pharmacology \& Physiology 1984;11:395-8.

\section{Erwteman 1984 \{published data only\}}

Erwteman TM, Nagelkerke N, Lubsen J, Koster M, Dunning AJ. B Blockade, diuretics and salt restriction for the management of mild hypertension: a randomised double blind trial. British Medical Journal 1984;289(6442):406-9.

Effects of low sodium diet versus high sodium diet on blood pressure, renin, aldosterone, catecholamines, cholesterol, and triglyceride 
1025 Koolen 1984 \{published data only\}

Koolen MI, Brummelen P. Sodium sensitivity in essential hypertension: Role of the renin-angiotensin-aldosterone system and the predictive value of an intravenous frusemide test. Journal of Hypertension 1984;2:55-9.

1026 Koolen 1984(2) \{published data only\}

Koolen MI, Brummelen P. Adrenergic activity and peripheral hemodynamics in relation to sodium sensitivity in patients with essential hypertension. Hypertension 1984;6:820-5.

\section{Fagerberg 1984 \{published data only\}}

Fagerberg B, Anderson OK, Isakson B, Björntop P. Blood pressure control during weight reduction in obese hypertensive men: separate effects of sodium and energy restriction. British Medical Journal 1984;288(6410):11-4.

\section{Maxwell 1984 \{published data only\}}

Maxwell MH, Kushiro T, Dornfeld LP, Tuck ML, Waks AU. Blood pressure changes in obese hypertensive subjects during rapid weight loss. Comparison of restricted $v$ unchanged salt intake. Archives of Internal Medicine 1984;144:1581-4.

1029 Richards 1984 \{published data only\}

Richards AM, Espiner EA, Maslowski AH, Nicholls MG, Ikram H, Hamilton EJ, et al. Blood pressure response to moderate sodium restriction and to potassium supplementation in mild essential hypertension. Lancet 1984;1(8380):757-61.

1030 Resnick 1985 \{published data only\}

Resnick LM, Nicholson JP, Laragh JH. Alterations in calcium metabolism mediate dietary salt sensitivity in essential hypertension. Transactions of the Association of American Physicians 1985;98:313-21.

\section{Tuthill 1985 \{published data only\}}

Tuthill RW, Calabrese EJ. The Massachusetts Blood Pressure Study, Part 4. Modest sodium supplementation and blood pressure change in boarding school girls. Toxicology and Industrial Health 1985;1:35-43.

\section{Skrabal 1985 \{published data only\}}

Skrabal F, Hamberger L, Cerny E. Salt sensitivity in normotensives with and salt resistance in normotensives without heredity of hypertension. Scandinavian Journal of Clinical and Laboratory Investigation 1985;176:47-57.

\section{Watt 1985 \{published data only\}}

Watt GC, Foy CJ, Hart JT, Bingham G, Edwards C, Hart M, et al. Dietary sodium and arterial blood pressure: evidence against genetic susceptibility. British Medical Journal 1985;291(6508):1525-8

\section{Richards 1986 \{published data only\}}

Richards AM, Tonolo G, Cleland JG, Leckie BJ, McIntyre GD, Ingram $\mathrm{M}$, et al. Plasma atrial natriuretic peptide: responses to modest and severe sodium restriction. Journal of Hypertension Supplement 1986;4:S559-63.

\section{Teow 1986 \{published data only\}}

Teow BH, Nicolantonio RD, Morgan TO. Sodium chloride preference and recognition threshold in normotensive subjects on high and low salt diet. Clinical and Experimental Hypertension. Part A, Theory and Practice 1986;7(12):1681-95.

1038 Logan 1986 \{published data only\} Logan AG. Sodium manipulation in the management of hypertension. The view against its general use. Canadian Journal of Physiology and Pharmacology. 1986;64(6):793-802.

1039 ANHMRCDS 1986 \{published data only\}

Chalmers J, Morgan T, Doyle A, Dickson B, Hopper J, Mathews J, et al. Australian National Health and Medical Research Council dietary salt study in mild hypertension. Journal of Hypertension Supplement 1986;4:S629-37.

1040 El Ashry 1987 \{published data only\}

El Ashry A, Heagerty AM, Alton SM, Bing RF, Swales JD, Thurston $\mathrm{H}$. Effects of manipulation of sodium balance on erythrocyte sodium transport. Journal of Human Hypertension 1987;1:105-11.

\section{Fuchs 1987 \{published data only\}}

Fuchs FD, Wannmacher CMD, Wannmacher L, Guimarães FS, Rosito GA, Gastaldo G, et al. Effect of sodium intake on blood pressure, serum levels and renal excretion of sodium and potassium in normotensives with and without familial predisposition to hypertension. Brazilian Journal of Medical and Biological Research 1987;20(1):25-34.

1044 Morgan 1987 \{published data only\}

* Morgan T, Anderson A. Sodium restriction can delay the return of hypertension in patients previously well-controlled on drug therapy. Canadian Journal of Physiology and Pharmacology 1987;65:1752-1755.

\section{Kurtz 1987 \{published data only\}}

Kurtz TW, Al-Bander H, Morris RC. "Salt sensitive" essential hypertension in men. Is the sodium ion alone important?. New England Journal of Medicine 1987;317:1043-8.

1046 Grobbee 1987 \{published data only\}

Grobbee DE, Hofman A. Does sodium restriction lower blood pressure?. British Medical Journal 1987;293:27-9.

\section{MacGregor 1987 \{published data only\}}

McGregor GA, Markandu ND, Singer DRJ, Cappucio FP, Shore AC, Sagnella GA. Moderate sodium restriction with angiotensin converting enzyme inhibitor in essential hypertension: a double blind study. British Medical Journal 1987;294:531-4.

\section{Lawton 1988 \{published data only\}}

Lawton WJ, Sinkey CA, Fitz AE, Mark AL. Dietary salt produces abnormal renal vasoconstrictor responses to upright posture in borderline hypertensive subjects. Hypertension 1988;11:529-36.

1049 Lawton 1988 H $\{$ published data only\}

Lawton WJ, Sinkey CA, Fitz AE, Mark AL. Dietary salt produces abnormal renal vasoconstrictor responses to upright posture in borderline hypertensive subjects. Hypertension 1988;11:529-36.

Effects of low sodium diet versus high sodium diet on blood pressure, renin, aldosterone, catecholamines, cholesterol, and triglyceride 
1050 Morgan 1988 \{published data only\}

Morgan T, Anderson A. Interaction in hypertensive men between sodium intake, converting enzyme inhibitor (enalapril), plasma renin and blood pressure control. Journal of Human Hypertension 1988;1(4):311-5.

\section{Morgan 1988,2 \{published data only\}}

Morgan T, Anderson A. Interaction of slow-channel calcium blocking drugs with sodium restriction, diuretics and angiotensin converting enzyme inhibitors. Journal of Hypertension 1988;6(suppl 4):S652-S654.

\section{Shore 1988 \{published data only\}}

Shore AC, Markandu ND, McGregor GA. A randomised crossover study to compare the blood pressure response to sodium loading with and without chloride in patients with essential hypertension. Journal of Hypertension 1988;6:613-7.

\section{Sudhir 1989 \{published data only\}}

Sudhir K, Friberg P, Meredith IT, Woods RL, Esler MD, Jennings GL. Cardiac secretion and renal clearance of atrial natriuretic peptide in normal man: effect of salt restriction. Clinical Science 1989;77:605-10.

\section{Hargreaves 1989 \{published data only\}}

Hargreaves M, Morgan TO, Snow R, Guerin M. Exercise tolerance in the heat on low and normal salt intake. Clinical Science 1989;76:553-7.

\section{ANHMRCDS 1989 \{published data only\}}

Australian National Health and Medical Research Council Dietary Salt Study Management Committee. Fall in blood pressure with modest reduction in dietary salt intake in mild hypertension. Lancet 1989;1:399-402.

\section{MacGregor 1989 \{published data only\}}

McGregor GA, Markandu ND, Sagnella GA, Singer DRJ, Cappucio FP. Double-blind study of three sodium intakes and long-term effects of sodium restriction in essential hypertension. Lancet 1989;2(8674):1244-7.

\section{Dimsdale 1990 W \{published data only\}}

Dimsdale JE, Ziegler M, Mills P, Berry C. Prediction of salt sensitivity. American Journal of Hypertension 1990;3:429-35.

1058 Dimsdale 1990 WH \{published data only\} Dimsdale JE, Ziegler M, Mills P, Berry C. Prediction of salt sensitivity. Am J Hypertens 1990;3:429-35.

\section{Dimsdale 1990 B \{published data only\}}

Dimsdale JE, Ziegler M, Mills P, Berry C. Prediction of salt sensitivity. Am J Hypertens 1990;3:429-35.

\section{Dimsdale 1990 BH \{published data only\}}

Dimsdale JE, Ziegler M, Mills P, Berry C. Prediction of salt sensitivity. Am J Hypertens 1990;3:429-35.

\section{Schmid 1990 \{published data only\}}

Schmid M, Mann JF, Stein G, Herter M, Nussberger J, Klingbeil A, et al. Natriuresis-pressure relationship in polycystic kidney disease. Journal of Hypertension 1990;8:277-83.
1062 Schmid 1990 H \{published data only\}

Schmid M, Mann JF, Stein G, Herter M, Nussberger J, Klingbeil A, et al. Natriuresis-pressure relationship in polycystic kidney disease. Journal of Hypertension 1990;8:277-83.

\section{HPTRG 1990 \{published data only\}}

Hypertension Prevention Trial Research Group. The Hypertension Prevention Trial: three-year effects of dietary changes on blood pressure. Archives of Internal Medicine 1990;150:153-62.

\section{Bruun 1990 \{published data only\}}

Bruun NE, Skøtt P, Nielsen MD, Rasmussen S, Schütten HJ, Leth A, et al. Normal renal tubular response to changes of sodium intake in hypertensive man. Journal of Hypertension 1990;8:219-27.

\section{Bruun 1990 H \{published data only\}}

Bruun NE, Skøtt P, Nielsen MD, Rasmussen S, Schütten HJ, Leth A, et al. Normal renal tubular response to changes of sodium intake in hypertensive man. Journal of Hypertension 1990;8:219-27.

\section{Sharma 1990 \{published data only\}}

Sharma AM, Arntz HR, Kribben A, Schattenfroh S, Distler A. Dietary sodium restriction: adverse effect on plasma lipids. Klinische Wochenschrift 1990;68:664-8.

1067 Sharma 1990,2 \{published data only\}

Sharma AM, Kribben A, Schattenfroh S, Cetto C, Distler A. Salt sensitivity in humans is associated with abnormal acid-base regulation. Hypertension 1990;16:407-13.

1068 Friberg 1990 \{published data only\}

Friberg P, Meredith I, Jennings G, Lambert G, Fazio V, Esler M. Evidence for increased renal norepinephrine overflow during sodium restriction in humans. Hypertension 1990;16:121-30.

1069 Del Rio 1990 \{published data only\}

Del Rio A, Rodriguez-Villamil JL, Lopez-Campos JM, Carrera F. Effect of moderate salt restriction on the antihypertensive action of nifedipine: a double blind study [Influencia de la restriccion salina moderada sobre la actividad antihipertensiva de la nifedipina: un estudio doble ciego]. Revista Clinica Espanola 1990;186:5-10.

\section{Parker 1990 \{published data only\}}

Parker M, Puddey IB, Beilin LJ, Vandongen R. Two-way factorial study of alcohol and salt restriction in treated hypertensive men. Hypertension 1990;16:398-406.

\section{Mtabaji 1990 \{published data only\}}

Mtabaji JP, Nara Y, Yamori Y. The cardiac study in Tanzania: salt intake in the causation and treatment of hypertension. Journal of Human Hypertension 1990;4:80-1.

\section{Sharma 1991 \{published data only\}}

Sharma AM, Ruland K, Spies KP, Distler A. Salt sensitivity in young normotensive subjects is associated with a hyperinsulinemic response to oral glucose. Journal of Hypertension 1991;9:329-35.

Effects of low sodium diet versus high sodium diet on blood pressure, renin, aldosterone, catecholamines, cholesterol, and triglyceride 
1074 Howe 1991 \{published data only\}

Howe PRC, Cobiac L, Smith RM. Lack of effect of short-term changes in sodium intake on blood pressure in adolescent. Journal of Hypertension 1991;9:181-6.

\section{Mascioli 1991 \{published data only\}}

Mascioli S, Grimm R Jr, Launer C, et al. Sodium chloride raises blood pressure in normotensive subjects. The study of sodium and blood pressure. Hypertension 1991;17(Suppl 1):I21-6.

\section{Carney 1991 \{published data only\}}

Carney SL, Gillies AH, Smith AJ, Smitham S. Increased dietary sodium chloride in patients treated with antihypertensive drugs. Clinical and Experimental Hypertension. Part A, Theory and Practice 1991;13(3):401-7.

\section{Singer 1991 \{published data only\}}

Singer DR, Markandu ND, Sugden AL, Miller MA, MacGregor GA. Sodium restriction in hypertensive patients treated with a converting enzyme inhibitor and a thiazide. Hypertension 1991;17:798-803.

\section{Egan 1991 \{published data only\}}

Egan BM, Weder AB, Petrin J, Hoffman RG. Neurohumoral and metabolic effects of short-term dietary $\mathrm{NaCl}$ restriction in men: relationship to salt-sensitivity status. American Journal of Hypertension 1991;4:416-21.

\section{Gow 1992 \{published data only\}}

Gow IF, Dockrell M, Edwards CRW, Elder A, Grieve J, Kane G, et al. The sensitivity of human blood platelets to the aggregation agent ADP during different dietary sodium intakes in healthy men. European Journal of Clinical Pharmacology 1992;43(6):635-8.

\section{Huggins 1992 \{published data only\}}

Huggins RL, Di Nicolantonio R, Morgan, TO. Preferred salt levels and salt taste acuity in human subjects after ingestion of untasted salt. Appetite 1992;18:111-9.

\section{TOHP I 1992 \{published data only\}}

The Trials of Hypertension Prevention Collaborative Group. The effects of nonpharmacologic interventions on blood pressure of persons with high normal levels. JAMA 1992;267:1213-20.

\section{Cobiac 1992 \{published data only\}}

Cobiac L, Nestel PJ, Wing LMH, Howe PRC. A low sodium diet supplemented with fish oil lowers blood pressure in the elderly. Journal of Hypertension 1992;10:87-92.

\section{Benetos 1992 \{published data only\}}

Benetos A, Xiao YY, Cuche JL, Hannaert P, Safar M. Arterial effects of salt restriction in hypertensive patients. A 9-week, randomized, double-blind, crossover study. Journal of Hypertension 1992;10:355-60.

\section{Sciarrone 1992 \{published data only\}}

Sciarrone SEG, Beilin LJ, Rouse IL, Rogers PB. A factorial study of salt restriction and a low-fat/high-fibre diet in hypertensive subjects. Journal of Hypertension 1992;10:287-98.
1088 Ruppert 1993 \{published data only\}

Ruppert M, Overlack A, Kolloch R, Kraft K, Göbel B, Stumpe KO. Neurohormonal and metabolic effects of severe and moderate salt restriction in non-obese normotensive adults. Hypertension 1993;11:743-9.

\section{Burnier 1993 \{published data only\}}

Burnier M, Rutschmann B, Nussberger J, Versaggi J, Shahinfar S, Waeber B, et al. Salt dependent renal effects of an angiotensin II antagonist in healthy subjects. Hypertension 1993;22:339-47.

\section{Sharma 1993 \{published data only\}}

* Sharma AM, Schorr U, Thiede HM, Distler A. Effect of dietary salt restriction on urinary serotonin and 5-hydroxyindolacetic acid excretion in man. Journal of Hypertension 1993;11:1381-6.

1094 Sharma 1993,2 \{published data only\}

Sharma AM, Schorr U, Oelkers W, Distler A. Effects of sodium salts on plasma renin activity and norepinephrine response to orthostasis in salt-sensitive normotensive subjects. American Journal of Hypertension 1993;6:780-785.

1095 Fliser 1993 \{published data only\}

Fliser D, Nowack R, Allendorf-Ostwald N, Kohl B, Hubinger A, Ritz E. Serum lipid changes on low salt diet. Effects of alpha 1 -adrenergic blockade. American Journal of Hypertension 1993;6:320-4

\section{Nestel 1993 \{published data only\}}

Nestel PJ, Clifton PM, Noakes M, McArthur R, Howe PR. Enhanced blood pressure response to dietary salt in elderly women, especially those with small waist:hip ratio. Journal of Hypertension 1993;11:1387-94

1099 Donovan 1993 \{published data only\}

Donovan DS, Solomon CG, Seely EW, Williams GH, Simonson DC. Effect of sodium intake on insulin sensitivity. American Journal of Physiology 1993;264:E730-4.

\section{Fotherby 1993 \{published data only\}}

Fotherby MD, Potter JF. Effects of moderate sodium restriction on clinic and twenty-four-hour ambulatory blood pressure in elderly hypertensive subjects. Journal of Hypertension 1993;11:657-63.

\section{Redon-Mas 1993 \{published data only\}}

Redón-Más J, Abellán-Alemán J, Aranda-Lara P, de la Figueravon Wichmann M, Luque-Otero M, Rodicio-Díaz JL, et al. Antihypertensive activity of verapamil: impact of dietary sodium. Journal of Hypertension 1993;11:665-71.

1102 Ruilope 1993 \{published data only\}

Ruilope LM, Lahera V. Influence of salt intake on the antihypertensive effect of carvedilol. Journal of Hypertension 1993;11((Suppl 4)):S17-9.

\section{Del Rio 1993 \{published data only\}}

Del Rio A, Rodriguez Villamil JL. Metabolic effects of strict salt restriction in essential hypertensive patients. Journal of Internal Medicine 1993;233:409-14.

Effects of low sodium diet versus high sodium diet on blood pressure, renin, aldosterone, catecholamines, cholesterol, and triglyceride 


\section{Overlack 1993 \{published data only\}}

Overlack A, Ruppert M, Kolloch R, Kraft K, Göbel B, Stumpe KO. Divergent hemo dynamic and hormonal responses to varying salt intake in normotensive subjects. Hypertension 1993;22:331-8.

\section{MacFadyen 1994 \{published data only\}}

MacFadyen RJ, Lees KR, Reid JL. Responses to low dose intravenous perindoprilat infusion in salt deplete/salt replete normotensive volunteers. British Journal of Clinical Pharmacology 1994;38:329-34.

\section{Buckley 1994 \{published data only\}}

Buckley MG, Markandu ND, Sagnella GA, MacGregor GA. Brain and atrial natriuretic peptides: a dual peptide system of potential importance in sodium balance and blood pressure regulation in patients with essential hypertension. Journal of Hypertension 1994;12:809-13.

\section{Zoccali 1994 \{published data only\}}

Zoccali C, Mallamaci F, Parlongo S. The influence of salt intake on plasma calcitonin gene-related peptide in subjects with mild essential hypertension. Journal of Hypertension 1994;12:1249-53.

\section{Jula 1994 \{published data only\}}

Jula AM, Karanko HM. Effects on left ventricular hypertrophy of long-term nonpharmacological treatment with sodium restriction in mild to moderate essential hypertension. Circulation 1994;89:1023-31.

\section{Howe 1994 \{published data only\}}

Howe PRC, Lungershausen YK, Cobiac L, Dandy G, Nestel PJ. Effect of sodium restriction and fish oil supplementation on $\mathrm{BP}$ and thrombotic risk factors in patients treated with ACE inhibitors. Journal of Human Hypertension 1994;8:43-9.

\section{Iwaoka 1994 \{published data only\}}

Iwaoka T, Umeda T, Inoue J, Naomi S, Sasaki M, Fujimoto Y, et al. Dietary $\mathrm{NaCl}$ restriction deteriorates oral glucose tolerance in hypertensive patients with impairment of glucose tolerance. American Journal of Hypertension 1994;7:460-3.

\section{Miller 1995 \{published data only\}}

Miller SB, Friese M, Sita A. Parental history of hypertension, sodium loading, and cardiovascular response to stress. Psychosomatic Medicine 1995;57:381-9.

\section{Fliser 1995 \{published data only\}}

Fliser D, Fode P, Arnold U, Nowicki M, Kohl B, Ritz E. The effect of dietary salt on insulin sensitivity. European Journal of Clinical Investigation 1995;25:39-43.

\section{Doig 1995 \{published data only\}}

Doig JK, MacFadyen RJ, Sweet CS, Reid JL. Haemodynamic and renal responses to oral losartan potassium during salt depletion or salt repletion in normal human volunteers. Journal of Cardiovascular Pharmacology 1995;25:511-7.

\section{Stein 1995 \{published data only\}}

Stein CM, Nelson R, Brown M, He H, Wood M, Wood AJ. Dietary sodium intake modulates systemic but not forearm norepinephrine release. Clinical Pharmacology and Therapeutics 1995;58:425-33.

\section{Arrol 1995 \{published data only\}}

Arroll B, Beaglehole R. Salt restriction and physical activity in treated hypertensives. New Zealand Medical Journal 1995;108:266-8.

\section{Draaijer 1995 \{published data only\}}

Draaijer P, De Leeuw P, Maessen J, Van Hooff J, Leunissen K. Salt-sensitivity testing in patients with borderline hypertension: Reproducibility and potential mechanisms. Journal of Human Hypertension 1995;9:263-9.

\section{Overlack 1995 \{published data only\}}

Overlack A, Ruppert M, Kolloch R, Kraft K, Stumpe KO. Age is a major determinant of the divergent blood pressure responses to varying salt intake in essential hypertension. American Journal of Hypertension 1995;8:829-36.

\section{Dubbert 1995 \{published data only\}}

Dubbert PM, Cushman WC, Meydrech EF. Rowland AK, Maury P. Effects of dietary instruction and sodium excretion feedback in hypertension clinic patients. Behavior Therapy 1995;26:721-32.

\section{Weir 1995 \{published data only\}}

Weir MR, Dengel DR, Behrens MT, Goldberg AP. Salt-induced increases in systolic blood pressure affect renal hemodynamics and proteinuria. Hypertension 1995;25:1339-44

\section{Grey 1996 \{published data only\}}

Grey A, Braatvedt G, Holdaway I. Moderate dietary salt restriction does not alter insulin resistance or serum lipids in normal men. American Journal of Hypertension 1996;9:317-22.

1126 Feldman 1996 \{published data only\}

Feldmann RD, Logan AG, Schmidt ND. Dietary salt restriction increases vascular insulin resistance. Clinical Pharmacology \& Therapeutics 1996;60(4):444-51.

1127 Feldman 1996 H \{published data only\}

Feldmann RD, Logan AG, Schmidt ND. Dietary salt restriction increases vascular insulin resistance. Clinical Pharmacology \& Therapeutics 1996;60(4):444-51.

\section{Schorr 1996 \{published data only\}}

Schorr U, Distler A, Sharma AM. Effect of sodium chloride- and sodium bicarbonate-rich mineral water on blood pressure and metabolic parameters in elderly normotensive individuals: a randomized double-blind crossover trial. Journal of Hypertension 1996;14:131-5.

\section{Bellini 1996 \{published data only\}}

Bellini C, Ferri C, Carlomagno A, Necozione S, Lepore A, Desideri $\mathrm{G}$, et al. Impaired inactive to active kallikrein conversion in human salt-sensitive hypertension. Journal of the American Society of Nephrology: JASN 1996;7:2565-77.

Effects of low sodium diet versus high sodium diet on blood pressure, renin, aldosterone, catecholamines, cholesterol, and triglyceride 
1130 Inoue 1996 \{published data only\}

Inoue J, Cappuccio FP, Sagnella GA, Markandu ND, Folkerd EJ, Sampson B, et al. Glucose load and renal sodium handling in mild essential hypertension on different sodium intakes. Journal of Human Hypertension 1996;10:523-9.

1131 Ferri 1996 \{published data only\}

Ferri C, Bellini C, Carlomagno A, Desideri G, Santucci A. Active kallikrein respons to changes in sodium-chloride intake in essential hypertensive patients. Journal of the American Society of Nephrology 1996;7(3):443-53.

\section{Ishimitsu 1996 A \{published data only\}}

Ishimitsu T, Nishikimi T, Matsuoka H, Kangawa K, Kitamura K, Minami J, et al. Behaviour of adrenomedullin during acute and chronic salt loading in normotensive and hypertensive subjects. Clinical Science 1996;91:293-8.

\section{Ishimitsu 1996 AH \{published data only\}}

Ishimitsu T, Nishikimi T, Matsuoka H, Kangawa K, Kitamura K, Minami J, et al. Behaviour of adrenomedullin during acute and chronic salt loading in normotensive and hypertensive subjects. Clinical Science 1996;91:293-8.

\section{Cappuccio 1997 \{published data only\}}

Cappuccio FP, Markandu ND, Carney C, Sagnella CA, MacGregor GA. Double-blind randomised trial of modest salt restriction in older people. Lancet 1997;350:850-4.

\section{TOHP II 1997 \{published data only\}}

The Trials of Hypertension Prevention Collaborative Group. Effects of weight loss and sodium reduction intervention on blood pressure and hypertension incidence in overweight people with high-normal blood pressure. The Trials of Hypertension Prevention, phase II. Archives of Internal Medicine 1997;157(6):657-67.

\section{6 van Buul 1997 \{published data only\}}

Van Buul BJA, Steegers EAP, van der Maten GD, Delemarre FMC, Jongsma HW, Oosterbaan HP, et al. Dietary sodium restriction does not prevent gestational hypertension; a Dutch two-center randomized trial. Hypertension in Pregnancy 1997;16:335-46.

\section{Schorr 1997 \{published data only\}}

Schorr U, Beige J, Ringel J, Turan S, Kreutz R, Distler A, et al. Hpa II polymorphism of the atrial natriuretic peptide gene and the blood pressure response to salt intake in normotensive men. Journal of Hypertension 1997;15:715-8.

\section{McCarron 1997 \{published data only\}}

McCarron DA, Weder AB, Egan BE, Krishna GG, Morris CD, Cohen $\mathrm{M}$, et al. Blood pressure and metabolic responses to moderate sodium restriction in isradipine treated hypertensive patients. American Journal of Hypertension 1997;10:68-76.

\section{Meland 1997 \{published data only\}}

Meland E, Laerum E, Aakvaag A, Ulvik RJ, Hostmark AT. Salt restriction: effects on lipids and insulin production in hypertensive patients. Scandinavian Journal of Clinical and Laboratory Investigation 1997;57:501-6.
1140 Fotherby 1997 \{published data only\}

Fotherby MD, Potter JF. Metabolic and orthostatic blood pressure responses to a low-sodium diet in elderly hypertensives. Journal of Human Hypertension 1997;11:361-6.

\section{Ferri 1998 \{published data only\}}

Ferri C, Bellini C, Desideri G, Giuliani E, De Siati L, Cicogna S, et al. Clustering of endothelial markers of vascular damage in human salt-sensitive hypertension: influence of dietary sodium load and depletion. Hypertension 1998;32:862-8.

\section{Knuist 1998 \{published data only\}}

Knuist M, Bonsel GJ, Zondervan HA, Treffers PE. Low sodium diet and pregnancy-induced hypertension: a multi-centre randomised controlled trial. British Journal of Obstetrics and Gynaecology 1998;105:430-4.

\section{Bech 1998 \{published data only\}}

Bech JN, Nielsen CB, Ivarsen P, Jensen KT, Pedersen EB. Dietary sodium affects systemic and renal hemodynamic response to NO inhibition in healthy humans. American Journal of Physiology 1998;274:914-23.

\section{Foo 1998 \{published data only\}}

Foo M, Denver AE, Coppack SW, Yudkin JS. Effect of salt-loading on blood pressure, insulin sensitivity and limb blood flowin normal subjects. Clinical Science (London) 1998;95:157-64.

\section{Wing 1998 \{published data only\}}

Wing LMH, Arnolda LF, Harvey PJ, Upton J, Molloy D, Gabb GM, et al. Low-dose diuretic and/or dieatary sodium restriction when blood pressure is resistant to ACE inhibitor. Blood Pressure 1998;7:299-307.

\section{Herlitz 1998 \{published data only\}}

Herlitz H, Dahlöf B, Jonsson O, Friberg P. Relationship between salt and blood pressure in hypertensive patients on chronic ACE-inhibition. Blood Pressure 1998;7(1):47-52.

\section{Feldman 1999 \{published data only\}}

Feldman RD, Schmidt ND. Moderate dietary salt restriction increases vascular and systemic insulin resistance. American Journal of Hypertension 1999;12:643-7.

\section{Damasceno 1999 \{published data only\}}

Damasceno A, Santos A, Serrao P, Caupers P, Soares-daSilva P, Polonia J. Deficiency of renal dopaminergic-dependent natriuretic response to acute sodium load in black salt-sensitive subjects in contrast to salt-resistant subjects. Journal of Hypertension 1999;17:1995-2001.

\section{Davrath 1999 \{published data only\}}

Davrath LR, Gotshall RW, Tucker A, Sadeh WZ, Luckasen GJ, Downes TR, et al. Moderate sodium restiction does not alter lower body negative pressure tolerance. Avation, Space, and Environmental Medicine 1999;70(6):577-82.

1150 Schorr 1999 \{published data only\}

Schorr U, Blaschke K, Beige J, Distler A, Sharma AM. Angiotensinogen M235T variant and salt sensitivity in

Effects of low sodium diet versus high sodium diet on blood pressure, renin, aldosterone, catecholamines, cholesterol, and triglyceride 
young normotensive Caucasians. Journal of Hypertension 1999;17:475-9.

\section{Uzu 1999 \{published data only\}}

Uzu T, Fujii T, Nishimura M, Kuroda S, Nakamura S, Inenaga T, et al. Determinats of circadian blood pressure rhythm in essential hypertension. American Journal of Hypertension 1999;12(1 Pt 1):35-9.

\section{Chiolero 2000 \{published data only\}}

Chiolero, A, Maillard, M, Nussberger, J, Brunner HR. Renal sodium handling in acute and chronic salt loading/depletion protocols: the confounding influence of acute water loading. Journal of Hypertension 2000;36:631-7.

\section{Bruun 2000 \{published data only\}}

Bruun NE, Dige-Pedersen H, Skott P. Normal responses of atrial natriuretic factor and renal tubular function to sodium loading in hypertension-prone humans. Blood Pressure 2000;9:206-13.

\section{Burnier 2000 \{published data only\}}

Burnier M, Monod M, Chiolero A, Maillard M, Nussberger J, Brunner HR. Renal sodium handling in acute and chronic salt loading/depletion protocols: the confounding influence of acute water loading. Journal of Hypertension 2000;18:1657-64.

\section{Heer 2000 \{published data only\}}

Heer M, Baisch F, Kropp J, Gerzer R, Drummer C. High dietary sodium chloride consumption may not induce body fluid retention in humans. American Journal of Physiology 2000;278:585-95.

\section{Barba 2000 \{published data only\}}

Barba G, Vallance PJ, Strazzullo P, MacAllister RJ. Effects of sodium intake on the pressor and renal responses to nitric oxide synthesis inhibition in normotensive individuals with different sodium sensitivity. Journal of Hypertension 2000;18:615-21.

\section{Boero 2000 \{published data only\}}

Boero R, Pignataro A, Bancale E, Campo A, Morelli E, Nigra M, et al. Metabolic effects of changes in dietary sodium intake in patients with essential hypertension [Effetti metabolici delle variazioni dell'apporto alimentare di sodio in pazienti con ipertensione essenziale]. Minerva Urologica e Nefrologica 2000;52:13-6.

\section{Suzuki 2000 \{published data only\}}

Suzuki M, Kimura Y, Tsushima M, Harano Y. Association of insulin resistance with salt sensitivity and nocturnal fall of blood pressure. Hypertension 2000;35:864-8.

\section{Ames 2001 \{published data only\}}

Ames R. The effect of sodium supplementation on glucose tolerance and insulin concentrations in patients with hypertension and diabetes mellitus. American Journal of Hypertension 2001;14:653-9.

\section{DASH 2001 W \{published data only\}}

Sacks F, Svetkey LP, Vollmer WM, Appel LJ, Bray GA, Harsha D, et al. Effects on blood pressure of reduced dietary sodium and the dietary approaches to stop hypertension (DASH) diet. New England Journal of Medicine 2001;344:3-10.

1161 DASH 2001 WH \{published data only\}

Sacks F, Svetkey LP, Vollmer WM, Appel LJ, Bray GA, Harsha D, et al. Effects on blood pressure of reduced dietary sodium and the dietary approaches to stop hypertension (DASH) diet. New England Journal of Medicine 2001;344:3-10.

\section{DASH 2001 B \{published data only\}}

Sacks F, Svetkey LP, Vollmer WM, Appel LJ, Bray GA, Harsha D, et al. Effects on blood pressure of reduced dietary sodium and the dietary approaches to stop hypertension (DASH) diet. New England Journal of Medicine 2001;344:3-10.

\section{DASH 2001 BH $\{$ published data only\}}

Sacks F, Svetkey LP, Vollmer WM, Appel LJ, Bray GA, Harsha D, et al. Effects on blood pressure of reduced dietary sodium and the dietary approaches to stop hypertension (DASH) diet. New England Journal of Medicine 2001;344:3-10.

\section{Cuzzola 2001 \{published data only\}}

Cuzzola F, Mallamaci F, Tripepi G, Parlongo S, Cutrupi S, Cataliotti A, et al. Urinary adrenomedullin is related to ET-1 and salt intake in patients with mild essential hypertension. American Journal of Hypertension 2001;14(3):224-30.

\section{Seals 2001 \{published data only\}}

Seals DR, Tanaka H, Clevenger CM, Monahan KD, Reiling MJ, Hiatt WR, et al. Blood pressure reductions with exercise and sodium restriction in postmenopausal women with elevated systolic pressure: role of arterial stiffness. Journal of the American College of Cardiology 2001;38:506-13.

\section{TONE $2001 \mathbf{W}$ \{published data only\}}

Appel LJ, Espeland MA, Easter L, Wilson AC, Folmar s, Lacy CR. Effects of reduced sodium intake on hypertension control in older individuals. Archives of Internal Medicine 2001;161:685-93.

\section{TONE 2001 B $\{$ published data only}

Appel LJ, Espeland MA, Easter L, Wilson AC, Folmar s, Lacy CR. Effects of reduced sodium intake on hypertension control in older individuals. Archives of Internal Medicine 2001;161:685-93.

\section{Johnson 2001 \{published data only\}}

Johnson AG, Nguyen TV, Davis D. Blood pressure is linked to salt intake and modulated by the angiotensinogen gene in normotensive and hypertensive elderly subjects. Journal of Hypertension 2001;19:1053-60.

\section{Manunta 2001 \{published data only\}}

Manunta P, Messaggio E, Ballabeni C, Sciarrone MT, Lanzani C, Ferrandi M, et al. Plasma ouabain-like factor during acute and chronic changes in sodium balance in essential hypertension. Plasma ouabain-like factor during acute and chronic changes in sodium balance in essential hypertension. Hypertension 2001;38:198-203.

\section{Kleij 2002 \{published data only\}}

van der Kleij FGH, de Jong PE, Henning RH, de Zeeuw D, Navis G. Enhanced responses of blood pressure, renal function,

Effects of low sodium diet versus high sodium diet on blood pressure, renin, aldosterone, catecholamines, cholesterol, and triglyceride 
and aldosterone to angiotensin I in the DD genotype are blunted by low sodium intake. Journal of the American Society of Nephrology 2002;13:1025-33.

\section{Kerstens 2003 \{published data only\}}

Kerstens MN, van der Kleij FG, Boonstra AH, Sluiter WJ, Koerts J, Navis G, et al. Salt loading affects cortisol metabolism in normotensive subjects: relationships with salt sensitivity. Journal of Clinical Endocrinology and Metabolism 2003;88(9):4180-5.

\section{Dishy 2003 \{published data only\}}

Dishy V, Sofowora GG, Imamura H, Nishimi Y, Xie HG, Wood AJ, et al. Nitric oxide production decreases after salt loading but is not related to blood pressure changes or nitric oxide-mediated vascular responses. Journal of Hypertension 2003;21:153-7.

\section{Nowson 2003 \{published data only\}}

Nowson CA, Morgan TO, Gibbons C. Decreasing dietary sodium while following a self-selected potassium-rich diet reduces blood pressure. Journal of Nutrition 2003;133:4118-23.

\section{Perry 2003 \{published data only\}}

Perry CG, Palmer T, Cleland SJ, Morton IJ, Salt IP, Petrie JR, et al. Decreased insulin sensitivity during dietary sodium restriction is not mediatedby effects of angiotensin II on insulin action. Clinical Science 2003;105:187-94.

\section{Nakamura 2003 A \{published data only\}}

Nakamura M, Aoki N, Yamada T, Kubo N. Feasibility and effect on blood pressure of 6-week trial of low sodium soy sauce and miso (fermented soybean paste). Circulation Journal 2003;67:530-4

\section{Palacios 2004 \{published data only\}}

Palacios C, Wigertz K, Martin BR, Jackman L, Pratt JH, Peacock M, et al. Sodium retention in black and white female adolescents in response to salt intake. Journal of Clinical Endocrinology \& Metabolism 2004;89:1858-63.

\section{Beeks 2004 \{published data only\}}

Beeks E, van der Klauw MM, Kroon AA, Spiering W, FussLejeune MJMJ, de Leeuw PW. Alpha-adducin Gly460Trp polymorphism and renal hemodynamics in essential hypertension. Hypertension 2004;44:419-23.

\section{Berge-Landry 2004 \{published data only\}} van Berge-Landry $H$, James, GD. Serum electrolyte, serum protein, serum fat and renal responses to a dietary sodium challenge: allostasis and allostatic load. Annals of Human Biology 2004;31:477-87.

\section{Gates 2004 \{published data only\}}

Gates PE, Tanaka H, Hiatt WR, Seals DR. Dietary sodium restriction rapidly improves large elastic artery compliance inolder adults with systolic hypertension. Hypertension 2004;44:35-41.

\section{Harsha 2004 \{published data only\}}

Harsha DW, Sacks FM, Obarzanek E, Svetkey LP, Lin P, Bray GA, et al. Effect of dietary sodium intake on blood lipids: results from the DASH-sodium trial. Hypertension 2004;43 (part 2):393-8.

\section{Zanchi 2004 \{published data only\}}

Zanchi A, Chiolero A, Maillard M, Nussberger J, Brunner HR, Burnier M. Effects of the peroxisomal proliferator-activated receptor-gamma agonist pioglitazone on renal and hormonal responses to salt in healthy men. Journal of Clinical Endocrinology \& Metabolism 2004;89:1140-5.

1186 Forrester $2005 \mathrm{~N}$ \{published data only\}

Forrester T, Adeyemo A, Soarres-Wynter S, Sargent L, Bennett F, Wilks $\mathrm{R}$, et al. A randomized trial on sodium reduction in two developing countries. Journal of Human Hypertension 2005;19:55-60.

\section{Forrester $2005 \mathrm{~J}\{$ published data only\}}

Forrester T, Adeyemo A, Soarres-Wynter S, Sargent L, Bennett F, Wilks $\mathrm{R}$, et al. A randomized trial on sodium reduction in two developing countries. Journal of Human Hypertension 2005;19:55-60.

\section{Swift 2005 \{published data only\}}

Swift P, Markandu N, Sagnella G, He F, MacGregor GA. Modest salt reduction reduces blood pressure and urine protein excretion in black hypertensives: a randomized control trial. Hypertension 2005;46:308-12.

\section{Damgaard 2006 \{published data only\}}

Damgaard M, Norsk P, Gustafsson F, Kanters JK, Christensen NJ, Bie $P$, et al. Hemodynamic and neuroendocrine responses to changes in sodium intake in compensated heart failure. American Journal of Physiology - Regulatory Integrative \& Comparative Physiology 2006;290:R1294-R1301.

1190 Takahashi 2006 \{published data only\}

Takahashi Y, Sasaki S, Okubo S, Hayashi M, Tsugane S. Blood pressure change in a free-living population-based dietary modificationstudy in Japan. Journal of Hypertension 2006;24:451-8.

\section{Melander 2007 \{published data only\}}

Melander O, von Wowern F, Frandsen E, Burri P, Willsteen G, Aurell $\mathrm{M}$, et al. Moderate salt restriction effectively lowers blood pressure and degree of salt sensitivity is related to baseline concentration of renin and $\mathrm{N}$-terminal atrial natriuretic peptide in plasma. Journal of Hypertension 2007;25:619-27.

\section{Townsend 2007 \{published data only\}}

Townsend RR, Kapoor S, McFadden CB. Salt intake and insulin sensitivity in healthy human volunteers. Clinical Science (London) 2007;113:141-8.

\section{Dengel 2007 \{published data only\}}

Dengel DR, Brown MD, Ferrell RE, Reynolds TH, Supiano MA. A preliminary study on T-786C endothelial nitric oxide synthase gene and renal hemodynamic and blood pressure responses to dietary sodium. Physiological Research 2007;56:393-401.

Effects of low sodium diet versus high sodium diet on blood pressure, renin, aldosterone, catecholamines, cholesterol, and triglyceride 
1194 Tzemos 2008 \{published data only\}

Tzemos N, Lim PO, Wong S, Struthers AD, MacDonald TM. Adverse cardiovascular effects of acute salt loading in young normotensive individuals. Hypertension 2008;51:1525-35.

\section{Jessani 2008 \{published data only\}}

Jessani S, Hatcher J, Chaturvedi N, Jafar TH. Effect of low vs. high dietary sodium on blood pressure levels in a normotensive Indo-Asian population. American Journal of Hypertension 2008;21:1238-44.

\section{Paulsen 2009 \{published data only\}}

Paulsen L, Holst LM, Bech JN, Starklint J, Pedersen EB. Glomerular filtration rate and blood pressure are unchanged by increased sodium intake in atorvastatin-treated healthy men. Scandinavian Journal of Clinical \& Laboratory Investigation 2009;69:323-9.

\section{Dickinson 2009 \{published data only\}}

Dickinson KM, Keogh JB, Clifton PM. Effects of a low-salt diet on flow-mediated dilatation in humans. American Journal of Clinical Nutrition 2009;89:485-90.

\section{He 2009 \{published data only\}}

He FJ, Marciniak M, Visagie E, Markandu ND, Anand V, Dalton RN, et al. Effect of modest salt reduction on blood pressure, urinary albumin, and pulse wave velocity in white, black, and Asian mild hypertensives. Hypertension 2009;54:482-8.

\section{Meland 2009 \{published data only\}}

Meland E, Aamland A. Salt restriction among hypertensive patients: modest blood pressure effect and no adverse effects. Scandinavian Journal of Primary Health Care 2009;27:97-103.

\section{Pimenta 2009 \{published data only\}}

Pimenta E, Gaddam KK, Oparil S, Aban I, Husain S, Dell'Italia LJ, et al. Effects of dietary sodium reduction on blood pressure in subjects with resistant hypertension: results from a randomized trial. Hypertension 2009;54:475-81.

\section{Nowson 2009 \{published data only\}}

Nowson CA, Wattanapenpaiboon N, Pachett A. Low-sodium Dietary Approaches to Stop Hypertension-type diet including lean red meat lowers blood pressure in postmenopausal women. Nutrition Research 2009;29:8-18.

\section{Weir 2010 \{published data only\}}

Weir MR, Yadao AM, Purkayastha D, Charney AN. Effects of highand low-sodium diets on ambulatory blood pressure in patients with hypertension receiving aliskiren. Journal of Cardiovascular Pharmacology and Therapeutics 2010;15:356-63.

\section{Starmans-Kool 2011 \{published data only\}}

Starmans-Kool MJ, Stanton AV, Xu YY, McG Thom SA, Parker KH, Hughes AD. High dietary salt intake increases carotid blood pressure and wave reflection in normotensive healthy young men. Journal of Applied Physiology 2011;110(2):468-71.

\section{Carey 2012 \{published data only\}}

Carey RM, Schoeffel CD, Gildea JJ, Jones JE, MCGrath HE, Gordon LN, et al. Salt sensitivity of blood pressure is associated with polymorphisms in thesodium-bicarbonate cotransporter. Hypertension 2012;60:1359-66.

1205 Carey 2012 Hyperpath \{published data only\}

Carey RM, Schoeffel CD, Gildea JJ, Jones JE, McGrath HE, Gordon LN, et al. Salt sensitivity of blood pressure is associated with polymorphisms in thesodium-bicarbonate cotransporter. Hypertension 2012;60:1359-66.

1206 Graffe 2012 \{published data only\}

Graffe CC, Bech JN, Pedersen EB. Effect of high and low sodium intake on urinary aquaporin-2 excretion in healthy humans. American Journal of Physiology. Renal Physiology. 2012;15(2):F264-75.

\section{Krikken 2012 \{published data only\}}

Krikken JA, Dallinga-Thie GM, Navis G, Dullaart RP. Short term dietary sodium restriction decreases HDL cholesterol, apolipoproteinA-I and high molecular weight adiponectin in healthy young men: relationshipswith renal hemodynamics and RAAS activation. Nutrition, Metabolism and Cardiovascular Diseases 2012;22(1):35-41.

\section{Todd 2012 \{published data only\}}

Todd AS, Macginley RJ, Schollum JB, Williams SM, Sutherland WH, Mann JI, et al. Dietary sodium loading in normotensive healthy volunteers does not increase arterial vascular reactivity or blood pressure. Nephrology 2012;17:249-56.

\section{Bonfils 2013 \{published data only\}}

Bonfils PK, Taskiran M, Damgaard M, Goetze JP, Floyd AK, Funch-Jensen $P$, et al. The influence of high versus low sodium intake on blood pressure andhaemodynamics in patients with morbid obesity. Journal of Hypertension 2013;31:2220-9.

\section{Mak 2013 \{published data only\}}

Mak GS, Sawaya H, Khan AM, Arora P, Martinez A, Ryan A, et al. Effects of subacute dietary salt intake and acute volume expansion on diastolic function in young normotensive individuals. European Heart Journal Cardiovascular Imaging 2013;14:1092-8.

\section{Mallamaci 2013 \{published data only\}}

Mallamaci F, Leonardis D, Pizzini P, Cutrupi S, Tripepi G, Zoccali C. Procalcitonin and the inflammatory response to salt in essential hypertension: a randomized cross-over clinical trial. Journal of Hypertension 2013;31:1424-30.

\section{Dickinson 2014 \{published data only\}}

Dickinson KM, Clifton PM, Burrell LM, Barrett PH, Keogh JB. Postprandial effects of a high salt meal on serum sodium, arterial stiffness, markers of nitric oxide production and markers of endothelial function. Atherosclerosis 2014;232:211-6.

\section{Allen 2014 \{published data only\}}

Allen AR, Gullixson LR, Wolhart SC, Kost SL, Schroeder DR, Eisenach JH. Dietary sodium influences the effect of mental stress on heart rate variability: a randomized trial in healthy adults. Journal of Hypertension 2014;32:374-82.

Effects of low sodium diet versus high sodium diet on blood pressure, renin, aldosterone, catecholamines, cholesterol, and triglyceride 


\section{Barros 2015 \{published data only\}}

Barros CL, Sousa AL, Chinem BM, Rodrigues RB, Jardim TS, Carneiro SB, et al. Impact of light salt substitution for regular salt on blood pressure of hypertensive patients. Arquivos Brasileiros de Cardiologia 2015;104(2):128-35.

1217 Markota 2015 \{published data only\}

Pinjuh Markota N, Rumboldt M, Rumboldt Z. Emphasized warning reduces salt intake: a randomized controlled trial. Journal of the American Society of Hypertension 2015;9:214-20.

\section{Visser 2008 \{published data only\}}

Visser FW, Boonstra AH, Titia Lely A, Boomsma F, Navis G. Renal response to angiotensin II is blunted in sodiumsensitive normotensive men. American Journal of Hypertension 2008;21:323-8.

\section{Sharma 31993 \{published data only\}}

Sharma AM, Schorr U, Distler A. Insulin resistance in young saltsensitive normotensive subjects. Hypertension 1993;21:273-9.

\section{Gomi 1998 \{published data only\}}

Gomi T, Shibuya Y, Sakurai J, Hirawa N, Hasegawa K, Ikeda T. Strict dietary sodium reduction worsens insulin sensitivity by increasingsympathetic nervous activity in patients with primary hypertension. American Journal of Hypertension 1998;11:1048-55.

\section{Facchini 1999 \{published data only\}}

Facchini FS, DoNascimento C, Reaven GM, Yip JW, Ni XP, Humphreys $\mathrm{MH}$. Blood pressure, sodium intake, insulin resistance, and urinary nitrate excretion. Hypertension 1999;33:1008-12.

\section{Pechere-Bertschi 2000 \{published data only\}}

Pechère-Bertschi A, Maillard M, Stalder H, Brunner HR, Burnier M. Blood pressure and renal haemodynamic response to salt during the normal menstrual cycle. Clinical Science (London) 2000;98:697-702.

\section{Pechère-Bertschi 2003 \{published data only\}}

Pechère-Bertschi $A$, Maillard $M$, Stalder $H$, Bischof $P$, Fathi $M$, Brunner HR, Burnier M. Renal hemodynamic and tubular responses to salt in women using oralcontraceptives. Kidney International 2003;64(4):1374-80.

\section{Ho 2007 \{published data only\}}

Ho JT, Keogh JB, Bornstein SR, Ehrhart-Bornstein M, Lewis JG, Clifton PM, et al. Moderate weight loss reduces renin and aldosterone but does not influence basalor stimulated pituitaryadrenal axis function. Hormone and Metabolic Research 2007;39(9):694-9.

\section{Gijsbers 2015 \{published data only\}}

Gijsbers L, Dower JI, Schalkwijk CG, Kusters YH, Bakker SJ, Hollman PC, et al. Effects of sodium and potassium supplementation on endothelial function: a fully controlled dietary intervention study. British Journal of Nutrition 2015;114:1419-26.
1226 Cavka 2015 \{published data only\}

Cavka A, Cosic A, Jukic I, Jelakovic B, Lombard JH, Phillips SA. The role of cyclo-oxygenase-1 in high-salt dietinducedmicrovascular dysfunction in humans. Journal of Physiology 2015;593(24):5313-24.

\section{McManus 2015 \{published data only\}}

McManus F, Fraser R, Davies E, Connell JMC, Freel EM. Plasma steroid profiling and response to trophins to illustrate intra-adrenal dynamics. Clinical Endocrinology (Oxford) 2015;82:149-57.

\section{References to studies excluded from this review}

Anderson 1990 \{published data only\}

Anderson A, Morgan T. Interaction of enalapril with sodium restriction, diuretics, and slow-channel calcium-blocking drugs. Nephron 1990;55((Suppl 1)):70-2.

Dodson 1989 \{published data only\}

Dodson PM, Beevers M, Hallworth R, Webberley MJ, Fletcher RF, Taylor KG. Sodium restriction and blood pressure in hypertensive type II diabetics: randomised blind controlled and crossover studies of moderate sodium restriction and sodium supplementation. BMJ 1989;298:227-30.

Imanishi 2001 \{published data only\}

Imanishi M, Yoshioka K, Okumura M, Konishi Y, Okada N, Morikawa T, et al. Sodium sensitivity related to albuminuria appearing before hypertension in type 2 diabetic patients. Diabetes Care 2001;24(1):111-6.

\section{Jula-Karanko 1992 \{published data only\}}

Jula AM, Rönnemaa T, Tikkanen I, Karanko HM. Responses of atrial natriuretic factor to long-term sodium restriction in mild to moderate hypertension. Journal of Internal Medicine 1992;231(5):521-9.

\section{Jula-Mäki 1992 \{published data only\}}

Jula AM, Rönnemaa T, Piha SJ, Måki JP. Response of diastolic blood pressure to long-term sodium restriction is posture related. Scandinavian Journal of Clinical and Laboratory Investigation 1992;52(3):159-67.

Miller 1997 \{published data only\} Miller JA. Renal responses to sodium restriction in patients with early diabetes mellitus. Journal of the American Society of Nephrology 1997;8(5):749-55.

\section{Mühlhauser 1996 \{published data only\}}

Mulhauser I, Prange K, Sawicki PT, Bender R, Dworschak A, Schaden W, et al. Effects of dietary sodium on blood pressure in IDDM patients with nephropathy. Diabetologia Diabetologia 1996;39:212-9.

\section{Palmer 1989 \{published data only\}}

Palmer RM, Osterweil D, Loon-Lustig G, Stern N. The effect of dietary salt ingestion on blood pressure of old-old subjects. A double-blind, placebo-controlled, crossover trial. Journal of the American Geriatrics Society 1989;37:931-6.

Effects of low sodium diet versus high sodium diet on blood pressure, renin, aldosterone, catecholamines, cholesterol, and triglyceride 
Parfrey 1981 \{published data only\}

Parfrey PS, Condon K, Wright P, Vandenburg MJ, Holly JM, Goodwin FJ, et al. Blood pressure and hormonal changes following alteration in dietary sodium and potassium in young men with and without a familial predisposition to hypertension. Lancet 1981;1:113-7.

\section{Ruppert 1991 \{published data only\}}

Ruppert M, Diehl J, Kolloch R, Overlack A, Kraft K, Göbel B, et al. Short term dietary sodium restriction increases serum lipids and insulin in salt-sensitive and salt-resistant normotensive adults. Klinische Wochenschrift 1991;69(suppl 25):51-7.

\section{Ruppert 1994 \{published data only\}}

Ruppert M, Overlack A, Kolloch R, Kraft K, Lennarz M, Stumpe KO. Effects of severe and moderate salt restriction on serum lipids in nonobese normotensive adults. American Journal of the Medical Sciences 1994;307(Suppl 1):S87-90.

\section{Steegers 1991 \{published data only\}}

Steegers EA, Van Lakwijk HP, Jongsma HW, Fast JH, De Boo T, Eskes TK, et al. (Patho)physiological implications of chronic dietary sodium restriction during pregnancy; a longitudinal prospective randomized study. British Journal of Obstetrics and Gynaecology 1991;98:980-7.

\section{Additional references}

\section{Aburto 2013}

Aburto NJ, Ziolkovska A, Hooper L, Elliott P, Cappuccio FP, Meerpohl JJ. Effect of lower sodium intake on health: systematic review and meta-analyses. BMJ 2013;346:f1326.

\section{ADG 2015}

US Department of Health and Human Services, US Department of Agriculture. 2015-2020 DietaryGuidelines for Americans. 8th ed.Washington, DC: http://www.health.gov/DietaryGuidelines. Accessed December 16, 20152015.

\section{Adler 2014}

Adler AJ, Taylor F, Martin N, Gottlieb S, Taylor RS, Ebrahim S. Reduced dietary salt for the prevention of cardiovascular disease. Cochrane Database of Systematic Reviews 2014, Issue 12. [DOI: 10.1002/14651858.CD009217.pub3]

\section{Alderman 1998}

Alderman $\mathrm{MH}$, Cohen $\mathrm{H}$, Madhavan S. Dietary sodium intake andmortality: the National Health and Nutrition Examination Survey (NHANES I). Lancet 1998;351:781-5.

\section{Alderman 2010}

Alderman $\mathrm{MH}$. Reducing dietary sodium: the case for caution. JAMA 2010;303(5):448-9.

\section{Ambard 1904}

Ambard L, Beaujard E. Causes of arterial hypertension [Causes de l'hypertension artérielle]. Archives of General Medicine 1904;81:520-33.

\section{Bayer 2012}

Bayer R, Johns DM, Galea S. Salt and public health: contested science and the challenge of evidence-based decision making. Health Affairs 2012;31(12):2738-46.

\section{Brunner 1972}

Brunner HR, Laragh JH, Baer L, Newton MA, Goodwin FT, Krakoff LR, et al. Essential hypertension: renin and aldosterone, heart attack and stroke. New England Journal of Medicine 1972;286(9):441-9.

\section{Brunström 2016}

Brunström M, Carlberg B. Effect of antihypertensive treatment at different blood pressure levels in patients with diabetes mellitus: systematic review and meta-analyses. $B M J$ 2016;352:i717.

\section{Chapman 1949}

Chapmann CP, Gibbons TB. The diet and hypertension. A review. Medicine 1949;29:29-69.

\section{Cobb 2014}

Cobb LK, Anderson CA, Elliott P, Hu FB, Liu K, Neaton JD, et al. American Heart Association Council on Lifestyle and Metabolic Health. Methodological issues in cohort studies that relate sodium intake to cardiovascular disease outcomes: a science advisory from the American Heart Association. Circulation 2014;129(10):1173-86.

\section{Cohen 2006}

Cohen HW, Hailpern SM, Fang J, Alderman MH. Sodium intake and mortality in the NHANES II follow-up study. American Journal of Medicine 2006;119(3):275.e7-14.

\section{Cohen 2008}

Cohen HW, Hailpern SM, Alderman MH. Sodium intake and mortality follow-up in the Third National Health and Nutrition Examination Survey (NHANES III). Jornal of General Internal Medicine 2008;23(9):1297-1302.

\section{Collins 1990}

Collins R, Peto R, MacMahon S, Hebert P, Fiebach NH, Eberlein KA, Godwin J, et al. Blood pressure, stroke and coronary heart disease. Part 2, short term reductions in blood pressure; overview of randomised drug trials in their epidemiological context. Lancet 1990;335(8693):827-38.

\section{Cutler 1991}

Cutler JA, Follmann D, Elliot P, Suh I. An overveiw of randomised trials of sodium reduction and blood pressure. Hypertension 1991;17 (suppl 1):127-33.

\section{Cutler 1997}

Cutler JA, Follmann D, Allender PS. Randomized trials of sodium reduction: an overview. American Journal of Clinical Nutrition 1997;65(2 Suppl):643S-651S

\section{DASH 2001}

Sacks F, Svetkey LP, Vollmer WM, Appel LJ, Bray GA, Harsha D, et al. Effects on blood pressure of reduced dietary sodium and

Effects of low sodium diet versus high sodium diet on blood pressure, renin, aldosterone, catecholamines, cholesterol, and triglyceride 
the dietary approaches to stop hypertension (DASH) diet. New England Journal of Medicine 2001;344:3-10.

\section{Ebrahim 1998}

Ebrahim S, Smith GD. Lowering blood pressure: a systematic review of sustained effects of non-pharmacological interventions. Journal of Public Health Medicine 1998;20(4):441-8.

\section{Folkow 2011}

Folkow B. On bias in medical research; reflections on present salt-cholesterol controversies. Scandinavian Cardiovascular Journal 2011;45(4):194-7.

\section{Freedman 2001}

Freedman DA, Petitti DB. Salt and blood pressure: conventional wisdom reconsidered. Evaluation Review 2001;25(3):267-87.

\section{Frieden TR 2016}

Frieden TR. Sodium reduction-saving lives by putting choice into consumers hands. JAMA 2016;316(6):579-80.

\section{Gardener 2012}

Gardener H, Rundek T, Wright CB, Elkind MS, Sacco RL. Dietary sodium and risk of stroke in the Northern Manhattan study. Stroke 2012;43:1200-5.

\section{Geerling 2008}

Geerling JC, Loewy AD. Central regulation of sodium appetite. Experimental Physiology 2008;93(2):177-209.

\section{Gelijnse 2007}

Geleijnse JM, Witteman JC, Stijnen T, Kloos MW, Hofman A, Grobbee DE. Sodium and potassium intake and risk of cardiovascular eventsand all-cause mortality: the Rotterdam Study. European Journal of Epidemiology 2007;22(11):763-70.

\section{Goff 2001}

Goff DC, Howard G, Russel GB, Labarthe DR. Birth cohort evidence of population influences on blood pressure in the United states 1887-1994. Annals of Epidemiology 2001;11(4):271-9.

\section{Graudal (1) 2016}

Graudal N. A radical sodium reduction policy is not supported by randomized controlled trials or observational studies: grading the evidence. American Journal of Hypertension 2016;Jan 27 Epub ahead of print:1-6.

\section{Graudal (2) 2016}

Graudal NA, Hubeck-Graudal T, Jürgens G. Reduced dietary sodium intake increases heart rate. a meta-analysis of 63 randomized controlled trials including 72 study populations. Front Physiology 2016;7:111.

\section{Graudal (3) 2016}

Graudal N. Con: Reducing salt intake at the population level: is it really a public health priority?. Nephrology Dialysis Transplantation 2016;pii: gfw280. [Epub ahead of print]:1-6.

\section{Graudal 2005}

Graudal N. Commentary: Possible role of salt intake in the development of essential hypertension. International Journal of Epidemiology 2005;34(5):972-4.

\section{Graudal 2014}

Graudal N, Jürgens G, Baslund B, Alderman MH. Compared with usual sodium intake, low- and excessive-sodium diets are associated with increased mortality: a meta-analysis. American Journal of Hypertension 2014;27:1129-37.

\section{Graudal 2015}

Graudal NA, Hubeck-Graudal T, Jurgens G, McCarron DA. The significance of duration and dose of sodium reduction intervention in normotensive and hypertensive individuals. A meta-analysis. Advances in Nutrition 2015;6(2):169-77.

\section{Graudal 2015b}

Graudal N, Jürgens $\mathrm{G}$. The blood pressure sensitivity to changes in sodium intake is similar in Asians, Blacks and Whites. An analysis of 92 randomized controlled trials. Front Physiology 2015;6:157

\section{Grobbee 1986}

Grobbee DE, Hofman A. Does sodium restriction lower blood pressure?. BMJ 1986;293:27-9.

\section{Gunn 2013}

Gunn JP, Barron JL, Bowman BA, Merritt RK, Cogswell ME, Angell SY, et al. Sodium reduction is a public health priority: reflections on the Institute of Medicine's report, sodium intake in populations: assessment of evidence. American Journal of Hypertension 2013;26(10):1178-80.

\section{He 1999}

He J, Ogden LG, Bazzano LA, Vupputuri S, Loria C, Whelton PK. Dietary sodium intake and incidence of congestive heart failure in overweight US men and women: first National Health and Nutrition Examination Survey Epidemiologic Follow-up Study. Archives of Internal Medicine 2002;162:1619-24.

\section{Heaney 2013}

Heaney RP. Sodium: how and how not to set a nutrient intake recommendation. American Journal of Hypertension 2013;26:1194-7.

\section{Ho 2014}

Ho JE, Larson MG, Ghorbani A, Cheng S, Coglianese EE, Vasan RS, et al. Long-term cardiovascular risks associated with an elevated heart rate: theFramingham Heart Study [2014 May 8;3(3):e000668. doi: 10.1161/JAHA.113.000668.]. Journal of the American Heart Association 2014;3(3):e000668.

\section{Hooper 2002}

Hooper L, Bartlett C, Smith GD, Ebrahim S. Systematic review of long term effects of advice to reduce dietary salt in adults. $B M J$ 2002;325:628-35

\section{Intersalt 1988}

Intersalt Cooperative Research Group. Intersalt: an international study of electrolyte excretion and blood pressure.

Effects of low sodium diet versus high sodium diet on blood pressure, renin, aldosterone, catecholamines, cholesterol, and triglyceride 
Results for 24 hour urinary sodium and potassium excretion. BMJ 1988;297(6644):319-28.

\section{IOM 2005}

Institute of Medicine. Dietary Reference Intakes: Water, Potassium, Sodium, Chloride, and Sulfate. Washington DC: National Academies Press, 2005.

\section{IOM 2006}

Institute of Medicine. Dietary Reference Intakes: Essential Guide to Nutrient Requirements. Washington DC: National Academies Press, 2006.

\section{IOM 2013}

Institute of Medicine. Sodium Intake in Populations: Assessment of Evidence. Washington DC: National Academies Press, 2013.

\section{Jensen 2012}

Jensen MT, Marott JL, Allin KH, Nordestgaard BG, Jensen GB. Resting heart rate is associated with cardiovascular and allcause mortality after adjusting for inflammatory markers: the Copenhagen City Heart Study. European Journal of Preventive Cardiology 2012;19(1):102-8.

\section{Kagan 1985}

Kagan A, Popper JS, Rhoads GG, Yano K. Dietary and other risk factorsfor stroke in Hawaiian Japanese men. Stroke 1985;16:390-6.

\section{Law 1991}

Law M, Frost CD, Wald NJ. . By how much does dietary salt reduction lower blood pressure? III--Analysis of data from trials of salt reduction.. BMJ 1991;302:819-24.

\section{Löwenstein 1907}

Löwenstein C. No English title [Über Beziehungen zwischen Kochsalzhaushalt und Blutdruck bei Nierenkranken]. Archiv für Experimentelle Pathologie und Pharmakologie 1907;57(1):13761.

\section{McCarron 2013}

McCarron DA, Kazaks AG, Geerling JC, Stern JS, Graudal NA. Normal range of human dietary sodium intake: a perspective based on 24-hour urinary sodium excretion worldwide. American Journal of Hypertension 2013;26:1218-23.

\section{Mente 2016}

Mente A, O'Donnell M, Rangarajan S, Dagenais G, Lear S, McQueen $M$, et al. PURE, EPIDREAM and ONTARGET/ TRANSCEND Investigators. Associations of urinary sodium excretion with cardiovascular events in individuals with and without hypertension: a pooled analysis of data from four studies. Lancet 2016;388:465-75.

\section{Midgley 1996}

Midgley JP, Matthew AG, Greenwood CMT, Logan AG. Effect of reduced dietary sodium on blood pressure. A meta-analysis of randomised controlled trials. JAMA 1996;275:1590-7.

\section{O'Donnell 2011}

O'Donnell MJ, Yusuf S, Mente A, Gao P, Mann JF, Teo K, et al. Urinary sodium and potassium excretion and risk of cardiovascular events. JAMA. 2011;306:2229-38.

\section{O'Donnell 2014}

O'Donnell M, Mente A, Rangarajan S, McQueen MJ, Wang X, Liu L, et al. PURE Investigators. Urinary sodium and potassium excretion, mortality, and cardiovascular events. New England Journal of Medicine 2014;371(7):612-23.

\section{Oliver 1975}

Oliver JW, Cohen EL, Neel JV. Blood pressure, sodium intake, and sodium related hormones in the Yanomamo indians, a "nosalt" culture. Circulation 1975;52:146-51.

\section{Palmer 2008}

Palmer BF, Alpern RJ, Seldin DW. Physiology and pathophysiology of sodium retention and wastage. In: Alpern RJ, Hebert SC editor(s). Seldin and Giebisch's The Kidney. 4th Edition. Amsterdam: Elsevier, Academic Press, 2008:1005-49.

\section{Pfister 2014}

PfisterR, Michels G, Sharp SJ, Luben R, Wareham NJ, Khaw KT. Estimated urinary sodium excretion and risk of heart failure in men and women in the EPIC-Norfolk study. European Journal of Heart Failure 2014;16:394-402.

\section{Powles 2013}

Powles J, Fahimi S, Micha R, Khatibzadeh S, Shi P, Ezzati M, et al. Global, regional and national sodium intakesin 1990 and 2010: a systematic analysis of $24 \mathrm{~h}$ urinary sodium excretion and dietary surveys worldwide. BMJ Open 2013;3:e003733.

\section{Stolarz-Skrzypek 2011}

Stolarz-Skrzypek K, Kuznetsova T, Thijs L, Tikhonoff V, Seidlerová J, Richart T, et al. European Project on Genesin Hypertension (EPOGH) Investigators. Fatal and nonfatal outcomes, incidence of hypertension, and blood pressure changes in relation tourinary sodium excretion. JAMA 2011;305:1777-85.

\section{Strazzulo 2009}

Strazzullo P, D'Elia L, Kandala NB, Cappuccio FP. Salt intake, stroke, and cardiovascular disease: meta-analysis of prospective studies. BMJ 2009;339:b4567.

\section{Taubes 1998}

Taubes G. The (political) science of salt. Science 1998;281:898-907.

\section{Thomas 2011}

Thomas MC, Moran J, Forsblom C, Harjutsalo V, Thorn L, Ahola A, et al. FinnDiane Study Group. The association between dietary sodium intake, ESRD, and all-cause mortality inpatients with type 1 diabetes. Diabetes Care 2011;34:861-6.

\section{Tozawa 2002}

Tozawa M, Iseki K, Iseki C, Oshiro S, Yamazato M, Higashiuesato $\mathrm{Y}$, et al. Evidence for elevated pulse pressure in

Effects of low sodium diet versus high sodium diet on blood pressure, renin, aldosterone, catecholamines, cholesterol, and triglyceride 
patients on chronic hemodialysis: acase-control study. Kidney International 2002;62:2195-201.

\section{Tuomilehto 2001}

Tuomilehto J, Jousilahti P, Rastenyte D, Moltchanov V, Tanskanen A, Pietinen $P$, et al. Urinary sodium excretion and cardiovascularmortality in Finland: a prospective study. Lancet 2001;357:848-51.

\section{Warren 1980}

Warren SE, Vieweg WVR, O'Connor DT. Sympathetic nervous system activity during sodium restriction in essential hypertension. Clinical Cardiology 1980;3:348-51.

\section{Whelton 2012}

Whelton PK, Appel LJ, Sacco RL, Anderson CA, Antman EM, Campbell N, et al. Sodium, blood pressure, and cardiovascular disease: further evidence supporting the American HeartAssociation sodium reduction recommendations. Circulation 2012;126(24):1280-9.

\section{WHO 2012}

WHO. Sodium Intake for Adults and Children. Geneva: WHO, 2012.

\section{Wiysonge 2012}

Wiysonge CS, Bradley HA, Volmink J, Mayosi BM, Mbewu A, Opie LH. Beta-blockers for hypertension. Cochrane Database of Systematic Reviews 2012, Issue 11. [DOI: 10.1002/14651858.CD002003.pub4]

\section{Wright 2011}

Wright JD, Hughes, JP, Ostchega Y, Yoon SS, Nwankwo T. Mean systolic and diastolic blood pressure in adults aged 18 and

\section{CHARACTERISTICS OF STUDIES}

Characteristics of included studies [ordered by study ID] over in the United States, 2001-2008. National Health Statistics Report 2011;35:1-24.

\section{Yang 2011}

Yang Q, Liu T, Kuklina EV, Flanders WD, Hong Y, Gillespie C, et al. Sodium and potassium intake and mortality among US adults: prospective data from the Third National Health and Nutrition Examination Survey. Archives of Internal Medicine 2011;171:1183-91.

\section{References to other published versions of this review Graudal 1998}

Graudal, NA, Galløe, AM, Garred, P. Effects of sodium restriction on blood pressure, renin, aldosterone, catecholamines, cholesterols, and triglyceride. JAMA 1998;279(17):1383-91.

\section{Graudal 2011}

Graudal N, Hubeck-Graudal T, Jürgens G. Effects of low sodium diet versus high sodium diet on blood pressure, renin, aldosterone, catecholamines, cholesterol, and triglyceride. Cochrane Database of Systematic Reviews 2011, Issue 11. [DOI: 10.1002/14651858.CD004022.pub3]

\section{Jürgens 2003}

Jürgens $G$, Graudal NA. Effects of low sodium diet versus high sodium diet on blood pressure, renin, aldosterone, catecholamines, cholesterols, and triglyceride. Cochrane Database of Systematic Reviews 2003, Issue 1. [DOI: 10.1002/14651858.CD004022.pub2]

* Indicates the major publication for the study

1000 Parijs 1973

\begin{tabular}{ll}
\hline Methods & Op \\
& CO \\
\hline Participants & N 17 (22) \\
& Hyp \\
& Age 41 \\
\hline Interventions & SR 98 \\
& Dur 28 \\
\hline Outcomes & SBP \\
& DBP \\
\hline Notes & LoFo: 5 \\
& IT: No
\end{tabular}

\section{Risk of bias}

Bias Authors' judgement Support for judgement

Effects of low sodium diet versus high sodium diet on blood pressure, renin, aldosterone, catecholamines, cholesterol, and triglyceride 
1000 Parijs 1973 (Continued)

Random sequence genera- High risk $\quad$ Each patient received a number
tion (selection bias)

Allocation concealment High risk
(selection bias)

(selection bias)

\begin{tabular}{lll}
\hline Blinding (performance & High risk & Open study \\
bias and detection bias) & & \\
All outcomes &
\end{tabular}

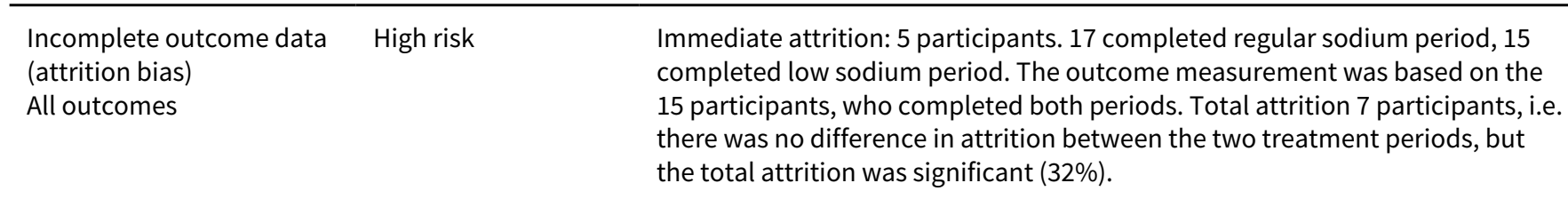

\begin{tabular}{lll}
\hline $\begin{array}{l}\text { Selective reporting (re- } \\
\text { porting bias) }\end{array}$ & Low risk & No distinct selective outcome reporting \\
\hline $\begin{array}{l}\text { Blinding of participants } \\
\text { and personnel (perfor- } \\
\text { mance bias) } \\
\text { All outcomes }\end{array}$ & High risk & $\begin{array}{l}\text { Open study: Performance bias due to knowledge of the allocated interventions } \\
\text { by participants and personnel during the study. }\end{array}$ \\
\hline $\begin{array}{l}\text { Blinding of outcome as- } \\
\text { sessment (detection bias) } \\
\text { All outcomes }\end{array}$ & High risk & $\begin{array}{l}\text { Open study: Detection bias due to knowledge of the allocated interventions by } \\
\text { outcome assessors }\end{array}$ \\
\hline
\end{tabular}

\section{Mark 1975}

\begin{tabular}{ll}
\hline Methods & Op \\
& CO \\
\hline Participants & N 6 \\
& Hyp \\
& Age 28 \\
\hline Interventions & SR 305 \\
& Dur 10 \\
\hline Outcomes & SBP \\
& DBP \\
Renin \\
\hline Notes & LoFo: 0 \\
\hline
\end{tabular}

\section{Risk of bias}

\begin{tabular}{lll}
\hline Bias & Authors' judgement & Support for judgement \\
\hline $\begin{array}{l}\text { Random sequence genera- } \\
\text { tion (selection bias) }\end{array}$ & Unclear risk & Insufficient information \\
\hline
\end{tabular}

Effects of low sodium diet versus high sodium diet on blood pressure, renin, aldosterone, catecholamines, cholesterol, and triglyceride 


\section{Mark 1975 (Continued)

Allocation concealment Unclear risk Insufficient information
(selection bias)

\begin{tabular}{lll}
\hline Blinding (performance & High risk & Open study \\
bias and detection bias) & & \\
All outcomes &
\end{tabular}

\begin{tabular}{|c|c|c|}
\hline $\begin{array}{l}\text { Incomplete outcome data } \\
\text { (attrition bias) } \\
\text { All outcomes }\end{array}$ & Low risk & Lost to follow-up 0 \\
\hline $\begin{array}{l}\text { Selective reporting (re- } \\
\text { porting bias) }\end{array}$ & Low risk & No distinct selective outcome reporting \\
\hline $\begin{array}{l}\text { Blinding of participants } \\
\text { and personnel (perfor- } \\
\text { mance bias) } \\
\text { All outcomes }\end{array}$ & High risk & $\begin{array}{l}\text { Open study: Performance bias due to knowledge of the allocated interventions } \\
\text { by participants and personnel during the study. }\end{array}$ \\
\hline $\begin{array}{l}\text { Blinding of outcome as- } \\
\text { sessment (detection bias) } \\
\text { All outcomes }\end{array}$ & High risk & $\begin{array}{l}\text { Open study: Performance bias due to knowledge of the allocated interventions } \\
\text { by participants and personnel during the study. }\end{array}$ \\
\hline
\end{tabular}

\section{Morgan 1978}

\begin{tabular}{ll}
\hline Methods & SB \\
& P \\
\hline Participants & $\begin{array}{l}\text { N 62, M/F:62/0 } \\
\text { Hyp } 60 \\
\text { Age } 60\end{array}$ \\
\hline Interventions & SR 23 \\
& Dur 90 \\
\hline Outcomes & SBP \\
& DBP \\
\hline Notes & LoFO: 3 \\
& IT: No \\
\hline
\end{tabular}

\section{Risk of bias}

\section{Bias}

Random sequence generation (selection bias)

\begin{tabular}{lll}
\hline $\begin{array}{l}\text { Allocation concealment } \\
\text { (selection bias) }\end{array}$ & Unclear risk & Insufficient information \\
\hline $\begin{array}{l}\text { Blinding (performance } \\
\text { bias and detection bias) }\end{array}$ & High risk & Open study \\
All outcomes & & \\
\hline
\end{tabular}

Effects of low sodium diet versus high sodium diet on blood pressure, renin, aldosterone, catecholamines, cholesterol, and triglyceride

\section{Authors' judgement Support for judgement}

Unclear risk Insufficient information

(Review)

Copyright ( 2017 The Cochrane Collaboration. Published by John Wiley \& Sons, Ltd. 
1002 Morgan 1978 (Continued)

Incomplete outcome data Low risk Lost to follow-up 3/62
(attrition bias)
All outcomes

\begin{tabular}{|c|c|c|}
\hline $\begin{array}{l}\text { Selective reporting (re- } \\
\text { porting bias) }\end{array}$ & Low risk & No distinct selective outcome reporting \\
\hline $\begin{array}{l}\text { Blinding of participants } \\
\text { and personnel (perfor- } \\
\text { mance bias) } \\
\text { All outcomes }\end{array}$ & High risk & $\begin{array}{l}\text { Open study: Performance bias due to knowledge of the allocated interventions } \\
\text { by participants and personnel during the study. }\end{array}$ \\
\hline $\begin{array}{l}\text { Blinding of outcome as- } \\
\text { sessment (detection bias) } \\
\text { All outcomes }\end{array}$ & Low risk & Outcome detection blinded \\
\hline
\end{tabular}

1003 Sullivan 1980

\begin{tabular}{ll}
\hline Methods & S \\
& CO \\
\hline Participants & N 27 \\
& Norm \\
& Age 29 \\
\hline Interventions & SR 146 \\
& Dur 4 \\
\hline Outcomes & SBP \\
& DBP \\
& Aldo \\
Renin
\end{tabular}

\section{Risk of bias}

\begin{tabular}{lll}
\hline Bias & Authors' judgement & Support for judgement \\
\hline $\begin{array}{l}\text { Random sequence genera- } \\
\text { tion (selection bias) }\end{array}$ & Unclear risk & Insufficient information \\
\hline $\begin{array}{l}\text { Allocation concealment } \\
\text { (selection bias) }\end{array}$ & High risk & $\begin{array}{l}\text { Only the 10 first participants received the high and low salt diets in random or- } \\
\text { der until it was established that the order of administration did not appear to } \\
\text { make a difference in the results }\end{array}$ \\
\hline $\begin{array}{l}\text { Blinding (performance } \\
\text { bias and detection bias) }\end{array}$ & High risk & Open study \\
\hline $\begin{array}{l}\text { All outcomes } \\
\text { (attrition bias) } \\
\text { All outcomes }\end{array}$ & Low to follow-up 0 \\
\hline
\end{tabular}


1003 Sullivan 1980 (Continued)

Selective reporting (re- Low risk No distinct selective outcome reporting
porting bias)

Blinding of participants High risk and personnel (performance bias)

All outcomes
Open study: Performance bias due to knowledge of the allocated interventions by participants and personnel during the study.

\begin{tabular}{|c|c|c|}
\hline $\begin{array}{l}\text { Blinding of outcome as- } \\
\text { sessment (detection bias) }\end{array}$ & Low risk & $\begin{array}{l}\text { Measurements were mad by } 2 \text { observers who were not aware of the partici- } \\
\text { pant's dietary state }\end{array}$ \\
\hline
\end{tabular}

All outcomes

1004 Sullivan $1980 \mathrm{H}$

Methods $\quad$ OP

\begin{tabular}{ll}
\hline Participants & N 19 \\
& Hyp \\
& Age27 \\
\hline Interventions & SR153 \\
& Dur4 \\
\hline \multirow{2}{*}{ Outcomes } & SBP \\
& DBP \\
& Aldo \\
& Renin \\
\hline Notes & LoFo: 0 \\
\hline
\end{tabular}

\section{Risk of bias}

\begin{tabular}{|c|c|c|}
\hline Bias & Authors' judgement & Support for judgement \\
\hline $\begin{array}{l}\text { Random sequence genera- } \\
\text { tion (selection bias) }\end{array}$ & Unclear risk & Insufficient information \\
\hline $\begin{array}{l}\text { Allocation concealment } \\
\text { (selection bias) }\end{array}$ & High risk & $\begin{array}{l}\text { Only the } 10 \text { first participants received the high-and low-salt diets in random } \\
\text { order until it was established that the order of administration did not appear } \\
\text { to make a difference in the results }\end{array}$ \\
\hline $\begin{array}{l}\text { Blinding (performance } \\
\text { bias and detection bias) } \\
\text { All outcomes }\end{array}$ & High risk & Open study \\
\hline $\begin{array}{l}\text { Incomplete outcome data } \\
\text { (attrition bias) } \\
\text { All outcomes }\end{array}$ & Low risk & Lost to follow-up 0 \\
\hline $\begin{array}{l}\text { Selective reporting (re- } \\
\text { porting bias) }\end{array}$ & Low risk & No distinct selective outcome reporting \\
\hline $\begin{array}{l}\text { Blinding of participants } \\
\text { and personnel (perfor- } \\
\text { mance bias) }\end{array}$ & High risk & $\begin{array}{l}\text { Open study: Performance bias due to knowledge of the allocated interventions } \\
\text { by participants and personnel during the study. }\end{array}$ \\
\hline
\end{tabular}

Effects of low sodium diet versus high sodium diet on blood pressure, renin, aldosterone, catecholamines, cholesterol, and triglyceride 
1004 Sullivan $1980 \mathrm{H}$ (Continued)

All outcomes

\begin{tabular}{|c|c|c|}
\hline $\begin{array}{l}\text { Blinding of outcome as- } \\
\text { sessment (detection bias) }\end{array}$ & Low risk & $\begin{array}{l}\text { Measurements were mad by } 2 \text { observers who were not aware of the participant } \\
\text { 's dietary state }\end{array}$ \\
\hline
\end{tabular}

All outcomes

1005 Rankin 1981

\begin{tabular}{ll}
\hline Methods & Op \\
& CO \\
\hline Participants & $\begin{array}{l}\text { N 8 (M/F:8/0) } \\
\text { Normotension } \\
\text { Age } 30\end{array}$ \\
\hline Interventions & SR $776(796-20)$ \\
& Dur 6 \\
\hline Outcomes & MAP, NE \\
\hline Notes & LoFo: 0 \\
\hline
\end{tabular}

\section{Risk of bias}

\begin{tabular}{|c|c|c|}
\hline Bias & Authors' judgement & Support for judgement \\
\hline $\begin{array}{l}\text { Random sequence genera- } \\
\text { tion (selection bias) }\end{array}$ & Unclear risk & Insufficient information \\
\hline $\begin{array}{l}\text { Allocation concealment } \\
\text { (selection bias) }\end{array}$ & Unclear risk & Insufficient information \\
\hline $\begin{array}{l}\text { Blinding (performance } \\
\text { bias and detection bias) } \\
\text { All outcomes }\end{array}$ & High risk & Open study \\
\hline $\begin{array}{l}\text { Incomplete outcome data } \\
\text { (attrition bias) } \\
\text { All outcomes }\end{array}$ & Low risk & Lost to follow-up 0 \\
\hline $\begin{array}{l}\text { Selective reporting (re- } \\
\text { porting bias) }\end{array}$ & Low risk & No distinct selective outcome reporting \\
\hline $\begin{array}{l}\text { Blinding of participants } \\
\text { and personnel (perfor- } \\
\text { mance bias) } \\
\text { All outcomes }\end{array}$ & High risk & $\begin{array}{l}\text { Open study: Performance bias due to knowledge of the allocated interventions } \\
\text { by participants and personnel during the study. }\end{array}$ \\
\hline $\begin{array}{l}\text { Blinding of outcome as- } \\
\text { sessment (detection bias) } \\
\text { All outcomes }\end{array}$ & High risk & $\begin{array}{l}\text { Open study: Detection bias due to knowledge of the allocated interventions by } \\
\text { outcome assessors }\end{array}$ \\
\hline
\end{tabular}


1006 Skrabal 1981

\begin{tabular}{ll}
\hline Methods & Op \\
& CO \\
\hline Participants & N 20 \\
& Norm \\
& Age 23 \\
\hline Interventions & SR 150 \\
& Dur 14 \\
\hline Outcomes & SBP \\
& DBP \\
& Aldo \\
Renin \\
NA \\
A \\
\hline Notes & LoFo:0
\end{tabular}

\section{Risk of bias}

\begin{tabular}{|c|c|c|}
\hline Bias & Authors' judgement & Support for judgement \\
\hline $\begin{array}{l}\text { Random sequence genera- } \\
\text { tion (selection bias) }\end{array}$ & Unclear risk & Insufficient information \\
\hline $\begin{array}{l}\text { Allocation concealment } \\
\text { (selection bias) }\end{array}$ & Unclear risk & Insufficient information \\
\hline $\begin{array}{l}\text { Blinding (performance } \\
\text { bias and detection bias) } \\
\text { All outcomes }\end{array}$ & High risk & Open study \\
\hline $\begin{array}{l}\text { Incomplete outcome data } \\
\text { (attrition bias) } \\
\text { All outcomes }\end{array}$ & Low risk & Lost to follow up 0 \\
\hline $\begin{array}{l}\text { Selective reporting (re- } \\
\text { porting bias) }\end{array}$ & Low risk & No distinct selective outcome reporting \\
\hline $\begin{array}{l}\text { Blinding of participants } \\
\text { and personnel (perfor- } \\
\text { mance bias) } \\
\text { All outcomes }\end{array}$ & High risk & $\begin{array}{l}\text { Open study: Performance bias due to knowledge of the allocated interventions } \\
\text { by participants and personnel during the study. }\end{array}$ \\
\hline $\begin{array}{l}\text { Blinding of outcome as- } \\
\text { sessment (detection bias) } \\
\text { All outcomes }\end{array}$ & High risk & $\begin{array}{l}\text { Open study: Detection bias due to knowledge of the allocated interventions by } \\
\text { outcome assessors }\end{array}$ \\
\hline
\end{tabular}

1007 Morgan 1981

\begin{tabular}{ll}
\hline Methods & SB \\
& $P$ \\
\hline Participants & N 12
\end{tabular}


1007 Morgan 1981 (Continued)

\section{Hyp}

Age 38

\begin{tabular}{ll}
\hline Interventions & SR 67 \\
& Dur 56 \\
\hline Outcomes & DBP \\
\hline Notes & LoFo:0
\end{tabular}

\section{Risk of bias}

\begin{tabular}{lll}
\hline Bias & Authors' judgement & Support for judgement \\
\hline $\begin{array}{l}\text { Random sequence genera- } \\
\text { tion (selection bias) }\end{array}$ & Unclear risk & Insufficient information \\
\hline $\begin{array}{l}\text { Allocation concealment } \\
\text { (selection bias) }\end{array}$ & Unclear risk & Insufficient information \\
\hline
\end{tabular}

Blinding (performance High risk Open study

bias and detection bias)

All outcomes

Incomplete outcome data Low risk Lost to follow-up 0

(attrition bias)

All outcomes

Selective reporting (re- High risk $\quad$ SBP effect not reported
porting bias)

porting bias)

\begin{tabular}{lll}
\hline $\begin{array}{l}\text { Blinding of participants } \\
\text { and personnel (perfor- }\end{array}$ & High risk & $\begin{array}{l}\text { Open study: Performance bias due to knowledge of the allocated interventions } \\
\text { by participants and personnel during the study. }\end{array}$
\end{tabular}

mance bias)

All outcomes

$\begin{array}{ll}\text { Blinding of outcome as- } & \text { Low risk }\end{array}$

All outcomes

\section{Ambrosioni 1982}

\begin{tabular}{ll}
\hline Methods & SB \\
& CO \\
\hline Participants & N 25 \\
& Hyp \\
& Age 23 \\
\hline Interventions & SR 60 \\
& Dur 42 \\
\hline Outcomes & SBP \\
& DBP \\
\hline Notes & LoFo:1 \\
\hline
\end{tabular}

Effects of low sodium diet versus high sodium diet on blood pressure, renin, aldosterone, catecholamines, cholesterol, and triglyceride 
1009 Ambrosioni 1982 (Continued)

$$
\text { IT: No }
$$

\section{Risk of bias}

\begin{tabular}{|c|c|c|}
\hline Bias & Authors' judgement & Support for judgement \\
\hline $\begin{array}{l}\text { Random sequence genera- } \\
\text { tion (selection bias) }\end{array}$ & Unclear risk & Insufficient information \\
\hline $\begin{array}{l}\text { Allocation concealment } \\
\text { (selection bias) }\end{array}$ & Unclear risk & Insufficient information \\
\hline $\begin{array}{l}\text { Blinding (performance } \\
\text { bias and detection bias) } \\
\text { All outcomes }\end{array}$ & High risk & Open study \\
\hline $\begin{array}{l}\text { Incomplete outcome data } \\
\text { (attrition bias) } \\
\text { All outcomes }\end{array}$ & Low risk & Lost to follow-up 1 \\
\hline $\begin{array}{l}\text { Selective reporting (re- } \\
\text { porting bias) }\end{array}$ & Low risk & No distinct selective outcome reporting \\
\hline $\begin{array}{l}\text { Blinding of participants } \\
\text { and personnel (perfor- } \\
\text { mance bias) } \\
\text { All outcomes }\end{array}$ & High risk & $\begin{array}{l}\text { Open study: Performance bias due to knowledge of the allocated interventions } \\
\text { by participants and personnel during the study. }\end{array}$ \\
\hline $\begin{array}{l}\text { Blinding of outcome as- } \\
\text { sessment (detection bias) } \\
\text { All outcomes }\end{array}$ & Low risk & Outcome detection blinded \\
\hline
\end{tabular}

\section{Myers 1982}

\begin{tabular}{ll}
\hline Methods & Op \\
& CO \\
\hline Participants & Norm 136 \\
& Age 39 \\
\hline Interventions & SR 130 \\
& Dur 14 \\
\hline Outcomes & SBP \\
& DBP \\
\hline Notes & Included 182 \\
& LoFo: 46 \\
IT: yes (results not shown, but reported to be "similar")
\end{tabular}

\section{Risk of bias}

Bias Authors' judgement Support for judgement


1010 Myers 1982 (Continued)

\begin{tabular}{lll}
$\begin{array}{l}\text { Random sequence genera- } \\
\text { tion (selection bias) }\end{array}$ & Unclear risk & Insufficient information \\
\hline $\begin{array}{l}\text { Allocation concealment } \\
\text { (selection bias) }\end{array}$ & Unclear risk & Insufficient information \\
\hline $\begin{array}{l}\text { Blinding (performance } \\
\text { bias and detection bias) }\end{array}$ & High risk & Open study \\
$\begin{array}{l}\text { All outcomes } \\
\text { Incomplete outcome data } \\
\text { (attrition bias) } \\
\text { All outcomes }\end{array}$ & High risk & Lost to follow-up 46/182 \\
\hline
\end{tabular}

\begin{tabular}{|c|c|c|}
\hline $\begin{array}{l}\text { Selective reporting (re- } \\
\text { porting bias) }\end{array}$ & Low risk & No distinct selective outcome reporting \\
\hline $\begin{array}{l}\text { Blinding of participants } \\
\text { and personnel (perfor- } \\
\text { mance bias) } \\
\text { All outcomes }\end{array}$ & High risk & $\begin{array}{l}\text { Open study: Performance bias due to knowledge of the allocated interventions } \\
\text { by participants and personnel during the study. }\end{array}$ \\
\hline $\begin{array}{l}\text { Blinding of outcome as- } \\
\text { sessment (detection bias) } \\
\text { All outcomes }\end{array}$ & High risk & $\begin{array}{l}\text { Open study: Detection bias due to knowledge of the allocated interventions by } \\
\text { outcome assessors }\end{array}$ \\
\hline
\end{tabular}

\section{MacGregor 1982}

\begin{tabular}{ll}
\hline Methods & DB \\
& CO \\
\hline Participants & N19 \\
& Hyp 49 \\
\hline Interventions & SR 76 \\
& Dur 28 \\
\hline Outcomes & SBP \\
& DBP \\
Aldo \\
Renin
\end{tabular}

\section{Risk of bias}

\begin{tabular}{lll}
\hline Bias & Authors' judgement & Support for judgement \\
\hline $\begin{array}{l}\text { Random sequence genera- } \\
\text { tion (selection bias) }\end{array}$ & Unclear risk & Insufficient information \\
\hline $\begin{array}{l}\text { Allocation concealment } \\
\text { (selection bias) }\end{array}$ & Unclear risk & Insufficient information \\
\hline
\end{tabular}

Effects of low sodium diet versus high sodium diet on blood pressure, renin, aldosterone, catecholamines, cholesterol, and triglyceride 
1011 MacGregor 1982 (Continued)
Blinding (performance
Low risk
Double-blind study
bias and detection bias)

All outcomes

Incomplete outcome data Low risk $\quad$ Lost to follow-up 0
(attrition bias)
All outcomes

\begin{tabular}{|c|c|c|}
\hline $\begin{array}{l}\text { Selective reporting (re- } \\
\text { porting bias) }\end{array}$ & Low risk & No distinct selective outcome reporting \\
\hline $\begin{array}{l}\text { Blinding of participants } \\
\text { and personnel (perfor- } \\
\text { mance bias) } \\
\text { All outcomes }\end{array}$ & Low risk & Double-blind study \\
\hline $\begin{array}{l}\text { Blinding of outcome as- } \\
\text { sessment (detection bias) } \\
\text { All outcomes }\end{array}$ & Low risk & Double-blind study \\
\hline
\end{tabular}

\section{Beard 1982}

\begin{tabular}{ll}
\hline Methods & Op \\
& $P$ \\
\hline Participants & N90 \\
& Hyp \\
& Age48 \\
\hline Interventions & SR124 \\
& Dur 84 \\
\hline Outcomes & SBP \\
& DBP \\
\hline Notes & Included 113 \\
& LoFo:23 \\
IT: No
\end{tabular}

\section{Risk of bias}

\begin{tabular}{lll}
\hline Bias & Authors' judgement & Support for judgement \\
\hline $\begin{array}{l}\text { Random sequence genera- } \\
\text { tion (selection bias) }\end{array}$ & Unclear risk & Insufficient information \\
\hline $\begin{array}{l}\text { Allocation concealment } \\
\text { (selection bias) }\end{array}$ & Unclear risk & Insufficient information \\
\hline $\begin{array}{l}\text { Blinding (performance } \\
\text { bias and detection bias) } \\
\text { All outcomes }\end{array}$ & High risk & Open study \\
\hline $\begin{array}{l}\text { Incomplete outcome data } \\
\text { (attrition bias) }\end{array}$ & High risk & Lost to follow up LS: 11/56; US: 12/57 \\
\hline $\begin{array}{l}\text { Effects of low sodium diet versus high sodium diet on blood pressure, renin, aldosterone, catecholamines, cholesterol, and triglyceride } \\
\text { (Review) } \\
\text { Copyright } \odot \text { 2017 The Cochrane Collaboration. Published by John Wiley \& Sons, Ltd. }\end{array}$
\end{tabular}


1012 Beard 1982 (Continued)

All outcomes

\begin{tabular}{lll}
\hline $\begin{array}{l}\text { Selective reporting (re- } \\
\text { porting bias) }\end{array}$ & Low risk & No distinct selective outcome reporting \\
\hline $\begin{array}{l}\text { Blinding of participants } \\
\text { and personnel (perfor- } \\
\text { mance bias) } \\
\text { All outcomes }\end{array}$ & High risk & $\begin{array}{l}\text { Open study: Performance bias due to knowledge of the allocated interventions } \\
\text { by participants and personnel during the study. }\end{array}$ \\
\hline $\begin{array}{l}\text { Blinding of outcome as- } \\
\text { sessment (detection bias) } \\
\text { All outcomes }\end{array}$ & High risk & $\begin{array}{l}\text { Open study: Detection bias due to knowledge of the allocated interventions by } \\
\text { outcome assessors }\end{array}$ \\
\hline
\end{tabular}

\section{Puska 1983}

\begin{tabular}{ll}
\hline Methods & SB \\
& P \\
\hline Participants & N38 \\
& Norm \\
& Age40 \\
\hline Interventions & SR90 \\
& Dur72 \\
\hline Outcomes & SBP \\
& DBP \\
\hline Notes & LoFo: 4 \\
\hline
\end{tabular}

\section{Risk of bias}

\begin{tabular}{lll}
\hline Bias & Authors' judgement & Support for judgement \\
\hline $\begin{array}{l}\text { Random sequence genera- } \\
\text { tion (selection bias) }\end{array}$ & Unclear risk & Insufficient information \\
\hline $\begin{array}{l}\text { Allocation concealment } \\
\text { (selection bias) }\end{array}$ & Unclear risk & Insufficient information \\
\hline $\begin{array}{l}\text { Blinding (performance } \\
\text { bias and detection bias) } \\
\text { All outcomes }\end{array}$ & High risk & Open study \\
\hline $\begin{array}{l}\text { Incomplete outcome data } \\
\text { (attrition bias) }\end{array}$ & Unclear risk & Lost to follow up normotensive, LS: 2/19; US: 0/19; Lost to follow up hyperten- \\
$\begin{array}{l}\text { All outcomes } \\
\text { Selective reporting (re- } \\
\text { porting bias) }\end{array}$ & Low risk $2 / 15 ;$ US: 0/19 \\
\hline $\begin{array}{l}\text { Blinding of participants } \\
\begin{array}{l}\text { and personnel (perfor- } \\
\text { mance bias) }\end{array}\end{array}$ & High risk & No distinct selective outcome reporting \\
\hline
\end{tabular}


1013 Puska 1983 (Continued)

All outcomes

Blinding of outcome as- Low risk $\quad$ outcome detection blinded
sessment (detection bias)

All outcomes

1015 Bulpitt 1984

\begin{tabular}{ll}
\hline Methods & Op \\
& $P$ \\
\hline Participants & $\begin{array}{l}\text { N 65 (M/F29/36)(B/W/A.0/65/0) } \\
\text { Hypertension } \\
\text { Age 54.6 }\end{array}$ \\
\hline Interventions & SR 59 (161-102) \\
\hline Dur 90 \\
\hline Notes & SBP, DBP, Chol \\
\hline
\end{tabular}

\section{Risk of bias}

\begin{tabular}{|c|c|c|}
\hline Bias & Authors' judgement & Support for judgement \\
\hline $\begin{array}{l}\text { Random sequence genera- } \\
\text { tion (selection bias) }\end{array}$ & Unclear risk & Insufficient information \\
\hline $\begin{array}{l}\text { Allocation concealment } \\
\text { (selection bias) }\end{array}$ & Unclear risk & Insufficient information \\
\hline $\begin{array}{l}\text { Blinding (performance } \\
\text { bias and detection bias) } \\
\text { All outcomes }\end{array}$ & High risk & Open study \\
\hline $\begin{array}{l}\text { Incomplete outcome data } \\
\text { (attrition bias) } \\
\text { All outcomes }\end{array}$ & Low risk & Lost to follow up 0 \\
\hline $\begin{array}{l}\text { Selective reporting (re- } \\
\text { porting bias) }\end{array}$ & Low risk & No distinct selective outcome reporting \\
\hline $\begin{array}{l}\text { Blinding of participants } \\
\text { and personnel (perfor- } \\
\text { mance bias) } \\
\text { All outcomes }\end{array}$ & High risk & The low sodium group received dietary advice, the reference group did not \\
\hline $\begin{array}{l}\text { Blinding of outcome as- } \\
\text { sessment (detection bias) } \\
\text { All outcomes }\end{array}$ & High risk & $\begin{array}{l}\text { Open study: Detection bias due to knowledge of the allocated interventions by } \\
\text { outcome assessors }\end{array}$ \\
\hline
\end{tabular}


1016 Silman 1983

\begin{tabular}{ll}
\hline Methods & Op \\
& P \\
\hline Participants & N28 \\
& Hyp \\
& Age55 \\
\hline Interventions & SR 63 \\
& Dur 90 \\
\hline Outcomes & SBP \\
& DBP \\
\hline Notes & LoFo: 7 \\
IT: No \\
Weighted average of BP effects obtained ar $1,2,3,6$ and 12 months.
\end{tabular}

\section{Risk of bias}

\begin{tabular}{|c|c|c|}
\hline Bias & Authors' judgement & Support for judgement \\
\hline $\begin{array}{l}\text { Random sequence genera- } \\
\text { tion (selection bias) }\end{array}$ & Unclear risk & Insufficient information \\
\hline $\begin{array}{l}\text { Allocation concealment } \\
\text { (selection bias) }\end{array}$ & Unclear risk & Insufficient information \\
\hline $\begin{array}{l}\text { Blinding (performance } \\
\text { bias and detection bias) } \\
\text { All outcomes }\end{array}$ & High risk & Open study \\
\hline $\begin{array}{l}\text { Incomplete outcome data } \\
\text { (attrition bias) } \\
\text { All outcomes }\end{array}$ & High risk & Lost to follow up LS: 0/12; US: 7/16 \\
\hline $\begin{array}{l}\text { Selective reporting (re- } \\
\text { porting bias) }\end{array}$ & Low risk & No distinct selective outcome reporting \\
\hline $\begin{array}{l}\text { Blinding of participants } \\
\text { and personnel (perfor- } \\
\text { mance bias) } \\
\text { All outcomes }\end{array}$ & High risk & $\begin{array}{l}\text { Open study: Performance bias due to knowledge of the allocated interventions } \\
\text { by participants and personnel during the study. }\end{array}$ \\
\hline $\begin{array}{l}\text { Blinding of outcome as- } \\
\text { sessment (detection bias) } \\
\text { All outcomes }\end{array}$ & High risk & $\begin{array}{l}\text { Open study: Detection bias due to knowledge of the allocated interventions by } \\
\text { outcome assessors }\end{array}$ \\
\hline
\end{tabular}

1017 Sowers 1983

\begin{tabular}{ll}
\hline Methods & Op \\
& CO \\
\hline Participants & N 9 (M/F:9/0) \\
& Normotension \\
& Age 23 \\
\hline
\end{tabular}

Effects of low sodium diet versus high sodium diet on blood pressure, renin, aldosterone, catecholamines, cholesterol, and triglyceride 
1017 Sowers 1983 (Continued)

\begin{tabular}{ll} 
Interventions & $\begin{array}{l}\text { SR } 154 \text { (196-42) } \\
\text { Dur 5 }\end{array}$ \\
\hline Outcomes & renin, Aldo \\
\hline Notes & LoFo: 0
\end{tabular}

\section{Risk of bias}

\begin{tabular}{|c|c|c|}
\hline Bias & Authors' judgement & Support for judgement \\
\hline $\begin{array}{l}\text { Random sequence genera- } \\
\text { tion (selection bias) }\end{array}$ & Unclear risk & Insufficient information \\
\hline $\begin{array}{l}\text { Allocation concealment } \\
\text { (selection bias) }\end{array}$ & Unclear risk & Insufficient information \\
\hline $\begin{array}{l}\text { Blinding (performance } \\
\text { bias and detection bias) } \\
\text { All outcomes }\end{array}$ & High risk & open study \\
\hline $\begin{array}{l}\text { Incomplete outcome data } \\
\text { (attrition bias) } \\
\text { All outcomes }\end{array}$ & Low risk & Lost to follow up LS 0 \\
\hline $\begin{array}{l}\text { Selective reporting (re- } \\
\text { porting bias) }\end{array}$ & Low risk & No distinct selective outcome reporting \\
\hline $\begin{array}{l}\text { Blinding of participants } \\
\text { and personnel (perfor- } \\
\text { mance bias) } \\
\text { All outcomes }\end{array}$ & High risk & $\begin{array}{l}\text { Open study: Performance bias due to knowledge of the allocated interventions } \\
\text { by participants and personnel during the study. }\end{array}$ \\
\hline $\begin{array}{l}\text { Blinding of outcome as- } \\
\text { sessment (detection bias) } \\
\text { All outcomes }\end{array}$ & High risk & $\begin{array}{l}\text { Open study: Detection bias due to knowledge of the allocated interventions by } \\
\text { outcome assessors }\end{array}$ \\
\hline
\end{tabular}

1018 Watt 1983

\begin{tabular}{ll}
\hline Methods & DB \\
& CO \\
\hline Participants & N18 \\
& Hyp \\
& Age52 \\
\hline Interventions & SR 56 \\
& Dur 28 \\
\hline Outcomes & SBP \\
& DBP \\
Renin \\
\hline Notes & Included 20 \\
& LoFo:2 \\
\hline
\end{tabular}

Effects of low sodium diet versus high sodium diet on blood pressure, renin, aldosterone, catecholamines, cholesterol, and triglyceride 
1018 Watt 1983 (Continued)

$$
\text { IT: No }
$$

\section{Risk of bias}

\begin{tabular}{|c|c|c|}
\hline Bias & Authors' judgement & Support for judgement \\
\hline $\begin{array}{l}\text { Random sequence genera- } \\
\text { tion (selection bias) }\end{array}$ & Unclear risk & Insufficient information \\
\hline $\begin{array}{l}\text { Allocation concealment } \\
\text { (selection bias) }\end{array}$ & Unclear risk & Insufficient information \\
\hline $\begin{array}{l}\text { Blinding (performance } \\
\text { bias and detection bias) } \\
\text { All outcomes }\end{array}$ & Low risk & Double blind study \\
\hline $\begin{array}{l}\text { Incomplete outcome data } \\
\text { (attrition bias) } \\
\text { All outcomes }\end{array}$ & Unclear risk & Insufficient information \\
\hline $\begin{array}{l}\text { Selective reporting (re- } \\
\text { porting bias) }\end{array}$ & Low risk & Lost to follow up $2 / 20$ \\
\hline $\begin{array}{l}\text { Blinding of participants } \\
\text { and personnel (perfor- } \\
\text { mance bias) } \\
\text { All outcomes }\end{array}$ & Low risk & Double blind study \\
\hline $\begin{array}{l}\text { Blinding of outcome as- } \\
\text { sessment (detection bias) } \\
\text { All outcomes }\end{array}$ & Low risk & Double blind study \\
\hline
\end{tabular}

\section{Cooper 1984}

\begin{tabular}{ll}
\hline Methods & SB \\
& CO \\
\hline Participants & N59 \\
& Norm \\
& Age16 \\
\hline Interventions & SR55 \\
& Dur 24 \\
\hline Outcomes & SBP \\
& DBP \\
\hline Notes & Included 124(1984+1984b) \\
& LoFo: 11 \\
IT: No
\end{tabular}

\section{Risk of bias}

Bias Authors' judgement Support for judgement




\section{Cooper 1984 (Continued)}

Random sequence genera- Unclear risk Insufficient information tion (selection bias)

\begin{tabular}{lll}
\hline $\begin{array}{l}\text { Allocation concealment } \\
\text { (selection bias) }\end{array}$ & Unclear risk
\end{tabular}

\begin{tabular}{lll}
\hline $\begin{array}{l}\text { Blinding (performance } \\
\text { bias and detection bias) } \\
\text { All outcomes }\end{array}$ & High risk & Open study \\
\hline $\begin{array}{l}\text { Incomplete outcome data } \\
\begin{array}{l}\text { (attrition bias) } \\
\text { All outcomes }\end{array}\end{array}$ & Low risk & Lost to follow up: 11/24 \\
\hline
\end{tabular}

\begin{tabular}{|c|c|c|}
\hline $\begin{array}{l}\text { Selective reporting (re- } \\
\text { porting bias) }\end{array}$ & Low risk & No distinct selective outcome reporting \\
\hline $\begin{array}{l}\text { Blinding of participants } \\
\text { and personnel (perfor- } \\
\text { mance bias) } \\
\text { All outcomes }\end{array}$ & High risk & $\begin{array}{l}\text { Open study: Performance bias due to knowledge of the allocated interventions } \\
\text { by participants and personnel during the study. }\end{array}$ \\
\hline $\begin{array}{l}\text { Blinding of outcome as- } \\
\text { sessment (detection bias) } \\
\text { All outcomes }\end{array}$ & Low risk & Outcome detection blinded \\
\hline
\end{tabular}

\section{Skrabal 1984}

\begin{tabular}{ll}
\hline Methods & Op \\
& CO \\
\hline Participants & N30 \\
& Norm \\
& Age23 \\
\hline Interventions & SR137 \\
& Dur14 \\
\hline Outcomes & SBP \\
& DBP \\
& Aldo \\
Renin \\
NA \\
A \\
\hline Notes & LoFo: 0 \\
\hline
\end{tabular}

\section{Risk of bias}

\begin{tabular}{lll}
\hline Bias & Authors' judgement & Support for judgement \\
\hline $\begin{array}{l}\text { Random sequence genera- } \\
\text { tion (selection bias) }\end{array}$ & Unclear risk & Insufficient information \\
\hline
\end{tabular}

Effects of low sodium diet versus high sodium diet on blood pressure, renin, aldosterone, catecholamines, cholesterol, and triglyceride 
1021 Skrabal 1984 (Continued)

\begin{tabular}{lll}
$\begin{array}{l}\text { Allocation concealment } \\
\text { (selection bias) }\end{array}$ & Unclear risk & Insufficient information \\
\hline $\begin{array}{l}\text { Blinding (performance } \\
\text { bias and detection bias) }\end{array}$ & High risk & Open study \\
All outcomes & &
\end{tabular}

\begin{tabular}{lll}
\hline $\begin{array}{l}\text { Incomplete outcome data } \\
\text { (attrition bias) } \\
\text { All outcomes }\end{array}$ & Low risk & Lost to follow up 0 \\
\hline $\begin{array}{l}\text { Selective reporting (re- } \\
\text { porting bias) }\end{array}$ & Low risk & No distinct selective outcome reporting \\
\hline $\begin{array}{l}\text { Blinding of participants } \\
\begin{array}{l}\text { and personnel (perfor- } \\
\text { mance bias) }\end{array}\end{array}$ & High risk & $\begin{array}{l}\text { Open study: Performance bias due to knowledge of the allocated interventions } \\
\text { by participants and personnel during the study. }\end{array}$ \\
\hline $\begin{array}{l}\text { Blinding of outcome as- } \\
\text { sessment (detection bias) } \\
\text { All outcomes }\end{array}$ & High risk & $\begin{array}{l}\text { Open study: Detection bias due to knowledge of the allocated interventions by } \\
\text { outcome assessors }\end{array}$ \\
\hline
\end{tabular}

\section{Gillies 1984}

\begin{tabular}{ll}
\hline Methods & Op \\
CO \\
\hline Participants & $\begin{array}{l}\text { N } 24 \text { (M/F:14/10)(B/W/A.0/24/0) } \\
\text { Hypertension } \\
\text { Age } 56.7\end{array}$ \\
\hline Interventions & SR 77 (169-92) \\
\hline Dur 42
\end{tabular}

\section{Risk of bias}

\begin{tabular}{lll}
\hline Bias & Authors' judgement & Support for judgement \\
\hline $\begin{array}{l}\text { Random sequence genera- } \\
\text { tion (selection bias) }\end{array}$ & Unclear risk & Insufficient information \\
\hline $\begin{array}{l}\text { Allocation concealment } \\
\text { (selection bias) }\end{array}$ & Unclear risk & Insufficient information \\
\hline $\begin{array}{l}\text { Blinding (performance } \\
\text { bias and detection bias) } \\
\text { All outcomes }\end{array}$ & High risk & Open study \\
\hline
\end{tabular}

Incomplete outcome data Low risk $\quad$ Lost to follow up: 4/28
(attrition bias)

Effects of low sodium diet versus high sodium diet on blood pressure, renin, aldosterone, catecholamines, cholesterol, and triglyceride 
1023 Gillies 1984 (Continued)

All outcomes

Selective reporting (re- Low risk No distinct selective outcome reporting
porting bias)

\begin{tabular}{lll}
\hline $\begin{array}{l}\text { Blinding of participants } \\
\text { and personnel (perfor- } \\
\text { mance bias) }\end{array}$ & High risk & $\begin{array}{l}\text { Open study: Performance bias due to knowledge of the allocated interventions } \\
\text { by participants and personnel during the study. }\end{array}$ \\
$\begin{array}{ll}\text { All outcomes } \\
\begin{array}{l}\text { Blinding of outcome as- } \\
\text { sessment (detection bias) } \\
\text { All outcomes }\end{array}\end{array}$ & High risk & $\begin{array}{l}\text { Open study: Detection bias due to knowledge of the allocated interventions by } \\
\text { outcome assessors }\end{array}$ \\
\end{tabular}

\section{Erwteman 1984}

\begin{tabular}{ll}
\hline Methods & S \\
& BP \\
\hline Participants & $\begin{array}{l}\text { N94 (22 blacks) } \\
\text { Hyp } \\
\text { Age46 }\end{array}$ \\
\hline Interventions & SR58 \\
& Dur28 \\
\hline Outcomes & SBP \\
& DBP \\
\hline Notes & Included 107 \\
& LoFo: 13 \\
IT: No
\end{tabular}

\section{Risk of bias}

\begin{tabular}{|c|c|c|}
\hline Bias & Authors' judgement & Support for judgement \\
\hline $\begin{array}{l}\text { Random sequence genera- } \\
\text { tion (selection bias) }\end{array}$ & Unclear risk & Insufficient information \\
\hline $\begin{array}{l}\text { Allocation concealment } \\
\text { (selection bias) }\end{array}$ & Unclear risk & Insufficient information \\
\hline $\begin{array}{l}\text { Blinding (performance } \\
\text { bias and detection bias) } \\
\text { All outcomes }\end{array}$ & High risk & Open study \\
\hline $\begin{array}{l}\text { Incomplete outcome data } \\
\text { (attrition bias) } \\
\text { All outcomes }\end{array}$ & Low risk & $\begin{array}{l}\text { Lost to follow up 13/107. " No apparent relation between treatment and dis- } \\
\text { continuing the trial" }\end{array}$ \\
\hline $\begin{array}{l}\text { Selective reporting (re- } \\
\text { porting bias) }\end{array}$ & Low risk & No distinct selective outcome reporting \\
\hline
\end{tabular}




\section{Erwteman 1984 (Continued)}

Blinding of participants High risk and personnel (performance bias)

All outcomes

\section{Blinding of outcome as- Low risk} sessment (detection bias)

All outcomes
Open study: Performance bias due to knowledge of the allocated interventions by participants and personnel during the study.

\section{Koolen 1984}

\begin{tabular}{ll}
\hline Methods & Op \\
& CO \\
\hline Participants & N20 \\
& Hyp \\
& Age41 \\
\hline Interventions & SR213 \\
& Dur14 \\
\hline \multirow{2}{*}{ Outcomes } & SBP \\
& DBP \\
& Aldo \\
Renin \\
NA \\
\hline Notes & LoFo: 0 \\
\hline
\end{tabular}

\section{Risk of bias}

\begin{tabular}{lll}
\hline Bias & Authors' judgement & Support for judgement \\
\hline $\begin{array}{l}\text { Random sequence genera- } \\
\text { tion (selection bias) }\end{array}$ & Unclear risk & Insufficient information \\
\hline $\begin{array}{l}\text { Allocation concealment } \\
\text { (selection bias) }\end{array}$ & Unclear risk & Insufficient information \\
\hline $\begin{array}{l}\text { Blinding (performance } \\
\text { bias and detection bias) }\end{array}$ & High risk & Open study \\
$\begin{array}{l}\text { All outcomes } \\
\begin{array}{l}\text { Incomplete outcome data } \\
\text { (attrition bias) } \\
\text { All outcomes }\end{array}\end{array}$ & Low risk \\
\hline $\begin{array}{l}\text { Selective reporting (re- } \\
\text { porting bias) }\end{array}$ & Low risk & Lost to follow up 0 \\
\hline $\begin{array}{l}\text { Blinding of participants } \\
\text { and personnel (perfor- } \\
\text { mance bias) } \\
\text { All outcomes }\end{array}$ & High risk & No distinct selective outcome reporting \\
\hline
\end{tabular}

Effects of low sodium diet versus high sodium diet on blood pressure, renin, aldosterone, catecholamines, cholesterol, and triglyceride 
1025 Koolen 1984 (Continued)

Blinding of outcome as- High risk Open study: Detection bias due to knowledge of the allocated interventions by sessment (detection bias)

All outcomes

1026 Koolen 1984(2)

\begin{tabular}{ll}
\hline Methods & S \\
& CO \\
\hline Participants & $\begin{array}{l}\text { Nyp Caucasians } \\
\text { Age41 }\end{array}$ \\
\hline Interventions & SR 208 \\
& Dur 14 \\
\hline Outcomes & NA \\
\hline Notes & LoFo:0
\end{tabular}

\section{Risk of bias}

\begin{tabular}{|c|c|c|}
\hline Bias & Authors' judgement & Support for judgement \\
\hline $\begin{array}{l}\text { Random sequence genera- } \\
\text { tion (selection bias) }\end{array}$ & Unclear risk & Insufficient information \\
\hline $\begin{array}{l}\text { Allocation concealment } \\
\text { (selection bias) }\end{array}$ & Unclear risk & Insufficient information \\
\hline $\begin{array}{l}\text { Blinding (performance } \\
\text { bias and detection bias) } \\
\text { All outcomes }\end{array}$ & High risk & Open study \\
\hline $\begin{array}{l}\text { Incomplete outcome data } \\
\text { (attrition bias) } \\
\text { All outcomes }\end{array}$ & Low risk & Lost to follow up 0 \\
\hline $\begin{array}{l}\text { Selective reporting (re- } \\
\text { porting bias) }\end{array}$ & Low risk & No distinct selective outcome reporting \\
\hline $\begin{array}{l}\text { Blinding of participants } \\
\text { and personnel (perfor- } \\
\text { mance bias) } \\
\text { All outcomes }\end{array}$ & High risk & $\begin{array}{l}\text { Open study: Performance bias due to knowledge of the allocated interventions } \\
\text { by participants and personnel during the study. }\end{array}$ \\
\hline $\begin{array}{l}\text { Blinding of outcome as- } \\
\text { sessment (detection bias) } \\
\text { All outcomes }\end{array}$ & Low risk & Outcome detection blinded \\
\hline
\end{tabular}

\section{Fagerberg 1984}

Methods Op

Effects of low sodium diet versus high sodium diet on blood pressure, renin, aldosterone, catecholamines, cholesterol, and triglyceride 
1027 Fagerberg 1984 (Continued)

\section{$\mathrm{P}$}

\begin{tabular}{ll}
\hline Participants & N30 \\
& Hyp \\
& Age51 \\
\hline Interventions & SR99 \\
& Dur63 \\
\hline Outcomes & SBP \\
& DBP \\
\hline Notes & Included 34 \\
& LoFo: 4 \\
IT: No
\end{tabular}

\section{Risk of bias}

\begin{tabular}{|c|c|c|}
\hline Bias & Authors' judgement & Support for judgement \\
\hline $\begin{array}{l}\text { Random sequence genera- } \\
\text { tion (selection bias) }\end{array}$ & Unclear risk & Insufficient information \\
\hline $\begin{array}{l}\text { Allocation concealment } \\
\text { (selection bias) }\end{array}$ & Unclear risk & Insufficient information \\
\hline $\begin{array}{l}\text { Blinding (performance } \\
\text { bias and detection bias) } \\
\text { All outcomes }\end{array}$ & High risk & Open study \\
\hline $\begin{array}{l}\text { Incomplete outcome data } \\
\text { (attrition bias) } \\
\text { All outcomes }\end{array}$ & Unclear risk & Lost to follow up 4/34. Group association unclear \\
\hline $\begin{array}{l}\text { Selective reporting (re- } \\
\text { porting bias) }\end{array}$ & Low risk & No distinct selective outcome reporting \\
\hline $\begin{array}{l}\text { Blinding of participants } \\
\text { and personnel (perfor- } \\
\text { mance bias) } \\
\text { All outcomes }\end{array}$ & High risk & $\begin{array}{l}\text { Open study: Performance bias due to knowledge of the allocated interventions } \\
\text { by participants and personnel during the study. }\end{array}$ \\
\hline $\begin{array}{l}\text { Blinding of outcome as- } \\
\text { sessment (detection bias) } \\
\text { All outcomes }\end{array}$ & High risk & $\begin{array}{l}\text { Open study: Detection bias due to knowledge of the allocated interventions by } \\
\text { outcome assessors }\end{array}$ \\
\hline
\end{tabular}

1028 Maxwell 1984

\begin{tabular}{ll}
\hline Methods & Op \\
& P \\
\hline Participants & N30 \\
& Hyp \\
& Age 46 \\
\hline Interventions & SR161 \\
\hline
\end{tabular}

Effects of low sodium diet versus high sodium diet on blood pressure, renin, aldosterone, catecholamines, cholesterol, and triglyceride 
1028 Maxwell 1984 (Continued)

Dur 84

\begin{tabular}{ll}
\hline Outcomes & SBP \\
& DBP \\
\hline Notes & LoFo: 0 \\
\hline
\end{tabular}

\section{Risk of bias}

\begin{tabular}{|c|c|c|}
\hline Bias & Authors' judgement & Support for judgement \\
\hline $\begin{array}{l}\text { Random sequence genera- } \\
\text { tion (selection bias) }\end{array}$ & Unclear risk & Insufficient information \\
\hline $\begin{array}{l}\text { Allocation concealment } \\
\text { (selection bias) }\end{array}$ & Unclear risk & Insufficient information \\
\hline $\begin{array}{l}\text { Blinding (performance } \\
\text { bias and detection bias) } \\
\text { All outcomes }\end{array}$ & High risk & Open study \\
\hline $\begin{array}{l}\text { Incomplete outcome data } \\
\text { (attrition bias) } \\
\text { All outcomes }\end{array}$ & Low risk & Lost to follow up 0 \\
\hline $\begin{array}{l}\text { Selective reporting (re- } \\
\text { porting bias) }\end{array}$ & Low risk & No distinct selective outcome reporting \\
\hline $\begin{array}{l}\text { Blinding of participants } \\
\text { and personnel (perfor- } \\
\text { mance bias) } \\
\text { All outcomes }\end{array}$ & High risk & $\begin{array}{l}\text { Open study: Performance bias due to knowledge of the allocated interventions } \\
\text { by participants and personnel during the study. }\end{array}$ \\
\hline $\begin{array}{l}\text { Blinding of outcome as- } \\
\text { sessment (detection bias) } \\
\text { All outcomes }\end{array}$ & High risk & $\begin{array}{l}\text { Open study: Detection bias due to knowledge of the allocated interventions by } \\
\text { outcome assessors }\end{array}$ \\
\hline
\end{tabular}

1029 Richards 1984

\begin{tabular}{|c|c|}
\hline Methods & $\begin{array}{l}\mathrm{SB} \\
\mathrm{CO}\end{array}$ \\
\hline Participants & $\begin{array}{l}\text { N12 } \\
\text { Hyp } \\
\text { Age36 }\end{array}$ \\
\hline Interventions & $\begin{array}{l}\text { SR100 } \\
\text { Dur28 }\end{array}$ \\
\hline Outcomes & $\begin{array}{l}\text { SBP } \\
\text { DBP } \\
\text { Aldo } \\
\text { Renin } \\
\text { NA }\end{array}$ \\
\hline
\end{tabular}

Effects of low sodium diet versus high sodium diet on blood pressure, renin, aldosterone, catecholamines, cholesterol, and triglyceride 
1029 Richards 1984 (Continued)

$$
\begin{aligned}
& \text { LoFo: } 4 \\
& \text { IT: No }
\end{aligned}
$$

\begin{tabular}{|c|c|c|}
\hline Bias & Authors' judgement & Support for judgement \\
\hline $\begin{array}{l}\text { Random sequence genera- } \\
\text { tion (selection bias) }\end{array}$ & Unclear risk & Insufficient information \\
\hline $\begin{array}{l}\text { Allocation concealment } \\
\text { (selection bias) }\end{array}$ & Unclear risk & Insufficient information \\
\hline $\begin{array}{l}\text { Blinding (performance } \\
\text { bias and detection bias) } \\
\text { All outcomes }\end{array}$ & High risk & Open study \\
\hline $\begin{array}{l}\text { Incomplete outcome data } \\
\text { (attrition bias) } \\
\text { All outcomes }\end{array}$ & High risk & Lost to follow up $4 / 16$ \\
\hline $\begin{array}{l}\text { Selective reporting (re- } \\
\text { porting bias) }\end{array}$ & Low risk & No distinct selective outcome reporting \\
\hline $\begin{array}{l}\text { Blinding of participants } \\
\text { and personnel (perfor- } \\
\text { mance bias) } \\
\text { All outcomes }\end{array}$ & High risk & $\begin{array}{l}\text { Open study: Performance bias due to knowledge of the allocated interventions } \\
\text { by participants and personnel during the study. }\end{array}$ \\
\hline $\begin{array}{l}\text { Blinding of outcome as- } \\
\text { sessment (detection bias) } \\
\text { All outcomes }\end{array}$ & Low risk & Outcome detection blinded \\
\hline
\end{tabular}

\section{Risk of bias}

1030 Resnick 1985

\begin{tabular}{ll}
\hline Methods & Op \\
& CO \\
\hline Participants & N12 \\
& Hyp \\
& Age \\
\hline Interventions & SR190 \\
& Dur5 \\
\hline Outcomes & SBP \\
& DBP \\
Renin \\
\hline
\end{tabular}

\section{Risk of bias}

Bias Authors' judgement Support for judgement




\section{Resnick 1985 (Continued)}

\begin{tabular}{lll}
$\begin{array}{l}\text { Random sequence genera- } \\
\text { tion (selection bias) }\end{array}$ & Unclear risk & Insufficient information \\
\hline $\begin{array}{l}\text { Allocation concealment } \\
\text { (selection bias) }\end{array}$ & Unclear risk & Insufficient information \\
\hline $\begin{array}{l}\text { Blinding (performance } \\
\text { bias and detection bias) } \\
\text { All outcomes }\end{array}$ & High risk & Open study \\
\hline
\end{tabular}

Incomplete outcome data Low risk $\quad$ Lost to follow up 0
(attrition bias)
All outcomes

\begin{tabular}{|c|c|c|}
\hline $\begin{array}{l}\text { Selective reporting (re- } \\
\text { porting bias) }\end{array}$ & Low risk & No distinct selective outcome reporting \\
\hline $\begin{array}{l}\text { Blinding of participants } \\
\text { and personnel (perfor- } \\
\text { mance bias) } \\
\text { All outcomes }\end{array}$ & High risk & $\begin{array}{l}\text { Open study: Performance bias due to knowledge of the allocated interventions } \\
\text { by participants and personnel during the study. }\end{array}$ \\
\hline $\begin{array}{l}\text { Blinding of outcome as- } \\
\text { sessment (detection bias) } \\
\text { All outcomes }\end{array}$ & High risk & $\begin{array}{l}\text { Open study: Detection bias due to knowledge of the allocated interventions by } \\
\text { outcome assessors }\end{array}$ \\
\hline
\end{tabular}

\section{Tuthill 1985}

\begin{tabular}{ll}
\hline Methods & DB \\
\hline Participants & $\begin{array}{l}\text { N } 191(\mathrm{M} / \mathrm{F}: 0 / 191) \\
\text { Age } 17\end{array}$ \\
\hline Interventions & SR $14(600 \mathrm{mg})$ \\
& Dur 56 \\
\hline Outcomes & SBP, DBP \\
\hline Notes & LoFo: 13.191 of 204 completed the study. IT: No
\end{tabular}

\section{Risk of bias}

\begin{tabular}{lll}
\hline Bias & Authors' judgement & Support for judgement \\
\hline $\begin{array}{l}\text { Random sequence genera- } \\
\text { tion (selection bias) }\end{array}$ & Unclear risk & Insufficient information \\
\hline $\begin{array}{l}\text { Allocation concealment } \\
\text { (selection bias) }\end{array}$ & Unclear risk & Insufficient information \\
\hline $\begin{array}{l}\text { Blinding (performance } \\
\text { bias and detection bias) } \\
\text { All outcomes }\end{array}$ & Low risk & Double blind study \\
\hline
\end{tabular}

Effects of low sodium diet versus high sodium diet on blood pressure, renin, aldosterone, catecholamines, cholesterol, and triglyceride 
1031 Tuthill 1985 (Continued)
Incomplete outcome data
Low risk
Lost to follow up 13/204. Group association unclear
(attrition bias)

All outcomes

\begin{tabular}{|c|c|c|}
\hline $\begin{array}{l}\text { Selective reporting (re- } \\
\text { porting bias) }\end{array}$ & Low risk & No distinct selective outcome reporting \\
\hline $\begin{array}{l}\text { Blinding of participants } \\
\text { and personnel (perfor- } \\
\text { mance bias) } \\
\text { All outcomes }\end{array}$ & Low risk & Double blind study \\
\hline $\begin{array}{l}\text { Blinding of outcome as- } \\
\text { sessment (detection bias) } \\
\text { All outcomes }\end{array}$ & Low risk & Double blind study \\
\hline
\end{tabular}

\section{Skrabal 1985}

\begin{tabular}{ll}
\hline Methods & SB \\
& CO \\
\hline Participants & N34 \\
& Norm \\
& Age23 \\
\hline Interventions & SR144 \\
& Dur14 \\
\hline Outcomes & SBP \\
& DBP \\
\hline Notes & LoFo: 0 \\
\hline
\end{tabular}

\section{Risk of bias}

\begin{tabular}{|c|c|c|}
\hline Bias & Authors' judgement & Support for judgement \\
\hline $\begin{array}{l}\text { Random sequence genera- } \\
\text { tion (selection bias) }\end{array}$ & Unclear risk & Insufficient information \\
\hline $\begin{array}{l}\text { Allocation concealment } \\
\text { (selection bias) }\end{array}$ & Unclear risk & Insufficient information \\
\hline $\begin{array}{l}\text { Blinding (performance } \\
\text { bias and detection bias) } \\
\text { All outcomes }\end{array}$ & High risk & Open study \\
\hline $\begin{array}{l}\text { Incomplete outcome data } \\
\text { (attrition bias) } \\
\text { All outcomes }\end{array}$ & Low risk & Lost to follow up 0 \\
\hline $\begin{array}{l}\text { Selective reporting (re- } \\
\text { porting bias) }\end{array}$ & Low risk & No distinct selective outcome reporting \\
\hline
\end{tabular}




\section{Skrabal 1985 (Continued)}

Blinding of participants High risk Open study: Performance bias due to knowledge of the allocated interventions and personnel (perfor-

mance bias)

All outcomes

Blinding of outcome as- Low risk Outcome detection blinded

sessment (detection bias)

All outcomes

\section{Watt 1985}

\begin{tabular}{ll}
\hline Methods & DB \\
& CO \\
\hline Participants & N31 \\
& Norm \\
& Age23 \\
\hline Interventions & SR60 \\
& Dur28 \\
\hline \multirow{2}{*}{ Outcomes } & SBP \\
& DBP \\
\hline Notes & Included $75(1985+1985 \mathrm{~b})$ \\
& LoFo: 9 \\
IT: No
\end{tabular}

\section{Risk of bias}

\begin{tabular}{|c|c|c|}
\hline Bias & Authors' judgement & Support for judgement \\
\hline $\begin{array}{l}\text { Random sequence genera- } \\
\text { tion (selection bias) }\end{array}$ & Unclear risk & Insufficient information \\
\hline $\begin{array}{l}\text { Allocation concealment } \\
\text { (selection bias) }\end{array}$ & Low risk & $\begin{array}{l}\text { The statistician randomised and labelled the containers of the tablets without } \\
\text { calling on the research team }\end{array}$ \\
\hline $\begin{array}{l}\text { Blinding (performance } \\
\text { bias and detection bias) } \\
\text { All outcomes }\end{array}$ & Low risk & Double blind study \\
\hline $\begin{array}{l}\text { Incomplete outcome data } \\
\text { (attrition bias) } \\
\text { All outcomes }\end{array}$ & Low risk & Lost to follow up $9 / 75$ \\
\hline $\begin{array}{l}\text { Selective reporting (re- } \\
\text { porting bias) }\end{array}$ & Low risk & No distinct selective outcome reporting \\
\hline $\begin{array}{l}\text { Blinding of participants } \\
\text { and personnel (perfor- } \\
\text { mance bias) } \\
\text { All outcomes }\end{array}$ & Low risk & Double blind study \\
\hline $\begin{array}{l}\text { Blinding of outcome as- } \\
\text { sessment (detection bias) }\end{array}$ & Low risk & Double blind study \\
\hline
\end{tabular}

Effects of low sodium diet versus high sodium diet on blood pressure, renin, aldosterone, catecholamines, cholesterol, and triglyceride 
1034 Watt 1985 (Continued)

All outcomes

1036 Richards 1986

\begin{tabular}{ll}
\hline Methods & SB \\
& CO \\
\hline Participants & N 8 males \\
& Norm \\
& Age36 \\
\hline Interventions & SR181 \\
& Dur4 \\
\hline \multirow{2}{*}{ Outcomes } & SBP \\
& DBP \\
& Aldo \\
Renin
\end{tabular}

\section{Risk of bias}

\begin{tabular}{|c|c|c|}
\hline Bias & Authors' judgement & Support for judgement \\
\hline $\begin{array}{l}\text { Random sequence genera- } \\
\text { tion (selection bias) }\end{array}$ & Unclear risk & Insufficient information \\
\hline $\begin{array}{l}\text { Allocation concealment } \\
\text { (selection bias) }\end{array}$ & Unclear risk & Insufficient information \\
\hline $\begin{array}{l}\text { Blinding (performance } \\
\text { bias and detection bias) } \\
\text { All outcomes }\end{array}$ & High risk & Open study \\
\hline $\begin{array}{l}\text { Incomplete outcome data } \\
\text { (attrition bias) } \\
\text { All outcomes }\end{array}$ & Low risk & Lost to follow up 0 \\
\hline $\begin{array}{l}\text { Selective reporting (re- } \\
\text { porting bias) }\end{array}$ & Low risk & No distinct selective outcome reporting \\
\hline $\begin{array}{l}\text { Blinding of participants } \\
\text { and personnel (perfor- } \\
\text { mance bias) } \\
\text { All outcomes }\end{array}$ & High risk & $\begin{array}{l}\text { Open study: Performance bias due to knowledge of the allocated interventions } \\
\text { by participants and personnel during the study. }\end{array}$ \\
\hline $\begin{array}{l}\text { Blinding of outcome as- } \\
\text { sessment (detection bias) } \\
\text { All outcomes }\end{array}$ & Low risk & Outcome detection blinded \\
\hline
\end{tabular}

\section{Teow 1986}

Methods Op

Effects of low sodium diet versus high sodium diet on blood pressure, renin, aldosterone, catecholamines, cholesterol, and triglyceride 
1037 Teow 1986 (Continued)

CO

\begin{tabular}{ll}
\hline Participants & N9 \\
& Norm \\
& Age25 \\
\hline Interventions & SR 200 \\
& Dur 14 \\
\hline Outcomes & SBP \\
& DBP \\
\hline Notes & LoFo: 0
\end{tabular}

\section{Risk of bias}

\begin{tabular}{|c|c|c|}
\hline Bias & Authors' judgement & Support for judgement \\
\hline $\begin{array}{l}\text { Random sequence genera- } \\
\text { tion (selection bias) }\end{array}$ & Unclear risk & Insufficient information \\
\hline $\begin{array}{l}\text { Allocation concealment } \\
\text { (selection bias) }\end{array}$ & Unclear risk & Insufficient information \\
\hline $\begin{array}{l}\text { Blinding (performance } \\
\text { bias and detection bias) } \\
\text { All outcomes }\end{array}$ & High risk & Open study \\
\hline $\begin{array}{l}\text { Incomplete outcome data } \\
\text { (attrition bias) } \\
\text { All outcomes }\end{array}$ & Low risk & Lost to follow up 0 \\
\hline $\begin{array}{l}\text { Selective reporting (re- } \\
\text { porting bias) }\end{array}$ & Low risk & No distinct selective outcome reporting \\
\hline $\begin{array}{l}\text { Blinding of participants } \\
\text { and personnel (perfor- } \\
\text { mance bias) } \\
\text { All outcomes }\end{array}$ & High risk & $\begin{array}{l}\text { Open study: Performance bias due to knowledge of the allocated interventions } \\
\text { by participants and personnel during the study. }\end{array}$ \\
\hline $\begin{array}{l}\text { Blinding of outcome as- } \\
\text { sessment (detection bias) } \\
\text { All outcomes }\end{array}$ & High risk & $\begin{array}{l}\text { Open study: Detection bias due to knowledge of the allocated interventions by } \\
\text { outcome assessors }\end{array}$ \\
\hline
\end{tabular}

1038 Logan 1986

\begin{tabular}{ll}
\hline Methods & Op \\
& P \\
\hline Participants & N86 \\
& Hyp \\
& Age47 \\
\hline Interventions & SR43 \\
& Dur180 \\
\hline
\end{tabular}

Effects of low sodium diet versus high sodium diet on blood pressure, renin, aldosterone, catecholamines, cholesterol, and triglyceride 
1038 Logan 1986 (Continued)

$\begin{array}{ll}\text { Outcomes } & \text { SBP } \\ \text { DBP }\end{array}$

Notes LoFo:?

\section{Risk of bias}

Bias Authors' judgement Support for judgement

Random sequence genera- Unclear risk Insufficient information

tion (selection bias)

Allocation concealment
(selection bias)

\begin{tabular}{|c|c|c|}
\hline $\begin{array}{l}\text { Blinding (performance } \\
\text { bias and detection bias) } \\
\text { All outcomes }\end{array}$ & High risk & Open study \\
\hline
\end{tabular}

\begin{tabular}{lll}
\hline $\begin{array}{l}\text { Incomplete outcome data } \\
\text { (attrition bias) } \\
\text { All outcomes }\end{array}$ & Unclear risk & Insufficient information \\
\hline $\begin{array}{l}\text { Selective reporting (re- } \\
\text { porting bias) }\end{array}$ & Low risk & No distinct selective outcome reporting \\
\hline $\begin{array}{l}\text { Blinding of participants } \\
\text { and personnel (perfor- } \\
\text { mance bias) }\end{array}$ & High risk & $\begin{array}{l}\text { Open study: Performance bias due to knowledge of the allocated interventions } \\
\text { by participants and personnel during the study. }\end{array}$ \\
\hline $\begin{array}{l}\text { Bll outcomes } \\
\text { sessment (detection bias) } \\
\text { All outcomes }\end{array}$ & High risk & $\begin{array}{l}\text { Open study: Detection bias due to knowledge of the allocated interventions by } \\
\text { outcome assessors }\end{array}$ \\
\hline
\end{tabular}

\section{ANHMRCDS 1986}

\begin{tabular}{ll}
\hline Methods & SB \\
& $P$ \\
\hline Participants & N100 \\
& Hyp \\
& Age53 \\
\hline Interventions & SR70 \\
& Dur 84 \\
\hline Outcomes & SBP \\
& DBP \\
\hline Notes & Included 107 \\
& LoFo:19 \\
IT: No
\end{tabular}

\section{Risk of bias}

Effects of low sodium diet versus high sodium diet on blood pressure, renin, aldosterone, catecholamines, cholesterol, and triglyceride 
1039 ANHMRCDS 1986 (Continued)

\begin{tabular}{|c|c|c|}
\hline Bias & Authors' judgement & Support for judgement \\
\hline $\begin{array}{l}\text { Random sequence genera- } \\
\text { tion (selection bias) }\end{array}$ & Unclear risk & Insufficient information \\
\hline $\begin{array}{l}\text { Allocation concealment } \\
\text { (selection bias) }\end{array}$ & Unclear risk & Insufficient information \\
\hline $\begin{array}{l}\text { Blinding (performance } \\
\text { bias and detection bias) } \\
\text { All outcomes }\end{array}$ & High risk & Open study \\
\hline $\begin{array}{l}\text { Incomplete outcome data } \\
\text { (attrition bias) } \\
\text { All outcomes }\end{array}$ & Low risk & Lost to follow up LS: 10/52; US: 9/55 \\
\hline $\begin{array}{l}\text { Selective reporting (re- } \\
\text { porting bias) }\end{array}$ & Low risk & No distinct selective outcome reporting \\
\hline $\begin{array}{l}\text { Blinding of participants } \\
\text { and personnel (perfor- } \\
\text { mance bias) } \\
\text { All outcomes }\end{array}$ & High risk & $\begin{array}{l}\text { Open study: Performance bias due to knowledge of the allocated interventions } \\
\text { by participants and personnel during the study. }\end{array}$ \\
\hline $\begin{array}{l}\text { Blinding of outcome as- } \\
\text { sessment (detection bias) } \\
\text { All outcomes }\end{array}$ & Low risk & Outcome detection blinded \\
\hline
\end{tabular}

\section{El Ashry 1987}

Methods SB

$\mathrm{CO}$

\begin{tabular}{ll}
\hline Participants & N13 \\
& Norm \\
& Age24 \\
\hline Interventions & SR222 \\
& Dur14 \\
\hline Outcomes & SBP \\
& DBP \\
\hline Notes & Renin \\
\hline
\end{tabular}

\section{Risk of bias}

\begin{tabular}{lll}
\hline Bias & Authors' judgement & Support for judgement \\
\hline $\begin{array}{l}\text { Random sequence genera- } \\
\text { tion (selection bias) }\end{array}$ & Unclear risk & Insufficient information \\
\hline $\begin{array}{l}\text { Allocation concealment } \\
\text { (selection bias) }\end{array}$ & Unclear risk & Insufficient information \\
\hline
\end{tabular}

Effects of low sodium diet versus high sodium diet on blood pressure, renin, aldosterone, catecholamines, cholesterol, and triglyceride 70 
1040 El Ashry 1987 (Continued)
Blinding (performance
bias and detection bias)
All outcomes
High risk
Open study

Incomplete outcome data Low risk Lost to follow up 0
(attrition bias)
All outcomes

\begin{tabular}{|c|c|c|}
\hline $\begin{array}{l}\text { Selective reporting (re- } \\
\text { porting bias) }\end{array}$ & Low risk & No distinct selective outcome reporting \\
\hline $\begin{array}{l}\text { Blinding of participants } \\
\text { and personnel (perfor- } \\
\text { mance bias) } \\
\text { All outcomes }\end{array}$ & High risk & $\begin{array}{l}\text { Open study: Performance bias due to knowledge of the allocated interventions } \\
\text { by participants and personnel during the study. }\end{array}$ \\
\hline $\begin{array}{l}\text { Blinding of outcome as- } \\
\text { sessment (detection bias) } \\
\text { All outcomes }\end{array}$ & Low risk & Outcome detection blinded \\
\hline
\end{tabular}

\section{Fuchs 1987}

\begin{tabular}{ll}
\hline Methods & Op \\
& CO \\
\hline Participants & N6 \\
& Norm \\
& Age20 \\
\hline Interventions & SR99 \\
& Dur9 \\
\hline Outcomes & SBP \\
& DBP \\
\hline Notes & LoFo:0
\end{tabular}

\section{Risk of bias}

\begin{tabular}{lll}
\hline Bias & Authors' judgement & Support for judgement \\
\hline $\begin{array}{l}\text { Random sequence genera- } \\
\text { tion (selection bias) }\end{array}$ & Unclear risk & Insufficient information \\
\hline $\begin{array}{l}\text { Allocation concealment } \\
\text { (selection bias) }\end{array}$ & Unclear risk & Insufficient information \\
\hline $\begin{array}{l}\text { Blinding (performance } \\
\text { bias and detection bias) } \\
\text { All outcomes }\end{array}$ & High risk & Open study \\
\hline $\begin{array}{l}\text { Incomplete outcome data } \\
\text { (attrition bias) } \\
\text { All outcomes }\end{array}$ & Low risk & Lost to follow up 0 \\
\hline
\end{tabular}




\section{Fuchs 1987 (Continued)}

Selective reporting (re- Low risk No distinct selective outcome reporting
porting bias)

Blinding of participants

High risk

Open study: Performance bias due to knowledge of the allocated interventions and personnel (perforby participants and personnel during the study. mance bias)

All outcomes

Blinding of outcome as- High risk
sessment (detection bias) All outcomes

Open study: Detection bias due to knowledge of the allocated interventions by outcome assessors

\section{Morgan 1987}

\begin{tabular}{ll}
\hline Methods & SB \\
& P \\
\hline Participants & N20 \\
& Hyp \\
& Age58 \\
\hline Interventions & SR57 \\
& Dur60 \\
\hline Outcomes & SBP \\
\hline Notes & DBP \\
\hline
\end{tabular}

\section{Risk of bias}

\begin{tabular}{|c|c|c|}
\hline Bias & Authors' judgement & Support for judgement \\
\hline $\begin{array}{l}\text { Random sequence genera- } \\
\text { tion (selection bias) }\end{array}$ & Unclear risk & Insufficient information \\
\hline $\begin{array}{l}\text { Allocation concealment } \\
\text { (selection bias) }\end{array}$ & Unclear risk & Insufficient information \\
\hline $\begin{array}{l}\text { Blinding (performance } \\
\text { bias and detection bias) } \\
\text { All outcomes }\end{array}$ & High risk & Open study \\
\hline $\begin{array}{l}\text { Incomplete outcome data } \\
\text { (attrition bias) } \\
\text { All outcomes }\end{array}$ & Low risk & Lost to follow up 0 \\
\hline $\begin{array}{l}\text { Selective reporting (re- } \\
\text { porting bias) }\end{array}$ & Low risk & No distinct selective outcome reporting \\
\hline $\begin{array}{l}\text { Blinding of participants } \\
\text { and personnel (perfor- } \\
\text { mance bias) } \\
\text { All outcomes }\end{array}$ & High risk & $\begin{array}{l}\text { Open study: Performance bias due to knowledge of the allocated interventions } \\
\text { by participants and personnel during the study. }\end{array}$ \\
\hline
\end{tabular}

Effects of low sodium diet versus high sodium diet on blood pressure, renin, aldosterone, catecholamines, cholesterol, and triglyceride 
1044 Morgan 1987 (Continued)
Blinding of outcome as-
Low risk
Outcome detection blinded sessment (detection bias)

All outcomes

\section{Kurtz 1987}

\begin{tabular}{ll}
\hline Methods & DB \\
& CO
\end{tabular}

\begin{tabular}{ll}
\hline Participants & N5 \\
& Hyp \\
& Age58 \\
\hline Interventions & SR217 \\
& Dur7 \\
\hline Outcomes & SBP \\
& DBP \\
\hline Notes & Included 7 \\
& LoFo: 2 \\
IT: No
\end{tabular}

\section{Risk of bias}

\begin{tabular}{|c|c|c|}
\hline Bias & Authors' judgement & Support for judgement \\
\hline $\begin{array}{l}\text { Random sequence genera- } \\
\text { tion (selection bias) }\end{array}$ & Unclear risk & Insufficient information \\
\hline $\begin{array}{l}\text { Allocation concealment } \\
\text { (selection bias) }\end{array}$ & Unclear risk & Insufficient information \\
\hline $\begin{array}{l}\text { Blinding (performance } \\
\text { bias and detection bias) } \\
\text { All outcomes }\end{array}$ & Low risk & Double blind study \\
\hline $\begin{array}{l}\text { Incomplete outcome data } \\
\text { (attrition bias) } \\
\text { All outcomes }\end{array}$ & High risk & Lost to follow up $2 / 7$ \\
\hline $\begin{array}{l}\text { Selective reporting (re- } \\
\text { porting bias) }\end{array}$ & Low risk & No distinct selective outcome reporting \\
\hline $\begin{array}{l}\text { Blinding of participants } \\
\text { and personnel (perfor- } \\
\text { mance bias) } \\
\text { All outcomes }\end{array}$ & Low risk & Double blind study \\
\hline $\begin{array}{l}\text { Blinding of outcome as- } \\
\text { sessment (detection bias) } \\
\text { All outcomes }\end{array}$ & Low risk & Double blind study \\
\hline
\end{tabular}


1046 Grobbee 1987

\begin{tabular}{ll}
\hline Methods & DB \\
& CO \\
\hline Participants & N40 \\
& Hyp \\
& Age24 \\
\hline Interventions & SR72 (129-57) \\
& Dur42 \\
\hline \multirow{2}{*}{ Outcomes } & SBP \\
& DBP \\
& Renin \\
NA \\
A \\
Chol \\
\hline Notes & Included 42 \\
& LoFo: 2 \\
IT: No
\end{tabular}

\section{Risk of bias}

\begin{tabular}{|c|c|c|}
\hline Bias & Authors' judgement & Support for judgement \\
\hline $\begin{array}{l}\text { Random sequence genera- } \\
\text { tion (selection bias) }\end{array}$ & Unclear risk & Insufficient information \\
\hline $\begin{array}{l}\text { Allocation concealment } \\
\text { (selection bias) }\end{array}$ & Unclear risk & Insufficient information \\
\hline $\begin{array}{l}\text { Blinding (performance } \\
\text { bias and detection bias) } \\
\text { All outcomes }\end{array}$ & Low risk & Double blind \\
\hline $\begin{array}{l}\text { Incomplete outcome data } \\
\text { (attrition bias) } \\
\text { All outcomes }\end{array}$ & Low risk & Lost to follow up $2 / 42$ \\
\hline $\begin{array}{l}\text { Selective reporting (re- } \\
\text { porting bias) }\end{array}$ & Low risk & No distinct selective outcome reporting \\
\hline $\begin{array}{l}\text { Blinding of participants } \\
\text { and personnel (perfor- } \\
\text { mance bias) } \\
\text { All outcomes }\end{array}$ & Low risk & Double blind study \\
\hline $\begin{array}{l}\text { Blinding of outcome as- } \\
\text { sessment (detection bias) } \\
\text { All outcomes }\end{array}$ & Low risk & Double blind study \\
\hline
\end{tabular}

\section{MacGregor 1987}

$\begin{array}{ll}\text { Methods } & \text { DB } \\ & \text { CO }\end{array}$

Effects of low sodium diet versus high sodium diet on blood pressure, renin, aldosterone, catecholamines, cholesterol, and triglyceride 


\section{MacGregor 1987 (Continued)}

\begin{tabular}{ll} 
Participants & N15 \\
& Hyp \\
& Age52 \\
\hline Interventions & SR100 \\
& Dur30 \\
\hline Outcomes & SBP \\
& DBP \\
\hline Notes & LoFo:0
\end{tabular}

\section{Risk of bias}

\begin{tabular}{lll}
\hline Bias & Authors' judgement & Support for judgement \\
\hline
\end{tabular}

Random sequence genera- Unclear risk Insufficient information
tion (selection bias)

\begin{tabular}{|c|c|c|}
\hline $\begin{array}{l}\text { Allocation concealment } \\
\text { (selection bias) }\end{array}$ & Unclear risk & Insufficient information \\
\hline $\begin{array}{l}\text { Blinding (performance } \\
\text { bias and detection bias) } \\
\text { All outcomes }\end{array}$ & Low risk & Double blind \\
\hline $\begin{array}{l}\text { Incomplete outcome data } \\
\text { (attrition bias) } \\
\text { All outcomes }\end{array}$ & Low risk & Lost to follow up 0 \\
\hline $\begin{array}{l}\text { Selective reporting (re- } \\
\text { porting bias) }\end{array}$ & Low risk & No distinct selective outcome reporting \\
\hline $\begin{array}{l}\text { Blinding of participants } \\
\text { and personnel (perfor- } \\
\text { mance bias) } \\
\text { All outcomes }\end{array}$ & Low risk & Double blind study \\
\hline $\begin{array}{l}\text { Blinding of outcome as- } \\
\text { sessment (detection bias) } \\
\text { All outcomes }\end{array}$ & Low risk & Double blind study \\
\hline
\end{tabular}

\section{Lawton 1988}

\begin{tabular}{ll}
\hline Methods & Op \\
& CO \\
\hline Participants & N13 \\
& Norm \\
& Age24 \\
\hline Interventions & SR313 \\
& Dur6 \\
\hline Outcomes & SBP \\
& DBP
\end{tabular}

Effects of low sodium diet versus high sodium diet on blood pressure, renin, aldosterone, catecholamines, cholesterol, and triglyceride 
1048 Lawton 1988 (Continued)

Renin

NA

LoFo: 0

\section{Risk of bias}

\begin{tabular}{|c|c|c|}
\hline Bias & Authors' judgement & Support for judgement \\
\hline $\begin{array}{l}\text { Random sequence genera- } \\
\text { tion (selection bias) }\end{array}$ & Unclear risk & Insufficient information \\
\hline $\begin{array}{l}\text { Allocation concealment } \\
\text { (selection bias) }\end{array}$ & Unclear risk & Insufficient information \\
\hline $\begin{array}{l}\text { Blinding (performance } \\
\text { bias and detection bias) } \\
\text { All outcomes }\end{array}$ & High risk & Open study \\
\hline $\begin{array}{l}\text { Incomplete outcome data } \\
\text { (attrition bias) } \\
\text { All outcomes }\end{array}$ & Low risk & Lost to follow up 0 \\
\hline $\begin{array}{l}\text { Selective reporting (re- } \\
\text { porting bias) }\end{array}$ & Low risk & No distinct selective outcome reporting \\
\hline $\begin{array}{l}\text { Blinding of participants } \\
\text { and personnel (perfor- } \\
\text { mance bias) } \\
\text { All outcomes }\end{array}$ & High risk & $\begin{array}{l}\text { Open study: Performance bias due to knowledge of the allocated interventions } \\
\text { by participants and personnel during the study. }\end{array}$ \\
\hline $\begin{array}{l}\text { Blinding of outcome as- } \\
\text { sessment (detection bias) } \\
\text { All outcomes }\end{array}$ & High risk & $\begin{array}{l}\text { Open study: Detection bias due to knowledge of the allocated interventions by } \\
\text { outcome assessors }\end{array}$ \\
\hline
\end{tabular}

\section{Lawton 1988 H}

\begin{tabular}{ll}
\hline Methods & Op \\
& CO \\
\hline Participants & N9 \\
& Hyp \\
& Age25 \\
\hline Interventions & SR328 \\
& Dur6 \\
\hline Outcomes & SBP \\
& DBP \\
& Renin \\
NA
\end{tabular}

\section{Risk of bias}

Effects of low sodium diet versus high sodium diet on blood pressure, renin, aldosterone, catecholamines, cholesterol, and triglyceride 
1049 Lawton 1988 H (Continued)

\begin{tabular}{|c|c|c|}
\hline Bias & Authors' judgement & Support for judgement \\
\hline $\begin{array}{l}\text { Random sequence genera- } \\
\text { tion (selection bias) }\end{array}$ & Unclear risk & Insufficient information \\
\hline $\begin{array}{l}\text { Allocation concealment } \\
\text { (selection bias) }\end{array}$ & Unclear risk & Insufficient information \\
\hline $\begin{array}{l}\text { Blinding (performance } \\
\text { bias and detection bias) } \\
\text { All outcomes }\end{array}$ & High risk & Open study \\
\hline $\begin{array}{l}\text { Incomplete outcome data } \\
\text { (attrition bias) } \\
\text { All outcomes }\end{array}$ & Low risk & Lost to follow up 0 \\
\hline $\begin{array}{l}\text { Selective reporting (re- } \\
\text { porting bias) }\end{array}$ & Low risk & No distinct selective outcome reporting \\
\hline $\begin{array}{l}\text { Blinding of participants } \\
\text { and personnel (perfor- } \\
\text { mance bias) } \\
\text { All outcomes }\end{array}$ & High risk & $\begin{array}{l}\text { Open study: Performance bias due to knowledge of the allocated interventions } \\
\text { by participants and personnel during the study. }\end{array}$ \\
\hline $\begin{array}{l}\text { Blinding of outcome as- } \\
\text { sessment (detection bias) } \\
\text { All outcomes }\end{array}$ & High risk & $\begin{array}{l}\text { Open study: Detection bias due to knowledge of the allocated interventions by } \\
\text { outcome assessors }\end{array}$ \\
\hline
\end{tabular}

\section{Morgan 1988}

\begin{tabular}{ll}
\hline Methods & SB \\
& CO \\
\hline Participants & N16 \\
& Hyp \\
& Age63 \\
\hline Interventions & SR50 \\
& Dur14 \\
\hline Outcomes & SBP \\
& DBP \\
Renin \\
\hline Notes & LoFo: 0 \\
\hline
\end{tabular}

\section{Risk of bias}

\begin{tabular}{lll}
\hline Bias & Authors' judgement & Support for judgement \\
\hline $\begin{array}{l}\text { Random sequence genera- } \\
\text { tion (selection bias) }\end{array}$ & Unclear risk & Insufficient information \\
\hline $\begin{array}{l}\text { Allocation concealment } \\
\text { (selection bias) }\end{array}$ & Unclear risk & Insufficient information \\
\hline
\end{tabular}

Effects of low sodium diet versus high sodium diet on blood pressure, renin, aldosterone, catecholamines, cholesterol, and triglyceride 
1050 Morgan 1988 (Continued)

Blinding (performance $\quad$ High risk
bias and detection bias)
All outcomes

\begin{tabular}{lll}
\hline $\begin{array}{l}\text { Incomplete outcome data } \\
\text { (attrition bias) } \\
\text { All outcomes }\end{array}$ & Low risk & Lost to follow up 0 \\
\hline $\begin{array}{l}\text { Selective reporting (re- } \\
\text { porting bias) }\end{array}$ & Low risk & No distinct selective outcome reporting \\
\hline $\begin{array}{l}\text { Blinding of participants } \\
\begin{array}{l}\text { and personnel (perfor- } \\
\text { mance bias) } \\
\text { All outcomes }\end{array}\end{array}$ & High risk & $\begin{array}{l}\text { Open study: Detection bias due to knowledge of the allocated interventions by } \\
\text { outcome assessors }\end{array}$ \\
\hline $\begin{array}{l}\text { Blinding of outcome as- } \\
\text { sessment (detection bias) } \\
\text { All outcomes }\end{array}$ & Low risk & outcome detection blinded \\
\hline
\end{tabular}

\section{Morgan 1988,2}

\begin{tabular}{ll}
\hline Methods & DB \\
CO \\
\hline Participants & $\begin{array}{l}\text { Nypertension } \\
\text { Age 63 }\end{array}$ \\
\hline Interventions & SR $67(135-68)$ \\
& Dur 14 \\
\hline Outcomes & SBP, DBP \\
\hline Notes & LoFo: 0
\end{tabular}

\section{Risk of bias}

\begin{tabular}{lll}
\hline Bias & Authors' judgement & Support for judgement \\
\hline $\begin{array}{l}\text { Random sequence genera- } \\
\text { tion (selection bias) }\end{array}$ & Unclear risk & Insufficient information \\
\hline $\begin{array}{l}\text { Allocation concealment } \\
\text { (selection bias) }\end{array}$ & Unclear risk & Insufficient information \\
\hline $\begin{array}{l}\text { Blinding (performance } \\
\text { bias and detection bias) } \\
\text { All outcomes }\end{array}$ & Low risk & Double blind study \\
\hline $\begin{array}{l}\text { Incomplete outcome data } \\
\text { (attrition bias) }\end{array}$ & Low risk & Lost to follow up 0 \\
\begin{tabular}{l} 
All outcomes \\
\hline
\end{tabular} & & \\
\hline
\end{tabular}


1051 Morgan 1988,2 (Continued)

Selective reporting (re- Low risk No distinct selective outcome reporting
porting bias)

Blinding of participants Low risk Double blind study
and personnel (performance bias)

All outcomes

\begin{tabular}{lll}
\hline Blinding of outcome as- & Low risk & Double blind study \\
sessment (detection bias) &
\end{tabular}

All outcomes

1052 Shore 1988

\begin{tabular}{ll}
\hline Methods & SB \\
& CO
\end{tabular}

\begin{tabular}{ll}
\hline Participants & N6 \\
& Hyp \\
& Age \\
\hline Interventions & SR 97 \\
& Dur5 \\
\hline Outcomes & SBP \\
& DBP \\
& Aldo \\
& Renin \\
\hline Notes & LoFo: 0 \\
\hline
\end{tabular}

\section{Risk of bias}

\begin{tabular}{|c|c|c|}
\hline Bias & Authors' judgement & Support for judgement \\
\hline $\begin{array}{l}\text { Random sequence genera- } \\
\text { tion (selection bias) }\end{array}$ & Unclear risk & Insufficient information \\
\hline $\begin{array}{l}\text { Allocation concealment } \\
\text { (selection bias) }\end{array}$ & Unclear risk & Insufficient information \\
\hline $\begin{array}{l}\text { Blinding (performance } \\
\text { bias and detection bias) } \\
\text { All outcomes }\end{array}$ & High risk & Open study \\
\hline $\begin{array}{l}\text { Incomplete outcome data } \\
\text { (attrition bias) } \\
\text { All outcomes }\end{array}$ & Low risk & Lost to follow up 0 \\
\hline $\begin{array}{l}\text { Selective reporting (re- } \\
\text { porting bias) }\end{array}$ & Low risk & No distinct selective outcome reporting \\
\hline $\begin{array}{l}\text { Blinding of participants } \\
\text { and personnel (perfor- } \\
\text { mance bias) }\end{array}$ & High risk & $\begin{array}{l}\text { Open study: Detection bias due to knowledge of the allocated interventions by } \\
\text { outcome assessors }\end{array}$ \\
\hline
\end{tabular}


1052 Shore 1988 (Continued)

All outcomes

Blinding of outcome as- Low risk $\quad$ outcome detection blinded
sessment (detection bias)

All outcomes

1053 Sudhir 1989

\begin{tabular}{ll}
\hline Methods & Op \\
& CO
\end{tabular}

\begin{tabular}{ll}
\hline Participants & N 6 (M/F:6/0)(B/W/A.0/6/0) \\
& Normotension \\
& Age 35 \\
\hline Interventions & SR $134(163-29)$ \\
& Dur 12 \\
\hline Outcomes & SBP, DBP, renin \\
\hline Notes & LoFo: 0 \\
\hline
\end{tabular}

\section{Risk of bias}

\begin{tabular}{|c|c|c|}
\hline Bias & Authors' judgement & Support for judgement \\
\hline $\begin{array}{l}\text { Random sequence genera- } \\
\text { tion (selection bias) }\end{array}$ & Unclear risk & Insufficient information \\
\hline $\begin{array}{l}\text { Allocation concealment } \\
\text { (selection bias) }\end{array}$ & Unclear risk & Insufficient information \\
\hline $\begin{array}{l}\text { Blinding (performance } \\
\text { bias and detection bias) } \\
\text { All outcomes }\end{array}$ & High risk & Open study \\
\hline $\begin{array}{l}\text { Incomplete outcome data } \\
\text { (attrition bias) } \\
\text { All outcomes }\end{array}$ & Low risk & Lost to follow up 0 \\
\hline $\begin{array}{l}\text { Selective reporting (re- } \\
\text { porting bias) }\end{array}$ & Low risk & No distinct selective outcome reporting \\
\hline $\begin{array}{l}\text { Blinding of participants } \\
\text { and personnel (perfor- } \\
\text { mance bias) } \\
\text { All outcomes }\end{array}$ & High risk & $\begin{array}{l}\text { Open study: Detection bias due to knowledge of the allocated interventions by } \\
\text { outcome assessors }\end{array}$ \\
\hline $\begin{array}{l}\text { Blinding of outcome as- } \\
\text { sessment (detection bias) } \\
\text { All outcomes }\end{array}$ & Low risk & Outcome detection blinded \\
\hline
\end{tabular}


1054 Hargreaves 1989

\begin{tabular}{ll}
\hline Methods & DB \\
& CO
\end{tabular}

\begin{tabular}{ll}
\hline Participants & N8 \\
& Norm \\
& Age23 \\
\hline Interventions & SR106 \\
& Dur14 \\
\hline Outcomes & SBP \\
& DBP \\
& Aldo \\
& Renin \\
\hline Notes & LoFo: 0 \\
\hline
\end{tabular}

\section{Risk of bias}

\begin{tabular}{|c|c|c|}
\hline Bias & Authors' judgement & Support for judgement \\
\hline $\begin{array}{l}\text { Random sequence genera- } \\
\text { tion (selection bias) }\end{array}$ & Unclear risk & Insufficient information \\
\hline $\begin{array}{l}\text { Allocation concealment } \\
\text { (selection bias) }\end{array}$ & Unclear risk & Insufficient information \\
\hline $\begin{array}{l}\text { Blinding (performance } \\
\text { bias and detection bias) } \\
\text { All outcomes }\end{array}$ & Low risk & Double blind study \\
\hline $\begin{array}{l}\text { Incomplete outcome data } \\
\text { (attrition bias) } \\
\text { All outcomes }\end{array}$ & Low risk & Lost to follow up 0 \\
\hline $\begin{array}{l}\text { Selective reporting (re- } \\
\text { porting bias) }\end{array}$ & Low risk & No distinct selective outcome reporting \\
\hline $\begin{array}{l}\text { Blinding of participants } \\
\text { and personnel (perfor- } \\
\text { mance bias) } \\
\text { All outcomes }\end{array}$ & Low risk & Double blind study \\
\hline $\begin{array}{l}\text { Blinding of outcome as- } \\
\text { sessment (detection bias) } \\
\text { All outcomes }\end{array}$ & Low risk & Double blind study \\
\hline
\end{tabular}

1055 ANHMRCDS 1989

\begin{tabular}{ll}
\hline Methods & Op \\
& $\mathrm{P}$ \\
\hline Participants & N103 \\
& Hyp \\
& Age58 \\
\hline
\end{tabular}

Effects of low sodium diet versus high sodium diet on blood pressure, renin, aldosterone, catecholamines, cholesterol, and triglyceride 
1055 ANHMRCDS 1989 (Continued)

\begin{tabular}{ll} 
Interventions & $\begin{array}{l}\text { SR63 } \\
\text { Dur 48 }\end{array}$ \\
\hline Outcomes & SBP \\
& DBP \\
\hline Notes & Included 111 \\
& LoFo: 8 \\
& IT: No
\end{tabular}

\section{Risk of bias}

\begin{tabular}{|c|c|c|}
\hline Bias & Authors' judgement & Support for judgement \\
\hline $\begin{array}{l}\text { Random sequence genera- } \\
\text { tion (selection bias) }\end{array}$ & Unclear risk & Insufficient information \\
\hline $\begin{array}{l}\text { Allocation concealment } \\
\text { (selection bias) }\end{array}$ & Unclear risk & Insufficient information \\
\hline $\begin{array}{l}\text { Blinding (performance } \\
\text { bias and detection bias) } \\
\text { All outcomes }\end{array}$ & High risk & Open study \\
\hline $\begin{array}{l}\text { Incomplete outcome data } \\
\text { (attrition bias) } \\
\text { All outcomes }\end{array}$ & Low risk & Lost to follow up LS: $4 / 54 ;$ US: $4 / 57$ \\
\hline $\begin{array}{l}\text { Selective reporting (re- } \\
\text { porting bias) }\end{array}$ & Low risk & No distinct selective outcome reporting \\
\hline $\begin{array}{l}\text { Blinding of participants } \\
\text { and personnel (perfor- } \\
\text { mance bias) } \\
\text { All outcomes }\end{array}$ & High risk & $\begin{array}{l}\text { Open study: Performance bias due to knowledge of the allocated interventions } \\
\text { by participants and personnel during the study. }\end{array}$ \\
\hline $\begin{array}{l}\text { Blinding of outcome as- } \\
\text { sessment (detection bias) } \\
\text { All outcomes }\end{array}$ & High risk & $\begin{array}{l}\text { Open study: Detection bias due to knowledge of the allocated interventions by } \\
\text { outcome assessors }\end{array}$ \\
\hline
\end{tabular}

\section{MacGregor 1989}

\begin{tabular}{ll}
\hline Methods & DB \\
& CO \\
\hline Participants & N20 \\
& Hyp \\
& Age57 \\
\hline Interventions & SR150 \\
& Dur30 \\
\hline \multirow{2}{*}{ Outcomes } & SBP \\
& DBP \\
& Aldo \\
Renin
\end{tabular}

Effects of low sodium diet versus high sodium diet on blood pressure, renin, aldosterone, catecholamines, cholesterol, and triglyceride 
1056 MacGregor 1989 (Continued)

NA

$\begin{array}{ll}\text { Notes } & \text { LoFo: } 0\end{array}$

\section{Risk of bias}

\begin{tabular}{|c|c|c|}
\hline Bias & Authors' judgement & Support for judgement \\
\hline $\begin{array}{l}\text { Random sequence genera- } \\
\text { tion (selection bias) }\end{array}$ & Unclear risk & Insufficient information \\
\hline $\begin{array}{l}\text { Allocation concealment } \\
\text { (selection bias) }\end{array}$ & Unclear risk & Insufficient information \\
\hline $\begin{array}{l}\text { Blinding (performance } \\
\text { bias and detection bias) } \\
\text { All outcomes }\end{array}$ & Low risk & Double blind study \\
\hline $\begin{array}{l}\text { Incomplete outcome data } \\
\text { (attrition bias) } \\
\text { All outcomes }\end{array}$ & Low risk & Lost to follow up 0 \\
\hline $\begin{array}{l}\text { Selective reporting (re- } \\
\text { porting bias) }\end{array}$ & Low risk & No distinct selective outcome reporting \\
\hline $\begin{array}{l}\text { Blinding of participants } \\
\text { and personnel (perfor- } \\
\text { mance bias) } \\
\text { All outcomes }\end{array}$ & Low risk & Double blind study \\
\hline $\begin{array}{l}\text { Blinding of outcome as- } \\
\text { sessment (detection bias) } \\
\text { All outcomes }\end{array}$ & Low risk & Double blind study \\
\hline
\end{tabular}

\section{Dimsdale 1990 W}

\begin{tabular}{ll}
\hline Methods & Op \\
& CO \\
\hline Participants & N19 (White) \\
& Norm \\
& Age34 \\
\hline Interventions & SR183 \\
& Dur5 \\
\hline Outcomes & SBP \\
& DBP \\
& Renin \\
\hline Notes & LoFo: 0 \\
\hline
\end{tabular}

\section{Risk of bias}

Bias Authors' judgement Support for judgement

Effects of low sodium diet versus high sodium diet on blood pressure, renin, aldosterone, catecholamines, cholesterol, and triglyceride 


\section{Dimsdale 1990 W (Continued)}

\begin{tabular}{lll}
$\begin{array}{l}\text { Random sequence genera- } \\
\text { tion (selection bias) }\end{array}$ & Unclear risk & Insufficient information \\
\hline $\begin{array}{l}\text { Allocation concealment } \\
\text { (selection bias) }\end{array}$ & Unclear risk & Insufficient information \\
\hline $\begin{array}{l}\text { Blinding (performance } \\
\text { bias and detection bias) } \\
\text { All outcomes }\end{array}$ & High risk & Open study \\
\hline
\end{tabular}

\begin{tabular}{|c|c|c|}
\hline $\begin{array}{l}\text { Incomplete outcome data } \\
\text { (attrition bias) } \\
\text { All outcomes }\end{array}$ & Low risk & Lost to follow up 0 \\
\hline $\begin{array}{l}\text { Selective reporting (re- } \\
\text { porting bias) }\end{array}$ & Low risk & No distinct selective outcome reporting \\
\hline $\begin{array}{l}\text { Blinding of participants } \\
\text { and personnel (perfor- } \\
\text { mance bias) } \\
\text { All outcomes }\end{array}$ & High risk & $\begin{array}{l}\text { Open study: Performance bias due to knowledge of the allocated interventions } \\
\text { by participants and personnel during the study. }\end{array}$ \\
\hline $\begin{array}{l}\text { Blinding of outcome as- } \\
\text { sessment (detection bias) } \\
\text { All outcomes }\end{array}$ & High risk & $\begin{array}{l}\text { Open study: Detection bias due to knowledge of the allocated interventions by } \\
\text { outcome assessors }\end{array}$ \\
\hline
\end{tabular}

\section{Dimsdale 1990 WH}

\begin{tabular}{ll}
\hline Methods & Op \\
& CO \\
\hline Participants & $\begin{array}{l}\text { N17 (White) } \\
\text { Hyp } \\
\text { Age34 }\end{array}$ \\
\hline Interventions & SR 198 \\
& Dur 5 \\
\hline Outcomes & SBP \\
& DBP \\
Renin \\
\hline Notes & LoFo: 0 \\
\hline
\end{tabular}

\section{Risk of bias}

\section{Bias}

Random sequence generation (selection bias)

Allocation concealment
(selection bias)

\begin{tabular}{lll}
\hline $\begin{array}{l}\text { Blinding (performance } \\
\text { bias and detection bias) }\end{array}$ & High risk & Open study
\end{tabular}

Effects of low sodium diet versus high sodium diet on blood pressure, renin, aldosterone, catecholamines, cholesterol, and triglyceride 
1058 Dimsdale 1990 WH (Continued)

All outcomes

Incomplete outcome data $\quad$ Low risk
(attrition bias)

(attrition bias)

All outcomes

Selective reporting (re- Low risk No distinct selective outcome reporting
porting bias)

\begin{tabular}{|c|c|c|}
\hline $\begin{array}{l}\text { Blinding of participants } \\
\text { and personnel (perfor- } \\
\text { mance bias) } \\
\text { All outcomes }\end{array}$ & High risk & $\begin{array}{l}\text { Open study: Performance bias due to knowledge of the allocated interventions } \\
\text { by participants and personnel during the study. }\end{array}$ \\
\hline $\begin{array}{l}\text { Blinding of outcome as- } \\
\text { sessment (detection bias) } \\
\text { All outcomes }\end{array}$ & High risk & $\begin{array}{l}\text { Open study: Detection bias due to knowledge of the allocated interventions by } \\
\text { outcome assessors }\end{array}$ \\
\hline
\end{tabular}

\section{Dimsdale 1990 B}

\begin{tabular}{ll}
\hline Methods & Op \\
& CO \\
\hline Participants & N23 (Black) \\
& Norm \\
& Age34 \\
\hline Interventions & SR178 \\
& Dur5 \\
\hline Outcomes & SBP \\
& DBP \\
Renin
\end{tabular}

\section{Risk of bias}

\begin{tabular}{|c|c|c|}
\hline Bias & Authors' judgement & Support for judgement \\
\hline $\begin{array}{l}\text { Random sequence genera- } \\
\text { tion (selection bias) }\end{array}$ & Unclear risk & Insufficient information \\
\hline $\begin{array}{l}\text { Allocation concealment } \\
\text { (selection bias) }\end{array}$ & Unclear risk & Insufficient information \\
\hline $\begin{array}{l}\text { Blinding (performance } \\
\text { bias and detection bias) } \\
\text { All outcomes }\end{array}$ & High risk & Open study \\
\hline $\begin{array}{l}\text { Incomplete outcome data } \\
\text { (attrition bias) } \\
\text { All outcomes }\end{array}$ & Low risk & Lost to follow up 0 \\
\hline $\begin{array}{l}\text { Selective reporting (re- } \\
\text { porting bias) }\end{array}$ & Low risk & No distinct selective outcome reporting \\
\hline
\end{tabular}

Effects of low sodium diet versus high sodium diet on blood pressure, renin, aldosterone, catecholamines, cholesterol, and triglyceride 
1059 Dimsdale 1990 B (Continued)

Blinding of participants High risk Open study: Performance bias due to knowledge of the allocated interventions and personnel (performance bias)

All outcomes

Blinding of outcome as- High risk sessment (detection bias)

All outcomes by participants and personnel during the study.

Open study: Detection bias due to knowledge of the allocated interventions by outcome assessors

\section{Dimsdale 1990 BH}

\begin{tabular}{ll}
\hline Methods & CO
\end{tabular}

CO

\begin{tabular}{ll}
\hline Participants & N16 (Black) \\
& Hyp \\
& Age34 \\
\hline Interventions & SR178 \\
& Dur5 \\
\hline Outcomes & SBP \\
& DBP \\
& Renin \\
\hline
\end{tabular}

Notes LoFo: 0

\section{Risk of bias}

Bias Authors' judgement Support for judgement

Random sequence genera- Unclear risk Insufficient information
tion (selection bias)

\begin{tabular}{lll}
\hline $\begin{array}{l}\text { Allocation concealment } \\
\text { (selection bias) }\end{array}$ & Unclear risk Insufficient information
\end{tabular}

\begin{tabular}{|c|c|c|}
\hline $\begin{array}{l}\text { Blinding (performance } \\
\text { bias and detection bias) } \\
\text { All outcomes }\end{array}$ & High risk & Open study \\
\hline
\end{tabular}

Incomplete outcome data Low risk $\quad$ Lost to follow up 0
(attrition bias)
All outcomes

\begin{tabular}{|c|c|c|}
\hline $\begin{array}{l}\text { Selective reporting (re- } \\
\text { porting bias) }\end{array}$ & Low risk & No distinct selective outcome reporting \\
\hline $\begin{array}{l}\text { Blinding of participants } \\
\text { and personnel (perfor- } \\
\text { mance bias) } \\
\text { All outcomes }\end{array}$ & High risk & $\begin{array}{l}\text { Open study: Performance bias due to knowledge of the allocated interventions } \\
\text { by participants and personnel during the study. }\end{array}$ \\
\hline $\begin{array}{l}\text { Blinding of outcome as- } \\
\text { sessment (detection bias) }\end{array}$ & High risk & $\begin{array}{l}\text { Open study: Detection bias due to knowledge of the allocated interventions by } \\
\text { outcome assessors }\end{array}$ \\
\hline
\end{tabular}

Effects of low sodium diet versus high sodium diet on blood pressure, renin, aldosterone, catecholamines, cholesterol, and triglyceride 
1060 Dimsdale 1990 BH (Continued)

All outcomes

\section{Schmid 1990}

\begin{tabular}{ll}
\hline Methods & SB \\
& CO \\
\hline Participants & N9 \\
& Norm \\
& Age32 \\
\hline Interventions & SR190 \\
& Dur7 \\
\hline Outcomes & SBP \\
& DBP \\
\hline Notes & Allocation: random numbers \\
& LoFo: 0 \\
\hline
\end{tabular}

\section{Risk of bias}

\begin{tabular}{|c|c|c|}
\hline Bias & Authors' judgement & Support for judgement \\
\hline $\begin{array}{l}\text { Random sequence genera- } \\
\text { tion (selection bias) }\end{array}$ & Unclear risk & Insufficient information \\
\hline $\begin{array}{l}\text { Allocation concealment } \\
\text { (selection bias) }\end{array}$ & Unclear risk & Insufficient information \\
\hline $\begin{array}{l}\text { Blinding (performance } \\
\text { bias and detection bias) } \\
\text { All outcomes }\end{array}$ & High risk & Open study \\
\hline $\begin{array}{l}\text { Incomplete outcome data } \\
\text { (attrition bias) } \\
\text { All outcomes }\end{array}$ & Low risk & Lost to follow up 0 \\
\hline $\begin{array}{l}\text { Selective reporting (re- } \\
\text { porting bias) }\end{array}$ & Low risk & No distinct selective outcome reporting \\
\hline $\begin{array}{l}\text { Blinding of participants } \\
\text { and personnel (perfor- } \\
\text { mance bias) } \\
\text { All outcomes }\end{array}$ & High risk & $\begin{array}{l}\text { Open study: Performance bias due to knowledge of the allocated interventions } \\
\text { by participants and personnel during the study. }\end{array}$ \\
\hline $\begin{array}{l}\text { Blinding of outcome as- } \\
\text { sessment (detection bias) } \\
\text { All outcomes }\end{array}$ & Low risk & Outcome detection blinded \\
\hline
\end{tabular}

1062 Schmid 1990 H

Methods SB


1062 Schmid 1990 H (Continued)

\section{$\mathrm{CO}$}

\begin{tabular}{ll}
\hline Participants & N9 \\
& Hyp \\
& Age36 \\
\hline Interventions & SR \\
& Dur \\
\hline Outcomes & SBP \\
& DBP \\
\hline Notes & Allocation: random numbers \\
& LoFo: 0 \\
\hline
\end{tabular}

\section{Risk of bias}

\begin{tabular}{|c|c|c|}
\hline Bias & Authors' judgement & Support for judgement \\
\hline $\begin{array}{l}\text { Random sequence genera- } \\
\text { tion (selection bias) }\end{array}$ & Unclear risk & Insufficient information: "with the help of random numbers" \\
\hline $\begin{array}{l}\text { Allocation concealment } \\
\text { (selection bias) }\end{array}$ & Unclear risk & Insufficient information \\
\hline $\begin{array}{l}\text { Blinding (performance } \\
\text { bias and detection bias) } \\
\text { All outcomes }\end{array}$ & High risk & Open study \\
\hline $\begin{array}{l}\text { Incomplete outcome data } \\
\text { (attrition bias) } \\
\text { All outcomes }\end{array}$ & Low risk & Lost to follow up 0 \\
\hline $\begin{array}{l}\text { Selective reporting (re- } \\
\text { porting bias) }\end{array}$ & Low risk & No distinct selective outcome reporting \\
\hline $\begin{array}{l}\text { Blinding of participants } \\
\text { and personnel (perfor- } \\
\text { mance bias) } \\
\text { All outcomes }\end{array}$ & High risk & $\begin{array}{l}\text { Open study: Performance bias due to knowledge of the allocated interventions } \\
\text { by participants and personnel during the study. }\end{array}$ \\
\hline $\begin{array}{l}\text { Blinding of outcome as- } \\
\text { sessment (detection bias) } \\
\text { All outcomes }\end{array}$ & Low risk & Outcome detection blinded \\
\hline
\end{tabular}

\section{HPTRG 1990}

\begin{tabular}{ll}
\hline Methods & SB \\
& $P$ \\
\hline Participants & N 579 \\
& Norm \\
& Age40 \\
\hline Interventions & SR23 \\
& Dur 1100 \\
\hline \hline
\end{tabular}

Effects of low sodium diet versus high sodium diet on blood pressure, renin, aldosterone, catecholamines, cholesterol, and triglyceride 
1063 HPTRG 1990 (Continued)

\begin{tabular}{ll} 
Outcomes & SBP \\
& DBP \\
\hline Notes & Included 634 \\
& LoFo: 65 \\
& IT: No
\end{tabular}

\section{Risk of bias}

\begin{tabular}{|c|c|c|}
\hline Bias & Authors' judgement & Support for judgement \\
\hline $\begin{array}{l}\text { Random sequence genera- } \\
\text { tion (selection bias) }\end{array}$ & Unclear risk & Insufficient information \\
\hline $\begin{array}{l}\text { Allocation concealment } \\
\text { (selection bias) }\end{array}$ & Unclear risk & Insufficient information \\
\hline $\begin{array}{l}\text { Blinding (performance } \\
\text { bias and detection bias) } \\
\text { All outcomes }\end{array}$ & High risk & Open study \\
\hline $\begin{array}{l}\text { Incomplete outcome data } \\
\text { (attrition bias) } \\
\text { All outcomes }\end{array}$ & Low risk & Lost to follow up LS: 30/312; US: $35 / 322$ \\
\hline $\begin{array}{l}\text { Selective reporting (re- } \\
\text { porting bias) }\end{array}$ & Low risk & No distinct selective outcome reporting \\
\hline $\begin{array}{l}\text { Blinding of participants } \\
\text { and personnel (perfor- } \\
\text { mance bias) } \\
\text { All outcomes }\end{array}$ & High risk & $\begin{array}{l}\text { Open study: Performance bias due to knowledge of the allocated interventions } \\
\text { by participants and personnel during the study. }\end{array}$ \\
\hline $\begin{array}{l}\text { Blinding of outcome as- } \\
\text { sessment (detection bias) } \\
\text { All outcomes }\end{array}$ & Low risk & Outcome detection blinded \\
\hline
\end{tabular}

\section{Bruun 1990}

\begin{tabular}{ll}
\hline Methods & Op \\
& CO \\
\hline Participants & N10 \\
& Norm \\
& Age46 \\
\hline Interventions & SR341 \\
& Dur4 \\
\hline Outcomes & SBP \\
& DBP \\
& Aldo \\
Renin \\
\hline Notes & LoFo: 0 \\
\hline
\end{tabular}

Effects of low sodium diet versus high sodium diet on blood pressure, renin, aldosterone, catecholamines, cholesterol, and triglyceride 
1064 Bruun 1990 (Continued)

\section{Risk of bias}

\begin{tabular}{|c|c|c|}
\hline Bias & Authors' judgement & Support for judgement \\
\hline $\begin{array}{l}\text { Random sequence genera- } \\
\text { tion (selection bias) }\end{array}$ & Unclear risk & Insufficient information \\
\hline $\begin{array}{l}\text { Allocation concealment } \\
\text { (selection bias) }\end{array}$ & Unclear risk & Insufficient information \\
\hline $\begin{array}{l}\text { Blinding (performance } \\
\text { bias and detection bias) } \\
\text { All outcomes }\end{array}$ & High risk & Open study \\
\hline $\begin{array}{l}\text { Incomplete outcome data } \\
\text { (attrition bias) } \\
\text { All outcomes }\end{array}$ & Low risk & Lost to follow up 0 \\
\hline $\begin{array}{l}\text { Selective reporting (re- } \\
\text { porting bias) }\end{array}$ & Low risk & No distinct selective outcome reporting \\
\hline $\begin{array}{l}\text { Blinding of participants } \\
\text { and personnel (perfor- } \\
\text { mance bias) } \\
\text { All outcomes }\end{array}$ & High risk & $\begin{array}{l}\text { Open study: Performance bias due to knowledge of the allocated interventions } \\
\text { by participants and personnel during the study. }\end{array}$ \\
\hline $\begin{array}{l}\text { Blinding of outcome as- } \\
\text { sessment (detection bias) } \\
\text { All outcomes }\end{array}$ & High risk & $\begin{array}{l}\text { Open study: Detection bias due to knowledge of the allocated interventions by } \\
\text { outcome assessors }\end{array}$ \\
\hline
\end{tabular}

1065 Bruun $1990 \mathrm{H}$

\begin{tabular}{ll}
\hline Methods & Op \\
& CO \\
\hline Participants & N12 \\
& Hyp \\
& Age47 \\
\hline Interventions & SR331 \\
& Dur4 \\
\hline Outcomes & SBP \\
& DBP \\
& Aldo \\
Renin
\end{tabular}

\section{Risk of bias}

\begin{tabular}{lll}
\hline Bias & Authors' judgement & Support for judgement \\
\hline $\begin{array}{l}\text { Random sequence genera- } \\
\text { tion (selection bias) }\end{array}$ & Unclear risk & Insufficient information \\
\hline
\end{tabular}

Effects of low sodium diet versus high sodium diet on blood pressure, renin, aldosterone, catecholamines, cholesterol, and triglyceride 
1065 Bruun 1990 H (Continued)

\begin{tabular}{lll}
$\begin{array}{l}\text { Allocation concealment } \\
\text { (selection bias) }\end{array}$ & Unclear risk & Insufficient information \\
\hline $\begin{array}{l}\text { Blinding (performance } \\
\text { bias and detection bias) }\end{array}$ & High risk & Open study \\
All outcomes & &
\end{tabular}

Incomplete outcome data Low risk Lost to follow up 0
(attrition bias)
All outcomes

\begin{tabular}{lll}
$\begin{array}{l}\text { Selective reporting (re- } \\
\text { porting bias) }\end{array}$ & Low risk & No distinct selective outcome reporting \\
\hline $\begin{array}{l}\text { Blinding of participants } \\
\text { and personnel (perfor- } \\
\text { mance bias) } \\
\text { All outcomes }\end{array}$ & High risk & $\begin{array}{l}\text { Open study: Performance bias due to knowledge of the allocated interventions } \\
\text { by participants and personnel during the study. }\end{array}$ \\
\hline $\begin{array}{l}\text { Blinding of outcome as- } \\
\text { sessment (detection bias) } \\
\text { All outcomes }\end{array}$ & High risk & $\begin{array}{l}\text { Open study: Detection bias due to knowledge of the allocated interventions by } \\
\text { outcome assessors }\end{array}$ \\
\hline
\end{tabular}

\section{Sharma 1990}

\begin{tabular}{ll}
\hline Methods & SB \\
& CO \\
\hline Participants & N15 \\
& Norm \\
& Age24 \\
\hline Interventions & SR192 (210.7-18.7) \\
& Dur 7 \\
\hline Outcomes & SBP \\
& DBP \\
& Chol \\
& HDL \\
LDL & TG \\
\hline Notes & LoFo: 0 \\
\hline
\end{tabular}

\section{Risk of bias}

\begin{tabular}{lll}
\hline Bias & Authors' judgement & Support for judgement \\
\hline $\begin{array}{l}\text { Random sequence genera- } \\
\text { tion (selection bias) }\end{array}$ & Unclear risk & Insufficient information \\
\hline $\begin{array}{l}\text { Allocation concealment } \\
\text { (selection bias) }\end{array}$ & Unclear risk & Insufficient information \\
\hline $\begin{array}{l}\text { Blinding (performance } \\
\text { bias and detection bias) }\end{array}$ & High risk & Open study \\
\hline
\end{tabular}

Effects of low sodium diet versus high sodium diet on blood pressure, renin, aldosterone, catecholamines, cholesterol, and triglyceride 
1066 Sharma 1990 (Continued)

All outcomes

\begin{tabular}{|c|c|c|}
\hline $\begin{array}{l}\text { Incomplete outcome data } \\
\text { (attrition bias) } \\
\text { All outcomes }\end{array}$ & Low risk & Lost to follow up 0 \\
\hline $\begin{array}{l}\text { Selective reporting (re- } \\
\text { porting bias) }\end{array}$ & Low risk & No distinct selective outcome reporting \\
\hline $\begin{array}{l}\text { Blinding of outcome as- } \\
\text { sessment (detection bias) } \\
\text { All outcomes }\end{array}$ & Low risk & Outcome detection blinded \\
\hline
\end{tabular}

1067 Sharma 1990,2

\begin{tabular}{ll}
\hline Methods & SB \\
& CO \\
\hline Participants & $\begin{array}{l}\text { N } 40 \text { (M/F:40/0)(B/W/A.0/40/0) } \\
\text { Age } 25\end{array}$ \\
\hline Interventions & SR $214(239-25)$ \\
& Dur 7 \\
\hline Outcomes & SBP, DBP, renin, aldo \\
\hline Notes & LoFo: 5.40 of 45 completed the study. IT: No \\
\hline
\end{tabular}

\section{Risk of bias}

\begin{tabular}{|c|c|c|}
\hline Bias & Authors' judgement & Support for judgement \\
\hline $\begin{array}{l}\text { Random sequence genera- } \\
\text { tion (selection bias) }\end{array}$ & Unclear risk & Insufficient information \\
\hline $\begin{array}{l}\text { Allocation concealment } \\
\text { (selection bias) }\end{array}$ & Unclear risk & Insufficient information \\
\hline $\begin{array}{l}\text { Blinding (performance } \\
\text { bias and detection bias) } \\
\text { All outcomes }\end{array}$ & High risk & Open study \\
\hline $\begin{array}{l}\text { Incomplete outcome data } \\
\text { (attrition bias) } \\
\text { All outcomes }\end{array}$ & Unclear risk & Lost to follow up 0 \\
\hline $\begin{array}{l}\text { Selective reporting (re- } \\
\text { porting bias) }\end{array}$ & Low risk & No distinct selective outcome reporting \\
\hline
\end{tabular}


1067 Sharma 1990,2 (Continued)

Blinding of participants High risk Open study: Performance bias due to knowledge of the allocated interventions and personnel (perfor-

by participants and personnel during the study.

mance bias)

All outcomes

Blinding of outcome as- Low risk

sessment (detection bias)

All outcomes

1068 Friberg 1990

Methods

$\mathrm{CO}$

\begin{tabular}{ll}
\hline Participants & N10 \\
& Norm \\
& Age33
\end{tabular}

\begin{tabular}{ll}
\hline Interventions & SR117 \\
& Dur 13 \\
\hline Outcomes & SBP \\
& DBP \\
& Renin \\
& NA \\
\hline Notes & LoFo:4 \\
& IT: No \\
\hline
\end{tabular}

\section{Risk of bias}

\begin{tabular}{|c|c|c|}
\hline Bias & Authors' judgement & Support for judgement \\
\hline $\begin{array}{l}\text { Random sequence genera- } \\
\text { tion (selection bias) }\end{array}$ & Unclear risk & Insufficient information \\
\hline $\begin{array}{l}\text { Allocation concealment } \\
\text { (selection bias) }\end{array}$ & Unclear risk & Insufficient information \\
\hline $\begin{array}{l}\text { Blinding (performance } \\
\text { bias and detection bias) } \\
\text { All outcomes }\end{array}$ & High risk & Open study \\
\hline $\begin{array}{l}\text { Incomplete outcome data } \\
\text { (attrition bias) } \\
\text { All outcomes }\end{array}$ & High risk & Lost to follow up $4 / 10$ \\
\hline $\begin{array}{l}\text { Selective reporting (re- } \\
\text { porting bias) }\end{array}$ & Low risk & No distinct selective outcome reporting \\
\hline $\begin{array}{l}\text { Blinding of participants } \\
\text { and personnel (perfor- } \\
\text { mance bias) } \\
\text { All outcomes }\end{array}$ & High risk & $\begin{array}{l}\text { Open study: Performance bias due to knowledge of the allocated interventions } \\
\text { by participants and personnel during the study. }\end{array}$ \\
\hline
\end{tabular}

Effects of low sodium diet versus high sodium diet on blood pressure, renin, aldosterone, catecholamines, cholesterol, and triglyceride 
1068 Friberg 1990 (Continued)

Blinding of outcome as- High risk Open study: Detection bias due to knowledge of the allocated interventions by sessment (detection bias) outcome assessors

All outcomes

1069 Del Rio 1990

Methods DB

$\mathrm{CO}$

\begin{tabular}{ll}
\hline Participants & N 15 (B/W/A 0/15/0) \\
& Hypertension, Age 49
\end{tabular}

\begin{tabular}{ll}
\hline Interventions & SR $100(190-90)$ \\
& Dur 14 \\
\hline Outcomes & SBP, DBP, chol, trig \\
\hline Notes & LoFo: 0
\end{tabular}

\section{Risk of bias}

\begin{tabular}{|c|c|c|}
\hline Bias & Authors' judgement & Support for judgement \\
\hline $\begin{array}{l}\text { Random sequence genera- } \\
\text { tion (selection bias) }\end{array}$ & Unclear risk & Insufficient information \\
\hline $\begin{array}{l}\text { Allocation concealment } \\
\text { (selection bias) }\end{array}$ & Unclear risk & Insufficient information \\
\hline $\begin{array}{l}\text { Blinding (performance } \\
\text { bias and detection bias) } \\
\text { All outcomes }\end{array}$ & Low risk & Double blind study \\
\hline $\begin{array}{l}\text { Incomplete outcome data } \\
\text { (attrition bias) } \\
\text { All outcomes }\end{array}$ & Low risk & Lost to follow up 0 \\
\hline $\begin{array}{l}\text { Selective reporting (re- } \\
\text { porting bias) }\end{array}$ & Low risk & No distinct selective outcome reporting \\
\hline $\begin{array}{l}\text { Blinding of participants } \\
\text { and personnel (perfor- } \\
\text { mance bias) } \\
\text { All outcomes }\end{array}$ & Low risk & Double blind study \\
\hline $\begin{array}{l}\text { Blinding of outcome as- } \\
\text { sessment (detection bias) } \\
\text { All outcomes }\end{array}$ & Low risk & Double blind study \\
\hline
\end{tabular}

1070 Parker 1990

Methods DB

Effects of low sodium diet versus high sodium diet on blood pressure, renin, aldosterone, catecholamines, cholesterol, and triglyceride 


\begin{tabular}{ll}
1070 Parker 1990 (Continued) & \\
Participants & N31 \\
& Hyp \\
& Age50 \\
\hline Interventions & SR73 \\
& Dur28 \\
\hline Outcomes & SBP \\
& DBP \\
\hline Notes & 1990 + 1990 b Included 63 \\
& LoFo: 4 before randomization \\
& IT: No
\end{tabular}

\section{Risk of bias}

\begin{tabular}{|c|c|c|}
\hline Bias & Authors' judgement & Support for judgement \\
\hline $\begin{array}{l}\text { Random sequence genera- } \\
\text { tion (selection bias) }\end{array}$ & Unclear risk & Insufficient information \\
\hline $\begin{array}{l}\text { Allocation concealment } \\
\text { (selection bias) }\end{array}$ & Unclear risk & Insufficient information \\
\hline $\begin{array}{l}\text { Blinding (performance } \\
\text { bias and detection bias) } \\
\text { All outcomes }\end{array}$ & Low risk & Double blind study \\
\hline $\begin{array}{l}\text { Incomplete outcome data } \\
\text { (attrition bias) } \\
\text { All outcomes }\end{array}$ & Low risk & Lost to follow up 0 after randomization \\
\hline $\begin{array}{l}\text { Selective reporting (re- } \\
\text { porting bias) }\end{array}$ & Low risk & No distinct selective outcome reporting \\
\hline $\begin{array}{l}\text { Blinding of participants } \\
\text { and personnel (perfor- } \\
\text { mance bias) } \\
\text { All outcomes }\end{array}$ & Low risk & Double blind study \\
\hline $\begin{array}{l}\text { Blinding of outcome as- } \\
\text { sessment (detection bias) } \\
\text { All outcomes }\end{array}$ & Low risk & Double blind study \\
\hline
\end{tabular}

\section{Mtabaji 1990}

\begin{tabular}{ll}
\hline Methods & Op \\
& P \\
\hline Participants & N30 (Black) \\
& Norm \\
& Age \\
\hline Interventions & SR272 \\
& Dur7 \\
\hline
\end{tabular}

Effects of low sodium diet versus high sodium diet on blood pressure, renin, aldosterone, catecholamines, cholesterol, and triglyceride 
1072 Mtabaji 1990 (Continued)

$\begin{array}{ll}\text { Outcomes } & \text { SBP }(M B P+1 / 3 M B P) \\ & \text { DBP }(M B P-1 / 3 M B P)\end{array}$

Notes LoFo: 0

\section{Risk of bias}

Bias Authors' judgement Support for judgement

Random sequence genera- Unclear risk Insufficient information

tion (selection bias)

Allocation concealment $\quad$ Unclear risk Insufficient information
(selection bias)

\begin{tabular}{ll}
\hline Blinding (performance & High risk \\
bias and detection bias) & \\
All outcomes & \\
\hline
\end{tabular}

\begin{tabular}{lll}
\hline $\begin{array}{l}\text { Incomplete outcome data } \\
\text { (attrition bias) } \\
\text { All outcomes }\end{array}$ & Low risk & Lost to follow up 0 \\
\hline $\begin{array}{l}\text { Selective reporting (re- } \\
\text { porting bias) }\end{array}$ & Unclear risk & Insufficient information \\
\hline $\begin{array}{l}\text { Blinding of participants } \\
\begin{array}{l}\text { and personnel (perfor- } \\
\text { mance bias) }\end{array}\end{array}$ & High risk & $\begin{array}{l}\text { Open study: Performance bias due to knowledge of the allocated interventions } \\
\text { by participants and personnel during the study. }\end{array}$ \\
\hline $\begin{array}{l}\text { Bll outcomes } \\
\text { sessment (detection bias) } \\
\text { All outcomes }\end{array}$ & High risk & $\begin{array}{l}\text { Open study: Detection bias due to knowledge of the allocated interventions by } \\
\text { outcome assessors }\end{array}$ \\
\hline
\end{tabular}

\section{Sharma 1991}

\begin{tabular}{ll}
\hline Methods & SB \\
& CO \\
\hline Participants & N23 \\
& Norm \\
& Age25 \\
\hline Interventions & SR 246 \\
& Dur6 \\
\hline Outcomes & SBP \\
& DBP \\
Aldo \\
\hline Notes & 1991+ $1991 \mathrm{~b}$ \\
& included 25 \\
& LoFo. 2 \\
IT: No
\end{tabular}

Effects of low sodium diet versus high sodium diet on blood pressure, renin, aldosterone, catecholamines, cholesterol, and triglyceride 
1073 Sharma 1991 (Continued)

\section{Risk of bias}

\begin{tabular}{|c|c|c|}
\hline Bias & Authors' judgement & Support for judgement \\
\hline $\begin{array}{l}\text { Random sequence genera- } \\
\text { tion (selection bias) }\end{array}$ & Unclear risk & Insufficient information \\
\hline $\begin{array}{l}\text { Allocation concealment } \\
\text { (selection bias) }\end{array}$ & Unclear risk & Insufficient information \\
\hline $\begin{array}{l}\text { Blinding (performance } \\
\text { bias and detection bias) } \\
\text { All outcomes }\end{array}$ & High risk & Open study \\
\hline $\begin{array}{l}\text { Incomplete outcome data } \\
\text { (attrition bias) } \\
\text { All outcomes }\end{array}$ & Low risk & Lost to follow up $2 / 23$ \\
\hline $\begin{array}{l}\text { Selective reporting (re- } \\
\text { porting bias) }\end{array}$ & Low risk & No distinct selective outcome reporting \\
\hline $\begin{array}{l}\text { Blinding of participants } \\
\text { and personnel (perfor- } \\
\text { mance bias) } \\
\text { All outcomes }\end{array}$ & High risk & $\begin{array}{l}\text { Open study: Performance bias due to knowledge of the allocated interventions } \\
\text { by participants and personnel during the study }\end{array}$ \\
\hline $\begin{array}{l}\text { Blinding of outcome as- } \\
\text { sessment (detection bias) } \\
\text { All outcomes }\end{array}$ & Low risk & Outcome detection blinded \\
\hline
\end{tabular}

1074 Howe 1991

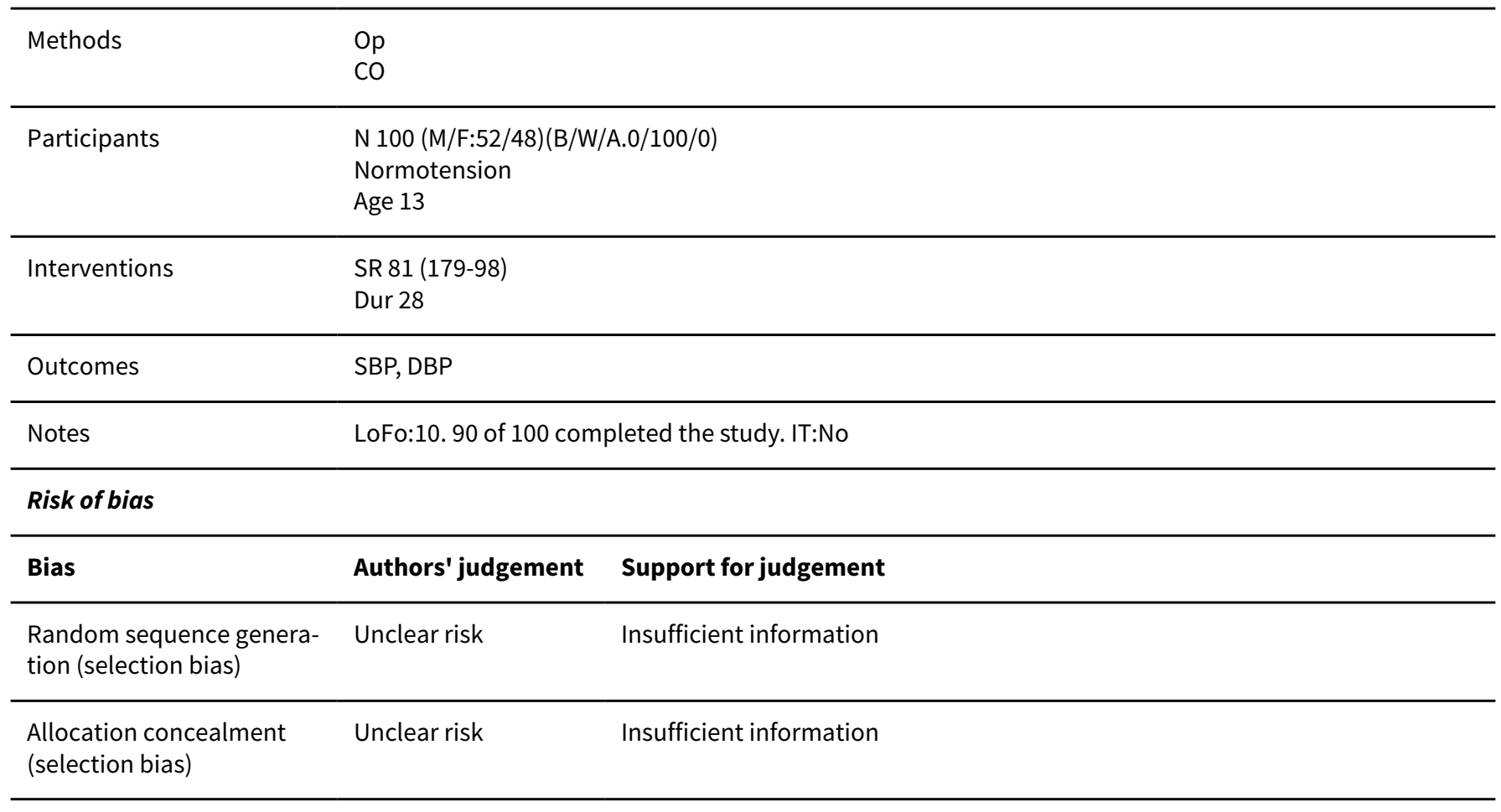

Effects of low sodium diet versus high sodium diet on blood pressure, renin, aldosterone, catecholamines, cholesterol, and triglyceride 
1074 Howe 1991 (Continued)

Blinding (performance $\quad$ High risk
bias and detection bias)
All outcomes

\begin{tabular}{|c|c|c|}
\hline $\begin{array}{l}\text { Incomplete outcome data } \\
\text { (attrition bias) } \\
\text { All outcomes }\end{array}$ & Low risk & Lost to follow up $10 / 100$ \\
\hline $\begin{array}{l}\text { Selective reporting (re- } \\
\text { porting bias) }\end{array}$ & Low risk & No distinct selective outcome reporting \\
\hline $\begin{array}{l}\text { Blinding of participants } \\
\text { and personnel (perfor- } \\
\text { mance bias) } \\
\text { All outcomes }\end{array}$ & High risk & $\begin{array}{l}\text { Open study: Performance bias due to knowledge of the allocated interventions } \\
\text { by participants and personnel during the study. }\end{array}$ \\
\hline $\begin{array}{l}\text { Blinding of outcome as- } \\
\text { sessment (detection bias) } \\
\text { All outcomes }\end{array}$ & High risk & $\begin{array}{l}\text { Open study: Detection bias due to knowledge of the allocated interventions by } \\
\text { outcome assessors }\end{array}$ \\
\hline
\end{tabular}

\section{Mascioli 1991}

\begin{tabular}{ll}
\hline Methods & DB \\
& CO \\
\hline Participants & N 48 (M/F:38/10) \\
& Agrm 52 \\
\hline Interventions & SR70 \\
& Dur28 \\
\hline Outcomes & SBP \\
& DBP \\
\hline Notes & included 50 \\
& LoFo. 2 \\
IT: No
\end{tabular}

\section{Risk of bias}

\begin{tabular}{|c|c|c|}
\hline Bias & Authors' judgement & Support for judgement \\
\hline $\begin{array}{l}\text { Random sequence genera- } \\
\text { tion (selection bias) }\end{array}$ & Unclear risk & Insufficient information \\
\hline $\begin{array}{l}\text { Allocation concealment } \\
\text { (selection bias) }\end{array}$ & Unclear risk & Insufficient information \\
\hline $\begin{array}{l}\text { Blinding (performance } \\
\text { bias and detection bias) } \\
\text { All outcomes }\end{array}$ & Low risk & Double blind study \\
\hline $\begin{array}{l}\text { Incomplete outcome data } \\
\text { (attrition bias) }\end{array}$ & Low risk & Lost to follow up 2/50 \\
\hline
\end{tabular}


1075 Mascioli 1991 (Continued)

All outcomes

Selective reporting (re- Low risk No distinct selective outcome reporting
porting bias)

\begin{tabular}{lll}
\hline $\begin{array}{l}\text { Blinding of participants } \\
\text { and personnel (perfor- }\end{array}$ & Low risk & \\
mance bias) & & \\
All outcomes & & \\
\hline $\begin{array}{l}\text { Blinding of outcome as- } \\
\text { sessment (detection bias) }\end{array}$ & Low risk & Double blind study \\
All outcomes & \\
\hline
\end{tabular}

\section{Carney 1991}

\begin{tabular}{ll}
\hline Methods & DB \\
& CO \\
\hline Participants & N11 \\
& Hyp \\
& Age54 \\
\hline Interventions & SR102 \\
& Dur 42 \\
\hline Outcomes & SBP \\
& DBP \\
Renin \\
\hline Notes & LoFo: 0 \\
\hline
\end{tabular}

\section{Risk of bias}

\begin{tabular}{lll}
\hline Bias & Authors' judgement & Support for judgement \\
\hline $\begin{array}{l}\text { Random sequence genera- } \\
\text { tion (selection bias) }\end{array}$ & Unclear risk & Insufficient information \\
\hline $\begin{array}{l}\text { Allocation concealment } \\
\text { (selection bias) }\end{array}$ & Unclear risk & Insufficient information \\
\hline $\begin{array}{l}\text { Blinding (performance } \\
\text { bias and detection bias) } \\
\text { All outcomes }\end{array}$ & Low risk & Double blind study \\
\hline $\begin{array}{l}\text { Incomplete outcome data } \\
\text { (attrition bias) }\end{array}$ & Low risk & \\
$\begin{array}{l}\text { All outcomes } \\
\text { Selective reporting (re- } \\
\text { porting bias) }\end{array}$ & Low risk & Lost to follow up 0 \\
\hline $\begin{array}{l}\text { Blinding of participants } \\
\text { and personnel (perfor- } \\
\text { mance bias) }\end{array}$ & Low risk & No distinct selective outcome reporting \\
\hline
\end{tabular}


1076 Carney 1991 (Continued)

All outcomes

Blinding of outcome as-
sessment (detection bias) $\quad$ Low risk Double blind study

All outcomes

1077 Singer 1991

$\begin{array}{ll}\text { Methods } & \text { DB } \\ & \text { CO }\end{array}$

\begin{tabular}{ll}
\hline Participants & N21(6 blacks) \\
& Hyp \\
& Age54 \\
\hline Interventions & SR91 \\
& Dur30 \\
\hline Outcomes & SBP \\
& DBP \\
& Aldo \\
& Renin \\
\hline Notes & LoFo: 0 \\
\hline
\end{tabular}

\section{Risk of bias}

\begin{tabular}{|c|c|c|}
\hline Bias & Authors' judgement & Support for judgement \\
\hline $\begin{array}{l}\text { Random sequence genera- } \\
\text { tion (selection bias) }\end{array}$ & Unclear risk & Insufficient information \\
\hline $\begin{array}{l}\text { Allocation concealment } \\
\text { (selection bias) }\end{array}$ & Unclear risk & Insufficient information \\
\hline $\begin{array}{l}\text { Blinding (performance } \\
\text { bias and detection bias) } \\
\text { All outcomes }\end{array}$ & Low risk & Double blind study \\
\hline $\begin{array}{l}\text { Incomplete outcome data } \\
\text { (attrition bias) } \\
\text { All outcomes }\end{array}$ & Low risk & Lost to follow up 0 \\
\hline $\begin{array}{l}\text { Selective reporting (re- } \\
\text { porting bias) }\end{array}$ & Low risk & No distinct selective outcome reporting \\
\hline $\begin{array}{l}\text { Blinding of participants } \\
\text { and personnel (perfor- } \\
\text { mance bias) } \\
\text { All outcomes }\end{array}$ & Low risk & Double blind study \\
\hline $\begin{array}{l}\text { Blinding of outcome as- } \\
\text { sessment (detection bias) } \\
\text { All outcomes }\end{array}$ & Low risk & Double blind study \\
\hline
\end{tabular}

Effects of low sodium diet versus high sodium diet on blood pressure, renin, aldosterone, catecholamines, cholesterol, and triglyceride 
1078 Egan 1991

\begin{tabular}{ll}
\hline Methods & DB \\
& CO \\
\hline Participants & N27 \\
& Hyp \\
& Age39 \\
\hline Interventions & SR194 (214-21) \\
& Dur7 \\
\hline Outcomes & SBP (MBP+1/3MBP) \\
& DBP (MBP-1/3MBP) \\
& Renin \\
& NAl \\
Chol \\
LDL \\
\hline Notes & Eandomisation schedule \\
& LoFo: 0 \\
\hline
\end{tabular}

\section{Risk of bias}

\begin{tabular}{|c|c|c|}
\hline Bias & Authors' judgement & Support for judgement \\
\hline $\begin{array}{l}\text { Random sequence genera- } \\
\text { tion (selection bias) }\end{array}$ & Unclear risk & Insufficient information \\
\hline $\begin{array}{l}\text { Allocation concealment } \\
\text { (selection bias) }\end{array}$ & Low risk & \\
\hline $\begin{array}{l}\text { Blinding (performance } \\
\text { bias and detection bias) } \\
\text { All outcomes }\end{array}$ & Low risk & Double blind study \\
\hline $\begin{array}{l}\text { Incomplete outcome data } \\
\text { (attrition bias) } \\
\text { All outcomes }\end{array}$ & Low risk & Lost to follow up $0 / 27$ \\
\hline $\begin{array}{l}\text { Selective reporting (re- } \\
\text { porting bias) }\end{array}$ & Low risk & No distinct selective outcome reporting \\
\hline $\begin{array}{l}\text { Blinding of participants } \\
\text { and personnel (perfor- } \\
\text { mance bias) } \\
\text { All outcomes }\end{array}$ & Low risk & Double blind study \\
\hline $\begin{array}{l}\text { Blinding of outcome as- } \\
\text { sessment (detection bias) } \\
\text { All outcomes }\end{array}$ & Low risk & Double blind study \\
\hline
\end{tabular}

\section{Gow 1992}

Methods Op


1079 Gow 1992 (Continued)

CO

\begin{tabular}{ll}
\hline Participants & N 9 \\
& Norm \\
& Age not given \\
\hline Interventions & SR 94 (111-17) \\
& Dur7 \\
\hline Outcomes & SBP \\
& DBP \\
\hline Notes & LoFo: 0
\end{tabular}

\section{Risk of bias}

\begin{tabular}{|c|c|c|}
\hline Bias & Authors' judgement & Support for judgement \\
\hline $\begin{array}{l}\text { Random sequence genera- } \\
\text { tion (selection bias) }\end{array}$ & Unclear risk & Insufficient information \\
\hline $\begin{array}{l}\text { Allocation concealment } \\
\text { (selection bias) }\end{array}$ & Unclear risk & Insufficient information \\
\hline $\begin{array}{l}\text { Blinding (performance } \\
\text { bias and detection bias) } \\
\text { All outcomes }\end{array}$ & High risk & Open study \\
\hline $\begin{array}{l}\text { Incomplete outcome data } \\
\text { (attrition bias) } \\
\text { All outcomes }\end{array}$ & Low risk & Lost to follow up 0 \\
\hline $\begin{array}{l}\text { Selective reporting (re- } \\
\text { porting bias) }\end{array}$ & Low risk & \\
\hline $\begin{array}{l}\text { Blinding of participants } \\
\text { and personnel (perfor- } \\
\text { mance bias) } \\
\text { All outcomes }\end{array}$ & High risk & $\begin{array}{l}\text { Open study: Performance bias due to knowledge of the allocated interventions } \\
\text { by participants and personnel during the study. }\end{array}$ \\
\hline $\begin{array}{l}\text { Blinding of outcome as- } \\
\text { sessment (detection bias) } \\
\text { All outcomes }\end{array}$ & High risk & $\begin{array}{l}\text { Open study: Detection bias due to knowledge of the allocated interventions by } \\
\text { outcome assessors }\end{array}$ \\
\hline
\end{tabular}

\section{Huggins 1992}

\begin{tabular}{ll}
\hline Methods & DB \\
& CO
\end{tabular}

\begin{tabular}{ll}
\hline Participants & N 9 (M/F:7/2)(B/W/A.0/9/0) \\
& Normotension \\
& Age 25 \\
\hline Interventions & SR $97(170-73)$ \\
& Dur 14 \\
\hline
\end{tabular}

Effects of low sodium diet versus high sodium diet on blood pressure, renin, aldosterone, catecholamines, cholesterol, and triglyceride 
1080 Huggins 1992 (Continued)

\begin{tabular}{ll} 
Outcomes & SBP, DBP, renin, aldo \\
\hline Notes & LoFo:0
\end{tabular}

\section{Risk of bias}

\begin{tabular}{|c|c|c|}
\hline Bias & Authors' judgement & Support for judgement \\
\hline $\begin{array}{l}\text { Random sequence genera- } \\
\text { tion (selection bias) }\end{array}$ & Unclear risk & Insufficient information \\
\hline $\begin{array}{l}\text { Allocation concealment } \\
\text { (selection bias) }\end{array}$ & Unclear risk & Insufficient information \\
\hline $\begin{array}{l}\text { Blinding (performance } \\
\text { bias and detection bias) } \\
\text { All outcomes }\end{array}$ & Low risk & Double blind study \\
\hline $\begin{array}{l}\text { Incomplete outcome data } \\
\text { (attrition bias) } \\
\text { All outcomes }\end{array}$ & Low risk & Lost to follow up 0 \\
\hline $\begin{array}{l}\text { Selective reporting (re- } \\
\text { porting bias) }\end{array}$ & Low risk & No distinct selective outcome reporting \\
\hline $\begin{array}{l}\text { Blinding of participants } \\
\text { and personnel (perfor- } \\
\text { mance bias) } \\
\text { All outcomes }\end{array}$ & Low risk & Double blind study \\
\hline $\begin{array}{l}\text { Blinding of outcome as- } \\
\text { sessment (detection bias) } \\
\text { All outcomes }\end{array}$ & Low risk & Double blind study \\
\hline
\end{tabular}

\section{TOHP | 1992}

\begin{tabular}{|c|c|}
\hline Methods & $\begin{array}{l}S B \\
P\end{array}$ \\
\hline Participants & $\begin{array}{l}\text { N744 (131 blacks) } \\
\text { Norm } \\
\text { Age43 }\end{array}$ \\
\hline Interventions & $\begin{array}{l}\text { SR } 47 \\
\text { Dur } 550\end{array}$ \\
\hline Outcomes & $\begin{array}{l}\text { SBP } \\
\text { DBP }\end{array}$ \\
\hline Notes & $\begin{array}{l}\text { LoFo: } 0 \\
\text { IT: yes }\end{array}$ \\
\hline
\end{tabular}

\section{Risk of bias}

\section{Bias}

\section{Authors' judgement Support for judgement}

Effects of low sodium diet versus high sodium diet on blood pressure, renin, aldosterone, catecholamines, cholesterol, and triglyceride 
1082 Cobiac 1992 (Continued)
Blinding (performance
Low risk
Double blind study
bias and detection bias)

All outcomes

Incomplete outcome data Low risk $\quad$ Lost to follow up 1/107
(attrition bias)
All outcomes

\begin{tabular}{lll}
\hline $\begin{array}{l}\text { Selective reporting (re- } \\
\text { porting bias) }\end{array}$ & Low risk & No distinct selective outcome reporting \\
\hline $\begin{array}{l}\text { Blinding of participants } \\
\begin{array}{l}\text { and personnel (perfor- } \\
\text { mance bias) }\end{array}\end{array}$ & Low risk & Double blind study \\
$\begin{array}{l}\text { All outcomes } \\
\text { Blinding of outcome as- } \\
\text { sessment (detection bias) } \\
\begin{array}{l}\text { All outcomes } \\
\hline\end{array}\end{array}$ & Low risk & Double blind study \\
\hline
\end{tabular}

\section{Benetos 1992}

\begin{tabular}{ll}
\hline Methods & DB \\
& CO \\
\hline Participants & N20 \\
& Hyp \\
& Age42 \\
\hline Interventions & SR78 \\
& Dur 28 \\
\hline Outcomes & SBP \\
& DBP \\
& Aldo \\
& Renin \\
NA \\
A \\
\hline Notes & Included 22 \\
& LoFo: 2 \\
IT: No \\
\hline
\end{tabular}

\section{Risk of bias}

\begin{tabular}{lll}
\hline Bias & Authors' judgement & Support for judgement \\
\hline $\begin{array}{l}\text { Random sequence genera- } \\
\text { tion (selection bias) }\end{array}$ & Unclear risk & Insufficient information \\
\hline $\begin{array}{l}\text { Allocation concealment } \\
\text { (selection bias) }\end{array}$ & Unclear risk & Insufficient information \\
\hline $\begin{array}{l}\text { Blinding (performance } \\
\text { bias and detection bias) }\end{array}$ & Low risk & Double blind study \\
\hline
\end{tabular}

Effects of low sodium diet versus high sodium diet on blood pressure, renin, aldosterone, catecholamines, cholesterol, and triglyceride 
1084 Benetos 1992 (Continued)

All outcomes

Incomplete outcome data Low risk $\quad$ Lost to follow up 2/22
(attrition bias)

(attrition bias)

All outcomes

\begin{tabular}{lll}
\hline $\begin{array}{l}\text { Selective reporting (re- } \\
\text { porting bias) }\end{array}$ & Low risk & No distinct selective outcome reporting \\
\hline $\begin{array}{l}\text { Blinding of participants } \\
\text { and personnel (perfor- } \\
\text { mance bias) }\end{array}$ & Low risk & Double blind study \\
All outcomes & \\
\hline
\end{tabular}

Blinding of outcome as- Low risk Double blind study

sessment (detection bias)

All outcomes

\section{Sciarrone 1992}

\begin{tabular}{ll}
\hline Methods & DB \\
& P \\
\hline Participants & N91 \\
& Age54 \\
\hline Interventions & SR82 \\
& Dur 56 \\
\hline Outcomes & SBP \\
& DBP \\
& Chol \\
& HDL \\
& LDL \\
& TG \\
Notes & 95 included \\
& LoFO: 4 \\
IT: No \\
Lipid values were estimated on the basis of initial values(table 2) and changes (figure 4)
\end{tabular}

\section{Risk of bias}

\begin{tabular}{lll}
\hline Bias & Authors' judgement & Support for judgement \\
\hline $\begin{array}{l}\text { Random sequence genera- } \\
\text { tion (selection bias) }\end{array}$ & Unclear risk & Insufficient information \\
\hline $\begin{array}{l}\text { Allocation concealment } \\
\text { (selection bias) }\end{array}$ & Unclear risk & Insufficient information \\
\hline $\begin{array}{l}\text { Blinding (performance } \\
\text { bias and detection bias) } \\
\text { All outcomes }\end{array}$ & Low risk & Double blind study \\
\hline
\end{tabular}

Effects of low sodium diet versus high sodium diet on blood pressure, renin, aldosterone, catecholamines, cholesterol, and triglyceride 
1085 Sciarrone 1992 (Continued)
Incomplete outcome data Low risk
Lost to follow up 4/95. Group association unclear
(attrition bias)

All outcomes

\begin{tabular}{|c|c|c|}
\hline $\begin{array}{l}\text { Selective reporting (re- } \\
\text { porting bias) }\end{array}$ & Low risk & No distinct selective outcome reporting \\
\hline $\begin{array}{l}\text { Blinding of participants } \\
\text { and personnel (perfor- } \\
\text { mance bias) } \\
\text { All outcomes }\end{array}$ & Low risk & Double blind study \\
\hline $\begin{array}{l}\text { Blinding of outcome as- } \\
\text { sessment (detection bias) } \\
\text { All outcomes }\end{array}$ & Low risk & Double blind study \\
\hline
\end{tabular}

\section{Ruppert 1993}

\begin{tabular}{ll}
\hline Methods & SB \\
& CO \\
\hline Participants & N30 \\
& Norm \\
& Age46 \\
& salt sensitive \\
\hline Interventions & SR270 \\
& Dur7 \\
\hline Outcomes & SBP \\
& DBP \\
Aldo \\
Renin \\
NA \\
\hline Notes & LoFo: 0 \\
\hline
\end{tabular}

\section{Risk of bias}

\section{Bias}

Authors' judgement Support for judgement

Random sequence genera- Unclear risk Insufficient information
tion (selection bias)

\begin{tabular}{lll}
\hline $\begin{array}{l}\text { Allocation concealment } \\
\text { (selection bias) }\end{array}$ & Unclear risk & Insufficient information \\
\hline $\begin{array}{l}\text { Blinding (performance } \\
\text { bias and detection bias) } \\
\text { All outcomes }\end{array}$ & High risk & Open study \\
\hline $\begin{array}{l}\text { Incomplete outcome data } \\
\text { (attrition bias) } \\
\text { All outcomes }\end{array}$ & Low risk & Lost to follow up 0 \\
\hline
\end{tabular}


1088 Ruppert 1993 (Continued)

Selective reporting (re- Low risk No distinct selective outcome reporting
porting bias)

\begin{tabular}{|c|c|c|}
\hline $\begin{array}{l}\text { Blinding of participants } \\
\text { and personnel (perfor- } \\
\text { mance bias) } \\
\text { All outcomes }\end{array}$ & High risk & $\begin{array}{l}\text { Open study: Performance bias due to knowledge of the allocated interventions } \\
\text { by participants and personnel during the study. }\end{array}$ \\
\hline $\begin{array}{l}\text { Blinding of outcome as- } \\
\text { sessment (detection bias) } \\
\text { All outcomes }\end{array}$ & Low risk & Outcome detection blinded \\
\hline
\end{tabular}

1091 Burnier 1993

\begin{tabular}{ll}
\hline Methods & Op \\
& CO \\
\hline Participants & N16 \\
& Norm \\
& Age29 \\
\hline Interventions & SR186 \\
& Dur6 \\
\hline Outcomes & SBP \\
& DBP \\
& Aldo \\
Renin
\end{tabular}

\section{Risk of bias}

\begin{tabular}{|c|c|c|}
\hline Bias & Authors' judgement & Support for judgement \\
\hline $\begin{array}{l}\text { Random sequence genera- } \\
\text { tion (selection bias) }\end{array}$ & Unclear risk & Insufficient information \\
\hline $\begin{array}{l}\text { Allocation concealment } \\
\text { (selection bias) }\end{array}$ & Unclear risk & Insufficient information \\
\hline $\begin{array}{l}\text { Blinding (performance } \\
\text { bias and detection bias) } \\
\text { All outcomes }\end{array}$ & High risk & Open study \\
\hline $\begin{array}{l}\text { Incomplete outcome data } \\
\text { (attrition bias) } \\
\text { All outcomes }\end{array}$ & Low risk & Lost to follow-up 0 \\
\hline $\begin{array}{l}\text { Selective reporting (re- } \\
\text { porting bias) }\end{array}$ & Low risk & No distinct selective outcome reporting \\
\hline $\begin{array}{l}\text { Blinding of participants } \\
\text { and personnel (perfor- } \\
\text { mance bias) }\end{array}$ & High risk & $\begin{array}{l}\text { Open study: Performance bias due to knowledge of the allocated interventions } \\
\text { by participants and personnel during the study. }\end{array}$ \\
\hline
\end{tabular}


1091 Burnier 1993 (Continued)

All outcomes

Blinding of outcome assessment (detection bias) All outcomes

\section{High risk}

Open study: Detection bias due to knowledge of the allocated interventions by outcome assessors

1093 Sharma 1993

Methods $\mathrm{SB}$

\begin{tabular}{ll}
\hline Participants & N16 \\
& Norm \\
& Age24 \\
\hline Interventions & SR 224 \\
& Dur7 \\
\hline Outcomes & SBP \\
& DBP \\
\hline Notes & LoFo: 0
\end{tabular}

\section{Risk of bias}

\begin{tabular}{|c|c|c|}
\hline Bias & Authors' judgement & Support for judgement \\
\hline $\begin{array}{l}\text { Random sequence genera- } \\
\text { tion (selection bias) }\end{array}$ & Unclear risk & Insufficient information \\
\hline $\begin{array}{l}\text { Allocation concealment } \\
\text { (selection bias) }\end{array}$ & Unclear risk & Insufficient information \\
\hline $\begin{array}{l}\text { Blinding (performance } \\
\text { bias and detection bias) } \\
\text { All outcomes }\end{array}$ & High risk & Open study \\
\hline $\begin{array}{l}\text { Incomplete outcome data } \\
\text { (attrition bias) } \\
\text { All outcomes }\end{array}$ & Low risk & Lost to follow-up 0 \\
\hline $\begin{array}{l}\text { Selective reporting (re- } \\
\text { porting bias) }\end{array}$ & Low risk & No distinct selective outcome reporting \\
\hline $\begin{array}{l}\text { Blinding of participants } \\
\text { and personnel (perfor- } \\
\text { mance bias) } \\
\text { All outcomes }\end{array}$ & High risk & $\begin{array}{l}\text { Open study: Performance bias due to knowledge of the allocated interventions } \\
\text { by participants and personnel during the study. }\end{array}$ \\
\hline $\begin{array}{l}\text { Blinding of outcome as- } \\
\text { sessment (detection bias) } \\
\text { All outcomes }\end{array}$ & Low risk & Outcome detection blinded \\
\hline
\end{tabular}


1094 Sharma 1993,2

\begin{tabular}{|c|c|c|}
\hline Methods & \multicolumn{2}{|l|}{$\begin{array}{l}\text { Op } \\
\text { CO }\end{array}$} \\
\hline Participants & \multicolumn{2}{|c|}{$\begin{array}{l}\text { N } 15 \text { (M/F:15/0)(B/W/A.0/15/0) } \\
\text { Normotension } \\
\text { Age } 25\end{array}$} \\
\hline Interventions & \multicolumn{2}{|l|}{$\begin{array}{l}\text { SR } 198(219-21) \\
\text { Dur } 6\end{array}$} \\
\hline Outcomes & \multicolumn{2}{|l|}{ Renin, aldo, NE } \\
\hline Notes & \multicolumn{2}{|c|}{ LoFo: 5.15 of 20 completed the study. IT: No } \\
\hline \multicolumn{3}{|l|}{ Risk of bias } \\
\hline Bias & Authors' judgement & Support for judgement \\
\hline $\begin{array}{l}\text { Random sequence genera- } \\
\text { tion (selection bias) }\end{array}$ & Unclear risk & Insufficient information \\
\hline $\begin{array}{l}\text { Allocation concealment } \\
\text { (selection bias) }\end{array}$ & Unclear risk & Randomisation according to a Latin-Square design \\
\hline $\begin{array}{l}\text { Blinding (performance } \\
\text { bias and detection bias) } \\
\text { All outcomes }\end{array}$ & High risk & Open \\
\hline $\begin{array}{l}\text { Incomplete outcome data } \\
\text { (attrition bias) } \\
\text { All outcomes }\end{array}$ & High risk & Lost to follow up $5 / 20$ \\
\hline $\begin{array}{l}\text { Selective reporting (re- } \\
\text { porting bias) }\end{array}$ & Low risk & No distinct selective outcome reporting \\
\hline $\begin{array}{l}\text { Blinding of participants } \\
\text { and personnel (perfor- } \\
\text { mance bias) } \\
\text { All outcomes }\end{array}$ & High risk & $\begin{array}{l}\text { Open study: Performance bias due to knowledge of the allocated interventions } \\
\text { by participants and personnel during the study. }\end{array}$ \\
\hline $\begin{array}{l}\text { Blinding of outcome as- } \\
\text { sessment (detection bias) } \\
\text { All outcomes }\end{array}$ & High risk & $\begin{array}{l}\text { Open study: Detection bias due to knowledge of the allocated interventions by } \\
\text { outcome assessors }\end{array}$ \\
\hline
\end{tabular}

\section{Fliser 1993}

\begin{tabular}{ll}
\hline Methods & SB \\
& CO
\end{tabular}

\begin{tabular}{ll}
\hline Participants & N8 \\
& Norm \\
& Age25 \\
& + Doxazosin \\
\hline
\end{tabular}

Interventions

SR190 (211-21)

Effects of low sodium diet versus high sodium diet on blood pressure, renin, aldosterone, catecholamines, cholesterol, and triglyceride 
1095 Fliser 1993 (Continued)

Dur8

\begin{tabular}{ll}
\hline Outcomes & SBP (MBP+1/3MBP) \\
& DBP (MBP-1/3MBP) \\
NA \\
Chol \\
HDL \\
LDL \\
TG \\
\hline Notes & LoFo: 0 \\
\hline
\end{tabular}

\section{Risk of bias}

\begin{tabular}{|c|c|c|}
\hline Bias & Authors' judgement & Support for judgement \\
\hline $\begin{array}{l}\text { Random sequence genera- } \\
\text { tion (selection bias) }\end{array}$ & Unclear risk & Insufficient information \\
\hline $\begin{array}{l}\text { Allocation concealment } \\
\text { (selection bias) }\end{array}$ & Unclear risk & Insufficient information \\
\hline $\begin{array}{l}\text { Blinding (performance } \\
\text { bias and detection bias) } \\
\text { All outcomes }\end{array}$ & High risk & Open study \\
\hline $\begin{array}{l}\text { Incomplete outcome data } \\
\text { (attrition bias) } \\
\text { All outcomes }\end{array}$ & Low risk & Lost to follow-up 0 \\
\hline $\begin{array}{l}\text { Selective reporting (re- } \\
\text { porting bias) }\end{array}$ & Low risk & No distinct selective outcome reporting \\
\hline $\begin{array}{l}\text { Blinding of participants } \\
\text { and personnel (perfor- } \\
\text { mance bias) } \\
\text { All outcomes }\end{array}$ & High risk & $\begin{array}{l}\text { Open study: Performance bias due to knowledge of the allocated interventions } \\
\text { by participants and personnel during the study. }\end{array}$ \\
\hline $\begin{array}{l}\text { Blinding of outcome as- } \\
\text { sessment (detection bias) } \\
\text { All outcomes }\end{array}$ & Low risk & Outcome detection blinded \\
\hline
\end{tabular}

\section{Nestel 1993}

\begin{tabular}{ll}
\hline Methods & DB \\
& $P$ \\
\hline Participants & N36 \\
& Norm \\
& Age66 \\
\hline Interventions & SR56 \\
& Dur42 \\
\hline Outcomes & SBP \\
\hline \hline
\end{tabular}

Effects of low sodium diet versus high sodium diet on blood pressure, renin, aldosterone, catecholamines, cholesterol, and triglyceride 
1097 Nestel 1993 (Continued)

$\begin{array}{ll}\text { Notes } & \text { Included } 70(1993+1993 b) \\ & \text { LoFo: } 4 \\ & \text { IT: No }\end{array}$

\section{Risk of bias}

\begin{tabular}{|c|c|c|}
\hline Bias & Authors' judgement & Support for judgement \\
\hline $\begin{array}{l}\text { Random sequence genera- } \\
\text { tion (selection bias) }\end{array}$ & Unclear risk & Insufficient information \\
\hline $\begin{array}{l}\text { Allocation concealment } \\
\text { (selection bias) }\end{array}$ & Unclear risk & Insufficient information \\
\hline $\begin{array}{l}\text { Blinding (performance } \\
\text { bias and detection bias) } \\
\text { All outcomes }\end{array}$ & Low risk & Double blind study \\
\hline $\begin{array}{l}\text { Incomplete outcome data } \\
\text { (attrition bias) } \\
\text { All outcomes }\end{array}$ & Low risk & Lost to follow up 4/70. Group association unclear \\
\hline $\begin{array}{l}\text { Selective reporting (re- } \\
\text { porting bias) }\end{array}$ & Low risk & No distinct selective outcome reporting \\
\hline $\begin{array}{l}\text { Blinding of participants } \\
\text { and personnel (perfor- } \\
\text { mance bias) } \\
\text { All outcomes }\end{array}$ & Low risk & Double blind study \\
\hline $\begin{array}{l}\text { Blinding of outcome as- } \\
\text { sessment (detection bias) } \\
\text { All outcomes }\end{array}$ & Low risk & Double blind study \\
\hline
\end{tabular}

\section{Donovan 1993}

\begin{tabular}{ll}
\hline Methods & SB \\
& CO \\
\hline Participants & N8 \\
& Norm \\
& Age36 \\
\hline Interventions & SR152 \\
& Dur5 \\
\hline Outcomes & SBP \\
& DBP \\
& Aldo \\
Renin \\
\hline Notes & LoFo. 0 \\
\hline
\end{tabular}

\section{Risk of bias}

Effects of low sodium diet versus high sodium diet on blood pressure, renin, aldosterone, catecholamines, cholesterol, and triglyceride 
1099 Donovan 1993 (Continued)

\begin{tabular}{|c|c|c|}
\hline Bias & Authors' judgement & Support for judgement \\
\hline $\begin{array}{l}\text { Random sequence genera- } \\
\text { tion (selection bias) }\end{array}$ & Unclear risk & Insufficient information \\
\hline $\begin{array}{l}\text { Allocation concealment } \\
\text { (selection bias) }\end{array}$ & Unclear risk & Insufficient information \\
\hline $\begin{array}{l}\text { Blinding (performance } \\
\text { bias and detection bias) } \\
\text { All outcomes }\end{array}$ & High risk & Open study \\
\hline $\begin{array}{l}\text { Incomplete outcome data } \\
\text { (attrition bias) } \\
\text { All outcomes }\end{array}$ & Low risk & Lost to follow-up 0 \\
\hline $\begin{array}{l}\text { Selective reporting (re- } \\
\text { porting bias) }\end{array}$ & Low risk & No distinct selective outcome reporting \\
\hline $\begin{array}{l}\text { Blinding of participants } \\
\text { and personnel (perfor- } \\
\text { mance bias) } \\
\text { All outcomes }\end{array}$ & High risk & $\begin{array}{l}\text { Open study: Performance bias due to knowledge of the allocated interventions } \\
\text { by participants and personnel during the study. }\end{array}$ \\
\hline
\end{tabular}

Blinding of outcome as- $\quad$ Low risk $\quad$ Outcome detection blinded
sessment (detection bias)
All outcomes

\section{Fotherby 1993}

\begin{tabular}{ll}
\hline Methods & DB \\
& CO \\
\hline Participants & N17 \\
& Hyp \\
& Age73 \\
\hline Interventions & SR79 \\
& Dur 35 \\
\hline Outcomes & SBP \\
& DBP \\
& Aldo \\
Renin \\
\hline Notes & Included 18 \\
& LoFo. 1 \\
IT: No
\end{tabular}

\section{Risk of bias}

\begin{tabular}{lll}
\hline Bias & Authors' judgement & Support for judgement \\
\hline $\begin{array}{l}\text { Random sequence genera- } \\
\text { tion (selection bias) }\end{array}$ & Unclear risk & Insufficient information \\
\hline
\end{tabular}

Effects of low sodium diet versus high sodium diet on blood pressure, renin, aldosterone, catecholamines, cholesterol, and triglyceride 
1100 Fotherby 1993 (Continued)

\begin{tabular}{lll}
$\begin{array}{l}\text { Allocation concealment } \\
\text { (selection bias) }\end{array}$ & Unclear risk & Insufficient information \\
\hline $\begin{array}{l}\text { Blinding (performance } \\
\text { bias and detection bias) }\end{array}$ & Low risk & Double blind study \\
All outcomes & &
\end{tabular}

\begin{tabular}{lll}
\hline $\begin{array}{l}\text { Incomplete outcome data } \\
\text { (attrition bias) } \\
\text { All outcomes }\end{array}$ & Low risk & Lost to follow-up $1 / 18$ \\
\hline $\begin{array}{l}\text { Selective reporting (re- } \\
\text { porting bias) }\end{array}$ & Low risk & No distinct selective outcome reporting \\
\hline $\begin{array}{l}\text { Blinding of participants } \\
\text { and personnel (perfor- } \\
\text { mance bias) } \\
\begin{array}{l}\text { All outcomes } \\
\text { Blinding of outcome as- }\end{array}\end{array}$ & Low risk & Double blind study \\
\hline $\begin{array}{l}\text { sessment (detection bias) } \\
\text { All outcomes }\end{array}$ & & Double blind study \\
\hline
\end{tabular}

\section{Redon-Mas 1993}

\begin{tabular}{ll}
\hline Methods & Op \\
& P \\
\hline Participants & $\begin{array}{l}\text { N418 } \\
\text { Hyp } \\
\text { Age55 }\end{array}$ \\
\hline Interventions & SR104 \\
& Dur28 \\
\hline Outcomes & SBP \\
& DBP \\
\hline Notes & 574 included \\
& LoFo: 156 \\
IT: 0
\end{tabular}

\section{Risk of bias}

\begin{tabular}{lll}
\hline Bias & Authors' judgement & Support for judgement \\
\hline $\begin{array}{l}\text { Random sequence genera- } \\
\text { tion (selection bias) }\end{array}$ & Unclear risk & Insufficient information \\
\hline $\begin{array}{l}\text { Allocation concealment } \\
\text { (selection bias) }\end{array}$ & Unclear risk & Insufficient information \\
\hline $\begin{array}{l}\text { Blinding (performance } \\
\text { bias and detection bias) } \\
\text { All outcomes }\end{array}$ & High risk & Open study \\
\hline
\end{tabular}

Effects of low sodium diet versus high sodium diet on blood pressure, renin, aldosterone, catecholamines, cholesterol, and triglyceride 
1101 Redon-Mas 1993 (Continued)
Incomplete outcome data High risk
Lost to follow up LS: 57/287; US: 99/287
(attrition bias)
High risk
All outcomes

Selective reporting (re- Low risk No distinct selective outcome reporting
porting bias)

\begin{tabular}{|c|c|c|}
\hline $\begin{array}{l}\text { Blinding of participants } \\
\text { and personnel (perfor- } \\
\text { mance bias) } \\
\text { All outcomes }\end{array}$ & High risk & $\begin{array}{l}\text { Open study: Performance bias due to knowledge of the allocated interventions } \\
\text { by participants and personnel during the study. }\end{array}$ \\
\hline $\begin{array}{l}\text { Blinding of outcome as- } \\
\text { sessment (detection bias) } \\
\text { All outcomes }\end{array}$ & High risk & $\begin{array}{l}\text { Open study: Detection bias due to knowledge of the allocated interventions by } \\
\text { outcome assessors }\end{array}$ \\
\hline
\end{tabular}

\section{Ruilope 1993}

\begin{tabular}{ll}
\hline Methods & DB \\
& P \\
\hline Participants & N19 \\
& Hyp \\
\hline Interventions & SR69 \\
\hline Outcomes & Dur21 \\
\hline Notes & SBP \\
\hline
\end{tabular}

\section{Risk of bias}

\begin{tabular}{|c|c|c|}
\hline Bias & Authors' judgement & Support for judgement \\
\hline $\begin{array}{l}\text { Random sequence genera- } \\
\text { tion (selection bias) }\end{array}$ & Unclear risk & Insufficient information \\
\hline $\begin{array}{l}\text { Allocation concealment } \\
\text { (selection bias) }\end{array}$ & Unclear risk & Insufficient information \\
\hline $\begin{array}{l}\text { Blinding (performance } \\
\text { bias and detection bias) } \\
\text { All outcomes }\end{array}$ & Low risk & Double blind study \\
\hline $\begin{array}{l}\text { Incomplete outcome data } \\
\text { (attrition bias) } \\
\text { All outcomes }\end{array}$ & Low risk & Lost to follow-up 0 \\
\hline $\begin{array}{l}\text { Selective reporting (re- } \\
\text { porting bias) }\end{array}$ & Low risk & No distinct selective outcome reporting \\
\hline
\end{tabular}

Effects of low sodium diet versus high sodium diet on blood pressure, renin, aldosterone, catecholamines, cholesterol, and triglyceride 
1102 Ruilope 1993 (Continued)
Blinding of participants
Low risk
Double blind study and personnel (perfor- mance bias)
All outcomes

\begin{tabular}{lll}
\hline Blinding of outcome as- & Low risk & Double blind study \\
sessment (detection bias) &
\end{tabular}

All outcomes

\section{Del Rio 1993}

\begin{tabular}{ll}
\hline Methods & DB \\
& CO \\
\hline Participants & N30 \\
& Hyp \\
& Age49 \\
\hline Interventions & SR151 (198-47) \\
& Dur 14 \\
\hline \multirow{2}{*}{ Outcomes } & SBP \\
& DBP \\
& Renin \\
Chol \\
HDL \\
TG \\
\hline Notes & Included 47 \\
& LoFo. 17 \\
IT: no
\end{tabular}

\section{Risk of bias}

\begin{tabular}{|c|c|c|}
\hline Bias & Authors' judgement & Support for judgement \\
\hline $\begin{array}{l}\text { Random sequence genera- } \\
\text { tion (selection bias) }\end{array}$ & Unclear risk & Insufficient information \\
\hline $\begin{array}{l}\text { Allocation concealment } \\
\text { (selection bias) }\end{array}$ & Unclear risk & Insufficient information \\
\hline $\begin{array}{l}\text { Blinding (performance } \\
\text { bias and detection bias) } \\
\text { All outcomes }\end{array}$ & Low risk & Double blind study \\
\hline $\begin{array}{l}\text { Incomplete outcome data } \\
\text { (attrition bias) } \\
\text { All outcomes }\end{array}$ & High risk & Lost to follow up $17 / 47$ \\
\hline $\begin{array}{l}\text { Selective reporting (re- } \\
\text { porting bias) }\end{array}$ & Low risk & No distinct selective outcome reporting \\
\hline $\begin{array}{l}\text { Blinding of participants } \\
\text { and personnel (perfor- } \\
\text { mance bias) }\end{array}$ & Low risk & Double blind study \\
\hline
\end{tabular}

Effects of low sodium diet versus high sodium diet on blood pressure, renin, aldosterone, catecholamines, cholesterol, and triglyceride 
1103 Del Rio 1993 (Continued)

All outcomes

Blinding of outcome as-
sessment (detection bias) $\quad$ Low risk $\quad$ Double blind study

All outcomes

\section{Overlack 1993}

Methods $\mathrm{SB}$

\begin{tabular}{ll}
\hline Participants & N30 \\
& salt sensitive \\
& Norm \\
& Age46 \\
\hline Interventions & SR270 \\
& Dur7 \\
\hline Outcomes & Aldo \\
& Renin \\
& NA \\
\hline Notes & LoFo: 0
\end{tabular}

\section{Risk of bias}

\begin{tabular}{|c|c|c|}
\hline Bias & Authors' judgement & Support for judgement \\
\hline $\begin{array}{l}\text { Random sequence genera- } \\
\text { tion (selection bias) }\end{array}$ & Unclear risk & Insufficient information \\
\hline $\begin{array}{l}\text { Allocation concealment } \\
\text { (selection bias) }\end{array}$ & Unclear risk & Insufficient information \\
\hline $\begin{array}{l}\text { Blinding (performance } \\
\text { bias and detection bias) } \\
\text { All outcomes }\end{array}$ & High risk & Open study \\
\hline $\begin{array}{l}\text { Incomplete outcome data } \\
\text { (attrition bias) } \\
\text { All outcomes }\end{array}$ & Low risk & Lost to follow-up 0 \\
\hline $\begin{array}{l}\text { Selective reporting (re- } \\
\text { porting bias) }\end{array}$ & Low risk & No distinct selective outcome reporting \\
\hline $\begin{array}{l}\text { Blinding of participants } \\
\text { and personnel (perfor- } \\
\text { mance bias) } \\
\text { All outcomes }\end{array}$ & High risk & $\begin{array}{l}\text { Open study: Performance bias due to knowledge of the allocated interventions } \\
\text { by participants and personnel during the study. }\end{array}$ \\
\hline $\begin{array}{l}\text { Blinding of outcome as- } \\
\text { sessment (detection bias) } \\
\text { All outcomes }\end{array}$ & Low risk & Outcome detection blinded \\
\hline
\end{tabular}




\begin{tabular}{ll}
\hline Methods & DB \\
& CO \\
\hline Participants & $\begin{array}{l}\text { N } 12(\mathrm{M} / \mathrm{F}: 12 / 0)(\mathrm{B} / \mathrm{W} / \mathrm{A} .0 / 12 / 0) \\
\text { Normotension } 24\end{array}$ \\
\hline Interventions & SR $40(165-115)$ \\
& Dur 4 \\
\hline Outcomes & SBP, DBP, renin \\
\hline Notes & LoFo:0
\end{tabular}

\section{Risk of bias}

\begin{tabular}{|c|c|c|}
\hline Bias & Authors' judgement & Support for judgement \\
\hline $\begin{array}{l}\text { Random sequence genera- } \\
\text { tion (selection bias) }\end{array}$ & Unclear risk & Insufficient information \\
\hline $\begin{array}{l}\text { Allocation concealment } \\
\text { (selection bias) }\end{array}$ & Low risk & Independently prepared schedule by Department of Pharmacy \\
\hline $\begin{array}{l}\text { Blinding (performance } \\
\text { bias and detection bias) } \\
\text { All outcomes }\end{array}$ & Low risk & Double blind study \\
\hline $\begin{array}{l}\text { Incomplete outcome data } \\
\text { (attrition bias) } \\
\text { All outcomes }\end{array}$ & Low risk & Lost to follow-up 0 \\
\hline $\begin{array}{l}\text { Selective reporting (re- } \\
\text { porting bias) }\end{array}$ & Low risk & No distinct selective outcome reporting \\
\hline $\begin{array}{l}\text { Blinding of participants } \\
\text { and personnel (perfor- } \\
\text { mance bias) } \\
\text { All outcomes }\end{array}$ & Low risk & Double blind study \\
\hline $\begin{array}{l}\text { Blinding of outcome as- } \\
\text { sessment (detection bias) } \\
\text { All outcomes }\end{array}$ & Low risk & Double blind study \\
\hline
\end{tabular}

1108 Buckley 1994

\begin{tabular}{ll}
\hline Methods & SB \\
& CO \\
\hline Participants & N12 (3 blacks) \\
& Hyp \\
& Age49 \\
\hline Interventions & SR 296 \\
\hline
\end{tabular}

Effects of low sodium diet versus high sodium diet on blood pressure, renin, aldosterone, catecholamines, cholesterol, and triglyceride 
1108 Buckley 1994 (Continued)

Dur 5

\begin{tabular}{ll}
\hline Outcomes & SBP \\
& DBP \\
\hline Notes & LoFo: 0 \\
\hline
\end{tabular}

\section{Risk of bias}

\begin{tabular}{|c|c|c|}
\hline Bias & Authors' judgement & Support for judgement \\
\hline $\begin{array}{l}\text { Random sequence genera- } \\
\text { tion (selection bias) }\end{array}$ & Unclear risk & Insufficient information \\
\hline $\begin{array}{l}\text { Allocation concealment } \\
\text { (selection bias) }\end{array}$ & Unclear risk & Insufficient information \\
\hline $\begin{array}{l}\text { Blinding (performance } \\
\text { bias and detection bias) } \\
\text { All outcomes }\end{array}$ & High risk & Open study \\
\hline $\begin{array}{l}\text { Incomplete outcome data } \\
\text { (attrition bias) } \\
\text { All outcomes }\end{array}$ & Low risk & Lost to follow-up 0 \\
\hline $\begin{array}{l}\text { Selective reporting (re- } \\
\text { porting bias) }\end{array}$ & Low risk & No distinct selective outcome reporting \\
\hline $\begin{array}{l}\text { Blinding of participants } \\
\text { and personnel (perfor- } \\
\text { mance bias) } \\
\text { All outcomes }\end{array}$ & High risk & $\begin{array}{l}\text { Open study: Performance bias due to knowledge of the allocated interventions } \\
\text { by participants and personnel during the study. }\end{array}$ \\
\hline
\end{tabular}

Blinding of outcome as- Low risk Outcome detection blinded

sessment (detection bias)

All outcomes

\section{Zoccali 1994}

\begin{tabular}{ll}
\hline Methods & SB \\
& CO \\
\hline Participants & N 15 \\
& Hyp \\
& Age 45 \\
\hline Interventions & SR 163 \\
& Dur 7 \\
\hline Outcomes & SBP \\
& DBP \\
& Aldo \\
& Renin \\
\hline Notes & LoFo: 0 \\
\hline
\end{tabular}


1109 Zoccali 1994 (Continued)

\section{Risk of bias}

\begin{tabular}{|c|c|c|}
\hline Bias & Authors' judgement & Support for judgement \\
\hline $\begin{array}{l}\text { Random sequence genera- } \\
\text { tion (selection bias) }\end{array}$ & Unclear risk & Insufficient information \\
\hline $\begin{array}{l}\text { Allocation concealment } \\
\text { (selection bias) }\end{array}$ & Unclear risk & Insufficient information \\
\hline $\begin{array}{l}\text { Blinding (performance } \\
\text { bias and detection bias) } \\
\text { All outcomes }\end{array}$ & High risk & Open study \\
\hline $\begin{array}{l}\text { Incomplete outcome data } \\
\text { (attrition bias) } \\
\text { All outcomes }\end{array}$ & Low risk & Lost to follow-up 0 \\
\hline $\begin{array}{l}\text { Selective reporting (re- } \\
\text { porting bias) }\end{array}$ & Low risk & No distinct selective outcome reporting \\
\hline $\begin{array}{l}\text { Blinding of participants } \\
\text { and personnel (perfor- } \\
\text { mance bias) } \\
\text { All outcomes }\end{array}$ & High risk & $\begin{array}{l}\text { Open study: Performance bias due to knowledge of the allocated interventions } \\
\text { by participants and personnel during the study. }\end{array}$ \\
\hline $\begin{array}{l}\text { Blinding of outcome as- } \\
\text { sessment (detection bias) } \\
\text { All outcomes }\end{array}$ & Low risk & Outcome detection blinded \\
\hline
\end{tabular}

\section{Jula 1994}

\begin{tabular}{ll}
\hline Methods & Op \\
& P \\
\hline Participants & N76 \\
& Hyp \\
& Age44 \\
\hline Interventions & SR57 \\
& Dur365 \\
\hline \multirow{2}{*}{ Outcomes } & SBP \\
& DBP \\
& Aldo \\
Renin \\
NA \\
A \\
\hline Notes & Included 91 \\
& LoFo: 15 \\
IT: No
\end{tabular}

\section{Risk of bias}

Effects of low sodium diet versus high sodium diet on blood pressure, renin, aldosterone, catecholamines, cholesterol, and triglyceride 
1110 Jula 1994 (Continued)

\begin{tabular}{|c|c|c|}
\hline Bias & Authors' judgement & Support for judgement \\
\hline $\begin{array}{l}\text { Random sequence genera- } \\
\text { tion (selection bias) }\end{array}$ & Unclear risk & Insufficient information \\
\hline $\begin{array}{l}\text { Allocation concealment } \\
\text { (selection bias) }\end{array}$ & Unclear risk & Insufficient information \\
\hline $\begin{array}{l}\text { Blinding (performance } \\
\text { bias and detection bias) } \\
\text { All outcomes }\end{array}$ & High risk & Open study \\
\hline $\begin{array}{l}\text { Incomplete outcome data } \\
\text { (attrition bias) } \\
\text { All outcomes }\end{array}$ & Unclear risk & Lost to follow-up 0 \\
\hline $\begin{array}{l}\text { Selective reporting (re- } \\
\text { porting bias) }\end{array}$ & Low risk & No distinct selective outcome reporting \\
\hline $\begin{array}{l}\text { Blinding of participants } \\
\text { and personnel (perfor- } \\
\text { mance bias) } \\
\text { All outcomes }\end{array}$ & High risk & $\begin{array}{l}\text { Open study: Performance bias due to knowledge of the allocated interventions } \\
\text { by participants and personnel during the study }\end{array}$ \\
\hline $\begin{array}{l}\text { Blinding of outcome as- } \\
\text { sessment (detection bias) } \\
\text { All outcomes }\end{array}$ & High risk & $\begin{array}{l}\text { Open study: Detection bias due to knowledge of the allocated interventions by } \\
\text { outcome assessors }\end{array}$ \\
\hline
\end{tabular}

\section{Howe 1994}

\begin{tabular}{ll}
\hline Methods & $\begin{array}{l}\text { DB } \\
\text { Participants }\end{array}$ \\
& $\begin{array}{l}\text { N } 56 \text { (M/F:31/25)(B/W/A.0/56/0) } \\
\text { Age 55 }\end{array}$ \\
\hline Interventions & SR 80 (158-78) \\
\hline Outcomes & SBP, DBP, aldo \\
\hline Notes & LoFo:5.56 of 61 completed the study. IT:No \\
\hline
\end{tabular}

\section{Risk of bias}

\begin{tabular}{lll}
\hline Bias & Authors' judgement & Support for judgement \\
\hline $\begin{array}{l}\text { Random sequence genera- } \\
\text { tion (selection bias) }\end{array}$ & Unclear risk & Insufficient information \\
\hline $\begin{array}{l}\text { Allocation concealment } \\
\text { (selection bias) }\end{array}$ & Unclear risk & Insufficient information \\
\hline $\begin{array}{l}\text { Blinding (performance } \\
\text { bias and detection bias) }\end{array}$ & Low risk & Double blind study \\
\hline
\end{tabular}

Effects of low sodium diet versus high sodium diet on blood pressure, renin, aldosterone, catecholamines, cholesterol, and triglyceride 
1111 Howe 1994 (Continued)

All outcomes

Incomplete outcome data Low risk $\quad$ Lost to follow up 5/61. Group association unclear
(attrition bias)

(attrition bias)

All outcomes

\begin{tabular}{lll}
\hline $\begin{array}{l}\text { Selective reporting (re- } \\
\text { porting bias) }\end{array}$ & Low risk & No distinct selective outcome reporting \\
\hline $\begin{array}{l}\text { Blinding of participants } \\
\begin{array}{l}\text { and personnel (perfor- } \\
\text { mance bias) }\end{array}\end{array}$ & Low risk & Double blind study \\
All outcomes & \\
\hline
\end{tabular}

Blinding of outcome as- Low risk Double blind study

sessment (detection bias)

All outcomes

\section{Iwaoka 1994}

\begin{tabular}{ll}
\hline Methods & Op \\
CO
\end{tabular}

\section{Risk of bias}

\begin{tabular}{|c|c|c|}
\hline Bias & Authors' judgement & Support for judgement \\
\hline $\begin{array}{l}\text { Random sequence genera- } \\
\text { tion (selection bias) }\end{array}$ & Unclear risk & Insufficient information \\
\hline $\begin{array}{l}\text { Allocation concealment } \\
\text { (selection bias) }\end{array}$ & Unclear risk & Insufficient information \\
\hline $\begin{array}{l}\text { Blinding (performance } \\
\text { bias and detection bias) } \\
\text { All outcomes }\end{array}$ & High risk & Open study \\
\hline $\begin{array}{l}\text { Incomplete outcome data } \\
\text { (attrition bias) } \\
\text { All outcomes }\end{array}$ & Low risk & Lost to follow-up 0 \\
\hline $\begin{array}{l}\text { Selective reporting (re- } \\
\text { porting bias) }\end{array}$ & Low risk & No distinct selective outcome reporting \\
\hline
\end{tabular}




\section{Iwaoka 1994 (Continued)}

Blinding of participants High risk Open study: Performance bias due to knowledge of the allocated interventions and personnel (perfor-

mance bias)

All outcomes

Blinding of outcome as- High risk sessment (detection bias)

All outcomes
Open study: Detection bias due to knowledge of the allocated interventions by outcome assessors

\section{Miller 1995}

\begin{tabular}{ll}
\hline Methods & DB \\
& CO \\
\hline Participants & $\begin{array}{l}\text { N } 36 \text { (M/F:36/0)(B/W/A.0/36/0) } \\
\text { Normotension }\end{array}$ \\
\hline Interventions & SR 58 (191-133) \\
\hline Outcomes & Sur 14 \\
\hline Notes & LoFo: DBP, NE 36 of 40 completed the study. IT: No
\end{tabular}

\section{Risk of bias}

\begin{tabular}{|c|c|c|}
\hline Bias & Authors' judgement & Support for judgement \\
\hline $\begin{array}{l}\text { Random sequence genera- } \\
\text { tion (selection bias) }\end{array}$ & Unclear risk & Insufficient information \\
\hline $\begin{array}{l}\text { Allocation concealment } \\
\text { (selection bias) }\end{array}$ & Unclear risk & Insufficient information \\
\hline $\begin{array}{l}\text { Blinding (performance } \\
\text { bias and detection bias) } \\
\text { All outcomes }\end{array}$ & Low risk & Double blind study \\
\hline $\begin{array}{l}\text { Incomplete outcome data } \\
\text { (attrition bias) } \\
\text { All outcomes }\end{array}$ & Low risk & Lost to follow up $4 / 40$ \\
\hline $\begin{array}{l}\text { Selective reporting (re- } \\
\text { porting bias) }\end{array}$ & Low risk & No distinct selective outcome reporting \\
\hline $\begin{array}{l}\text { Blinding of participants } \\
\text { and personnel (perfor- } \\
\text { mance bias) } \\
\text { All outcomes }\end{array}$ & Low risk & Double blind study \\
\hline $\begin{array}{l}\text { Blinding of outcome as- } \\
\text { sessment (detection bias) } \\
\text { All outcomes }\end{array}$ & Low risk & Double blind study \\
\hline
\end{tabular}


1114 Fliser 1995

\begin{tabular}{ll}
\hline Methods & Op \\
CO
\end{tabular}

\section{Risk of bias}

\begin{tabular}{|c|c|c|}
\hline Bias & Authors' judgement & Support for judgement \\
\hline $\begin{array}{l}\text { Random sequence genera- } \\
\text { tion (selection bias) }\end{array}$ & Unclear risk & Insufficient information \\
\hline $\begin{array}{l}\text { Allocation concealment } \\
\text { (selection bias) }\end{array}$ & Unclear risk & Insufficient information \\
\hline $\begin{array}{l}\text { Blinding (performance } \\
\text { bias and detection bias) } \\
\text { All outcomes }\end{array}$ & High risk & Open study \\
\hline $\begin{array}{l}\text { Incomplete outcome data } \\
\text { (attrition bias) } \\
\text { All outcomes }\end{array}$ & Low risk & Lost to follow-up 0 \\
\hline $\begin{array}{l}\text { Selective reporting (re- } \\
\text { porting bias) }\end{array}$ & Low risk & No distinct selective outcome reporting \\
\hline $\begin{array}{l}\text { Blinding of participants } \\
\text { and personnel (perfor- } \\
\text { mance bias) } \\
\text { All outcomes }\end{array}$ & High risk & $\begin{array}{l}\text { Open study: Performance bias due to knowledge of the allocated interventions } \\
\text { by participants and personnel during the study. }\end{array}$ \\
\hline $\begin{array}{l}\text { Blinding of outcome as- } \\
\text { sessment (detection bias) } \\
\text { All outcomes }\end{array}$ & High risk & $\begin{array}{l}\text { Open study: Detection bias due to knowledge of the allocated interventions by } \\
\text { outcome assessors }\end{array}$ \\
\hline
\end{tabular}

\section{Doig 1995}

Methods DB

$\mathrm{CO}$

\begin{tabular}{ll}
\hline Participants & N 81(M/F 81/0 (B/W/A 0/81/0) \\
& Normotension, Age 25
\end{tabular}

Interventions

SR $112(130-18)$

Effects of low sodium diet versus high sodium diet on blood pressure, renin, aldosterone, catecholamines, cholesterol, and triglyceride 
1115 Doig 1995 (Continued)

Dur 4

\begin{tabular}{ll}
\hline Outcomes & SBP, DBP \\
\hline Notes & LoFo: 0 \\
\hline
\end{tabular}

\section{Risk of bias}

\begin{tabular}{|c|c|c|}
\hline Bias & Authors' judgement & Support for judgement \\
\hline $\begin{array}{l}\text { Random sequence genera- } \\
\text { tion (selection bias) }\end{array}$ & Unclear risk & Insufficient information \\
\hline $\begin{array}{l}\text { Allocation concealment } \\
\text { (selection bias) }\end{array}$ & Unclear risk & Insufficient information \\
\hline $\begin{array}{l}\text { Blinding (performance } \\
\text { bias and detection bias) } \\
\text { All outcomes }\end{array}$ & Low risk & Double blind study \\
\hline $\begin{array}{l}\text { Incomplete outcome data } \\
\text { (attrition bias) } \\
\text { All outcomes }\end{array}$ & Low risk & Lost to follow-up 0 \\
\hline $\begin{array}{l}\text { Selective reporting (re- } \\
\text { porting bias) }\end{array}$ & Low risk & No distinct selective outcome reporting \\
\hline $\begin{array}{l}\text { Blinding of participants } \\
\text { and personnel (perfor- } \\
\text { mance bias) } \\
\text { All outcomes }\end{array}$ & Low risk & Double blind study \\
\hline $\begin{array}{l}\text { Blinding of outcome as- } \\
\text { sessment (detection bias) } \\
\text { All outcomes }\end{array}$ & Low risk & Double blind study \\
\hline
\end{tabular}

\section{Stein 1995}

\begin{tabular}{ll}
\hline Methods & Op \\
& CO \\
\hline Participants & $\begin{array}{l}\text { N } 7 \text { (M/F:7/0)(B/W/A.0/7/0) } \\
\text { Normotension } \\
\text { Age 33.7 }\end{array}$ \\
\hline Interventions & SR 183 (201-18) \\
\hline Dur 5 \\
\hline Notes & SBP, DBP, renin, NE \\
\hline
\end{tabular}

\section{Risk of bias}

Bias Authors' judgement Support for judgement

Effects of low sodium diet versus high sodium diet on blood pressure, renin, aldosterone, catecholamines, cholesterol, and triglyceride 
1116 Stein 1995 (Continued)

\begin{tabular}{lll}
$\begin{array}{l}\text { Random sequence genera- } \\
\text { tion (selection bias) }\end{array}$ & Unclear risk & Insufficient information \\
\hline $\begin{array}{l}\text { Allocation concealment } \\
\text { (selection bias) }\end{array}$ & Unclear risk & Insufficient information \\
\hline $\begin{array}{l}\text { Blinding (performance } \\
\text { bias and detection bias) } \\
\text { All outcomes }\end{array}$ & High risk & Open study \\
\hline
\end{tabular}

\begin{tabular}{lll}
\hline $\begin{array}{l}\text { Incomplete outcome data } \\
\text { (attrition bias) } \\
\text { All outcomes }\end{array}$ & Low risk & Lost to follow-up 0 \\
\hline $\begin{array}{l}\text { Selective reporting (re- } \\
\text { porting bias) }\end{array}$ & Low risk & No distinct selective outcome reporting \\
\hline $\begin{array}{l}\text { Blinding of participants } \\
\begin{array}{l}\text { and personnel (perfor- } \\
\text { mance bias) }\end{array}\end{array}$ & High risk & $\begin{array}{l}\text { Open study: Performance bias due to knowledge of the allocated interventions } \\
\text { bll outcomes }\end{array}$ \\
\hline $\begin{array}{l}\text { Blinding of outcome as- } \\
\text { sessment (detection bias) } \\
\text { All outcomes }\end{array}$ & High risk & $\begin{array}{l}\text { Open study: Detection bias due to knowledge of the allocated interventions by } \\
\text { outcome assessors }\end{array}$ \\
\hline
\end{tabular}

\section{Arrol 1995}

\begin{tabular}{ll}
\hline Methods & Op \\
& $P$ \\
\hline Participants & $\begin{array}{l}\text { N } 181 \text { (M/F:95/86)(B/W/A.0/181/0) } \\
\text { Hypertension } \\
\text { Age } 55\end{array}$ \\
\hline Interventions & SR 16 (122-106) \\
\hline Dur 182 \\
\hline Notes & SBP, DBP \\
\hline
\end{tabular}

\section{Risk of bias}

\begin{tabular}{lll}
\hline Bias & Authors' judgement & Support for judgement \\
\hline $\begin{array}{l}\text { Random sequence genera- } \\
\text { tion (selection bias) }\end{array}$ & Unclear risk & Insufficient information \\
\hline $\begin{array}{l}\text { Allocation concealment } \\
\text { (selection bias) }\end{array}$ & Unclear risk & Insufficient information \\
\hline $\begin{array}{l}\text { Blinding (performance } \\
\text { bias and detection bias) } \\
\text { All outcomes }\end{array}$ & High risk & Open study \\
\hline
\end{tabular}

Effects of low sodium diet versus high sodium diet on blood pressure, renin, aldosterone, catecholamines, cholesterol, and triglyceride 


\section{Arrol 1995 (Continued)}

Incomplete outcome data Low risk Lost to follow up 27/208. group association unclear
(attrition bias)

All outcomes

\begin{tabular}{|c|c|c|}
\hline $\begin{array}{l}\text { Selective reporting (re- } \\
\text { porting bias) }\end{array}$ & Low risk & No distinct selective outcome reporting \\
\hline $\begin{array}{l}\text { Blinding of participants } \\
\text { and personnel (perfor- } \\
\text { mance bias) } \\
\text { All outcomes }\end{array}$ & High risk & $\begin{array}{l}\text { Open study: Performance bias due to knowledge of the allocated interventions } \\
\text { by participants and personnel during the study. }\end{array}$ \\
\hline $\begin{array}{l}\text { Blinding of outcome as- } \\
\text { sessment (detection bias) } \\
\text { All outcomes }\end{array}$ & High risk & $\begin{array}{l}\text { Open study: Detection bias due to knowledge of the allocated interventions by } \\
\text { outcome assessors }\end{array}$ \\
\hline
\end{tabular}

\section{Draaijer 1995}

\begin{tabular}{ll}
\hline Methods & $\begin{array}{l}\text { Op } \\
\text { CO }\end{array}$ \\
\hline Participants & $\begin{array}{l}\text { N } 10 \text { (M/F:10/0)(B/W/A.0/10/0) } \\
\text { Hypertension } 41\end{array}$ \\
\hline Interventions & SR 131 (283-24) \\
\hline Dur 7 \\
\hline Notes & SBP, DBP, renin, aldo \\
\hline
\end{tabular}

\section{Risk of bias}

\begin{tabular}{|c|c|c|}
\hline Bias & Authors' judgement & Support for judgement \\
\hline $\begin{array}{l}\text { Random sequence genera- } \\
\text { tion (selection bias) }\end{array}$ & Unclear risk & Insufficient information \\
\hline $\begin{array}{l}\text { Allocation concealment } \\
\text { (selection bias) }\end{array}$ & Unclear risk & Insufficient information \\
\hline $\begin{array}{l}\text { Blinding (performance } \\
\text { bias and detection bias) } \\
\text { All outcomes }\end{array}$ & High risk & Open study \\
\hline $\begin{array}{l}\text { Incomplete outcome data } \\
\text { (attrition bias) } \\
\text { All outcomes }\end{array}$ & Low risk & Lost to follow-up 0 \\
\hline $\begin{array}{l}\text { Selective reporting (re- } \\
\text { porting bias) }\end{array}$ & Low risk & No distinct selective outcome reporting \\
\hline $\begin{array}{l}\text { Blinding of participants } \\
\text { and personnel (perfor- } \\
\text { mance bias) }\end{array}$ & High risk & $\begin{array}{l}\text { Open study: Performance bias due to knowledge of the allocated interventions } \\
\text { by participants and personnel during the study. }\end{array}$ \\
\hline
\end{tabular}

Effects of low sodium diet versus high sodium diet on blood pressure, renin, aldosterone, catecholamines, cholesterol, and triglyceride 
1118 Draaijer 1995 (Continued)

All outcomes

Blinding of outcome assessment (detection bias) All outcomes
High risk

Open study: Detection bias due to knowledge of the allocated interventions by outcome assessors

\section{Overlack 1995}

Methods $\quad$ DB

\begin{tabular}{ll}
\hline Participants & N11 \\
& Hyp \\
& Age61 \\
\hline Interventions & SR240 \\
& Dur7
\end{tabular}

\begin{tabular}{ll}
\hline Outcomes & SBP (MBP+1/3MBP) \\
& DBP (MBP-1/3MBP) \\
& Aldo \\
& Renin \\
& NA
\end{tabular}

Notes LoFo: 0

\section{Risk of bias}

\begin{tabular}{|c|c|c|}
\hline Bias & Authors' judgement & Support for judgement \\
\hline $\begin{array}{l}\text { Random sequence genera- } \\
\text { tion (selection bias) }\end{array}$ & Unclear risk & Insufficient information \\
\hline $\begin{array}{l}\text { Allocation concealment } \\
\text { (selection bias) }\end{array}$ & Unclear risk & Insufficient information \\
\hline $\begin{array}{l}\text { Blinding (performance } \\
\text { bias and detection bias) } \\
\text { All outcomes }\end{array}$ & Low risk & Double blind study \\
\hline $\begin{array}{l}\text { Incomplete outcome data } \\
\text { (attrition bias) } \\
\text { All outcomes }\end{array}$ & Low risk & Lost to follow-up 0 \\
\hline $\begin{array}{l}\text { Selective reporting (re- } \\
\text { porting bias) }\end{array}$ & Low risk & No distinct selective outcome reporting \\
\hline $\begin{array}{l}\text { Blinding of participants } \\
\text { and personnel (perfor- } \\
\text { mance bias) } \\
\text { All outcomes }\end{array}$ & Low risk & Double blind study \\
\hline $\begin{array}{l}\text { Blinding of outcome as- } \\
\text { sessment (detection bias) } \\
\text { All outcomes }\end{array}$ & Low risk & Double blind study \\
\hline
\end{tabular}


1122 Dubbert 1995

\begin{tabular}{ll}
\hline Methods & S \\
\hline Participants & $\begin{array}{l}\text { N } 122 \text { (B/W/A.67/55/0) } \\
\text { Hypertension } \\
\text { Age 62 }\end{array}$ \\
\hline Interventions & SR 45 (187-142) \\
\hline Dur 90 \\
\hline Notes & SBP, DBP \\
\hline
\end{tabular}

\section{Risk of bias}

\begin{tabular}{|c|c|c|}
\hline Bias & Authors' judgement & Support for judgement \\
\hline $\begin{array}{l}\text { Random sequence genera- } \\
\text { tion (selection bias) }\end{array}$ & Low risk & random number table, randomisation procedure stratified by race \\
\hline $\begin{array}{l}\text { Allocation concealment } \\
\text { (selection bias) }\end{array}$ & Unclear risk & Insufficient information \\
\hline $\begin{array}{l}\text { Blinding (performance } \\
\text { bias and detection bias) } \\
\text { All outcomes }\end{array}$ & High risk & Open study \\
\hline $\begin{array}{l}\text { Incomplete outcome data } \\
\text { (attrition bias) } \\
\text { All outcomes }\end{array}$ & High risk & Lost to follow up LS:24/106; US: $12 / 52$ \\
\hline $\begin{array}{l}\text { Selective reporting (re- } \\
\text { porting bias) }\end{array}$ & Low risk & No distinct selective outcome reporting \\
\hline $\begin{array}{l}\text { Blinding of participants } \\
\text { and personnel (perfor- } \\
\text { mance bias) } \\
\text { All outcomes }\end{array}$ & High risk & $\begin{array}{l}\text { Open study: Performance bias due to knowledge of the allocated interventions } \\
\text { by participants and personnel during the study }\end{array}$ \\
\hline $\begin{array}{l}\text { Blinding of outcome as- } \\
\text { sessment (detection bias) } \\
\text { All outcomes }\end{array}$ & Low risk & Outcome detection blinded \\
\hline
\end{tabular}

\section{Weir 1995}

\begin{tabular}{ll}
\hline Methods & SB \\
& CO \\
\hline Participants & N11 (8 black) \\
& Hyp \\
& Age60 \\
& sodium sensitive \\
\hline
\end{tabular}

Effects of low sodium diet versus high sodium diet on blood pressure, renin, aldosterone, catecholamines, cholesterol, and triglyceride 
1124 Weir 1995 (Continued)

\begin{tabular}{ll} 
Interventions & SR146 \\
& Dur14 \\
\hline Outcomes & SBP \\
& DBP
\end{tabular}

LoFo: 0

\section{Risk of bias}

\begin{tabular}{|c|c|c|}
\hline Bias & Authors' judgement & Support for judgement \\
\hline $\begin{array}{l}\text { Random sequence genera- } \\
\text { tion (selection bias) }\end{array}$ & Unclear risk & Insufficient information \\
\hline $\begin{array}{l}\text { Allocation concealment } \\
\text { (selection bias) }\end{array}$ & Unclear risk & Insufficient information \\
\hline $\begin{array}{l}\text { Blinding (performance } \\
\text { bias and detection bias) } \\
\text { All outcomes }\end{array}$ & High risk & Open study \\
\hline $\begin{array}{l}\text { Incomplete outcome data } \\
\text { (attrition bias) } \\
\text { All outcomes }\end{array}$ & Low risk & Lost to follow-up 0 \\
\hline $\begin{array}{l}\text { Selective reporting (re- } \\
\text { porting bias) }\end{array}$ & Low risk & No distinct selective outcome reporting \\
\hline $\begin{array}{l}\text { Blinding of participants } \\
\text { and personnel (perfor- } \\
\text { mance bias) } \\
\text { All outcomes }\end{array}$ & High risk & $\begin{array}{l}\text { Open study: Performance bias due to knowledge of the allocated interventions } \\
\text { by participants and personnel during the study }\end{array}$ \\
\hline $\begin{array}{l}\text { Blinding of outcome as- } \\
\text { sessment (detection bias) } \\
\text { All outcomes }\end{array}$ & Low risk & Outcome detection blinded \\
\hline
\end{tabular}

\section{Grey 1996}

\begin{tabular}{ll}
\hline Methods & DB \\
& CO \\
\hline Participants & N34 \\
& Norm \\
& Age23 \\
\hline Interventions & SR133 (185-52) \\
& Dur7 \\
\hline Outcomes & SBP \\
& DBP \\
Chol \\
HDL \\
LDL
\end{tabular}

Effects of low sodium diet versus high sodium diet on blood pressure, renin, aldosterone, catecholamines, cholesterol, and triglyceride 
1125 Grey 1996 (Continued)

Notes LoFo: 0

\section{Risk of bias}

\begin{tabular}{|c|c|c|}
\hline Bias & Authors' judgement & Support for judgement \\
\hline $\begin{array}{l}\text { Random sequence genera- } \\
\text { tion (selection bias) }\end{array}$ & Unclear risk & Insufficient information \\
\hline $\begin{array}{l}\text { Allocation concealment } \\
\text { (selection bias) }\end{array}$ & Unclear risk & Insufficient information \\
\hline $\begin{array}{l}\text { Blinding (performance } \\
\text { bias and detection bias) } \\
\text { All outcomes }\end{array}$ & Low risk & Double blind study \\
\hline $\begin{array}{l}\text { Incomplete outcome data } \\
\text { (attrition bias) } \\
\text { All outcomes }\end{array}$ & Low risk & Lost to follow-up 0 \\
\hline $\begin{array}{l}\text { Selective reporting (re- } \\
\text { porting bias) }\end{array}$ & Low risk & No distinct selective outcome reporting \\
\hline $\begin{array}{l}\text { Blinding of participants } \\
\text { and personnel (perfor- } \\
\text { mance bias) } \\
\text { All outcomes }\end{array}$ & Low risk & Double blind study \\
\hline $\begin{array}{l}\text { Blinding of outcome as- } \\
\text { sessment (detection bias) } \\
\text { All outcomes }\end{array}$ & Low risk & Double blind study \\
\hline
\end{tabular}

1126 Feldman 1996

\begin{tabular}{ll}
\hline Methods & DB \\
& CO \\
\hline Participants & N5 \\
& Norm \\
& Age27 \\
\hline Interventions & SR176 \\
& Dur7 \\
\hline Outcomes & SBP (MBP+1/3MBP) \\
& DBP (MBP-1/3MBP) \\
& A A \\
Chol \\
\hline Notes & LoFo: 0 \\
\hline
\end{tabular}

\section{Risk of bias}

Effects of low sodium diet versus high sodium diet on blood pressure, renin, aldosterone, catecholamines, cholesterol, and triglyceride 
1126 Feldman 1996 (Continued)

\begin{tabular}{|c|c|c|}
\hline Bias & Authors' judgement & Support for judgement \\
\hline $\begin{array}{l}\text { Random sequence genera- } \\
\text { tion (selection bias) }\end{array}$ & Unclear risk & Insufficient information \\
\hline $\begin{array}{l}\text { Allocation concealment } \\
\text { (selection bias) }\end{array}$ & Unclear risk & Insufficient information \\
\hline $\begin{array}{l}\text { Blinding (performance } \\
\text { bias and detection bias) } \\
\text { All outcomes }\end{array}$ & Low risk & Double blind study \\
\hline $\begin{array}{l}\text { Incomplete outcome data } \\
\text { (attrition bias) } \\
\text { All outcomes }\end{array}$ & Low risk & Lost to follow-up 0 \\
\hline $\begin{array}{l}\text { Selective reporting (re- } \\
\text { porting bias) }\end{array}$ & Low risk & No distinct selective outcome reporting \\
\hline $\begin{array}{l}\text { Blinding of participants } \\
\text { and personnel (perfor- } \\
\text { mance bias) } \\
\text { All outcomes }\end{array}$ & Low risk & Double blind study \\
\hline $\begin{array}{l}\text { Blinding of outcome as- } \\
\text { sessment (detection bias) } \\
\text { All outcomes }\end{array}$ & Low risk & Double blind study \\
\hline
\end{tabular}

\section{Feldman $1996 \mathrm{H}$}

\begin{tabular}{ll}
\hline Methods & DB \\
& CO \\
\hline Participants & N8 \\
& Hyp \\
& Age27 \\
\hline Interventions & SR178 \\
& Dur7 \\
\hline Outcomes & SBP (MBP+1/3MBP) \\
& DBP (MBP-1/3MBP) \\
& NA \\
Chol \\
\hline Notes & LoFo: 0 \\
\hline
\end{tabular}

\section{Risk of bias}

\begin{tabular}{lll}
\hline Bias & Authors' judgement & Support for judgement \\
\hline $\begin{array}{l}\text { Random sequence genera- } \\
\text { tion (selection bias) }\end{array}$ & Unclear risk & Insufficient information \\
\hline
\end{tabular}


1127 Feldman 1996 H (Continued)

\begin{tabular}{lll}
$\begin{array}{l}\text { Allocation concealment } \\
\text { (selection bias) }\end{array}$ & Unclear risk & Insufficient information \\
\hline $\begin{array}{l}\text { Blinding (performance } \\
\text { bias and detection bias) } \\
\text { All outcomes }\end{array}$ & Low risk & Double blind study \\
\hline
\end{tabular}

\begin{tabular}{|c|c|c|}
\hline $\begin{array}{l}\text { Incomplete outcome data } \\
\text { (attrition bias) } \\
\text { All outcomes }\end{array}$ & Low risk & Lost to follow-up 0 \\
\hline $\begin{array}{l}\text { Selective reporting (re- } \\
\text { porting bias) }\end{array}$ & Low risk & No distinct selective outcome reporting \\
\hline $\begin{array}{l}\text { Blinding of participants } \\
\text { and personnel (perfor- } \\
\text { mance bias) } \\
\text { All outcomes }\end{array}$ & Low risk & Double blind study \\
\hline $\begin{array}{l}\text { Blinding of outcome as- } \\
\text { sessment (detection bias) } \\
\text { All outcomes }\end{array}$ & Low risk & Double blind study \\
\hline
\end{tabular}

\section{Schorr 1996}

\begin{tabular}{ll}
\hline Methods & DB \\
& CO \\
\hline Participants & N16 \\
& Norm \\
& Age 64 \\
\hline Interventions & SR 74 (175.2-104.8) \\
& Dur28 \\
\hline Outcomes & SBP \\
& DBP \\
& Aldo \\
& Renin \\
Chol \\
HDL \\
LDL \\
TG \\
Included 21 \\
LoFo: 5 \\
IT: 0 \\
\hline Notes & \\
\hline
\end{tabular}

\section{Risk of bias}

\begin{tabular}{lll}
\hline Bias & Authors' judgement & Support for judgement \\
\hline $\begin{array}{l}\text { Random sequence genera- } \\
\text { tion (selection bias) }\end{array}$ & Unclear risk & Insufficient information \\
\hline
\end{tabular}


1128 Schorr 1996 (Continued)

\begin{tabular}{lll}
$\begin{array}{l}\text { Allocation concealment } \\
\text { (selection bias) }\end{array}$ & Unclear risk & Insufficient information \\
\hline $\begin{array}{l}\text { Blinding (performance } \\
\text { bias and detection bias) }\end{array}$ & Low risk & Double blind study \\
All outcomes & &
\end{tabular}

\begin{tabular}{l}
\hline Incomplete outcome data High risk $\quad$ Lost to follow up 5/21 \\
(attrition bias) \\
All outcomes
\end{tabular}

\begin{tabular}{lll}
\hline $\begin{array}{l}\text { Selective reporting (re- } \\
\text { porting bias) }\end{array}$ & Low risk & No distinct selective outcome reporting \\
\hline $\begin{array}{l}\text { Blinding of participants } \\
\begin{array}{l}\text { and personnel (perfor- } \\
\text { mance bias) }\end{array}\end{array}$ & Low risk & \\
$\begin{array}{l}\text { All outcomes } \\
\text { Blinding of outcome as- } \\
\text { sessment (detection bias) } \\
\begin{array}{l}\text { All outcomes } \\
\text { Low risk }\end{array}\end{array}$ & \\
\hline
\end{tabular}

\section{Bellini 1996}

\begin{tabular}{ll}
\hline Methods & DB \\
CO \\
\hline Participants & $\begin{array}{l}\text { N } 43 \text { (M/F:43/0)(B/W/A.0/43/0) } \\
\text { Hypertension } 46\end{array}$ \\
\hline Interventions & SR 121 (233-112) \\
\hline Outcomes & SBP, DBP, renin, aldo, NE \\
\hline Notes & LoFo: 12.43 of 55 completed study. IT: No
\end{tabular}

\section{Risk of bias}

\begin{tabular}{lll}
\hline Bias & Authors' judgement & Support for judgement \\
\hline $\begin{array}{l}\text { Random sequence genera- } \\
\text { tion (selection bias) }\end{array}$ & Unclear risk & Insufficient information \\
\hline $\begin{array}{l}\text { Allocation concealment } \\
\text { (selection bias) }\end{array}$ & Unclear risk & Insufficient information \\
\hline $\begin{array}{l}\text { Blinding (performance } \\
\text { bias and detection bias) } \\
\text { All outcomes }\end{array}$ & Low risk & Double blind study \\
\hline
\end{tabular}

Incomplete outcome data High risk $\quad$ Lost to follow up 12/55
(attrition bias)

Effects of low sodium diet versus high sodium diet on blood pressure, renin, aldosterone, catecholamines, cholesterol, and triglyceride 
1129 Bellini 1996 (Continued)

All outcomes

Selective reporting (re- Low risk No distinct selective outcome reporting
porting bias)

\begin{tabular}{lll}
\hline $\begin{array}{l}\text { Blinding of participants } \\
\text { and personnel (perfor- }\end{array}$ & Low risk & \\
mance bias) & & \\
All outcomes & & \\
\hline $\begin{array}{l}\text { Blinding of outcome as- } \\
\text { sessment (detection bias) } \\
\text { All outcomes }\end{array}$ & Low risk & Double blind study \\
\end{tabular}

\section{Inoue 1996}

\begin{tabular}{|c|c|c|}
\hline Methods & \multicolumn{2}{|l|}{$\begin{array}{l}\text { DB } \\
\text { CO }\end{array}$} \\
\hline Participants & \multicolumn{2}{|c|}{$\begin{array}{l}\mathrm{N} 14(\mathrm{M} / \mathrm{F}: 8 / 6)(\mathrm{B} / \mathrm{W} / \mathrm{A} .4 / 7 / 3) \\
\text { Hypertension } \\
\text { Age } 46\end{array}$} \\
\hline Interventions & \multicolumn{2}{|l|}{$\begin{array}{l}\text { SR } 293(329-36) \\
\text { Dur } 7\end{array}$} \\
\hline Outcomes & \multicolumn{2}{|l|}{ SBP, DBP } \\
\hline Notes & \multicolumn{2}{|l|}{ LoFo:0 } \\
\hline \multicolumn{3}{|l|}{ Risk of bias } \\
\hline Bias & Authors' judgement & Support for judgement \\
\hline $\begin{array}{l}\text { Random sequence genera- } \\
\text { tion (selection bias) }\end{array}$ & Unclear risk & Insufficient information \\
\hline $\begin{array}{l}\text { Allocation concealment } \\
\text { (selection bias) }\end{array}$ & Unclear risk & Insufficient information \\
\hline $\begin{array}{l}\text { Blinding (performance } \\
\text { bias and detection bias) } \\
\text { All outcomes }\end{array}$ & Low risk & Double blind study \\
\hline $\begin{array}{l}\text { Incomplete outcome data } \\
\text { (attrition bias) } \\
\text { All outcomes }\end{array}$ & Low risk & Lost to follow-up 0 \\
\hline $\begin{array}{l}\text { Selective reporting (re- } \\
\text { porting bias) }\end{array}$ & Low risk & No distinct selective outcome reporting \\
\hline $\begin{array}{l}\text { Blinding of participants } \\
\text { and personnel (perfor- } \\
\text { mance bias) } \\
\text { All outcomes }\end{array}$ & Low risk & Double blind study \\
\hline
\end{tabular}


1130 Inoue 1996 (Continued)
Blinding of outcome as-
Low risk
Double blind study sessment (detection bias)

All outcomes

\section{Ferri 1996}

\begin{tabular}{ll}
\hline Methods & DB \\
& CO \\
\hline Participants & N61 \\
& Hyp \\
& Age47 \\
\hline Interventions & SR264 \\
& Dur14 \\
\hline Outcomes & SBP \\
& DBP \\
Aldo \\
Renin \\
\hline Notes & 79 were included. \\
& 65 were randomised. \\
& LoFo: 4 \\
IT: No
\end{tabular}

\section{Risk of bias}

\begin{tabular}{|c|c|c|}
\hline Bias & Authors' judgement & Support for judgement \\
\hline $\begin{array}{l}\text { Random sequence genera- } \\
\text { tion (selection bias) }\end{array}$ & Unclear risk & Insufficient information \\
\hline $\begin{array}{l}\text { Allocation concealment } \\
\text { (selection bias) }\end{array}$ & Unclear risk & Insufficient information \\
\hline $\begin{array}{l}\text { Blinding (performance } \\
\text { bias and detection bias) } \\
\text { All outcomes }\end{array}$ & Low risk & Double blind study \\
\hline $\begin{array}{l}\text { Incomplete outcome data } \\
\text { (attrition bias) } \\
\text { All outcomes }\end{array}$ & Low risk & Lost to follow up 4/65 \\
\hline $\begin{array}{l}\text { Selective reporting (re- } \\
\text { porting bias) }\end{array}$ & Low risk & No distinct selective outcome reporting \\
\hline $\begin{array}{l}\text { Blinding of participants } \\
\text { and personnel (perfor- } \\
\text { mance bias) } \\
\text { All outcomes }\end{array}$ & Low risk & Double blind study \\
\hline $\begin{array}{l}\text { Blinding of outcome as- } \\
\text { sessment (detection bias) } \\
\text { All outcomes }\end{array}$ & Low risk & Double blind study \\
\hline
\end{tabular}

Effects of low sodium diet versus high sodium diet on blood pressure, renin, aldosterone, catecholamines, cholesterol, and triglyceride 
1132 Ishimitsu 1996 A

\begin{tabular}{ll}
\hline Methods & Op \\
\hline Participants & $\begin{array}{l}\text { N HT: 23 (M/F:11/12) NT 7 (M/F:3/4)(B/W/A.0/0/30) } \\
\text { Age 54 }\end{array}$ \\
\hline Interventions & SR 194 (217-23) \\
\hline Dur 7 \\
\hline Outcomes & SBP, DBP, renin, aldo \\
\hline Notes & LoFo: 0 \\
\hline
\end{tabular}

\section{Risk of bias}

\begin{tabular}{|c|c|c|}
\hline Bias & Authors' judgement & Support for judgement \\
\hline $\begin{array}{l}\text { Random sequence genera- } \\
\text { tion (selection bias) }\end{array}$ & Unclear risk & Insufficient information \\
\hline $\begin{array}{l}\text { Allocation concealment } \\
\text { (selection bias) }\end{array}$ & Unclear risk & Insufficient information \\
\hline $\begin{array}{l}\text { Blinding (performance } \\
\text { bias and detection bias) } \\
\text { All outcomes }\end{array}$ & High risk & Open study \\
\hline $\begin{array}{l}\text { Incomplete outcome data } \\
\text { (attrition bias) } \\
\text { All outcomes }\end{array}$ & Low risk & Lost to follow up 0 \\
\hline $\begin{array}{l}\text { Selective reporting (re- } \\
\text { porting bias) }\end{array}$ & Low risk & No distinct selective outcome reporting \\
\hline $\begin{array}{l}\text { Blinding of participants } \\
\text { and personnel (perfor- } \\
\text { mance bias) } \\
\text { All outcomes }\end{array}$ & High risk & $\begin{array}{l}\text { Open study: Performance bias due to knowledge of the allocated interventions } \\
\text { by participants and personnel during the study. }\end{array}$ \\
\hline $\begin{array}{l}\text { Blinding of outcome as- } \\
\text { sessment (detection bias) } \\
\text { All outcomes }\end{array}$ & High risk & $\begin{array}{l}\text { Open study: Detection bias due to knowledge of the allocated interventions by } \\
\text { outcome assessors }\end{array}$ \\
\hline
\end{tabular}

1133 Ishimitsu 1996 AH

\begin{tabular}{ll}
\hline Methods & Op \\
& CO
\end{tabular}

\begin{tabular}{ll}
\hline Participants & N HT: 23 (M/F:11/12) NT 7 (M/F:3/4)(B/W/A.0/0/30) \\
& Hypertension and normotension \\
& Age 54 \\
\hline Interventions & SR 194 (217-23) \\
\hline
\end{tabular}

Effects of low sodium diet versus high sodium diet on blood pressure, renin, aldosterone, catecholamines, cholesterol, and triglyceride 
1133 Ishimitsu 1996 AH (Continued)

$$
\text { Dur } 7
$$

\begin{tabular}{ll}
\hline Outcomes & SBP, DBP, renin, aldo \\
\hline Notes & LoFo: 0 \\
\hline
\end{tabular}

\section{Risk of bias}

\begin{tabular}{|c|c|c|}
\hline Bias & Authors' judgement & Support for judgement \\
\hline $\begin{array}{l}\text { Random sequence genera- } \\
\text { tion (selection bias) }\end{array}$ & Unclear risk & Insufficient information \\
\hline $\begin{array}{l}\text { Allocation concealment } \\
\text { (selection bias) }\end{array}$ & Unclear risk & Insufficient information \\
\hline $\begin{array}{l}\text { Blinding (performance } \\
\text { bias and detection bias) } \\
\text { All outcomes }\end{array}$ & High risk & Open study \\
\hline $\begin{array}{l}\text { Incomplete outcome data } \\
\text { (attrition bias) } \\
\text { All outcomes }\end{array}$ & Low risk & Lost to follow up 0 \\
\hline $\begin{array}{l}\text { Selective reporting (re- } \\
\text { porting bias) }\end{array}$ & Low risk & No distinct selective outcome reporting \\
\hline $\begin{array}{l}\text { Blinding of participants } \\
\text { and personnel (perfor- } \\
\text { mance bias) } \\
\text { All outcomes }\end{array}$ & High risk & $\begin{array}{l}\text { Open study: Performance bias due to knowledge of the allocated interventions } \\
\text { by participants and personnel during the study. }\end{array}$ \\
\hline $\begin{array}{l}\text { Blinding of outcome as- } \\
\text { sessment (detection bias) } \\
\text { All outcomes }\end{array}$ & High risk & $\begin{array}{l}\text { Open study: Detection bias due to knowledge of the allocated interventions by } \\
\text { outcome assessors }\end{array}$ \\
\hline
\end{tabular}

\section{Cappuccio 1997}

\begin{tabular}{ll}
\hline Methods & DB \\
& CO \\
\hline Participants & N47 \\
& Hyp \\
& Age67 \\
\hline Interventions & SR83 \\
& Dur 30 \\
\hline \multirow{2}{*}{ Outcomes } & SBP \\
& DBP \\
\hline Notes & Included 52 \\
& randomised 48 \\
& LoFo: 1 \\
IT: No \\
\hline
\end{tabular}

Effects of low sodium diet versus high sodium diet on blood pressure, renin, aldosterone, catecholamines, cholesterol, and triglyceride 
1134 Cappuccio 1997 (Continued)

Risk of bias

\begin{tabular}{|c|c|c|}
\hline Bias & Authors' judgement & Support for judgement \\
\hline $\begin{array}{l}\text { Random sequence genera- } \\
\text { tion (selection bias) }\end{array}$ & Unclear risk & Insufficient information \\
\hline $\begin{array}{l}\text { Allocation concealment } \\
\text { (selection bias) }\end{array}$ & Unclear risk & Insufficient information \\
\hline $\begin{array}{l}\text { Blinding (performance } \\
\text { bias and detection bias) } \\
\text { All outcomes }\end{array}$ & Low risk & Double blind study \\
\hline $\begin{array}{l}\text { Incomplete outcome data } \\
\text { (attrition bias) } \\
\text { All outcomes }\end{array}$ & Low risk & Lost to follow up 1 \\
\hline $\begin{array}{l}\text { Selective reporting (re- } \\
\text { porting bias) }\end{array}$ & Low risk & No distinct selective outcome reporting \\
\hline $\begin{array}{l}\text { Blinding of participants } \\
\text { and personnel (perfor- } \\
\text { mance bias) } \\
\text { All outcomes }\end{array}$ & Low risk & Double blind study \\
\hline $\begin{array}{l}\text { Blinding of outcome as- } \\
\text { sessment (detection bias) } \\
\text { All outcomes }\end{array}$ & Low risk & Double blind study \\
\hline
\end{tabular}

\section{TOHP || 1997}

\begin{tabular}{ll}
\hline Methods & SB \\
& $P$ \\
\hline Participants & $\begin{array}{l}\text { N1190 (203 blacks) } \\
\text { High norm } \\
\text { Age 42 }\end{array}$ \\
\hline Interventions & SR40 \\
& Dur 1100 \\
\hline Outcomes & SBP \\
& DBP \\
\hline Notes & LoFo:161 \\
\hline
\end{tabular}

\section{Risk of bias}

\section{Bias}

Random sequence genera-

tion (selection bias)

\section{Authors' judgement Support for judgement}

Unclear risk

Insufficient information 
1135 TOHP II 1997 (Continued)

\begin{tabular}{lll}
$\begin{array}{l}\text { Allocation concealment } \\
\text { (selection bias) }\end{array}$ & Low risk & $\begin{array}{l}\text { Randomization was performed by telephone contact with the TOHP coordinat- } \\
\text { ing center or by opening a sealed opaque envelope }\end{array}$ \\
\hline $\begin{array}{l}\text { Blinding (performance } \\
\text { bias and detection bias) } \\
\text { All outcomes }\end{array}$ & High risk & Open study \\
\hline
\end{tabular}

All outcomes

Incomplete outcome data Low risk

Lost to follow up LS: 79/596; US: 82/594

(attrition bias)

All outcomes

Selective reporting (re- Low risk No distinct selective outcome reporting
porting bias)

\begin{tabular}{|c|c|c|}
\hline $\begin{array}{l}\text { Blinding of participants } \\
\text { and personnel (perfor- } \\
\text { mance bias) } \\
\text { All outcomes }\end{array}$ & High risk & $\begin{array}{l}\text { Open study: Performance bias due to knowledge of the allocated interventions } \\
\text { by participants and personnel during the study }\end{array}$ \\
\hline $\begin{array}{l}\text { Blinding of outcome as- } \\
\text { sessment (detection bias) } \\
\text { All outcomes }\end{array}$ & Low risk & Outcome detection blinded \\
\hline
\end{tabular}

\section{6 van Buul 1997}

\begin{tabular}{ll}
\hline Methods & Op \\
& CO \\
\hline Participants & $\begin{array}{l}\text { N } 232(\mathrm{M} / \mathrm{F}: 0 / 232)(B / W / A .0 / 232 / 0) \\
\text { Normotension } \\
\end{array}$ \\
\hline Interventions 28 \\
\hline SR $65(140-75($ week 28$))$ \\
Dur 196 \\
\hline Notes & SBP, DBP \\
\hline
\end{tabular}

\section{Risk of bias}

\begin{tabular}{lll}
\hline Bias & Authors' judgement & Support for judgement \\
\hline $\begin{array}{l}\text { Random sequence genera- } \\
\text { tion (selection bias) }\end{array}$ & Unclear risk & Insufficient information \\
\hline $\begin{array}{l}\text { Allocation concealment } \\
\text { (selection bias) }\end{array}$ & Low risk & Randomisation by a closed envelope system \\
\hline $\begin{array}{l}\text { Blinding (performance } \\
\text { bias and detection bias) } \\
\text { All outcomes }\end{array}$ & High risk & Open study \\
\hline
\end{tabular}

Incomplete outcome data Low risk Lost to follow up 28/270
(attrition bias)

Effects of low sodium diet versus high sodium diet on blood pressure, renin, aldosterone, catecholamines, cholesterol, and triglyceride 
1136 van Buul 1997 (Continued)

All outcomes

Selective reporting (re- Low risk No distinct selective outcome reporting
porting bias)

\begin{tabular}{lll}
\hline $\begin{array}{l}\text { Blinding of participants } \\
\text { and personnel (perfor- } \\
\text { mance bias) } \\
\text { All outcomes }\end{array}$ & High risk & $\begin{array}{l}\text { Open study: Performance bias due to knowledge of the allocated interventions } \\
\text { by participants and personnel during the study. }\end{array}$ \\
\hline $\begin{array}{l}\text { Blinding of outcome as- } \\
\text { sessment (detection bias) } \\
\text { All outcomes }\end{array}$ & High risk & $\begin{array}{l}\text { Open study: Detection bias due to knowledge of the allocated interventions by } \\
\text { outcome assessors }\end{array}$ \\
\hline
\end{tabular}

\section{Schorr 1997}

\begin{tabular}{ll}
\hline Methods & SB \\
& CO \\
\hline Participants & N27 \\
& Norm \\
& Age25 \\
& sodium sensitive \\
\hline Interventions & SR208 \\
& Dur7 \\
\hline Outcomes & SBP (MBP+1/3MBP) \\
\hline Notes & DBP (MBP-1/3MBP) \\
\hline
\end{tabular}

\section{Risk of bias}

\begin{tabular}{|c|c|c|}
\hline Bias & Authors' judgement & Support for judgement \\
\hline $\begin{array}{l}\text { Random sequence genera- } \\
\text { tion (selection bias) }\end{array}$ & Unclear risk & Insufficient information \\
\hline $\begin{array}{l}\text { Allocation concealment } \\
\text { (selection bias) }\end{array}$ & Unclear risk & Insufficient information \\
\hline $\begin{array}{l}\text { Blinding (performance } \\
\text { bias and detection bias) } \\
\text { All outcomes }\end{array}$ & High risk & Open study \\
\hline $\begin{array}{l}\text { Incomplete outcome data } \\
\text { (attrition bias) } \\
\text { All outcomes }\end{array}$ & Low risk & Lost to follow up 0 \\
\hline $\begin{array}{l}\text { Selective reporting (re- } \\
\text { porting bias) }\end{array}$ & Unclear risk & Insufficient information \\
\hline $\begin{array}{l}\text { Blinding of participants } \\
\text { and personnel (perfor- } \\
\text { mance bias) }\end{array}$ & High risk & $\begin{array}{l}\text { Open study: Performance bias due to knowledge of the allocated interventions } \\
\text { by participants and personnel during the study }\end{array}$ \\
\hline
\end{tabular}


1137 Schorr 1997 (Continued)

All outcomes

Blinding of outcome as- Low risk $\quad$ Outcome detection blinded
sessment (detection bias)

All outcomes

1138 McCarron 1997

\begin{tabular}{ll}
\hline Methods & DB \\
& CO \\
\hline Participants & N99 (24 blacks) \\
& Hyp \\
& Age52 \\
\hline Interventions & SR 55.4 (175.9-120.5) \\
& Dur28 \\
\hline Outcomes & SBP \\
& DBP \\
& Chol \\
& HDL \\
LDL \\
TG \\
\hline Notes & LoFo: 0 \\
\hline
\end{tabular}

\section{Risk of bias}

\begin{tabular}{|c|c|c|}
\hline Bias & Authors' judgement & Support for judgement \\
\hline $\begin{array}{l}\text { Random sequence genera- } \\
\text { tion (selection bias) }\end{array}$ & Unclear risk & Insufficient information \\
\hline $\begin{array}{l}\text { Allocation concealment } \\
\text { (selection bias) }\end{array}$ & Unclear risk & Insufficient information \\
\hline $\begin{array}{l}\text { Blinding (performance } \\
\text { bias and detection bias) } \\
\text { All outcomes }\end{array}$ & Low risk & Double blind study \\
\hline $\begin{array}{l}\text { Incomplete outcome data } \\
\text { (attrition bias) } \\
\text { All outcomes }\end{array}$ & Low risk & Lost to follow up 0 \\
\hline $\begin{array}{l}\text { Selective reporting (re- } \\
\text { porting bias) }\end{array}$ & Low risk & No distinct selective outcome reporting \\
\hline $\begin{array}{l}\text { Blinding of participants } \\
\text { and personnel (perfor- } \\
\text { mance bias) } \\
\text { All outcomes }\end{array}$ & Low risk & Double blind study \\
\hline $\begin{array}{l}\text { Blinding of outcome as- } \\
\text { sessment (detection bias) } \\
\text { All outcomes }\end{array}$ & Low risk & Double blind study \\
\hline
\end{tabular}

Effects of low sodium diet versus high sodium diet on blood pressure, renin, aldosterone, catecholamines, cholesterol, and triglyceride 
1139 Meland 1997

\begin{tabular}{ll}
\hline Methods & DB \\
& CO \\
\hline Participants & $\begin{array}{l}\text { N } 16(\text { M/F:13/3)(B/W/A.0/16/0) } \\
\text { Hypertension } \\
\text { Age } 50\end{array}$ \\
\hline Interventions & SR $66(191-125)$ \\
& Dur 56 \\
\hline Outcomes & SBP, DBP, chol, HDL \\
\hline Notes & LoFo: 0
\end{tabular}

\section{Risk of bias}

\begin{tabular}{|c|c|c|}
\hline Bias & Authors' judgement & Support for judgement \\
\hline $\begin{array}{l}\text { Random sequence genera- } \\
\text { tion (selection bias) }\end{array}$ & Unclear risk & Insufficient information \\
\hline $\begin{array}{l}\text { Allocation concealment } \\
\text { (selection bias) }\end{array}$ & Unclear risk & Insufficient information \\
\hline $\begin{array}{l}\text { Blinding (performance } \\
\text { bias and detection bias) } \\
\text { All outcomes }\end{array}$ & Low risk & Double blind study \\
\hline $\begin{array}{l}\text { Incomplete outcome data } \\
\text { (attrition bias) } \\
\text { All outcomes }\end{array}$ & Low risk & Lost to follow up 0 \\
\hline $\begin{array}{l}\text { Selective reporting (re- } \\
\text { porting bias) }\end{array}$ & Low risk & No distinct selective outcome reporting \\
\hline $\begin{array}{l}\text { Blinding of participants } \\
\text { and personnel (perfor- } \\
\text { mance bias) } \\
\text { All outcomes }\end{array}$ & Low risk & Double blind study \\
\hline $\begin{array}{l}\text { Blinding of outcome as- } \\
\text { sessment (detection bias) } \\
\text { All outcomes }\end{array}$ & Low risk & Double blind study \\
\hline
\end{tabular}

1140 Fotherby 1997

\begin{tabular}{ll}
\hline Methods & DB \\
& CO \\
\hline Participants & $\begin{array}{l}\text { N } 17 \text { (M/F:4/13)(B/W/A.0/17/0) } \\
\text { Hypertension } \\
\text { Age 73 }\end{array}$ \\
\hline Interventions & SR 79 (174-95)
\end{tabular}

Effects of low sodium diet versus high sodium diet on blood pressure, renin, aldosterone, catecholamines, cholesterol, and triglyceride 
1140 Fotherby 1997 (Continued)

Dur 35

\begin{tabular}{ll}
\hline Outcomes & Chol, HDL, LDL, Trig \\
\hline Notes & LoFo: 0 \\
\hline
\end{tabular}

\section{Risk of bias}

\begin{tabular}{|c|c|c|}
\hline Bias & Authors' judgement & Support for judgement \\
\hline $\begin{array}{l}\text { Random sequence genera- } \\
\text { tion (selection bias) }\end{array}$ & Unclear risk & Insufficient information \\
\hline $\begin{array}{l}\text { Allocation concealment } \\
\text { (selection bias) }\end{array}$ & Unclear risk & Insufficient information \\
\hline $\begin{array}{l}\text { Blinding (performance } \\
\text { bias and detection bias) } \\
\text { All outcomes }\end{array}$ & Low risk & Double blind study \\
\hline $\begin{array}{l}\text { Incomplete outcome data } \\
\text { (attrition bias) } \\
\text { All outcomes }\end{array}$ & Low risk & Lost to follow-up 0 \\
\hline $\begin{array}{l}\text { Selective reporting (re- } \\
\text { porting bias) }\end{array}$ & Low risk & No distinct selective outcome reporting \\
\hline $\begin{array}{l}\text { Blinding of participants } \\
\text { and personnel (perfor- } \\
\text { mance bias) } \\
\text { All outcomes }\end{array}$ & Low risk & Double blind study \\
\hline $\begin{array}{l}\text { Blinding of outcome as- } \\
\text { sessment (detection bias) } \\
\text { All outcomes }\end{array}$ & Low risk & Double blind study \\
\hline
\end{tabular}

\section{Ferri 1998}

\begin{tabular}{ll}
\hline Methods & DB \\
& CO \\
\hline Participants & $\begin{array}{l}\text { N, HT: 39; NT 8 (B/W/A.0/47/0) } \\
\text { Hypertension and normotension } \\
\text { Age 45 }\end{array}$ \\
\hline Interventions & SR $170(200-30)$ \\
\hline Outcomes 14
\end{tabular}

\section{Risk of bias}


1141 Ferri 1998 (Continued)

\begin{tabular}{|c|c|c|}
\hline Bias & Authors' judgement & Support for judgement \\
\hline $\begin{array}{l}\text { Random sequence genera- } \\
\text { tion (selection bias) }\end{array}$ & Unclear risk & Insufficient information \\
\hline $\begin{array}{l}\text { Allocation concealment } \\
\text { (selection bias) }\end{array}$ & Unclear risk & Insufficient information \\
\hline $\begin{array}{l}\text { Blinding (performance } \\
\text { bias and detection bias) } \\
\text { All outcomes }\end{array}$ & Low risk & Double blind study \\
\hline $\begin{array}{l}\text { Incomplete outcome data } \\
\text { (attrition bias) } \\
\text { All outcomes }\end{array}$ & Unclear risk & Lost to follow up $7 / 46 \mathrm{HT}$ \\
\hline $\begin{array}{l}\text { Selective reporting (re- } \\
\text { porting bias) }\end{array}$ & Low risk & No distinct selective outcome reporting \\
\hline $\begin{array}{l}\text { Blinding of participants } \\
\text { and personnel (perfor- } \\
\text { mance bias) } \\
\text { All outcomes }\end{array}$ & Low risk & Double blind study \\
\hline $\begin{array}{l}\text { Blinding of outcome as- } \\
\text { sessment (detection bias) } \\
\text { All outcomes }\end{array}$ & Low risk & Double blind study \\
\hline
\end{tabular}

\section{Knuist 1998}

\begin{tabular}{ll}
\hline Methods & Op \\
& $P$ \\
\hline Participants & $\begin{array}{l}\text { N 361 (80\% Caucasian) } \\
\text { Pregnant women, Normotension } \\
\text { Age 27.5 }\end{array}$ \\
\hline Interventions & SR 40 (124-84) \\
\hline Dur 35 (mean duration) \\
\hline Notes & DBP \\
\hline
\end{tabular}

\section{Risk of bias}

\begin{tabular}{lll}
\hline Bias & Authors' judgement & Support for judgement \\
\hline $\begin{array}{l}\text { Random sequence genera- } \\
\text { tion (selection bias) }\end{array}$ & Unclear risk & Insufficient information \\
\hline $\begin{array}{l}\text { Allocation concealment } \\
\text { (selection bias) }\end{array}$ & Low risk & Block randomisation. Treatment allocation in opaque sealed envelopes. \\
\hline $\begin{array}{l}\text { Blinding (performance } \\
\text { bias and detection bias) }\end{array}$ & High risk & Open study \\
\hline
\end{tabular}

Effects of low sodium diet versus high sodium diet on blood pressure, renin, aldosterone, catecholamines, cholesterol, and triglyceride 
1142 Knuist 1998 (Continued)

All outcomes

Incomplete outcome data High risk $\quad$ Lost to follow up LS: 35/184; US: 32/177
(attrition bias)

(attrition bias)

All outcomes

\begin{tabular}{lll}
\hline $\begin{array}{l}\text { Selective reporting (re- } \\
\text { porting bias) }\end{array}$ & High risk & SBP effect not reported \\
\hline $\begin{array}{l}\text { Blinding of participants } \\
\begin{array}{l}\text { and personnel (perfor- } \\
\text { mance bias) }\end{array}\end{array}$ & High risk & $\begin{array}{l}\text { Open study: Performance bias due to knowledge of the allocated interventions } \\
\text { by participants and personnel during the study. }\end{array}$ \\
$\begin{array}{ll}\text { All outcomes } \\
\begin{array}{l}\text { Blinding of outcome as- } \\
\text { sessment (detection bias) } \\
\text { All outcomes }\end{array}\end{array}$ & High risk & $\begin{array}{l}\text { Open study: Detection bias due to knowledge of the allocated interventions by } \\
\text { outcome assessors }\end{array}$ \\
\hline
\end{tabular}

\section{Bech 1998}

\begin{tabular}{ll}
\hline Methods & Op \\
CO \\
\hline Participants & $\begin{array}{l}\text { N } 12 \text { (M/F:6/6)(B/W/A.0/12/0) } \\
\text { Normotension }\end{array}$ \\
\hline Interventions 23.8 \\
\hline SR $235(273-38)$ \\
Dutcomes 5
\end{tabular}

\section{Risk of bias}

\begin{tabular}{|c|c|c|}
\hline Bias & Authors' judgement & Support for judgement \\
\hline $\begin{array}{l}\text { Random sequence genera- } \\
\text { tion (selection bias) }\end{array}$ & Unclear risk & Insufficient information \\
\hline $\begin{array}{l}\text { Allocation concealment } \\
\text { (selection bias) }\end{array}$ & Unclear risk & Insufficient information \\
\hline $\begin{array}{l}\text { Blinding (performance } \\
\text { bias and detection bias) } \\
\text { All outcomes }\end{array}$ & High risk & Open study \\
\hline $\begin{array}{l}\text { Incomplete outcome data } \\
\text { (attrition bias) } \\
\text { All outcomes }\end{array}$ & Low risk & Lost to follow-up 0 \\
\hline $\begin{array}{l}\text { Selective reporting (re- } \\
\text { porting bias) }\end{array}$ & Unclear risk & Insufficient information \\
\hline
\end{tabular}




\section{Bech 1998 (Continued)}

Blinding of participants and personnel (performance bias)

All outcomes

\section{Blinding of outcome as- High risk} sessment (detection bias)

All outcomes
High risk Open study: Performance bias due to knowledge of the allocated interventions by participants and personnel during the study.

\section{Foo 1998}

$\begin{array}{ll}\text { Methods } & \text { DB } \\ & \text { CO }\end{array}$

$\mathrm{CO}$

\begin{tabular}{ll}
\hline Participants & $\begin{array}{l}\text { N 18, (8 males, } 10 \text { females) } \\
\text { Normotensive } \\
\text { Mean age 51 }\end{array}$ \\
\hline Interventions & SR $149(227-78)$ \\
& Dur 6 \\
\hline Outcomes & SBP \\
& DBP \\
& Renin Aldosterone \\
\hline
\end{tabular}

\section{Notes}

LoFo: 0

SDs estimated on the basis of $p$-values

\section{Risk of bias}

\section{Bias}

\section{Authors' judgement Support for judgement}

Random sequence genera- Unclear risk Insufficient information
tion (selection bias)

\begin{tabular}{ll}
\hline $\begin{array}{l}\text { Allocation concealment } \\
\text { (selection bias) }\end{array}$ & Unclear risk
\end{tabular}

Blinding (performance Low risk Double blind study

bias and detection bias)

All outcomes

\begin{tabular}{lll}
$\begin{array}{l}\text { Incomplete outcome data } \\
\text { (attrition bias) } \\
\text { All outcomes }\end{array}$ & Low risk & Lost to follow-up 0 \\
\hline $\begin{array}{l}\text { Selective reporting (re- } \\
\text { porting bias) }\end{array}$ & Low risk & No distinct selective outcome reporting \\
\hline $\begin{array}{l}\text { Blinding of participants } \\
\begin{array}{l}\text { and personnel (perfor- } \\
\text { mance bias) }\end{array}\end{array}$ & Low risk & Double blind study \\
$\begin{array}{l}\text { All outcomes } \\
\text { a }\end{array}$ & &
\end{tabular}

Effects of low sodium diet versus high sodium diet on blood pressure, renin, aldosterone, catecholamines, cholesterol, and triglyceride 
1144 Foo 1998 (Continued)

Blinding of outcome as- Low risk Double blind study sessment (detection bias)

All outcomes

\section{Wing 1998}

\begin{tabular}{ll}
\hline Methods & DB \\
& CO
\end{tabular}

\begin{tabular}{ll}
\hline Participants & N17 \\
& Hyp \\
& Age6 \\
\hline Interventions & SR59 \\
& Dur4 \\
\hline Outcomes & SBP \\
& DBP
\end{tabular}

\begin{tabular}{ll}
\hline Notes & 39 included \\
& 19 randomised \\
& LoFo: 2 \\
& IT: No
\end{tabular}

\section{Risk of bias}

\begin{tabular}{|c|c|c|}
\hline Bias & Authors' judgement & Support for judgement \\
\hline $\begin{array}{l}\text { Random sequence genera- } \\
\text { tion (selection bias) }\end{array}$ & Unclear risk & Insufficient information \\
\hline $\begin{array}{l}\text { Allocation concealment } \\
\text { (selection bias) }\end{array}$ & Unclear risk & Insufficient information \\
\hline $\begin{array}{l}\text { Blinding (performance } \\
\text { bias and detection bias) } \\
\text { All outcomes }\end{array}$ & Low risk & Double blind study \\
\hline $\begin{array}{l}\text { Incomplete outcome data } \\
\text { (attrition bias) } \\
\text { All outcomes }\end{array}$ & Low risk & Lost to follow up $2 / 19$ \\
\hline $\begin{array}{l}\text { Selective reporting (re- } \\
\text { porting bias) }\end{array}$ & Low risk & No distinct selective outcome reporting \\
\hline $\begin{array}{l}\text { Blinding of participants } \\
\text { and personnel (perfor- } \\
\text { mance bias) } \\
\text { All outcomes }\end{array}$ & Low risk & Double blind study \\
\hline $\begin{array}{l}\text { Blinding of outcome as- } \\
\text { sessment (detection bias) } \\
\text { All outcomes }\end{array}$ & Low risk & Double blind study \\
\hline
\end{tabular}


1146 Herlitz 1998

\begin{tabular}{ll}
\hline Methods & DB \\
& CO \\
\hline Participants & $\begin{array}{l}\text { N6 (M/F 6/0)(B/W/A 0/6/0) } \\
\text { treated hypertension (from 150/106 to 124/82) } \\
\text { Age 46 }\end{array}$ \\
\hline Interventions & SR 98 (325-227) \\
& Dur 6 \\
\hline Outcomes & SBP \\
& DBP \\
& Renin \\
\hline Notes & Included 8 \\
& LoFO: 2 \\
IT: No
\end{tabular}

\section{Risk of bias}

\begin{tabular}{|c|c|c|}
\hline Bias & Authors' judgement & Support for judgement \\
\hline $\begin{array}{l}\text { Random sequence genera- } \\
\text { tion (selection bias) }\end{array}$ & Unclear risk & Insufficient information \\
\hline $\begin{array}{l}\text { Allocation concealment } \\
\text { (selection bias) }\end{array}$ & Unclear risk & Insufficient information \\
\hline $\begin{array}{l}\text { Blinding (performance } \\
\text { bias and detection bias) } \\
\text { All outcomes }\end{array}$ & Low risk & Double blind study \\
\hline $\begin{array}{l}\text { Incomplete outcome data } \\
\text { (attrition bias) } \\
\text { All outcomes }\end{array}$ & High risk & Lost to follow up $2 / 8$ \\
\hline $\begin{array}{l}\text { Selective reporting (re- } \\
\text { porting bias) }\end{array}$ & Low risk & No distinct selective outcome reporting \\
\hline $\begin{array}{l}\text { Blinding of participants } \\
\text { and personnel (perfor- } \\
\text { mance bias) } \\
\text { All outcomes }\end{array}$ & Low risk & Double blind study \\
\hline $\begin{array}{l}\text { Blinding of outcome as- } \\
\text { sessment (detection bias) } \\
\text { All outcomes }\end{array}$ & Low risk & Double blind study \\
\hline
\end{tabular}

\section{Feldman 1999}

\begin{tabular}{ll}
\hline Methods & Op \\
& CO \\
\hline Participants & $\begin{array}{l}\text { N } 8(M / F: 8 / 0)(B / W / A .0 / 8 / 0) \\
\text { Normotension }\end{array}$
\end{tabular}

Effects of low sodium diet versus high sodium diet on blood pressure, renin, aldosterone, catecholamines, cholesterol, and triglyceride 
1147 Feldman 1999 (Continued)

\section{Age 33}

\begin{tabular}{ll}
\hline Interventions & SR $159(207-48)$ \\
& Dur 7 \\
\hline Outcomes & SBP, DBP, chol, NE \\
\hline Notes & LoFo: 0 \\
\hline
\end{tabular}

\section{Risk of bias}

\begin{tabular}{|c|c|c|}
\hline Bias & Authors' judgement & Support for judgement \\
\hline $\begin{array}{l}\text { Random sequence genera- } \\
\text { tion (selection bias) }\end{array}$ & Unclear risk & Insufficient information \\
\hline $\begin{array}{l}\text { Allocation concealment } \\
\text { (selection bias) }\end{array}$ & Unclear risk & Insufficient information \\
\hline $\begin{array}{l}\text { Blinding (performance } \\
\text { bias and detection bias) } \\
\text { All outcomes }\end{array}$ & High risk & Open study \\
\hline $\begin{array}{l}\text { Incomplete outcome data } \\
\text { (attrition bias) } \\
\text { All outcomes }\end{array}$ & Low risk & Lost to follow-up 0 \\
\hline $\begin{array}{l}\text { Selective reporting (re- } \\
\text { porting bias) }\end{array}$ & Low risk & No distinct selective outcome reporting \\
\hline $\begin{array}{l}\text { Blinding of participants } \\
\text { and personnel (perfor- } \\
\text { mance bias) } \\
\text { All outcomes }\end{array}$ & High risk & $\begin{array}{l}\text { Open study: Performance bias due to knowledge of the allocated interventions } \\
\text { by participants and personnel during the study. }\end{array}$ \\
\hline $\begin{array}{l}\text { Blinding of outcome as- } \\
\text { sessment (detection bias) } \\
\text { All outcomes }\end{array}$ & High risk & $\begin{array}{l}\text { Open study: Detection bias due to knowledge of the allocated interventions by } \\
\text { outcome assessors }\end{array}$ \\
\hline
\end{tabular}

\section{Damasceno 1999}

\begin{tabular}{ll}
\hline Methods & DB \\
& CO \\
\hline Participants & $\begin{array}{l}\text { N } 39 \text { (19HT and 20NT) (M/F:19/20)(B/W/A 39/0/0) } \\
\text { Hypertension and normotension } \\
\text { Age HT 43; NT 38 }\end{array}$ \\
\hline Interventions & SR HT: 81 (114-33); NT: 180 (210-30) \\
\hline Our 7
\end{tabular}


1148 Damasceno 1999 (Continued)

\section{Risk of bias}

\begin{tabular}{|c|c|c|}
\hline Bias & Authors' judgement & Support for judgement \\
\hline $\begin{array}{l}\text { Random sequence genera- } \\
\text { tion (selection bias) }\end{array}$ & Unclear risk & Insufficient information \\
\hline $\begin{array}{l}\text { Allocation concealment } \\
\text { (selection bias) }\end{array}$ & Unclear risk & Insufficient information \\
\hline $\begin{array}{l}\text { Blinding (performance } \\
\text { bias and detection bias) } \\
\text { All outcomes }\end{array}$ & Low risk & Double blind study \\
\hline $\begin{array}{l}\text { Incomplete outcome data } \\
\text { (attrition bias) } \\
\text { All outcomes }\end{array}$ & Low risk & Lost to follow-up 0 \\
\hline $\begin{array}{l}\text { Selective reporting (re- } \\
\text { porting bias) }\end{array}$ & Low risk & No distinct selective outcome reporting \\
\hline $\begin{array}{l}\text { Blinding of participants } \\
\text { and personnel (perfor- } \\
\text { mance bias) } \\
\text { All outcomes }\end{array}$ & Low risk & Double blind study \\
\hline $\begin{array}{l}\text { Blinding of outcome as- } \\
\text { sessment (detection bias) } \\
\text { All outcomes }\end{array}$ & Low risk & Double blind study \\
\hline
\end{tabular}

\section{Davrath 1999}

\begin{tabular}{ll}
\hline Methods & SB \\
& CO \\
\hline Participants & N 8 \\
& Norm \\
& Age 25 \\
\hline Interventions & SR 95 \\
& Dur 5 \\
\hline Outcomes & SBP \\
& DBP \\
& Renin \\
NA \\
A
\end{tabular}

\section{Risk of bias}

Bias Authors' judgement Support for judgement


1149 Davrath 1999 (Continued)

\begin{tabular}{lll}
$\begin{array}{l}\text { Random sequence genera- } \\
\text { tion (selection bias) }\end{array}$ & Unclear risk & Insufficient information \\
\hline $\begin{array}{l}\text { Allocation concealment } \\
\text { (selection bias) }\end{array}$ & Unclear risk & Insufficient information \\
\hline $\begin{array}{l}\text { Blinding (performance } \\
\text { bias and detection bias) } \\
\text { All outcomes }\end{array}$ & High risk & Open study \\
\hline
\end{tabular}

\begin{tabular}{|c|c|c|}
\hline $\begin{array}{l}\text { Incomplete outcome data } \\
\text { (attrition bias) } \\
\text { All outcomes }\end{array}$ & Low risk & Lost to follow-up 0 \\
\hline $\begin{array}{l}\text { Selective reporting (re- } \\
\text { porting bias) }\end{array}$ & Low risk & No distinct selective outcome reporting \\
\hline $\begin{array}{l}\text { Blinding of participants } \\
\text { and personnel (perfor- } \\
\text { mance bias) } \\
\text { All outcomes }\end{array}$ & High risk & $\begin{array}{l}\text { Open study: Performance bias due to knowledge of the allocated interventions } \\
\text { by participants and personnel during the study }\end{array}$ \\
\hline $\begin{array}{l}\text { Blinding of outcome as- } \\
\text { sessment (detection bias) } \\
\text { All outcomes }\end{array}$ & Low risk & Outcome detection blinded \\
\hline
\end{tabular}

\section{Schorr 1999}

\begin{tabular}{ll}
\hline Methods & SB \\
& CO \\
\hline Participants & $\begin{array}{l}\text { N } 187 \text { (M/F:187/0)(B/W/A.0/187/0) } \\
\text { Age 25 }\end{array}$ \\
\hline Interventions & SR $206(225-19)$ \\
& Dur 7 \\
\hline Outcomes & SBP, DBP, renin, aldo \\
\hline Notes & LoFo: 13.187 of 200 completed study. IT: No.
\end{tabular}

\section{Risk of bias}

\begin{tabular}{lll}
\hline Bias & Authors' judgement & Support for judgement \\
\hline $\begin{array}{l}\text { Random sequence genera- } \\
\text { tion (selection bias) }\end{array}$ & Unclear risk & Insufficient information \\
\hline $\begin{array}{l}\text { Allocation concealment } \\
\text { (selection bias) }\end{array}$ & Unclear risk & Insufficient information \\
\hline $\begin{array}{l}\text { Blinding (performance } \\
\text { bias and detection bias) } \\
\text { All outcomes }\end{array}$ & High risk & Open study \\
\hline
\end{tabular}

Effects of low sodium diet versus high sodium diet on blood pressure, renin, aldosterone, catecholamines, cholesterol, and triglyceride 
1150 Schorr 1999 (Continued)
Incomplete outcome data
Low risk
Lost to follow up $13 / 200$
(attrition bias)

All outcomes

Selective reporting (re- Low risk No distinct selective outcome reporting
porting bias)

\begin{tabular}{|c|c|c|}
\hline $\begin{array}{l}\text { Blinding of participants } \\
\text { and personnel (perfor- } \\
\text { mance bias) } \\
\text { All outcomes }\end{array}$ & High risk & $\begin{array}{l}\text { Open study: Performance bias due to knowledge of the allocated interventions } \\
\text { by participants and personnel during the study }\end{array}$ \\
\hline
\end{tabular}

\begin{tabular}{ll}
\hline Blinding of outcome as- & Low risk \\
sessment (detection bias) & \\
All outcomes & \\
\hline
\end{tabular}

\section{Uzu 1999}

\begin{tabular}{ll}
\hline Methods & SB \\
& CO \\
\hline Participants & $\begin{array}{l}\text { N70 (Japanese) } \\
\text { Hyp } \\
\text { Age50 }\end{array}$ \\
\hline Interventions & SR173 (204-31) \\
\hline Outcomes & SBP \\
\hline Notes & LBP \\
\hline
\end{tabular}

\section{Risk of bias}

\begin{tabular}{|c|c|c|}
\hline Bias & Authors' judgement & Support for judgement \\
\hline $\begin{array}{l}\text { Random sequence genera- } \\
\text { tion (selection bias) }\end{array}$ & Unclear risk & Insufficient information \\
\hline $\begin{array}{l}\text { Allocation concealment } \\
\text { (selection bias) }\end{array}$ & Unclear risk & Insufficient information \\
\hline $\begin{array}{l}\text { Blinding (performance } \\
\text { bias and detection bias) } \\
\text { All outcomes }\end{array}$ & High risk & Open study \\
\hline $\begin{array}{l}\text { Incomplete outcome data } \\
\text { (attrition bias) } \\
\text { All outcomes }\end{array}$ & Low risk & Lost to follow-up 0 \\
\hline $\begin{array}{l}\text { Selective reporting (re- } \\
\text { porting bias) }\end{array}$ & Low risk & No distinct selective outcome reporting \\
\hline
\end{tabular}




\section{Uzu 1999 (Continued)}

Blinding of participants and personnel (performance bias)

All outcomes
Open study: Performance bias due to knowledge of the allocated interventions by participants and personnel during the study

Blinding of outcome as- Low risk

Outcome detection blinded

sessment (detection bias)

All outcomes

\section{Chiolero 2000}

\begin{tabular}{ll}
\hline Methods & Op \\
& CO
\end{tabular}

\begin{tabular}{|c|c|}
\hline Participants & $\begin{array}{l}\text { N Hyp: } 38 \text { (M/F:21/17); Norm: } 12 \text { (M/F:6/6) (B/W/A.0/50/0) } \\
\text { Hypertension and normotension } \\
\text { Age } 43 \text { and } 40\end{array}$ \\
\hline Interventions & $\begin{array}{l}\text { SR } 183(255-72) \text { and } 201 \text { (265-64) } \\
\text { Dur } 7\end{array}$ \\
\hline Outcomes & SBP, DBP, renin, aldo \\
\hline Notes & LoFo: 5.38 of 43 and 12 of 12 completed study. IT: No \\
\hline
\end{tabular}

\section{Risk of bias}

\begin{tabular}{|c|c|c|}
\hline Bias & Authors' judgement & Support for judgement \\
\hline $\begin{array}{l}\text { Random sequence genera- } \\
\text { tion (selection bias) }\end{array}$ & Unclear risk & Insufficient information \\
\hline $\begin{array}{l}\text { Allocation concealment } \\
\text { (selection bias) }\end{array}$ & Unclear risk & Insufficient information \\
\hline $\begin{array}{l}\text { Blinding (performance } \\
\text { bias and detection bias) } \\
\text { All outcomes }\end{array}$ & High risk & Open study \\
\hline $\begin{array}{l}\text { Incomplete outcome data } \\
\text { (attrition bias) } \\
\text { All outcomes }\end{array}$ & Low risk & Lost to follow up 5/43 (Hyp) and 0/12 (Norm) \\
\hline $\begin{array}{l}\text { Selective reporting (re- } \\
\text { porting bias) }\end{array}$ & Low risk & No distinct selective outcome reporting \\
\hline $\begin{array}{l}\text { Blinding of participants } \\
\text { and personnel (perfor- } \\
\text { mance bias) } \\
\text { All outcomes }\end{array}$ & High risk & $\begin{array}{l}\text { Open study: Performance bias due to knowledge of the allocated interventions } \\
\text { by participants and personnel during the study. }\end{array}$ \\
\hline $\begin{array}{l}\text { Blinding of outcome as- } \\
\text { sessment (detection bias) } \\
\text { All outcomes }\end{array}$ & High risk & $\begin{array}{l}\text { Open study: Detection bias due to knowledge of the allocated interventions by } \\
\text { outcome assessors }\end{array}$ \\
\hline
\end{tabular}

Effects of low sodium diet versus high sodium diet on blood pressure, renin, aldosterone, catecholamines, cholesterol, and triglyceride 
1153 Bruun 2000

\begin{tabular}{ll}
\hline Methods & Op \\
& CO \\
\hline Participants & $\begin{array}{l}\text { N } 42 \text { (M/F:34/8)(B/W/A.0/42/0) } \\
\text { Normotension }\end{array}$ \\
& Age 26 \\
\hline Interventions & SR 237 (273-36) \\
\hline Outcomes & SBP, DBP, renin, aldo, NE, E, chol, HDL, LDL, Trig \\
\hline Notes & LoFo: 0
\end{tabular}

\section{Risk of bias}

\begin{tabular}{|c|c|c|}
\hline Bias & Authors' judgement & Support for judgement \\
\hline $\begin{array}{l}\text { Random sequence genera- } \\
\text { tion (selection bias) }\end{array}$ & Unclear risk & Insufficient information \\
\hline $\begin{array}{l}\text { Allocation concealment } \\
\text { (selection bias) }\end{array}$ & Unclear risk & Insufficient information \\
\hline $\begin{array}{l}\text { Blinding (performance } \\
\text { bias and detection bias) } \\
\text { All outcomes }\end{array}$ & High risk & Open study \\
\hline $\begin{array}{l}\text { Incomplete outcome data } \\
\text { (attrition bias) } \\
\text { All outcomes }\end{array}$ & Low risk & Lost to follow-up 0 \\
\hline $\begin{array}{l}\text { Selective reporting (re- } \\
\text { porting bias) }\end{array}$ & Low risk & No distinct selective outcome reporting \\
\hline $\begin{array}{l}\text { Blinding of participants } \\
\text { and personnel (perfor- } \\
\text { mance bias) } \\
\text { All outcomes }\end{array}$ & High risk & $\begin{array}{l}\text { Open study: Performance bias due to knowledge of the allocated interventions } \\
\text { by participants and personnel during the study. }\end{array}$ \\
\hline $\begin{array}{l}\text { Blinding of outcome as- } \\
\text { sessment (detection bias) } \\
\text { All outcomes }\end{array}$ & High risk & $\begin{array}{l}\text { Open study: Detection bias due to knowledge of the allocated interventions by } \\
\text { outcome assessors }\end{array}$ \\
\hline
\end{tabular}

1154 Burnier 2000

\begin{tabular}{ll}
\hline Methods & Op \\
& CO \\
\hline Participants & $\begin{array}{l}\text { N } 15 \text { (M/F:15/0)(B/W/A.0/15/0) } \\
\text { Hypertension and normotension } \\
\text { Age } 22.7\end{array}$ \\
\hline Interventions & SR $131(144-13)$ \\
\hline
\end{tabular}

Effects of low sodium diet versus high sodium diet on blood pressure, renin, aldosterone, catecholamines, cholesterol, and triglyceride 
1154 Burnier 2000 (Continued)

$$
\text { Dur } 7
$$

\begin{tabular}{ll}
\hline Outcomes & SBP, DBP, renin, aldo, NE, E \\
\hline
\end{tabular}

Notes LoFo: 0

\section{Risk of bias}

\begin{tabular}{|c|c|c|}
\hline Bias & Authors' judgement & Support for judgement \\
\hline $\begin{array}{l}\text { Random sequence genera- } \\
\text { tion (selection bias) }\end{array}$ & Unclear risk & Insufficient information \\
\hline $\begin{array}{l}\text { Allocation concealment } \\
\text { (selection bias) }\end{array}$ & Unclear risk & Insufficient information \\
\hline $\begin{array}{l}\text { Blinding (performance } \\
\text { bias and detection bias) } \\
\text { All outcomes }\end{array}$ & High risk & Open study \\
\hline $\begin{array}{l}\text { Incomplete outcome data } \\
\text { (attrition bias) } \\
\text { All outcomes }\end{array}$ & Low risk & Lost to follow-up 0 \\
\hline $\begin{array}{l}\text { Selective reporting (re- } \\
\text { porting bias) }\end{array}$ & Low risk & No distinct selective outcome reporting \\
\hline $\begin{array}{l}\text { Blinding of participants } \\
\text { and personnel (perfor- } \\
\text { mance bias) } \\
\text { All outcomes }\end{array}$ & High risk & $\begin{array}{l}\text { Open study: Performance bias due to knowledge of the allocated interventions } \\
\text { by participants and personnel during the study. }\end{array}$ \\
\hline $\begin{array}{l}\text { Blinding of outcome as- } \\
\text { sessment (detection bias) } \\
\text { All outcomes }\end{array}$ & High risk & $\begin{array}{l}\text { Open study: Detection bias due to knowledge of the allocated interventions by } \\
\text { outcome assessors }\end{array}$ \\
\hline
\end{tabular}

\section{Heer 2000}

\begin{tabular}{ll}
\hline Methods & Op \\
& CO \\
\hline Participants & $\begin{array}{l}\text { N } 32 \text { (M/F:32/0)(B/W/A.0/32/0) } \\
\text { Age 25 }\end{array}$ \\
\hline Interventions & SR139 (226-87) \\
& Dur 7 \\
\hline Outcomes & SBP, DBP, renin, aldo \\
\hline Notes & LoFo: 0 \\
\hline
\end{tabular}

\section{Risk of bias}

Bias Authors' judgement Support for judgement

Effects of low sodium diet versus high sodium diet on blood pressure, renin, aldosterone, catecholamines, cholesterol, and triglyceride 
1155 Heer 2000 (Continued)

\begin{tabular}{lll}
$\begin{array}{l}\text { Random sequence genera- } \\
\text { tion (selection bias) }\end{array}$ & Unclear risk & Insufficient information \\
\hline $\begin{array}{l}\text { Allocation concealment } \\
\text { (selection bias) }\end{array}$ & Unclear risk & Insufficient information \\
\hline $\begin{array}{l}\text { Blinding (performance } \\
\text { bias and detection bias) } \\
\text { All outcomes }\end{array}$ & High risk & Open study \\
\hline
\end{tabular}

\begin{tabular}{lll}
\hline $\begin{array}{l}\text { Incomplete outcome data } \\
\text { (attrition bias) } \\
\text { All outcomes }\end{array}$ & Low risk & Lost to follow-up 0 \\
\hline $\begin{array}{l}\text { Selective reporting (re- } \\
\text { porting bias) }\end{array}$ & Low risk & No distinct selective outcome reporting \\
\hline $\begin{array}{l}\text { Blinding of participants } \\
\begin{array}{l}\text { and personnel (perfor- } \\
\text { mance bias) }\end{array}\end{array}$ & High risk & $\begin{array}{l}\text { Open study: Performance bias due to knowledge of the allocated interventions } \\
\text { bll outcomes }\end{array}$ \\
\hline $\begin{array}{l}\text { Blinding of outcome as- } \\
\text { sessment (detection bias) } \\
\text { All outcomes }\end{array}$ & High risk & $\begin{array}{l}\text { Open study: Detection bias due to knowledge of the allocated interventions by } \\
\text { outcome assessors }\end{array}$ \\
\hline
\end{tabular}

\section{Barba 2000}

\begin{tabular}{ll}
\hline Methods & DB \\
CO \\
\hline Participants & $\begin{array}{l}\text { N } 7 \text { (M/F:7/0)(B/W/A.0/7/0) } \\
\text { Normotension } \\
\text { Age 32 }\end{array}$ \\
\hline Interventions & SR 154 (177-23) \\
\hline Dur 7 \\
\hline Notes & MAP \\
\hline
\end{tabular}

\section{Risk of bias}

\begin{tabular}{lll}
\hline Bias & Authors' judgement & Support for judgement \\
\hline $\begin{array}{l}\text { Random sequence genera- } \\
\text { tion (selection bias) }\end{array}$ & Unclear risk & Insufficient information \\
\hline $\begin{array}{l}\text { Allocation concealment } \\
\text { (selection bias) }\end{array}$ & Unclear risk & Insufficient information \\
\hline $\begin{array}{l}\text { Blinding (performance } \\
\text { bias and detection bias) } \\
\text { All outcomes }\end{array}$ & Low risk & Double blind study \\
\hline
\end{tabular}

Effects of low sodium diet versus high sodium diet on blood pressure, renin, aldosterone, catecholamines, cholesterol, and triglyceride 
1156 Barba 2000 (Continued)

Incomplete outcome data Low risk $\quad$ Lost to follow-up 0
(attrition bias)

All outcomes

Selective reporting (re- Unclear risk Insufficient information
porting bias)

\begin{tabular}{lll}
\hline $\begin{array}{l}\text { Blinding of participants } \\
\text { and personnel (perfor- }\end{array}$ & Low risk & \\
mance bias) & & \\
All outcomes & & \\
\hline $\begin{array}{l}\text { Blinding of outcome as- } \\
\text { sessment (detection bias) }\end{array}$ & Low risk & Double blind study \\
All outcomes & \\
\hline
\end{tabular}

\section{Boero 2000}

\begin{tabular}{ll}
\hline Methods & Op \\
CO
\end{tabular}

\section{Risk of bias}

\begin{tabular}{|c|c|c|}
\hline Bias & Authors' judgement & Support for judgement \\
\hline $\begin{array}{l}\text { Random sequence genera- } \\
\text { tion (selection bias) }\end{array}$ & Unclear risk & Insufficient information \\
\hline $\begin{array}{l}\text { Allocation concealment } \\
\text { (selection bias) }\end{array}$ & Unclear risk & Insufficient information \\
\hline $\begin{array}{l}\text { Blinding (performance } \\
\text { bias and detection bias) } \\
\text { All outcomes }\end{array}$ & High risk & Open study \\
\hline $\begin{array}{l}\text { Incomplete outcome data } \\
\text { (attrition bias) } \\
\text { All outcomes }\end{array}$ & Low risk & Lost to follow-up 0 \\
\hline $\begin{array}{l}\text { Selective reporting (re- } \\
\text { porting bias) }\end{array}$ & Low risk & No distinct selective outcome reporting \\
\hline $\begin{array}{l}\text { Blinding of participants } \\
\text { and personnel (perfor- } \\
\text { mance bias) }\end{array}$ & High risk & $\begin{array}{l}\text { Open study: Performance bias due to knowledge of the allocated interventions } \\
\text { by participants and personnel during the study }\end{array}$ \\
\hline
\end{tabular}

Effects of low sodium diet versus high sodium diet on blood pressure, renin, aldosterone, catecholamines, cholesterol, and triglyceride 
1157 Boero 2000 (Continued)

All outcomes

Blinding of outcome as-
sessment (detection bias) $\quad$ Unclear risk Insufficient information

All outcomes

\section{Suzuki 2000}

$\begin{array}{ll}\text { Methods } & \text { Op } \\ & \text { CO }\end{array}$

\begin{tabular}{ll}
\hline Participants & $\begin{array}{l}\text { N } 20(\mathrm{M} / \mathrm{F}: 9 / 11)(\mathrm{B} / \mathrm{W} / \mathrm{A} .0 / 0 / 20) \\
\text { Hypertension } \\
\text { Age } 59\end{array}$ \\
\hline Interventions & SR $116(167-51)$ \\
& Dur 7 \\
\hline Outcomes & nocturnal MAP, NE and E \\
\hline Notes & LoFo:0 \\
\hline
\end{tabular}

\section{Risk of bias}

\begin{tabular}{|c|c|c|}
\hline Bias & Authors' judgement & Support for judgement \\
\hline $\begin{array}{l}\text { Random sequence genera- } \\
\text { tion (selection bias) }\end{array}$ & Unclear risk & Insufficient information \\
\hline $\begin{array}{l}\text { Allocation concealment } \\
\text { (selection bias) }\end{array}$ & Unclear risk & Insufficient information \\
\hline $\begin{array}{l}\text { Blinding (performance } \\
\text { bias and detection bias) } \\
\text { All outcomes }\end{array}$ & High risk & Open study \\
\hline $\begin{array}{l}\text { Incomplete outcome data } \\
\text { (attrition bias) } \\
\text { All outcomes }\end{array}$ & Low risk & Lost to follow-up 0 \\
\hline $\begin{array}{l}\text { Selective reporting (re- } \\
\text { porting bias) }\end{array}$ & Low risk & No distinct selective outcome reporting \\
\hline $\begin{array}{l}\text { Blinding of participants } \\
\text { and personnel (perfor- } \\
\text { mance bias) } \\
\text { All outcomes }\end{array}$ & High risk & $\begin{array}{l}\text { Open study: Performance bias due to knowledge of the allocated interventions } \\
\text { by participants and personnel during the study. }\end{array}$ \\
\hline $\begin{array}{l}\text { Blinding of outcome as- } \\
\text { sessment (detection bias) } \\
\text { All outcomes }\end{array}$ & High risk & $\begin{array}{l}\text { Open study: Detection bias due to knowledge of the allocated interventions by } \\
\text { outcome assessors }\end{array}$ \\
\hline
\end{tabular}


1159 Ames 2001

\begin{tabular}{ll}
\hline Methods & SB \\
& CO \\
\hline Participants & $13(\mathrm{M} / \mathrm{F}: 6 / 7)$ \\
& Hyp 60 \\
\hline Interventions & SR $133(265-132)$ \\
& Dur 28 \\
\hline Outcomes & SBP \\
& DBP \\
& NA \\
& A \\
TG: \\
Chol: \\
HDL: \\
LDL: \\
\hline 21 patients included \\
8diabetes patients excluded \\
LoFo: 0 \\
\hline
\end{tabular}

\section{Risk of bias}

\begin{tabular}{|c|c|c|}
\hline Bias & Authors' judgement & Support for judgement \\
\hline $\begin{array}{l}\text { Random sequence genera- } \\
\text { tion (selection bias) }\end{array}$ & Unclear risk & Insufficient information \\
\hline $\begin{array}{l}\text { Allocation concealment } \\
\text { (selection bias) }\end{array}$ & Unclear risk & Insufficient information \\
\hline $\begin{array}{l}\text { Blinding (performance } \\
\text { bias and detection bias) } \\
\text { All outcomes }\end{array}$ & High risk & Single blind study \\
\hline $\begin{array}{l}\text { Incomplete outcome data } \\
\text { (attrition bias) } \\
\text { All outcomes }\end{array}$ & Low risk & Lost to follow-up 0 \\
\hline $\begin{array}{l}\text { Selective reporting (re- } \\
\text { porting bias) }\end{array}$ & Unclear risk & Insufficient information \\
\hline $\begin{array}{l}\text { Blinding of participants } \\
\text { and personnel (perfor- } \\
\text { mance bias) } \\
\text { All outcomes }\end{array}$ & High risk & $\begin{array}{l}\text { Open study: Performance bias due to knowledge of the allocated interventions } \\
\text { by participants and personnel during the study }\end{array}$ \\
\hline $\begin{array}{l}\text { Blinding of outcome as- } \\
\text { sessment (detection bias) } \\
\text { All outcomes }\end{array}$ & Low risk & Outcome detection blinded \\
\hline
\end{tabular}

\section{DASH $2001 \mathrm{~W}$}

Methods DB

Effects of low sodium diet versus high sodium diet on blood pressure, renin, aldosterone, catecholamines, cholesterol, and triglyceride 
1160 DASH 2001 W (Continued)

$\mathrm{CO}$

\begin{tabular}{ll}
\hline Participants & N54 \\
& Norm \\
& Non-black \\
& Age 48 \\
\hline Interventions & SR55 \\
& Dur30 \\
\hline Outcomes & SBP \\
& DBP not mentioned, see DASH 2 \\
\hline Notes & LoFo: $5 \%$ \\
& IT: No \\
\hline
\end{tabular}

\section{Risk of bias}

\begin{tabular}{|c|c|c|}
\hline Bias & Authors' judgement & Support for judgement \\
\hline $\begin{array}{l}\text { Random sequence genera- } \\
\text { tion (selection bias) }\end{array}$ & Unclear risk & Insufficient information \\
\hline $\begin{array}{l}\text { Allocation concealment } \\
\text { (selection bias) }\end{array}$ & Unclear risk & Insufficient information \\
\hline $\begin{array}{l}\text { Blinding (performance } \\
\text { bias and detection bias) } \\
\text { All outcomes }\end{array}$ & High risk & Open study \\
\hline $\begin{array}{l}\text { Incomplete outcome data } \\
\text { (attrition bias) } \\
\text { All outcomes }\end{array}$ & Low risk & Lost to follow up $5 \%$ \\
\hline $\begin{array}{l}\text { Selective reporting (re- } \\
\text { porting bias) }\end{array}$ & Low risk & No distinct selective outcome reporting \\
\hline $\begin{array}{l}\text { Blinding of participants } \\
\text { and personnel (perfor- } \\
\text { mance bias) } \\
\text { All outcomes }\end{array}$ & High risk & $\begin{array}{l}\text { Performance bias due to knowledge of the allocated interventions by partici- } \\
\text { pants and personnel during the study }\end{array}$ \\
\hline $\begin{array}{l}\text { Blinding of outcome as- } \\
\text { sessment (detection bias) } \\
\text { All outcomes }\end{array}$ & Low risk & $\begin{array}{l}\text { The personnel involved in the collection of the outcome data were unaware of } \\
\text { participants diet assignment }\end{array}$ \\
\hline
\end{tabular}

\section{DASH 2001 WH}

\begin{tabular}{ll}
\hline Methods & DB \\
& CO \\
\hline Participants & N37 \\
& Hyp \\
& Non-black \\
& Age 48 \\
\hline
\end{tabular}


1161 DASH 2001 WH (Continued)

$\begin{array}{ll}\text { Interventions } & \text { SR } 55 \\ & \text { Dur } 30\end{array}$

Outcomes SBP

DBP not mentioned, see DASH $2 b$

\begin{tabular}{ll}
\hline Notes & LoFo: $5 \%$ \\
& IT: No
\end{tabular}

\section{Risk of bias}

\begin{tabular}{|c|c|c|}
\hline Bias & Authors' judgement & Support for judgement \\
\hline $\begin{array}{l}\text { Random sequence genera- } \\
\text { tion (selection bias) }\end{array}$ & Unclear risk & Insufficient information \\
\hline $\begin{array}{l}\text { Allocation concealment } \\
\text { (selection bias) }\end{array}$ & Unclear risk & Insufficient information \\
\hline $\begin{array}{l}\text { Blinding (performance } \\
\text { bias and detection bias) } \\
\text { All outcomes }\end{array}$ & High risk & Open study \\
\hline $\begin{array}{l}\text { Incomplete outcome data } \\
\text { (attrition bias) } \\
\text { All outcomes }\end{array}$ & Low risk & Lost to follow up $5 \%$ \\
\hline $\begin{array}{l}\text { Selective reporting (re- } \\
\text { porting bias) }\end{array}$ & Low risk & No distinct selective outcome reporting \\
\hline $\begin{array}{l}\text { Blinding of participants } \\
\text { and personnel (perfor- } \\
\text { mance bias) } \\
\text { All outcomes }\end{array}$ & High risk & $\begin{array}{l}\text { Performance bias due to knowledge of the allocated interventions by partici- } \\
\text { pants and personnel during the study }\end{array}$ \\
\hline $\begin{array}{l}\text { Blinding of outcome as- } \\
\text { sessment (detection bias) } \\
\text { All outcomes }\end{array}$ & Low risk & $\begin{array}{l}\text { The personnel involved in the collection of the outcome data were unaware of } \\
\text { participants diet assignment }\end{array}$ \\
\hline
\end{tabular}

\section{DASH 2001 B}

\begin{tabular}{ll}
\hline Methods & DB \\
& CO \\
\hline Participants & N68 \\
& Norm \\
& Alack 48 \\
\hline Interventions & SR55 \\
& Dur30 \\
\hline Outcomes & SBP \\
& DBP not mentioned, see DASH 2C \\
\hline Notes & LoFo: $5 \%$
\end{tabular}

Effects of low sodium diet versus high sodium diet on blood pressure, renin, aldosterone, catecholamines, cholesterol, and triglyceride 
1162 DASH 2001 B (Continued)

$$
\text { IT: No }
$$

\section{Risk of bias}

\begin{tabular}{|c|c|c|}
\hline Bias & Authors' judgement & Support for judgement \\
\hline $\begin{array}{l}\text { Random sequence genera- } \\
\text { tion (selection bias) }\end{array}$ & Unclear risk & Insufficient information \\
\hline $\begin{array}{l}\text { Allocation concealment } \\
\text { (selection bias) }\end{array}$ & Unclear risk & Insufficient information \\
\hline $\begin{array}{l}\text { Blinding (performance } \\
\text { bias and detection bias) } \\
\text { All outcomes }\end{array}$ & High risk & Open study \\
\hline $\begin{array}{l}\text { Incomplete outcome data } \\
\text { (attrition bias) } \\
\text { All outcomes }\end{array}$ & Low risk & Lost to follow up 5\% \\
\hline $\begin{array}{l}\text { Selective reporting (re- } \\
\text { porting bias) }\end{array}$ & Low risk & No distinct selective outcome reporting \\
\hline $\begin{array}{l}\text { Blinding of participants } \\
\text { and personnel (perfor- } \\
\text { mance bias) } \\
\text { All outcomes }\end{array}$ & High risk & $\begin{array}{l}\text { Performance bias due to knowledge of the allocated interventions by partici- } \\
\text { pants and personnel during the study }\end{array}$ \\
\hline $\begin{array}{l}\text { Blinding of outcome as- } \\
\text { sessment (detection bias) } \\
\text { All outcomes }\end{array}$ & Low risk & $\begin{array}{l}\text { The personnel involved in the collection of the outcome data were unaware of } \\
\text { participants diet assignment }\end{array}$ \\
\hline
\end{tabular}

\section{DASH 2001 BH}

\begin{tabular}{ll}
\hline Methods & DB \\
& CO \\
\hline Participants & N46 \\
& Hyp \\
& Alack 48 \\
\hline Interventions & SR 55 \\
& Dur 30 \\
\hline Outcomes & SBP \\
& DBP not mentioned, see DASH 2d \\
\hline Notes & LoFo: $5 \%$ \\
\hline
\end{tabular}

\section{Risk of bias}

Bias Authors' judgement Support for judgement


1163 DASH 2001 BH (Continued)

\begin{tabular}{lll}
$\begin{array}{l}\text { Random sequence genera- } \\
\text { tion (selection bias) }\end{array}$ & Unclear risk & Insufficient information \\
\hline $\begin{array}{l}\text { Allocation concealment } \\
\text { (selection bias) }\end{array}$ & Unclear risk & Insufficient information \\
\hline $\begin{array}{l}\text { Blinding (performance } \\
\text { bias and detection bias) } \\
\text { All outcomes }\end{array}$ & High risk & Open study \\
\hline
\end{tabular}

\begin{tabular}{lll}
\hline $\begin{array}{l}\text { Incomplete outcome data } \\
\text { (attrition bias) } \\
\text { All outcomes }\end{array}$ & Low risk & Lost to follow up 5\% \\
\hline $\begin{array}{l}\text { Selective reporting (re- } \\
\text { porting bias) }\end{array}$ & Low risk & No distinct selective outcome reporting \\
\hline $\begin{array}{l}\text { Blinding of participants } \\
\begin{array}{l}\text { and personnel (perfor- } \\
\text { mance bias) }\end{array}\end{array}$ & High risk & Performance bias due to knowledge of the allocated interventions by partici- \\
$\begin{array}{l}\text { All outcomes } \\
\text { pants and personnel during the study }\end{array}$ \\
\hline $\begin{array}{l}\text { Blinding of outcome as- } \\
\text { sessment (detection bias) } \\
\text { All outcomes }\end{array}$ & Low risk & $\begin{array}{l}\text { The personnel involved in the collection of the outcome data were unaware of } \\
\text { participants diet assignment }\end{array}$ \\
\hline
\end{tabular}

\section{Cuzzola 2001}

\begin{tabular}{|c|c|c|}
\hline Methods & $\begin{array}{l}\mathrm{DB} \\
\mathrm{CO}\end{array}$ & \\
\hline Participants & $\begin{array}{l}\text { N } 19 \\
\text { Hyp } \\
\text { Age } 47\end{array}$ & \\
\hline Interventions & $\begin{array}{l}\text { SR } 161 \\
\text { Dur: } 14\end{array}$ & \\
\hline Outcomes & $\begin{array}{l}\text { SBP } \\
\text { DBP } \\
\text { Aldo } \\
\text { Renin }\end{array}$ & \\
\hline Notes & Data available in pati & ts in upper tertile of sodium excretion (19 of 55 patients) \\
\hline \multicolumn{3}{|l|}{ Risk of bias } \\
\hline Bias & Authors' judgement & Support for judgement \\
\hline $\begin{array}{l}\text { Random sequence genera- } \\
\text { tion (selection bias) }\end{array}$ & Unclear risk & Insufficient information \\
\hline $\begin{array}{l}\text { Allocation concealment } \\
\text { (selection bias) }\end{array}$ & Unclear risk & Insufficient information \\
\hline
\end{tabular}

Effects of low sodium diet versus high sodium diet on blood pressure, renin, aldosterone, catecholamines, cholesterol, and triglyceride 
1168 Cuzzola 2001 (Continued)
Blinding (performance
Low risk
Double blind study
bias and detection bias)

All outcomes

\begin{tabular}{|c|c|c|}
\hline $\begin{array}{l}\text { Incomplete outcome data } \\
\text { (attrition bias) } \\
\text { All outcomes }\end{array}$ & High risk & $\begin{array}{l}\text { Data available in patients in upper tertile of sodium excretion (19 of } 55 \text { pa- } \\
\text { tients) }\end{array}$ \\
\hline $\begin{array}{l}\text { Selective reporting (re- } \\
\text { porting bias) }\end{array}$ & High risk & Only BP data for the upper sodium reduction tertile was reported \\
\hline $\begin{array}{l}\text { Blinding of participants } \\
\text { and personnel (perfor- } \\
\text { mance bias) } \\
\text { All outcomes }\end{array}$ & Low risk & Double blind study \\
\hline $\begin{array}{l}\text { Blinding of outcome as- } \\
\text { sessment (detection bias) } \\
\text { All outcomes }\end{array}$ & Low risk & Double blind study \\
\hline
\end{tabular}

\section{Seals 2001}

\begin{tabular}{|c|c|c|}
\hline Methods & \multicolumn{2}{|l|}{$\begin{array}{l}\text { Op } \\
\text { P }\end{array}$} \\
\hline Participants & \multicolumn{2}{|c|}{$\begin{array}{l}\text { N } 35 \text { (M/F:0/35)(B/W/A.0/34/1) } \\
\text { Hypertension } \\
\text { Age } 64\end{array}$} \\
\hline Interventions & \multicolumn{2}{|l|}{$\begin{array}{l}\text { SR } 46(132-86) \\
\text { Dur } 90\end{array}$} \\
\hline Outcomes & \multicolumn{2}{|c|}{ SBP, DBP, Chol, HDL, LDL, Trig } \\
\hline Notes & \multicolumn{2}{|c|}{ LoFo: 4.35 of 39 completed the study. IT: No } \\
\hline \multicolumn{3}{|l|}{ Risk of bias } \\
\hline Bias & Authors' judgement & Support for judgement \\
\hline $\begin{array}{l}\text { Random sequence genera- } \\
\text { tion (selection bias) }\end{array}$ & Unclear risk & Insufficient information \\
\hline $\begin{array}{l}\text { Allocation concealment } \\
\text { (selection bias) }\end{array}$ & Unclear risk & Insufficient information \\
\hline $\begin{array}{l}\text { Blinding (performance } \\
\text { bias and detection bias) } \\
\text { All outcomes }\end{array}$ & High risk & Open study \\
\hline $\begin{array}{l}\text { Incomplete outcome data } \\
\text { (attrition bias) } \\
\text { All outcomes }\end{array}$ & Low risk & Lost to follow up LS: $1 / 18 ;$ US: $3 / 21$ \\
\hline
\end{tabular}

Effects of low sodium diet versus high sodium diet on blood pressure, renin, aldosterone, catecholamines, cholesterol, and triglyceride 
1169 Seals 2001 (Continued)

Selective reporting (re- Low risk No distinct selective outcome reporting
porting bias)

Blinding of participants

High risk

Open study: Performance bias due to knowledge of the allocated interventions and personnel (perforby participants and personnel during the study.

mance bias)

All outcomes

\section{Blinding of outcome as- High risk} sessment (detection bias)

All outcomes

Open study: Detection bias due to knowledge of the allocated interventions by outcome assessors

\section{TONE $2001 \mathrm{~W}$}

\begin{tabular}{ll}
\hline Methods & SB \\
& $P$ \\
\hline Participants & $\begin{array}{l}\text { N 471 } \\
\text { (non-blacks) } \\
\text { Hyp } \\
\text { Age 66 }\end{array}$ \\
\hline Interventions & SR 40 \\
& DUR: 105 \\
\hline Outcomes & SBP \\
& DBP \\
\hline Notes & 2001 + 2001b \\
included 681 (LS: 340; US: 341) & Attended last visit: LS 310; US: 314 \\
& IT: No \\
\hline
\end{tabular}

\section{Risk of bias}

\begin{tabular}{|c|c|c|}
\hline Bias & Authors' judgement & Support for judgement \\
\hline $\begin{array}{l}\text { Random sequence genera- } \\
\text { tion (selection bias) }\end{array}$ & Unclear risk & Insufficient information \\
\hline $\begin{array}{l}\text { Allocation concealment } \\
\text { (selection bias) }\end{array}$ & Unclear risk & Insufficient information \\
\hline $\begin{array}{l}\text { Blinding (performance } \\
\text { bias and detection bias) } \\
\text { All outcomes }\end{array}$ & High risk & Open study \\
\hline $\begin{array}{l}\text { Incomplete outcome data } \\
\text { (attrition bias) } \\
\text { All outcomes }\end{array}$ & Low risk & Lost to follow up 57/681. Group association unclear \\
\hline $\begin{array}{l}\text { Selective reporting (re- } \\
\text { porting bias) }\end{array}$ & Low risk & No distinct selective outcome reporting \\
\hline
\end{tabular}




\section{TONE 2001 W (Continued)}

Blinding of participants and personnel (perfor-

High risk mance bias)

All outcomes
Open study: Performance bias due to knowledge of the allocated interventions by participants and personnel during the study.

Blinding of outcome as- Low risk Outcome detection blinded

sessment (detection bias)

All outcomes

\section{TONE 2001 B}

\begin{tabular}{ll}
\hline Methods & SB \\
& $P$ \\
\hline Participants & $\begin{array}{l}\text { N } 142 \text { (blacks) } \\
\text { Hyp } 66\end{array}$ \\
& Sge 6 \\
\hline Interventions & SR 40 \\
& DUR: 105 \\
\hline Outcomes & SBP \\
& DBP \\
\hline Notes & 2001+ 2001b \\
included 681 (LS: $340 ;$ US: 341) & Attended last visit: LS 310; US: 314 \\
IT: No
\end{tabular}

\section{Risk of bias}

\begin{tabular}{|c|c|c|}
\hline Bias & Authors' judgement & Support for judgement \\
\hline $\begin{array}{l}\text { Random sequence genera- } \\
\text { tion (selection bias) }\end{array}$ & Unclear risk & Insufficient information \\
\hline $\begin{array}{l}\text { Allocation concealment } \\
\text { (selection bias) }\end{array}$ & Unclear risk & Insufficient information \\
\hline $\begin{array}{l}\text { Blinding (performance } \\
\text { bias and detection bias) } \\
\text { All outcomes }\end{array}$ & High risk & Open study \\
\hline $\begin{array}{l}\text { Incomplete outcome data } \\
\text { (attrition bias) } \\
\text { All outcomes }\end{array}$ & Low risk & Lost to follow up 57/681. Group association unclear \\
\hline $\begin{array}{l}\text { Selective reporting (re- } \\
\text { porting bias) }\end{array}$ & Low risk & No distinct selective outcome reporting \\
\hline $\begin{array}{l}\text { Blinding of participants } \\
\text { and personnel (perfor- } \\
\text { mance bias) } \\
\text { All outcomes }\end{array}$ & High risk & $\begin{array}{l}\text { Open study: Performance bias due to knowledge of the allocated interventions } \\
\text { by participants and personnel during the study. }\end{array}$ \\
\hline
\end{tabular}

Effects of low sodium diet versus high sodium diet on blood pressure, renin, aldosterone, catecholamines, cholesterol, and triglyceride 
1171 TONE 2001 B (Continued)
Blinding of outcome assessment (detection bias)

All outcomes

\section{Johnson 2001}

\begin{tabular}{ll}
\hline Methods & DB \\
& CO \\
\hline Participants & $\begin{array}{l}\text { Hypertension } \\
\text { Age } 69\end{array}$ \\
\hline Interventions & SR $73(185-112)$ \\
& Dur 14 \\
\hline Outcomes & SBP, DBP \\
\hline Notes & LoFo:6; 40 of 46 completed the study. IT: No
\end{tabular}

\section{Risk of bias}

\begin{tabular}{lll}
\hline Bias & Authors' judgement & Support for judgement \\
\hline Random sequence genera- & Unclear risk & Insufficient information
\end{tabular}

tion (selection bias)

\begin{tabular}{lll}
\hline $\begin{array}{l}\text { Allocation concealment } \\
\text { (selection bias) }\end{array}$ & Unclear risk & Sequenced treatments in Latin square design \\
\hline $\begin{array}{l}\text { Blinding (performance } \\
\text { bias and detection bias) }\end{array}$ & Low risk & Double blind study \\
All outcomes & &
\end{tabular}

\begin{tabular}{|c|c|c|}
\hline $\begin{array}{l}\text { Incomplete outcome data } \\
\text { (attrition bias) } \\
\text { All outcomes }\end{array}$ & Low risk & Lost to follow up $6 / 46$ \\
\hline $\begin{array}{l}\text { Selective reporting (re- } \\
\text { porting bias) }\end{array}$ & Low risk & No distinct selective outcome reporting \\
\hline $\begin{array}{l}\text { Blinding of participants } \\
\text { and personnel (perfor- } \\
\text { mance bias) } \\
\text { All outcomes }\end{array}$ & Low risk & Double blind study \\
\hline $\begin{array}{l}\text { Blinding of outcome as- } \\
\text { sessment (detection bias) } \\
\text { All outcomes }\end{array}$ & Low risk & Double blind study \\
\hline
\end{tabular}

1173 Manunta 2001

Methods SB

Effects of low sodium diet versus high sodium diet on blood pressure, renin, aldosterone, catecholamines, cholesterol, and triglyceride 
1173 Manunta 2001 (Continued)

$\mathrm{CO}$

\begin{tabular}{ll}
\hline Participants & N20 (M/F: 16/4) \\
& Hyp \\
& Age 48 \\
\hline Interventions & SR 110 \\
& Dur 14 \\
\hline Outcomes & Renin \\
& Aldosteron \\
\hline
\end{tabular}

Notes

138 included in acute study. 20 with SR> $100 \mathrm{mmol}$ included in 14 day study. LoFo: 0

\section{Risk of bias}

\begin{tabular}{|c|c|c|}
\hline Bias & Authors' judgement & Support for judgement \\
\hline $\begin{array}{l}\text { Random sequence genera- } \\
\text { tion (selection bias) }\end{array}$ & Unclear risk & Insufficient information \\
\hline $\begin{array}{l}\text { Allocation concealment } \\
\text { (selection bias) }\end{array}$ & Unclear risk & Insufficient information \\
\hline $\begin{array}{l}\text { Blinding (performance } \\
\text { bias and detection bias) } \\
\text { All outcomes }\end{array}$ & High risk & Open study \\
\hline $\begin{array}{l}\text { Incomplete outcome data } \\
\text { (attrition bias) } \\
\text { All outcomes }\end{array}$ & Low risk & Lost to follow up 0 \\
\hline $\begin{array}{l}\text { Selective reporting (re- } \\
\text { porting bias) }\end{array}$ & Low risk & No distinct selective outcome reporting \\
\hline $\begin{array}{l}\text { Blinding of participants } \\
\text { and personnel (perfor- } \\
\text { mance bias) } \\
\text { All outcomes }\end{array}$ & High risk & $\begin{array}{l}\text { Open study: Performance bias due to knowledge of the allocated interventions } \\
\text { by participants and personnel during the study. }\end{array}$ \\
\hline $\begin{array}{l}\text { Blinding of outcome as- } \\
\text { sessment (detection bias) } \\
\text { All outcomes }\end{array}$ & Low risk & Outcome detection blinded \\
\hline
\end{tabular}

1174 Kleij 2002

\begin{tabular}{ll}
\hline Methods & Op \\
& CO \\
\hline Participants & N 27 (M/F:20/7)(B/W/A.0/27/0) \\
& Norm \\
& Age 24.8 \\
\hline Interventions & SR $186(236-50)$ \\
& Dur 7 \\
\hline
\end{tabular}

Effects of low sodium diet versus high sodium diet on blood pressure, renin, aldosterone, catecholamines, cholesterol, and triglyceride 
1174 Kleij 2002 (Continued)

\begin{tabular}{ll} 
Outcomes & MAP \\
& Ren, Aldo \\
\hline Notes & LoFo: 0
\end{tabular}

\section{Risk of bias}

\begin{tabular}{|c|c|c|}
\hline Bias & Authors' judgement & Support for judgement \\
\hline $\begin{array}{l}\text { Random sequence genera- } \\
\text { tion (selection bias) }\end{array}$ & Unclear risk & Insufficient information \\
\hline $\begin{array}{l}\text { Allocation concealment } \\
\text { (selection bias) }\end{array}$ & Unclear risk & Insufficient information \\
\hline $\begin{array}{l}\text { Blinding (performance } \\
\text { bias and detection bias) } \\
\text { All outcomes }\end{array}$ & High risk & Open study \\
\hline $\begin{array}{l}\text { Incomplete outcome data } \\
\text { (attrition bias) } \\
\text { All outcomes }\end{array}$ & Low risk & Lost to follow-up 0 \\
\hline $\begin{array}{l}\text { Selective reporting (re- } \\
\text { porting bias) }\end{array}$ & Low risk & No distinct selective outcome reporting \\
\hline $\begin{array}{l}\text { Blinding of participants } \\
\text { and personnel (perfor- } \\
\text { mance bias) } \\
\text { All outcomes }\end{array}$ & High risk & $\begin{array}{l}\text { Open study: Performance bias due to knowledge of the allocated interventions } \\
\text { by participants and personnel during the study. }\end{array}$ \\
\hline $\begin{array}{l}\text { Blinding of outcome as- } \\
\text { sessment (detection bias) } \\
\text { All outcomes }\end{array}$ & High risk & $\begin{array}{l}\text { Open study: Detection bias due to knowledge of the allocated interventions by } \\
\text { outcome assessors }\end{array}$ \\
\hline
\end{tabular}

\section{Kerstens 2003}

\begin{tabular}{ll}
\hline Methods & Op \\
& CO \\
\hline Participants & N 28 (M/F:21/7)(B/W/A.0/28/0) \\
& Norm 24 \\
\hline Interventions & SR 202 (248-42) \\
& Dur 7 \\
\hline Outcomes & MAP \\
\hline Notes & Ren, Aldo \\
\hline
\end{tabular}

\section{Risk of bias}

\section{Bias Authors' judgement Support for judgement}

Effects of low sodium diet versus high sodium diet on blood pressure, renin, aldosterone, catecholamines, cholesterol, and triglyceride 
1175 Kerstens 2003 (Continued)

\begin{tabular}{lll}
$\begin{array}{l}\text { Random sequence genera- } \\
\text { tion (selection bias) }\end{array}$ & Unclear risk & Insufficient information \\
\hline $\begin{array}{l}\text { Allocation concealment } \\
\text { (selection bias) }\end{array}$ & Unclear risk & Insufficient information \\
\hline $\begin{array}{l}\text { Blinding (performance } \\
\text { bias and detection bias) } \\
\text { All outcomes }\end{array}$ & High risk & Open study \\
\hline
\end{tabular}

\begin{tabular}{lll}
\hline $\begin{array}{l}\text { Incomplete outcome data } \\
\text { (attrition bias) } \\
\text { All outcomes }\end{array}$ & Low risk & Lost to follow-up 0 \\
\hline $\begin{array}{l}\text { Selective reporting (re- } \\
\text { porting bias) }\end{array}$ & Low risk & No distinct selective outcome reporting \\
\hline $\begin{array}{l}\text { Blinding of participants } \\
\begin{array}{l}\text { and personnel (perfor- } \\
\text { mance bias) }\end{array}\end{array}$ & High risk & $\begin{array}{l}\text { Open study: Performance bias due to knowledge of the allocated interventions } \\
\text { bll outcomes }\end{array}$ \\
\hline $\begin{array}{l}\text { Blinding of outcome as- } \\
\text { sessment (detection bias) } \\
\text { All outcomes }\end{array}$ & High risk & $\begin{array}{l}\text { Open study: Detection bias due to knowledge of the allocated interventions by } \\
\text { outcome assessors }\end{array}$ \\
\hline
\end{tabular}

\section{Dishy 2003}

\begin{tabular}{ll}
\hline Methods & Op \\
& CO \\
\hline Participants & N 25 (2 blacks, 23 whites) \\
& $\begin{array}{l}\text { Norm } \\
\text { Mean age 34 (18-50) }\end{array}$ \\
\hline Interventions & SR 300 (321-21) \\
& Dur 6 \\
\hline Outcomes & SBP \\
& DBP \\
Renin A \\
\hline Notes & LoFo: 0
\end{tabular}

\section{Risk of bias}

Bias Authors' judgement Support for judgement

Random sequence genera- Unclear risk Insufficient information tion (selection bias)

Allocation concealment
(selection bias)

\begin{tabular}{lll}
\hline $\begin{array}{l}\text { Blinding (performance } \\
\text { bias and detection bias) }\end{array}$ & High risk & Open study
\end{tabular}

Effects of low sodium diet versus high sodium diet on blood pressure, renin, aldosterone, catecholamines, cholesterol, and triglyceride 
1176 Dishy 2003 (Continued)

All outcomes

\begin{tabular}{|c|c|c|}
\hline $\begin{array}{l}\text { Incomplete outcome data } \\
\text { (attrition bias) } \\
\text { All outcomes }\end{array}$ & Low risk & Lost to follow-up 0 \\
\hline $\begin{array}{l}\text { Selective reporting (re- } \\
\text { porting bias) }\end{array}$ & Low risk & No distinct selective outcome reporting \\
\hline $\begin{array}{l}\text { Blinding of participants } \\
\text { and personnel (perfor- } \\
\text { mance bias) } \\
\text { All outcomes }\end{array}$ & High risk & $\begin{array}{l}\text { Open study: Performance bias due to knowledge of the allocated interventions } \\
\text { by participants and personnel during the study. }\end{array}$ \\
\hline $\begin{array}{l}\text { Blinding of outcome as- } \\
\text { sessment (detection bias) } \\
\text { All outcomes }\end{array}$ & High risk & $\begin{array}{l}\text { Open study: Detection bias due to knowledge of the allocated interventions by } \\
\text { outcome assessors }\end{array}$ \\
\hline
\end{tabular}

\section{Nowson 2003}

\begin{tabular}{ll}
\hline Methods & Op \\
& CO \\
\hline Participants & $\begin{array}{l}\text { N } 108 \text { (M/F:44/64/20 dropouts)(B/W/A.0/108/0) } \\
\text { normotension } \\
\text { Age } 47\end{array}$ \\
\hline Interventions & SR 90 (140-50) \\
\hline Dur 28
\end{tabular}

\section{Risk of bias}

\begin{tabular}{|c|c|c|}
\hline Bias & Authors' judgement & Support for judgement \\
\hline $\begin{array}{l}\text { Random sequence genera- } \\
\text { tion (selection bias) }\end{array}$ & Unclear risk & Insufficient information \\
\hline $\begin{array}{l}\text { Allocation concealment } \\
\text { (selection bias) }\end{array}$ & Unclear risk & Insufficient information \\
\hline $\begin{array}{l}\text { Blinding (performance } \\
\text { bias and detection bias) } \\
\text { All outcomes }\end{array}$ & High risk & Open study \\
\hline $\begin{array}{l}\text { Incomplete outcome data } \\
\text { (attrition bias) } \\
\text { All outcomes }\end{array}$ & Low risk & Lost to follow up $20 / 128$ \\
\hline $\begin{array}{l}\text { Selective reporting (re- } \\
\text { porting bias) }\end{array}$ & Low risk & No distinct selective outcome reporting \\
\hline
\end{tabular}




\section{Nowson 2003 (Continued)}

Blinding of participants and personnel (performance bias)

All outcomes

\section{Blinding of outcome as- High risk} sessment (detection bias)

All outcomes
High risk

Open study: Performance bias due to knowledge of the allocated interventions by participants and personnel during the study.

\section{Perry 2003}

\begin{tabular}{ll}
\hline Methods & Op \\
& CO \\
\hline Participants & $\begin{array}{l}\text { N } 15 \text { (M/F:15/0)(B/W/A.0/15/0) } \\
\text { Normotension } \\
\end{array}$ \\
\hline Interventions 26 \\
\hline Outcomes & SR 105 (175-70) \\
\hline Notes & SBP, DBP, renin, aldo, NE, Chol, trig \\
\hline
\end{tabular}

\section{Risk of bias}

\begin{tabular}{|c|c|c|}
\hline Bias & Authors' judgement & Support for judgement \\
\hline $\begin{array}{l}\text { Random sequence genera- } \\
\text { tion (selection bias) }\end{array}$ & Unclear risk & Insufficient information \\
\hline $\begin{array}{l}\text { Allocation concealment } \\
\text { (selection bias) }\end{array}$ & Unclear risk & Insufficient information \\
\hline $\begin{array}{l}\text { Blinding (performance } \\
\text { bias and detection bias) } \\
\text { All outcomes }\end{array}$ & High risk & Open study \\
\hline $\begin{array}{l}\text { Incomplete outcome data } \\
\text { (attrition bias) } \\
\text { All outcomes }\end{array}$ & Low risk & Lost to follow-up 0 \\
\hline $\begin{array}{l}\text { Selective reporting (re- } \\
\text { porting bias) }\end{array}$ & Low risk & No distinct selective outcome reporting \\
\hline $\begin{array}{l}\text { Blinding of participants } \\
\text { and personnel (perfor- } \\
\text { mance bias) } \\
\text { All outcomes }\end{array}$ & High risk & $\begin{array}{l}\text { Open study: Performance bias due to knowledge of the allocated interventions } \\
\text { by participants and personnel during the study. }\end{array}$ \\
\hline $\begin{array}{l}\text { Blinding of outcome as- } \\
\text { sessment (detection bias) } \\
\text { All outcomes }\end{array}$ & High risk & $\begin{array}{l}\text { Open study: Detection bias due to knowledge of the allocated interventions by } \\
\text { outcome assessors }\end{array}$ \\
\hline
\end{tabular}

Effects of low sodium diet versus high sodium diet on blood pressure, renin, aldosterone, catecholamines, cholesterol, and triglyceride 


\begin{tabular}{ll}
\hline Methods & DB \\
& $P$ \\
\hline Participants & $\begin{array}{l}\text { N 65 (M/F:41/24)(B/W/A.0/0/65) } \\
\text { Hypertension and normotension } \\
\text { Age 46.6 }\end{array}$ \\
\hline Interventions & SR 20 (1.4g) \\
\hline Dur 42 \\
\hline Notes & SBP, DBP, \\
\hline
\end{tabular}

\section{Risk of bias}

\begin{tabular}{|c|c|c|}
\hline Bias & Authors' judgement & Support for judgement \\
\hline $\begin{array}{l}\text { Random sequence genera- } \\
\text { tion (selection bias) }\end{array}$ & Unclear risk & Insufficient information \\
\hline $\begin{array}{l}\text { Allocation concealment } \\
\text { (selection bias) }\end{array}$ & Unclear risk & Insufficient information \\
\hline $\begin{array}{l}\text { Blinding (performance } \\
\text { bias and detection bias) } \\
\text { All outcomes }\end{array}$ & Low risk & Double blind study \\
\hline $\begin{array}{l}\text { Incomplete outcome data } \\
\text { (attrition bias) } \\
\text { All outcomes }\end{array}$ & Low risk & Lost to follow up LS: $1 / 33 ;$ US: $0 / 32$ \\
\hline $\begin{array}{l}\text { Selective reporting (re- } \\
\text { porting bias) }\end{array}$ & Low risk & No distinct selective outcome reporting \\
\hline $\begin{array}{l}\text { Blinding of participants } \\
\text { and personnel (perfor- } \\
\text { mance bias) } \\
\text { All outcomes }\end{array}$ & Low risk & Double blind study \\
\hline $\begin{array}{l}\text { Blinding of outcome as- } \\
\text { sessment (detection bias) } \\
\text { All outcomes }\end{array}$ & Low risk & Double blind study \\
\hline
\end{tabular}

1180 Palacios 2004

\begin{tabular}{ll}
\hline Methods & Op \\
& CO
\end{tabular}

\begin{tabular}{ll}
\hline Participants & N 40 (M/F:0/23/17 dropouts) (B/W/A.15/8/0) \\
& Normotension \\
& Age 13
\end{tabular}

Interventions SR 86 (120-34)

Effects of low sodium diet versus high sodium diet on blood pressure, renin, aldosterone, catecholamines, cholesterol, and triglyceride 
1180 Palacios 2004 (Continued)

$$
\text { Dur } 21
$$

\begin{tabular}{ll}
\hline Outcomes & SBP, DBP, renin, aldo \\
\hline Notes & LoFo: 17.23 completed study \\
\hline
\end{tabular}

\section{Risk of bias}

\begin{tabular}{|c|c|c|}
\hline Bias & Authors' judgement & Support for judgement \\
\hline $\begin{array}{l}\text { Random sequence genera- } \\
\text { tion (selection bias) }\end{array}$ & Unclear risk & Insufficient information \\
\hline $\begin{array}{l}\text { Allocation concealment } \\
\text { (selection bias) }\end{array}$ & Unclear risk & Insufficient information \\
\hline $\begin{array}{l}\text { Blinding (performance } \\
\text { bias and detection bias) } \\
\text { All outcomes }\end{array}$ & High risk & Open study \\
\hline $\begin{array}{l}\text { Incomplete outcome data } \\
\text { (attrition bias) } \\
\text { All outcomes }\end{array}$ & High risk & Lost to follow up $17 / 40$ \\
\hline $\begin{array}{l}\text { Selective reporting (re- } \\
\text { porting bias) }\end{array}$ & Low risk & No distinct selective outcome reporting \\
\hline $\begin{array}{l}\text { Blinding of participants } \\
\text { and personnel (perfor- } \\
\text { mance bias) } \\
\text { All outcomes }\end{array}$ & High risk & $\begin{array}{l}\text { Open study: Performance bias due to knowledge of the allocated interventions } \\
\text { by participants and personnel during the study. }\end{array}$ \\
\hline $\begin{array}{l}\text { Blinding of outcome as- } \\
\text { sessment (detection bias) } \\
\text { All outcomes }\end{array}$ & High risk & $\begin{array}{l}\text { Open study: Detection bias due to knowledge of the allocated interventions by } \\
\text { outcome assessors }\end{array}$ \\
\hline
\end{tabular}

\section{Beeks 2004}

\begin{tabular}{ll}
\hline Methods & OP \\
& CO \\
\hline Participants & N $117(\mathrm{M} / \mathrm{F}: 67 / 50)(\mathrm{B} / \mathrm{W} / \mathrm{A} \cdot 0 / 117 / 0)$ \\
& Hyp 54 \\
& Age 54 \\
\hline Interventions & SR $99(171-72)$ \\
& Dur 7 \\
\hline Outcomes & SBP \\
& DBP \\
Aldo \\
\hline Notes & LoFo: 0 \\
\hline
\end{tabular}

\section{Risk of bias}

Effects of low sodium diet versus high sodium diet on blood pressure, renin, aldosterone, catecholamines, cholesterol, and triglyceride 
1181 Beeks 2004 (Continued)

\begin{tabular}{|c|c|c|}
\hline Bias & Authors' judgement & Support for judgement \\
\hline $\begin{array}{l}\text { Random sequence genera- } \\
\text { tion (selection bias) }\end{array}$ & Unclear risk & Insufficient information \\
\hline $\begin{array}{l}\text { Allocation concealment } \\
\text { (selection bias) }\end{array}$ & Unclear risk & Insufficient information \\
\hline $\begin{array}{l}\text { Blinding (performance } \\
\text { bias and detection bias) } \\
\text { All outcomes }\end{array}$ & High risk & Open study \\
\hline $\begin{array}{l}\text { Incomplete outcome data } \\
\text { (attrition bias) } \\
\text { All outcomes }\end{array}$ & Low risk & Lost to follow up 0 \\
\hline $\begin{array}{l}\text { Selective reporting (re- } \\
\text { porting bias) }\end{array}$ & Low risk & No distinct selective outcome reporting \\
\hline $\begin{array}{l}\text { Blinding of participants } \\
\text { and personnel (perfor- } \\
\text { mance bias) } \\
\text { All outcomes }\end{array}$ & High risk & $\begin{array}{l}\text { Open study: Performance bias due to knowledge of the allocated interventions } \\
\text { by participants and personnel during the study. }\end{array}$ \\
\hline $\begin{array}{l}\text { Blinding of outcome as- } \\
\text { sessment (detection bias) } \\
\text { All outcomes }\end{array}$ & High risk & $\begin{array}{l}\text { Open study: Detection bias due to knowledge of the allocated interventions by } \\
\text { outcome assessors }\end{array}$ \\
\hline
\end{tabular}

\section{Berge-Landry 2004}

\begin{tabular}{ll}
\hline Methods & Op \\
& CO \\
\hline Participants & N 48 (M/F:38/10)(B/W/A.12/34/2) \\
& Hyp 51 \\
\hline Interventions & SR $285(309-24)$ \\
& Dur 28 \\
\hline Outcomes & SBP \\
& DBP \\
& Cho Trig \\
\hline Notes & LoFo: 0
\end{tabular}

\section{Risk of bias}

\begin{tabular}{lll}
\hline Bias & Authors' judgement & Support for judgement \\
\hline $\begin{array}{l}\text { Random sequence genera- } \\
\text { tion (selection bias) }\end{array}$ & Unclear risk & Insufficient information \\
\hline $\begin{array}{l}\text { Allocation concealment } \\
\text { (selection bias) }\end{array}$ & Unclear risk & Insufficient information \\
\hline
\end{tabular}

Effects of low sodium diet versus high sodium diet on blood pressure, renin, aldosterone, catecholamines, cholesterol, and triglyceride 
1182 Berge-Landry 2004 (Continued)
Blinding (performance
bias and detection bias)
All outcomes
High risk
Open study

\begin{tabular}{|c|c|c|}
\hline $\begin{array}{l}\text { Incomplete outcome data } \\
\text { (attrition bias) } \\
\text { All outcomes }\end{array}$ & Low risk & Lost to follow up 0 \\
\hline $\begin{array}{l}\text { Selective reporting (re- } \\
\text { porting bias) }\end{array}$ & Low risk & No distinct selective outcome reporting \\
\hline $\begin{array}{l}\text { Blinding of participants } \\
\text { and personnel (perfor- } \\
\text { mance bias) } \\
\text { All outcomes }\end{array}$ & High risk & $\begin{array}{l}\text { Open study: Performance bias due to knowledge of the allocated interventions } \\
\text { by participants and personnel during the study. }\end{array}$ \\
\hline $\begin{array}{l}\text { Blinding of outcome as- } \\
\text { sessment (detection bias) } \\
\text { All outcomes }\end{array}$ & High risk & $\begin{array}{l}\text { Open study: Detection bias due to knowledge of the allocated interventions by } \\
\text { outcome assessors }\end{array}$ \\
\hline
\end{tabular}

\section{Gates 2004}

\begin{tabular}{ll}
\hline Methods & DB \\
& CO \\
\hline Participants & $\begin{array}{l}\text { N } 12 \text { (M/F:6/6)(B/W/A.0/12/0) } \\
\text { Hyper } \\
\text { Age } 64\end{array}$ \\
\hline Interventions & SR 95 (155-60) \\
\hline Outcomes 28 \\
SBP \\
DBP \\
Chol, HDL, LDL, Trig, Renin, NE, E \\
\hline Notes & LoFo: 0
\end{tabular}

\section{Risk of bias}

\begin{tabular}{lll}
\hline Bias & Authors' judgement & Support for judgement \\
\hline $\begin{array}{l}\text { Random sequence genera- } \\
\text { tion (selection bias) }\end{array}$ & Unclear risk & Insufficient information \\
\hline $\begin{array}{l}\text { Allocation concealment } \\
\text { (selection bias) }\end{array}$ & Unclear risk & Insufficient information \\
\hline $\begin{array}{l}\text { Blinding (performance } \\
\text { bias and detection bias) }\end{array}$ & Low risk & Double blind \\
$\begin{array}{l}\text { All outcomes } \\
\text { Incomplete outcome data }\end{array}$ & Low risk & \\
$\begin{array}{l}\text { (attrition bias) } \\
\text { All outcomes }\end{array}$ & & \\
\hline
\end{tabular}

Effects of low sodium diet versus high sodium diet on blood pressure, renin, aldosterone, catecholamines, cholesterol, and triglyceride 


\section{Gates 2004 (Continued)}

\begin{tabular}{|c|c|c|}
\hline $\begin{array}{l}\text { Selective reporting (re- } \\
\text { porting bias) }\end{array}$ & Low risk & No distinct selective outcome reporting \\
\hline $\begin{array}{l}\text { Blinding of participants } \\
\text { and personnel (perfor- } \\
\text { mance bias) } \\
\text { All outcomes }\end{array}$ & Low risk & Double blind study \\
\hline $\begin{array}{l}\text { Blinding of outcome as- } \\
\text { sessment (detection bias) } \\
\text { All outcomes }\end{array}$ & Low risk & Double blind study \\
\hline
\end{tabular}

\section{Harsha 2004}

$\begin{array}{ll}\text { Methods } & \text { DB } \\ & \text { CO }\end{array}$

\begin{tabular}{ll}
\hline Participants & N 193 (M/F:89/104)(B/W/A.57/136/0) \\
& Mixed Hyper/Norm \\
& Age 49 \\
\hline Interventions & SR 77 (141-64) \\
& Dur 30 \\
\hline Outcomes & Chol, HDL, LDL, Trig, Renin, NE, E \\
\hline Notes & LoFo: 0 \\
\hline
\end{tabular}

\section{Risk of bias}

\begin{tabular}{|c|c|c|}
\hline Bias & Authors' judgement & Support for judgement \\
\hline $\begin{array}{l}\text { Random sequence genera- } \\
\text { tion (selection bias) }\end{array}$ & Unclear risk & Insufficient information \\
\hline $\begin{array}{l}\text { Allocation concealment } \\
\text { (selection bias) }\end{array}$ & Unclear risk & Insufficient information \\
\hline $\begin{array}{l}\text { Blinding (performance } \\
\text { bias and detection bias) } \\
\text { All outcomes }\end{array}$ & Low risk & Double blind \\
\hline $\begin{array}{l}\text { Incomplete outcome data } \\
\text { (attrition bias) } \\
\text { All outcomes }\end{array}$ & Low risk & Lost to follow up 0 \\
\hline $\begin{array}{l}\text { Selective reporting (re- } \\
\text { porting bias) }\end{array}$ & Low risk & No distinct selective outcome reporting \\
\hline $\begin{array}{l}\text { Blinding of participants } \\
\text { and personnel (perfor- } \\
\text { mance bias) } \\
\text { All outcomes }\end{array}$ & Low risk & Double blind study \\
\hline $\begin{array}{l}\text { Blinding of outcome as- } \\
\text { sessment (detection bias) }\end{array}$ & Low risk & Double blind study \\
\hline
\end{tabular}

Effects of low sodium diet versus high sodium diet on blood pressure, renin, aldosterone, catecholamines, cholesterol, and triglyceride 
1184 Harsha 2004 (Continued)

All outcomes

1185 Zanchi 2004

\begin{tabular}{ll}
\hline Methods & DB \\
& CO \\
\hline Participants & $\begin{array}{l}\text { N } 10 \text { (M/F:10/0)(B/W/A.0/10/0) } \\
\text { Age 25 }\end{array}$ \\
\hline Interventions & SR 250 (270-20) \\
& Dur 7 \\
\hline Outcomes & SBP, DBP, renin, aldo \\
\hline Notes & LoFo: 0
\end{tabular}

\section{Risk of bias}

\begin{tabular}{|c|c|c|}
\hline Bias & Authors' judgement & Support for judgement \\
\hline $\begin{array}{l}\text { Random sequence genera- } \\
\text { tion (selection bias) }\end{array}$ & Unclear risk & Insufficient information \\
\hline $\begin{array}{l}\text { Allocation concealment } \\
\text { (selection bias) }\end{array}$ & Unclear risk & Insufficient information \\
\hline $\begin{array}{l}\text { Blinding (performance } \\
\text { bias and detection bias) } \\
\text { All outcomes }\end{array}$ & Low risk & Double blind \\
\hline $\begin{array}{l}\text { Incomplete outcome data } \\
\text { (attrition bias) } \\
\text { All outcomes }\end{array}$ & Low risk & Lost to follow up 0 \\
\hline $\begin{array}{l}\text { Selective reporting (re- } \\
\text { porting bias) }\end{array}$ & Low risk & No distinct selective outcome reporting \\
\hline $\begin{array}{l}\text { Blinding of participants } \\
\text { and personnel (perfor- } \\
\text { mance bias) } \\
\text { All outcomes }\end{array}$ & Low risk & Double blind study \\
\hline $\begin{array}{l}\text { Blinding of outcome as- } \\
\text { sessment (detection bias) } \\
\text { All outcomes }\end{array}$ & Low risk & Double blind study \\
\hline
\end{tabular}

\section{Forrester $2005 \mathrm{~N}$}

$\begin{array}{ll}\text { Methods } & \text { Op } \\ & \text { CO }\end{array}$

Participants 58 Nigerians (M/F: 34/24)

Effects of low sodium diet versus high sodium diet on blood pressure, renin, aldosterone, catecholamines, cholesterol, and triglyceride 
1186 Forrester 2005 N (Continued)

Norm (114.6/72.9)

Mean age 46.6 (25-55)

\begin{tabular}{ll}
\hline Interventions & SR 72.2 \\
& Dur 21 \\
\hline Outcomes & SBP \\
DBP \\
\hline Notes & LoFo: 0 \\
\hline
\end{tabular}

\section{Risk of bias}

\begin{tabular}{|c|c|c|}
\hline Bias & Authors' judgement & Support for judgement \\
\hline $\begin{array}{l}\text { Random sequence genera- } \\
\text { tion (selection bias) }\end{array}$ & Unclear risk & Insufficient information \\
\hline $\begin{array}{l}\text { Allocation concealment } \\
\text { (selection bias) }\end{array}$ & Unclear risk & Block randomisation \\
\hline $\begin{array}{l}\text { Blinding (performance } \\
\text { bias and detection bias) } \\
\text { All outcomes }\end{array}$ & High risk & Open study \\
\hline $\begin{array}{l}\text { Incomplete outcome data } \\
\text { (attrition bias) } \\
\text { All outcomes }\end{array}$ & Low risk & Lost to follow up 0 \\
\hline $\begin{array}{l}\text { Selective reporting (re- } \\
\text { porting bias) }\end{array}$ & Low risk & No distinct selective outcome reporting \\
\hline $\begin{array}{l}\text { Blinding of participants } \\
\text { and personnel (perfor- } \\
\text { mance bias) } \\
\text { All outcomes }\end{array}$ & High risk & $\begin{array}{l}\text { Open study: Performance bias due to knowledge of the allocated interventions } \\
\text { by participants and personnel during the study. }\end{array}$ \\
\hline $\begin{array}{l}\text { Blinding of outcome as- } \\
\text { sessment (detection bias) } \\
\text { All outcomes }\end{array}$ & High risk & $\begin{array}{l}\text { Open study: Detection bias due to knowledge of the allocated interventions by } \\
\text { outcome assessors }\end{array}$ \\
\hline
\end{tabular}

\section{Forrester $2005 \mathrm{~J}$}

\begin{tabular}{ll}
\hline Methods & Op \\
& CO \\
\hline Participants & $\begin{array}{l}56 \text { Jamaicans (M/F: 34/22) } \\
\text { Norm (125.9/76.3) } \\
\text { Mean age 40.8 (25-55) }\end{array}$ \\
\hline Interventions & SR 78.8 \\
& Dur 21 \\
\hline Outcomes & SBP \\
& DBP \\
\hline
\end{tabular}

Effects of low sodium diet versus high sodium diet on blood pressure, renin, aldosterone, catecholamines, cholesterol, and triglyceride 
1187 Forrester $2005 \mathrm{~J}$ (Continued)
Notes
LoFo: 0

\section{Risk of bias}

\begin{tabular}{|c|c|c|}
\hline Bias & Authors' judgement & Support for judgement \\
\hline $\begin{array}{l}\text { Random sequence genera- } \\
\text { tion (selection bias) }\end{array}$ & Unclear risk & Insufficient information \\
\hline $\begin{array}{l}\text { Allocation concealment } \\
\text { (selection bias) }\end{array}$ & Unclear risk & Block randomisation \\
\hline $\begin{array}{l}\text { Blinding (performance } \\
\text { bias and detection bias) } \\
\text { All outcomes }\end{array}$ & High risk & Open study \\
\hline $\begin{array}{l}\text { Incomplete outcome data } \\
\text { (attrition bias) } \\
\text { All outcomes }\end{array}$ & Low risk & Lost to follow up 0 \\
\hline $\begin{array}{l}\text { Selective reporting (re- } \\
\text { porting bias) }\end{array}$ & Low risk & No distinct selective outcome reporting \\
\hline $\begin{array}{l}\text { Blinding of participants } \\
\text { and personnel (perfor- } \\
\text { mance bias) } \\
\text { All outcomes }\end{array}$ & High risk & $\begin{array}{l}\text { Open study: Performance bias due to knowledge of the allocated interventions } \\
\text { by participants and personnel during the study. }\end{array}$ \\
\hline $\begin{array}{l}\text { Blinding of outcome as- } \\
\text { sessment (detection bias) } \\
\text { All outcomes }\end{array}$ & High risk & $\begin{array}{l}\text { Open study: Detection bias due to knowledge of the allocated interventions by } \\
\text { outcome assessors }\end{array}$ \\
\hline
\end{tabular}

\section{Swift 2005}

\begin{tabular}{ll}
\hline Methods & DB \\
\hline Participants & $\begin{array}{l}\text { N 40 (M/F:17/23)(B/W/A 40/0/0) } \\
\text { Age } 50\end{array}$ \\
\hline Interventions & $\begin{array}{l}\text { SR 78 (167-89) } \\
\text { Dur 28 }\end{array}$ \\
\hline Outcomes & SBP, DBP, renin, aldo \\
\hline Notes & LoFo: 7. 40 of 47 completed study. IT: No \\
\hline Risk of bias & Authors' judgement Support for judgement \\
\hline Bias & Unclear risk Insufficient information \\
\hline Random sequence genera- \\
tion (selection bias)
\end{tabular}

Effects of low sodium diet versus high sodium diet on blood pressure, renin, aldosterone, catecholamines, cholesterol, and triglyceride 


\section{Swift 2005 (Continued)

\begin{tabular}{lll}
$\begin{array}{l}\text { Allocation concealment } \\
\text { (selection bias) }\end{array}$ & Unclear risk & Insufficient information \\
\hline $\begin{array}{l}\text { Blinding (performance } \\
\text { bias and detection bias) } \\
\text { All outcomes }\end{array}$ & Low risk & Double blind study \\
\hline
\end{tabular}

Incomplete outcome data Low risk $\quad$ Lost to follow up $7 / 47$
(attrition bias)

\begin{tabular}{|c|c|c|}
\hline $\begin{array}{l}\text { Selective reporting (re- } \\
\text { porting bias) }\end{array}$ & Low risk & No distinct selective outcome reporting \\
\hline $\begin{array}{l}\text { Blinding of participants } \\
\text { and personnel (perfor- } \\
\text { mance bias) } \\
\text { All outcomes }\end{array}$ & Low risk & Double blind study \\
\hline $\begin{array}{l}\text { Blinding of outcome as- } \\
\text { sessment (detection bias) } \\
\text { All outcomes }\end{array}$ & Low risk & Double blind study \\
\hline
\end{tabular}

\section{Damgaard 2006}

\begin{tabular}{|c|c|c|c|}
\hline \multicolumn{2}{|l|}{ Methods } & & \\
\hline & \multicolumn{2}{|r|}{$\begin{array}{l}\text { N } 14 \text { (M/F:14/0)(B/W/A.0/14/0) } \\
\text { Norm } \\
\text { Age } 57\end{array}$} & \\
\hline & \multicolumn{2}{|r|}{$\begin{array}{l}\text { SR } 129(188-59) \\
\text { Dur } 7\end{array}$} & \\
\hline & \multicolumn{2}{|r|}{$\begin{array}{l}\text { SBP } \\
\text { DBP } \\
\text { NE and E }\end{array}$} & \\
\hline & \multicolumn{2}{|r|}{ LoFo: 2 excluded because of side effects } & \\
\hline \multicolumn{4}{|l|}{ Risk of bias } \\
\hline & & Bias & Authors' judgement Support for judgement \\
\hline & & $\begin{array}{l}\text { Random sequence genera- } \\
\text { tion (selection bias) }\end{array}$ & Insufficient information \\
\hline & & $\begin{array}{l}\text { Allocation concealment } \\
\text { (selection bias) }\end{array}$ & Insufficient information \\
\hline & & $\begin{array}{l}\text { Blinding (performance } \\
\text { bias and detection bias) } \\
\text { All outcomes }\end{array}$ & Open study \\
\hline
\end{tabular}


1189 Damgaard 2006 (Continued)

Incomplete outcome data Low risk $\quad$ Lost to follow up 2/14
(attrition bias)
All outcomes

\begin{tabular}{|c|c|c|}
\hline $\begin{array}{l}\text { Selective reporting (re- } \\
\text { porting bias) }\end{array}$ & Low risk & No distinct selective outcome reporting \\
\hline $\begin{array}{l}\text { Blinding of participants } \\
\text { and personnel (perfor- } \\
\text { mance bias) } \\
\text { All outcomes }\end{array}$ & High risk & $\begin{array}{l}\text { Open study: Performance bias due to knowledge of the allocated interventions } \\
\text { by participants and personnel during the study. }\end{array}$ \\
\hline $\begin{array}{l}\text { Blinding of outcome as- } \\
\text { sessment (detection bias) } \\
\text { All outcomes }\end{array}$ & High risk & $\begin{array}{l}\text { Open study: Detection bias due to knowledge of the allocated interventions by } \\
\text { outcome assessors }\end{array}$ \\
\hline
\end{tabular}

\section{Takahashi 2006}

\begin{tabular}{ll}
\hline Methods & Op \\
& CO \\
\hline Participants & $\begin{array}{l}\text { N 448 (M/F:145/303)(B/W/A.0/0/448) } \\
\text { Hypertension (107) and normotension (341) } \\
\text { Age } 56.4\end{array}$ \\
\hline Interventions & SR 38 (237-199) \\
\hline Outcomes 365
\end{tabular}

\section{Risk of bias}

\begin{tabular}{|c|c|c|}
\hline Bias & Authors' judgement & Support for judgement \\
\hline $\begin{array}{l}\text { Random sequence genera- } \\
\text { tion (selection bias) }\end{array}$ & Low risk & Randomisation: computer generated random number \\
\hline $\begin{array}{l}\text { Allocation concealment } \\
\text { (selection bias) }\end{array}$ & Unclear risk & Insufficient information \\
\hline $\begin{array}{l}\text { Blinding (performance } \\
\text { bias and detection bias) } \\
\text { All outcomes }\end{array}$ & High risk & Open study \\
\hline $\begin{array}{l}\text { Incomplete outcome data } \\
\text { (attrition bias) } \\
\text { All outcomes }\end{array}$ & High risk & Lost to follow up $102 / 550$ \\
\hline $\begin{array}{l}\text { Selective reporting (re- } \\
\text { porting bias) }\end{array}$ & Low risk & No distinct selective outcome reporting \\
\hline $\begin{array}{l}\text { Blinding of participants } \\
\text { and personnel (perfor- } \\
\text { mance bias) }\end{array}$ & High risk & $\begin{array}{l}\text { Open study: Performance bias due to knowledge of the allocated interventions } \\
\text { by participants and personnel during the study. }\end{array}$ \\
\hline
\end{tabular}

Effects of low sodium diet versus high sodium diet on blood pressure, renin, aldosterone, catecholamines, cholesterol, and triglyceride 
1190 Takahashi 2006 (Continued)

All outcomes

Blinding of outcome assessment (detection bias) All outcomes
High risk

Open study: Detection bias due to knowledge of the allocated interventions by outcome assessors

1191 Melander 2007

\begin{tabular}{ll}
\hline Methods & DB \\
& CO
\end{tabular}

\begin{tabular}{ll}
\hline Participants & N 39 (M/F: 20/19) \\
& Mixed hypertensive and normotensive (144/90.6) \\
& Age 53 \\
\hline Interventions & SR 89 (140-51) \\
& Dur 28 \\
\hline Outcomes & SBP \\
& DBP \\
renin
\end{tabular}

\section{Risk of bias}

\begin{tabular}{|c|c|c|}
\hline Bias & Authors' judgement & Support for judgement \\
\hline $\begin{array}{l}\text { Random sequence genera- } \\
\text { tion (selection bias) }\end{array}$ & Unclear risk & Insufficient information \\
\hline $\begin{array}{l}\text { Allocation concealment } \\
\text { (selection bias) }\end{array}$ & Unclear risk & Insufficient information \\
\hline $\begin{array}{l}\text { Blinding (performance } \\
\text { bias and detection bias) } \\
\text { All outcomes }\end{array}$ & Low risk & Double blind study \\
\hline $\begin{array}{l}\text { Incomplete outcome data } \\
\text { (attrition bias) } \\
\text { All outcomes }\end{array}$ & Low risk & Lost to follow up $7 / 46$ \\
\hline $\begin{array}{l}\text { Selective reporting (re- } \\
\text { porting bias) }\end{array}$ & Low risk & No distinct selective outcome reporting \\
\hline $\begin{array}{l}\text { Blinding of participants } \\
\text { and personnel (perfor- } \\
\text { mance bias) } \\
\text { All outcomes }\end{array}$ & Low risk & Double blind study \\
\hline $\begin{array}{l}\text { Blinding of outcome as- } \\
\text { sessment (detection bias) } \\
\text { All outcomes }\end{array}$ & Low risk & Double blind study \\
\hline
\end{tabular}


1192 Townsend 2007

\begin{tabular}{ll}
\hline Methods & Op \\
& CO \\
\hline Participants & N 20 (M/F:12/8)(B/W/A.10/9/1) \\
& Norm \\
& Age 30 \\
\hline Interventions & SR 171 (194-23) \\
& Dur 6 \\
\hline Outcomes & SBP \\
& DBP \\
& Aldo \\
Renin \\
\hline Notes & Randomized 21. LoFo: 3 \\
& IT: No \\
\hline
\end{tabular}

\section{Risk of bias}

\section{Bias}

Authors' judgement Support for judgement

Random sequence genera- Low risk Prespecified randomised blocked table tion (selection bias)

\begin{tabular}{lll}
\hline $\begin{array}{l}\text { Allocation concealment } \\
\text { (selection bias) }\end{array}$ & Unclear risk & Insufficient information \\
\hline $\begin{array}{l}\text { Blinding (performance } \\
\text { bias and detection bias) } \\
\text { All outcomes }\end{array}$ & High risk & Open study \\
\hline
\end{tabular}

Incomplete outcome data Low risk $\quad$ Lost to follow up 3/21
(attrition bias)

All outcomes

\begin{tabular}{|c|c|c|}
\hline $\begin{array}{l}\text { Selective reporting (re- } \\
\text { porting bias) }\end{array}$ & Low risk & No distinct selective outcome reporting \\
\hline $\begin{array}{l}\text { Blinding of participants } \\
\text { and personnel (perfor- } \\
\text { mance bias) } \\
\text { All outcomes }\end{array}$ & High risk & $\begin{array}{l}\text { Open study: Performance bias due to knowledge of the allocated interventions } \\
\text { by participants and personnel during the study. }\end{array}$ \\
\hline $\begin{array}{l}\text { Blinding of outcome as- } \\
\text { sessment (detection bias) } \\
\text { All outcomes }\end{array}$ & High risk & $\begin{array}{l}\text { Open study: Detection bias due to knowledge of the allocated interventions by } \\
\text { outcome assessors }\end{array}$ \\
\hline
\end{tabular}

\section{Dengel 2007}

\begin{tabular}{ll}
\hline Methods & DB \\
& CO
\end{tabular}

\section{Participants}

N 28, 10 males, 18 females, 5 blacks, 23 whites

Effects of low sodium diet versus high sodium diet on blood pressure, renin, aldosterone, catecholamines, cholesterol, and triglyceride 
1193 Dengel 2007 (Continued)

Hypertension

Mean age 63

\begin{tabular}{ll}
\hline Interventions & SR 155 (191-36) \\
& Dur 8 \\
\hline Outcomes & SBP -10 \\
& $\begin{array}{l}\text { DBP }-4 \\
\text { Renin } 1.64 \mathrm{ng} / \mathrm{s} \text { Aldo } 334.2\end{array}$ \\
\hline Notes & LoFo: 0 \\
& Blood pressure effects estimated from figure 1. The effects of two genotype groups were added to one \\
& group and calculated as simple means.
\end{tabular}

\section{Risk of bias}

\begin{tabular}{|c|c|c|}
\hline Bias & Authors' judgement & Support for judgement \\
\hline $\begin{array}{l}\text { Random sequence genera- } \\
\text { tion (selection bias) }\end{array}$ & Unclear risk & Insufficient information \\
\hline $\begin{array}{l}\text { Allocation concealment } \\
\text { (selection bias) }\end{array}$ & Unclear risk & Insufficient information \\
\hline $\begin{array}{l}\text { Blinding (performance } \\
\text { bias and detection bias) } \\
\text { All outcomes }\end{array}$ & Low risk & Double blind study \\
\hline $\begin{array}{l}\text { Incomplete outcome data } \\
\text { (attrition bias) } \\
\text { All outcomes }\end{array}$ & Low risk & Lost to follow up 0 \\
\hline $\begin{array}{l}\text { Selective reporting (re- } \\
\text { porting bias) }\end{array}$ & Low risk & No distinct selective outcome reporting \\
\hline $\begin{array}{l}\text { Blinding of participants } \\
\text { and personnel (perfor- } \\
\text { mance bias) } \\
\text { All outcomes }\end{array}$ & Low risk & Double blind study \\
\hline $\begin{array}{l}\text { Blinding of outcome as- } \\
\text { sessment (detection bias) } \\
\text { All outcomes }\end{array}$ & Low risk & Double blind study \\
\hline
\end{tabular}

\section{Tzemos 2008}

\begin{tabular}{ll}
\hline Methods & DB \\
& CO \\
\hline Participants & N 16 (M/F:16/0)(B/W/A.0/16/0) \\
& Normotension \\
& Age 27 \\
\hline Interventions & SR $149(225-76)$ \\
& Dur 5 \\
\hline
\end{tabular}

Effects of low sodium diet versus high sodium diet on blood pressure, renin, aldosterone, catecholamines, cholesterol, and triglyceride 
1194 Tzemos 2008 (Continued)

\begin{tabular}{ll} 
Outcomes & SBP, DBP, renin, aldo, chol, HDL, LDL, Trig, \\
\hline Notes & LoFo: 0
\end{tabular}

\section{Risk of bias}

\begin{tabular}{|c|c|c|}
\hline Bias & Authors' judgement & Support for judgement \\
\hline $\begin{array}{l}\text { Random sequence genera- } \\
\text { tion (selection bias) }\end{array}$ & Unclear risk & Insufficient information \\
\hline $\begin{array}{l}\text { Allocation concealment } \\
\text { (selection bias) }\end{array}$ & Unclear risk & Insufficient information \\
\hline $\begin{array}{l}\text { Blinding (performance } \\
\text { bias and detection bias) } \\
\text { All outcomes }\end{array}$ & Low risk & Double blind study \\
\hline $\begin{array}{l}\text { Incomplete outcome data } \\
\text { (attrition bias) } \\
\text { All outcomes }\end{array}$ & Low risk & Lost to follow up 0 \\
\hline $\begin{array}{l}\text { Selective reporting (re- } \\
\text { porting bias) }\end{array}$ & Low risk & No distinct selective outcome reporting \\
\hline $\begin{array}{l}\text { Blinding of participants } \\
\text { and personnel (perfor- } \\
\text { mance bias) } \\
\text { All outcomes }\end{array}$ & Low risk & Double blind study \\
\hline $\begin{array}{l}\text { Blinding of outcome as- } \\
\text { sessment (detection bias) } \\
\text { All outcomes }\end{array}$ & Low risk & Double blind study \\
\hline
\end{tabular}

\section{Jessani 2008}

\begin{tabular}{ll}
\hline Methods & Op \\
& CO \\
\hline Participants & $\begin{array}{l}\text { Normotension } 184 \text { (M:87/97)(B/W/A.0/184/0) } \\
\text { Age } 50\end{array}$ \\
\hline Interventions & SR 81 (138-57) \\
\hline Dur 7
\end{tabular}


1195 Jessani 2008 (Continued)

Random sequence genera- Low risk Randomisation by computer generated numbers tion (selection bias)

\begin{tabular}{lll}
\hline $\begin{array}{l}\text { Allocation concealment } \\
\text { (selection bias) }\end{array}$ & Low risk & Insufficient information \\
\hline $\begin{array}{l}\text { Blinding (performance } \\
\text { bias and detection bias) }\end{array}$ & High risk & Open study \\
All outcomes & &
\end{tabular}

\begin{tabular}{|c|c|c|}
\hline $\begin{array}{l}\text { Incomplete outcome data } \\
\text { (attrition bias) } \\
\text { All outcomes }\end{array}$ & Low risk & Lost to follow up $16 / 200$ \\
\hline $\begin{array}{l}\text { Selective reporting (re- } \\
\text { porting bias) }\end{array}$ & Low risk & No distinct selective outcome reporting \\
\hline $\begin{array}{l}\text { Blinding of participants } \\
\text { and personnel (perfor- } \\
\text { mance bias) } \\
\text { All outcomes }\end{array}$ & High risk & $\begin{array}{l}\text { Open study: Performance bias due to knowledge of the allocated interventions } \\
\text { by participants and personnel during the study. }\end{array}$ \\
\hline $\begin{array}{l}\text { Blinding of outcome as- } \\
\text { sessment (detection bias) } \\
\text { All outcomes }\end{array}$ & High risk & $\begin{array}{l}\text { Open study: Detection bias due to knowledge of the allocated interventions by } \\
\text { outcome assessors }\end{array}$ \\
\hline
\end{tabular}

\section{Paulsen 2009}

\begin{tabular}{ll}
\hline Methods & DB \\
& CO \\
\hline Participants & $\begin{array}{l}\text { N 22 (M/F:12/10)(B/W/A.0/22/0) } \\
\text { Age 47 }\end{array}$ \\
\hline Interventions & SR 47 (357-310) \\
\hline Outcomes & SBP, DBP, renin, aldo \\
\hline Notes & LoFo: 5.22 of 27 completed study. IT: No.
\end{tabular}

\section{Risk of bias}

\begin{tabular}{lll}
\hline Bias & Authors' judgement & Support for judgement \\
\hline $\begin{array}{l}\text { Random sequence genera- } \\
\text { tion (selection bias) }\end{array}$ & Unclear risk & Insufficient information \\
\hline $\begin{array}{l}\text { Allocation concealment } \\
\text { (selection bias) }\end{array}$ & Unclear risk & Insufficient information \\
\hline $\begin{array}{l}\text { Blinding (performance } \\
\text { bias and detection bias) } \\
\text { All outcomes }\end{array}$ & Low risk & Double blind study \\
\hline
\end{tabular}

Effects of low sodium diet versus high sodium diet on blood pressure, renin, aldosterone, catecholamines, cholesterol, and triglyceride 
1196 Paulsen 2009 (Continued)

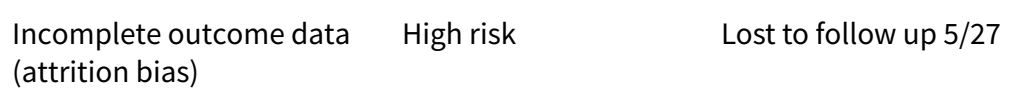

All outcomes

No distinct selective outcome reporting

Selective reporting (re- Low risk No distinct selective outcome reporting
porting bias)

Blinding of participants Low risk $\quad$ Double blind study
and personnel (perfor-
mance bias)
All outcomes

\begin{tabular}{lll}
\hline Blinding of outcome as- $\quad$ Low risk $\quad$ Double blind study
\end{tabular}

sessment (detection bias)

All outcomes

\section{Dickinson 2009}

\begin{tabular}{ll}
\hline Methods & Op \\
& CO \\
\hline Participants & $\begin{array}{l}\text { N 29 (M/F: 7/22) } \\
\text { Normotension (116/73) } \\
\text { Mean age 63 }\end{array}$ \\
\hline Interventions & SR 92 (156-64) \\
\hline Dur 14 \\
\hline SBP \\
DBP \\
\hline Notes & 32 included. LoFo: 3 \\
\hline
\end{tabular}

\section{Risk of bias}

\begin{tabular}{|c|c|c|}
\hline Bias & Authors' judgement & Support for judgement \\
\hline $\begin{array}{l}\text { Random sequence genera- } \\
\text { tion (selection bias) }\end{array}$ & Low risk & computer generated \\
\hline $\begin{array}{l}\text { Allocation concealment } \\
\text { (selection bias) }\end{array}$ & Unclear risk & Insufficient information \\
\hline $\begin{array}{l}\text { Blinding (performance } \\
\text { bias and detection bias) } \\
\text { All outcomes }\end{array}$ & High risk & Open study \\
\hline $\begin{array}{l}\text { Incomplete outcome data } \\
\text { (attrition bias) } \\
\text { All outcomes }\end{array}$ & Low risk & Lost to follow up $3 / 32$ \\
\hline $\begin{array}{l}\text { Selective reporting (re- } \\
\text { porting bias) }\end{array}$ & Low risk & No distinct selective outcome reporting \\
\hline
\end{tabular}

Effects of low sodium diet versus high sodium diet on blood pressure, renin, aldosterone, catecholamines, cholesterol, and triglyceride 


\section{Dickinson 2009 (Continued)}

Blinding of participants High risk Open study: Performance bias due to knowledge of the allocated interventions and personnel (performance bias)

All outcomes

\section{Blinding of outcome as- High risk} sessment (detection bias)

All outcomes

\section{by participants and personnel during the study.}

Open study: Detection bias due to knowledge of the allocated interventions by outcome assessors

\section{He 2009}

\begin{tabular}{ll}
\hline Methods & DB \\
& CO
\end{tabular}

\begin{tabular}{ll}
\hline Participants & Whites: 77; Blacks: 75; Asians: 35 \\
& Hypertension (Baseline BP 147/91) \\
& Mean Age 50 \\
\hline Interventions & SR 55 (165-110) \\
& Dur 42 \\
\hline Outcomes & SBP \\
& DBP \\
Renin Aldosterone
\end{tabular}

\begin{tabular}{ll}
\hline Notes & LoFO: W/B/A: $6 / 6 / 6$ \\
& IT: No
\end{tabular}

\section{Risk of bias}

\begin{tabular}{|c|c|c|}
\hline Bias & Authors' judgement & Support for judgement \\
\hline $\begin{array}{l}\text { Random sequence genera- } \\
\text { tion (selection bias) }\end{array}$ & Low risk & Computer generated, ethnic stratification \\
\hline $\begin{array}{l}\text { Allocation concealment } \\
\text { (selection bias) }\end{array}$ & Low risk & Tablets supplied by independent company \\
\hline $\begin{array}{l}\text { Blinding (performance } \\
\text { bias and detection bias) } \\
\text { All outcomes }\end{array}$ & Low risk & Double blind study \\
\hline $\begin{array}{l}\text { Incomplete outcome data } \\
\text { (attrition bias) } \\
\text { All outcomes }\end{array}$ & Low risk & Lost to follow up $18 / 187$ \\
\hline $\begin{array}{l}\text { Selective reporting (re- } \\
\text { porting bias) }\end{array}$ & Low risk & No distinct selective outcome reporting \\
\hline $\begin{array}{l}\text { Blinding of participants } \\
\text { and personnel (perfor- } \\
\text { mance bias) } \\
\text { All outcomes }\end{array}$ & Low risk & Double blind study \\
\hline $\begin{array}{l}\text { Blinding of outcome as- } \\
\text { sessment (detection bias) }\end{array}$ & Low risk & Double blind study \\
\hline
\end{tabular}

Effects of low sodium diet versus high sodium diet on blood pressure, renin, aldosterone, catecholamines, cholesterol, and triglyceride 
$1198 \mathrm{He} 2009$ (Continued)

All outcomes

1199 Meland 2009

\begin{tabular}{ll}
\hline Methods & $\begin{array}{l}\text { Op } \\
\text { P }\end{array}$ \\
\hline Participants & $\begin{array}{l}\text { N 46 (M/F:34/12)(B/W/A.0/46/0) } \\
\text { Hypertension } \\
\text { Age } 56\end{array}$ \\
\hline Interventions & $\begin{array}{l}\text { SR 43 (126-83) } \\
\text { Dur 56 }\end{array}$ \\
\hline Outcomes & SBP, DBP, \\
Aldo, Chol, Trig
\end{tabular}

\section{Risk of bias}

\begin{tabular}{|c|c|c|}
\hline Bias & Authors' judgement & Support for judgement \\
\hline $\begin{array}{l}\text { Random sequence genera- } \\
\text { tion (selection bias) }\end{array}$ & Unclear risk & Insufficient information \\
\hline $\begin{array}{l}\text { Allocation concealment } \\
\text { (selection bias) }\end{array}$ & Unclear risk & Insufficient information \\
\hline $\begin{array}{l}\text { Blinding (performance } \\
\text { bias and detection bias) } \\
\text { All outcomes }\end{array}$ & High risk & Open study \\
\hline $\begin{array}{l}\text { Incomplete outcome data } \\
\text { (attrition bias) } \\
\text { All outcomes }\end{array}$ & Low risk & Lost to follow up $0 / 46$ \\
\hline $\begin{array}{l}\text { Selective reporting (re- } \\
\text { porting bias) }\end{array}$ & Low risk & No distinct selective outcome reporting \\
\hline $\begin{array}{l}\text { Blinding of participants } \\
\text { and personnel (perfor- } \\
\text { mance bias) } \\
\text { All outcomes }\end{array}$ & High risk & $\begin{array}{l}\text { Open study: Performance bias due to knowledge of the allocated interventions } \\
\text { by participants and personnel during the study. }\end{array}$ \\
\hline $\begin{array}{l}\text { Blinding of outcome as- } \\
\text { sessment (detection bias) } \\
\text { All outcomes }\end{array}$ & High risk & $\begin{array}{l}\text { Open study: Detection bias due to knowledge of the allocated interventions by } \\
\text { outcome assessors }\end{array}$ \\
\hline
\end{tabular}

\section{Pimenta 2009}

\begin{tabular}{ll}
\hline Methods & Op \\
& CO
\end{tabular}

Effects of low sodium diet versus high sodium diet on blood pressure, renin, aldosterone, catecholamines, cholesterol, and triglyceride 
1200 Pimenta 2009 (Continued)

\begin{tabular}{ll} 
Participants & $\begin{array}{l}\text { N } 12 \text { (M/F:4/8)(B/W/A.6/6) } \\
\text { Hypertension } \\
\text { Age } 55.5\end{array}$ \\
\hline Interventions & $\begin{array}{l}\text { SR } 206(252-46) \\
\text { Dur } 7\end{array}$ \\
\hline Outcomes & SBP, DBP, renin, aldo \\
\hline Notes & LoFo: 1.12 of 13 completed study. IT: No
\end{tabular}

\section{Risk of bias}

\begin{tabular}{|c|c|c|}
\hline Bias & Authors' judgement & Support for judgement \\
\hline $\begin{array}{l}\text { Random sequence genera- } \\
\text { tion (selection bias) }\end{array}$ & Unclear risk & Insufficient information \\
\hline $\begin{array}{l}\text { Allocation concealment } \\
\text { (selection bias) }\end{array}$ & Unclear risk & Insufficient information \\
\hline $\begin{array}{l}\text { Blinding (performance } \\
\text { bias and detection bias) } \\
\text { All outcomes }\end{array}$ & High risk & Open study \\
\hline $\begin{array}{l}\text { Incomplete outcome data } \\
\text { (attrition bias) } \\
\text { All outcomes }\end{array}$ & Low risk & Lost to follow up $1 / 13$ \\
\hline $\begin{array}{l}\text { Selective reporting (re- } \\
\text { porting bias) }\end{array}$ & Low risk & No distinct selective outcome reporting \\
\hline $\begin{array}{l}\text { Blinding of participants } \\
\text { and personnel (perfor- } \\
\text { mance bias) } \\
\text { All outcomes }\end{array}$ & High risk & $\begin{array}{l}\text { Open study: Performance bias due to knowledge of the allocated interventions } \\
\text { by participants and personnel during the study. }\end{array}$ \\
\hline $\begin{array}{l}\text { Blinding of outcome as- } \\
\text { sessment (detection bias) } \\
\text { All outcomes }\end{array}$ & High risk & $\begin{array}{l}\text { Open study: Detection bias due to knowledge of the allocated interventions by } \\
\text { outcome assessors }\end{array}$ \\
\hline
\end{tabular}

\section{Nowson 2009}

\begin{tabular}{ll}
\hline Methods & Op \\
& P \\
\hline Participants & N 111 women \\
& $\begin{array}{l}\text { Mean normotensives and } 35 \text { hypertensives completed } \\
\text { Interventions }\end{array}$ \\
& SR 42 (108-66) \\
\hline Outcomes & SBP 98 \\
\hline
\end{tabular}

Effects of low sodium diet versus high sodium diet on blood pressure, renin, aldosterone, catecholamines, cholesterol, and triglyceride 
1201 Nowson 2009 (Continued)

Notes

LoFo: 16 IT: No. Two different diets were compared and there was other differences between the diets

than sodium intake. These differences were assumed not to influence blood pressure.

\section{Risk of bias}

\begin{tabular}{|c|c|c|}
\hline Bias & Authors' judgement & Support for judgement \\
\hline $\begin{array}{l}\text { Random sequence genera- } \\
\text { tion (selection bias) }\end{array}$ & Unclear risk & Insufficient information. Randomisation stratified by BMI \\
\hline $\begin{array}{l}\text { Allocation concealment } \\
\text { (selection bias) }\end{array}$ & Unclear risk & Insufficient information \\
\hline $\begin{array}{l}\text { Blinding (performance } \\
\text { bias and detection bias) } \\
\text { All outcomes }\end{array}$ & High risk & Open study \\
\hline $\begin{array}{l}\text { Incomplete outcome data } \\
\text { (attrition bias) } \\
\text { All outcomes }\end{array}$ & Low risk & Lost to follow up LS: $7 / 53$; US: $9 / 58$ \\
\hline $\begin{array}{l}\text { Selective reporting (re- } \\
\text { porting bias) }\end{array}$ & Low risk & No distinct selective outcome reporting \\
\hline $\begin{array}{l}\text { Blinding of participants } \\
\text { and personnel (perfor- } \\
\text { mance bias) } \\
\text { All outcomes }\end{array}$ & High risk & $\begin{array}{l}\text { Open study: Performance bias due to knowledge of the allocated interventions } \\
\text { by participants and personnel during the study. }\end{array}$ \\
\hline $\begin{array}{l}\text { Blinding of outcome as- } \\
\text { sessment (detection bias) } \\
\text { All outcomes }\end{array}$ & High risk & $\begin{array}{l}\text { Open study: Detection bias due to knowledge of the allocated interventions by } \\
\text { outcome assessors }\end{array}$ \\
\hline
\end{tabular}

1202 Weir 2010

\begin{tabular}{ll}
\hline Methods & CO, SB \\
\hline Participants & N 132 (M/F: 73/59, W/B/A: 115/15/2) \\
& Hypertension \\
& Mean age: 51.5 \\
\hline Interventions & SR 123 (208-85) \\
& 28 days \\
\hline Outcomes & SBP \\
\hline Notes & DBP \\
\hline
\end{tabular}

\section{Risk of bias}

\section{Bias}

Authors' judgement Support for judgement

Effects of low sodium diet versus high sodium diet on blood pressure, renin, aldosterone, catecholamines, cholesterol, and triglyceride 
1202 Weir 2010 (Continued)

\begin{tabular}{lll}
$\begin{array}{l}\text { Random sequence genera- } \\
\text { tion (selection bias) }\end{array}$ & Unclear risk & Insufficient information \\
\hline $\begin{array}{l}\text { Allocation concealment } \\
\text { (selection bias) }\end{array}$ & Unclear risk & Insufficient information \\
\hline $\begin{array}{l}\text { Blinding (performance } \\
\text { bias and detection bias) } \\
\text { All outcomes }\end{array}$ & High risk & Single blind \\
\hline $\begin{array}{l}\text { Incomplete outcome data } \\
\text { (attrition bias) }\end{array}$ & Low risk & Lost to follow up 17/132 \\
All outcomes & &
\end{tabular}

\begin{tabular}{|c|c|c|}
\hline $\begin{array}{l}\text { Selective reporting (re- } \\
\text { porting bias) }\end{array}$ & Low risk & No distinct selective outcome reporting \\
\hline $\begin{array}{l}\text { Blinding of participants } \\
\text { and personnel (perfor- } \\
\text { mance bias) } \\
\text { All outcomes }\end{array}$ & High risk & $\begin{array}{l}\text { Performance bias due to knowledge of the allocated interventions by partici- } \\
\text { pants and personnel during the study. }\end{array}$ \\
\hline $\begin{array}{l}\text { Blinding of outcome as- } \\
\text { sessment (detection bias) } \\
\text { All outcomes }\end{array}$ & Low risk & Outcome detection blinded \\
\hline
\end{tabular}

\section{Starmans-Kool 2011}

\begin{tabular}{ll}
\hline Methods & CO \\
& DB \\
\hline Participants & Normales \\
& Mean age 32 \\
\hline Interventions & SR 97 (191-94) \\
\hline 14 days \\
\hline SBP \\
\hline Notcomes & DBP \\
\hline Risk of bias & LoFo 0 \\
\hline Bias & Authors' judgement Support for judgement \\
\hline $\begin{array}{l}\text { Random sequence genera- } \\
\text { tion (selection bias) }\end{array}$ & Unclear risk Insufficient information \\
\hline
\end{tabular}


1203 Starmans-Kool 2011 (Continued)

\begin{tabular}{lll}
$\begin{array}{l}\text { Allocation concealment } \\
\text { (selection bias) }\end{array}$ & Unclear risk & Insufficient information \\
\hline $\begin{array}{l}\text { Blinding (performance } \\
\text { bias and detection bias) } \\
\text { All outcomes }\end{array}$ & Low risk & Double blind study \\
\hline
\end{tabular}

\begin{tabular}{l}
\hline Incomplete outcome data $\quad$ Low risk \\
(attrition bias)
\end{tabular}

\begin{tabular}{lll}
\hline $\begin{array}{l}\text { Selective reporting (re- } \\
\text { porting bias) }\end{array}$ & Low risk & No distinct selective outcome reporting \\
\hline $\begin{array}{l}\text { Blinding of participants } \\
\begin{array}{l}\text { and personnel (perfor- } \\
\text { mance bias) }\end{array}\end{array}$ & Low risk & \\
$\begin{array}{l}\text { All outcomes } \\
\text { Blinding of outcome as- } \\
\text { sessment (detection bias) } \\
\begin{array}{l}\text { All outcomes } \\
\text { Low risk }\end{array}\end{array}$ & \\
\hline
\end{tabular}

\section{Carey 2012}

\begin{tabular}{|c|c|}
\hline Methods & $\begin{array}{l}\text { Op } \\
\text { CO }\end{array}$ \\
\hline Participants & $\begin{array}{l}\text { N } 185 \text { (M/F:72/113)(B/W/A.0/183/0) } \\
\text { Norm } \\
\text { Age } 47\end{array}$ \\
\hline Interventions & $\begin{array}{l}\text { SR } 204 \text { (188-59) } \\
\text { Dur } 7\end{array}$ \\
\hline Outcomes & SBP, DBP, renin, aldo \\
\hline Notes & No report of excluded participants. LoFo of those reported 0. \\
\hline
\end{tabular}

\section{Risk of bias}

\begin{tabular}{lll}
\hline Bias & Authors' judgement & Support for judgement \\
\hline $\begin{array}{l}\text { Random sequence genera- } \\
\text { tion (selection bias) }\end{array}$ & Unclear risk & Insufficient information \\
\hline $\begin{array}{l}\text { Allocation concealment } \\
\text { (selection bias) }\end{array}$ & Unclear risk & Insufficient information \\
\hline $\begin{array}{l}\text { Blinding (performance } \\
\text { bias and detection bias) } \\
\text { All outcomes }\end{array}$ & High risk & Open study \\
\hline
\end{tabular}

Incomplete outcome data Unclear risk No report of screening of participants. LoFo of those reported 0.

(attrition bias) 
1204 Carey 2012 (Continued)

All outcomes

\begin{tabular}{|c|c|c|}
\hline $\begin{array}{l}\text { Selective reporting (re- } \\
\text { porting bias) }\end{array}$ & Unclear risk & Insufficient information \\
\hline $\begin{array}{l}\text { Blinding of participants } \\
\text { and personnel (perfor- } \\
\text { mance bias) } \\
\text { All outcomes }\end{array}$ & High risk & $\begin{array}{l}\text { Open study: Performance bias due to knowledge of the allocated interventions } \\
\text { by participants and personnel during the study. }\end{array}$ \\
\hline $\begin{array}{l}\text { Blinding of outcome as- } \\
\text { sessment (detection bias) } \\
\text { All outcomes }\end{array}$ & High risk & $\begin{array}{l}\text { Open study: Detection bias due to knowledge of the allocated interventions by } \\
\text { outcome assessors }\end{array}$ \\
\hline
\end{tabular}

\section{Carey 2012 Hyperpath}

\begin{tabular}{ll}
\hline Methods & $\begin{array}{l}\text { Op } \\
\text { CO }\end{array}$ \\
\hline Participants & $\begin{array}{l}\text { N } 211 \text { (M/F:129/82)(B/W/A.Mixed) } \\
\text { Hypertension } \\
\text { Age } 49.2\end{array}$ \\
\hline Interventions & SR 211 \\
& Dur 7 \\
\hline Outcomes & SBP, DBP, renin, aldo \\
\hline Notes & No report of excluded participants. LoFo of those reported 0.
\end{tabular}

\section{Risk of bias}

\begin{tabular}{|c|c|c|}
\hline Bias & Authors' judgement & Support for judgement \\
\hline $\begin{array}{l}\text { Random sequence genera- } \\
\text { tion (selection bias) }\end{array}$ & Unclear risk & Insufficient information \\
\hline $\begin{array}{l}\text { Allocation concealment } \\
\text { (selection bias) }\end{array}$ & Unclear risk & Insufficient information \\
\hline $\begin{array}{l}\text { Blinding (performance } \\
\text { bias and detection bias) } \\
\text { All outcomes }\end{array}$ & High risk & Open study \\
\hline $\begin{array}{l}\text { Incomplete outcome data } \\
\text { (attrition bias) } \\
\text { All outcomes }\end{array}$ & Unclear risk & No report of excluded participants. LoFo of those reported 0. \\
\hline $\begin{array}{l}\text { Selective reporting (re- } \\
\text { porting bias) }\end{array}$ & Low risk & No distinct selective outcome reporting \\
\hline $\begin{array}{l}\text { Blinding of participants } \\
\text { and personnel (perfor- } \\
\text { mance bias) } \\
\text { All outcomes }\end{array}$ & High risk & $\begin{array}{l}\text { Open study: Performance bias due to knowledge of the allocated interventions } \\
\text { by participants and personnel during the study. }\end{array}$ \\
\hline
\end{tabular}

Effects of low sodium diet versus high sodium diet on blood pressure, renin, aldosterone, catecholamines, cholesterol, and triglyceride 
1205 Carey 2012 Hyperpath (Continued)

Blinding of outcome as- High risk Open study: Detection bias due to knowledge of the allocated interventions by sessment (detection bias)

All outcomes

\section{Graffe 2012}

\begin{tabular}{ll}
\hline Methods & DB \\
& CO \\
\hline Participants & N $21($ M/F:10/11)(B/W/A.0/11/0) \\
& Age 26 \\
\hline Interventions & SR 172 \\
& Dur 4 \\
\hline Outcomes & SBP, DBP, renin, aldo \\
\hline Notes & Included 25 \\
& LoFo: 4
\end{tabular}

\section{Risk of bias}

\begin{tabular}{|c|c|c|}
\hline Bias & Authors' judgement & Support for judgement \\
\hline $\begin{array}{l}\text { Random sequence genera- } \\
\text { tion (selection bias) }\end{array}$ & Low risk & $\begin{array}{l}\text { A computer-generated randomization list was } \\
\text { drawn up by an independent colleague. }\end{array}$ \\
\hline $\begin{array}{l}\text { Allocation concealment } \\
\text { (selection bias) }\end{array}$ & Low risk & $\begin{array}{l}\text { A copy of the list was given to the hospital kitchen, and the original was kept in } \\
\text { a sealed envelope at the department. The code was revealed when the study } \\
\text { was finished. }\end{array}$ \\
\hline $\begin{array}{l}\text { Blinding (performance } \\
\text { bias and detection bias) } \\
\text { All outcomes }\end{array}$ & Low risk & Double blind study \\
\hline $\begin{array}{l}\text { Incomplete outcome data } \\
\text { (attrition bias) } \\
\text { All outcomes }\end{array}$ & Low risk & Lost to follow-up $4 / 25$ \\
\hline $\begin{array}{l}\text { Selective reporting (re- } \\
\text { porting bias) }\end{array}$ & Low risk & No distinct selective outcome reporting \\
\hline $\begin{array}{l}\text { Blinding of participants } \\
\text { and personnel (perfor- } \\
\text { mance bias) } \\
\text { All outcomes }\end{array}$ & Low risk & Double blind study \\
\hline $\begin{array}{l}\text { Blinding of outcome as- } \\
\text { sessment (detection bias) } \\
\text { All outcomes }\end{array}$ & Low risk & Double blind study \\
\hline
\end{tabular}


1207 Krikken 2012

\begin{tabular}{|c|c|c|}
\hline Methods & \multicolumn{2}{|l|}{ Op, CO } \\
\hline Participants & \multicolumn{2}{|c|}{ N 65 (M/F:65/0)(B/W/A.0/65/0) } \\
\hline \multirow[t]{2}{*}{ Interventions } & \multicolumn{2}{|l|}{ SR 192} \\
\hline & \multicolumn{2}{|l|}{ Dur 7} \\
\hline Outcomes & \multicolumn{2}{|c|}{ SBP, DBP, Ren, Aldo, Chol, HDL, LDL } \\
\hline Notes & \multicolumn{2}{|c|}{ No report of excluded participants. LoFo of those reported 0.} \\
\hline \multicolumn{3}{|l|}{ Risk of bias } \\
\hline Bias & Authors' judgement & Support for judgement \\
\hline $\begin{array}{l}\text { Random sequence genera- } \\
\text { tion (selection bias) }\end{array}$ & Unclear risk & Insufficient information \\
\hline $\begin{array}{l}\text { Allocation concealment } \\
\text { (selection bias) }\end{array}$ & Unclear risk & Insufficient information \\
\hline $\begin{array}{l}\text { Blinding (performance } \\
\text { bias and detection bias) } \\
\text { All outcomes }\end{array}$ & High risk & Open study \\
\hline $\begin{array}{l}\text { Incomplete outcome data } \\
\text { (attrition bias) } \\
\text { All outcomes }\end{array}$ & Unclear risk & No report of excluded participants. LoFo of those reported 0. \\
\hline $\begin{array}{l}\text { Selective reporting (re- } \\
\text { porting bias) }\end{array}$ & Unclear risk & No distinct selective outcome reporting \\
\hline $\begin{array}{l}\text { Blinding of participants } \\
\text { and personnel (perfor- } \\
\text { mance bias) } \\
\text { All outcomes }\end{array}$ & High risk & $\begin{array}{l}\text { Open study: Performance bias due to knowledge of the allocated interventions } \\
\text { by participants and personnel during the study. }\end{array}$ \\
\hline $\begin{array}{l}\text { Blinding of outcome as- } \\
\text { sessment (detection bias) } \\
\text { All outcomes }\end{array}$ & Low risk & Outcome detection blinded \\
\hline
\end{tabular}

\section{Todd 2012}

\begin{tabular}{ll}
\hline Methods & SB, Co \\
\hline Participants & N 23 (M/F:5/18)(B/W/A.0/23/0) \\
& Normotension \\
& Age 43.7 \\
\hline Interventions & SR 140 \\
& Dur 28 \\
\hline
\end{tabular}


1208 Todd 2012 (Continued)

\begin{tabular}{ll} 
Outcomes & SBP, DBP \\
\hline Notes & 28 screened, 25 included, 23 randomized. LoFo. 4
\end{tabular}

\section{Risk of bias}

\begin{tabular}{|c|c|c|}
\hline Bias & Authors' judgement & Support for judgement \\
\hline $\begin{array}{l}\text { Random sequence genera- } \\
\text { tion (selection bias) }\end{array}$ & Low risk & $\begin{array}{l}\text { Randomization was carried out by a third party using http:// www.randomiza- } \\
\text { tion.com to generate the randomization } \\
\text { sequence for the tomato juice interventions. }\end{array}$ \\
\hline $\begin{array}{l}\text { Allocation concealment } \\
\text { (selection bias) }\end{array}$ & Low risk & $\begin{array}{l}\text { The sequence was given to the Dunedin hospital pharmacy, where a study } \\
\text { dedicated } \\
\text { pharmacist added the allocated amount of salt to the tomato juice. }\end{array}$ \\
\hline $\begin{array}{l}\text { Blinding (performance } \\
\text { bias and detection bias) } \\
\text { All outcomes }\end{array}$ & Low risk & Single blind study \\
\hline $\begin{array}{l}\text { Incomplete outcome data } \\
\text { (attrition bias) } \\
\text { All outcomes }\end{array}$ & Low risk & Lost to follow up $4 / 23$ \\
\hline $\begin{array}{l}\text { Selective reporting (re- } \\
\text { porting bias) }\end{array}$ & Unclear risk & No distinct selective reporting \\
\hline $\begin{array}{l}\text { Blinding of participants } \\
\text { and personnel (perfor- } \\
\text { mance bias) } \\
\text { All outcomes }\end{array}$ & Low risk & $\begin{array}{l}\text { The investigators remained blind to the randomization sequence throughout } \\
\text { the study. Participants were initially blind to the randomization sequence, but } \\
\text { once they began each phase of the intervention they were aware of the pres- } \\
\text { ence or absence of added salt. They were asked not to tell the investigator } \\
\text { which tomato juice they had received. }\end{array}$ \\
\hline $\begin{array}{l}\text { Blinding of outcome as- } \\
\text { sessment (detection bias) } \\
\text { All outcomes }\end{array}$ & Low risk & Outcome detection blinded \\
\hline
\end{tabular}

\section{Bonfils 2013}

\begin{tabular}{ll}
\hline Methods & Op, CO \\
\hline Participants & 12 obese with treated hypertension, N 12 (M/F:5/7)(B/W/A.0/12/0), Age 43 \\
& 12 obese with normal BP, N 12 (M/F:5/7)(B/W/A.0/12/0), Age 39 \\
& 12 non-obese controls with normal BP, N 12 (M/F:5/7)(B/W/A.0/12/0), Age 39 \\
\hline Interventions & SR 131 \\
\hline Outcomes & Dur 5 \\
\hline Notes & SBP, DBP \\
\hline
\end{tabular}

\section{Risk of bias}

Effects of low sodium diet versus high sodium diet on blood pressure, renin, aldosterone, catecholamines, cholesterol, and triglyceride 
1209 Bonfils 2013 (Continued)

Bias Authors' judgement Support for judgement

Random sequence genera- High risk tion (selection bias)

Simple randomization, that is tossing a coin to decide whether patients should have low-salt diet followed

by high-salt diet or vice versa.

\begin{tabular}{lll}
\hline $\begin{array}{l}\text { Allocation concealment } \\
\text { (selection bias) }\end{array}$ & High risk & $\begin{array}{l}\text { The primary investigator assigned participants to the interventions according } \\
\text { to the randomization } \\
\text { sequence. The patients were not blinded for treatment assignment. }\end{array}$ \\
\hline $\begin{array}{l}\text { Blinding (performance } \\
\text { bias and detection bias) } \\
\text { All outcomes }\end{array}$ & High risk & Open study \\
\hline
\end{tabular}

\begin{tabular}{|c|c|c|}
\hline $\begin{array}{l}\text { Incomplete outcome data } \\
\text { (attrition bias) } \\
\text { All outcomes }\end{array}$ & Unclear risk & No report of excluded participants. LoFo of those reported 0. \\
\hline $\begin{array}{l}\text { Selective reporting (re- } \\
\text { porting bias) }\end{array}$ & Unclear risk & No distinct reporting bias \\
\hline $\begin{array}{l}\text { Blinding of participants } \\
\text { and personnel (perfor- } \\
\text { mance bias) } \\
\text { All outcomes }\end{array}$ & High risk & $\begin{array}{l}\text { Open study: Performance bias due to knowledge of the allocated interventions } \\
\text { by participants and personnel during the study. }\end{array}$ \\
\hline $\begin{array}{l}\text { Blinding of outcome as- } \\
\text { sessment (detection bias) } \\
\text { All outcomes }\end{array}$ & Low risk & Outcome detection blinded \\
\hline
\end{tabular}

\section{Mak 2013}

\begin{tabular}{ll}
\hline Methods & Op, CO \\
\hline Participants & N 13 (M/F:12/1)(B/W/A.0/13/0) \\
& Normotension \\
& Age 24 \\
\hline Interventions & SR: 190 \\
\hline Dur: 7 \\
\hline Notes & SBP, DBP \\
\hline Risk of bias & No report of excluded participants. LoFo of those reported 0. \\
\hline Bias & Authors' judgement Support for judgement \\
\hline $\begin{array}{l}\text { Random sequence genera- } \\
\text { tion (selection bias) }\end{array}$ & Unclear risk Insufficient information \\
\hline
\end{tabular}

Effects of low sodium diet versus high sodium diet on blood pressure, renin, aldosterone, catecholamines, cholesterol, and triglyceride 
1212 Mak 2013 (Continued)

\begin{tabular}{lll}
$\begin{array}{l}\text { Allocation concealment } \\
\text { (selection bias) }\end{array}$ & Unclear risk & Insufficient information \\
\hline $\begin{array}{l}\text { Blinding (performance } \\
\text { bias and detection bias) }\end{array}$ & High risk & Open study \\
All outcomes & &
\end{tabular}

\begin{tabular}{lll}
\hline $\begin{array}{l}\text { Incomplete outcome data } \\
\text { (attrition bias) } \\
\text { All outcomes }\end{array}$ & Unclear risk & No report of excluded participants. Lost to follow up of those reported 0. \\
\hline $\begin{array}{l}\text { Selective reporting (re- } \\
\text { porting bias) }\end{array}$ & Unclear risk & Insufficient information \\
\hline $\begin{array}{l}\text { Blinding of participants } \\
\text { and personnel (perfor- } \\
\text { mance bias) } \\
\begin{array}{l}\text { All outcomes } \\
\text { Blinding of outcome as- }\end{array}\end{array}$ & High risk & $\begin{array}{l}\text { Open study: Performance bias due to knowledge of the allocated interventions } \\
\text { by participants and personnel during the study. }\end{array}$ \\
$\begin{array}{l}\text { sessment (detection bias) } \\
\text { All outcomes }\end{array}$ & & \\
\hline
\end{tabular}

\section{Mallamaci 2013}

\begin{tabular}{ll}
\hline Methods & Op, CO \\
\hline Participants & $\begin{array}{l}\text { N } 32 \text { (M/F:23/9)(B/W/A.0/32/0) } \\
\text { Agpertension } 48\end{array}$ \\
\hline Interventions & SR 165 \\
Dur 14 \\
\hline Outcomes & SBP, DBP, renin, aldo \\
\hline Notes & 32 of 102 screened were randomized. LoFo: 0 \\
\hline
\end{tabular}

\section{Risk of bias}

\begin{tabular}{lll}
\hline Bias & Authors' judgement & Support for judgement \\
\hline $\begin{array}{l}\text { Random sequence genera- } \\
\text { tion (selection bias) }\end{array}$ & Unclear risk & Insufficient information \\
\hline $\begin{array}{l}\text { Allocation concealment } \\
\text { (selection bias) }\end{array}$ & Unclear risk & Insufficient information \\
\hline $\begin{array}{l}\text { Blinding (performance } \\
\text { bias and detection bias) } \\
\text { All outcomes }\end{array}$ & High risk & Open study \\
\hline
\end{tabular}

Incomplete outcome data Low risk $\quad$ Lost to follow up 0/32
(attrition bias)


1213 Mallamaci 2013 (Continued)

All outcomes

Selective reporting (re- Low risk No distinct selective outcome reporting
porting bias)

\begin{tabular}{|c|c|c|}
\hline $\begin{array}{l}\text { Blinding of participants } \\
\text { and personnel (perfor- } \\
\text { mance bias) } \\
\text { All outcomes }\end{array}$ & High risk & $\begin{array}{l}\text { Open study: Performance bias due to knowledge of the allocated interventions } \\
\text { by participants and personnel during the study. }\end{array}$ \\
\hline $\begin{array}{l}\text { Blinding of outcome as- } \\
\text { sessment (detection bias) } \\
\text { All outcomes }\end{array}$ & Low risk & Outcome detection blinded \\
\hline
\end{tabular}

\section{Dickinson 2014}

\begin{tabular}{ll}
\hline Methods & SB, CO \\
\hline Participants & $\begin{array}{l}\text { N 25 (M/F:/)(B/W/A.0/25/0) } \\
\text { Normotension } \\
\text { Age 35.1 }\end{array}$ \\
\hline Interventions & SR 42 \\
& Dur 42 \\
\hline Outcomes & SBP, DBP, renin, aldo, \\
\hline Notes & Screened 87, Randomized 50, allocated to diet 34, received diet 25 \\
\hline
\end{tabular}

\section{Risk of bias}

\begin{tabular}{|c|c|c|}
\hline Bias & Authors' judgement & Support for judgement \\
\hline $\begin{array}{l}\text { Random sequence genera- } \\
\text { tion (selection bias) }\end{array}$ & Unclear risk & Insufficient information \\
\hline $\begin{array}{l}\text { Allocation concealment } \\
\text { (selection bias) }\end{array}$ & Unclear risk & Insufficient information \\
\hline $\begin{array}{l}\text { Blinding (performance } \\
\text { bias and detection bias) } \\
\text { All outcomes }\end{array}$ & Unclear risk & Single blind \\
\hline $\begin{array}{l}\text { Incomplete outcome data } \\
\text { (attrition bias) } \\
\text { All outcomes }\end{array}$ & High risk & Lost to follow up $9 / 34$ \\
\hline $\begin{array}{l}\text { Selective reporting (re- } \\
\text { porting bias) }\end{array}$ & Unclear risk & No distinct selective reporting \\
\hline $\begin{array}{l}\text { Blinding of participants } \\
\text { and personnel (perfor- } \\
\text { mance bias) } \\
\text { All outcomes }\end{array}$ & High risk & $\begin{array}{l}\text { Performance bias due to knowledge of the allocated interventions by partici- } \\
\text { pants and personnel during the study. }\end{array}$ \\
\hline
\end{tabular}

Effects of low sodium diet versus high sodium diet on blood pressure, renin, aldosterone, catecholamines, cholesterol, and triglyceride 
1214 Dickinson 2014 (Continued)
Blinding of outcome as-
Low risk
Outcome detection blinded sessment (detection bias)

All outcomes

\section{Allen 2014}

\begin{tabular}{ll}
\hline Methods & Op, CO \\
\hline Participants & N 70 (M/F:26/44)(B/W/A.0/70/0) \\
& Normotension \\
& Age 24 \\
\hline Interventions & SR 83 \\
\hline Outcomes & Dur 5 \\
\hline Notes & SBP, DBP \\
\hline
\end{tabular}

\section{Risk of bias}

\begin{tabular}{|c|c|c|}
\hline Bias & Authors' judgement & Support for judgement \\
\hline $\begin{array}{l}\text { Random sequence genera- } \\
\text { tion (selection bias) }\end{array}$ & Unclear risk & Insufficient information \\
\hline $\begin{array}{l}\text { Allocation concealment } \\
\text { (selection bias) }\end{array}$ & Unclear risk & Insufficient information \\
\hline $\begin{array}{l}\text { Blinding (performance } \\
\text { bias and detection bias) } \\
\text { All outcomes }\end{array}$ & High risk & Open study \\
\hline $\begin{array}{l}\text { Incomplete outcome data } \\
\text { (attrition bias) } \\
\text { All outcomes }\end{array}$ & Unclear risk & No report of excluded participants. lost to follow up of those reported $0 / 70$. \\
\hline $\begin{array}{l}\text { Selective reporting (re- } \\
\text { porting bias) }\end{array}$ & Unclear risk & No distinct selective reporting \\
\hline $\begin{array}{l}\text { Blinding of participants } \\
\text { and personnel (perfor- } \\
\text { mance bias) } \\
\text { All outcomes }\end{array}$ & High risk & $\begin{array}{l}\text { Open study: Performance bias due to knowledge of the allocated interventions } \\
\text { by participants and personnel during the study. }\end{array}$ \\
\hline $\begin{array}{l}\text { Blinding of outcome as- } \\
\text { sessment (detection bias) } \\
\text { All outcomes }\end{array}$ & High risk & $\begin{array}{l}\text { Open study: Detection bias due to knowledge of the allocated interventions by } \\
\text { outcome assessors }\end{array}$ \\
\hline
\end{tabular}

\section{Barros 2015}

Methods Op,

Effects of low sodium diet versus high sodium diet on blood pressure, renin, aldosterone, catecholamines, cholesterol, and triglyceride 
1216 Barros 2015 (Continued)

P

\begin{tabular}{ll}
\hline Participants & $\begin{array}{l}\text { N } 35(\mathrm{M} / \mathrm{F}: 12 / 24)(\mathrm{B} / \mathrm{W} / \mathrm{A} . \text { ? Brazilians) } \\
\text { Hypertension } \\
\text { Age } 55.5\end{array}$ \\
\hline Interventions & SR: 48 \\
& Dur: 28 \\
\hline Outcomes & SBP, DBP \\
\hline Notes & 38 of 56 screened were randomized. LoFo 3 \\
\hline
\end{tabular}

\section{Risk of bias}

\begin{tabular}{|c|c|c|}
\hline Bias & Authors' judgement & Support for judgement \\
\hline $\begin{array}{l}\text { Random sequence genera- } \\
\text { tion (selection bias) }\end{array}$ & High risk & Participants were randomized "according to the order of visit" \\
\hline $\begin{array}{l}\text { Allocation concealment } \\
\text { (selection bias) }\end{array}$ & High risk & $\begin{array}{l}\text { "Participants received plastic bags containing the daily amount of salt." "Par- } \\
\text { ticipants were not aware of the type of salt they were receiving" (but the re- } \\
\text { searcher was. }\end{array}$ \\
\hline $\begin{array}{l}\text { Blinding (performance } \\
\text { bias and detection bias) } \\
\text { All outcomes }\end{array}$ & High risk & Single blind (participant) \\
\hline $\begin{array}{l}\text { Incomplete outcome data } \\
\text { (attrition bias) } \\
\text { All outcomes }\end{array}$ & Low risk & Lost to follow up LS: 3/19; US: 0/19 \\
\hline $\begin{array}{l}\text { Selective reporting (re- } \\
\text { porting bias) }\end{array}$ & Low risk & No distinct selective outcome reporting \\
\hline $\begin{array}{l}\text { Blinding of participants } \\
\text { and personnel (perfor- } \\
\text { mance bias) } \\
\text { All outcomes }\end{array}$ & High risk & $\begin{array}{l}\text { Open study: Performance bias due to knowledge of the allocated interventions } \\
\text { by personnel during the study. }\end{array}$ \\
\hline $\begin{array}{l}\text { Blinding of outcome as- } \\
\text { sessment (detection bias) } \\
\text { All outcomes }\end{array}$ & High risk & $\begin{array}{l}\text { Open study: Detection bias due to knowledge of the allocated interventions by } \\
\text { outcome assessors }\end{array}$ \\
\hline
\end{tabular}

1217 Markota 2015

\begin{tabular}{ll}
\hline Methods & Op, $\mathrm{P}$ \\
\hline Participants & $\begin{array}{l}\text { N } 150 \text { (M/F:77/73) (B/W/A. 0/150/0) } \\
\text { Hypertension } \\
\text { Age } 59.4\end{array}$ \\
\hline Interventions & SR: 28 \\
& Dur: 60 \\
\hline
\end{tabular}

Effects of low sodium diet versus high sodium diet on blood pressure, renin, aldosterone, catecholamines, cholesterol, and triglyceride 
1217 Markota 2015 (Continued)

\begin{tabular}{ll} 
Outcomes & SBP, DBP \\
\hline Notes & 150 of 171 fulfilling inclusion criteria were randomized. LoFo 0
\end{tabular}

\section{Risk of bias}

\begin{tabular}{|c|c|c|}
\hline Bias & Authors' judgement & Support for judgement \\
\hline $\begin{array}{l}\text { Random sequence genera- } \\
\text { tion (selection bias) }\end{array}$ & Unclear risk & Insufficient information \\
\hline $\begin{array}{l}\text { Allocation concealment } \\
\text { (selection bias) }\end{array}$ & Low risk & instructions in sealed envelopes \\
\hline $\begin{array}{l}\text { Blinding (performance } \\
\text { bias and detection bias) } \\
\text { All outcomes }\end{array}$ & High risk & Open study \\
\hline $\begin{array}{l}\text { Incomplete outcome data } \\
\text { (attrition bias) } \\
\text { All outcomes }\end{array}$ & Low risk & Lost to follow up $0 / 150$ \\
\hline $\begin{array}{l}\text { Selective reporting (re- } \\
\text { porting bias) }\end{array}$ & Low risk & No distinct selective outcome reporting \\
\hline $\begin{array}{l}\text { Blinding of participants } \\
\text { and personnel (perfor- } \\
\text { mance bias) } \\
\text { All outcomes }\end{array}$ & High risk & $\begin{array}{l}\text { Open study: Performance bias due to knowledge of the allocated interventions } \\
\text { by participants and personnel during the study. }\end{array}$ \\
\hline $\begin{array}{l}\text { Blinding of outcome as- } \\
\text { sessment (detection bias) } \\
\text { All outcomes }\end{array}$ & High risk & $\begin{array}{l}\text { Open study: Detection bias due to knowledge of the allocated interventions by } \\
\text { outcome assessors }\end{array}$ \\
\hline
\end{tabular}

1218 Visser 2008

\begin{tabular}{ll}
\hline Methods & Op, CO \\
\hline Participants & N 34 (M/F:34/0)(B/W/A.0/34/0) \\
& Normotension \\
& Age 26.5 \\
\hline Interventions & SR 181 \\
& Dur 7 \\
\hline Outcomes & SBP, DBP, renin, aldo, cholesterol \\
\hline Notes & No report of excluded participants. Lost to follow up of those reported 0.
\end{tabular}

\section{Risk of bias}

Bias Authors' judgement Support for judgement

Effects of low sodium diet versus high sodium diet on blood pressure, renin, aldosterone, catecholamines, cholesterol, and triglyceride 
1218 Visser 2008 (Continued)

\begin{tabular}{lll}
$\begin{array}{l}\text { Random sequence genera- } \\
\text { tion (selection bias) }\end{array}$ & Unclear risk & Insufficient information \\
\hline $\begin{array}{l}\text { Allocation concealment } \\
\text { (selection bias) }\end{array}$ & Unclear risk & Insufficient information \\
\hline $\begin{array}{l}\text { Blinding (performance } \\
\text { bias and detection bias) } \\
\text { All outcomes }\end{array}$ & High risk & Open study \\
\hline
\end{tabular}

\begin{tabular}{|c|c|c|}
\hline $\begin{array}{l}\text { Incomplete outcome data } \\
\text { (attrition bias) } \\
\text { All outcomes }\end{array}$ & Unclear risk & No report of excluded participants. Lost to follow up of those reported 0. \\
\hline $\begin{array}{l}\text { Selective reporting (re- } \\
\text { porting bias) }\end{array}$ & Unclear risk & No distinct selective reporting \\
\hline $\begin{array}{l}\text { Blinding of participants } \\
\text { and personnel (perfor- } \\
\text { mance bias) } \\
\text { All outcomes }\end{array}$ & High risk & $\begin{array}{l}\text { Open study: Performance bias due to knowledge of the allocated interventions } \\
\text { by participants and personnel during the study. }\end{array}$ \\
\hline $\begin{array}{l}\text { Blinding of outcome as- } \\
\text { sessment (detection bias) } \\
\text { All outcomes }\end{array}$ & High risk & $\begin{array}{l}\text { Open study: Detection bias due to knowledge of the allocated interventions by } \\
\text { outcome assessors }\end{array}$ \\
\hline
\end{tabular}

1219 Sharma 31993

\begin{tabular}{ll}
\hline Methods & SB, CO \\
\hline Participants & N 18 (M/F:18/0)(B/W/A.0/18/0) \\
& Normotension \\
& Age 24 \\
\hline Interventions & SR 218 \\
& Dur 7 \\
\hline Outcomes & SBP, DBP \\
\hline Notes & No report of excluded participants. Lost to follow up 0. \\
\hline
\end{tabular}

\section{Risk of bias}

\begin{tabular}{lll}
\hline Bias & Authors' judgement & Support for judgement \\
\hline $\begin{array}{l}\text { Random sequence genera- } \\
\text { tion (selection bias) }\end{array}$ & Unclear risk & Insufficient information \\
\hline $\begin{array}{l}\text { Allocation concealment } \\
\text { (selection bias) }\end{array}$ & Unclear risk & Insufficient information \\
\hline $\begin{array}{l}\text { Blinding (performance } \\
\text { bias and detection bias) }\end{array}$ & High risk & Open study \\
\hline
\end{tabular}

Effects of low sodium diet versus high sodium diet on blood pressure, renin, aldosterone, catecholamines, cholesterol, and triglyceride 
1219 Sharma 31993 (Continued)

All outcomes

Incomplete outcome data $\quad$ Low risk $\quad$ Lost to follow up 0/18
(attrition bias)

(attrition bias)

All outcomes

Selective reporting (re- Low risk No distinct selective reporting
porting bias)

\begin{tabular}{|c|c|c|}
\hline $\begin{array}{l}\text { Blinding of participants } \\
\text { and personnel (perfor- } \\
\text { mance bias) } \\
\text { All outcomes }\end{array}$ & High risk & $\begin{array}{l}\text { Open study: Performance bias due to knowledge of the allocated interventions } \\
\text { by participants and personnel during the study. }\end{array}$ \\
\hline
\end{tabular}

\begin{tabular}{|c|c|c|}
\hline $\begin{array}{l}\text { Blinding of outcome as- } \\
\text { sessment (detection bias) } \\
\text { All outcomes }\end{array}$ & Low risk & Outcome detection blinded \\
\hline
\end{tabular}

\section{Gomi 1998}

\begin{tabular}{ll}
\hline Methods & Op, CO \\
\hline Participants & N 12 (M/F:8/4)(B/W/A.0/0/12) \\
& Hypertension \\
& Age 51.8 \\
\hline Interventions & SR 70 \\
\hline Outcomes & Dur 7 \\
\hline Notes & SBP, DBP, renin, aldosterone, noradrenalin \\
\hline
\end{tabular}

\section{Risk of bias}

\begin{tabular}{|c|c|c|}
\hline Bias & Authors' judgement & Support for judgement \\
\hline $\begin{array}{l}\text { Random sequence genera- } \\
\text { tion (selection bias) }\end{array}$ & Unclear risk & Insufficient information \\
\hline $\begin{array}{l}\text { Allocation concealment } \\
\text { (selection bias) }\end{array}$ & Unclear risk & Insufficient information \\
\hline $\begin{array}{l}\text { Blinding (performance } \\
\text { bias and detection bias) } \\
\text { All outcomes }\end{array}$ & High risk & Open study \\
\hline $\begin{array}{l}\text { Incomplete outcome data } \\
\text { (attrition bias) } \\
\text { All outcomes }\end{array}$ & Low risk & Lost to follow up 0. \\
\hline $\begin{array}{l}\text { Selective reporting (re- } \\
\text { porting bias) }\end{array}$ & Low risk & No distinct selective outcome reporting \\
\hline
\end{tabular}

Effects of low sodium diet versus high sodium diet on blood pressure, renin, aldosterone, catecholamines, cholesterol, and triglyceride 
1220 Gomi 1998 (Continued)

Blinding of participants High risk Open study: Performance bias due to knowledge of the allocated interventions and personnel (perfor-

mance bias)

All outcomes

Blinding of outcome as- Low risk Outcome detection blinded

sessment (detection bias)

All outcomes

\section{Facchini 1999}

\begin{tabular}{ll}
\hline Methods & Op, CO \\
\hline Participants & N 19 (M/F:17/2)(B/W/A.0/19/0) \\
& Normotension \\
& Age 43 \\
\hline Interventions & SR 168.7 \\
& Dur 5 \\
\hline Outcomes & SBP, DBP, renin, aldosterone \\
\hline Notes & LoFo 0 \\
\hline
\end{tabular}

\section{Risk of bias}

\begin{tabular}{|c|c|c|}
\hline Bias & Authors' judgement & Support for judgement \\
\hline $\begin{array}{l}\text { Random sequence genera- } \\
\text { tion (selection bias) }\end{array}$ & Unclear risk & Insufficient information \\
\hline $\begin{array}{l}\text { Allocation concealment } \\
\text { (selection bias) }\end{array}$ & Unclear risk & Insufficient information \\
\hline $\begin{array}{l}\text { Blinding (performance } \\
\text { bias and detection bias) } \\
\text { All outcomes }\end{array}$ & High risk & Open study \\
\hline $\begin{array}{l}\text { Incomplete outcome data } \\
\text { (attrition bias) } \\
\text { All outcomes }\end{array}$ & Low risk & Lost to follow up 0 \\
\hline $\begin{array}{l}\text { Selective reporting (re- } \\
\text { porting bias) }\end{array}$ & Low risk & No distinct selective outcome reporting \\
\hline $\begin{array}{l}\text { Blinding of participants } \\
\text { and personnel (perfor- } \\
\text { mance bias) } \\
\text { All outcomes }\end{array}$ & High risk & $\begin{array}{l}\text { Open study: Performance bias due to knowledge of the allocated interventions } \\
\text { by participants and personnel during the study. }\end{array}$ \\
\hline $\begin{array}{l}\text { Blinding of outcome as- } \\
\text { sessment (detection bias) } \\
\text { All outcomes }\end{array}$ & Low risk & Outcome detection blinded \\
\hline
\end{tabular}

Effects of low sodium diet versus high sodium diet on blood pressure, renin, aldosterone, catecholamines, cholesterol, and triglyceride 


\begin{tabular}{ll}
\hline Methods & Op, CO \\
\hline Participants & N 35 (M/F:0/35)(B/W/A.0/35/0) \\
& Normotension \\
& Age 28.9 \\
\hline Interventions & SR 177.8 \\
& Dur 7 \\
\hline Outcomes & SBP, DBP, renin, aldosterone, noradrenalin \\
\hline Notes & LoFo 0
\end{tabular}

\section{Risk of bias}

Bias Authors' judgement Support for judgement

\begin{tabular}{l}
$\begin{array}{l}\text { Random sequence genera- } \\
\text { tion (selection bias) }\end{array}$ \\
\hline
\end{tabular}

\begin{tabular}{|c|c|c|}
\hline $\begin{array}{l}\text { Allocation concealment } \\
\text { (selection bias) }\end{array}$ & Unclear risk & Insufficient information \\
\hline $\begin{array}{l}\text { Blinding (performance } \\
\text { bias and detection bias) } \\
\text { All outcomes }\end{array}$ & High risk & Open study \\
\hline $\begin{array}{l}\text { Incomplete outcome data } \\
\text { (attrition bias) } \\
\text { All outcomes }\end{array}$ & Low risk & Lost to follow up $0 / 35$ \\
\hline $\begin{array}{l}\text { Selective reporting (re- } \\
\text { porting bias) }\end{array}$ & Low risk & No distinct selective outcome reporting \\
\hline $\begin{array}{l}\text { Blinding of participants } \\
\text { and personnel (perfor- } \\
\text { mance bias) } \\
\text { All outcomes }\end{array}$ & High risk & $\begin{array}{l}\text { Open study: Performance bias due to knowledge of the allocated interventions } \\
\text { by participants and personnel during the study. }\end{array}$ \\
\hline $\begin{array}{l}\text { Blinding of outcome as- } \\
\text { sessment (detection bias) } \\
\text { All outcomes }\end{array}$ & Low risk & Outcome detection blinded \\
\hline
\end{tabular}

\section{Pechère-Bertschi 2003}

\begin{tabular}{ll}
\hline Methods & Op, CO \\
\hline Participants & N 27 (M/F:0/27)(B/W/A.0/27/0) \\
& Normotension
\end{tabular}


1223 Pechère-Bertschi 2003 (Continued)

Age 26

\begin{tabular}{ll}
\hline Interventions & SR 192.8 \\
& Dur 7 \\
\hline Outcomes & SBP, DBP, renin, aldosterone, noradrenalin, adrenalin \\
\hline Notes & LoFo 0 \\
\hline
\end{tabular}

Risk of bias

\begin{tabular}{|c|c|c|}
\hline Bias & Authors' judgement & Support for judgement \\
\hline $\begin{array}{l}\text { Random sequence genera- } \\
\text { tion (selection bias) }\end{array}$ & Unclear risk & Insufficient information \\
\hline $\begin{array}{l}\text { Allocation concealment } \\
\text { (selection bias) }\end{array}$ & Unclear risk & Insufficient information \\
\hline $\begin{array}{l}\text { Blinding (performance } \\
\text { bias and detection bias) } \\
\text { All outcomes }\end{array}$ & High risk & Open study \\
\hline $\begin{array}{l}\text { Incomplete outcome data } \\
\text { (attrition bias) } \\
\text { All outcomes }\end{array}$ & Low risk & Lost to follow up $0 / 27$ \\
\hline $\begin{array}{l}\text { Selective reporting (re- } \\
\text { porting bias) }\end{array}$ & Low risk & No distinct selective outcome reporting \\
\hline $\begin{array}{l}\text { Blinding of participants } \\
\text { and personnel (perfor- } \\
\text { mance bias) } \\
\text { All outcomes }\end{array}$ & High risk & $\begin{array}{l}\text { Open study: Performance bias due to knowledge of the allocated interventions } \\
\text { by participants and personnel during the study. }\end{array}$ \\
\hline $\begin{array}{l}\text { Blinding of outcome as- } \\
\text { sessment (detection bias) } \\
\text { All outcomes }\end{array}$ & Low risk & Outcome detection blinded \\
\hline
\end{tabular}

1224 Ho 2007

\begin{tabular}{ll}
\hline Methods & Op, CO \\
\hline Participants & N 25 (M/F:8/17)(B/W/A.0/25/0) \\
& Normotension \\
& Age 48.8 \\
\hline Interventions & SR 206.9 \\
\hline Outcomes & Dur 14 \\
\hline
\end{tabular}


1224 Ho 2007 (Continued)
Notes
101 screened, 44 included, LoFo 19

\section{Risk of bias}

\begin{tabular}{|c|c|c|}
\hline Bias & Authors' judgement & Support for judgement \\
\hline $\begin{array}{l}\text { Random sequence genera- } \\
\text { tion (selection bias) }\end{array}$ & Unclear risk & Insufficient information \\
\hline $\begin{array}{l}\text { Allocation concealment } \\
\text { (selection bias) }\end{array}$ & Unclear risk & Insufficient information \\
\hline $\begin{array}{l}\text { Blinding (performance } \\
\text { bias and detection bias) } \\
\text { All outcomes }\end{array}$ & High risk & Open study \\
\hline $\begin{array}{l}\text { Incomplete outcome data } \\
\text { (attrition bias) } \\
\text { All outcomes }\end{array}$ & High risk & Lost to follow up $19 / 44$ \\
\hline $\begin{array}{l}\text { Selective reporting (re- } \\
\text { porting bias) }\end{array}$ & Low risk & No distinct selective outcome reporting \\
\hline $\begin{array}{l}\text { Blinding of participants } \\
\text { and personnel (perfor- } \\
\text { mance bias) } \\
\text { All outcomes }\end{array}$ & High risk & $\begin{array}{l}\text { Open study: Performance bias due to knowledge of the allocated interventions } \\
\text { by participants and personnel during the study. }\end{array}$ \\
\hline $\begin{array}{l}\text { Blinding of outcome as- } \\
\text { sessment (detection bias) } \\
\text { All outcomes }\end{array}$ & Low risk & Outcome detection blinded \\
\hline
\end{tabular}

\section{Gijsbers 2015}

\begin{tabular}{ll}
\hline Methods & DB, CO \\
\hline Participants & N 36 (M/F:24/12)(B/W/A.0/36/0) \\
& Hypertension \\
& Age 65.8 \\
\hline Interventions & SR 206.9 \\
& Dur 28 \\
\hline Outcomes & SBP, DBP, cholesterol, triglyceride, HDL, LDL \\
\hline Notes & 83 screened, 37 randomized, lost to follow up 1 \\
\hline Risk of bias & Authors' judgement Support for judgement \\
\hline Bias & Low risk computer-generated table \\
\hline $\begin{array}{l}\text { Random sequence genera- } \\
\text { tion (selection bias) }\end{array}$ & \\
\hline \hline
\end{tabular}

Effects of low sodium diet versus high sodium diet on blood pressure, renin, aldosterone, catecholamines, cholesterol, and triglyceride 
1225 Gijsbers 2015 (Continued)

\begin{tabular}{|c|c|c|}
\hline $\begin{array}{l}\text { Allocation concealment } \\
\text { (selection bias) }\end{array}$ & Low risk & independent person \\
\hline $\begin{array}{l}\text { Blinding (performance } \\
\text { bias and detection bias) } \\
\text { All outcomes }\end{array}$ & Low risk & Double blind study \\
\hline
\end{tabular}

\begin{tabular}{|c|c|c|}
\hline $\begin{array}{l}\text { Incomplete outcome data } \\
\text { (attrition bias) } \\
\text { All outcomes }\end{array}$ & Low risk & lost to follow up $1 / 37$ \\
\hline $\begin{array}{l}\text { Selective reporting (re- } \\
\text { porting bias) }\end{array}$ & Low risk & No distinct selective outcome reporting \\
\hline $\begin{array}{l}\text { Blinding of participants } \\
\text { and personnel (perfor- } \\
\text { mance bias) } \\
\text { All outcomes }\end{array}$ & Low risk & Double blind study \\
\hline $\begin{array}{l}\text { Blinding of outcome as- } \\
\text { sessment (detection bias) } \\
\text { All outcomes }\end{array}$ & Low risk & Double blind study \\
\hline
\end{tabular}

\section{Cavka 2015}

\begin{tabular}{|c|c|c|}
\hline Methods & \multicolumn{2}{|l|}{$\mathrm{SB}, \mathrm{P}$} \\
\hline \multirow[t]{3}{*}{ Participants } & \multicolumn{2}{|c|}{ N 54 (M/F:0/54)(B/W/A.0/54/0) } \\
\hline & \multicolumn{2}{|l|}{ Normotension } \\
\hline & \multicolumn{2}{|l|}{ Age 20} \\
\hline \multirow[t]{2}{*}{ Interventions } & \multicolumn{2}{|l|}{ SR 149.4} \\
\hline & \multicolumn{2}{|l|}{ Dur 7} \\
\hline Outcomes & \multicolumn{2}{|c|}{ SBP, DBP, renin, aldosterone } \\
\hline Notes & \multicolumn{2}{|l|}{ LoFo 0} \\
\hline \multicolumn{3}{|l|}{ Risk of bias } \\
\hline Bias & Authors' judgement & Support for judgement \\
\hline $\begin{array}{l}\text { Random sequence genera- } \\
\text { tion (selection bias) }\end{array}$ & Unclear risk & Insufficient information \\
\hline $\begin{array}{l}\text { Allocation concealment } \\
\text { (selection bias) }\end{array}$ & Unclear risk & Insufficient information \\
\hline $\begin{array}{l}\text { Blinding (performance } \\
\text { bias and detection bias) } \\
\text { All outcomes }\end{array}$ & High risk & Single blind \\
\hline
\end{tabular}


1226 Cavka 2015 (Continued)
Incomplete outcome data
Low risk
Lost to follow up LS: 0/24; US: 0/30
(attrition bias)

All outcomes

Selective reporting (re- Low risk No distinct selective outcome reporting
porting bias)

\begin{tabular}{|c|c|c|}
\hline $\begin{array}{l}\text { Blinding of participants } \\
\text { and personnel (perfor- } \\
\text { mance bias) } \\
\text { All outcomes }\end{array}$ & High risk & $\begin{array}{l}\text { Open study: Performance bias due to knowledge of the allocated interventions } \\
\text { by participants and personnel during the study. }\end{array}$ \\
\hline
\end{tabular}

Blinding of outcome as- Low risk Outcome detection blinded

sessment (detection bias)

All outcomes

\section{McManus 2015}

\begin{tabular}{ll}
\hline Methods & Op, CO \\
\hline Participants & N 60 (M/F:27/33)(B/W/A.0/60/0) \\
& Normotension \\
& Age 50.1 \\
\hline Interventions & SR 102.7 \\
& Dur 5 \\
\hline Outcomes & Aldosterone \\
\hline Notes & LoFo 0 \\
\hline
\end{tabular}

\section{Risk of bias}

\begin{tabular}{|c|c|c|}
\hline Bias & Authors' judgement & Support for judgement \\
\hline $\begin{array}{l}\text { Random sequence genera- } \\
\text { tion (selection bias) }\end{array}$ & Unclear risk & Insufficient information \\
\hline $\begin{array}{l}\text { Allocation concealment } \\
\text { (selection bias) }\end{array}$ & Unclear risk & Insufficient information \\
\hline $\begin{array}{l}\text { Blinding (performance } \\
\text { bias and detection bias) } \\
\text { All outcomes }\end{array}$ & High risk & Open study \\
\hline $\begin{array}{l}\text { Incomplete outcome data } \\
\text { (attrition bias) } \\
\text { All outcomes }\end{array}$ & Low risk & Lost to follow up $0 / 60$ \\
\hline $\begin{array}{l}\text { Selective reporting (re- } \\
\text { porting bias) }\end{array}$ & Low risk & No distinct selective outcome reporting \\
\hline
\end{tabular}




\section{McManus 2015 (Continued)}
Blinding of participants
High risk
Open study: Performance bias due to knowledge of the allocated interventions and personnel (perfor- mance bias)
All outcomes

\section{by participants and personnel during the study.}

\begin{tabular}{lll}
\hline Blinding of outcome as- & Low risk & Outcome detection blinded \\
sessment (detection bias) &
\end{tabular}
All outcomes
A: adrenaline; Age: mean age of persons in trial; Chol: cholesterol; CO: cross-over; DB: double blind; DBP: net change of diastolic blood pressure, mmHg; Dur: duration of intervention, days; HDL: high-density lipoprotein; Hyp: hypertensive; LDL: low-density lipoprotein; TG: triglyceride; LoFo: number lost to follow-up; IT: "intention-to-treat" of those lost to follow-up; N: number of persons in trial; NA: noradrenaline; Norm: normotensive; Op: open; P: parallel; SB: single-blind; SBP: net change of systolic blood pressure, $\mathrm{mmHg}$; $\mathbf{S R}$ : sodium reduction, $\mathrm{mmol} / 24$ hours

\section{Characteristics of excluded studies [ordered by study ID]}

\begin{tabular}{|c|c|}
\hline Study & Reason for exclusion \\
\hline Anderson 1990 & No data on urine sodium excretion \\
\hline Dodson 1989 & Includes only patients with diabetes mellitus \\
\hline Imanishi 2001 & Includes only patients with diabetes mellitus \\
\hline Jula-Karanko 1992 & Duplicate: all data could be extracted from a later paper (1110 Jula 1994) \\
\hline Jula-Mäki 1992 & Duplicate: all data could be extracted from a later paper (1110 Jula 1994) \\
\hline Miller 1997 & Includes only patients with diabetes mellitus \\
\hline Mühlhauser 1996 & Includes only patients with diabetes mellitus \\
\hline Palmer 1989 & No data on urine sodium excretion \\
\hline Parfrey 1981 & Withdrawal of paper by the authors due to erroneous form \\
\hline Ruppert 1991 & Sub-study of 1088 Ruppert 1993 \\
\hline Ruppert 1994 & Sub-study of 1088 Ruppert 1993 \\
\hline Steegers 1991 & Sub-study of 1136 van Buul 1997 \\
\hline
\end{tabular}

\section{DATA AND ANALYSES}


Comparison 1. Effect of salt reduction on systolic blood pressure (SBP) and diastolic blood pressure (DBP) in Whites

\begin{tabular}{llllll}
\hline Outcome or subgroup title & $\begin{array}{l}\text { No. of } \\
\text { studies }\end{array}$ & $\begin{array}{l}\text { No. of } \\
\text { partici- } \\
\text { pants }\end{array}$ & Statistical method & Effect size \\
\hline $\begin{array}{l}1 \text { White population, normotensive, } \\
\text { SBP }\end{array}$ & 89 & 8569 & Mean Difference (Random, 95\% Cl) & $-1.09[-1.63,-0.56]$ \\
\hline $\begin{array}{l}\text { 2 White population, normotensive, } \\
\text { DBP }\end{array}$ & 90 & 8833 & Mean Difference (Random, 95\% Cl) & $0.03[-0.37,0.43]$ \\
\hline $\begin{array}{l}\text { 3 White population, hypertensive, } \\
\text { SBP }\end{array}$ & 84 & 5925 & Mean Difference (Random, 95\% Cl) & $-5.51[-6.45,-4.57]$ \\
\hline $\begin{array}{l}\text { 4 White population, hypertensive, } \\
\text { DBP }\end{array}$ & 85 & 6001 & Mean Difference (Random, 95\% Cl) & $-2.88[-3.44,-2.32]$ \\
\hline
\end{tabular}

Analysis 1.1. Comparison 1 Effect of salt reduction on systolic blood pressure (SBP) and diastolic blood pressure (DBP) in Whites, Outcome 1 White population, normotensive, SBP.

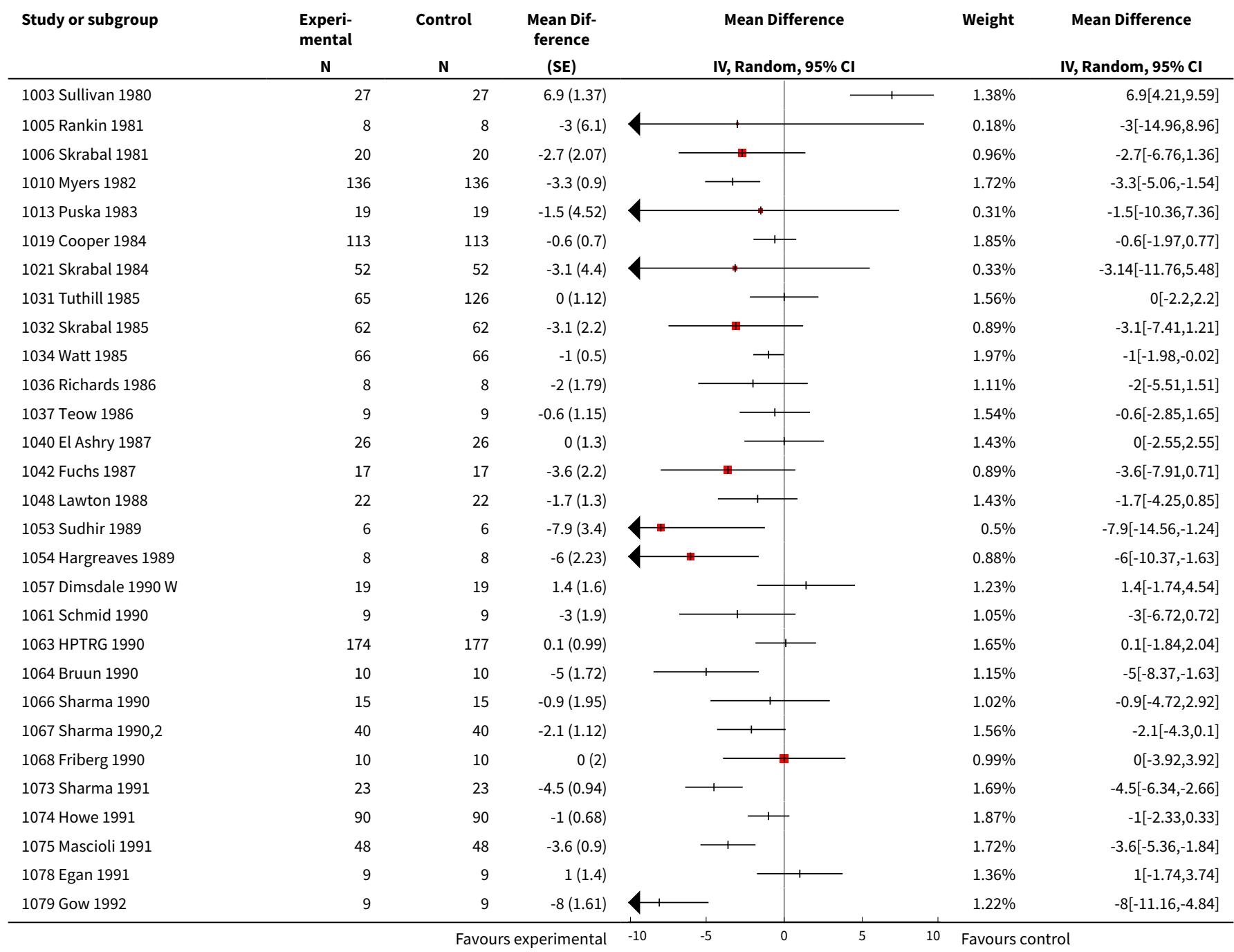

Effects of low sodium diet versus high sodium diet on blood pressure, renin, aldosterone, catecholamines, cholesterol, and triglyceride 


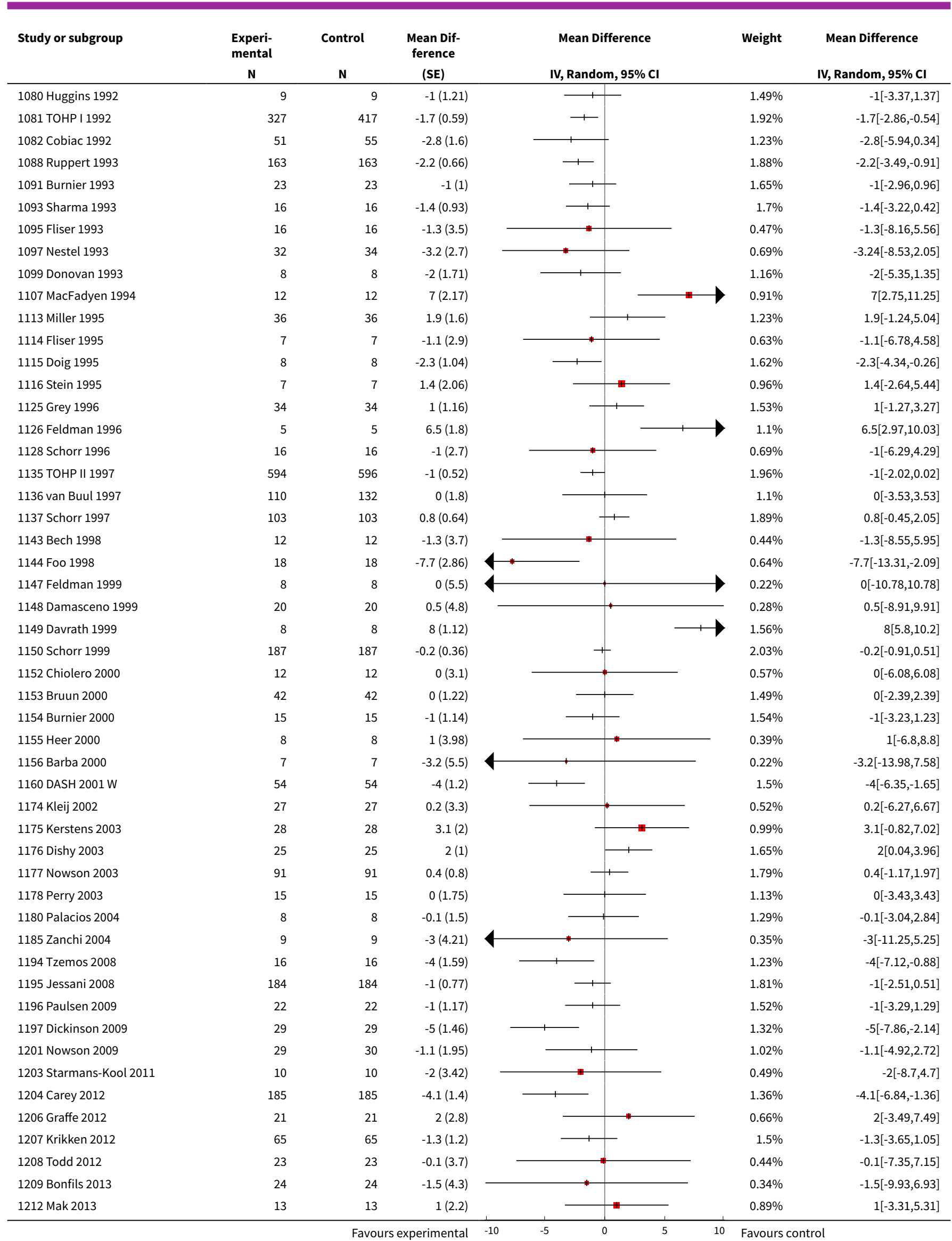

Effects of low sodium diet versus high sodium diet on blood pressure, renin, aldosterone, catecholamines, cholesterol, and triglyceride 216 (Review)

Copyright (c) 2017 The Cochrane Collaboration. Published by John Wiley \& Sons, Ltd. 


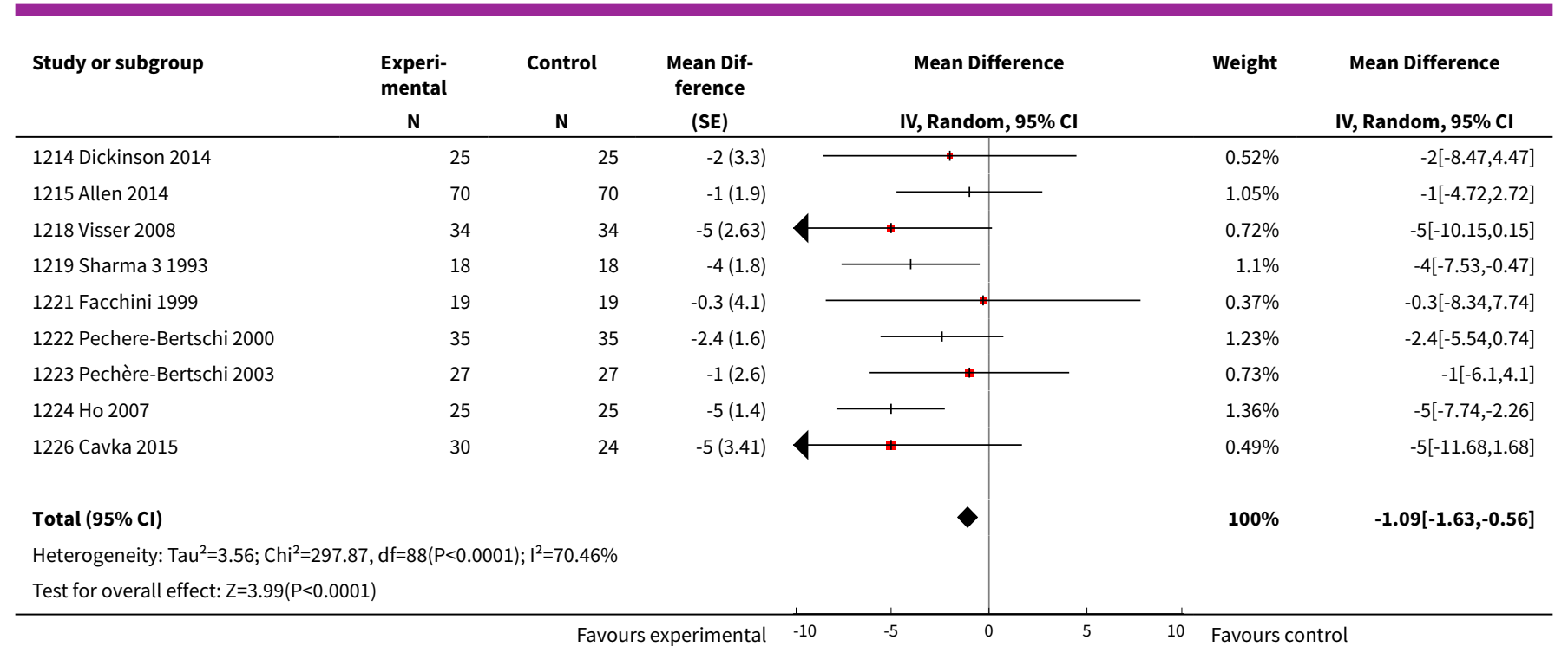

Analysis 1.2. Comparison 1 Effect of salt reduction on systolic blood pressure (SBP) and diastolic blood pressure (DBP) in Whites, Outcome 2 White population, normotensive, DBP.

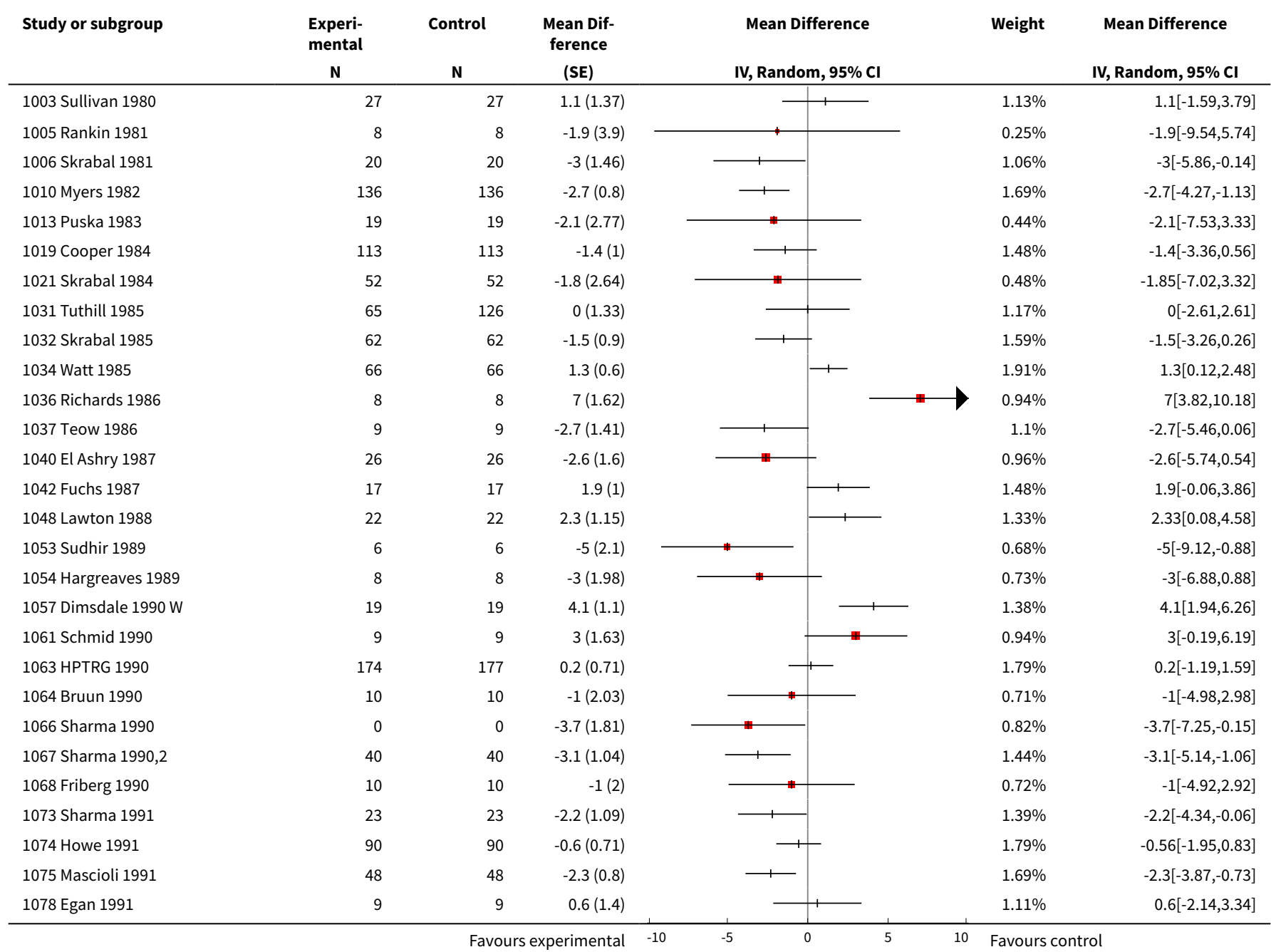




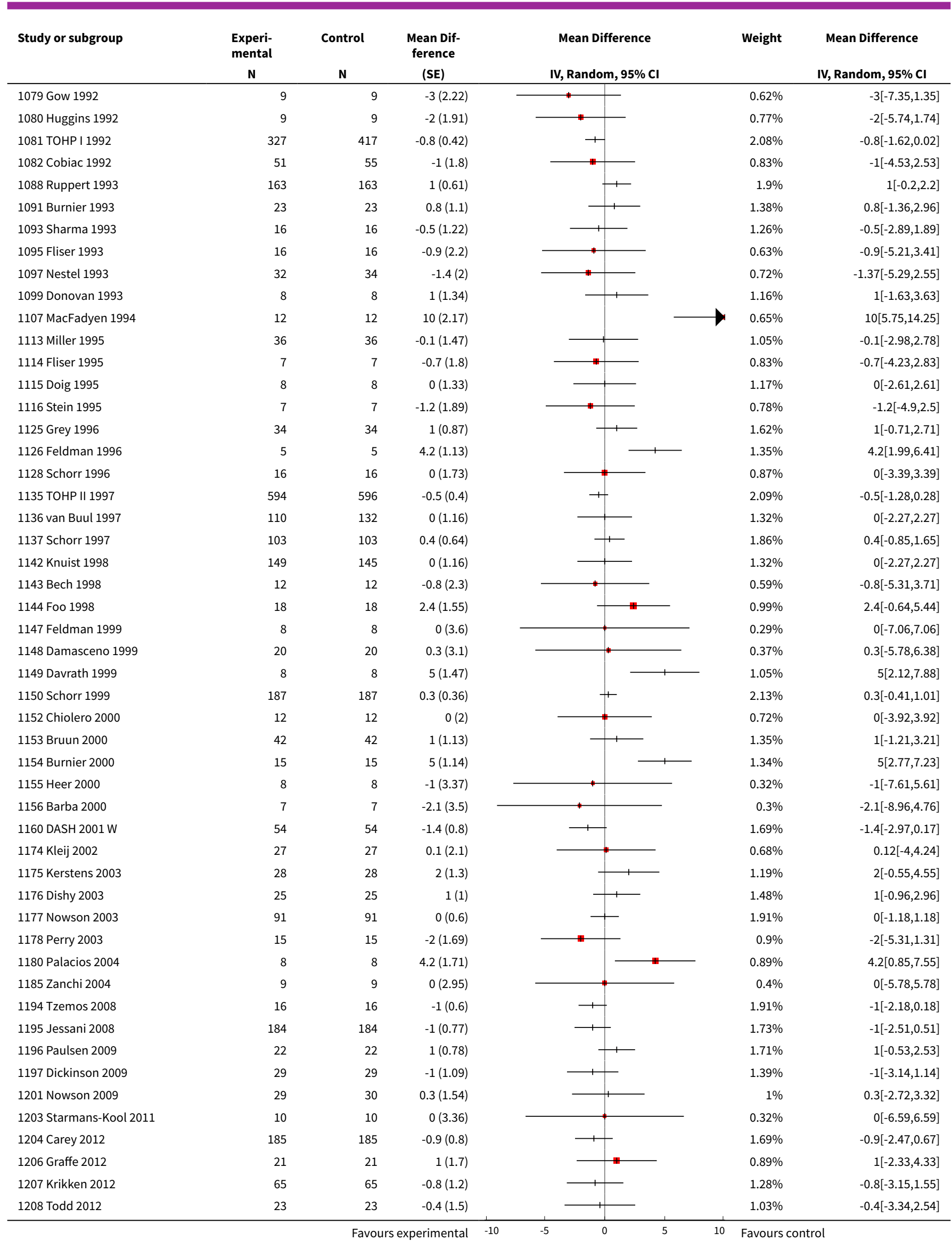

Effects of low sodium diet versus high sodium diet on blood pressure, renin, aldosterone, catecholamines, cholesterol, and triglyceride 


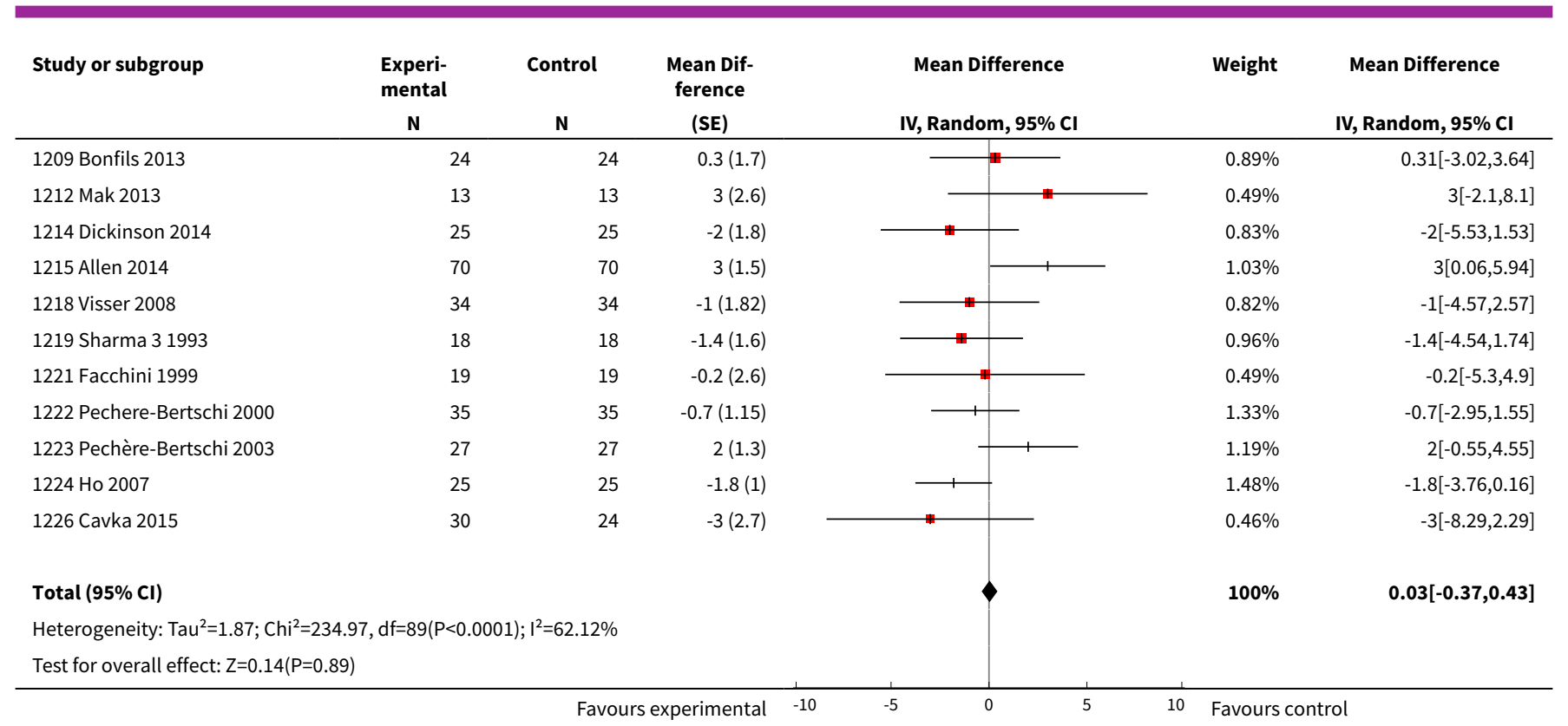

\section{Analysis 1.3. Comparison 1 Effect of salt reduction on systolic blood pressure (SBP) and diastolic blood pressure (DBP) in Whites, Outcome 3 White population, hypertensive, SBP.}

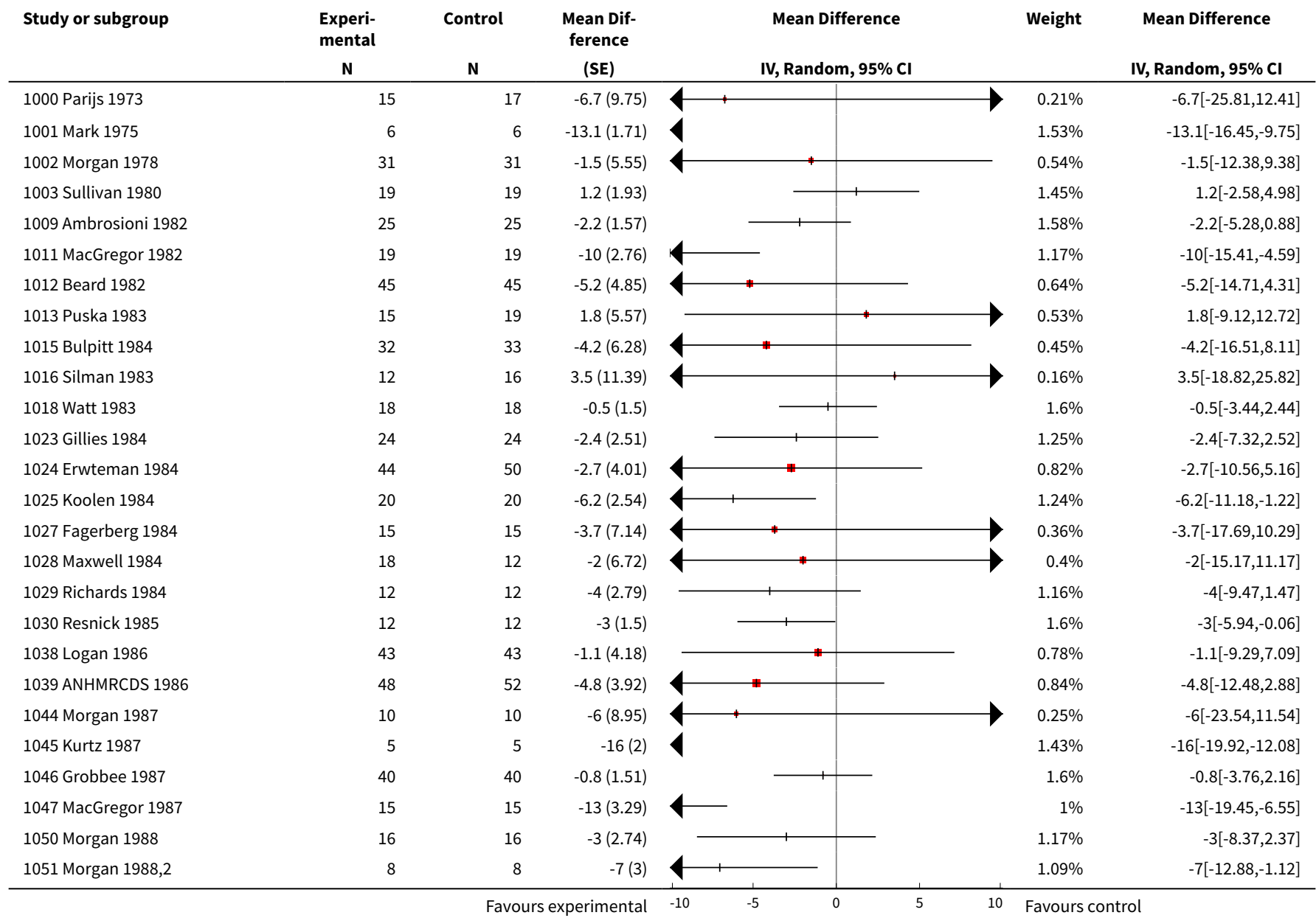






Effects of low sodium diet versus high sodium diet on blood pressure, renin, aldosterone, catecholamines, cholesterol, and triglyceride 


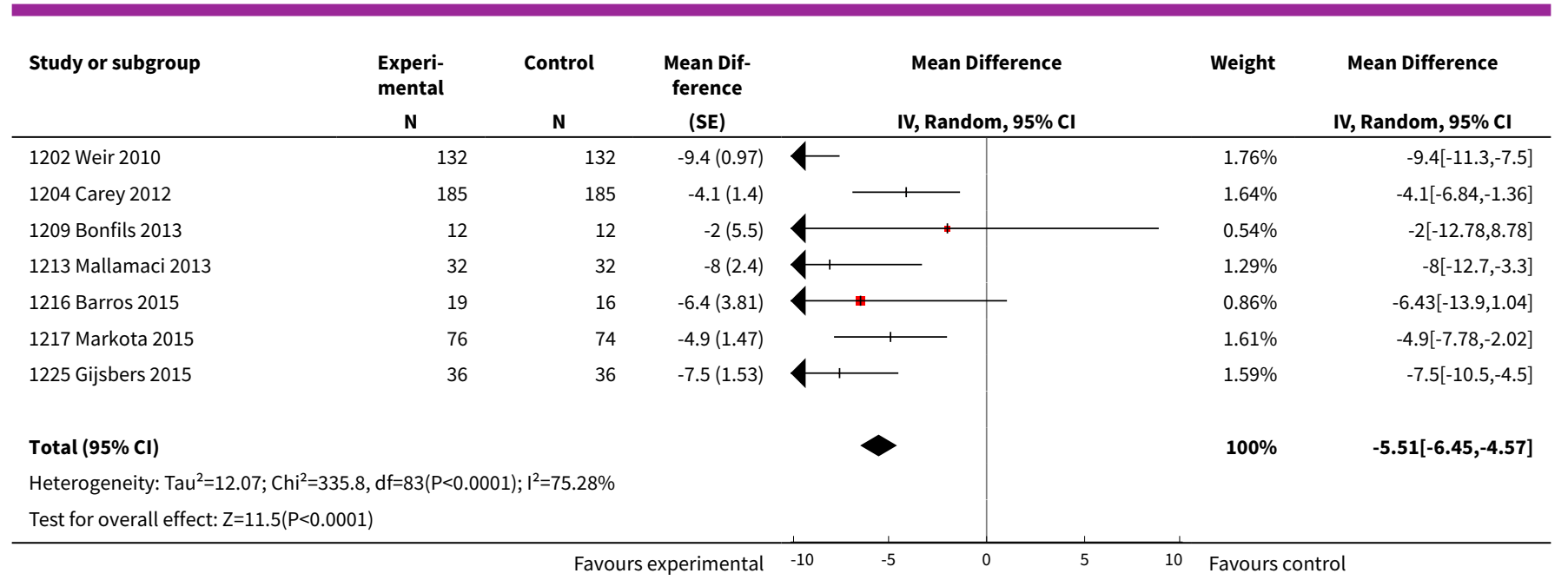

Analysis 1.4. Comparison 1 Effect of salt reduction on systolic blood pressure (SBP) and diastolic blood pressure (DBP) in Whites, Outcome 4 White population, hypertensive, DBP.

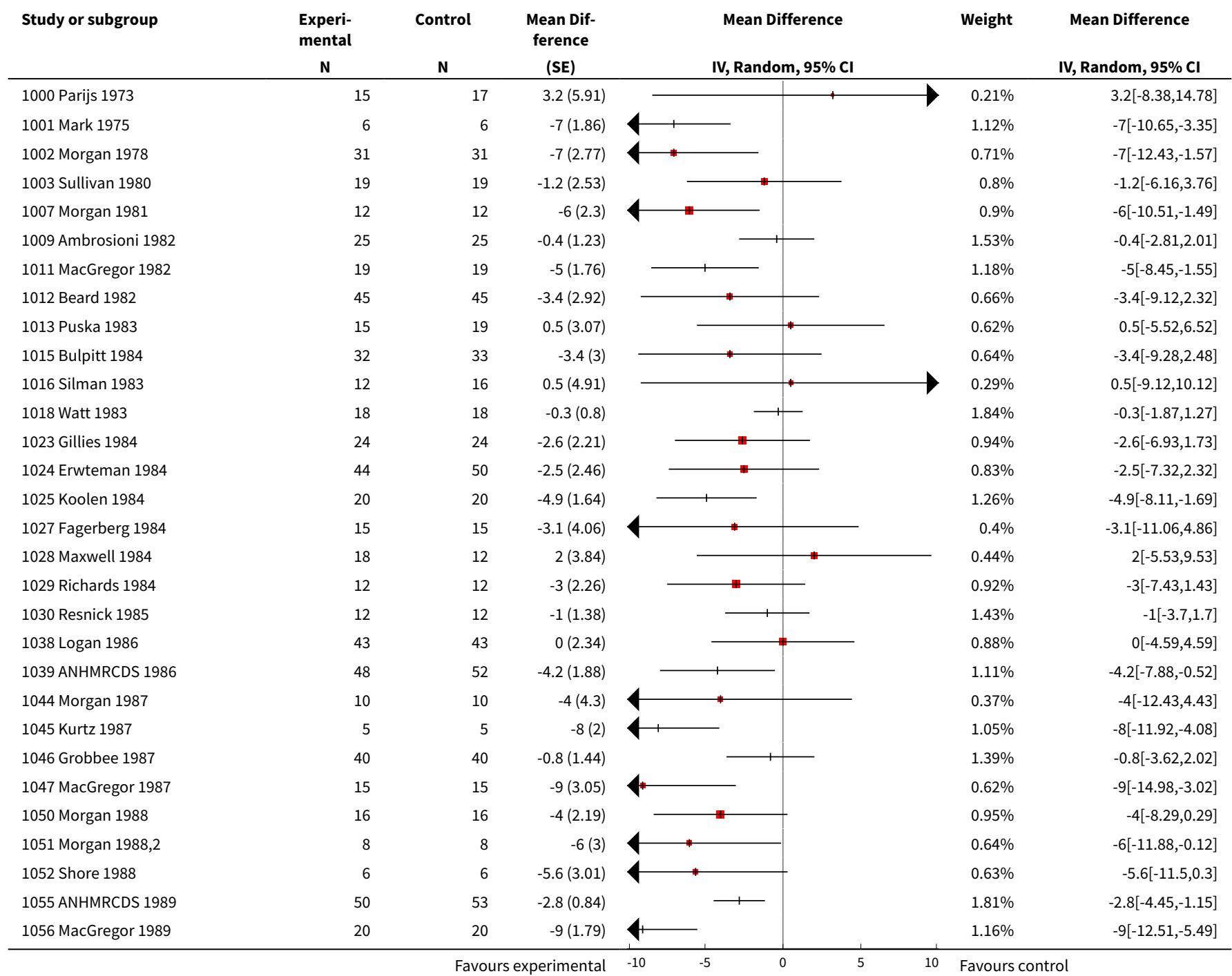

Effects of low sodium diet versus high sodium diet on blood pressure, renin, aldosterone, catecholamines, cholesterol, and triglyceride 221 (Review)

Copyright (c) 2017 The Cochrane Collaboration. Published by John Wiley \& Sons, Ltd. 


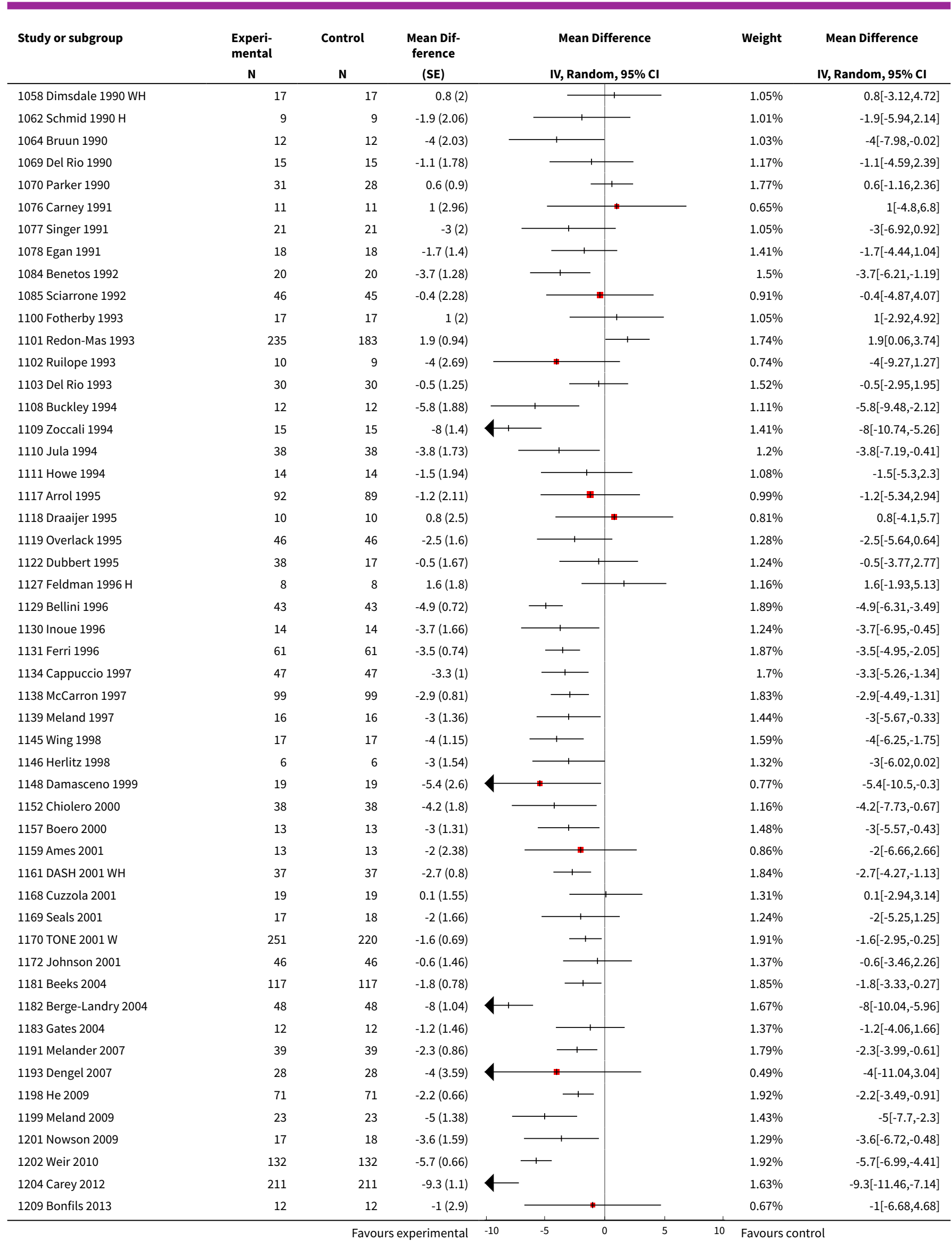

Effects of low sodium diet versus high sodium diet on blood pressure, renin, aldosterone, catecholamines, cholesterol, and triglyceride 


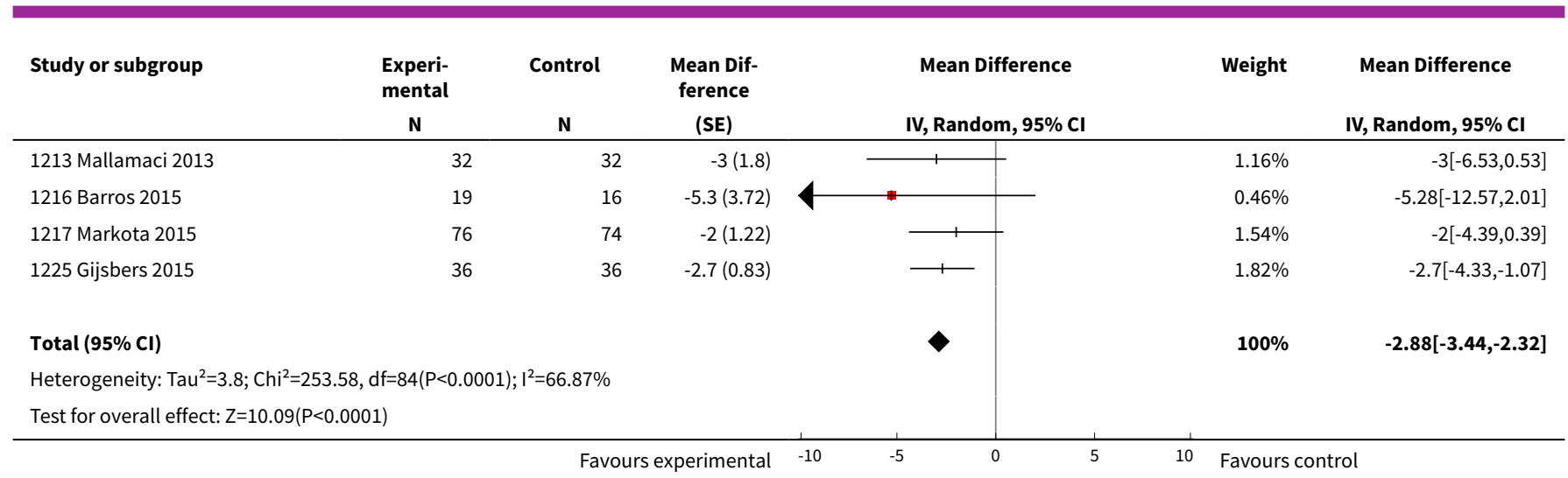

Comparison 2. Effect of salt reduction on systolic blood pressure (SBP) and diastolic blood pressure (DBP) in Blacks

\begin{tabular}{lllll}
\hline Outcome or subgroup title & $\begin{array}{l}\text { No. of } \\
\text { studies }\end{array}$ & $\begin{array}{l}\text { No. of } \\
\text { partici- } \\
\text { pants }\end{array}$ & Statistical method & Effect size \\
\hline $\begin{array}{l}1 \text { Black population, normotensive, } \\
\text { SBP }\end{array}$ & 7 & 506 & Mean Difference (Random, 95\% Cl) & $-4.02[-7.37,-0.68]$ \\
\hline $\begin{array}{l}\text { 2 Black population, normotensive, } \\
\text { DBP }\end{array}$ & 7 & 506 & Mean Difference (Random, 95\% Cl) & $-2.01[-4.37,0.35]$ \\
\hline $\begin{array}{l}\text { 3 Black population, hypertensive, } \\
\text { SBP }\end{array}$ & 8 & 619 & Mean Difference (Random, 95\% Cl) & $-6.64[-9.00,-4.27]$ \\
\hline $\begin{array}{l}\text { 4 Black population, hypertensive, } \\
\text { DBP }\end{array}$ & 8 & 619 & Mean Difference (Random, 95\% Cl) & $-2.91[-4.52,-1.30]$ \\
\hline
\end{tabular}

\begin{abstract}
Analysis 2.1. Comparison 2 Effect of salt reduction on systolic blood pressure (SBP) and diastolic blood pressure (DBP) in Blacks, Outcome 1 Black population, normotensive, SBP.
\end{abstract}

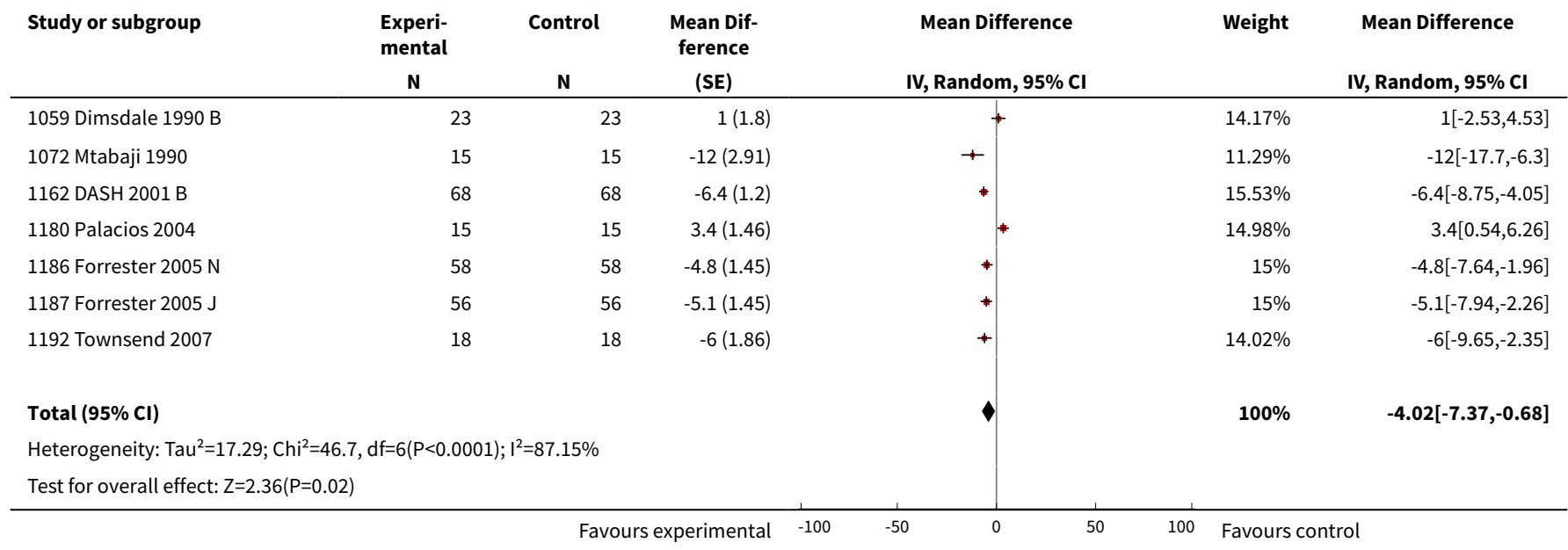


Analysis 2.2. Comparison 2 Effect of salt reduction on systolic blood pressure (SBP) and diastolic blood pressure (DBP) in Blacks, Outcome 2 Black population, normotensive, DBP.

\begin{tabular}{|c|c|c|c|c|c|c|}
\hline Study or subgroup & $\begin{array}{c}\text { Experi- } \\
\text { mental } \\
\mathbf{N}\end{array}$ & $\begin{array}{c}\text { Control } \\
\text { N }\end{array}$ & $\begin{array}{c}\text { Mean Dif- } \\
\text { ference } \\
\text { (SE) } \\
\end{array}$ & $\begin{array}{c}\text { Mean Difference } \\
\text { IV, Random, } 95 \% \text { Cl }\end{array}$ & Weight & $\begin{array}{c}\text { Mean Difference } \\
\text { IV, Random, } 95 \% \text { CI }\end{array}$ \\
\hline 1059 Dimsdale 1990 B & 23 & 23 & $4.3(1.4)$ & * & $15.15 \%$ & $4.3[1.56,7.04]$ \\
\hline 1072 Mtabaji 1990 & 15 & 15 & $-6(2.91)$ & + & $9.02 \%$ & $-6[-11.7,-0.3]$ \\
\hline 1162 DASH 2001 B & 68 & 68 & $-3.9(0.8)$ & $*$ & $17.58 \%$ & $-3.95[-5.52,-2.38]$ \\
\hline 1180 Palacios 2004 & 15 & 15 & $-0.1(1.94)$ & + & $12.75 \%$ & $-0.1[-3.9,3.7]$ \\
\hline 1187 Forrester $2005 \mathrm{~J}$ & 56 & 56 & $-2.2(1.45)$ & $*$ & $14.93 \%$ & $-2.2[-5.04,0.64]$ \\
\hline 1192 Townsend 2007 & 18 & 18 & $-4(1.72)$ & + & $13.72 \%$ & $-4[-7.37,-0.63]$ \\
\hline Total $(95 \% \mathrm{CI})$ & & & & 4 & $100 \%$ & $-2.01[-4.37,0.35]$ \\
\hline \multicolumn{7}{|c|}{ Heterogeneity: $\mathrm{Tau}^{2}=7.6 ; \mathrm{Chi}^{2}=31.12, \mathrm{df}=6(\mathrm{P}<0.0001) ; \mathrm{I}^{2}=80.72 \%$} \\
\hline Test for overall effect: 2 & & & & & & \\
\hline
\end{tabular}

Analysis 2.3. Comparison 2 Effect of salt reduction on systolic blood pressure (SBP) and diastolic blood pressure (DBP) in Blacks, Outcome 3 Black population, hypertensive, SBP.

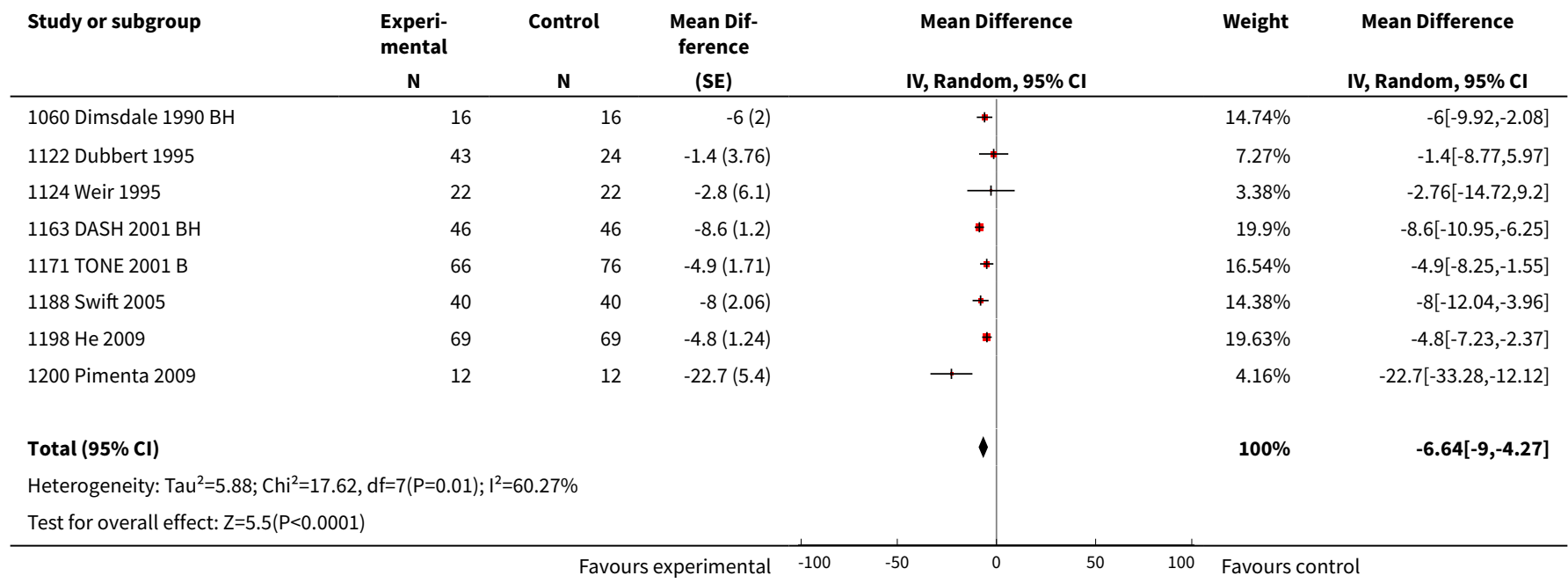

Analysis 2.4. Comparison 2 Effect of salt reduction on systolic blood pressure (SBP) and diastolic blood pressure (DBP) in Blacks, Outcome 4 Black population, hypertensive, DBP.

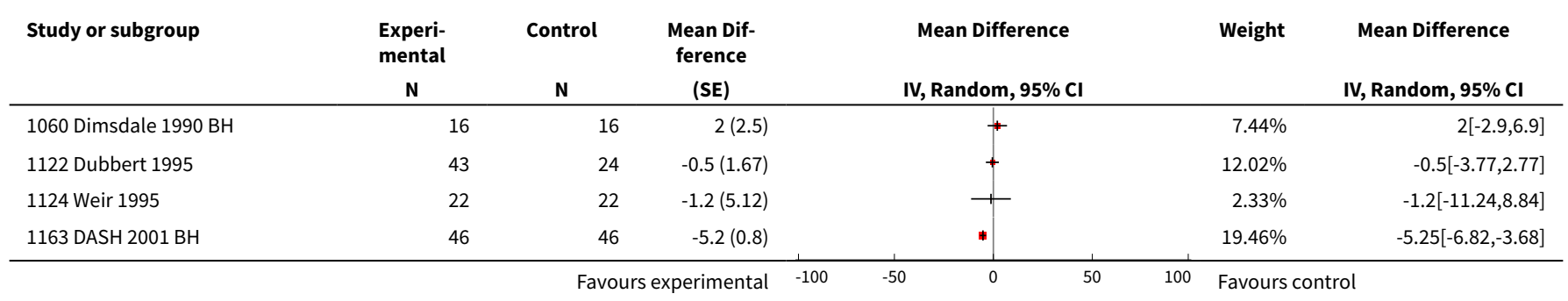




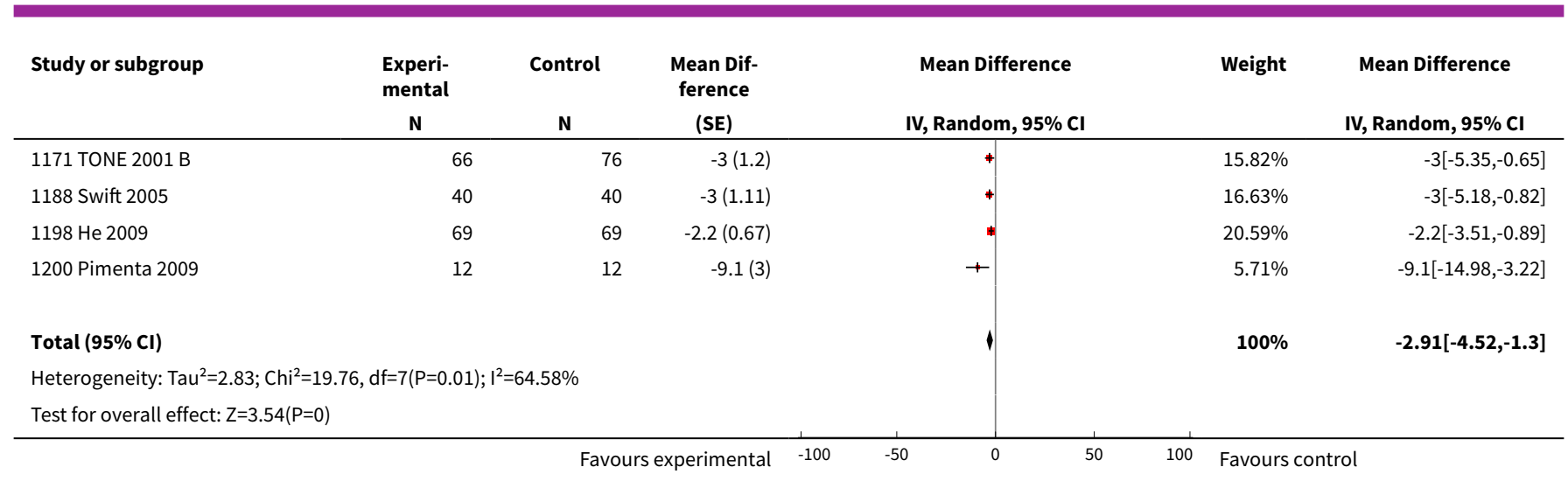

Comparison 3. Effect of salt reduction on systolic blood pressure (SBP) and diastolic blood pressure (DBP) in Asians

\begin{tabular}{lllll}
\hline Outcome or subgroup title & $\begin{array}{l}\text { No. of } \\
\text { studies }\end{array}$ & $\begin{array}{l}\text { No. of } \\
\text { partici- } \\
\text { pants }\end{array}$ & Statistical method & Effect size \\
\hline $\begin{array}{l}1 \text { Asians population normotensive, } \\
\text { SBP }\end{array}$ & 3 & 393 & Mean Difference (Random, 95\% Cl) & $-0.72[-3.86,2.41]$ \\
\hline $\begin{array}{l}\text { 2 Asian population, normotensive, } \\
\text { DBP }\end{array}$ & 3 & 393 & Mean Difference (Random, 95\% Cl) & $-1.63[-3.35,0.08]$ \\
\hline $\begin{array}{l}3 \text { Asian population, hypertensive, } \\
\text { SBP }\end{array}$ & 8 & 501 & Mean Difference (Random, 95\% Cl) & $-7.75[-11.44,-4.07]$ \\
\hline $\begin{array}{l}\text { 4 Asian population, hypertensive, } \\
\text { DBP }\end{array}$ & 8 & 501 & Mean Difference (Random, 95\% Cl) & $-2.68[-4.21,-1.15]$ \\
\hline
\end{tabular}

\begin{abstract}
Analysis 3.1. Comparison 3 Effect of salt reduction on systolic blood pressure (SBP) and diastolic blood pressure (DBP) in Asians, Outcome 1 Asians population normotensive, SBP.
\end{abstract}

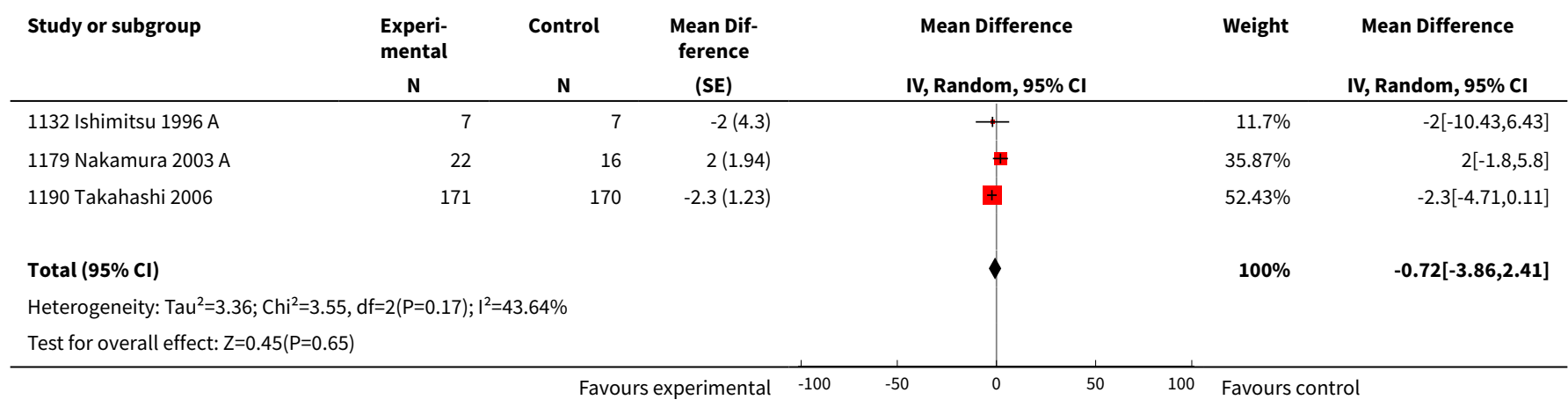


Analysis 3.2. Comparison 3 Effect of salt reduction on systolic blood pressure (SBP) and diastolic blood pressure (DBP) in Asians, Outcome 2 Asian population, normotensive, DBP.

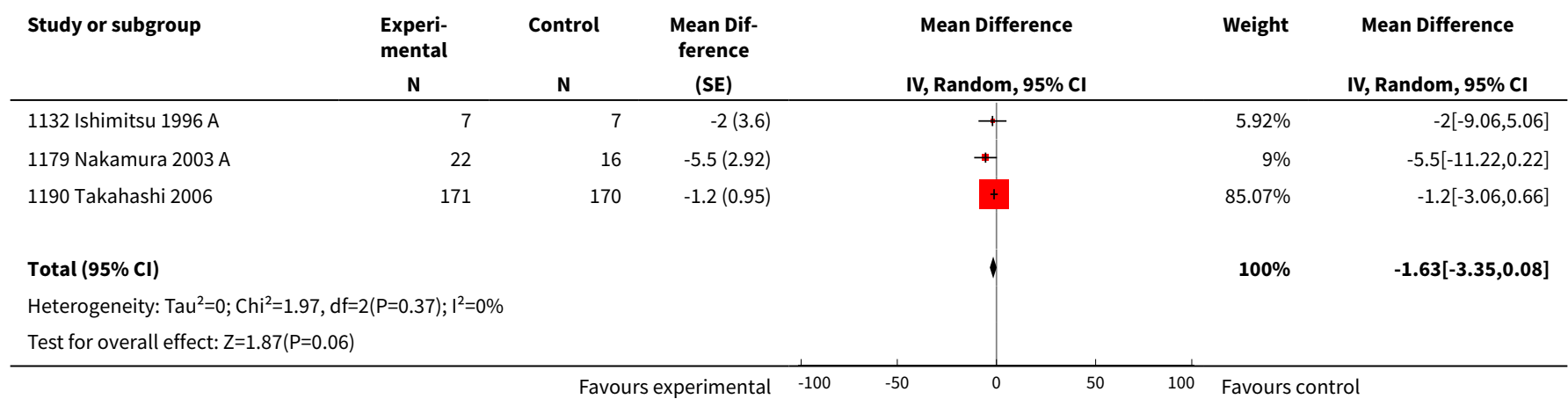

Analysis 3.3. Comparison 3 Effect of salt reduction on systolic blood pressure (SBP) and diastolic blood pressure (DBP) in Asians, Outcome 3 Asian population, hypertensive, SBP.

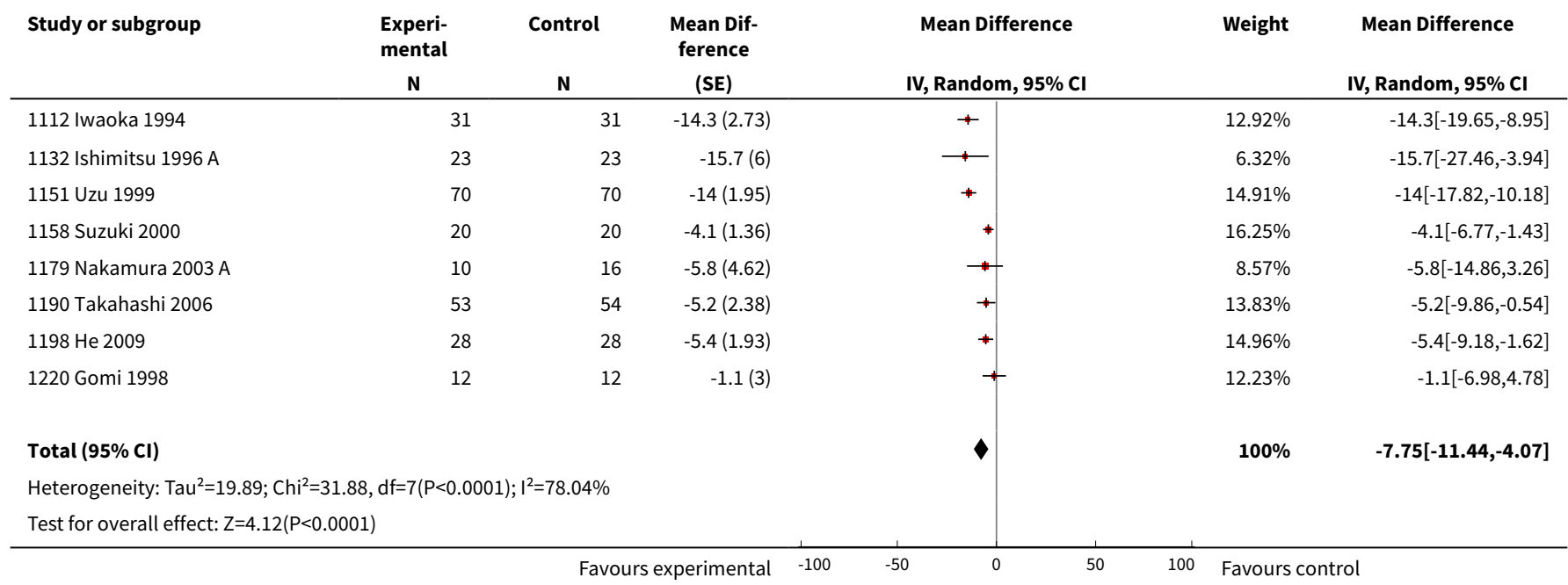

Analysis 3.4. Comparison 3 Effect of salt reduction on systolic blood pressure (SBP) and diastolic blood pressure (DBP) in Asians, Outcome 4 Asian population, hypertensive, DBP.

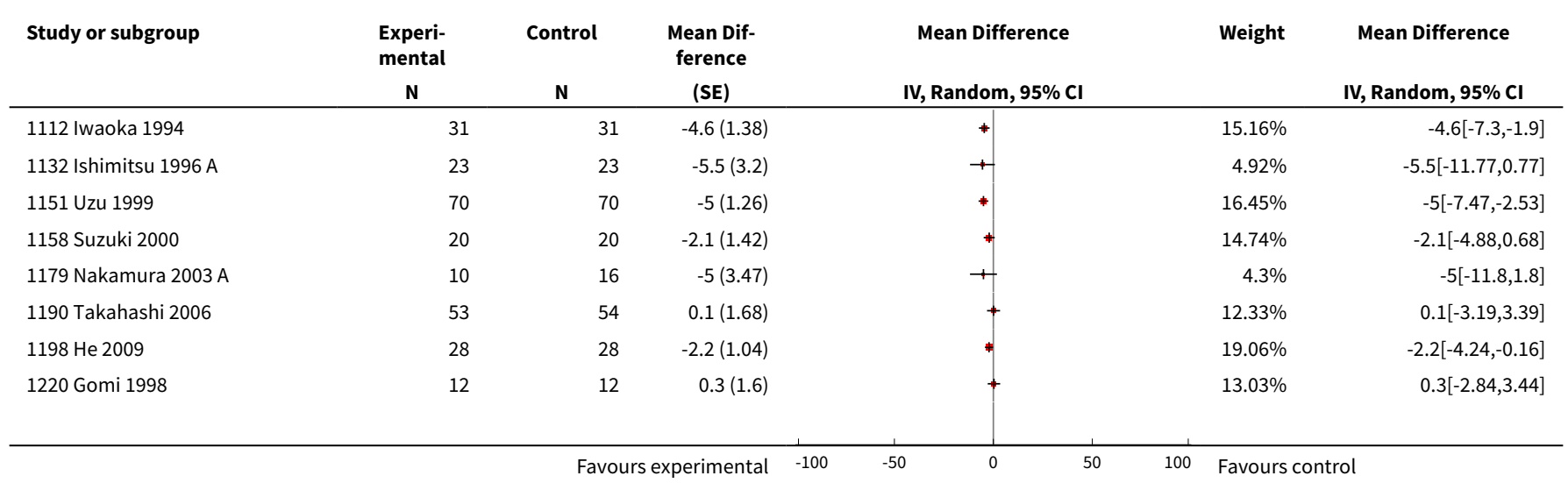

Effects of low sodium diet versus high sodium diet on blood pressure, renin, aldosterone, catecholamines, cholesterol, and triglyceride 226 (Review)

Copyright (c) 2017 The Cochrane Collaboration. Published by John Wiley \& Sons, Ltd. 




Comparison 4. Effect of salt reduction on systolic blood pressure (SBP) and diastolic blood pressure (DBP) in Whites, subgroup analysis

\begin{tabular}{lllll}
\hline Outcome or subgroup title & $\begin{array}{l}\text { No. of } \\
\text { studies }\end{array}$ & $\begin{array}{l}\text { No. of } \\
\text { partici- } \\
\text { pants }\end{array}$ & Statistical method & Effect size \\
\hline $\begin{array}{l}1 \text { White population, normotensive, } \\
\text { SBP }\end{array}$ & 59 & 7125 & Mean Difference (Random, 95\% CI) & $-1.31[-1.83,-0.80]$ \\
\hline $\begin{array}{l}2 \text { White population, normotensive, } \\
\text { DBP }\end{array}$ & 61 & Mean Difference (Random, 95\% Cl) & $-0.36[-0.79,0.07]$ \\
\hline $\begin{array}{l}3 \text { White population, hypertensive, } \\
\text { SBP }\end{array}$ & 63 & Mean Difference (Random, 95\% Cl) & $-5.02[-4.00,-4.05]$ \\
\hline $\begin{array}{l}\text { 4 White population, hypertensive, } \\
\text { DBP }\end{array}$ & 64 & Mean Difference (Random, 95\% Cl) & $-2.78[-3.42,-2.14]$ \\
\hline
\end{tabular}

Analysis 4.1. Comparison 4 Effect of salt reduction on systolic blood pressure (SBP) and diastolic blood pressure (DBP) in Whites, subgroup analysis, Outcome 1 White population, normotensive, SBP.

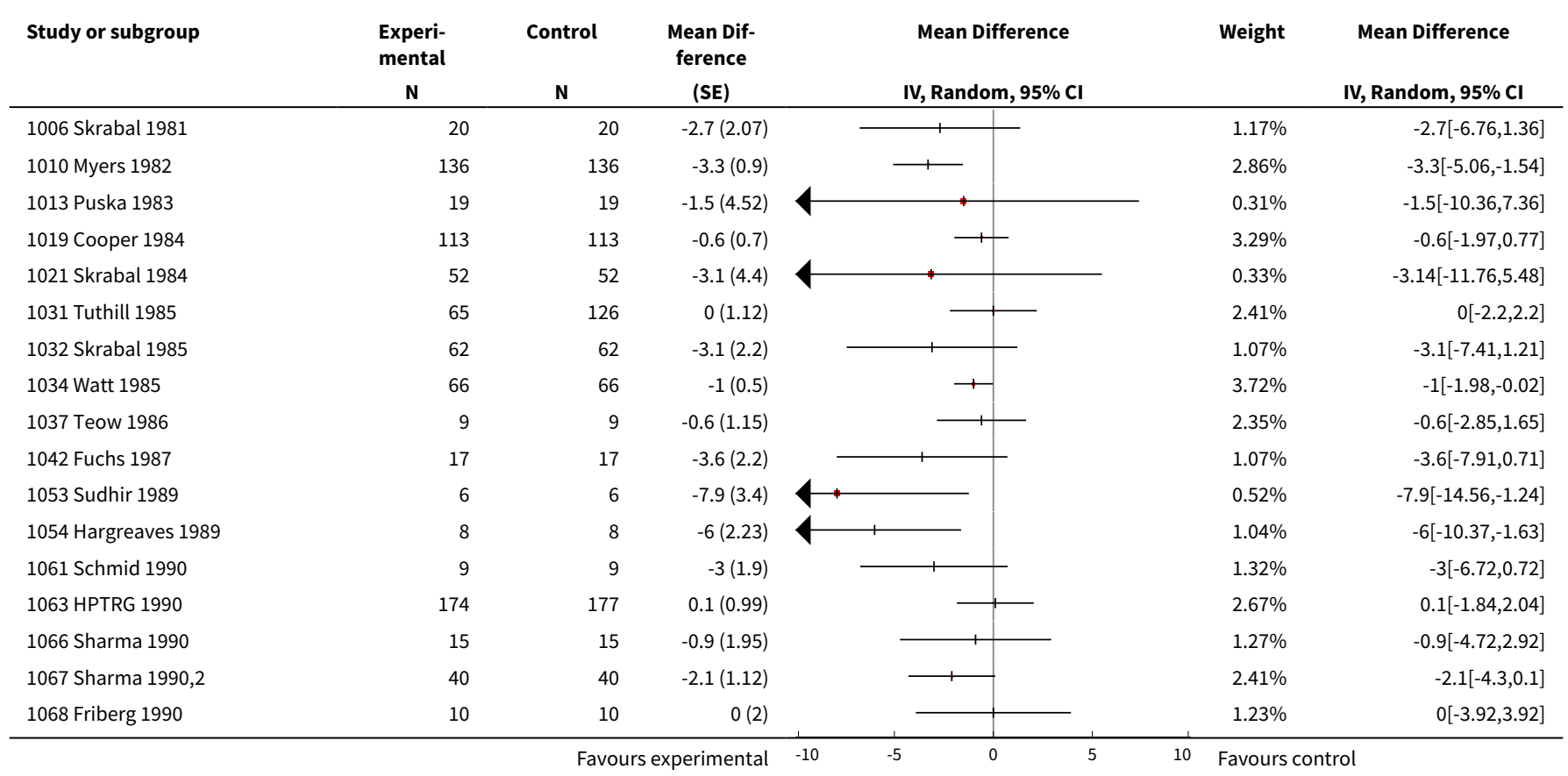




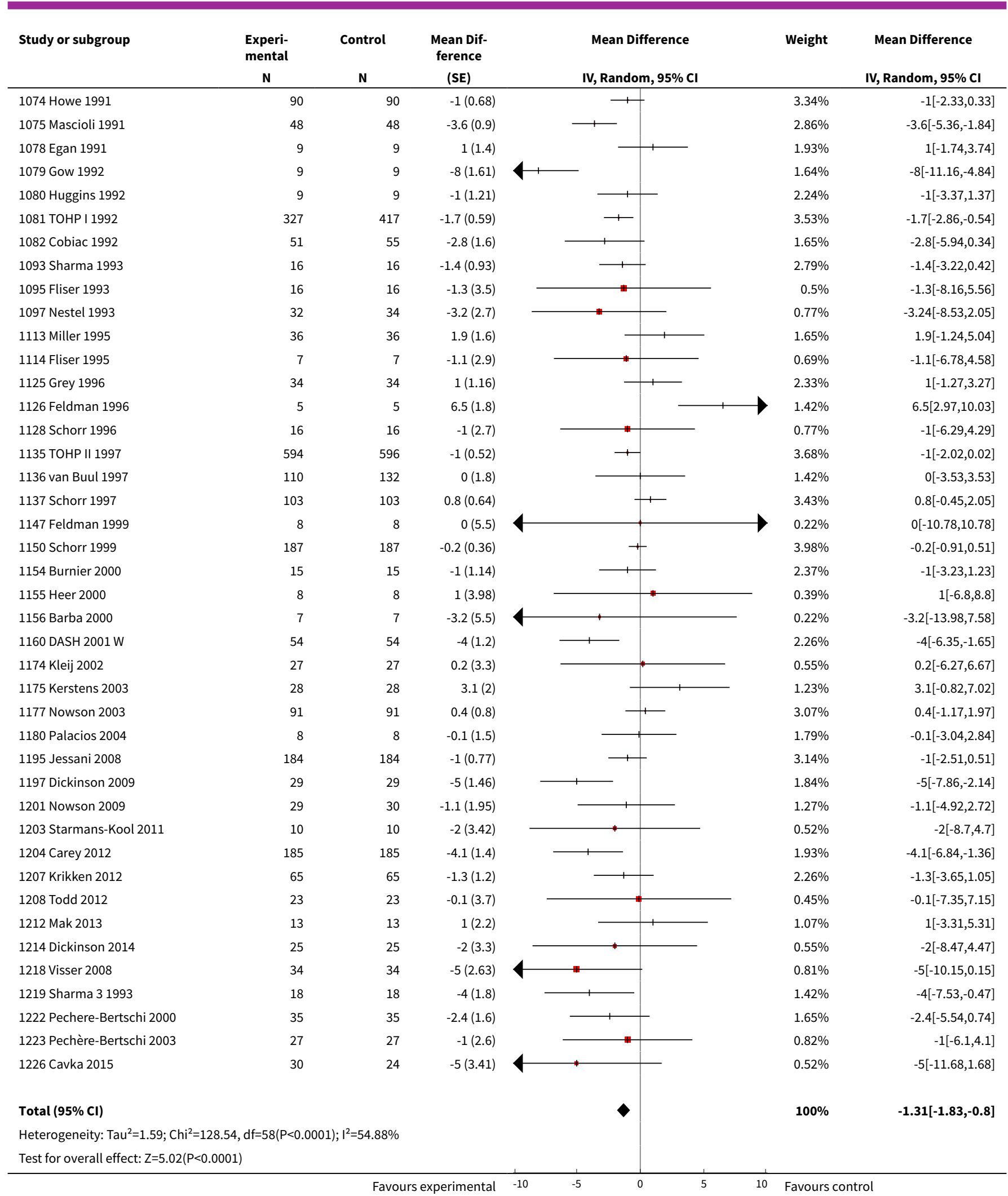

Effects of low sodium diet versus high sodium diet on blood pressure, renin, aldosterone, catecholamines, cholesterol, and triglyceride 
Analysis 4.2. Comparison 4 Effect of salt reduction on systolic blood pressure (SBP) and diastolic blood pressure (DBP) in Whites, subgroup analysis, Outcome 2 White population, normotensive, DBP.

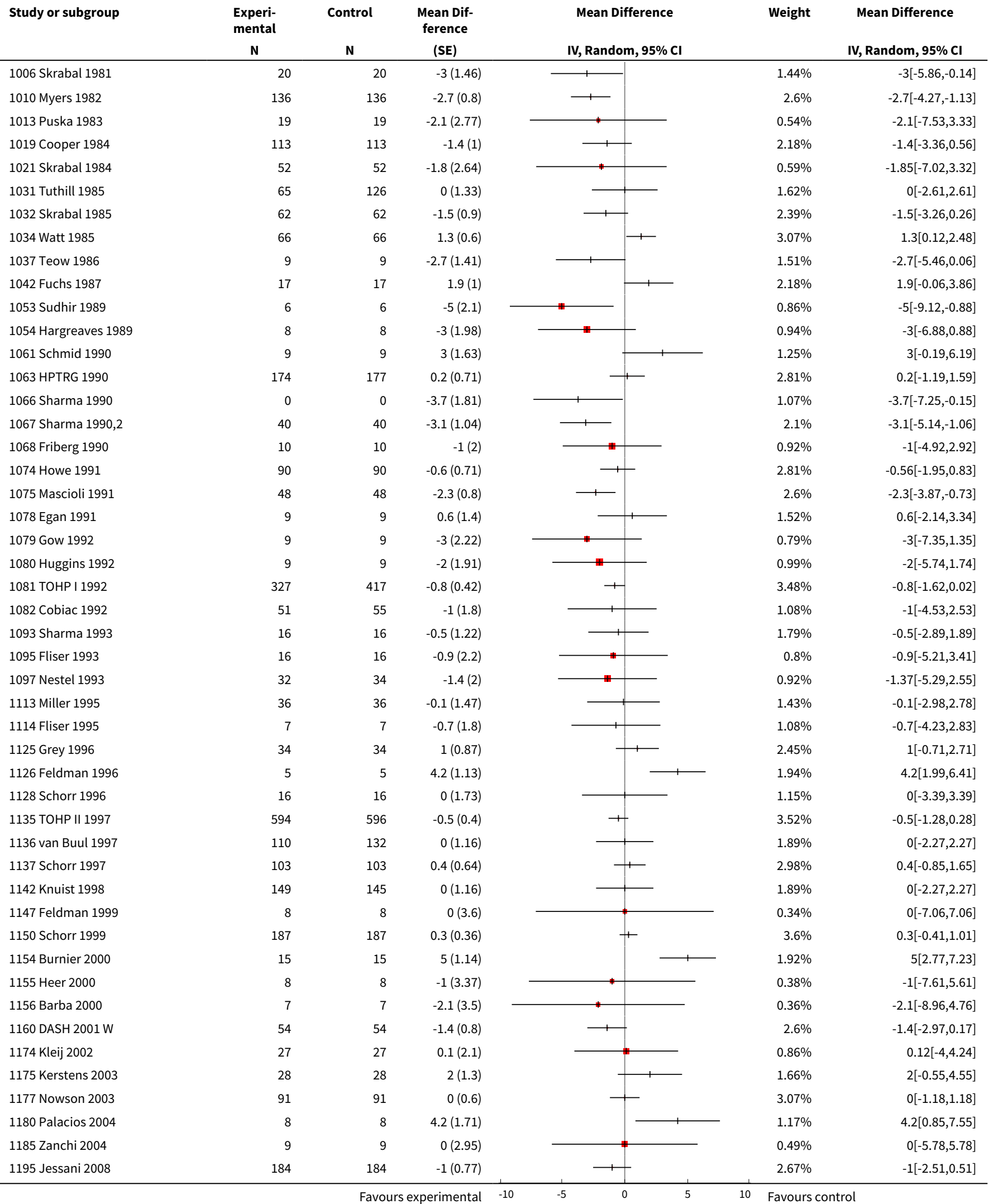

Effects of low sodium diet versus high sodium diet on blood pressure, renin, aldosterone, catecholamines, cholesterol, and triglyceride 


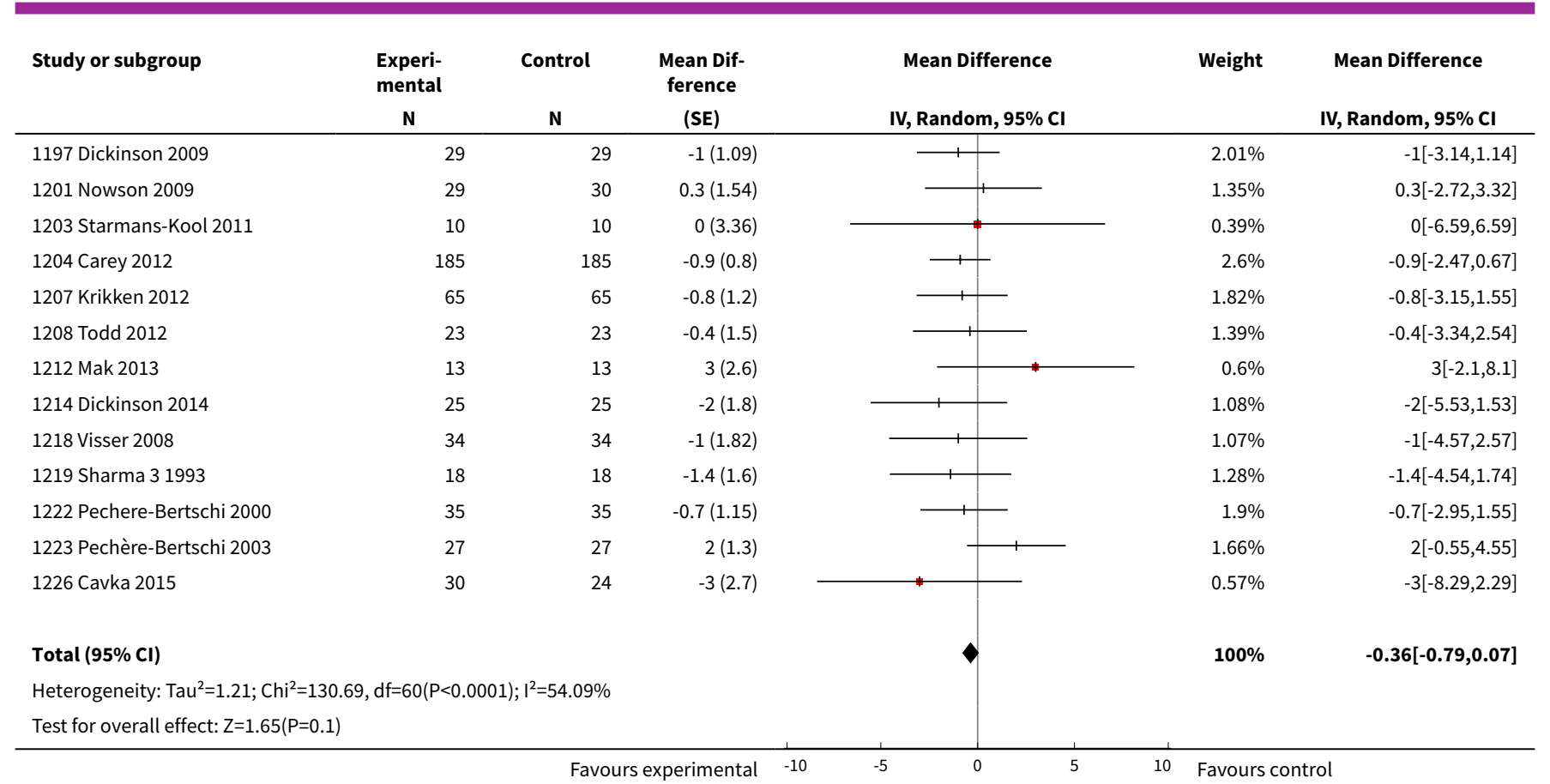

Analysis 4.3. Comparison 4 Effect of salt reduction on systolic blood pressure (SBP) and diastolic blood pressure (DBP) in Whites, subgroup analysis, Outcome 3 White population, hypertensive, SBP.

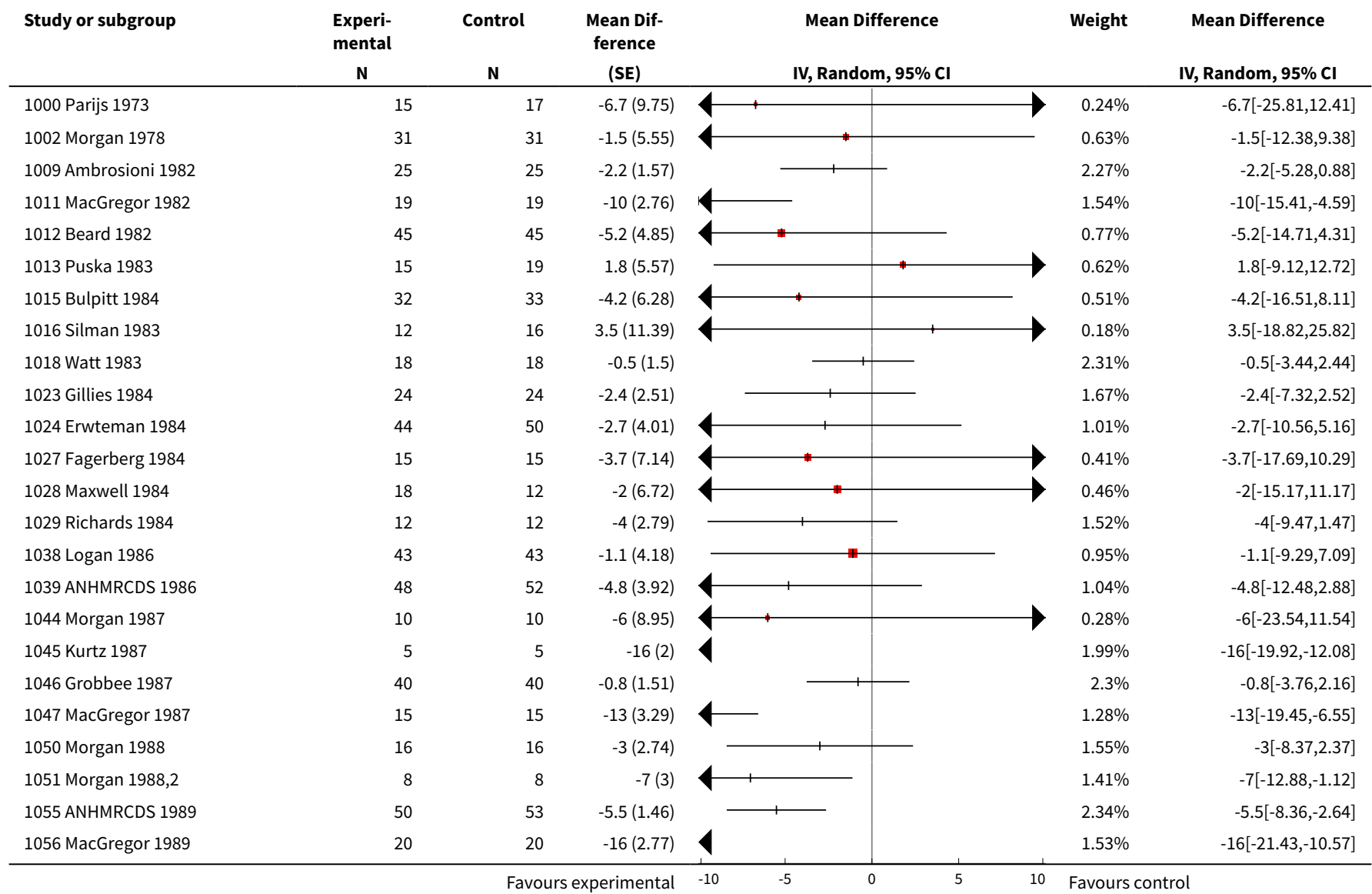






Effects of low sodium diet versus high sodium diet on blood pressure, renin, aldosterone, catecholamines, cholesterol, and triglyceride 
Analysis 4.4. Comparison 4 Effect of salt reduction on systolic blood pressure (SBP) and diastolic blood pressure (DBP) in Whites, subgroup analysis, Outcome 4 White population, hypertensive, DBP.

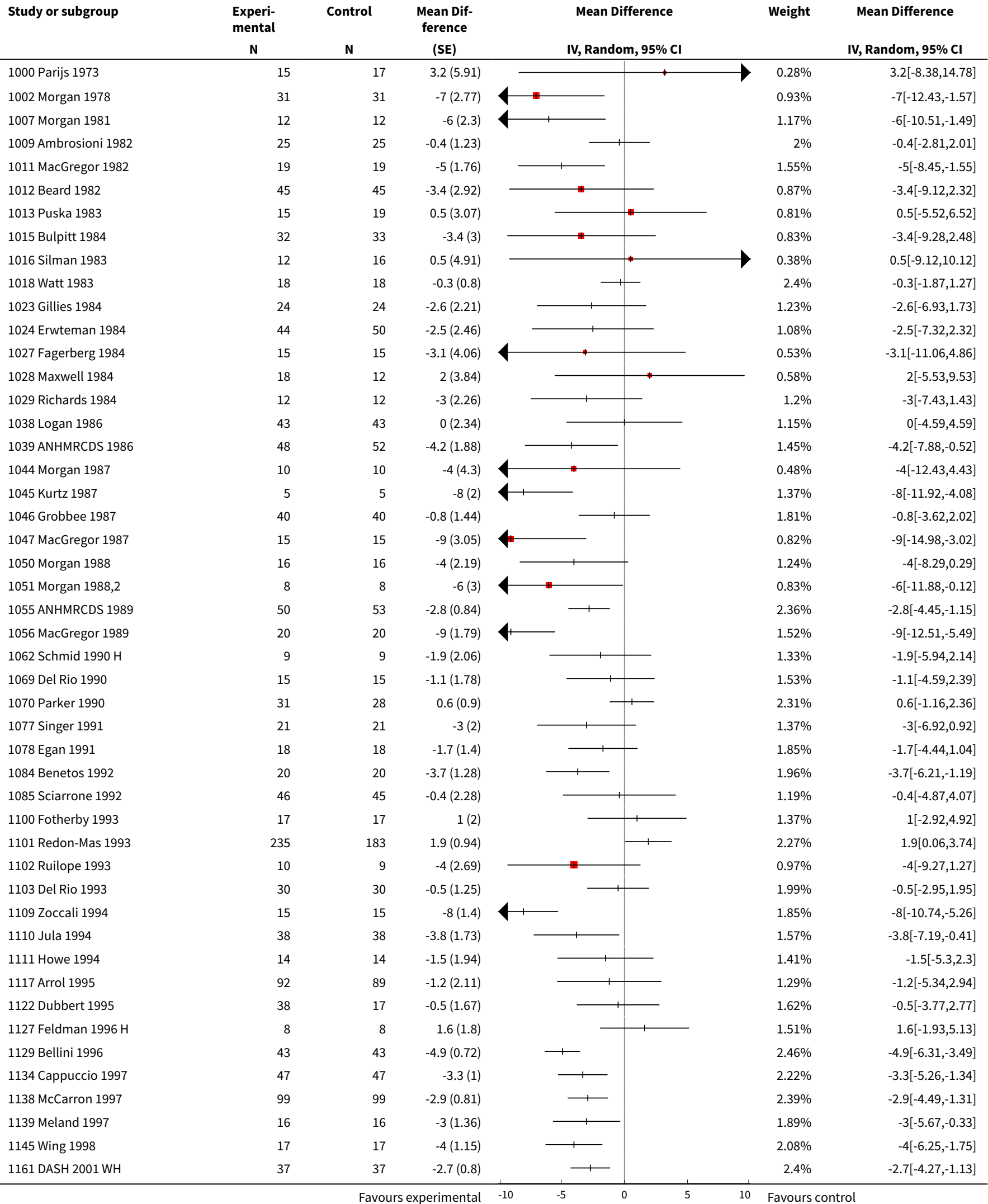

Effects of low sodium diet versus high sodium diet on blood pressure, renin, aldosterone, catecholamines, cholesterol, and triglyceride 


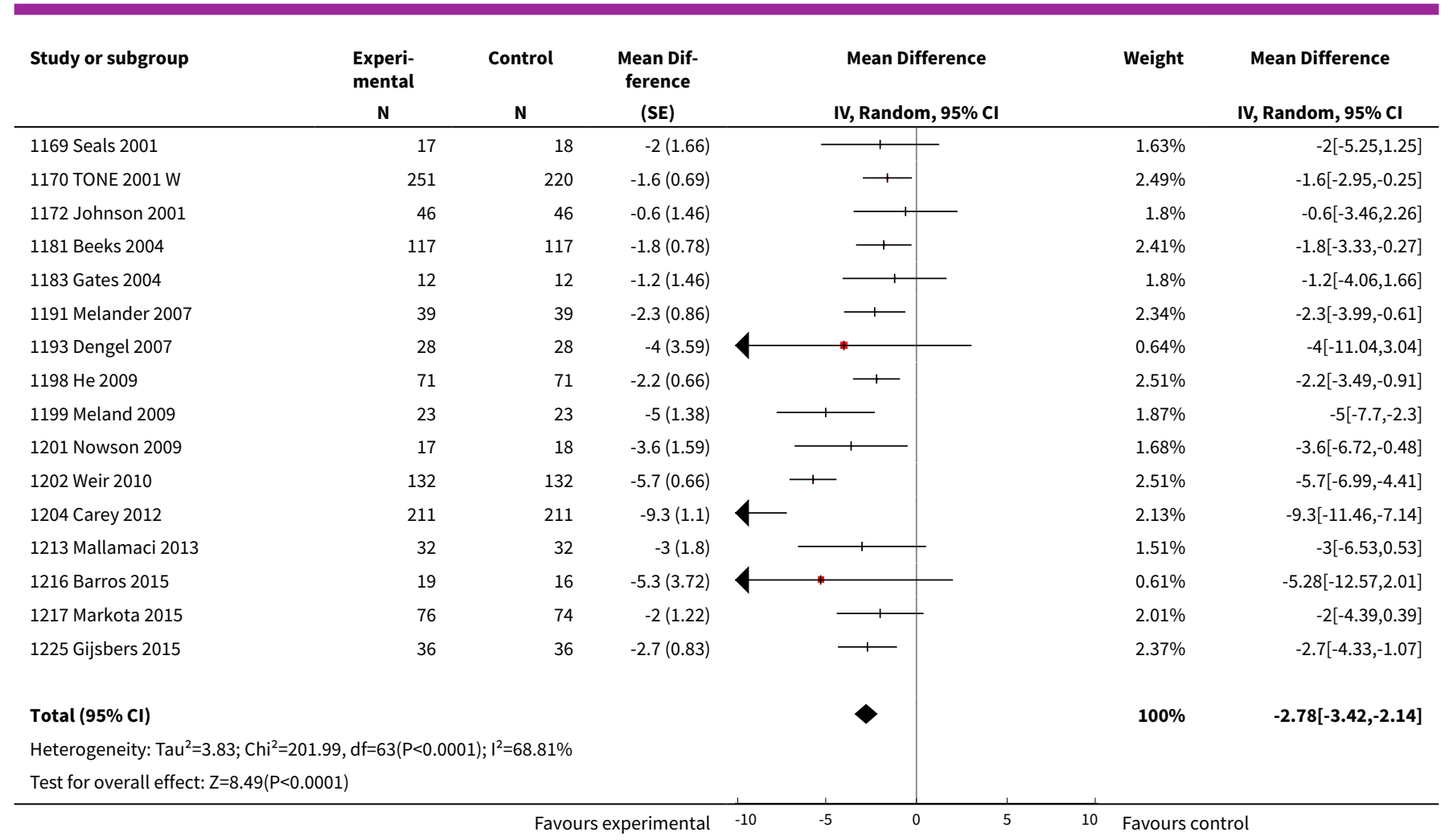

\section{Comparison 5. Effect of salt reduction on hormones}

\begin{tabular}{lllll}
\hline Outcome or subgroup title & $\begin{array}{l}\text { No. of } \\
\text { studies }\end{array}$ & $\begin{array}{l}\text { No. of } \\
\text { partici- } \\
\text { pants }\end{array}$ & Statistical method & Effect size \\
\hline 1 Renin $(\mathrm{ng} / \mathrm{mL} / \mathrm{hour})$ & 88 & 5498 & Std. Mean Difference (IV, Random, 95\% CI) & $1.22[1.07,1.37]$ \\
\hline 2 Aldosterone $(\mathrm{pg} / \mathrm{mL})$ & 65 & 4884 & Mean Difference (IV, Random, 95\% Cl) & $97.81[82.56,113.05]$ \\
\hline 3 Noradrenaline $(\mathrm{pg} / \mathrm{mL})$ & 36 & 1736 & Mean Difference (IV, Random, 95\% Cl) & $63.56[42.66,84.46]$ \\
\hline 4 Adrenaline $(\mathrm{pg} / \mathrm{mL})$ & 16 & 662 & Mean Difference (IV, Random, 95\% Cl) & $7.55[0.85,14.26]$ \\
\hline
\end{tabular}

Analysis 5.1. Comparison 5 Effect of salt reduction on hormones, Outcome 1 Renin (ng/mL/hour).

\begin{tabular}{|c|c|c|c|c|c|c|c|}
\hline \multirow[t]{2}{*}{ Study or subgroup } & \multicolumn{2}{|c|}{ Salt reduction } & \multicolumn{2}{|c|}{ Normal salt intake } & \multirow{2}{*}{$\begin{array}{c}\text { Std. Mean Difference } \\
\text { Random, } 95 \% \mathrm{Cl}\end{array}$} & \multirow[t]{2}{*}{ Weight } & \multirow{2}{*}{$\begin{array}{c}\text { Std. Mean Difference } \\
\text { Random, } 95 \% \mathrm{Cl}\end{array}$} \\
\hline & $\mathbf{N}$ & Mean(SD) & $\mathbf{N}$ & Mean(SD) & & & \\
\hline 1001 Mark 1975 & 6 & $7.3(1.7)$ & 6 & $1.7(0.7)$ & * & $0.36 \%$ & $3.93[1.7,6.16]$ \\
\hline 1003 Sullivan 1980 & 19 & $3.6(2.2)$ & 19 & $1.3(1.3)$ & t & $1.18 \%$ & $1.25[0.55,1.95]$ \\
\hline 1004 Sullivan $1980 \mathrm{H}$ & 27 & $3.3(2.6)$ & 27 & $0.7(0.4)$ & 1 & $1.27 \%$ & $1.38[0.78,1.97]$ \\
\hline 1006 Skrabal 1981 & 20 & $0.6(0.3)$ & 20 & $0.3(0.2)$ & ; & $1.22 \%$ & $1.03[0.37,1.7]$ \\
\hline 1011 MacGregor 1982 & 19 & $1.7(1.6)$ & 19 & $1(0.7)$ &  & $1.23 \%$ & $0.54[-0.11,1.19]$ \\
\hline 1017 Sowers 1983 & 9 & $12.5(2.7)$ & 9 & $1.3(0.9)$ & * & $0.38 \%$ & $5.3[3.13,7.47]$ \\
\hline
\end{tabular}




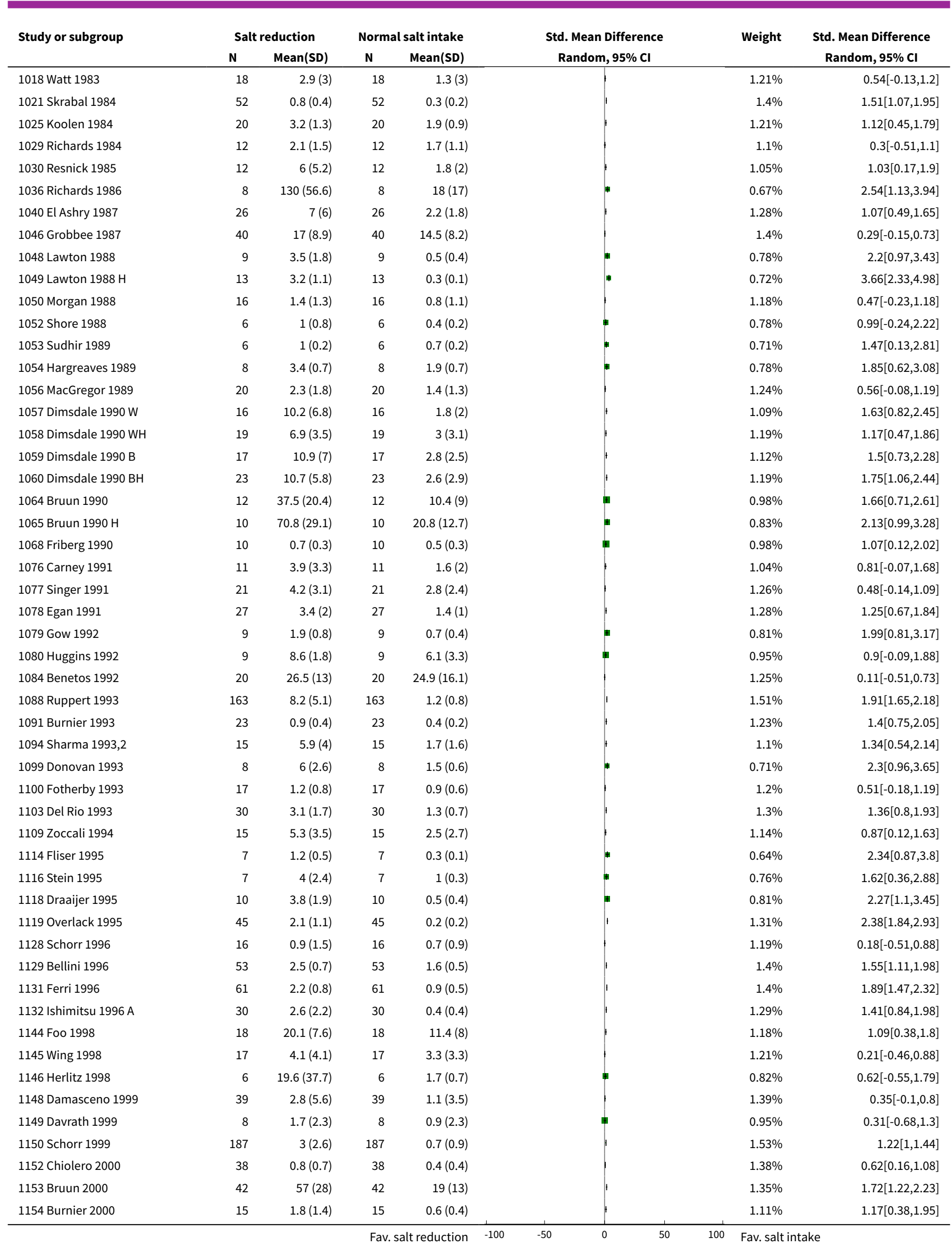

Effects of low sodium diet versus high sodium diet on blood pressure, renin, aldosterone, catecholamines, cholesterol, and triglyceride 


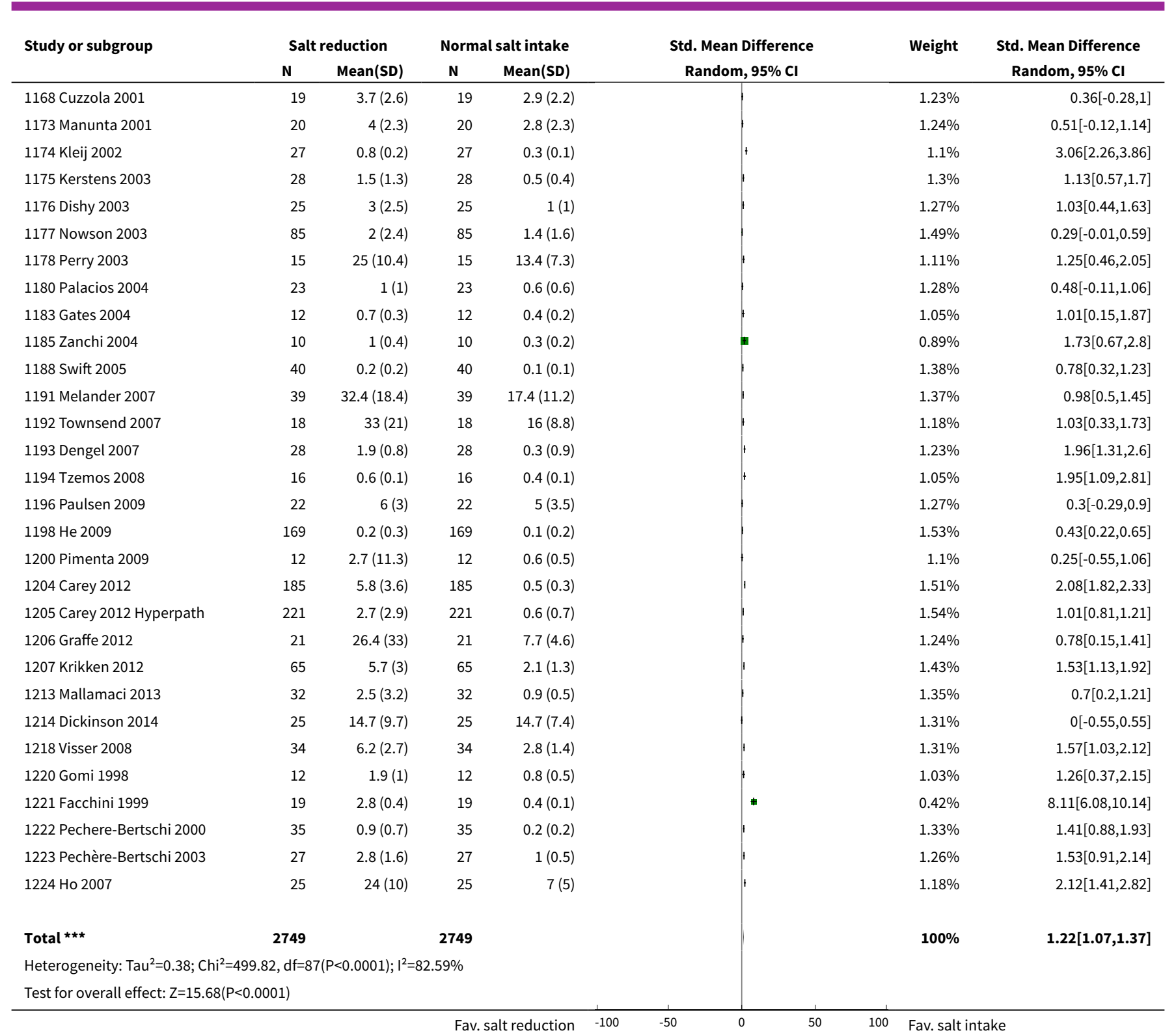

Analysis 5.2. Comparison 5 Effect of salt reduction on hormones, Outcome 2 Aldosterone $(\mathrm{pg} / \mathrm{mL})$.

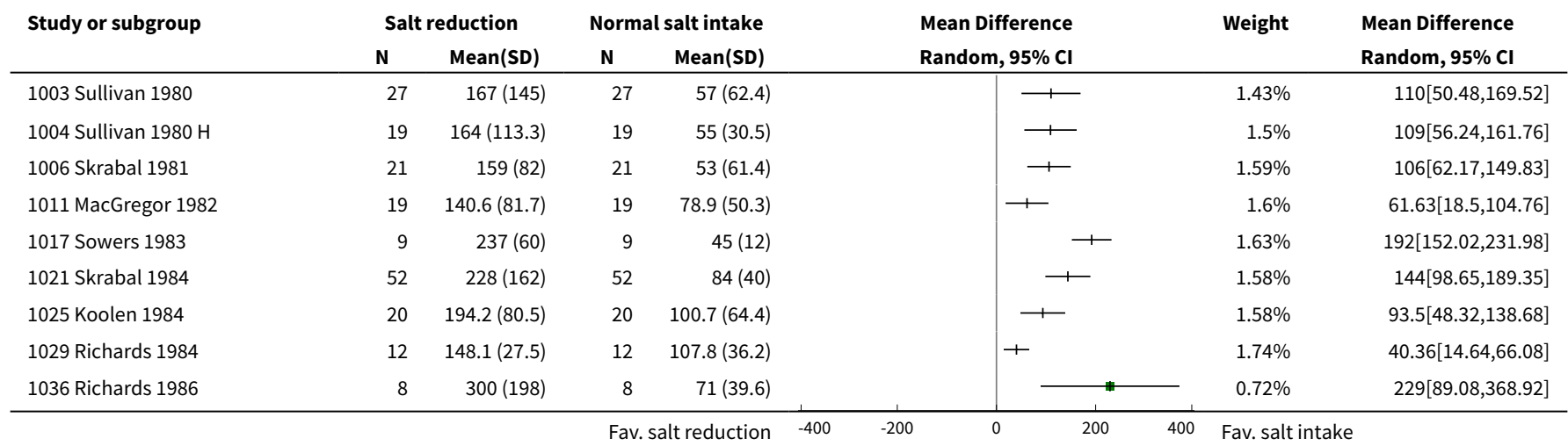

Effects of low sodium diet versus high sodium diet on blood pressure, renin, aldosterone, catecholamines, cholesterol, and triglyceride 235 (Review)

Copyright (c) 2017 The Cochrane Collaboration. Published by John Wiley \& Sons, Ltd. 


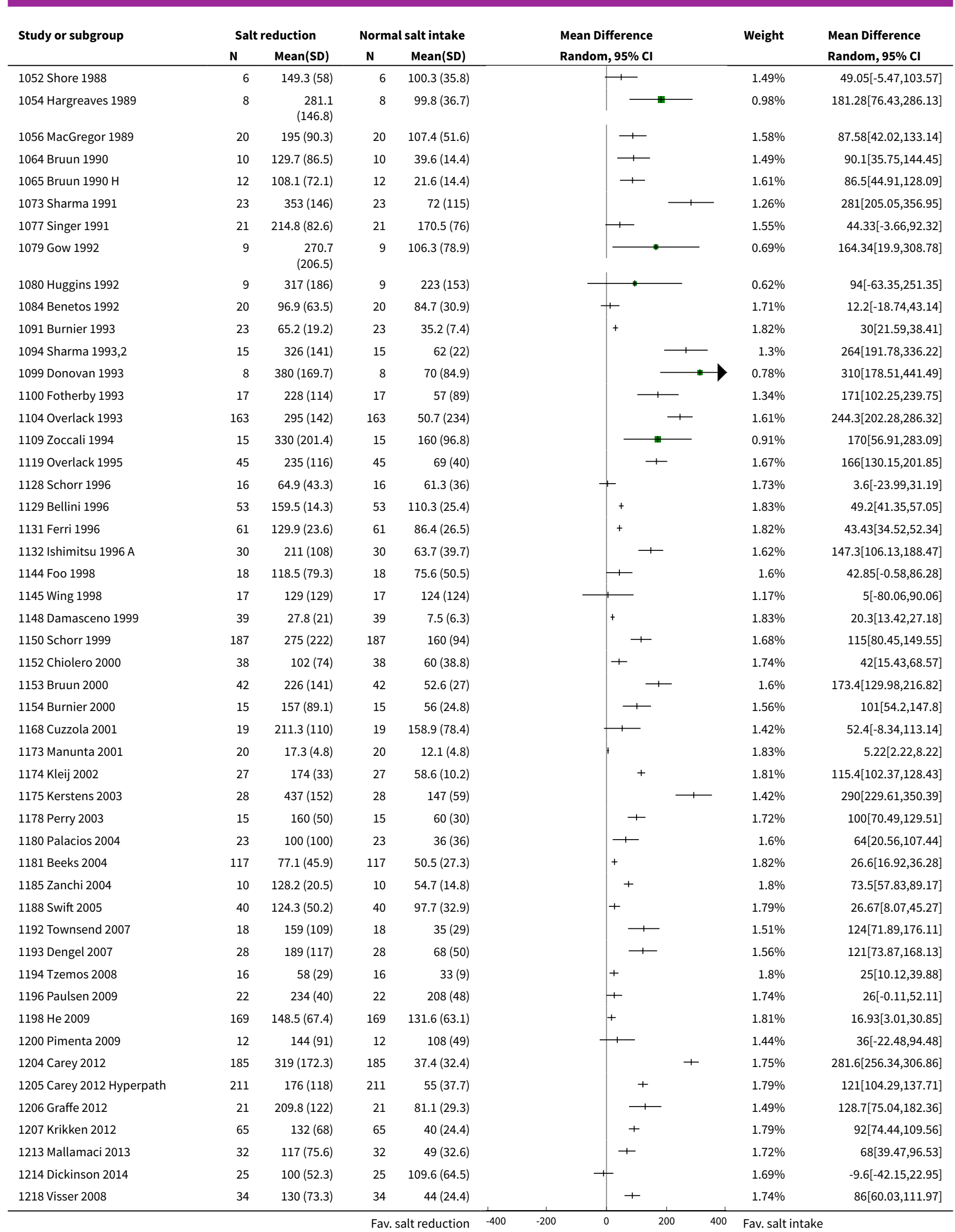

Effects of low sodium diet versus high sodium diet on blood pressure, renin, aldosterone, catecholamines, cholesterol, and triglyceride 236 (Review)

Copyright @ 2017 The Cochrane Collaboration. Published by John Wiley \& Sons, Ltd. 


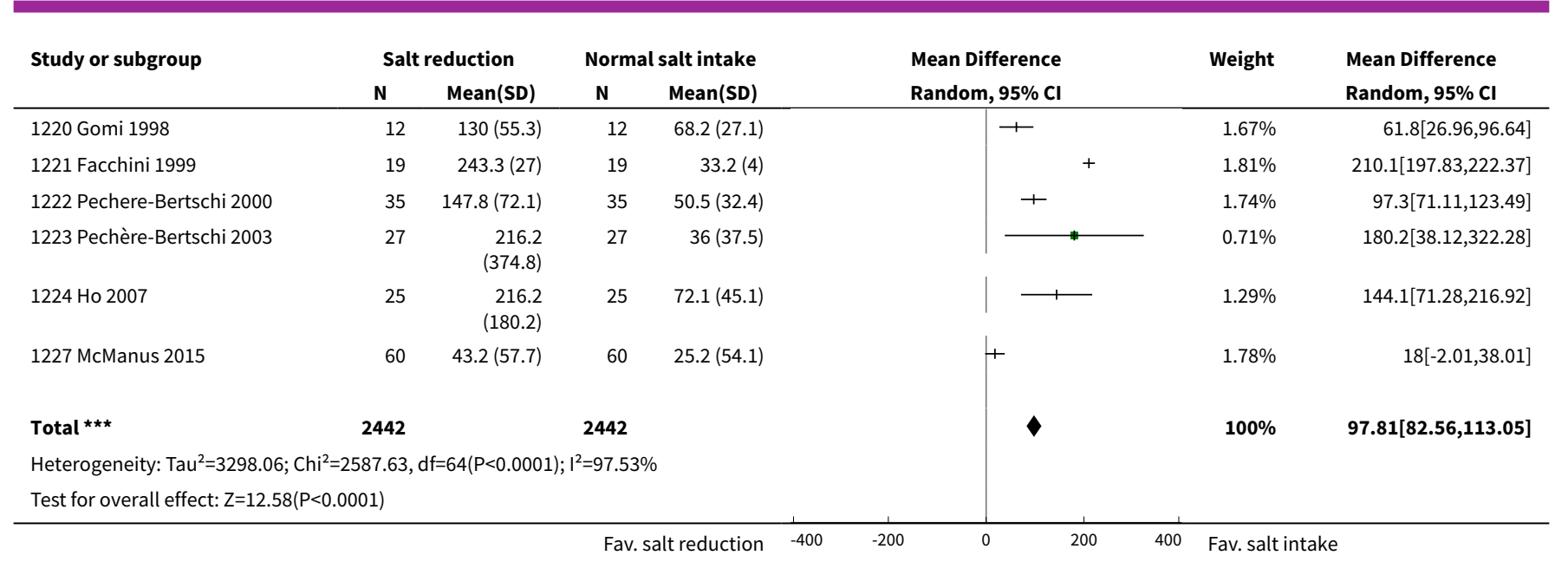

Analysis 5.3. Comparison 5 Effect of salt reduction on hormones, Outcome 3 Noradrenaline $(\mathrm{pg} / \mathrm{mL})$.

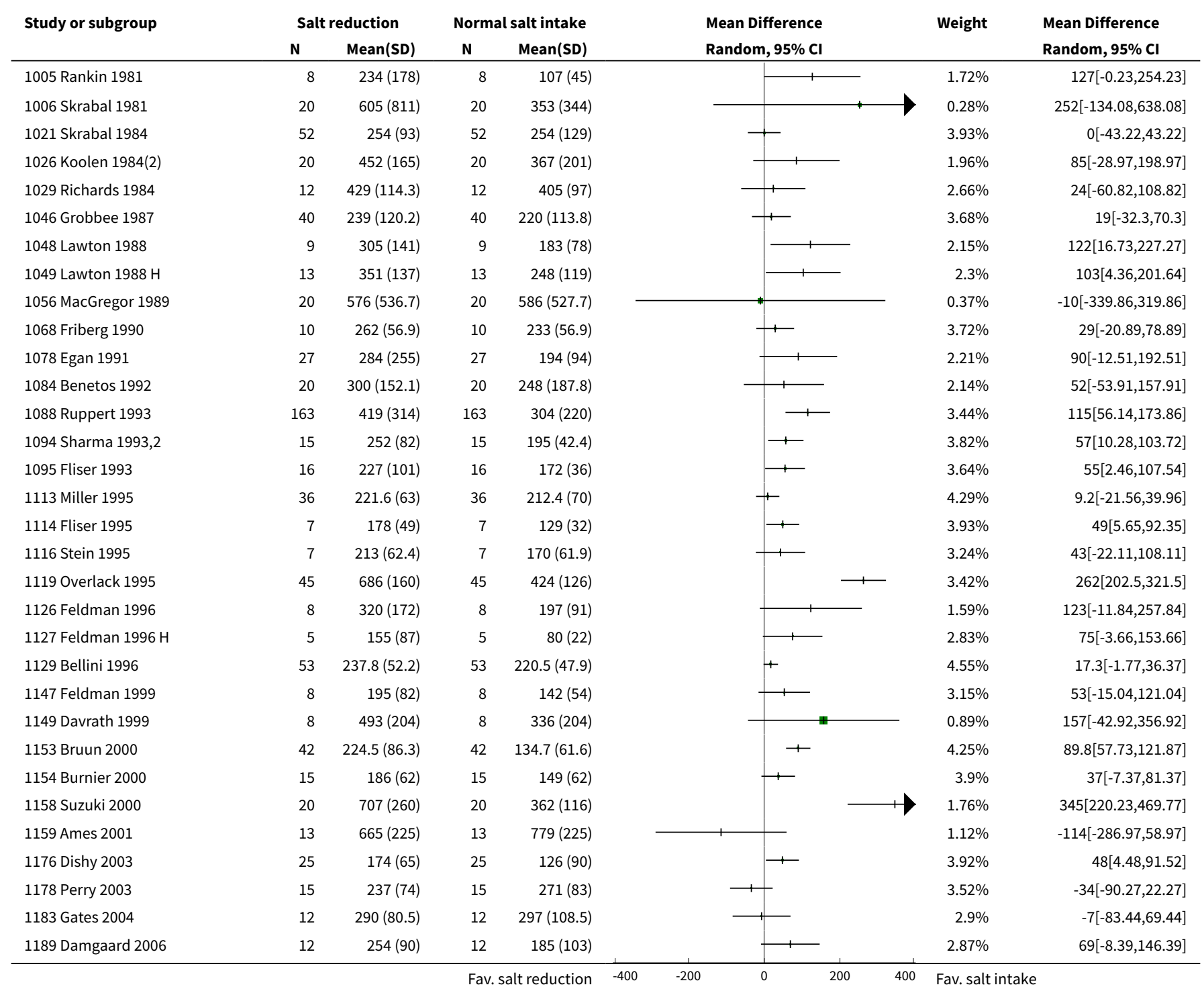

Effects of low sodium diet versus high sodium diet on blood pressure, renin, aldosterone, catecholamines, cholesterol, and triglyceride 


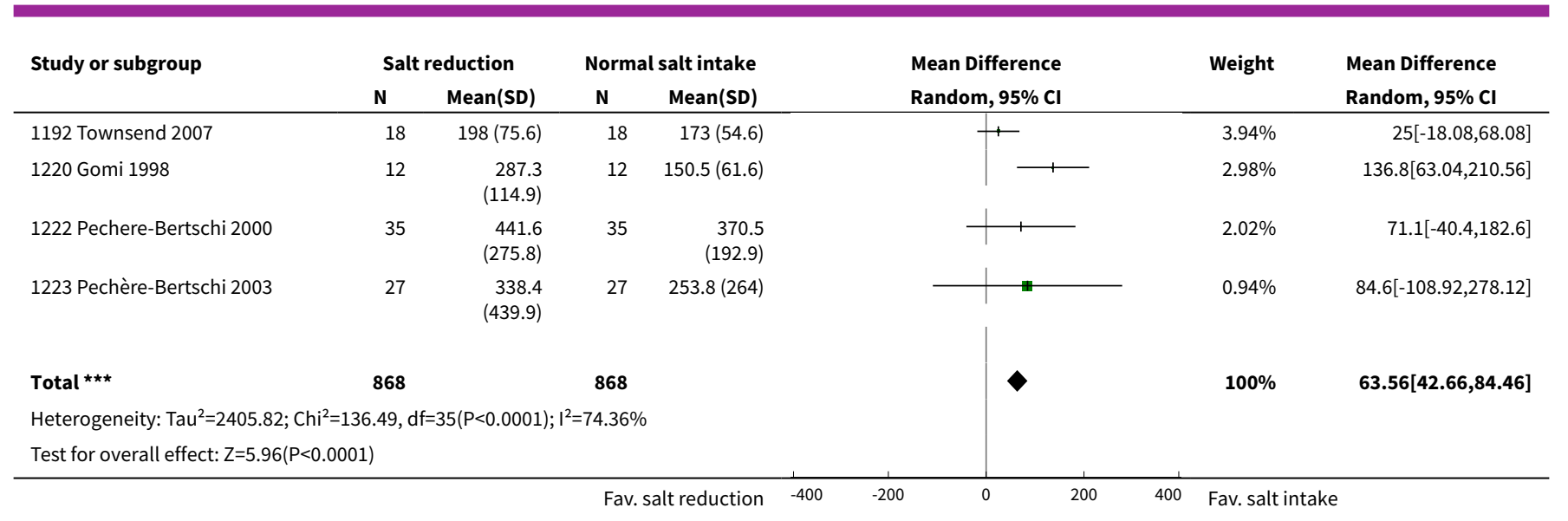

Analysis 5.4. Comparison 5 Effect of salt reduction on hormones, Outcome 4 Adrenaline ( $\mathrm{pg} / \mathrm{mL})$.

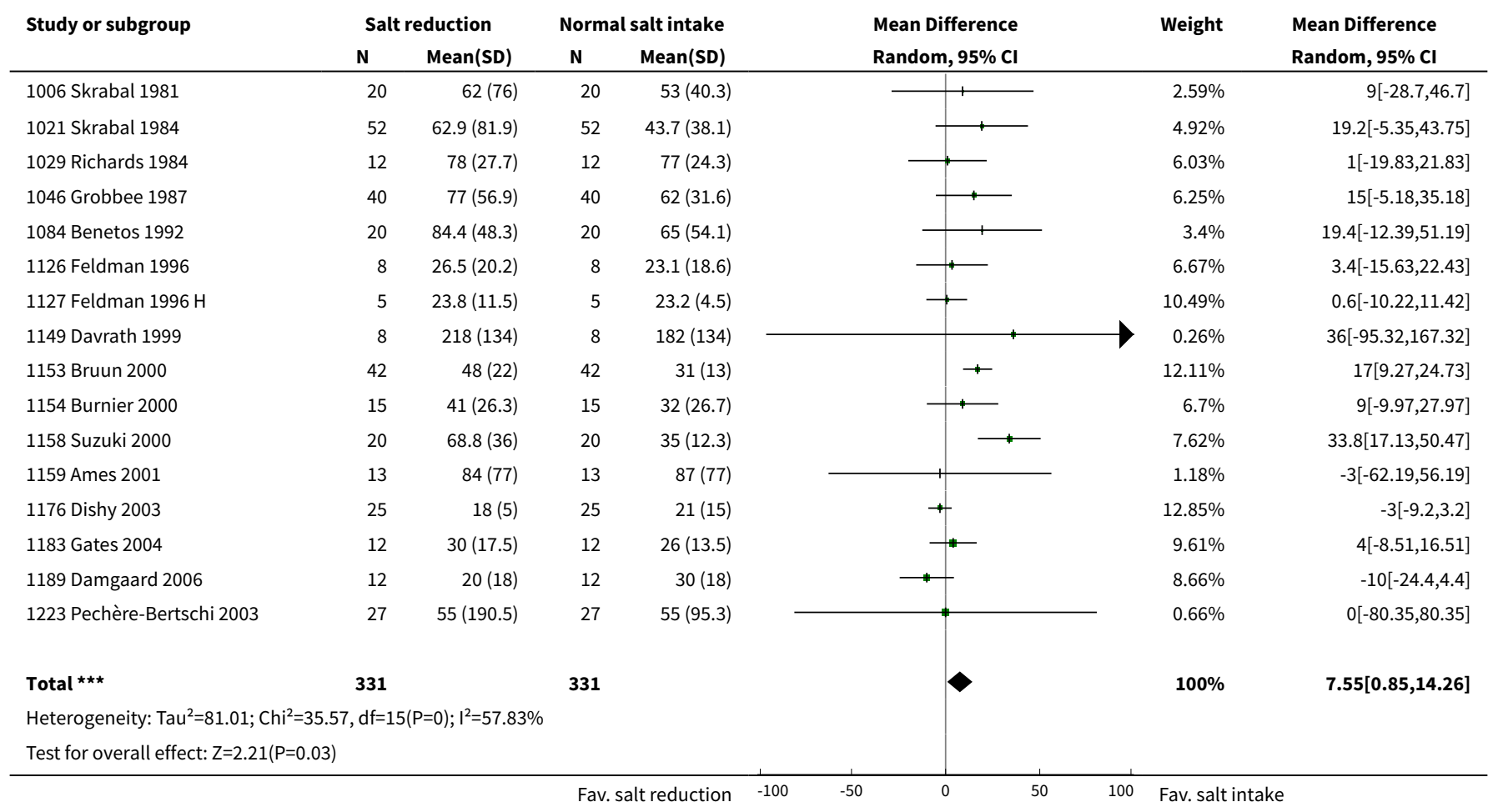

\section{Comparison 6. Effect of salt reduction on hormones, subgroup analysis}

\begin{tabular}{lllll}
\hline Outcome or subgroup title & $\begin{array}{l}\text { No. of } \\
\text { studies }\end{array}$ & $\begin{array}{l}\text { No. of } \\
\text { partici- } \\
\text { pants }\end{array}$ & Statistical method & Effect size \\
\hline 1 Renin $(\mathrm{ng} / \mathrm{mL} / \mathrm{hour})$ & 44 & 3470 & Std. Mean Difference (IV, Random, 95\% CI) & $1.05[0.85,1.24]$ \\
\hline 2 Aldosterone $(\mathrm{pg} / \mathrm{mL})$ & 34 & 3128 & Mean Difference (IV, Random, 95\% CI) & $95.59[74.12,117.05]$ \\
\hline
\end{tabular}

Effects of low sodium diet versus high sodium diet on blood pressure, renin, aldosterone, catecholamines, cholesterol, and triglyceride 


\begin{tabular}{lllll}
\hline Outcome or subgroup title & $\begin{array}{l}\text { No. of } \\
\text { studies }\end{array}$ & $\begin{array}{l}\text { No. of } \\
\text { partici- } \\
\text { pants }\end{array}$ & Statistical method & Effect size \\
\hline 3 Noradrenaline $(\mathrm{pg} / \mathrm{mL})$ & 23 & 964 & Mean Difference (IV, Random, 95\% Cl) & $48.66[28.88,68.44]$ \\
\hline 4 Adrenaline $(\mathrm{pg} / \mathrm{mL})$ & 12 & 486 & Mean Difference (IV, Random, 95\% Cl) & $7.79[0.31,15.28]$ \\
\hline
\end{tabular}

Analysis 6.1. Comparison 6 Effect of salt reduction on hormones, subgroup analysis, Outcome 1 Renin (ng/mL/hour).

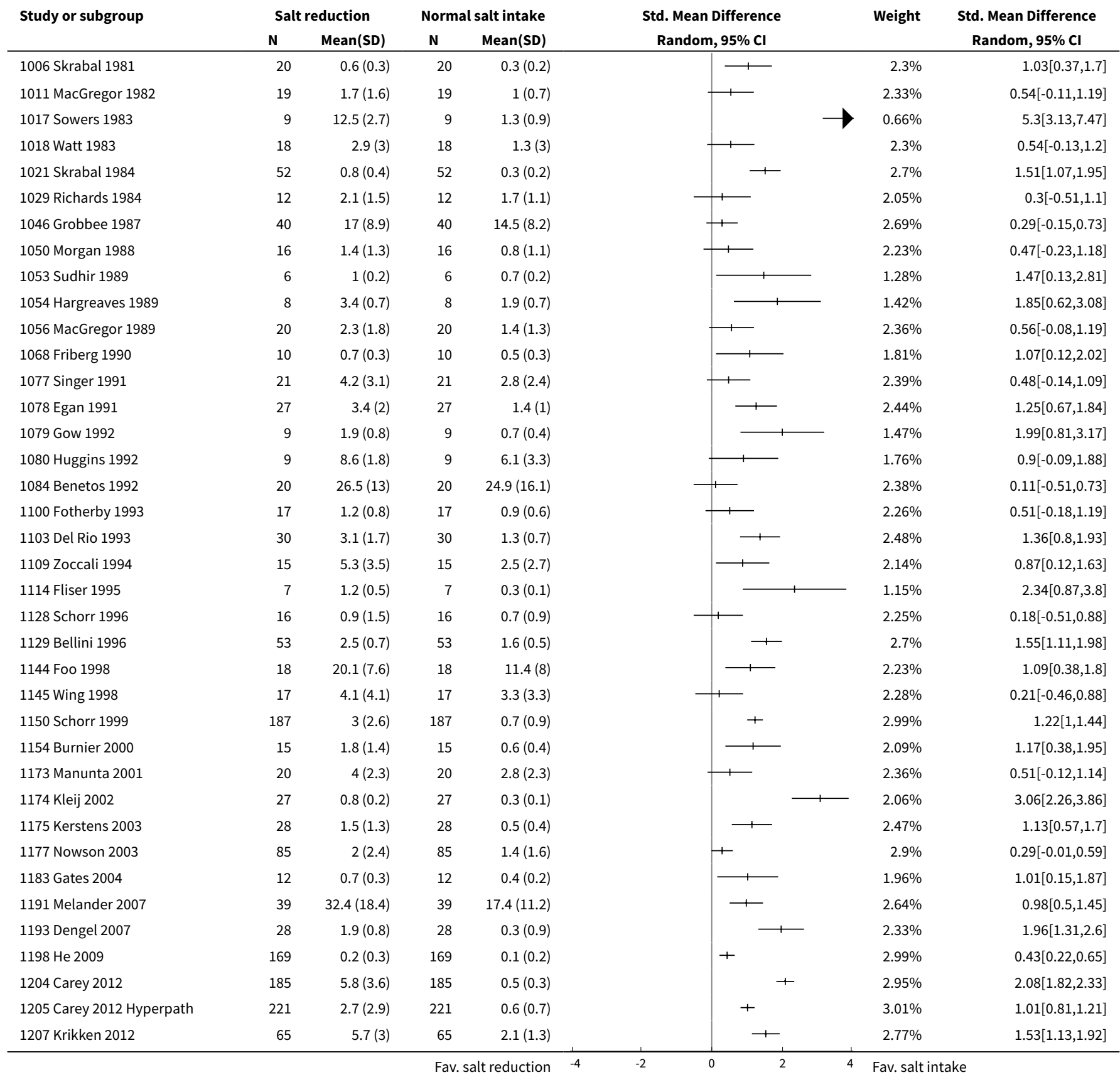






Analysis 6.2. Comparison 6 Effect of salt reduction on hormones, subgroup analysis, Outcome 2 Aldosterone $(\mathrm{pg} / \mathrm{mL})$.

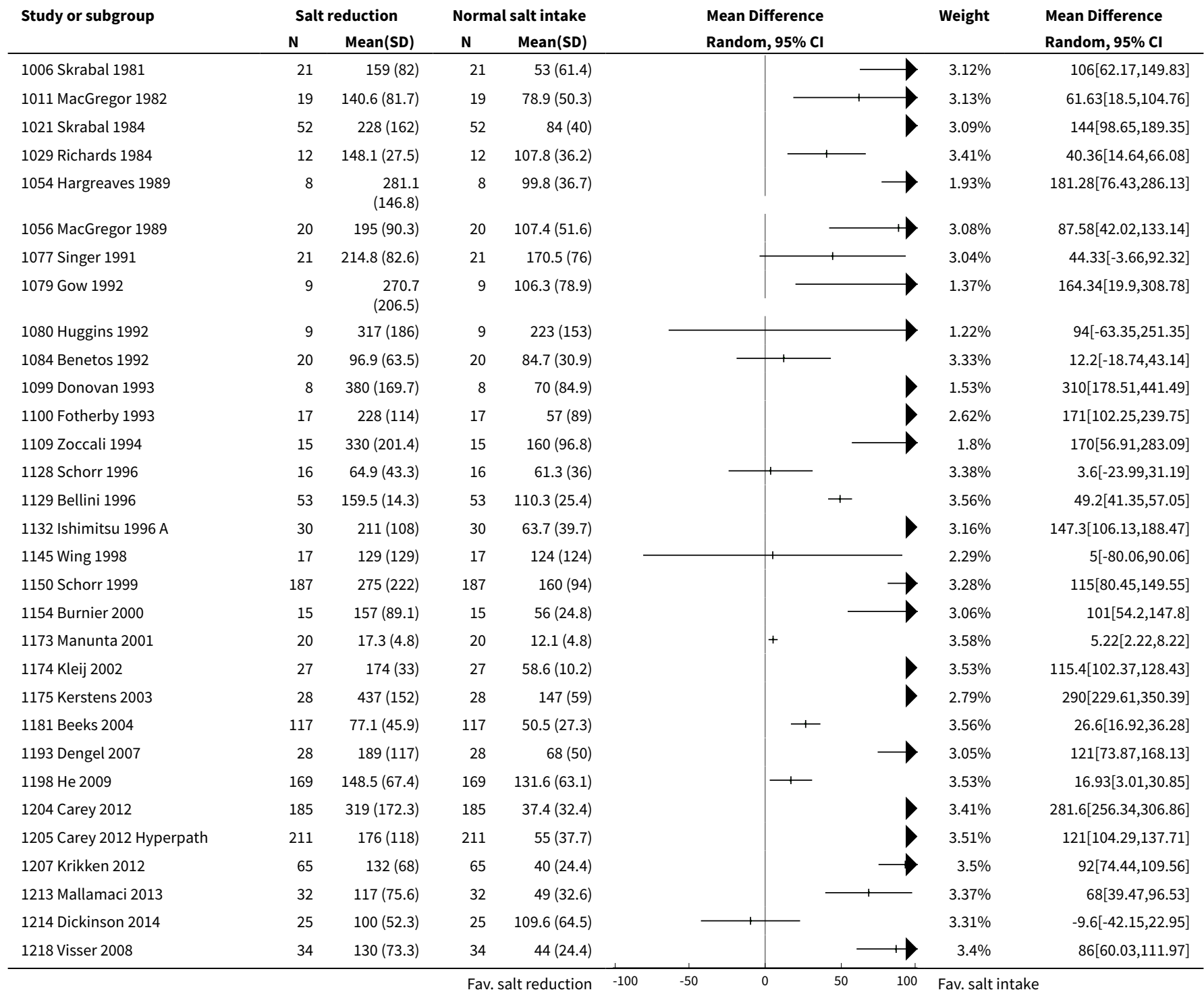

Effects of low sodium diet versus high sodium diet on blood pressure, renin, aldosterone, catecholamines, cholesterol, and triglyceride 240 (Review)

Copyright @ 2017 The Cochrane Collaboration. Published by John Wiley \& Sons, Ltd. 


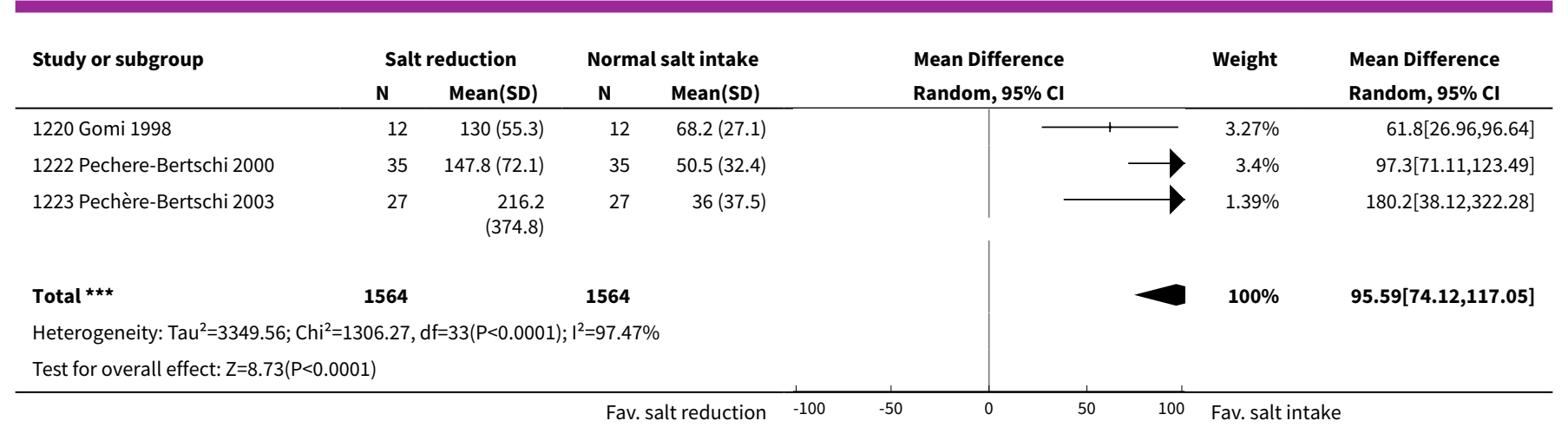

\section{Analysis 6.3. Comparison 6 Effect of salt reduction on hormones, subgroup analysis, Outcome 3 Noradrenaline $(\mathrm{pg} / \mathrm{mL})$.}

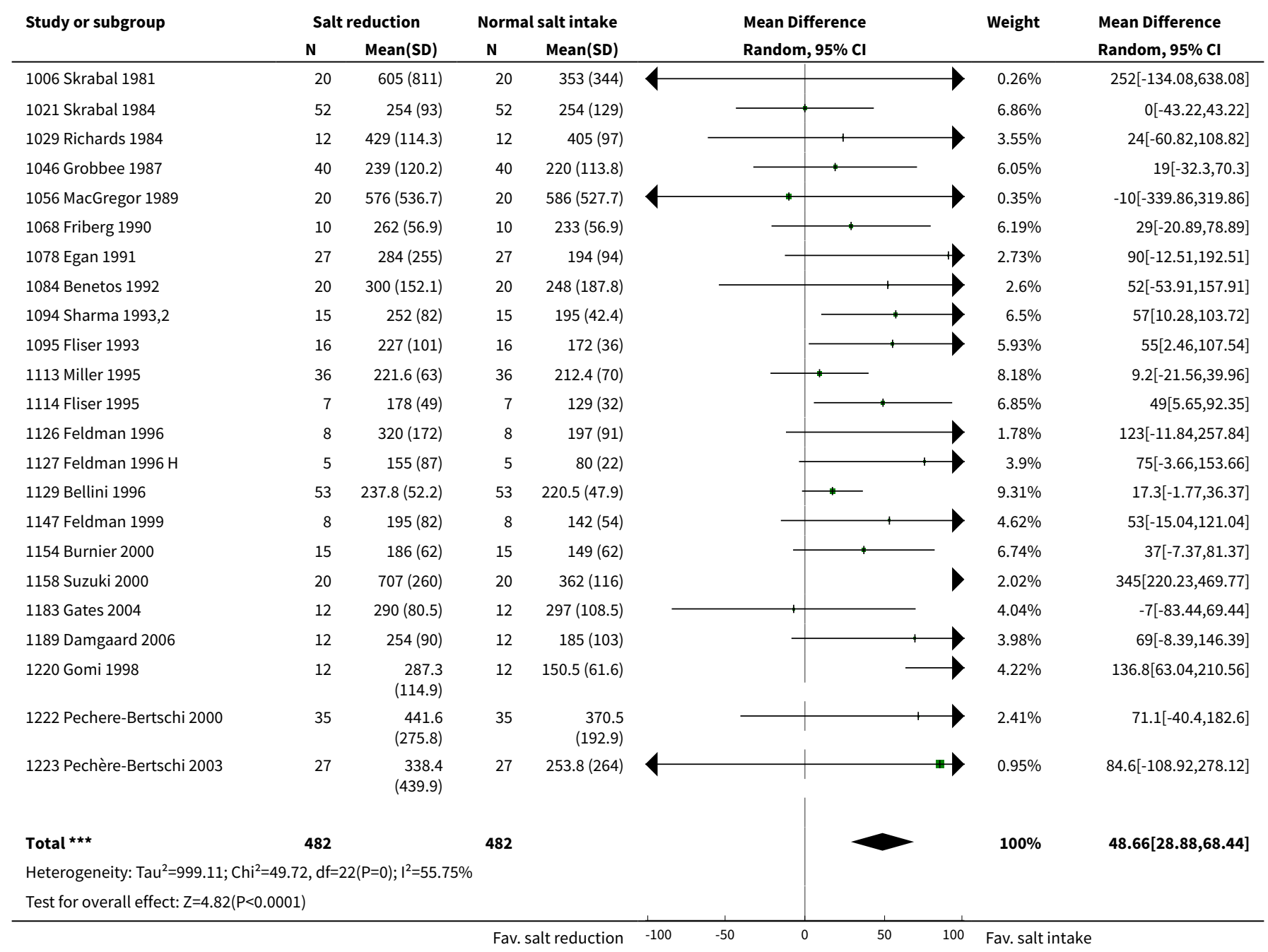




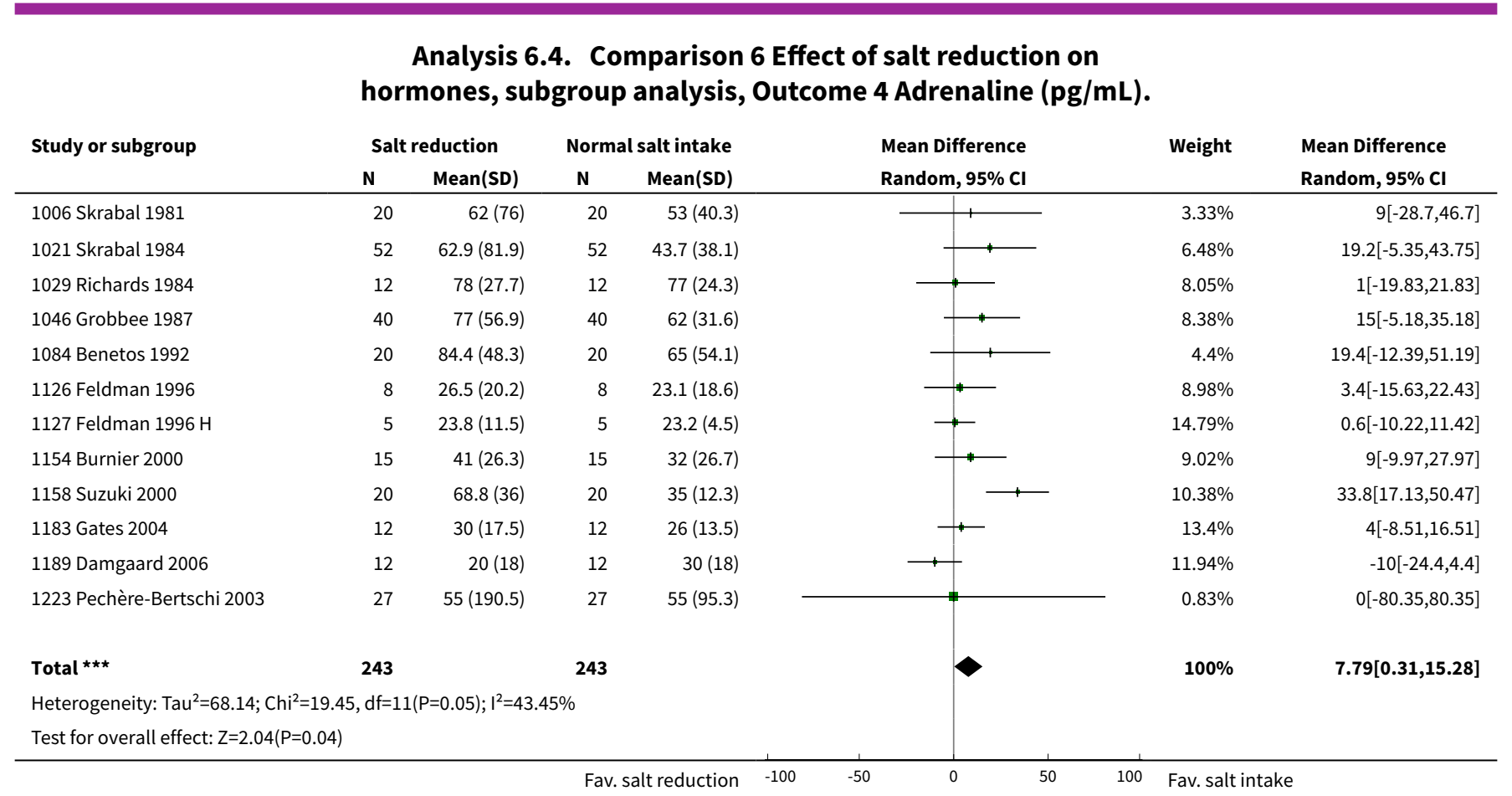

\section{Comparison 7. Effect of salt reduction on lipids}

\begin{tabular}{lllll}
\hline Outcome or subgroup title & $\begin{array}{l}\text { No. of } \\
\text { studies }\end{array}$ & $\begin{array}{l}\text { No. of } \\
\text { partici- } \\
\text { pants }\end{array}$ & Statistical method & Effect size \\
\hline 1 Cholesterol (mg/dL) & 27 & 1800 & $\begin{array}{l}\text { Mean Difference (IV, Random, 95\% } \\
\text { Cl) }\end{array}$ & $5.64[2.46,8.82]$ \\
\hline 2 Trigyceride (mg/dL) & 19 & 1390 & $\begin{array}{l}\text { Mean Difference (IV, Random, 95\% } \\
\text { Cl) }\end{array}$ & $7.04[3.04,11.05]$ \\
\hline 3 High density lipoprotein, HDL (mg/dL) & 19 & 1442 & $\begin{array}{l}\text { Mean Difference (IV, Random, 95\% } \\
\text { CI) }\end{array}$ & $-0.29[-1.66,1.08]$ \\
\hline 4 Low density lipoprotein, LDL (mg/dL) & 17 & 1358 & Mean Difference (IV, Fixed, 95\% CI) & $3.12[-0.41,6.64]$ \\
\hline
\end{tabular}

Analysis 7.1. Comparison 7 Effect of salt reduction on lipids, Outcome 1 Cholesterol (mg/dL).

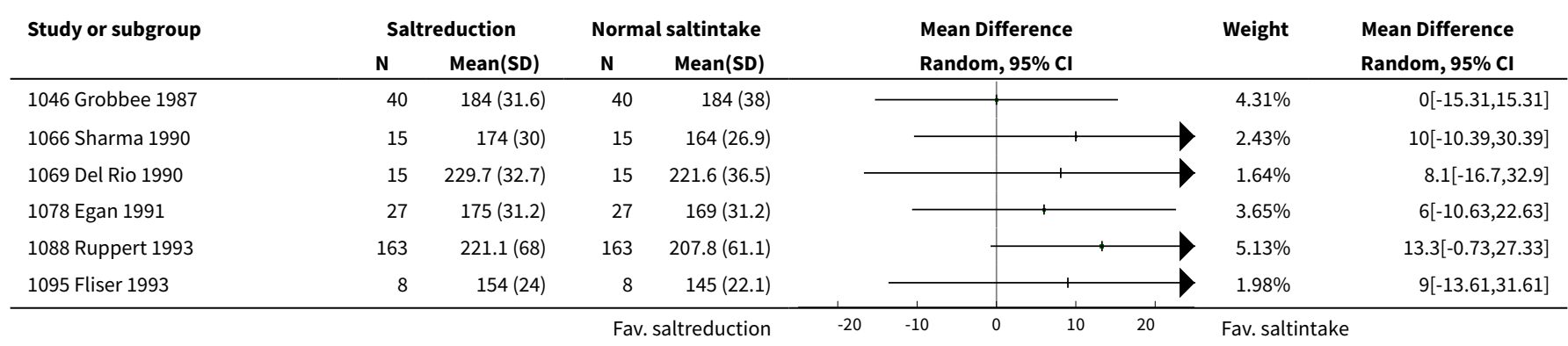




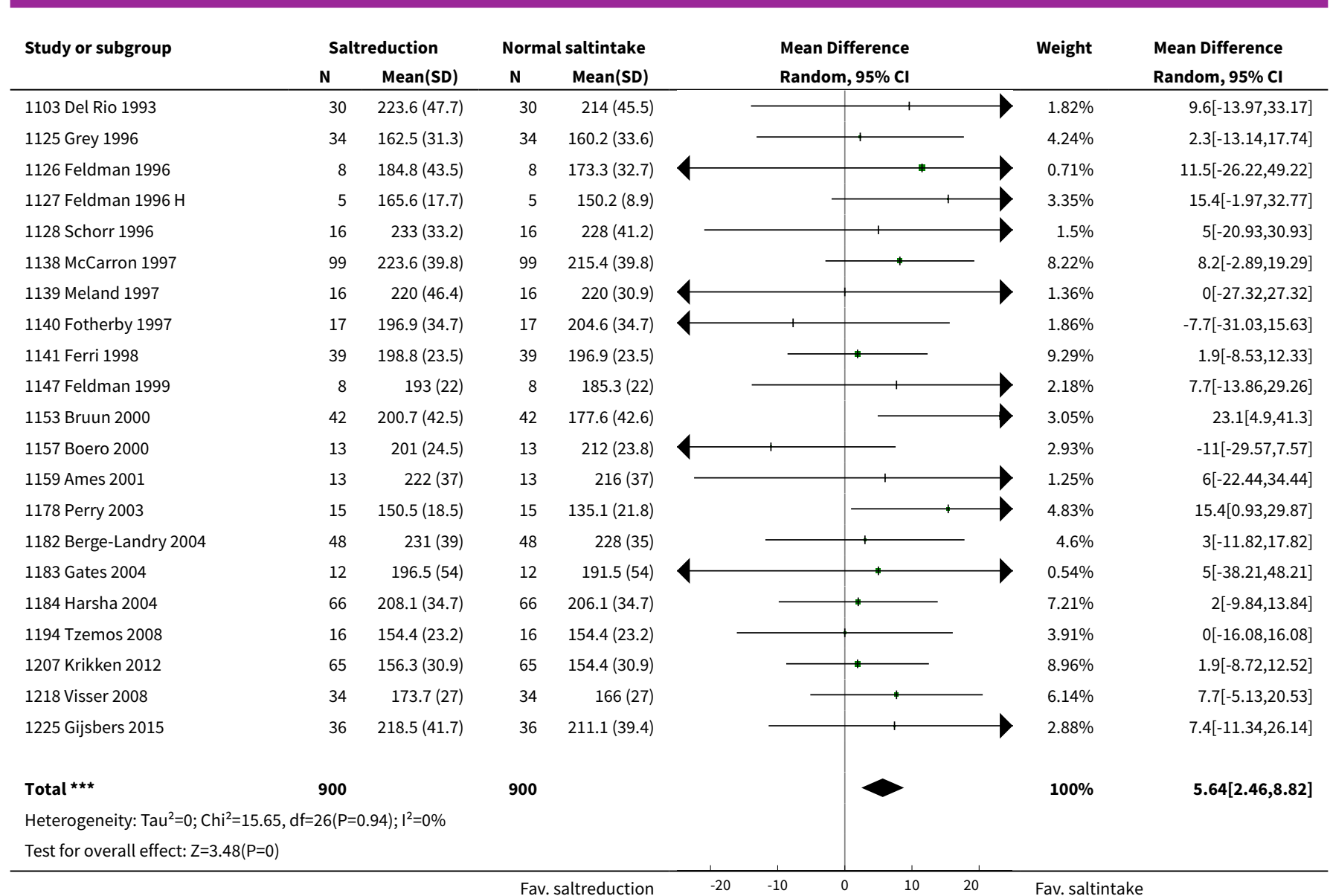

Analysis 7.2. Comparison 7 Effect of salt reduction on lipids, Outcome 2 Trigyceride (mg/dL).

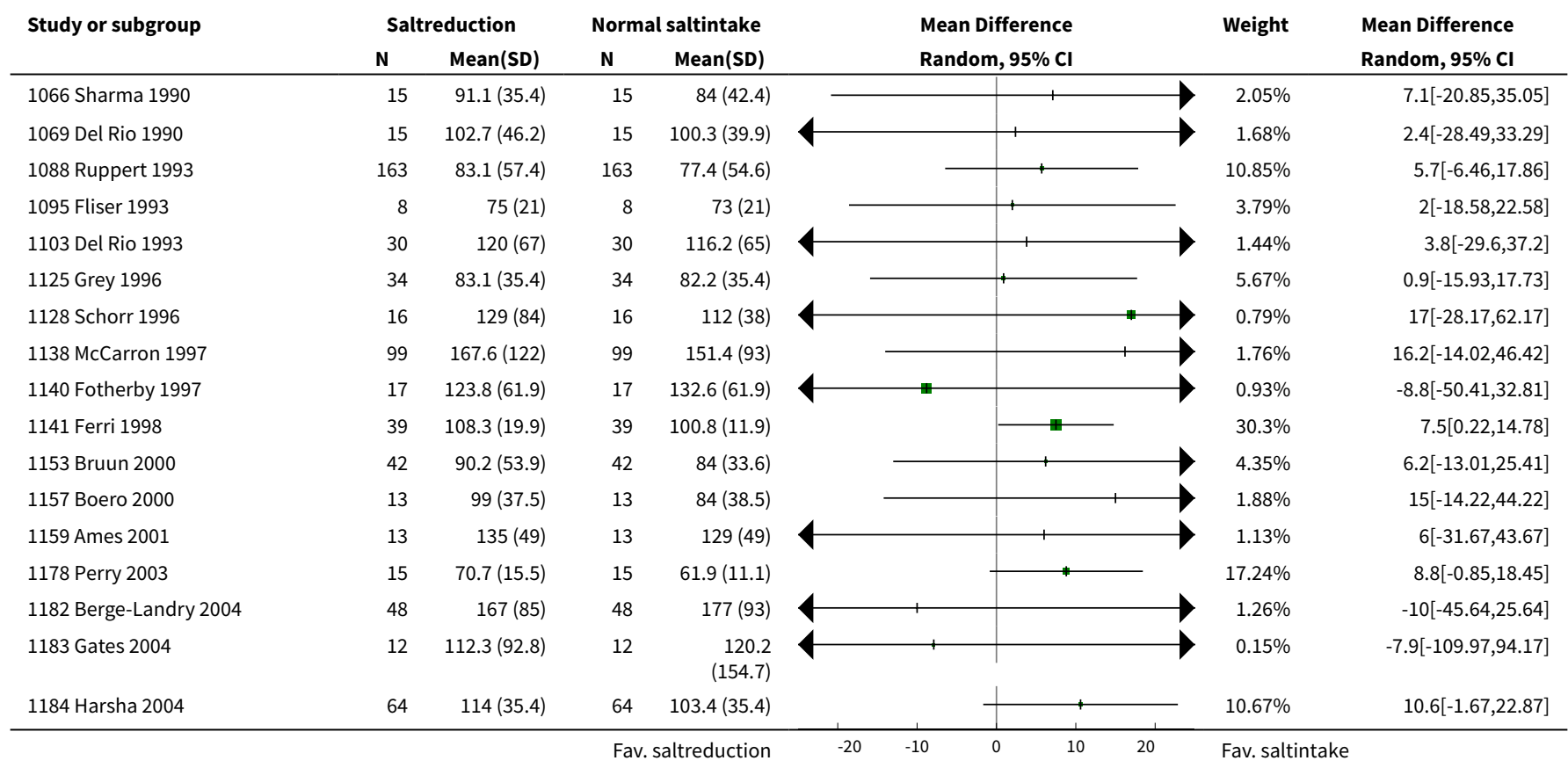




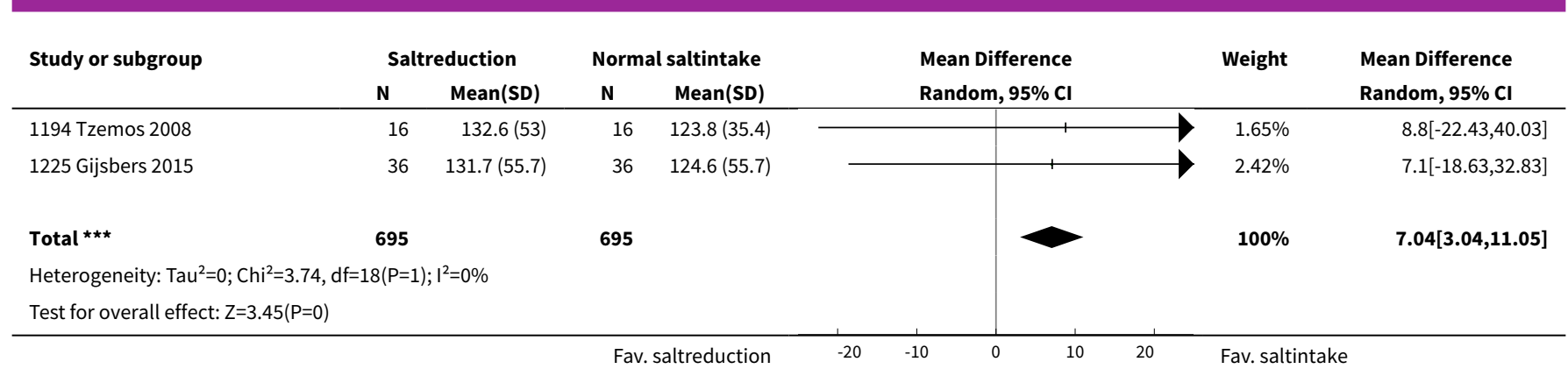

Analysis 7.3. Comparison 7 Effect of salt reduction on lipids, Outcome 3 High density lipoprotein, HDL (mg/dL).

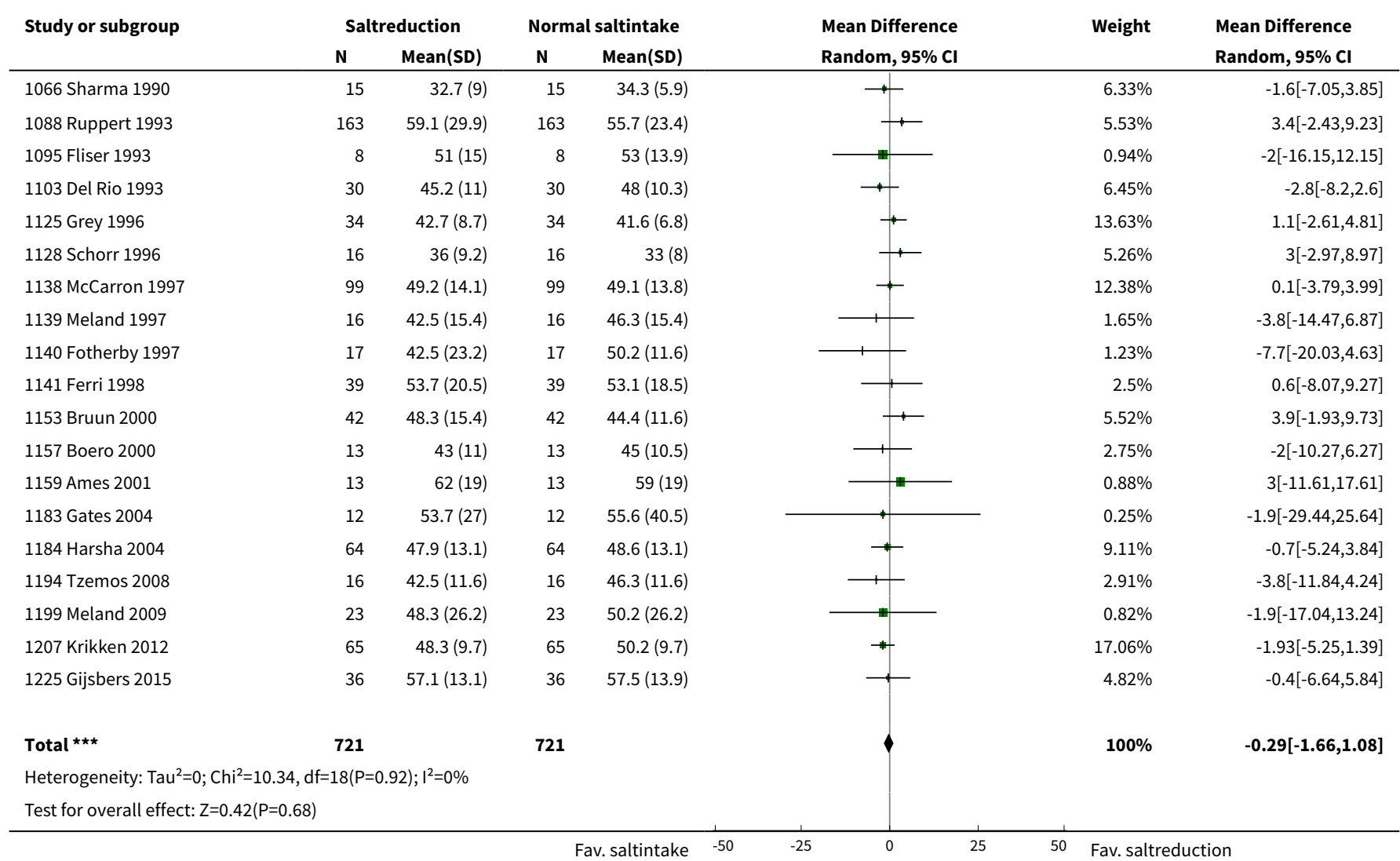

\section{Analysis 7.4. Comparison 7 Effect of salt reduction on lipids, Outcome 4 Low density lipoprotein, LDL (mg/dL).}

\begin{tabular}{|c|c|c|c|c|c|c|c|}
\hline \multirow{3}{*}{$\begin{array}{l}\text { Study or subgroup } \\
1066 \text { Sharma } 1990\end{array}$} & \multicolumn{2}{|c|}{ Saltreduction } & \multicolumn{2}{|c|}{ Normal saltintake } & \multirow{2}{*}{$\begin{array}{c}\text { Mean Difference } \\
\text { Fixed, } 95 \% \mathrm{Cl}\end{array}$} & \multirow[t]{2}{*}{ Weight } & \multirow{2}{*}{$\begin{array}{c}\text { Mean Difference } \\
\text { Fixed, } 95 \% \mathrm{Cl}\end{array}$} \\
\hline & $\mathbf{N}$ & $\operatorname{Mean}(S D)$ & $\mathbf{N}$ & Mean(SD) & & & \\
\hline & 15 & $120.3(30)$ & 15 & $110.1(24.6)$ & & $3.23 \%$ & $10.2[-9.43,29.83]$ \\
\hline 1078 Egan 1991 & 27 & $113.4(28.6)$ & 27 & $108.6(25.5)$ & + & $5.97 \%$ & $4.8[-9.64,19.24]$ \\
\hline 1088 Ruppert 1993 & 163 & $148.8(67.6)$ & 163 & $139.1(67.6)$ & & $5.78 \%$ & $9.7[-4.98,24.38]$ \\
\hline 1095 Fliser 1993 & 8 & $94(16.1)$ & 8 & $86(19)$ & & $4.19 \%$ & $8[-9.24,25.24]$ \\
\hline 1125 Grey 1996 & 34 & $101(29)$ & 34 & $102.8(31.3)$ & & $6.05 \%$ & $-1.8[-16.14,12.54]$ \\
\hline
\end{tabular}




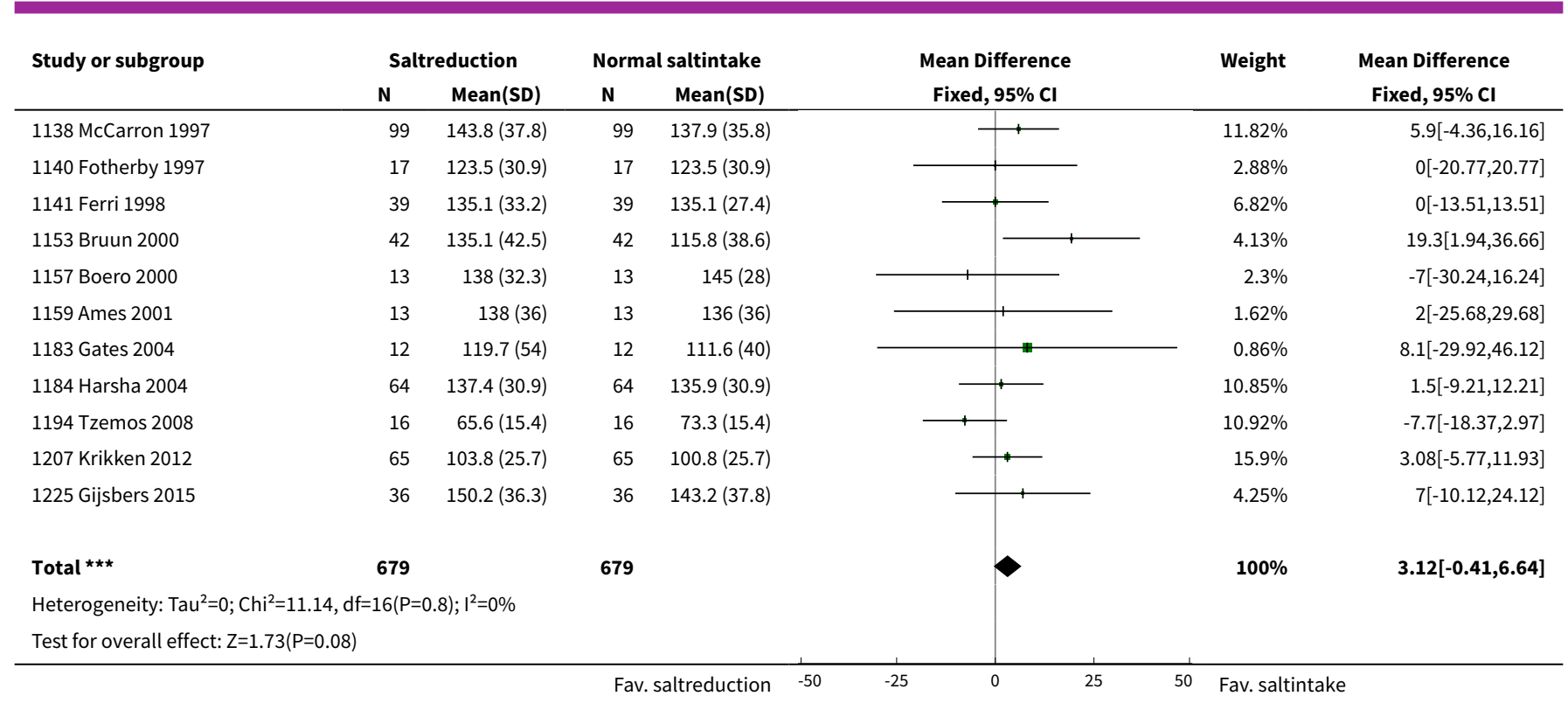

\section{Comparison 8. Effect of salt reduction on lipids, subgroup analysis}

\begin{tabular}{lllll}
\hline Outcome or subgroup title & $\begin{array}{l}\text { No. of } \\
\text { studies }\end{array}$ & $\begin{array}{l}\text { No. of } \\
\text { partici- } \\
\text { pants }\end{array}$ & Statistical method & Effect size \\
\hline 1 Cholesterol $(\mathrm{mg} / \mathrm{dL})$ & 20 & 1180 & $\begin{array}{l}\text { Mean Difference (IV, Random, 95\% } \\
\text { Cl) }\end{array}$ & $4.88[1.19,8.56]$ \\
\hline 2 Trigyceride (mg/dL) & 12 & 770 & Mean Difference (IV, Fixed, 95\% Cl) & $6.92[1.82,12.02]$ \\
\hline 3 High density lipoprotein, HDL (mg/dL) & 14 & 948 & Mean Difference (IV, Fixed, 95\% Cl) & $-0.67[-2.18,0.83]$ \\
\hline 4 Low density lipoprotein, LDL (mg/dL) & 12 & 864 & Mean Difference (IV, Fixed, 95\% Cl) & $3.63[-0.44,7.69]$ \\
\hline
\end{tabular}

Analysis 8.1. Comparison 8 Effect of salt reduction on lipids, subgroup analysis, Outcome 1 Cholesterol (mg/dL).

\begin{tabular}{|c|c|c|c|c|c|c|c|}
\hline \multirow[t]{2}{*}{ Study or subgroup } & \multicolumn{2}{|c|}{ Saltreduction } & \multicolumn{2}{|c|}{ Normal saltintake } & \multirow{2}{*}{$\begin{array}{l}\text { Mean Difference } \\
\text { Random, 95\% CI }\end{array}$} & \multirow[t]{2}{*}{ Weight } & \multirow{2}{*}{$\begin{array}{l}\text { Mean Difference } \\
\text { Random, } 95 \% \mathrm{Cl}\end{array}$} \\
\hline & $\mathbf{N}$ & Mean(SD) & $\mathbf{N}$ & Mean(SD) & & & \\
\hline 1046 Grobbee 1987 & 40 & $184(31.6)$ & 40 & $184(38)$ & & $5.81 \%$ & $0[-15.31,15.31]$ \\
\hline 1066 Sharma 1990 & 15 & $174(30)$ & 15 & $164(26.9)$ & & $3.27 \%$ & $10[-10.39,30.39]$ \\
\hline 1069 Del Rio 1990 & 15 & $229.7(32.7)$ & 15 & $221.6(36.5)$ & & $2.21 \%$ & $8.1[-16.7,32.9]$ \\
\hline 1078 Egan 1991 & 27 & $175(31.2)$ & 27 & $169(31.2)$ & & $4.92 \%$ & $6[-10.63,22.63]$ \\
\hline 1095 Fliser 1993 & 8 & $154(24)$ & 8 & $145(22.1)$ & & $2.66 \%$ & $9[-13.61,31.61]$ \\
\hline 1103 Del Rio 1993 & 30 & $223.6(47.7)$ & 30 & $214(45.5)$ & & $2.45 \%$ & $9.6[-13.97,33.17]$ \\
\hline 1125 Grey 1996 & 34 & $162.5(31.3)$ & 34 & $160.2(33.6)$ & & $5.71 \%$ & $2.3[-13.14,17.74]$ \\
\hline 1126 Feldman 1996 & 8 & $184.8(43.5)$ & 8 & $173.3(32.7)$ & & $0.96 \%$ & $11.5[-26.22,49.22]$ \\
\hline 1127 Feldman $1996 \mathrm{H}$ & 5 & $165.6(17.7)$ & 5 & $150.2(8.9)$ & & $4.51 \%$ & $15.4[-1.97,32.77]$ \\
\hline 1128 Schorr 1996 & 16 & $233(33.2)$ & 16 & $228(41.2)$ & & $2.02 \%$ & $5[-20.93,30.93]$ \\
\hline 1138 McCarron 1997 & 99 & $223.6(39.8)$ & 99 & $215.4(39.8)$ & & $11.07 \%$ & $8.2[-2.89,19.29]$ \\
\hline
\end{tabular}




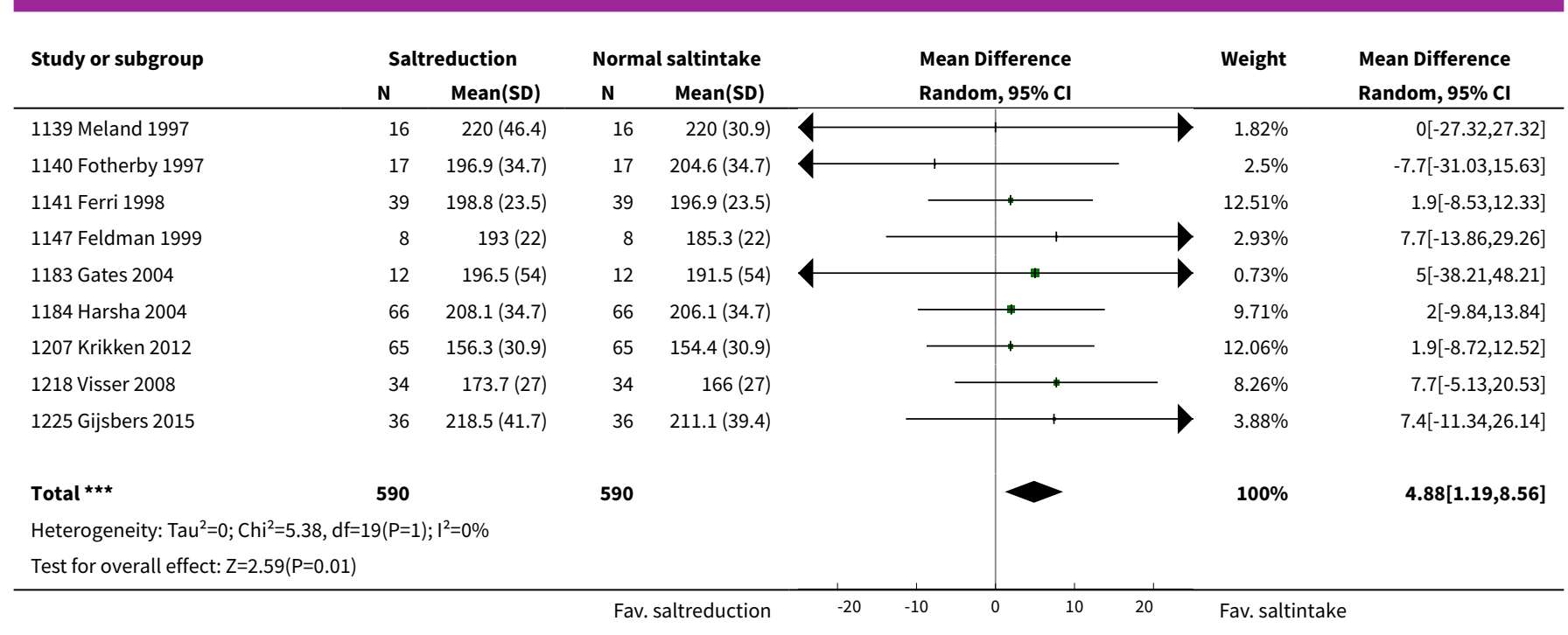

Analysis 8.2. Comparison 8 Effect of salt reduction on lipids, subgroup analysis, Outcome 2 Trigyceride (mg/dL).

\begin{tabular}{|c|c|c|c|c|c|c|c|}
\hline \multirow{3}{*}{$\begin{array}{l}\text { Study or subgroup } \\
1066 \text { Sharma } 1990\end{array}$} & \multicolumn{2}{|c|}{ Saltreduction } & \multicolumn{2}{|c|}{ Normal saltintake } & \multirow{2}{*}{$\begin{array}{c}\text { Mean Difference } \\
\text { Fixed, } 95 \% \mathrm{Cl}\end{array}$} & \multirow[t]{2}{*}{ Weight } & \multirow{2}{*}{$\begin{array}{c}\text { Mean Difference } \\
\text { Fixed, } 95 \% \mathrm{Cl} \\
\end{array}$} \\
\hline & $\mathbf{N}$ & Mean(SD) & $\mathbf{N}$ & Mean(SD) & & & \\
\hline & 15 & $91.1(35.4)$ & 15 & $84(42.4)$ & & $3.33 \%$ & $7.1[-20.85,35.05]$ \\
\hline 1069 Del Rio 1990 & 15 & $102.7(46.2)$ & 15 & $100.3(39.9)$ & & $2.73 \%$ & $2.4[-28.49,33.29]$ \\
\hline 1095 Fliser 1993 & 8 & $75(21)$ & 8 & $73(21)$ & & $6.15 \%$ & $2[-18.58,22.58]$ \\
\hline 1103 Del Rio 1993 & 30 & $120(67)$ & 30 & $116.2(65)$ & & $2.33 \%$ & $3.8[-29.6,37.2]$ \\
\hline 1125 Grey 1996 & 34 & $83.1(35.4)$ & 34 & $82.2(35.4)$ & 4 & $9.19 \%$ & $0.9[-15.93,17.73]$ \\
\hline 1138 McCarron 1997 & 99 & $167.6(122)$ & 99 & 151.4 (93) & & $2.85 \%$ & $16.2[-14.02,46.42]$ \\
\hline 1140 Fotherby 1997 & 17 & $123.8(61.9)$ & 17 & $132.6(61.9)$ & & $1.5 \%$ & $-8.8[-50.41,32.81]$ \\
\hline 1141 Ferri 1998 & 39 & $108.3(19.9)$ & 39 & $100.8(11.9)$ & & $49.16 \%$ & $7.5[0.22,14.78]$ \\
\hline 1183 Gates 2004 & 12 & $112.3(92.8)$ & 12 & $\begin{array}{r}120.2 \\
(154.7)\end{array}$ & & $0.25 \%$ & $-7.9[-109.97,94.17]$ \\
\hline 1184 Harsha 2004 & 64 & $114(35.4)$ & 64 & $103.4(35.4)$ & & $17.3 \%$ & $10.6[-1.67,22.87]$ \\
\hline  & 385 & & 385 & & & $100 \%$ & $6.92[1.82,12.02]$ \\
\hline \multicolumn{8}{|c|}{ Heterogeneity: Tau $^{2}=0 ; \mathrm{Chi}^{2}=2.38, \mathrm{df}=11(\mathrm{P}=1) ; \mathrm{I}^{2}=0 \%$} \\
\hline \multicolumn{5}{|c|}{ Test for overall effect: $Z=2.66(P=0.01)$} & & & \\
\hline
\end{tabular}

Analysis 8.3. Comparison 8 Effect of salt reduction on lipids, subgroup analysis, Outcome 3 High density lipoprotein, $\mathrm{HDL}(\mathrm{mg} / \mathrm{dL})$.

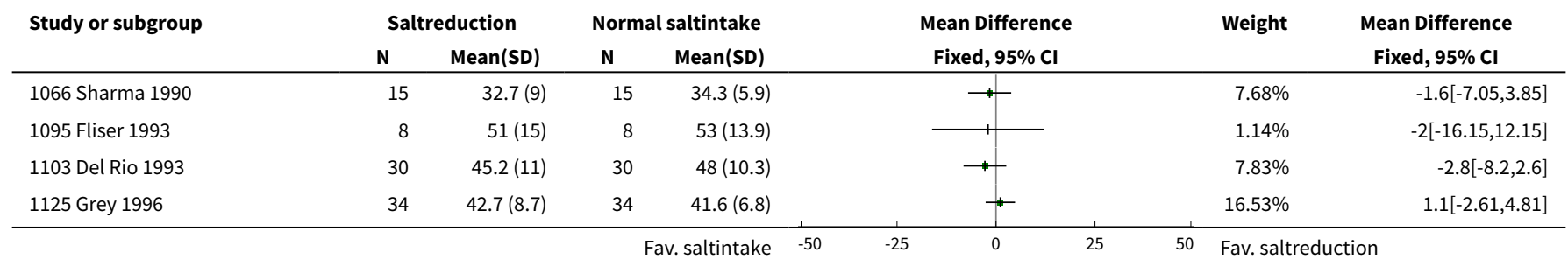




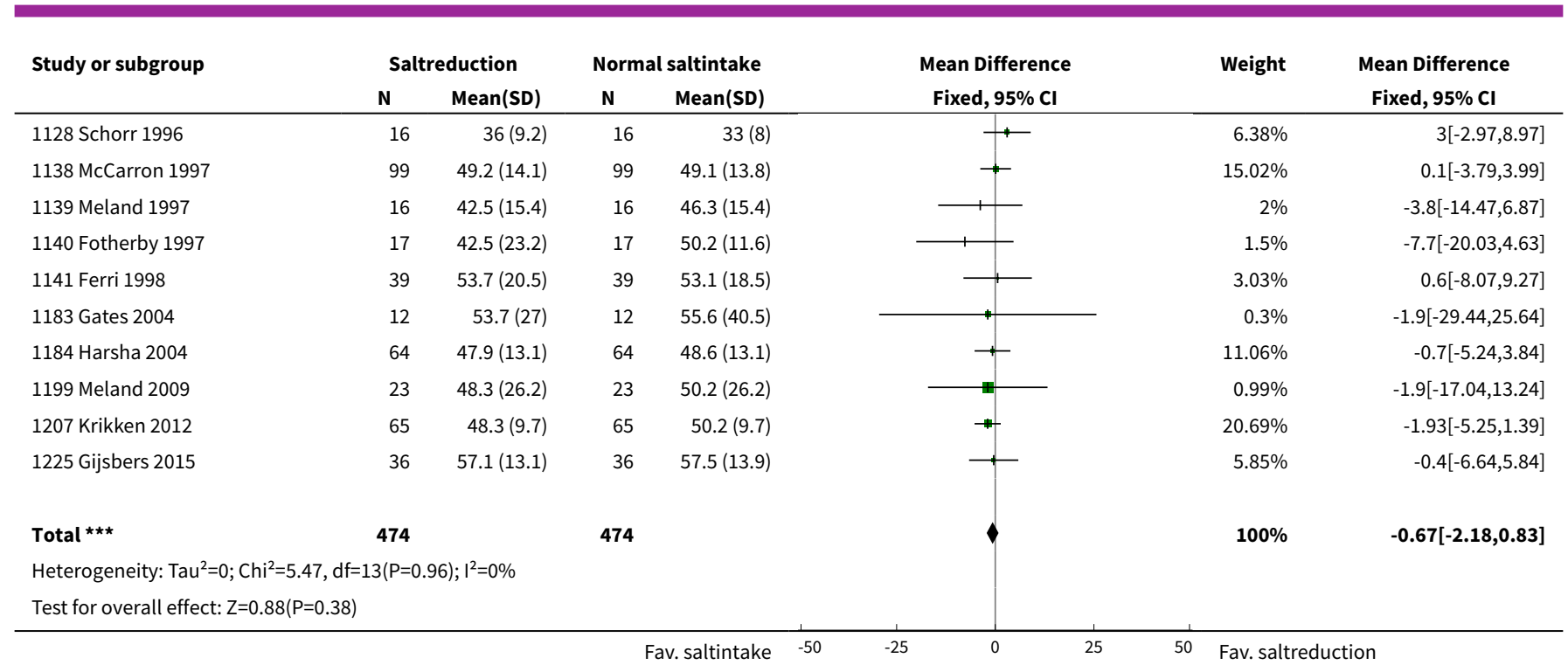

Analysis 8.4. Comparison 8 Effect of salt reduction on lipids, subgroup analysis, Outcome 4 Low density lipoprotein, LDL (mg/dL).

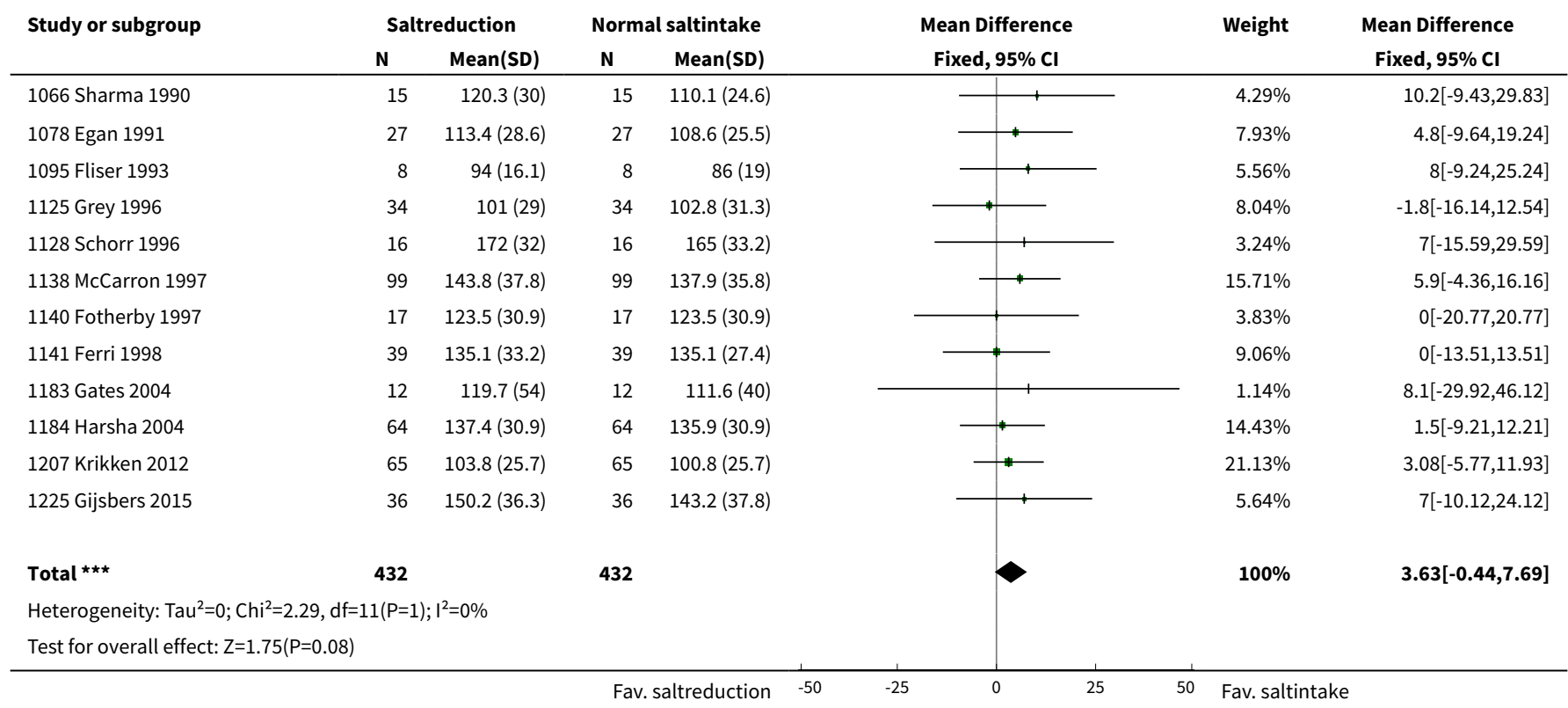

\section{Comparison 9. Bias analyses}

\begin{tabular}{lllll}
\hline Outcome or subgroup title & $\begin{array}{l}\text { No. of } \\
\text { studies }\end{array}$ & $\begin{array}{l}\text { No. of } \\
\text { partici- } \\
\text { pants }\end{array}$ & Statistical method & Effect size \\
\hline $\begin{array}{l}1 \text { White population, normotensive, SBP } \\
\text { blinding-high }\end{array}$ & 66 & 7100 & Mean Difference (Fixed, 95\% CI) & $-0.91[-1.19,-0.63]$ \\
\hline
\end{tabular}

Effects of low sodium diet versus high sodium diet on blood pressure, renin, aldosterone, catecholamines, cholesterol, and triglyceride 


\begin{tabular}{lllll}
\hline Outcome or subgroup title & $\begin{array}{l}\text { No. of } \\
\text { studies }\end{array}$ & $\begin{array}{l}\text { No. of } \\
\text { partici- } \\
\text { pants }\end{array}$ & Statistical method & Effect size \\
\hline $\begin{array}{l}2 \text { White population, normotensive, SBP } \\
\text { blinding-low }\end{array}$ & 24 & 1193 & Mean Difference (Fixed, 95\% Cl) & $-1.05[-1.61,-0.50]$ \\
\hline $\begin{array}{l}3 \text { White population, normotensive, SBP out- } \\
\text { come-assesed-high }\end{array}$ & 36 & 2771 & Mean Difference (Fixed, 95\% Cl) & $-1.12[-1.60,-0.65]$ \\
\hline $\begin{array}{l}4 \text { White population, normotensive, SBP out- } \\
\text { come-assesed-low }\end{array}$ & 56 & 5768 & Mean Difference (Fixed, 95\% Cl) & $-0.89[-1.18,-0.60]$ \\
\hline $\begin{array}{l}5 \text { White population, hypertensive, SBP } \\
\text { blinding-high }\end{array}$ & 45 & 3814 & Mean Difference (Fixed, 95\% Cl) & $-6.03[-6.64,-5.41]$ \\
\hline $\begin{array}{l}6 \text { White population, hypertensive, SBP } \\
\text { blinding-low }\end{array}$ & 36 & 1911 & Mean Difference (Fixed, 95\% Cl) & $-5.78[-6.39,-5.17]$ \\
\hline $\begin{array}{l}\text { 7 White population, hypertensive, SBP out- } \\
\text { come-assesed-high }\end{array}$ & 27 & 2470 & Mean Difference (Fixed, 95\% Cl) & $-6.07[-6.95,-5.19]$ \\
\hline $\begin{array}{l}\text { 8 White population, hypertensive, SBP out- } \\
\text { come-assesed-low }\end{array}$ & 55 & 3433 & Mean Difference (Fixed, 95\% Cl) & $-5.71[-6.23,-5.19]$ \\
\hline
\end{tabular}

\section{Analysis 9.1. Comparison 9 Bias analyses, Outcome 1 White population, normotensive, SBP blinding-high.}

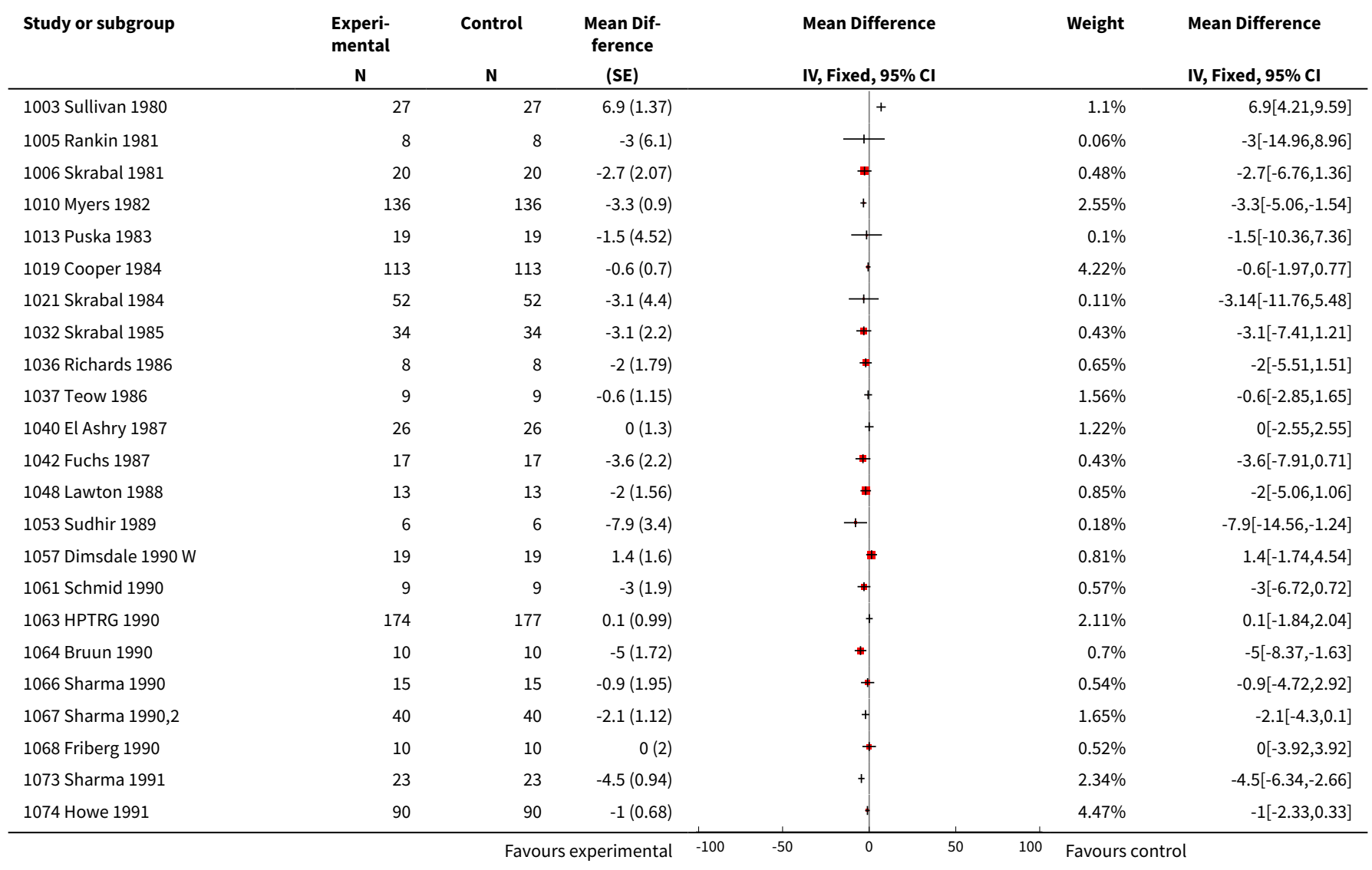




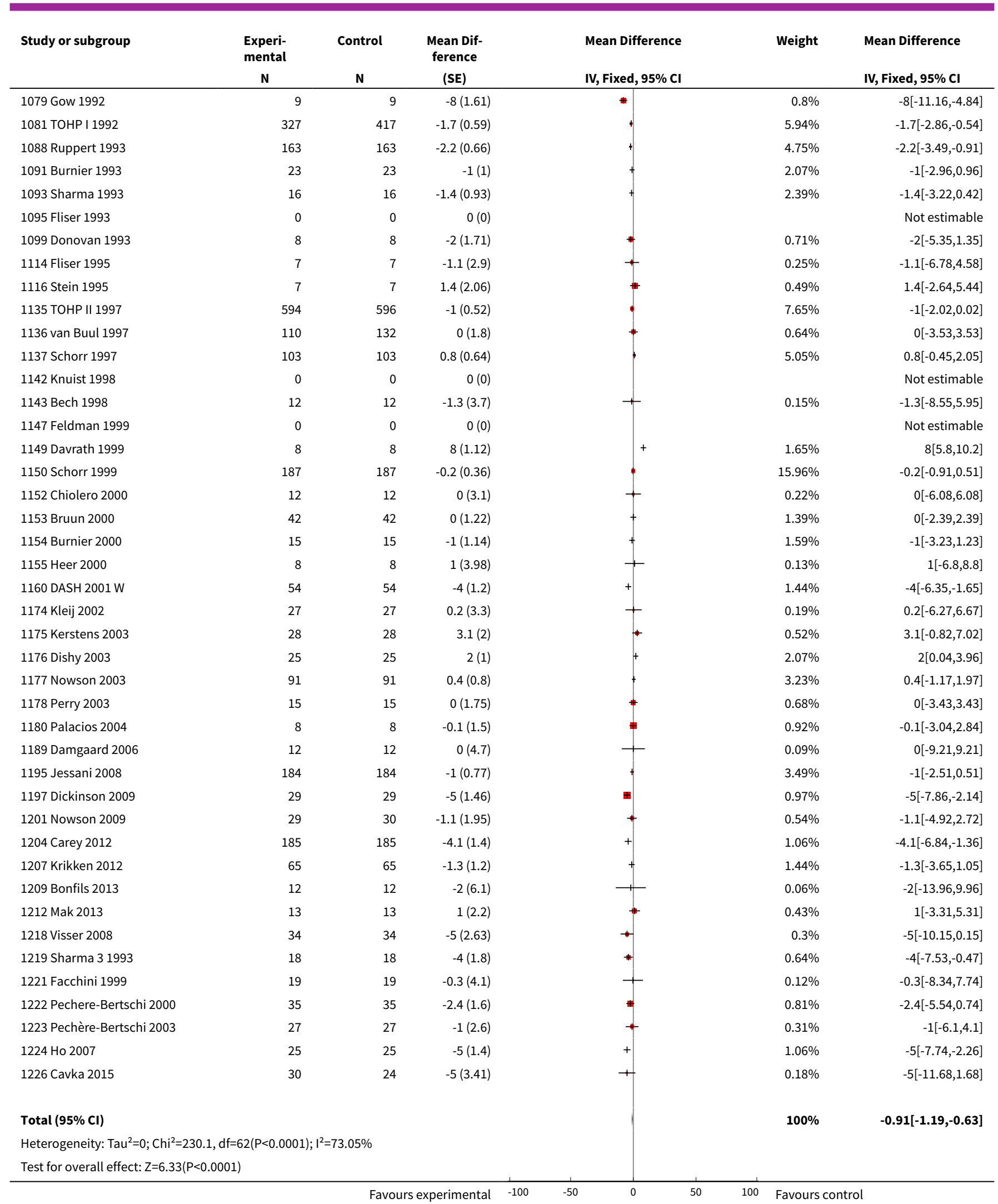

Effects of low sodium diet versus high sodium diet on blood pressure, renin, aldosterone, catecholamines, cholesterol, and triglyceride 
Analysis 9.2. Comparison 9 Bias analyses, Outcome 2 White population, normotensive, SBP blinding-low.

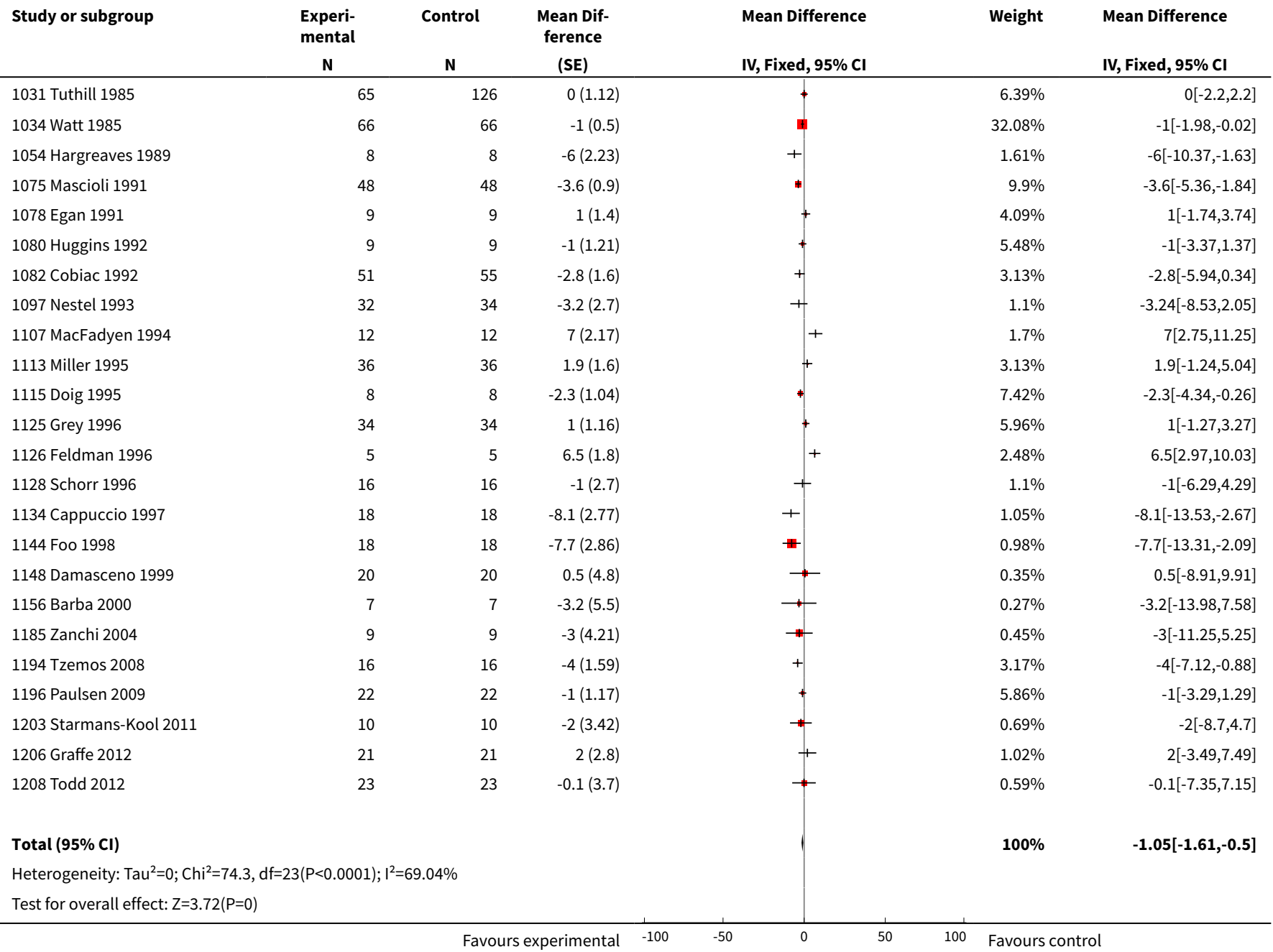

Analysis 9.3. Comparison 9 Bias analyses, Outcome 3 White population, normotensive, SBP outcome-assesed-high.

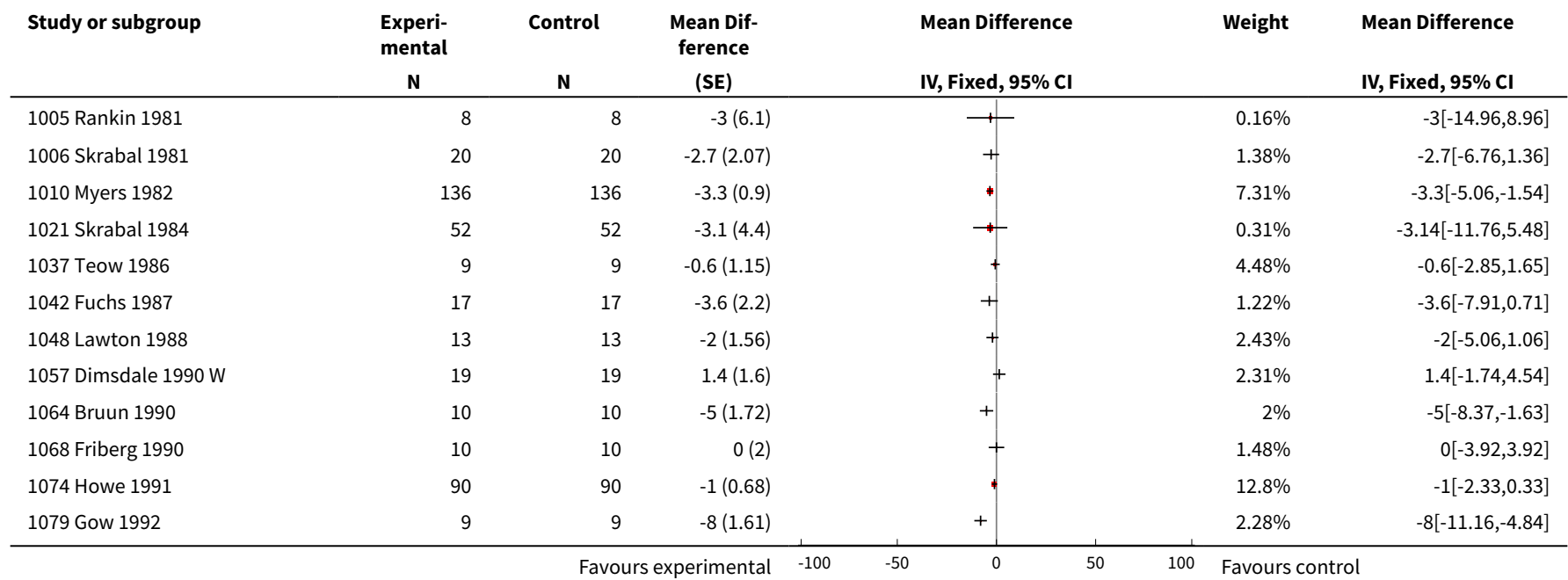

Effects of low sodium diet versus high sodium diet on blood pressure, renin, aldosterone, catecholamines, cholesterol, and triglyceride 


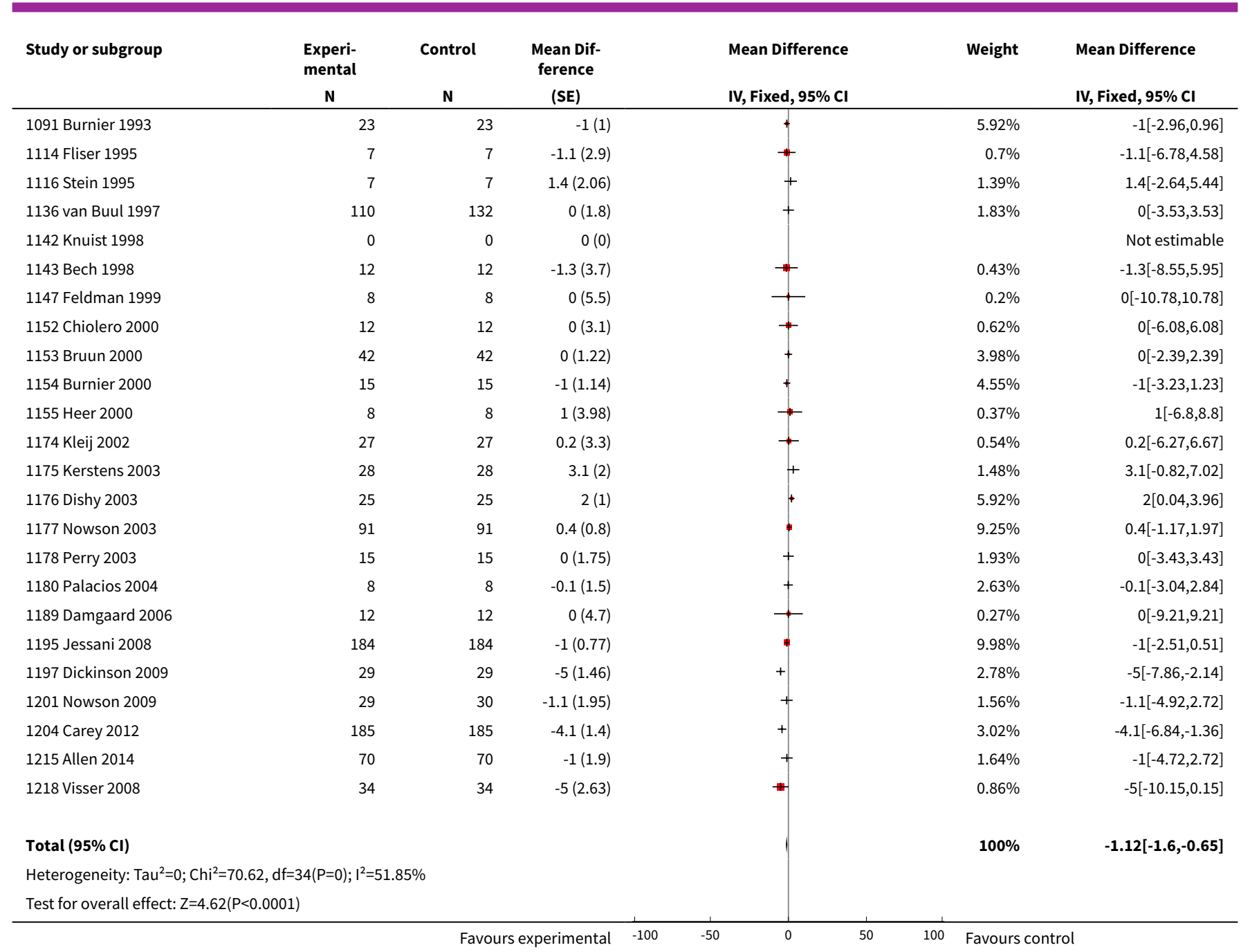

Analysis 9.4. Comparison 9 Bias analyses, Outcome 4 White population, normotensive, SBP outcome-assesed-low.

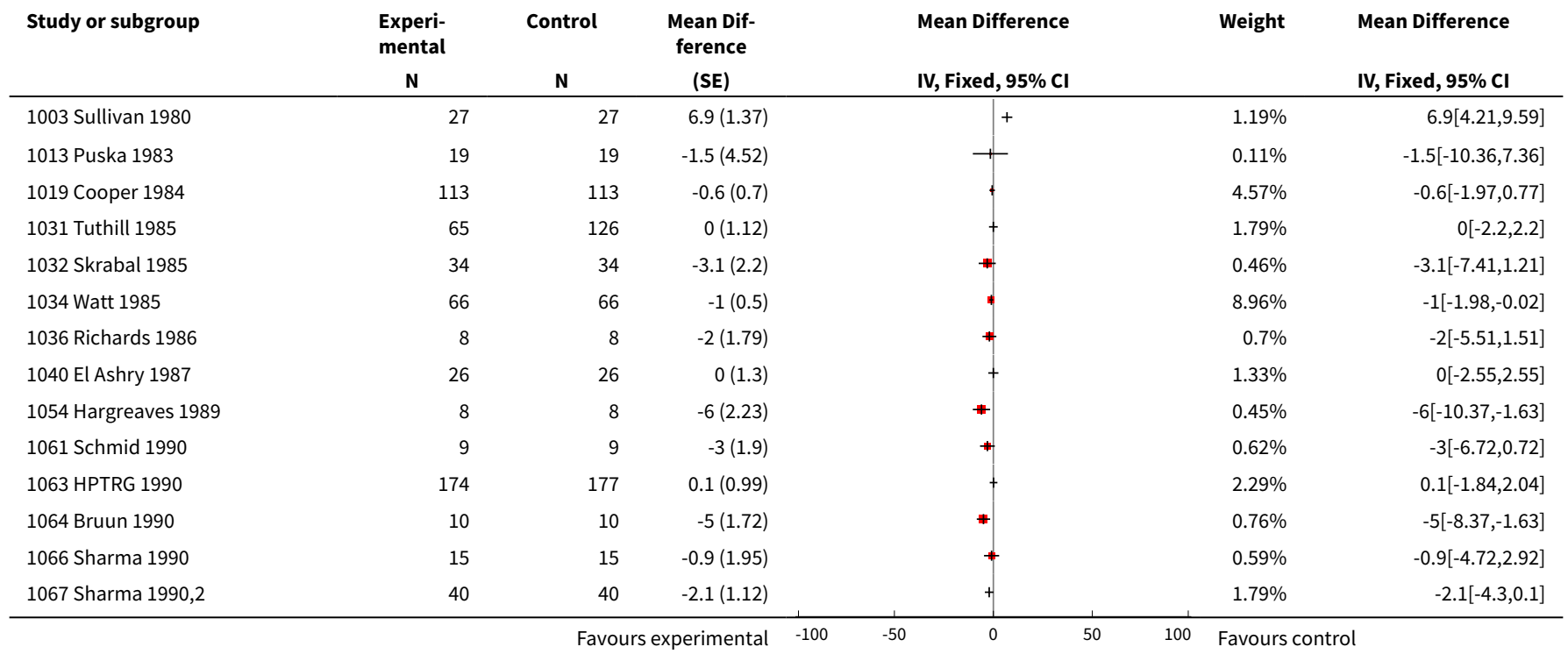

Effects of low sodium diet versus high sodium diet on blood pressure, renin, aldosterone, catecholamines, cholesterol, and triglyceride 251 (Review)

Copyright (c) 2017 The Cochrane Collaboration. Published by John Wiley \& Sons, Ltd. 


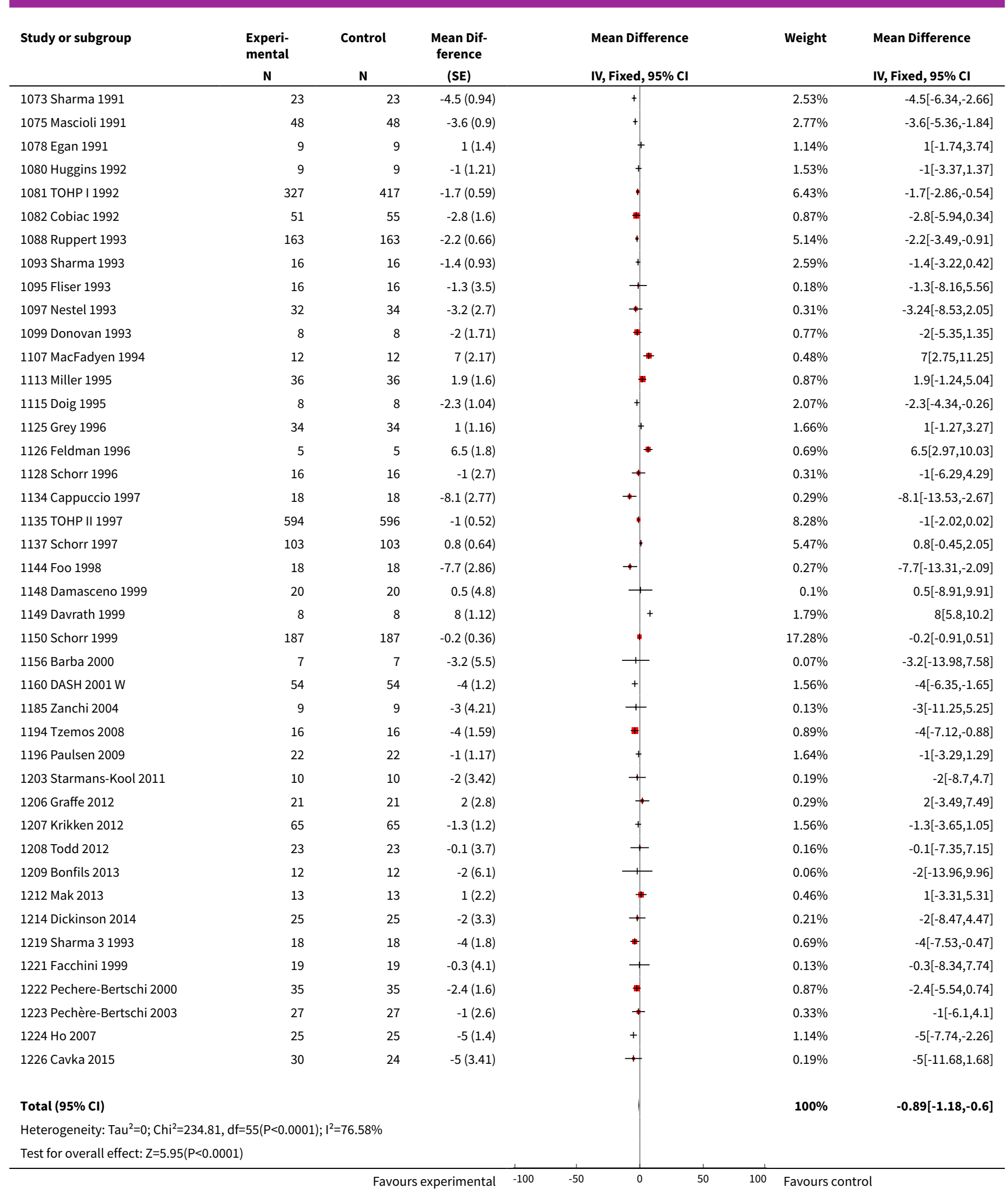

Effects of low sodium diet versus high sodium diet on blood pressure, renin, aldosterone, catecholamines, cholesterol, and triglyceride 
Analysis 9.5. Comparison 9 Bias analyses, Outcome 5 White population, hypertensive, SBP blinding-high.

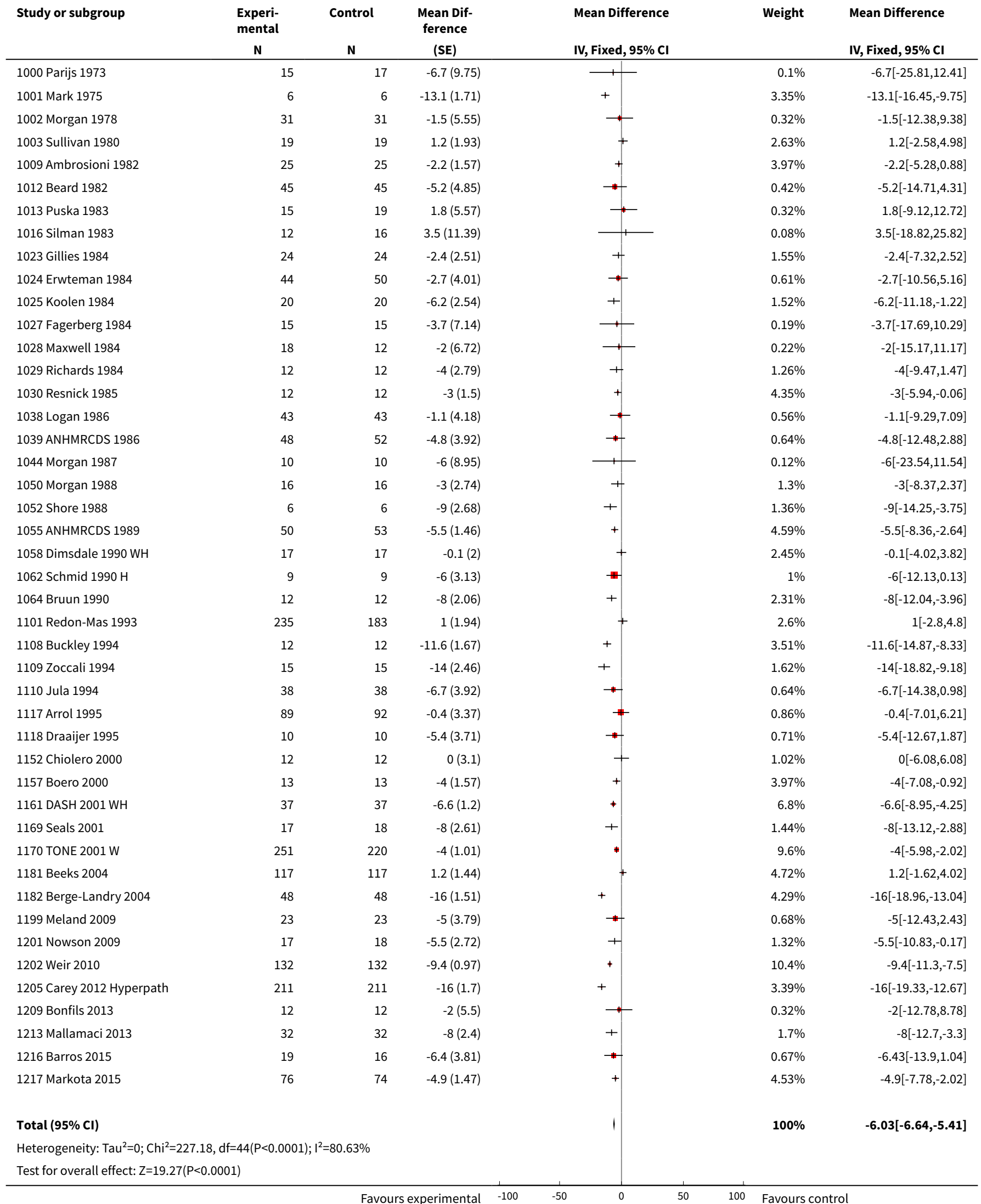

$\begin{array}{lllllll}\text { Favours experimental } & -100 & -50 & 0 & 50 & 100 & \text { Favours control }\end{array}$

Effects of low sodium diet versus high sodium diet on blood pressure, renin, aldosterone, catecholamines, cholesterol, and triglyceride 
Analysis 9.6. Comparison 9 Bias analyses, Outcome 6 White population, hypertensive, SBP blinding-low.

\begin{tabular}{|c|c|c|c|c|c|c|}
\hline \multirow[t]{2}{*}{ Study or subgroup } & $\begin{array}{l}\text { Experi- } \\
\text { mental }\end{array}$ & Control & $\begin{array}{l}\text { Mean Dif- } \\
\text { ference }\end{array}$ & Mean Difference & Weight & Mean Difference \\
\hline & $\mathbf{N}$ & $\mathbf{N}$ & (SE) & & IV, Fixed, 95\% CI \\
\hline 1011 MacGregor 1982 & 19 & 19 & $-10(2.76)$ & \multirow{2}{*}{+} & $1.27 \%$ & $-10[-15.41,-4.59]$ \\
\hline 1018 Watt 1983 & 18 & 18 & $-0.5(1.5)$ & & $4.31 \%$ & $-0.5[-3.44,2.44]$ \\
\hline 1045 Kurtz 1987 & 5 & 5 & $-16(2)$ & \multirow{2}{*}{+} & $2.42 \%$ & $-16[-19.92,-12.08]$ \\
\hline 1046 Grobbee 1987 & 40 & 40 & $-0.8(1.51)$ & & $4.25 \%$ & $-0.8[-3.76,2.16]$ \\
\hline 1047 MacGregor 1987 & 15 & 15 & $-13(3.29)$ & \#- & $0.9 \%$ & $-13[-19.45,-6.55]$ \\
\hline 1051 Morgan 1988,2 & 8 & 8 & $-7(3)$ & + & $1.08 \%$ & $-7[-12.88,-1.12]$ \\
\hline 1056 MacGregor 1989 & 20 & 20 & $-16(2.77)$ & + & $1.26 \%$ & $-16[-21.43,-10.57]$ \\
\hline 1069 Del Rio 1990 & 15 & 15 & $-3.4(2.02)$ & + & $2.37 \%$ & $-3.4[-7.36,0.56]$ \\
\hline 1070 Parker 1990 & 31 & 28 & $1.3(2.15)$ & + & $2.1 \%$ & $1.3[-2.91,5.51]$ \\
\hline 1076 Carney 1991 & 11 & 11 & $-1(3.49)$ & $\pi$ & $0.8 \%$ & $-1[-7.84,5.84]$ \\
\hline 1077 Singer 1991 & 21 & 21 & $-9(3)$ & + & $1.08 \%$ & $-9[-14.88,-3.12]$ \\
\hline 1084 Benetos 1992 & 20 & 20 & $-6.5(1.88)$ & + & $2.74 \%$ & $-6.5[-10.18,-2.82]$ \\
\hline 1085 Sciarrone 1992 & 46 & 45 & $-5.8(4.07)$ & $\rightarrow$ & $0.59 \%$ & $-5.8[-13.78,2.18]$ \\
\hline 1100 Fotherby 1993 & 17 & 17 & $-8(3.5)$ & $*$ & $0.79 \%$ & $-8[-14.86,-1.14]$ \\
\hline 1102 Ruilope 1993 & 10 & 9 & $-4(7.95)$ & 1 & $0.15 \%$ & $-4[-19.58,11.58]$ \\
\hline 1103 Del Rio 1993 & 30 & 30 & $-1.4(1.8)$ & + & $2.99 \%$ & $-1.4[-4.93,2.13]$ \\
\hline 1111 Howe 1994 & 14 & 14 & $-4.2(2.91)$ & + & $1.14 \%$ & $-4.2[-9.9,1.5]$ \\
\hline 1119 Overlack 1995 & 46 & 46 & $-3.9(2.5)$ & + & $1.55 \%$ & $-3.9[-8.8,1]$ \\
\hline 1127 Feldman $1996 \mathrm{H}$ & 8 & 0 & $2.6(2.9)$ & + & $1.15 \%$ & $2.62[-3.06,8.3]$ \\
\hline 1129 Bellini 1996 & 43 & 43 & $-3.9(1.8)$ & + & $2.99 \%$ & $-3.9[-7.43,-0.37]$ \\
\hline 1130 Inoue 1996 & 14 & 14 & $-15.2(1.91)$ & + & $2.66 \%$ & $-15.2[-18.94,-11.46]$ \\
\hline 1131 Ferri 1996 & 61 & 61 & $-7.4(1.13)$ & + & $7.59 \%$ & $-7.4[-9.61,-5.19]$ \\
\hline 1134 Cappuccio 1997 & 29 & 29 & $-6.6(2.51)$ & + & $1.54 \%$ & $-6.6[-11.52,-1.68]$ \\
\hline 1138 McCarron 1997 & 99 & 99 & $-4.9(1.23)$ & + & $6.41 \%$ & $-4.9[-7.31,-2.49]$ \\
\hline 1139 Meland 1997 & 16 & 16 & $-4(2.47)$ & + & $1.59 \%$ & $-4[-8.84,0.84]$ \\
\hline 1145 Wing 1998 & 17 & 17 & $-7(0.79)$ & $*$ & $15.53 \%$ & $-7[-8.55,-5.45]$ \\
\hline 1146 Herlitz 1998 & 6 & 6 & $-5(1.94)$ & + & $2.57 \%$ & $-5[-8.8,-1.2]$ \\
\hline 1148 Damasceno 1999 & 19 & 19 & $-8.5(4.1)$ & $\rightarrow$ & $0.58 \%$ & $-8.5[-16.54,-0.46]$ \\
\hline 1159 Ames 2001 & 13 & 13 & $-7(3.56)$ & 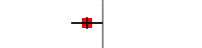 & $0.76 \%$ & $-7[-13.98,-0.02]$ \\
\hline 1168 Cuzzola 2001 & 19 & 19 & $-5.1(2.45)$ & + & $1.61 \%$ & $-5.1[-9.9,-0.3]$ \\
\hline 1172 Johnson 2001 & 46 & 46 & $-4.5(2.08)$ & + & $2.24 \%$ & $-4.5[-8.58,-0.42]$ \\
\hline 1183 Gates 2004 & 12 & 12 & $-3(1.84)$ & + & $2.86 \%$ & $-3[-6.61,0.61]$ \\
\hline 1191 Melander 2007 & 39 & 39 & $-6(1.18)$ & + & $6.96 \%$ & $-6[-8.31,-3.69]$ \\
\hline 1193 Dengel 2007 & 28 & 28 & $-10(3.64)$ & $*$ & $0.73 \%$ & $-10[-17.13,-2.87]$ \\
\hline $1198 \mathrm{He} 2009$ & 71 & 71 & $-4.8(1.24)$ & + & $6.3 \%$ & $-4.8[-7.23,-2.37]$ \\
\hline 1225 Gijsbers 2015 & 36 & 36 & $-7.5(1.53)$ & + & $4.14 \%$ & $-7.5[-10.5,-4.5]$ \\
\hline Total $(95 \% \mathrm{Cl})$ & & & & 1 & $100 \%$ & $-5.78[-6.39,-5.17]$ \\
\hline Heterogeneity: $\operatorname{Tau}^{2}=0$ & $=35(P<0.000$ & $=74.83 \%$ & & & & \\
\hline Test for overall effect: $z$ & & & & & & \\
\hline
\end{tabular}

Effects of low sodium diet versus high sodium diet on blood pressure, renin, aldosterone, catecholamines, cholesterol, and triglyceride 
Analysis 9.7. Comparison 9 Bias analyses, Outcome 7 White population, hypertensive, SBP outcome-assesed-high.

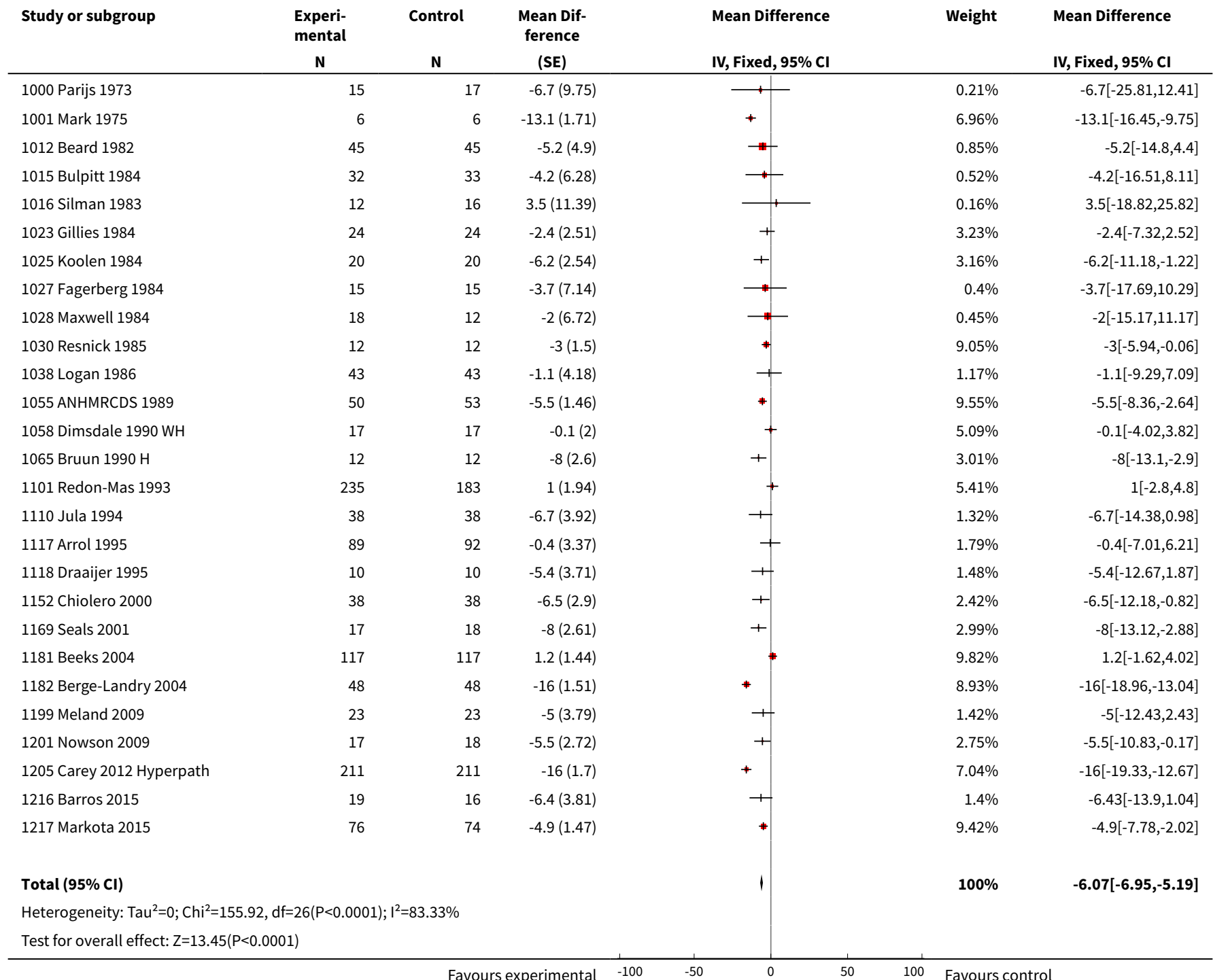

Analysis 9.8. Comparison 9 Bias analyses, Outcome 8 White population, hypertensive, SBP outcome-assesed-low.

\begin{tabular}{|c|c|c|c|c|c|c|}
\hline Study or subgroup & $\begin{array}{l}\text { Experi- } \\
\text { mental } \\
\mathrm{N}\end{array}$ & $\begin{array}{l}\text { Control } \\
\text { N }\end{array}$ & $\begin{array}{l}\text { Mean Dif- } \\
\text { ference } \\
\text { (SE) }\end{array}$ & $\begin{array}{l}\text { Mean Difference } \\
\text { IV, Fixed, } 95 \% \mathrm{CI}\end{array}$ & Weight & $\begin{array}{l}\text { Mean Difference } \\
\text { IV, Fixed, 95\% CI }\end{array}$ \\
\hline 1002 Morgan 1978 & 31 & 31 & $-1.5(5.55)$ & $\rightarrow$ & $0.23 \%$ & $-1.5[-12.38,9.38]$ \\
\hline 1003 Sullivan 1980 & 19 & 19 & $1.2(1.93)$ & + & $1.87 \%$ & $1.2[-2.58,4.98]$ \\
\hline 1009 Ambrosioni 1982 & 25 & 25 & $-2.2(1.57)$ & + & $2.83 \%$ & $-2.2[-5.28,0.88]$ \\
\hline 1011 MacGregor 1982 & 19 & 19 & $-10(2.76)$ & 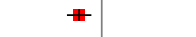 & $0.92 \%$ & $-10[-15.41,-4.59]$ \\
\hline 1013 Puska 1983 & 15 & 19 & $1.8(5.57)$ & $\rightarrow$ & $0.23 \%$ & $1.8[-9.12,12.72]$ \\
\hline 1018 Watt 1983 & 18 & 18 & $-0.5(1.5)$ & + & $3.1 \%$ & $-0.5[-3.44,2.44]$ \\
\hline 1024 Erwteman 1984 & 44 & 50 & $-2.7(4.01)$ & - & $0.43 \%$ & $-2.7[-10.56,5.16]$ \\
\hline 1029 Richards 1984 & 12 & 12 & $-4(2.79)$ & * & $0.9 \%$ & $-4[-9.47,1.47]$ \\
\hline 1039 ANHMRCDS 1986 & 48 & 52 & $-4.8(3.92)$ & \# & $0.45 \%$ & $-4.8[-12.48,2.88]$ \\
\hline
\end{tabular}

Effects of low sodium diet versus high sodium diet on blood pressure, renin, aldosterone, catecholamines, cholesterol, and triglyceride 255 (Review)

Copyright @ 2017 The Cochrane Collaboration. Published by John Wiley \& Sons, Ltd. 


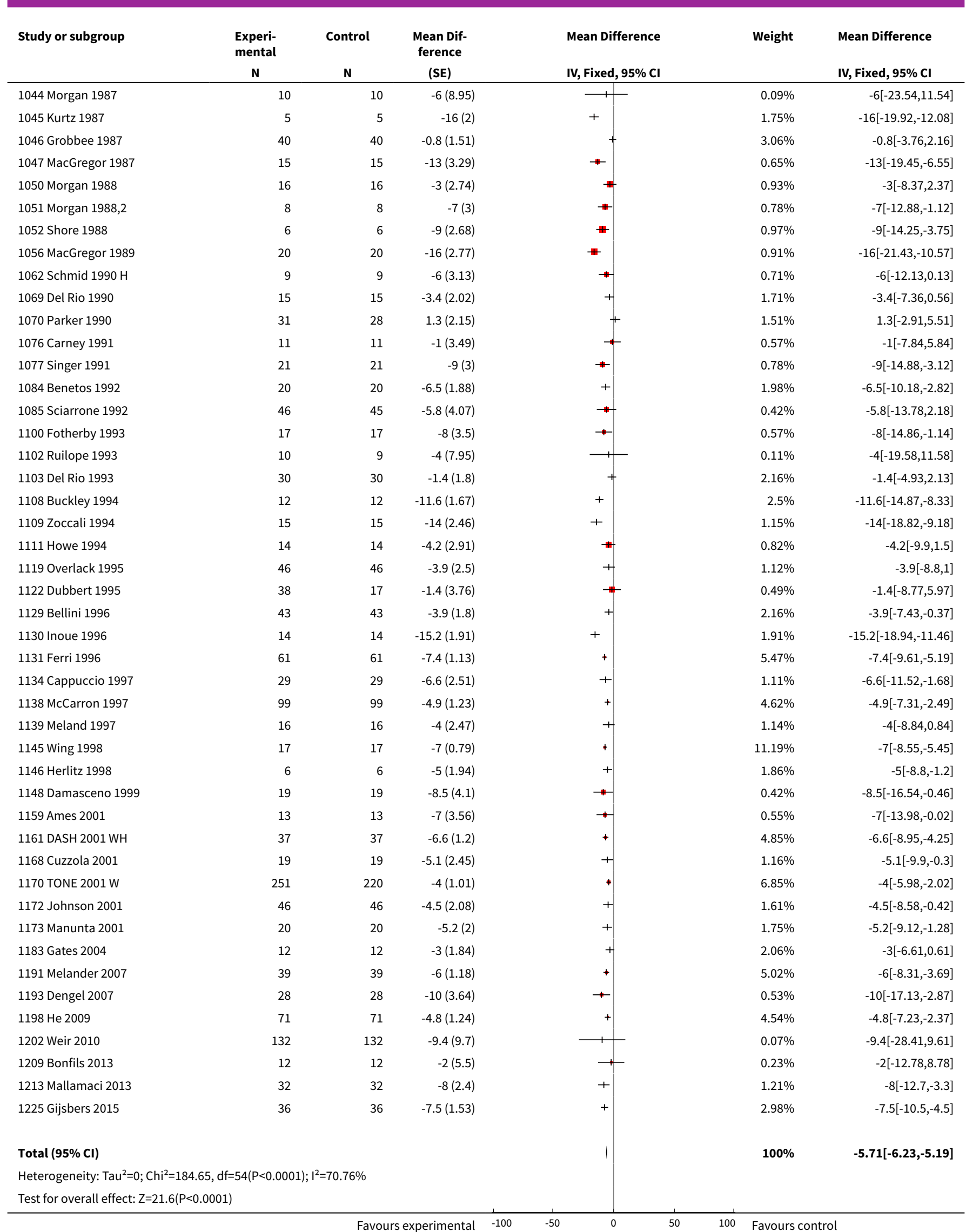

Effects of low sodium diet versus high sodium diet on blood pressure, renin, aldosterone, catecholamines, cholesterol, and triglyceride 


\section{ADDITIONAL TABLES}

Table 1. Sodium intake

\begin{tabular}{|c|c|c|c|c|c|c|}
\hline Reference & $\begin{array}{l}\text { Recommended } \\
\text { upper level }^{\star}\end{array}$ & $\begin{array}{l}\text { World, lower } \\
\text { range* }^{\star}\end{array}$ & $\begin{array}{l}\text { World, low- } \\
\text { er } \\
2.5 \% \text { * }\end{array}$ & $\begin{array}{l}\text { World, } \\
\text { mean* }\end{array}$ & $\begin{array}{l}\text { World, Up- } \\
\text { per } \\
97.5 \%{ }^{\star}\end{array}$ & $\begin{array}{l}\text { World, upper } \\
\text { range* }^{\star}\end{array}$ \\
\hline ADG 2015 & $\begin{array}{l}100(2300) \\
(5800)\end{array}$ & & & & & \\
\hline WHO 2012 & $\begin{array}{l}87(2000) \\
(5046)\end{array}$ & & & & & \\
\hline McCarron 2013 & & $\begin{array}{l}90(2070) \\
(5220)\end{array}$ & $\begin{array}{l}109(2500) \\
(6320)\end{array}$ & $\begin{array}{l}159(3660) \\
(9220)\end{array}$ & $\begin{array}{l}209(4810) \\
(12120)\end{array}$ & $\begin{array}{l}248(5700) \\
(14400)\end{array}$ \\
\hline Powles 2013 & & $\begin{array}{l}95(2200) \\
(5510)\end{array}$ & & $\begin{array}{l}172(3950) \\
(10000)\end{array}$ & & $\begin{array}{l}240(5520) \\
(13920)\end{array}$ \\
\hline
\end{tabular}

1. number: mmol; 2. number: $\mathrm{mg}$ sodium; 3. number: $\mathrm{mg}$ sodium chloride

Table 2. Differences in BP effects of reduced sodium intake at different time points in longitudinal studies

\begin{tabular}{|c|c|c|c|c|c|}
\hline $\begin{array}{l}\text { Compari- } \\
\text { son }\end{array}$ & References & $\begin{array}{l}\text { SBP diff. }(95 \% \\
\text { Cl) }\end{array}$ & $\mathrm{P}$ & $\begin{array}{l}\text { DBP diff. }(95 \% \\
\text { CI) }\end{array}$ & $P$ \\
\hline $\begin{array}{l}\text { Week } 1 \\
\text { vs. } 2\end{array}$ & $\begin{array}{l}1070 \text { Parker 1990;1180 Palacios 2004;1183 Gates } \\
\text { 2004;1188 Swift 2005 }\end{array}$ & $\begin{array}{l}-0.18(-3.03 \text { to } \\
2.67)\end{array}$ & 0.90 & $\begin{array}{l}0.12(-2.53 \text { to } \\
2.77)\end{array}$ & 0.93 \\
\hline $\begin{array}{l}\text { Week } 1 \\
\text { vs. } 4\end{array}$ & $\begin{array}{l}1070 \text { Parker 1990;1088 Ruppert 1993;1128 Schorr } \\
\text { 1996;1180 Palacios 2004;1183 Gates 2004;1186 Forrester } \\
2005 \text { N }\end{array}$ & $\begin{array}{l}-0.50(-3.20 \text { to } \\
2.20)\end{array}$ & 0.72 & $\begin{array}{l}0.35(-2.02 \text { to } \\
2.72)\end{array}$ & 0.77 \\
\hline $\begin{array}{l}\text { Week } 2 \\
\text { vs. } 4\end{array}$ & $\begin{array}{l}1011 \text { MacGregor 1982;1039 ANHMRCDS 1986;1055 } \\
\text { ANHMRCDS 1989;1070 Parker 1990;1075 Mascioli } \\
\text { 1991;1082 Cobiac } 1992 \\
\text { 1097 Nestel 1993;1100 Fotherby 1993;1080 Huggins } \\
\text { 1992;1183 Gates 2004;1186 Forrester } 2005 \text { N;1201 Now- } \\
\text { son } 2009\end{array}$ & $\begin{array}{l}-0.10(-1.88 \text { to } \\
1.68)\end{array}$ & 0.91 & $\begin{array}{l}-0.20(-1.12 \text { to } \\
0.72)\end{array}$ & 0.67 \\
\hline $\begin{array}{l}\text { Week } 2 \\
\text { vs. } 6\end{array}$ & $\begin{array}{l}1039 \text { ANHMRCDS 1986;1055 ANHMRCDS 1989;1085 Sciar- } \\
\text { rone 1992;1097 Nestel 1993;1201 Nowson 2009 }\end{array}$ & $\begin{array}{l}-0.50(-2.66 \text { to } \\
1.66)\end{array}$ & 0.65 & $\begin{array}{l}-0.42(-1.69 \text { to } \\
0.85)\end{array}$ & 0.52 \\
\hline $\begin{array}{l}\text { Week } 4 \\
\text { vs. } 6\end{array}$ & $\begin{array}{l}1039 \text { ANHMRCDS 1986;1055 ANHMRCDS 1989;1085 Sciar- } \\
\text { rone 1992;1097 Nestel 1993;1201 Nowson 2009 }\end{array}$ & $\begin{array}{l}0.39(-1.77 \text { to } \\
2.55)\end{array}$ & 0.72 & $\begin{array}{l}-0.22(-1.50 \text { to } \\
1.06)\end{array}$ & 0.74 \\
\hline
\end{tabular}

Data from Graudal 2015 
Table 3. Association of low sodium intake with mortality in prospective observational studies

\begin{tabular}{|c|c|c|c|c|c|}
\hline Study & $\begin{array}{l}\text { Multiple } \\
\text { adjust- } \\
\text { ment }^{\star}\end{array}$ & Exclusion & $N(L S)$ & $N(U S)$ & $\mathrm{RR} / \mathrm{OR}(95 \% \mathrm{Cl})$ \\
\hline Alderman 1998 (NHANES I) & Yes & None & 2837 & 8509 & $0.88(0.80$, to, 0.97$)$ \\
\hline He 1999 (NHANES I) & Yes & $\begin{array}{l}\text { Overweight (BMI > } \\
27.3 \text { ) }\end{array}$ & 1699 & 5098 & 0.98 (0.88 to 1.09$)$ \\
\hline Tuomilehto 2001 & Yes & Males** & 634 & 311 & 0.91 (0.56 to 1.48$)$ \\
\hline Cohen 2006 (NHANES II) & Yes & None & 3711 & 3443 & $0.78(0.67$ to 0.91$)$ \\
\hline Gelijnse 2007 & Yes & CVD and $\mathrm{HT}$ & 392 & 392 & 1.12 (0.86 to 1.46$)$ \\
\hline Cohen 2008 (NHANES III) & Yes & None & 2175 & 4350 & 0.83 (0.73 to 0.94$)$ \\
\hline Yang 2011 (NHANES III) & Yes & $\begin{array}{l}\text { Overweight (BMI > } \\
\text { 25) }\end{array}$ & 3067 & 6133 & $0.93(0.73$ to 1.18$)$ \\
\hline Stolarz-Skrzypek 2011 & Yes & None & 1250 & 1220 & $0.82(0.62$ to 1.08$)$ \\
\hline Gardener 2012 & Yes & None & 1138 & 961 & $0.89(0.74$ to 1.07$)$ \\
\hline Pfister 2014 (Norfolk) & Yes & $0-2$ year events & 3070 & 9249 & 0.92 (0.82 to 1.02$)$ \\
\hline O'Donnell 2014 (PURE) & Yes & $\begin{array}{l}\text { CVD, Cancer, DM, } \\
\text { smokers }\end{array}$ & 6162 & 38643 & $0.62(0.54$ to 0.71$)]$ \\
\hline Total $(95 \% \mathrm{Cl}) \#$ & & & 21369 & 67078 & 0.84 (0.76 to 0.93$)$ \\
\hline Total $(95 \% \mathrm{Cl}) \# \#$ & & & 21123 & 65450 & 0.87 (0.76 to 0.98$)$ \\
\hline
\end{tabular}

Only studies, which were representative for the general population and which adjusted for confounders were included.

If subgroup results were given, the results of the most healthy subgroup was used in the analysis to reduce

the possibility of reverse causation

\#With primary NHANES analyses (Alderman 1998, Cohen 2008)

\#\# With NHANES re-analyses (He 1999, Yang 2011)

* Studies were generally adjusted for at least sex, age and CVD risk factors

** In the male group a low salt intake group could not be identified, as the salt intake

in the lowest salt intake quartile was up to $159 \mathrm{mmol}$.

BMI: body mass index; CVD: cardiovascular disease; DM: diabetes mellitus; HT: hypertension

\section{A P P E N D I C E S}

\section{Appendix 1. Search strategies}

Database: Ovid MEDLINE(R) 1946 to Present with Daily Update

Search Date: 7 March 2016

1 sodium chloride, dietary/ (5340)

2 sodium, dietary/ (7840)

3 sodium/ (101026)

4 (sodium or salt).tw. (346998)

5 or/1-4 (400932)

Effects of low sodium diet versus high sodium diet on blood pressure, renin, aldosterone, catecholamines, cholesterol, and triglyceride 
6 diet, sodium-restricted/ (5815)

7 ((salt or sodium) adj5 (chang\$ or curb\$ or diet\$ or free or intake or limit\$ or load\$ or low\$ or minimi\$ or reduc\$ or restrict\$ or supplement

\$)).tw. (50878)

8 or/6-7 (53160)

9 hypertension/ (207011)

10 hypertens $\$ . t w . ~(322915)$

11 exp blood pressure/ (260732)

12 (blood pressure or bloodpressure or bp).tw. (317168)

13 or/9-12 (707443)

$14 \mathrm{renin} /(27614)$

15 renin.tw. (43610)

16 aldosterone/ (22706)

17 aldosterone.tw. (28823)

18 exp catecholamines/ (242929)

19 (catecholamine\$ or sympathin\$ or dopamine\$ or hydroxytyramine\$ or dihydroxyphenethylamine or intropin or epinephrine or adrenaline or epitrate or vaponefrin or medihaler-epi or micronefrin or micronephrine or racepinephrine or epifrin or lyophrin or norepinephrin\$ or noradrenaline or levarterenol or levonorepinephrine or levophed or arterenol or levonor or orciprenaline or metaproterenol or alupent or metaprel or alotec or astmopent).tw. (246296)

20 exp cholesterol/ (142389)

21 (cholesterol\$ or epicholesterol\$ or azacosterol\$ or diazacholesterol\$ or hydroxycholesterol\$ or 19-iodocholesterol\$ or iodocholesterol \$ or ketocholesterol\$ or oxocholesterol\$ or lipid\$ or glyceride\$ or triglyceride\$ or glycolipid\$ or lipoprotein\$ or ldl or hdl).tw. (533921)

22 or/14-21 (953557)

23 randomized controlled trial.pt. (407656)

24 controlled clinical trial.pt. (90132)

25 randomized.ab. (304936)

26 placebo.ab. (155515)

27 clinical trials as topic/ (175120)

28 randomly.ab. (215798)

29 trial.ti. $(132445)$

30 or/23-29 (931053)

31 animals/ not (humans/ and animals/) (4161827)

3230 not $31(852135)$

335 and 8 and (13 or 22) and 32 (1933)

34 remove duplicates from 33 (1925)

Database: Cochrane Central Register of Controlled Trials $<2016$, Issue $3>$ via Cochrane Register of Studies Online Search Date: 7 March 2016

\#1 MESH DESCRIPTOR Sodium Chloride, Dietary 211

\#2 MESH DESCRIPTOR Sodium, Dietary 328

\#3 MESH DESCRIPTOR Sodium 1917

\#4 (salt or sodium):TI,AB 18678

\#5 \#1 OR \#2 OR \#3 OR \#4 19256

\#6 MESH DESCRIPTOR Diet, Sodium-Restricted 518

\#7 (salt or sodium) near5 (chang ${ }^{\star}$ or curb ${ }^{\star}$ or diet ${ }^{\star}$ or free or intake or limit ${ }^{\star}$ or load ${ }^{\star}$ or low $^{\star}$ or minimi ${ }^{\star}$ or reduc or restrict $^{\star}$ or supplement $^{\star}$ ) 3206

\#8 \#6 OR \#7 3206

\#9 MESH DESCRIPTOR Hypertension 13753

\#10 (antihypertens* or hypertens $\left.{ }^{\star}\right): T I, A B 32980$

\#11 MESH DESCRIPTOR Blood Pressure EXPLODE ALL TREES 24184

\#12 (blood pressure or bloodpressure or bp) 55509

\#13 \#9 OR \#10 OR \#11 OR \#12 71017

\#14 renin 4518

\#15 aldosterone 3221

\#16 MESH DESCRIPTOR Catecholamines EXPLODE ALL TREES 8599

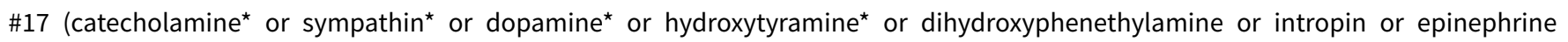
or adrenaline or epitrate or vaponefrin or medihaler-epi or micronefrin or micronephrine or racepinephrine or epifrin or lyophrin or norepinephrin* or noradrenaline or levarterenol or levonorepinephrine or levophed or arterenol or levonor or orciprenaline or metaproterenol or alupent or metaprel or alotec or astmopent) 16533

\#18 MESH DESCRIPTOR Cholesterol EXPLODE ALL TREES 8755

Effects of low sodium diet versus high sodium diet on blood pressure, renin, aldosterone, catecholamines, cholesterol, and triglyceride 
\#19 (cholesterol ${ }^{\star}$ or epicholesterol ${ }^{*}$ or azacosterol ${ }^{\star}$ or diazacholesterol $^{\star}$ or hydroxycholesterol ${ }^{\star}$ or 19 -iodocholesterol ${ }^{\star}$ or iodocholesterol $^{\star}$

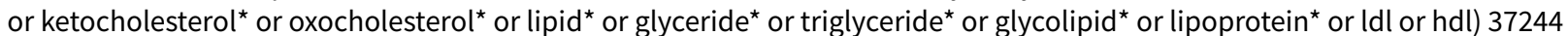
\#20 \#14 OR \#15 OR \#16 OR \#17 OR \#18 OR \#19 59594

\#21 \#5 AND \#8 AND \#13 OR \#20 1820

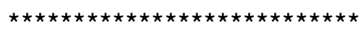

Database: Embase < 1980 to 2016 March 04>

Search Date: 7 March 2016

1 sodium chloride, dietary/ (7530)

2 sodium, dietary/ (6109)

3 sodium/ (91427)

4 (sodium or salt).tw. (424462)

5 or/1-4 (472096)

6 diet, sodium-restricted/ (8257)

7 ((salt or sodium) adj5 (chang\$ or curb\$ or diet\$ or free or intake or limit\$ or load\$ or low\$ or minimi\$ or reduc\$ or restrict\$ or supplement

\$)).tw. (61099)

8 or/6-7 (64792)

9 exp hypertension/ (545880)

10 hypertens\$.tw. (476727)

11 exp blood pressure/ (434877)

12 (blood pressure or bloodpressure or bp).tw. (428835)

13 or/9-12 (1125448)

14 renin/ (25693)

15 renin.tw. (51567)

16 aldosterone/ (30390)

17 aldosterone.tw. (34355)

18 exp catecholamine/ (324747)

19 (catecholamine\$ or sympathin\$ or dopamine\$ or hydroxytyramine\$ or dihydroxyphenethylamine or intropin or epinephrine or adrenaline or epitrate or vaponefrin or medihaler-epi or micronefrin or micronephrine or racepinephrine or epifrin or lyophrin or norepinephrin\$ or noradrenaline or levarterenol or levonorepinephrine or levophed or arterenol or levonor or orciprenaline or metaproterenol or alupent or metaprel or alotec or astmopent).tw. (288546)

20 exp cholesterol/ (239050)

21 (cholesterol\$ or epicholesterol\$ or azacosterol\$ or diazacholesterol\$ or hydroxycholesterol\$ or 19-iodocholesterol\$ or iodocholesterol $\$$ or ketocholesterol\$ or oxocholesterol\$ or lipid\$ or glyceride $\$$ or triglyceride $\$$ or glycolipid\$ or lipoprotein $\$$ or ldl or hdl).tw. (688622)

22 or/14-21 (1238526)

23 randomized controlled trial/ (394072)

24 crossover procedure/ (46238)

25 double-blind procedure/ (126561)

26 (randomi?ed or randomly).tw. (845561)

27 (crossover\$ or cross-over\$).tw. (78158)

28 placebo.ab. (219858)

29 (doubl\$ adj blind\$).tw. (159441)

30 assign\$.ab. (271379)

31 allocat\$.ab. (97448)

32 or/23-31 (1264495)

33 (exp animal/ or animal.hw. or nonhuman/) not (exp human/ or human cell/ or (human or humans).ti.) (5457724)

3432 not $33(1101675)$

355 and 8 and (13 or 22$)$ and 34 (2193)

36 remove duplicates from 35 (2167)

Database: Hypertension Group Specialised Register via Cochrane Register of Studies Search Date: 7 March 2016

\#1 ((salt or sodium):TI)

\#2 ((chang* or curb $^{\star}$ or diet ${ }^{\star}$ or free or intake or limit ${ }^{\star}$ or load ${ }^{\star}$ or low ${ }^{\star}$ or minimi ${ }^{\star}$ or reduc or restrict $^{\star}$ or supplement $\left.^{\star}\right)$ ) \#3 RCT:DE

\#4 (Meta-Analysis OR Review):MISC2

\#5 \#1 AND (\#2) AND ((\#3 OR \#4)) (708)

Effects of low sodium diet versus high sodium diet on blood pressure, renin, aldosterone, catecholamines, cholesterol, and triglyceride 
Database: ClinicalTrials.gov

Search Date: 7 March 2016

Search terms: (salt OR sodium) AND randomized

Study type: Interventional Studies

Interventions: diet

Outcome Measures: blood pressure (113)

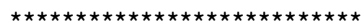

Medline In-Process: 98

Total: $1925+1820+2167+708+113+98=6831$

After de-duplication: 3269

WHAT'S NEW

\begin{tabular}{lll}
\hline Date & Event & Description \\
\hline 4 January 2017 & $\begin{array}{l}\text { New citation required but conclusions } \\
\text { have not changed }\end{array}$ & $\begin{array}{l}\text { updated version of the review with up-to-date search and } \\
\text { methodology }\end{array}$ \\
\hline 4 January 2017 & New search has been performed & $\begin{array}{l}\text { 1. Twenty-one new references were included. One erroneously } \\
\text { double-counted and two previously included duplicate refer- } \\
\text { ences were excluded. }\end{array}$ \\
& $\begin{array}{l}\text { 2. Separate analyses of mean blood pressure (MBP) in white par- } \\
\text { ticipants were excluded. Instead MBP effects were transformed } \\
\text { to SBP and DBP effects by means of regression analyses and in- } \\
\text { cluded in the SBP and DBP analyses. }\end{array}$ \\
& $\begin{array}{l}\text { 3. Previous subgroup analyses of studies with a duration of at } \\
\text { least four weeks (BP), two to four weeks (hormones and lipids) } \\
\text { and lipid studies with sodium reduction to moderate levels } \\
\text { were eliminated. } \\
\text { 4. Instead, a subgroup analysis of studies lasting at least seven } \\
\text { days and with a sodium intake of maximum 250 mmol/day in } \\
\text { the high sodium group was performed on all outcomes. }\end{array}$ \\
& $\begin{array}{l}\text { 5. The text of the review includes new subheadings available in } \\
\text { Rev Man. }\end{array}$
\end{tabular}

\section{H I S T O R Y}

Protocol first published: Issue 1, 2003

Review first published: Issue 1, 2003

\begin{tabular}{lll}
\hline Date & Event & Description \\
\hline 17 November 2002 & New search has been performed & Substantive amendment \\
\hline
\end{tabular}

Effects of low sodium diet versus high sodium diet on blood pressure, renin, aldosterone, catecholamines, cholesterol, and triglyceride 


\section{CONTRIBUTIONS OF AUTHORS}

Graudal NA: Study design and definition of selection criteria; Data collection and analysis; Formulation of manuscript

Hubeck-Graudal T: Data collection and analysis; Revision of manuscript.

Jürgens G: Data collection and analysis; Revision of manuscript.

\section{DECLARATIONS OF INTEREST}

None.

All authors are employed at public institutions. None of the authors has any connection with or receives funds from the food and salt industries or has commercial interests that might bear on this article.

\section{SOURCES OF SUPPORT}

\section{Internal sources}

- No sources of support supplied

\section{External sources}

- The A.P. Møller Foundation for the Advancement of Medical Science, Denmark.

The A.P.M. foundation is a non-profit funding source, which donated a grant for the pay of Niels Graudal

\section{DIFFERENCES BETWEEN PROTOCOL AND REVIEW}

This review was invited on the basis of the first published version in JAMA in 1998 and therefore a formal protocol was not performed.

The purpose and the methods of the present update are essentially identical with the 1998 JAMA version and the previous Cochrane versions.

\section{INDEX TERMS}

\section{Medical Subject Headings (MeSH)}

*Diet, Sodium-Restricted; African Continental Ancestry Group; Aldosterone [blood]; Asian Continental Ancestry Group; Blood Pressure [ ${ }^{*}$ drug effects] [radiation effects]; Catecholamines [blood]; Cholesterol [blood]; Epinephrine [blood]; European Continental Ancestry Group; Hypertension [ ${ }^{\star}$ diet therapy] [ethnology]; Norepinephrine [blood]; Randomized Controlled Trials as Topic; Recommended Dietary Allowances; Renin [blood]; Sodium Chloride, Dietary [ ${ }^{\star}$ pharmacology]; Triglycerides [blood]

\section{MeSH check words}

Humans 